Universidad Nacional de la Plata

FaCUltad de Humanidades y Ciencias de la Educación

Secretaría de Posgrado

PERSONA YÁMBICA. PROCESOS DE ENMASCARAMIENTO DEL 'YO' EN LA POESÍA YÁMBICA DE LA GRECIA ARCAICA Y HELENÍSTICA

TESIS PARA OPTAR POR EL TÍTULO DE DOCTOR EN LETRAS

SEBASTIÁN EDUARDO CARRIZO

Directora: Dra. Claudia FERnÁNDEZ

La Plata, 11 De octubre de 2017 


\section{AGRADECIMIENTOS}

Quiero agradecer profundamente a la Dra. Claudia Fernández por su apoyo y aliento incondicional a lo largo de todos estos años. Su compromiso con la investigación y la rigurosidad de sus intervenciones en cada una de las etapas no ha hecho más que enriquecer aquello que torpemente he tratado de esbozar en esta tesis. Su inmensa generosidad y humanismo fueron un refugio en momentos personales muy delicados que me han tocado vivir en el transcurso de este tiempo. Para ella solo tengo palabras de agradecimiento, ya que sin su invalorable dirección y consejo yo no hubiera sido capaz de llevar adelante este trabajo.

Quiero recordar también a la Prof. Daniela Antúnez (in memoriam), quien me inició en el camino de la investigación y me brindó su inmensa amistad a lo largo de veinte años. A ella le agradezco sus apasionadas enseñanzas sobre poesía griega y, en particular, sobre su siempre preferido Calímaco.

Por otra parte, quiero destacar la relevancia de las instituciones que con sus recursos humanos y económicos me han permitido concretar la realización de esta investigación. Particularmente, a los miembros del Centro de Estudios Helénicos de la Universidad Nacional de Rosario (Marcela Ristorto, Marina Larrosa, Clara Racca y Silvia Reyes) con quienes comparto la actividad académica. A la Facultad de Humanidades y Ciencias de la Educación de la Universidad Nacional de La Plata, que permitió radicar allí este proyecto y formalizar este trayecto de formación doctoral. También quiero destacar muy especialmente el apoyo del Consejo Nacional de Investigaciones Científicas y Técnicas, cuyo programa de Becas de Investigación me otorgó los recursos necesarios para concretar la realización del trabajo.

A la Lic.Verónica Alfonso por brindarme su guía y orientación en momentos críticos.

En el plano personal, quiero agradecer a los que estuvieron siempre. A mi madre Ángeles, por su infinito amor y devoción. A mis hermanos, Raúl, María de los Ángeles y Adriana, porque sin ellos nada de esto tendría sentido. A Pablo, a Juan, y a todos mis sobrinos. Y en especial a Ana Laura, mi compañera, por su amor y su fortaleza.

Finalmente, quiero agradecer a mi padre, Gilberto, por haberme comprado La Ilíada y La Odisea en edición Billiken cuando tenía seis años. A él, que hubiera querido acompañarme pero tuvo que partir antes, va dedicada esta tesis. 


\section{ÍNDICE}

\section{CAPÍTULO 1}

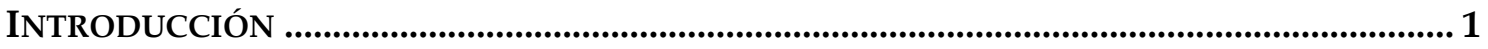

1. LINEAMIENTOS GENERALES ..................................................................................... 1

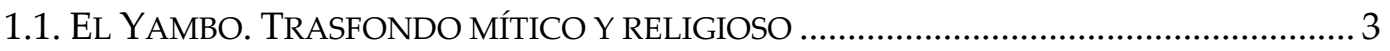

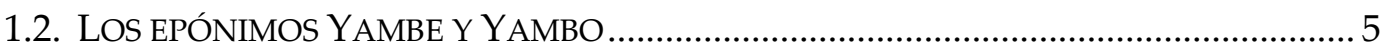

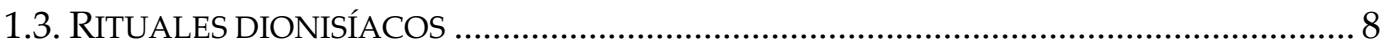

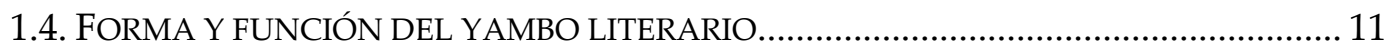

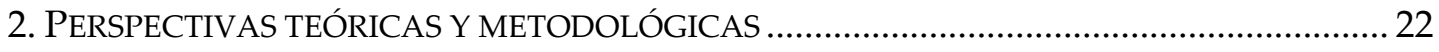

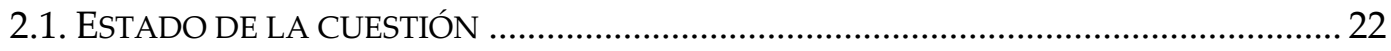

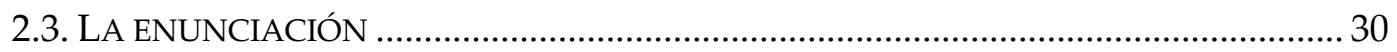

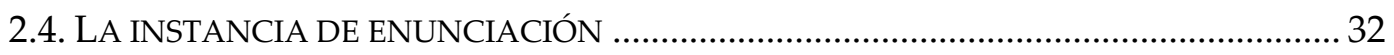

2.5. LA SITUACIÓN DE COMUNICACIÓN DEL YAMBO ARCAICO Y HELENÍSTICO ............ 33

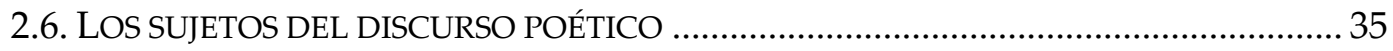

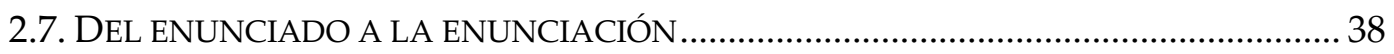

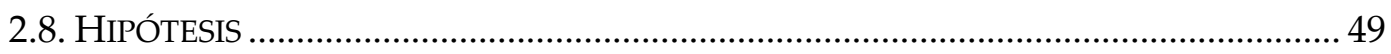

\section{CAPÍTULO 2}

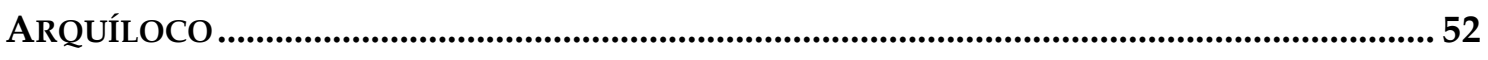

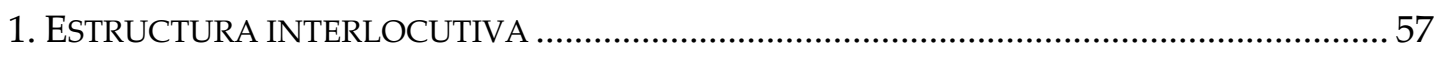

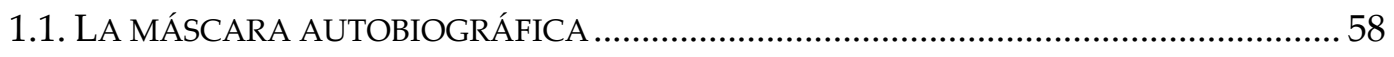

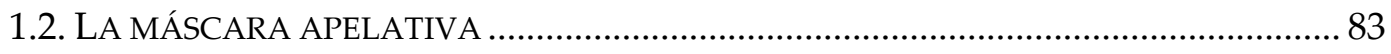

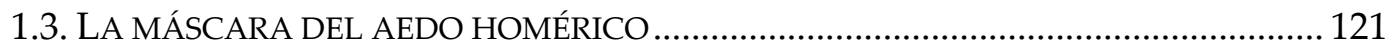

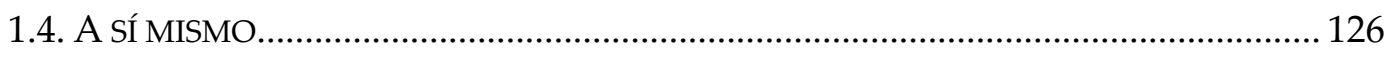

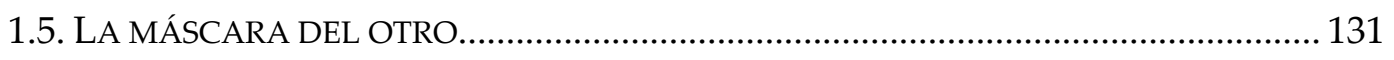

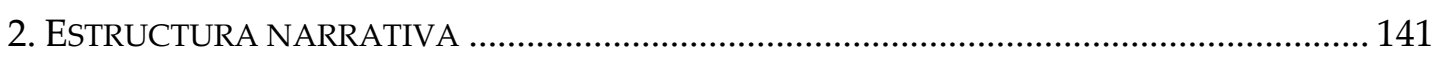

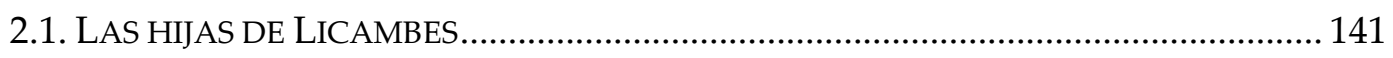

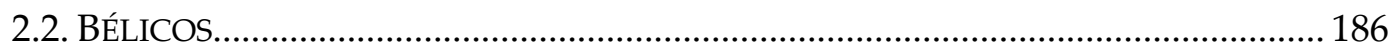

\section{CAPÍtulo 3}

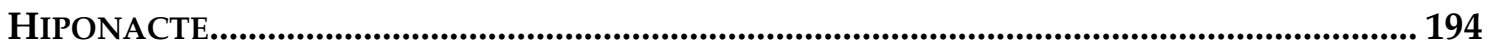

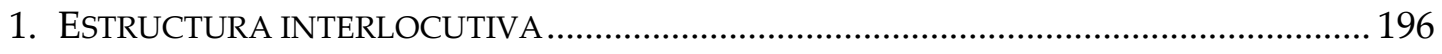

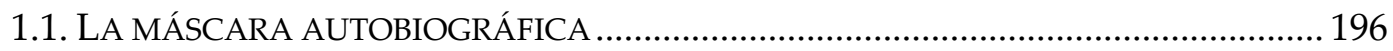

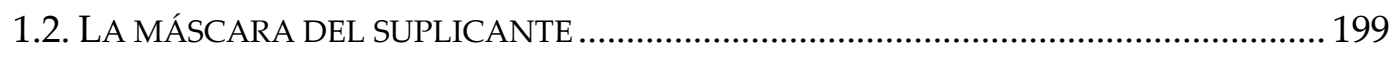

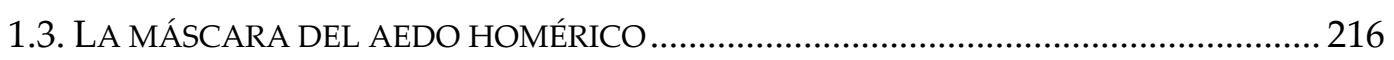




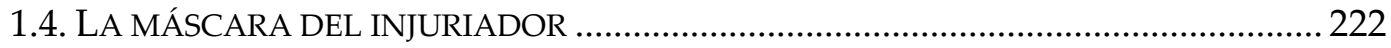

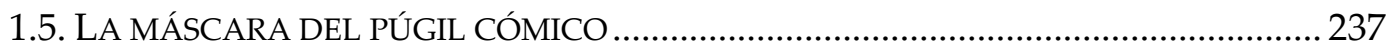

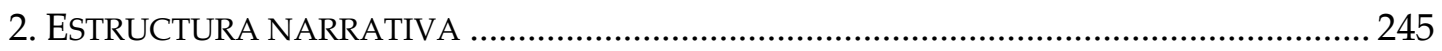

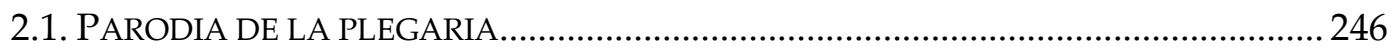

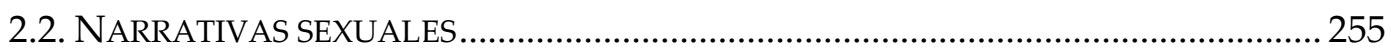

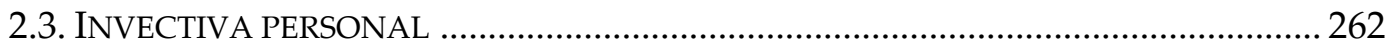

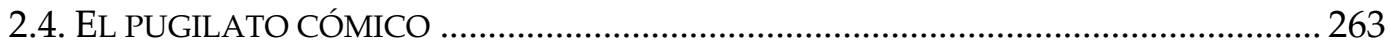

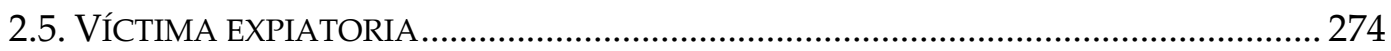

\section{CAPÍTULO 4}

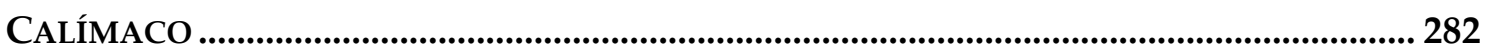

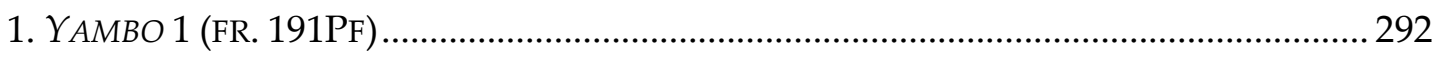

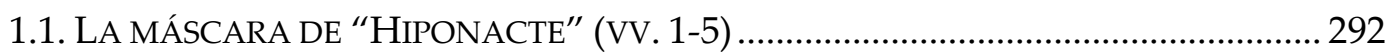

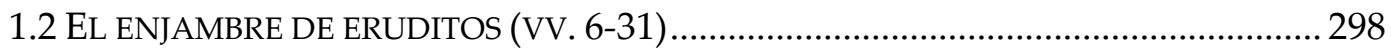

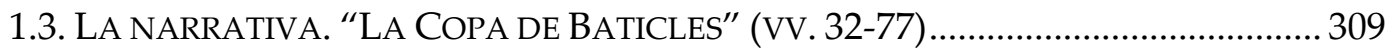

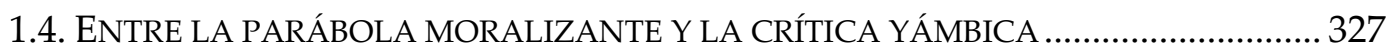

1.5. “CALÍMACO” E “HiPONACTE”. LA MÁSCARA DETRÁS DE LA MÁSCARA .............. 336

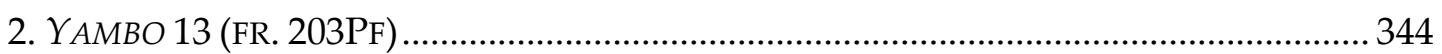

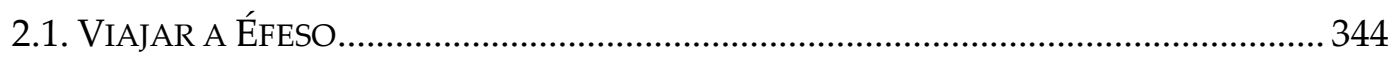

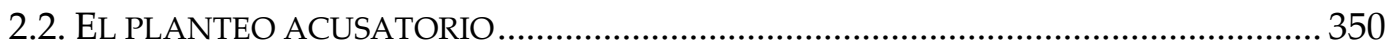

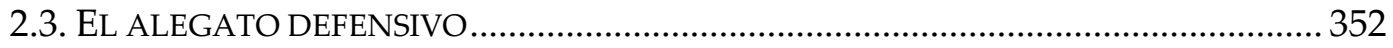

2.4. EL DESENMASCARAMIENTO DEL 'YO'. LA MÁSCARA DE “CALÍMACO” ............... 357

CONCLUSIONES

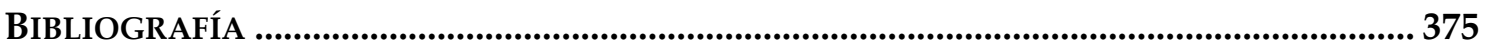




\section{AbreViaturas UTILIZADAS}

DELG Chantraine, P. (1968-1980). Dictionnaire étymologique de la langue grecque (Vols. 1-4). Paris: Klincksieck.

DK Diels, H. \& Kranz, W. (1951-1952). Die Fragmente der Vorsokratiker (5o ed., Vols. 1-3). Berlin: Weidmann.

DGE Diccionario Griego Español - Consejo Superior de Investigaciones Científicas (CSIC). [en línea] Disponible en: http://dge.cchs.csic.es/xdge/

Et.M Gaisford, T. (1848). Etymologicon Magnum. Oxford: Typographo Academico.

Et.Gen Carnuth, O. (1896). Etymologicum Florentinum Parvum. Etymologicum Magnum Genuinum. Königsberg: Hartungsche Verlagsdruckerei.

Et.Gud de Stefani, A. (1909-1920). Etymologicum Gudianum (Vols. 1-2). Leipzig:

Teubner.

FGrH Jacoby, F. (1923-1958). Die Fragmente der griechischen Historiker (Vols. 1-3). Leiden: Brill. [En línea] Disponible en: $\underline{\text { http://referenceworks.brillonline.com/reference-works }}$ [acceso 10 de octubre de 2017]

I.Delos $\quad$ Durrbach, F.; Roussel, P.; Launey, M.; Plassart, A.; Coupry, J. (1926-1972) Inscriptions de Délos (Vols. 1-7). Paris: H. Champion

I.Didyma Wiegand, T. (1958). Didyma 2. Die Inschriften von Albert Rehm. Berlin: Mann.

IG Brandenburgische Akademie der Wissenschaften (1873 -). Inscriptiones Graecae. Berlin. Sitio web: http://www.bbaw.de/forschung/ig/

IGUR Moretti, L. (1968-1990). Inscriptiones graecae urbis Romae. (Vols. 1-4). Roma: Istituto italiano per la storia antica.

I.Milet Wiegand, T. (1924) Milet. Ergebnisse des Ausgrabungen und Untersuchungen (Vol. 2 T. 2). Berlin: Hans Schoetz. [En línea] Disponible en: http://digi.ub.uni-heidelberg.de/diglit/wiegand1929 [acceso $10 \mathrm{de}$ octubre de 2017]

LSJ Liddell, H. G.-Scott, R.-Jones, H. S. (1996). A Greek-English Lexicon. With a Revised Suplement. Oxford: Clarendon Press.

OGIS Dittenberger, W. (1903-1905). Orientis Graeci Inscriptiones Selectae. Leipzig: Hirzel. 
PCG Kassel, R. \& Austin, C. (1983 -). Poetae Comici Graeci (Vols. 1-8). Berlin: G. de Gruyter.

PMG Page, D. L. (1962). Poetae Melici Graeci. Oxford: Oxford University Press.

P.Oxy Egypt Exploration Society (1898 -). The Oxyrhynchus Papyri XI. London. [En línea] Disponible en: http://www.papyrology.ox.ac.uk/POxy/ees/ees.html [acceso 10 de octubre de 2017]

SEG Supplementum Epigraphicum Graecum. Brill Online Reference Works. [En línea] Disponible en: http://referenceworks.brillonline.com/referenceworks [acceso 10 de octubre de 2017]

SIG Dittenberger, W. (1883). Sylloge Inscriptionum Graecarum. Leipzig: Hirzel. 


\section{$\underline{1}$ \\ INTRODUCCIÓN}

\section{LINEAMIENTOS GENERALES}

El principal objetivo de esta tesis consiste en analizar los modos en que la primera persona se inscribe en la poesía yámbica de la Grecia arcaica y helenística, para lo cual se abordan en particular las producciones de los reconocidos yambógrafos Arquíloco de Paros (c. 660 a. C.), Hiponacte de Éfeso (c. 500 a. C.) y Calímaco de Cirene (c. 310-244 a. C.). Con este propósito, se investigan los procesos de producción, transmisión y recepción de lo que tradicionalmente se conoce como "yo lírico" o "persona poética", es decir, una voz que se manifiesta en primera persona en una composición dada y que se interpreta como dramatización de la figura del poeta. Partiendo de implicancias teóricas y metodológicas diferentes a la perspectiva tradicional en que se acuñaron estos términos, el presente proyecto postula específicamente el concepto de persona yámbica, entendido como un determinado tipo de máscara $(\pi \varrho o ́ \sigma \omega \pi \mathrm{ov})^{1}$ propia de este género, que regula la legalidad del 'yo' en una tonalidad que puede ir desde un anclaje intimista, expresión en clave autobiográfica, hasta un artilugio de distanciamiento mediante el cual el 'yo'

${ }^{1}$ Véase la fundamentación del concepto de persona yámbica en el parágrafo metodológico (vid. inf. pág. 22). 
aparece bajo el disfraz de un personaje ficticio, de una figura típica o, probablemente, de personas reales pertenecientes al entorno social del poeta.

El desarrollo de la presente investigación se ha estructurado de la siguiente manera: en este capítulo introductorio (capítulo 1) se puntualizan las características del género yámbico, sobre todo en su período arcaico. Por un lado, ahondamos en lo atinente al trasfondo mítico y religioso de esta particular forma poética. En particular, nos remontamos a las relaciones que entabla en sus orígenes con los cultos eleusinos y dionisíacos, porque estos resultan fundamentales para entender los rasgos estructurales de su composición. Con este objetivo, se indaga en la figura de la mítica 'I $\alpha \dot{\mu} \beta \eta$ (Hymn. Hom. Dem. 122)

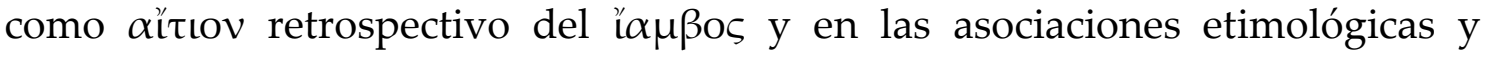
genéricas que el $\iota^{2} \alpha \mu \beta$ os mantiene con otras expresiones festivas ligadas al

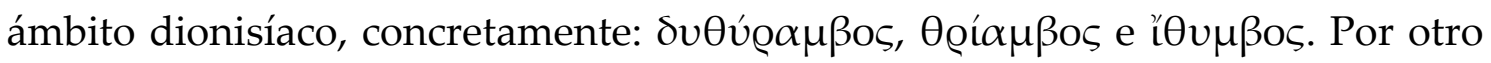
lado, se presentan las justificaciones y fundamentos del corpus seleccionado y las perspectivas teóricas y metodológicas seleccionadas para el análisis de los textos poéticos. En los tres capítulos siguientes (capítulos 2, 3 y 4 ) se desarrolla el estudio sistemático del corpus yambográfico. Al final de cada sección se consignan los resultados parciales sobre la escenografía enuncivo-enunciativa mediante un esquema que permite visualizar los distintos actantes y actores que intervienen en cada poema y sus relaciones de identidad. En estas secciones se realiza también una caracterización del enunciador a partir del concepto de persona yámbica, como máscara lingüística particular que posibilita la funcionalidad de este género poético. Por último, en el capítulo 5 se presentan las conclusiones finales considerando diacrónicamente las diferencias y similitudes entre las personas yámbicas de Arquíloco, Hiponacte y Calímaco, y entre las funciones particulares en el período arcaico y el helenístico. 


\subsection{El YAMBO. TRASFONDO MÍTICO Y RELIGIOSO}

En sus orígenes el yambo estuvo directamente vinculado con festividades comunitarias y rituales religiosos, particularmente con los cultos de Deméter y Dioniso. ${ }^{2}$ De su forma ritual solo se ha conservado alguna información tardía e indirecta que permite determinar la asociación de ciertos componentes del yambo con estos cultos, nos referimos especialmente al hecho de compartir los fenómenos de la invectiva, la obscenidad y la burla ritual. Tenemos testimonios de varias ceremonias, algunas estrictamente femeninas, que evidencian características de este tipo. A la ceremonia eleusina, que tiene su etiología en el mito del duelo de Deméter, ${ }^{3}$ pertenecen el lenguaje y las bromas

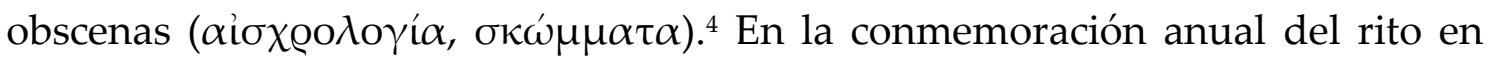

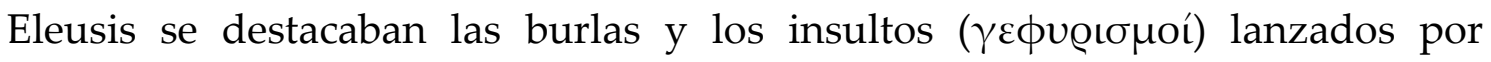
hombres y mujeres enmascarados a personajes destacados de la comunidad. ${ }^{5}$ Es probable, además, que en la fiesta nocturna posterior a la llegada a Eleusis ( $\pi \alpha v v v \chi i ́ s)$ se continuara con la $\alpha \grave{\imath} \chi \chi \varrho o \lambda o \gamma i ́ \alpha$ ritual. En la misma Eleusis, concretamente en las fiestas de las Haloa, las mujeres se reunían y realizaban un banquete nocturno con todo tipo de alimentos, entre los cuales estaban las tartas con formas de genitales masculinos y femeninos, y la $\alpha$ i̇ $\chi \varrho o \lambda o \gamma$ í $\alpha$ se daba acompañada por falos artificiales. ${ }^{6}$ Por otro lado, tenemos las Tesmoforias. Ps. Apolodoro (1.5.10) señala que en estas fiestas, otro ritual típicamente

\footnotetext{
2 Véanse Burkert (2007); Robertson (1998, págs. 547-75).

${ }^{3}$ Hymn. Hom. Dem. 198-211 (vid. inf. pág. 5).

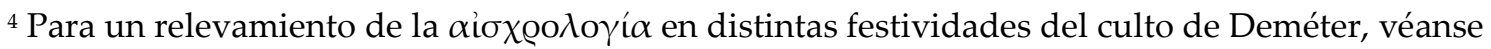
Richardson (1974, págs. 5-12, 22-3, 211-17); Foley (1993, págs. 45-8, 169-75).

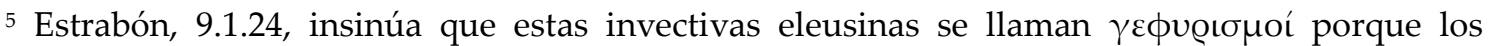
enmascarados se situaban en el $\gamma \varepsilon \dot{\phi v \rho \alpha ~(" p u e n t e ") ~ s o b r e ~ e l ~ r i ́ o ~ C e f i s o ; ~ c f . ~ H e s i q u i o ~} \gamma 469$ y 470,

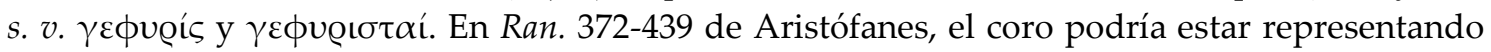

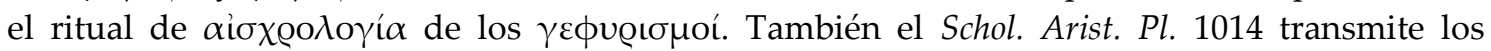

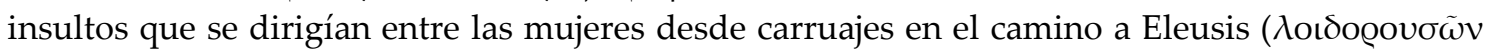
$\dot{\alpha} \lambda \lambda \hat{\eta} \lambda \alpha \varsigma \dot{\varepsilon} \nu \tau \tilde{\eta}$ ód $\tilde{\omega})$.

${ }^{6}$ Luciano, Dial. meretr. 280.14 Rabe; Schol. Luc. dial. deorum 1-5 (211.14-212.8 Rabe); Schol. Luc. dial. mertr. 7 (279-280 Rabe). Esta fiesta también aparece asociada a Dioniso.
} 
femenino, las mujeres se dirigían burlas obscenas unas a otras

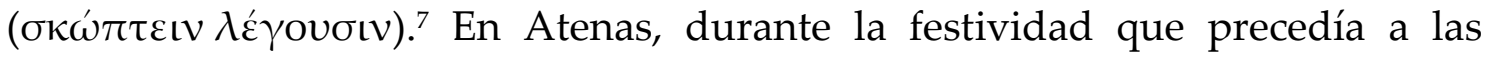
Tesmoforias, las Stenias, se realizaba un intercambio de invectivas e insultos entre hombres y mujeres. ${ }^{8}$ Este mismo comportamiento aparece en el protocolo

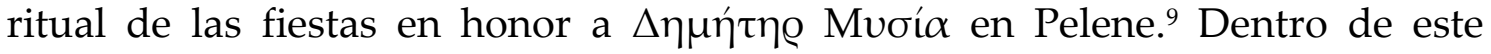
contexto debe comprenderse también el festival de Damia y Auxesia en Egina,

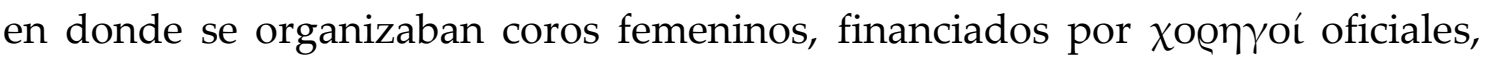
que confrontaban a través del intercambio de insultos y bromas obscenas. ${ }^{10}$

De las festividades dionisíacas, por su parte, deriva particularmente la presencia o mención del vino en relación al contexto del simposio, también

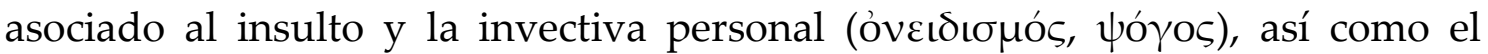
elemento fálico. Puede también ser clave para determinar estas asociaciones el propio término ‘́ $\alpha \mu \beta o \varsigma$, de etimología incierta, ${ }^{11}$ que comparte el formante -

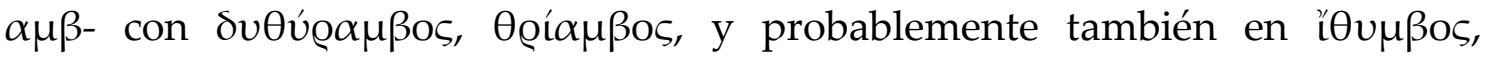
palabras relacionadas todas con el culto de Dioniso. ${ }^{12}$

7 Véanse también Cleomedes 2.2; Diodoro Sículo 5.4.7; este último señala expresamente que la

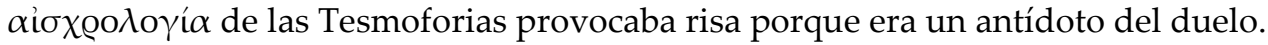

${ }^{8}$ Cf. Burkert (2007, pág. 144).

${ }^{9}$ Pausanias, 7.27.10.

${ }^{10}$ Heródoto, 5.83.2-3.

${ }^{11}$ Para un resumen de las discusiones antiguas sobre su etimología véanse Frisk (1960, pág. 704) y Chantraine (1968-1980, pág. 453). Brandenstein (1936, págs. 34-8) sostiene por ejemplo que ‘ $\alpha \mu \beta$ o $\varsigma$ es un vocablo pregriego compuesto de un elemento que significa "miembro" (cf. Sct. angam) y un numeral *dvi-, "dos", es decir "dos pasos", un tipo de danza. Del mismo modo, $\delta v \theta v ́ \varrho \alpha \mu \beta$ о у $\theta$ @í $\alpha \mu \beta$ os significarían "tres pasos" y "cuatro pasos" respectivamente. Versnel (1970, pág. 24) afirma que nada en ӨQí $\alpha \mu \beta$ os sustenta una relación con la danza y señala que cada uno de estos términos derivan de las formas exclamatorias ía, ${ }^{*} \theta \varrho \iota \alpha,{ }^{*} \delta \iota \vartheta v \varrho \alpha$, que se

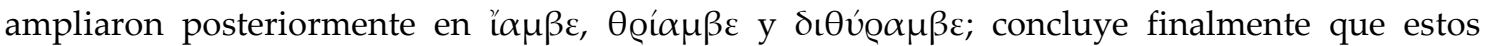
términos denotan diferentes tipos de cantos. West (1974, pág. 23) sostiene que estos vocablos están relacionados al culto de Dioniso y pueden referir tanto a una persona como a un tipo de composición determinada. Véase también Rotstein (2010, págs. 116-25).

12 Tanto $\delta v \theta v ́ \varrho \alpha \mu \beta o \varsigma$ como $\theta \varrho i ́ \alpha \mu \beta o \varsigma$ denotan un tipo de composición en honor a Dioniso y también aparecen como epítetos de esta divinidad. Por su parte, $\imath^{\imath} \theta v \mu \beta o \varsigma$ refiere un tipo de

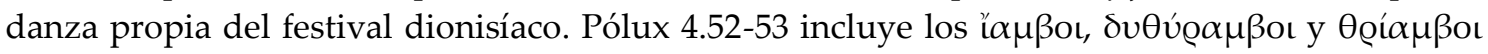




\subsection{LOS EPÓNIMOS YAMBE Y YAMBO}

Una de las explicaciones más comunes que nos llega desde la Antigüedad acerca del término ľ $\alpha \mu \beta$ os es de la derivación del epónimo 'I $\alpha ́ \mu \beta \eta .{ }^{13}$ El primer registro literario de la figura de Yambe la encontramos en el Himno Homérico a Deméter, compuesto con anterioridad a la segunda mitad del s. VI a. C., ${ }^{14}$ pero que transmite el $\alpha$ ítıov de un culto que podría remontarse hasta la Edad del Bronce. ${ }^{15}$ En los vv. 98-211 del citado himno se narra el arribo de Deméter a Eleusis tras haber abandonado el Olimpo y deambular alrededor de la tierra, irritada con los dioses al enterarse de que fue Hades quien, con el consentimiento de Zeus, raptó a su hija Perséfone. Profundamente dolorida por su pérdida, bajo el disfraz de anciana, Deméter se sienta al costado de un camino donde las hijas de Céleo y Metanira, soberanos de Eleusis, la encontraron. Ante las indagaciones de las jóvenes, la diosa les responde que su

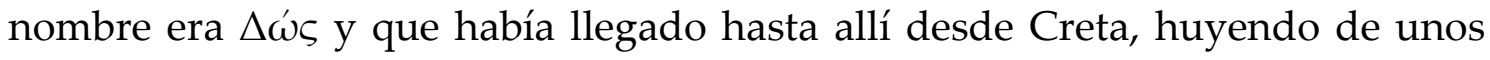
saqueadores que la habían esclavizado y pretendían venderla. Deméter es conducida al palacio real donde, sumida en una profunda aflicción, rechaza los ofrecimientos hospitalarios brindados por Metanira y sus hijas: no acepta sentarse, hablar, comer ni beber. ${ }^{16}$ Sin embargo Yambe, una de las sirvientas del rey Céleo, por medio de bromas y burlas obscenas ( $\chi \lambda \varepsilon$ vúnৎ... $\pi$ o $\lambda \lambda \dot{\alpha}$ $\pi \alpha \varrho \alpha \sigma \kappa \omega ́ \pi \tau o v \sigma \alpha$, vv. 202-3), ${ }^{17}$ incitó a la diosa a sonreír ( $\mu \varepsilon\llcorner\delta \tilde{\eta} \sigma \alpha \iota)$, luego a reír

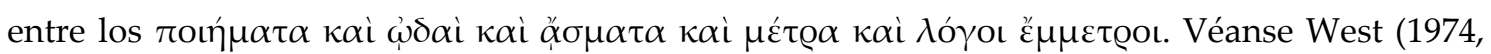
pág. 23); Bartol (1993, págs. 37-8); Brown (1997, págs. 13-42).

${ }^{13}$ Cf. West (1974, págs. 23-4); Brown (1997, págs. 16-24).

14 Para el tratamiento del Hymn. Hom. Dem., véanse particularmente Richarson (1974); Càssola (1994); Foley (1993). Para las implicaciones religiosas, véase Burkert (1983).

${ }^{15}$ Burkert (2007, pág. 13).

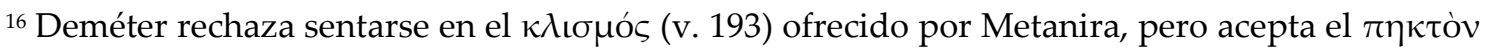
ह̌ठos (v. 196) que le dispone Yambe.

17 Cf. Brown (1997, pág. 20): “Commentators regularly undercut the remarkable nature of

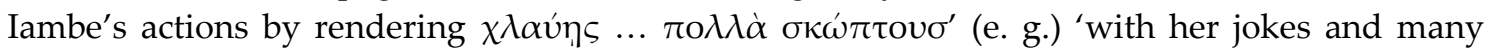
jests' (Athanassakis). Translations of this sort reflect the dignity of the epic treatment for the 
abiertamente $(\gamma \varepsilon \lambda \alpha ́ \alpha \sigma \mathrm{\iota})$ y finalmente tener un ánimo propicio (î̉ $\alpha$ ov $\sigma \chi \varepsilon \tilde{\imath} v$

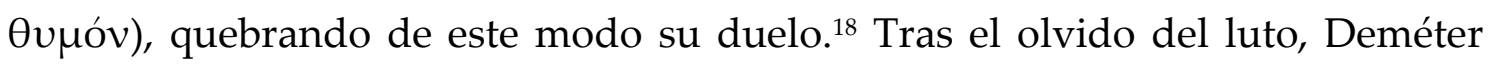
instruye la preparación del $\kappa v \kappa \varepsilon \omega ́ v$, una bebida hecha con harina de cebada, agua y poleo, y deja instituido el rito eleusino.

Otra versión del mito, muy similar aunque mucho más tardía, aparece en Ps. Apolodoro 1.5.1. En este pasaje, Yambe aparece como una anciana ( $\gamma \varrho \alpha i ̃ \alpha)$

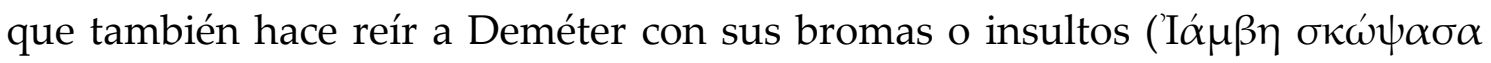

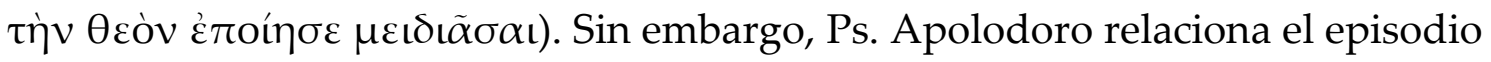
en el palacio de Céleo específicamente con las Tesmoforias, donde la $\alpha i َ \chi \varrho o \lambda o \gamma i ́ \alpha$ obscena y el insulto aparecen bien atestiguados. En relación a esta misma festividad según se desarrollaba en la isla de Sicilia, Diodoro Sículo (5.4.7) señala que durante los días de la celebración era la costumbre dirigirse

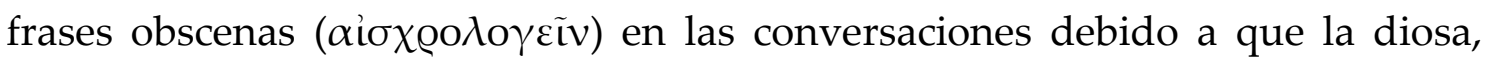
cuando estaba entristecida por el rapto de Core, se había puesto a reír gracias a este tipo de discurso ( $\alpha \grave{i} \sigma \chi \varrho o \lambda o \gamma \mathfrak{\alpha} \alpha v)$.

De ese modo, la escena entre la divinidad y la esclava fija el inicio de la

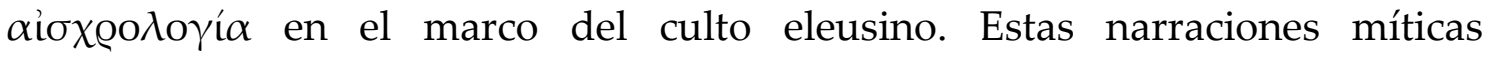
presentan un carácter claramente etiológico de las festividades que anualmente se realizaban en diversos lugares de Grecia en honor de la divinidad. ${ }^{19}$ Como

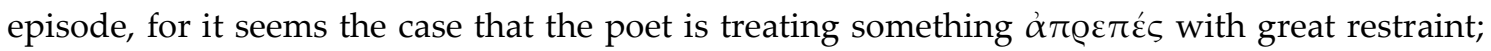
there is little place for obscenity in the language of epic (...) the words do not refer only to neutral jesting and jokes; they can be used of personal insult. Could this be the implication of the Hymn? If so, we are presented with a highly unusual turn of events: a goddess receiving insults without taking offence, a goddess who even appears to derive pleasure from this treatment."

${ }^{18}$ En el orfismo, el papel de Yambe lo desempeña Baubo, que hace reír a la diosa mostrándole sus genitales ; cf. Clemente de Alejandría, Protrept. 2.20.1-21.2 (=fr. 52 Kern); Arnobio, Adv. nat. 5.25-26; Eusebio, Praep. evang. 2.3.31-35. Para Baubo, véanse Scarpi (1976, pág. 151); Olender (1989, págs. 83-113). En Et.Gud ı 269.14 (= Et.M 463.24 K) transmite que las bromas de Yambe no fueron solamente verbales, sino que también empleó gestos obscenos $\sigma \chi \eta ́ \eta \alpha \tau \alpha \alpha \ddot{\chi} \varrho \eta \sigma \tau \alpha$.

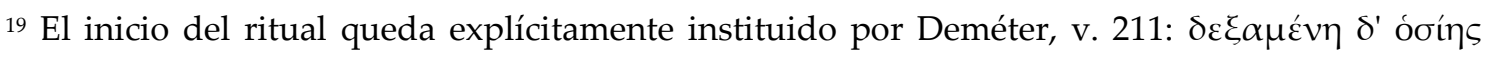

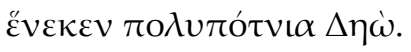


divinidad ctónica, Deméter está ligada a la agricultura, la fertilidad de las semillas, los alimentos que nacen de la tierra, la vegetación, y también a la fecundidad de los animales. Las distintas festividades en que se le ofrendaba las primicias de la tierra solían tener esquemas rituales bastante aproximados entre sí, identificados con los ciclos de la siembra, la cosecha, la trilla y la molienda, o con el transcurso de las estaciones en general. En ellas las bromas obscenas, la invectiva y la utilización de máscaras eran parte muy importante del rito, particularmente en relación con la ruptura del duelo, del silencio ritual y del ayuno. $^{20}$

Se ha postulado también otro epónimo para el vocablo "yambo", aunque en general se lo ha desestimado porque las fuentes que lo testimonian resultan muy posteriores a la manifestación literaria del género. Nos referimos al nombre del héroe 'I $\alpha \mu \beta$ os. En un pasaje acerca de los metros poéticos, el gramático bizantino Diomedes describe tres etimologías para el nombre

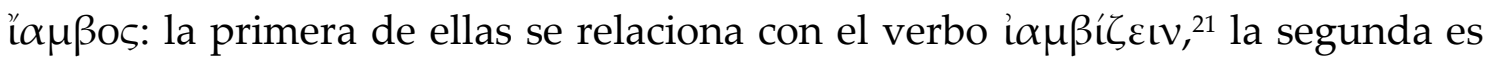
la que se vincula con el episodio de Deméter y la esclava en el palacio del rey Céleo, ya comentada en detalle, y la tercera, que solo se registra en este autor, emparenta el término con un mítico guerrero llamado Yambo:

alii a Marte ortum Iambum strenuum ducem tradunt, qui cum crebriter pugnas iniret et telum cum clamore torqueret, $\dot{\alpha} \pi$ ò $\tau o \tilde{v}$

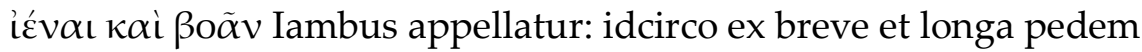
hunc esse compositum, quod hi qui iaculentur ex brevi accessu in extensum passum proferuntur, ut promptiore nisu telis iactum confirment. auctor huius rationis Arctinus Graecus his versibus perhibetur,

ó ’ $\mathrm{T} \alpha \mu \beta \mathrm{o} \propto \grave{\varepsilon} \xi$

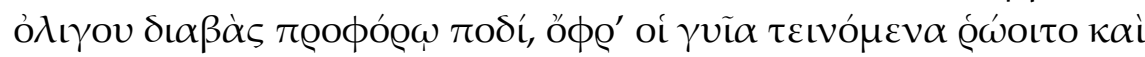

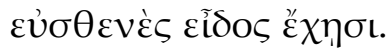

Diomedes, de poem. GL 1 p. 476.1.18-477.1. 20

\footnotetext{
${ }^{20}$ Cf. Richardson (1974, págs. 211-13); Parker (1991, págs. 1-17).

${ }^{21}$ Vid. inf. pág. 12.
} 
Otros cuentan acerca de un vigoroso jefe militar, descendiente de Marte, que con frecuencia iniciaba la batalla y arrojaba su lanza con un grito. Lo llamaron Yambo, de "ir (avanzar) y gritar". Por esto el pie está compuesto por una (sílaba) breve y una larga, porque aquellos que arrojan (la lanza) avanzan de un paso breve a uno largo, de tal modo que se impulsan con mayor fuerza al arrojar las lanzas. El griego Arctino es considerado el autor de este relato en los siguientes versos:

"Yambo separó de repente un pie hacia delante, para luego mover rápido las piernas tensas y obtener una disposición enérgica".

Esta explicación se refiere al yambo en tanto pie métrico, aunque también podría contener una alusión a la invectiva a través de la imagen de la lanza. Para argumentar esta explicación, Diomedes cita un pasaje de Arctino de Mileto (c. 744 a. C.), de quien se decía que había sido discípulo de Homero y había compuesto varios episodios del ciclo épico. Si realmente Arctino mencionó al héroe Yambo en alguno de sus poemas, no es posible conocer en qué contexto aparecía ni si realmente se lo relacionaba con el origen del metro yámbico, ya que apenas se han conservado algunos versos de su obra. ${ }^{22}$ La carencia de otros testimonios paralelos que relacionen al personaje de Yambo con el pie métrico da que pensar que este relato podría haber sido un aĺtıov retrospectivo, derivado de alguna lectura de los poemas de Arctino. ${ }^{23}$

\subsection{RitUALES DIONISÍACOS}

Como se ha observado anteriormente, lo más probable es que la poesía yámbica haya tenido sus orígenes en el activo ámbito religioso y popular de las

\footnotetext{
22 Cf. Bernabé (1979, pág. 92), que ubica estos versos como el fr. 7 de El Saco de Troya. Davies (1988, pág. 165) lo considera espurio. West (1974, pág. 23 n. 4) lo considera de procedencia helenística o posterior a causa de que presupone el yambo como pie métrico. Cf. Bartol (1993, pág. 37).

${ }^{23}$ Rotstein (2010, pág. 124) sugiere la posibilidad de una derivación de algún manual de métrica o de alguna otra fuente pedagógica de origen griego.
} 
festividades eleusinas y dionisíacas. Probablemente, un desprendimiento de estas manifestaciones rituales haya derivado hacia el s. VII a. C. en poemas con una especificidad literaria. En efecto, el yambo practicado por los poetas

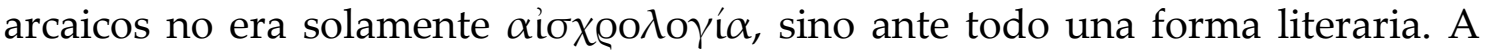
partir de la relación etimológica que la palabra mantiene con $\delta \_\theta u ́ \varrho \alpha \mu \beta o \varsigma$, Ө̣í $\alpha \mu \beta$ os e $\imath \Theta v \mu \beta o \varsigma$, todas vinculadas a cantos rituales del culto a Dioniso, se sugiere que el Ł̌ $\alpha \mu \beta$ o sea un desprendimiento de las plegarias o canciones religiosas, la parte más 'literaria' del ritual. ${ }^{24}$

En relación con esta hipótesis, es oportuno destacar un pasaje de Semo de Delos, citado por Ateneo, ${ }^{25}$ que refiere la ejecución por diferentes grupos de individuos de estas formas poéticas en espectáculos o ritos relacionados probablemente con Dioniso. ${ }^{26}$ En un primer momento, según Semo, los

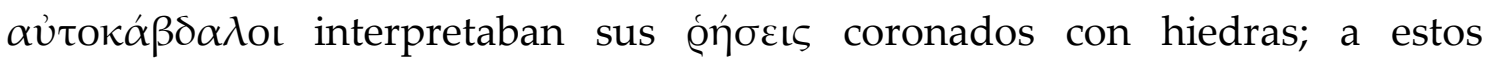

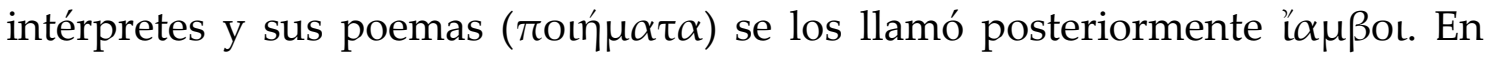
segundo lugar, Semo se refiere a los iӨú $\phi \alpha \lambda \lambda$ or, igualmente coronados, que llevaban máscaras e iban vestidos con un atuendo singular, con túnicas con una franja blanca en el medio, mangas cubiertas con flores y una leve capa

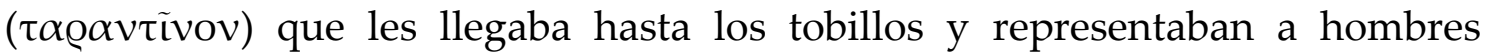

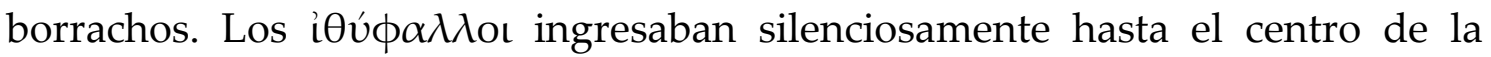
orquestra y se ubicaban de espaldas al auditorio, luego giraban y recitaban

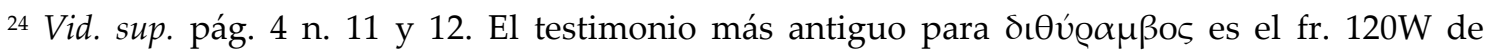

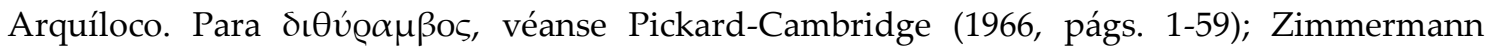
(1992). Para Ө0í $\alpha \mu \beta$ os, Versnel (1970, págs. 11-38).

${ }^{25}$ Ateneo 14.15-17 (=FGrHist 396 F 24).

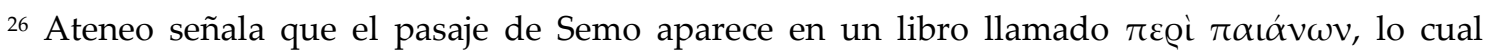

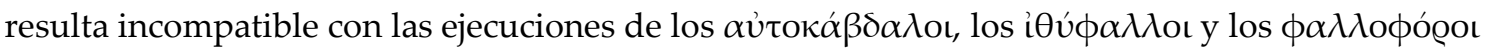
que describirá a continuación. La incompatibilidad surge de que el peán pertenece al culto de Apolo, y las vestimentas, las coronas de hiedras, los cantos y las formas de ejecución que se describen remiten claramente a Dioniso. Brown (1997, pág. 32) sostiene que posiblemente Semo discutía en ese pasaje el peán de Apolo en relación a su antítesis, los cantos en honor a Dioniso. West (1974, pág. 23) señala que las coronas de hiedras se relacionan con Dioniso y con el Ө̣í $\alpha \mu \beta$ os. Véanse también Bartol (1993, págs. 61-70) y Rotstein (2010, págs. 266-76). 


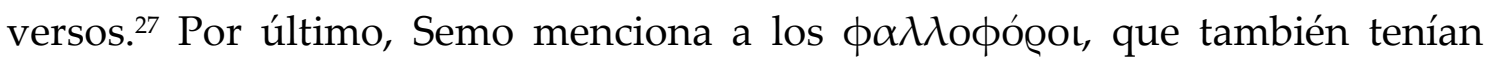
coronas de hiedra y violetas y una especie de velo, pero que no llevaban máscaras. Ellos ingresaban por la párodos del teatro marchando al compás de la música y entonando versos, ${ }^{28}$ luego se paraban delante del auditorio e insultaban a quienes ellos elegían.

Los tres tipos diferentes de intérpretes de poesía a los que se refiere Semo se asocian a Dioniso. Los $\alpha \hat{\tau} \tau o \kappa \alpha ́ \beta \beta \delta \alpha \lambda$ o, como su mismo nombre indica, remite a "improvisadores" de poemas que probablemente recitaban yambos; ${ }^{29}$ los

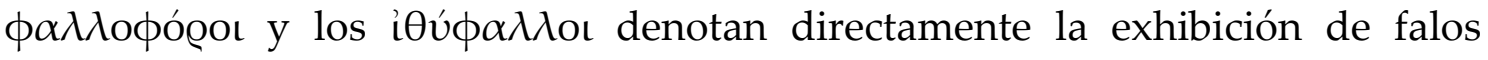
artificiales en sus ejecuciones poéticas.

También es oportuno mencionar un pasaje de Sosibio de Esparta (s. III a. C.), transmitido igualmente por Ateneo, ${ }^{30}$ que recuerda estos mismos tipos de espectáculos e intérpretes, pero en Lacedemonia. Sosibio señala que allí había una antigua tradición de entretenimientos cómicos $(\kappa \omega \mu \iota \kappa \tilde{\eta} \varsigma \pi \alpha \iota \delta \imath \tilde{\alpha} \varsigma)$ y que a

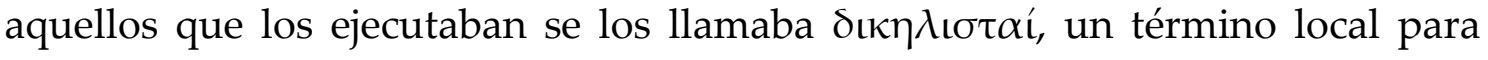

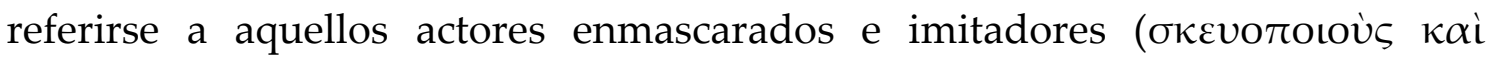
$\mu \iota \mu \eta \tau \alpha ́ \alpha)$. Agrega además que, en otras partes, por ejemplo, en Sición, se los conoce como $\phi \alpha \lambda \lambda$ oфógot, y en otros lugares como $\alpha u ̉ \tau o k \alpha ́ \alpha \delta \alpha \lambda$ ot, y los italianos los llaman $\phi \lambda u ́ \alpha \kappa \varepsilon \varsigma$, mientras que la mayoría los denominan

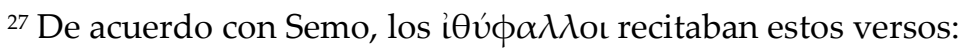

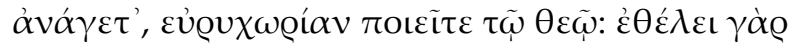

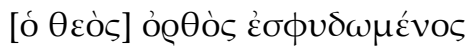

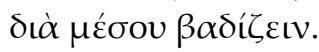

${ }^{28}$ Los $\phi \alpha \lambda \lambda$ oфó@oı recitaban estos versos:

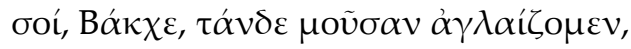

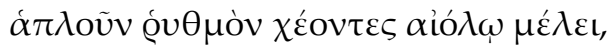

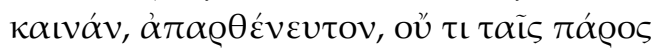

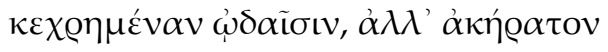

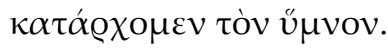

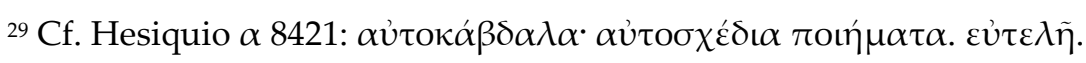

30 Ateneo 14.14-15 (=FGrH 595 F 10). 


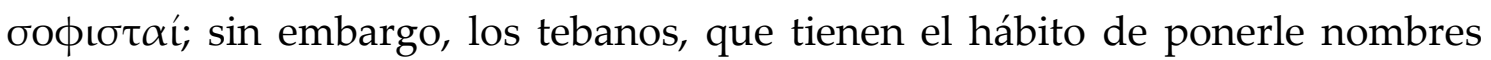
particulares a la mayoría de las cosas, los llaman $\varepsilon \dot{\theta} \varepsilon \lambda$ ov $\alpha \alpha i ́$.

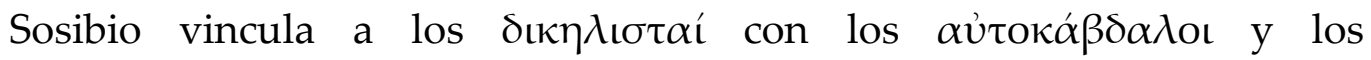
$\phi \alpha \lambda \lambda$ oфógol, aunque existe alguna diferencia en la forma en que los presenta

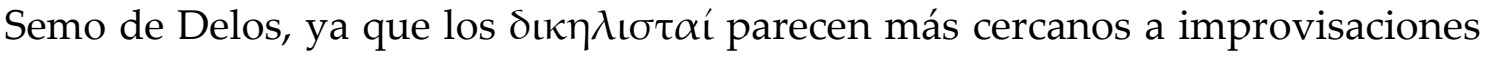
dramáticas. A raíz de sus cantos improvisados, por un lado, y de los falos, por otro, estos actores, bailarines e intérpretes de los rituales dionisíacos estarían relacionados con las improvisaciones de ditirambos y los cantos fálicos ( $\tau \dot{\alpha}$ $\phi \alpha \lambda \lambda \iota \kappa \alpha ́)$ de los cuales Aristóteles afirma que surgió la comedia y la tragedia, y que permanecían vigentes en su época. ${ }^{31}$

Posiblemente, como se ha afirmado, de alguno, varios o todos estos cantos rituales vinculados a Dioniso derivó una forma considerada ľ $\alpha \mu \beta o \beta_{\text {, que }}$ hacia el s. VII a. C. nuclea a los poemas específicamente literarios de los yambógrafos jonios.

\subsection{FORMA Y FUNCIÓN DEL YAMBO LITERARIO}

El término ľ $\alpha \mu \beta 0 \varsigma$, además, designa una forma métrica particular, independientemente de su contenido. La estructura de este pie se menciona explícitamente en Platón, Resp. 400.b.7, donde Sócrates utiliza la palabra ı̌ $\alpha \mu \beta$ os para referirse a un ritmo que consiste en una sílaba breve y una larga $(\cup-) .{ }^{32}$ También Heródoto (1.12.1) señala que Arquíloco mencionó a Giges ċv ía $\mu \beta \omega$ $\tau \varrho \mu \varepsilon ́ \tau \varrho \omega$, probablemente una referencia relacionada al fr. 19W, por lo que se podría sostener que el término remite a un determinado metro: los trímetros yámbicos. Sin embargo, ‘ $\alpha \mu \beta$ os también es empleado por otros autores en

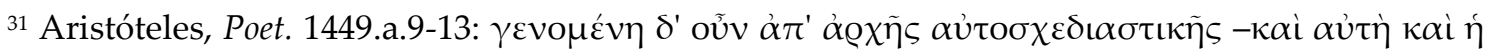

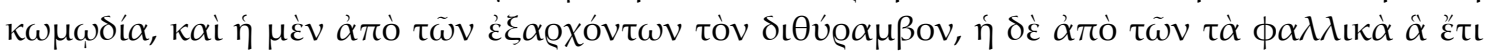

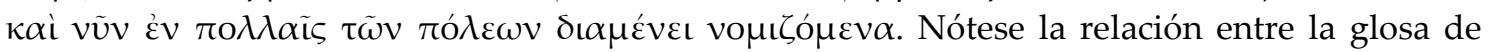

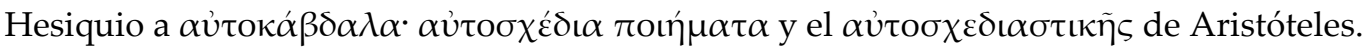

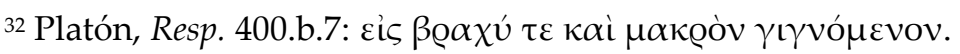


relación a composiciones de diversos metros. Por ejemplo, Aristóteles, Reth. 1418.b, utiliza $\dot{\varepsilon} \nu \tau \tilde{\omega}$ íd $\mu \beta \omega$ en referencia al fr. 19W de Arquíloco, pero también al fr. $122 \mathrm{~W}$, que está en tetrámetros trocaicos. Y Calímaco incluye dentro de su libro de Yambos composiciones epódicas, por lo cual podría deducirse que los epodos de Arquíloco e Hiponacte eran también considerados yambos en la Antigüedad. El fr. 126Dg de Hiponacte, que parodia en hexámetros la épica homérica, también podría haber sido concebido de esta forma. Ello nos lleva a señalar que el término ‘̌ $\alpha \mu \beta o \varsigma$ no se definía inmediatamente por un determinado patrón métrico o rítmico. Por el contrario, Aristóteles indica que el metro yámbico ( $\alpha \mu \beta \varepsilon \tilde{i} o v)$ adquirió ese nombre porque constituía el ritmo en que anteriormente se dirigían invectivas yámbicas ( $₫ \alpha \mu \beta \hat{\imath} \zeta \varepsilon \iota v)$ unos a otros. ${ }^{33} \mathrm{Si}$ Aristóteles tiene razón en su comentario, deberíamos considerar que el carácter yámbico de un poema no depende necesariamente del metro, y que el nombre

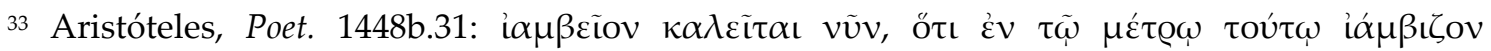
$\dot{\alpha} \lambda \lambda \eta \dot{\eta}$ ovs. Aunque no puede asegurarse que sea verídica, Ateneo (11.113) transmite una anécdota que concierne a Gorgias (DK 82 A 15a), en la que puede observarse que la invectiva

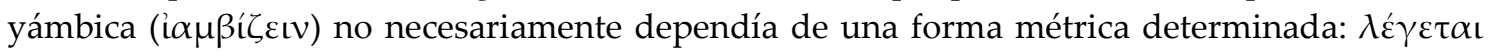

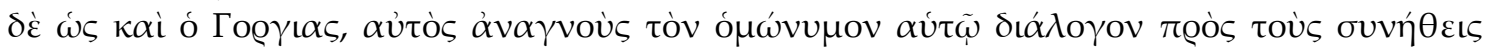

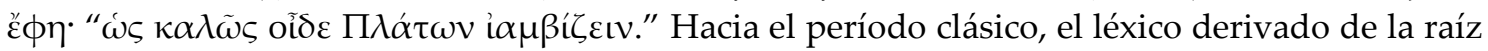
$i \alpha \mu \beta$ - podría enmarcarse principalmente en el campo semántico de estos tres términos: ‘ $\alpha \mu \beta$ o ,

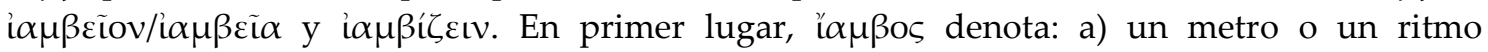
particular ligado a la función yámbica (Heródoto 1.12; Aristófanes, Ran. 661; Platón, Resp.400.b; Ion 534c; Aristóteles, Rhet. 1408.b.33, 1418.b.29); b) un poema ligado a la función yámbica (Platón, Leg. 935.e; Aristóteles, Pol. 1336.b.20); c) la ejecución de un poema ligado a la función yámbica (Aristóteles, Pol. 1336.b.12-23). En segundo lugar, i $\alpha \mu \beta \varepsilon$ ĩov/i $\alpha \mu \beta \varepsilon i \tilde{\alpha} \alpha$ denota el trímetro yámbico pero no necesariamente ligado a la función yámbica, como por ejemplo el empleo de este ritmo en el drama (Platón, Rep. 602.b; Aristóteles, Rhet. 1404.a.31, 1408.b.35, 1409.b.9, 1411.a.18; Poet. 1448.b.31, 1449.a.21, 1458.b.19, 1459.b.37; Aristófanes, Ran. 1133, 1204). Por último, el verbo $i \alpha \mu \beta i \zeta \varepsilon\llcorner v$, que no aparece atestiguado antes de Aristóteles, significa "realizar una invectiva contra alguien", independientemente de la forma métrica (Aristóteles, Poet. 1448.b.32; Ateneo 11.113). Véanse West (2005, págs. 22-3); Bartol (1993, págs. 30-41); Rotstein (2010, págs. 183-225). Brown (1997, pág. 16) señala que Aristóteles "appears to regard i $\alpha \mu \beta \varepsilon \tilde{\imath}$ ऽ and perhaps, by implication, $\iota \alpha \mu \beta o s$ as derivatives of $i \alpha \mu \beta i \zeta \omega$. As etymology this is most unlikely, since verbs in -í̧ $\omega$ are typically formed from nouns." Véase también Carey (2010, pág. 49): "In the classical period the term iambos is applied to compositions of different metrical form, which again suggests that as a designation of a type of composition it is not primarily metrical." 
del metro deriva de las composiciones de la yambografía arcaica y no de manera inversa. ${ }^{34}$

Por otro lado, también encontramos fuentes que han considerado el Ł $\alpha \mu \beta 0 \varsigma$, indistintamente su composición métrica, desde la perspectiva de las experiencias de vida del poeta y su entorno social. La mayoría de los pasajes en los que se formulan consideraciones de este tipo son tardíos y aparecen fuertemente influenciados por una tradición que interpretaba el contenido de los poemas de manera autobiográfica. ${ }^{35}$ Era frecuente que se tomaran las situaciones narradas en los yambos como reflejo de hechos reales en la vida de los yambógrafos, y se considerara que toda primera persona que aparecía en un poema debía ser atribuida al propio poeta y comprendida como una declaración testimonial acerca de su propia vida. Un reflejo claro de este tipo de lectura puede observarse en las críticas que realiza el sofista ateniense Critias (s. V a. C.) contra el yambógrafo Arquíloco. ${ }^{36}$ Como resultado de este tipo de interpretaciones, surgieron diferentes leyendas acerca de los poetas y sus motivos para componer yambos. Así pueden observarse, por ejemplo, lecturas de la obra de Arquíloco que terminan forzando la interpretación de los textos.

\footnotetext{
${ }^{34}$ Esta idea parecería confirmarse en Platón, Ion 524.e, donde los ľ $\alpha \mu \beta o t$ aparecen junto a otros tipos de formas poéticas: $\delta \iota \theta v ́ \varrho \alpha \mu \beta o \iota, \dot{\varepsilon} \gamma \kappa \omega \dot{\omega} \mu \alpha, \dot{v} \pi$

${ }_{35}$ Cf. Calímaco, fr. 191.1-4Pf; Dioscórides, Anth. Pal. 7.351; Melagro, Anth. Pal. 7.352; Luciano, Pseudol. 2; Ps. Acrón, Schol. Hor. Epod. 6.14; Schol. Hor. Epod. 6.13.

36 Eliano, Var. Hist. 10.13 (=Critias 88B 44DK). De acuerdo con Eliano, Critias decía que

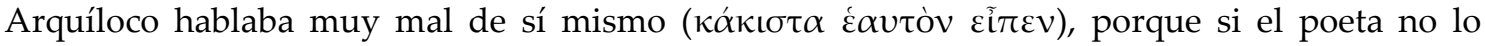
hubiera hecho público, nadie se habría enterado de que era hijo de la esclava Enipo ('Evıtroũs

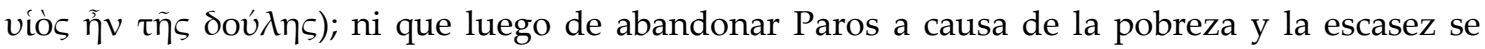

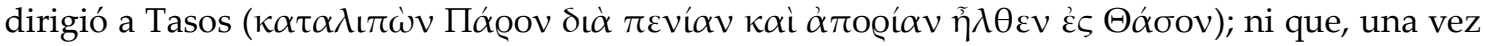

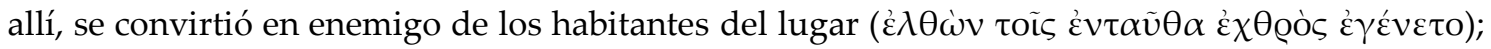

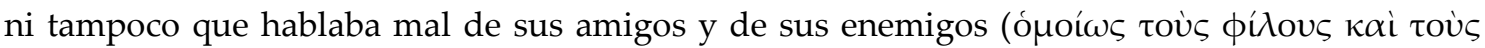

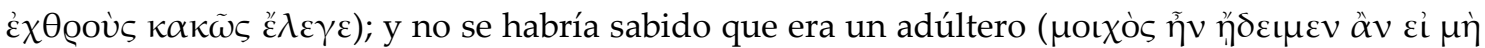

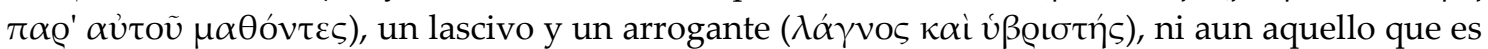

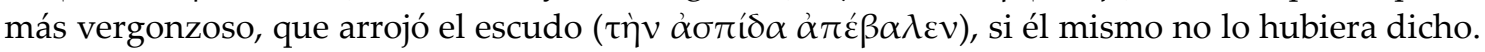
Estas acusaciones provienen de una lectura literal y autobiográfica hecha por Critias de los propios poemas de Arquíloco, ya que todo lo que enumera podría rastrearse en los fragmentos que se han conservado hasta hoy.
} 
Un ejemplo de esto constituye la lectura que ve en muchos de ellos la narración de episodios referidos a la supuesta ruptura del compromiso de casamiento entre el poeta y Neobule por parte de Licambes, el padre de la joven, y la posterior venganza del poeta a través de sus poemas que culmina, ni más ni menos, que con el suicidio de los licámbidas. ${ }^{37}$ Otro ejemplo, esta vez de Hiponacte, es el que interpreta de manera histórica la confrontación artística entre el poeta y los escultores Búpalo y Atenis, que culmina igualmente con el suicidio del primero, ignorando la posible existencia de otras versiones en que este último también le habría negado la mano de su hija al poeta yámbico. ${ }^{38}$ Se ve entonces que, a partir del s. V a. C., o tal vez con anterioridad, se había creado ya la imagen de la invectiva yámbica relacionada con los conflictos personales e individuales que estos poetas mantenían con sus enemigos. En cierta forma, los yambos habrían sido el instrumento de venganza personal de los yambógrafos. ${ }^{39}$ Sin embargo, como trataremos de demostrar en nuestro trabajo, en muchas ocasiones el 'yo' que se manifiesta en el poema no puede ser identificado con el propio poeta. ${ }^{40}$

${ }^{37}$ Cf. Schol. Hor. Ep. 6.13: Archilochum significat, qui Lycamben probrosis versibus usque eo insecatus est, ut ille mortem sibi conscisceret. hoc autem eo fecit, quod ille filiam suam in matrimonium promissam mox denegasset.

${ }^{38}$ Cf. Plinio, Nat. hist. 36.12 Mayhoff: Hipponacti notabilis foeditas vultus erat; quam ob rem imaginem eius lascivia iocosam hi proposuere ridentium circulis, quod Hipponax indignatus destrinxit amaritudinem carminum in tantum ut credatur aliquis ad loqueum eos compulisse: quod falsum est. compura enim in finitimis insulis simulacra postea fecere sicut in Delo, quibus subiecerunt carmen non vitibus tantum censeri Chion, sed et operibus Archemi filiorum. Ps. Acrón, Schol. Hor. Ep. 6.14 Keller: Hipponactem significat qui Bupali filiam nuptum petiit et pro dermitate contemptus est. Illud tamen verius volunt fuisse: Bupalum pictorem fuisse apud Laudiomenas, civitatem Asiae. Hic Hipponactem quendam poetam deformem pro risu pinxit; quo ille furore commotus tali eum carmine perculit ut se loqueo suspenderet. Unde nun similis carminis vim maledico minatur Horatius.

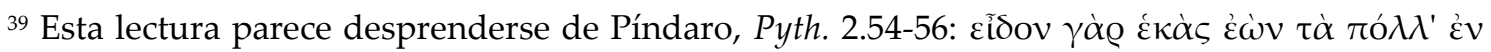

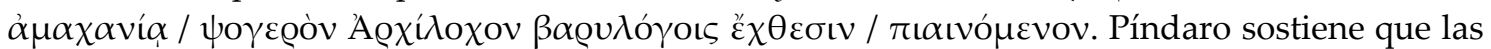
invectivas de Arquíloco provienen del odio y de la impotencia, lo que podría estar sugiriendo que sus poemas se originaron a partir de las confrontaciones personales del poeta.

${ }^{40}$ Esta línea de interpretación se hizo extensiva a la crítica moderna, véanse el relevamiento de la discusión y las posturas enfrentadas en Rösler (1985, págs. 131-44); Slings (1990). Para la 
Una mirada crítica contra la interpretación autobiográfica ha llevado a examinar el yambo desde la perspectiva de su función social en su contexto original. En este sentido, se ha buscado definir el ľ $\alpha \mu \beta$ os como un término que refiere un tipo particular de poemas compuestos para una "ocasión" determinada. ${ }^{41}$ En esta línea de lectura, es posible considerar el concepto de ocasión en relación a los orígenes rituales del yambo literario, con sus raíces fuertemente ligadas a conmemoraciones religiosas y festivas que incluían a toda la comunidad, y también a circunstancias más restringidas como las del simposio o festividades privadas. Las composiciones yámbicas de los poetas jonios tenían como ocasión casi exclusiva el contexto del simposio masculino. ${ }^{42}$

En esa dirección, especialmente interesantes han resultado las consideraciones de West (1974), quien sostiene la posibilidad de que el yambo de Arquíloco e Hiponacte haya conservado ciertos patrones de las festividades y los espectáculos rituales. Concretamente, postula que muy probablemente algunos de los nombres que aparecen en estas composiciones, no todos, podrían referir a personajes estereotipados ("stock characters") dentro de una suerte de entretenimiento tradicional, y no a personas reales como se ha venido considerando. ${ }^{43}$ En su argumentación, West señala en particular un ejemplo de

misma discusión y una crítica de la interpretación autobiográfica de los poetas arcaicos, véanse Tsagarakis (1977); Nagy (1976, págs. 191-205; 1999); los diferentes trabajos de Lefkowitz (1976, págs. 181-9; 1978, págs. 459-69; 1991; 2012, págs. 30-7); y también Kivilo (2010, págs. 87-133).

${ }^{41}$ Dover (1964, pág. 189): "This survey of terminology offers no grounds for doubting the conclusión which I drew from the community of ethos between the elegiacs and $i \alpha \mu \beta o$ of Archilochos: no grounds for believing that he regarded them as different genres. It also leaves open the possibility that he used the Word $i \alpha \mu \beta$ o with reference to all the forms of poem which he composed, their common characteristic being not their metre or language but the type of occasion for which they were composed - their 'social context', in fact."

${ }^{42}$ Pellizer (1990, pág. 180) sostiene: "almost all elegiac and iambic poetry from Archilochus onwards, as well as a substantial part of the enkomia, finds its natural focus in the symposion of the hetaireia or the symposion of tyrants." Para el simposio en general véanse Murray (1990); Slater (1991); Gerber (1997, págs. 4-6, 92-4).

${ }^{43}$ La hipótesis de West se restringe a los yambos de Arquíloco, ya que él mismo señala que los

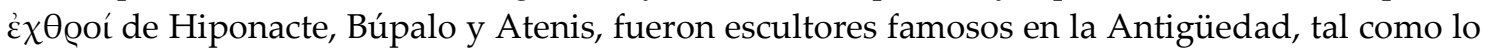


lo que para él podría habr sido un aĺtıov retrospectivo de una suerte de espectáculo similar ocurrido en la isla de Naxos. ${ }^{44}$ Sin embargo, más allá del relato transmitido por West, no hay ningún otro testimonio que permita sostener que esta historia constituya la etiología de algún tipo de espectáculo o entretenimiento tradicional, mucho menos de un conjunto de personajes dentro de un corpus poético como lo postula para Arquíloco.

Conforme a ese mismo trasfondo ritual, tal vez sea más oportuno pensar que la función del yambo literario de los compositores jonios podría haber mantenido algunas características relacionadas directamente con la

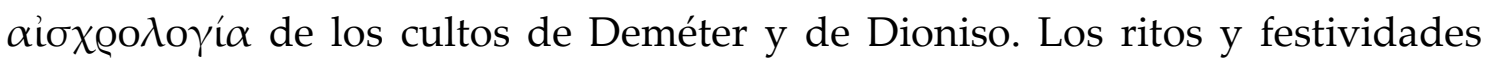
que hemos comentado en apartados anteriores implican ciertamente la

señalaran Plinio, Nat. hist. 36.12-13; Pausanias, 4.30.6, 9.35.6; Schol. Arist. Av. 573; (vid. inf. pág. 227 n. 81). Partiendo de la relación etimológica entre el nombre $\Lambda v \kappa \alpha ́ \alpha \beta \eta \varsigma$ y los términos

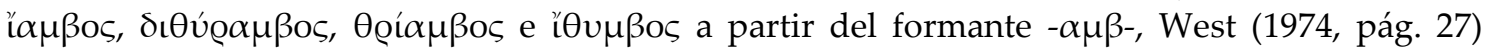
sostiene: "The possibility I am suggesting is that Lycambes and his libidinous daughters were not living contemporaries of Archilochus but stock characters in a traditional entertainment with some (perhaps forgotten) ritual basis. It may be objected immediately that Archilochus could not stand before the public and pretend to have been involved in a marriage arrangement with a fictitious family. But here we must heed Dover's warning (op. cit. pp. 206 ff.) that in an Archilochian iambus the poet is not necessarily speaking in his own person. There is room for 'the assumed personality and the imaginary situation'." En contra de esta hipótesis véanse Carey (1986, págs. 60-7); Bartol (1993, págs. 72-3).

${ }^{44} \mathrm{Su}$ ejemplo proviene de un pasaje de Aristóteles (fr. 558), transmitido por Ateneo 8.40, que cuenta la historia de cómo el tirano Lígdamis se alzó con el poder de Naxos en el s. VI a. C. Se dice que en Lestada, pequeño pueblo de Naxos, vivía un hombre rico y respetado llamado Telestágoras, muy estimado por los habitantes de la zona que solían enviarle presentes cotidianamente. Cuando llegaba un habitante de la ciudad y regateaba demasiado el precio de algún producto en el mercado, el vendedor decía: "Prefiero dárselo a Telestágoras." Un día unos jóvenes recién llegados quisieron comprar pescado y hartos de escuchar ese dicho, se emborracharon y realizaron un $\kappa \tilde{\omega} \mu \mathrm{s}$ hasta la casa de Telestágoras. El hombre los recibió cordialmente, pero ellos comenzaron a insultarlo a él y a sus dos hijas en edad de contraer matrimonio. Los habitantes del lugar, indignados, atacaron a los jóvenes y se produjo una revuelta generalizada. Lígdamis, que había tomado el mando en esta sedición, terminó como tirano de Naxos. West considera que las invectivas contra Telestágoras y sus dos hijas podría haber sido aĺtıov retrospectivo de entretenimientos tradicionales festejados en Naxos, semejantes a los que se realizarían en Paros con Licambes y sus hijas como protagonistas. Asocia además el nombre Telestágoras con el de Telesicles, padre de Arquíloco, a partir de los

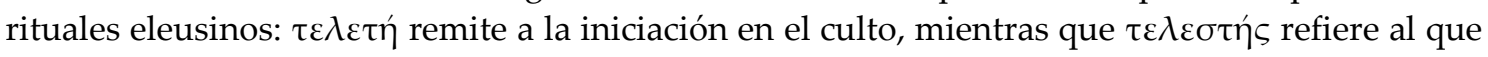
es iniciado en los misterios. 


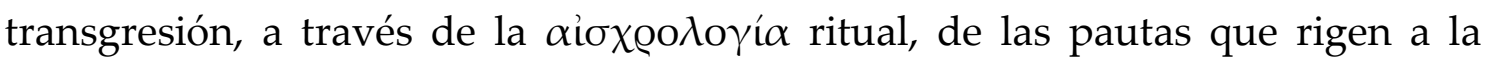
comunidad. Esta trasgresión, sin embargo, no conlleva la disolución del orden comunitario, sino que, por el contrario, refuerza su reafirmación cíclica. ${ }^{45}$ En el mito, por ejemplo, el luto de Deméter por la pérdida de su hija provoca la agonía de la tierra, el cese de toda forma de vegetación y de reproducción animal, lo cual se yergue como una amenaza para la vida humana. ${ }^{46}$ Mientras Perséfone permanece desaparecida y Deméter de luto, se produce una alteración del orden. La tierra se vuelve estéril, nada germina ni crece, y los bueyes tiran inútilmente del arado. La infertilidad se extiende a toda la raza humana y el temor alcanza a los dioses que podrían verse privados de las honras y sacrificios. Será necesaria la intervención de Zeus para que el ánimo de la diosa se aplaque y se instaure un nuevo orden. ${ }^{47}$

Una inversión similar puede observarse en la enajenación orgíastica

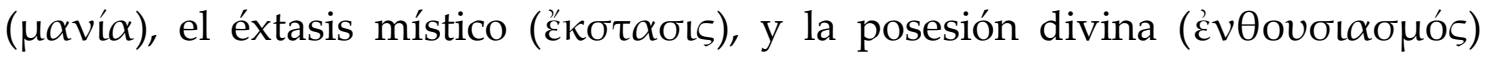
ligados a los ritos dionisíacos celebrados en diferentes regiones de Grecia. ${ }^{48} \mathrm{El}$

${ }^{45}$ Véase el desarrollo acerca de las funciones sociales del culto en Burkert (2007, págs. 329-34).

${ }^{46}$ A causa de la aflicción y del rencor por la complicidad de los dioses en la desaparición de su hija, Deméter provoca la agonía de la tierra. Zeus debe intervenir ante Hades para que Perséfone retorne y envía a Hermes para que la traiga a la superficie, sin embargo su regreso ya no vuelve a instaurar el antiguo orden. Al haber probado la granada en el inframundo queda vinculada a los muertos y debe pasar allí un tercio de cada año. Pero, anualmente, transcurrido ese ciclo, vuelve a la superficie. Cf. Richardson (1974, págs. 84, 156, 276). Para los misterios eleusinos véase particularmente Burkert (1983, págs. 248-97).

${ }^{47}$ Hymn. Hom. Dem. 305-12. Véase Burkert (2007, págs. 216-17).

${ }^{48}$ Bruit Zaidman \& Schmitt Pantel (1992, págs. 198-207). Todas las festividades dionisíacas se caracterizan por un período de tiempo de embriaguez y disipación, pero además cada una está signada por un elemento lúgubre que involucra la enajenación y la muerte que aparecen en los relatos míticos. Las Antesterias y las Leneas, en el ámbito jonio-ático, están particularmente asociadas al consumo de vino, pero el carácter festivo de estas celebraciones se ensombrece en el último día por la conmemoración del asesinato de Icario, a quien Dioniso enseñó a cultivar la vid y a hacer el vino, y el suicidio de su hija Erígone tras conocer la muerte de su padre. Las Agrionias, en el área dórica y eólica, involucran el trance femenino y la representación de la $\omega \mu$ $\phi \alpha \gamma \dot{\alpha} \alpha$. Las Dionisias agrarias se caracterizan por los sacrificios de cabras y procesiones fálicas, y en las Katagogia o Grandes Dionisias, que es la introducción de las Dionisias agrarias en el ámbito urbano de Atenas hacia el s. VI a. C., también se manifiesta este tipo de inversión 
séquito del dios está compuesto de ménades femeninas y de sátiros o silenos con rasgos animales y humanos. En la iconografía de los vasos del s. VI a. C., las ménades, vestidas por lo general con una piel de ciervo sobre los hombros, bailan en trance, con la cabeza inclinada hacia abajo o echada hacia atrás. Por su parte, el aspecto de los sátiros debe entenderse como una forma de enmascaramiento: una máscara con la nariz chata, barba y orejas de animal, oculta la identidad de quien la lleva, un falo erecto hecho con piel de animal sobresale de la ropa a la altura de la pelvis y una cola de caballo acentúa la fisonomía animal. ${ }^{49}$ Los sátiros acosan sexualmente a las ménades que aparecen en constante huida del acecho y la persecución. Estos seres híbridos parecen representar la naturaleza animal del hombre, su imagen se asemeja a la de un humano, pero los rasgos animales ponen en evidencia la inclinación instintiva al sexo. ${ }^{50}$ Seguramente, en el contexto de la festividad, la máscara del sátiro además de ocultar una identidad individual serviría también para poner de manifiesto los instintos animales que debían permanecer silenciados. Solo durante el intervalo ritual y bajo el estado de embriaguez podría haber sido aceptada la liberación de este comportamiento que atenta contra el orden social que prevalece durante todo el resto del año. En cierta forma, los rituales dionisíacos, por medio de la enajenación mística y de la embriaguez del vino,

del orden. Para las Antesterias véase particularmente Burkert (1983, págs. 213-47); para el resto de las festividades dionisíacas Burkert (1983, págs. 168-212).

${ }^{49}$ Para un estudio de la iconografía específicamente de Dioniso y de su séquito en la Grecia arcaica, véase Isler-Kerényi (2007).

50 Bremmer (1994, pág. 19): "Similar ambiguities came to the fore among the satyrs and maenads, his mythical followers. Satyric drama vases often show us the happy side of the Dionysiac world through the satyrs: buffoonery, drinking, and all kinds of sexual activities. Yet some of the latter, such as masturbating and coupling with animals, were definitely not socially acceptable, although the god himself was also sometimes associated with the mule, a very randy animal. And tragedy showed his female followers, the maenads, both resting in serene peace and committing the most gruesome murders in their ectasy, as Euripides' Bacchae so well illustrates." 
ponen en cuestionamiento el orden establecido. ${ }^{51}$ Sin embargo, la suspensión de las pautas sociales no perdura más allá del período de festividad. En Il. 6.130-40 se narra que Licurgo, rey de los edones en Tracia, persiguió a Dioniso y a sus nodrizas, las ménadas, por las llanuras de Nisa. Las mujeres fueron asesinadas por los golpes de Licurgo, y Dioniso, atemorizado, se sumergió en el mar y se refugió al amparo de Tetis. ${ }^{52}$ Es posible que este episodio se haya constituido en un $\alpha$ ítıov para la persecución de las mujeres y la búsqueda del desaparecido Dioniso durante las Agrionias en Orcómeno. Según Plutarco, el sacerdote encargado de estas festividades perseguía a las ménades, en este caso con una espada. ${ }^{53}$ De este modo, cada año Dioniso es expulsado y el orden social volvía a restablecerse, pero tras un período de ausencia surgirá nuevamente de las aguas excitando nuevamente la $\mu \alpha v i ́ \alpha .{ }^{54}$ Por otro lado, distintos relatos míticos transmiten el destino que le espera a quien rechace el culto. ${ }^{55}$ Es posible

${ }^{51}$ Bremmer (1994, pág. 19): “although his festivals abounded with merry-making, they also displayed characteristics of a break-up of the social order, such as the split of society into its two gender halves during the widespread Agrionia; the equality of slaves during the Anthesteria, or the prominence of the phallus during the Dionysia. At times, this "anti-order" aspect could make them unpleasantly ambiguous: on Chios armed forces occupied the streets leading to the agora, where, presumably, the sacrifice for Dionysus took place during the Dionysia."

${ }^{52}$ Cf. Schol. Hom. Il. 23.92 (=Estesícoro, fr. 234 Campbell). Para el mito de Dioniso y Licurgo con interpretaciones en relación al rito, véase Seaford (2006, págs. 27, 44-7, 91).

53 Plutarco, Quaest. Gr. 299.e-f; Quaest. conv. 717.a. Véase Burkert (1983, págs. 176-9) quien, a diferencia de las interpretaciones tradicionales, considera que Licurgo "actually occupies the position of the priest of Dionysus. Thus, it is not an historical conflict that is attested here, but the polar tension between divine madness and human order as acted out in a single ritual."

${ }^{54}$ En el Hym. Hom. Dion. 7 la divinidad aparece en la orilla del mar bajo la forma de un niño. A partir del s. VI a. C. se tienen registros de que la llegada del dios se celebraba con una peregrinación naval, la nave era llevada a cuestas por hombres o iba sobre ruedas durante la proscesión. También Filostrato, Vit. soph. 1.25.1. Véanse Burkert (1983, pág. 223; 2007, pág. 224),.

${ }^{55}$ Las hijas del rey Minias, Leucipe, Arsipe y Alcítoe, evitaron participar de los ritos dionisíacos, porque estaban dedicadas a trabajar en sus telares para Atenea. Dioniso enfurecido hizo crecer vides que se enroscaron en los telares, las serpientes anidaron en sus cestos y del techo comenzó a gotear vino y leche. Luego de echar suertes y tocarle a Leucipe, que había prometido entregar una víctima al dios, descuartizó a su propio hijo, Hípaso. Tras lo cual, las tres se fueron al monte convertidas en ménades. Cf. Eliano, Var. Hist. 3.42; Antonino Liberal 10.3; Eurípides, Bacch. 118. Este relato se remonta a Corina y Nicandro. También el rey Penteo, como lo presenta Eurípides, intenta suprimir el culto de Dioniso en Tebas. Pero el dios induce al rey a que vaya a espiar las 
considerar, por lo tanto, que los rituales dionisíacos ponen de manifiesto la tensión social que se produce en una secuencia de orden, subversión y restauración del orden. ${ }^{56}$ Esta suerte de inversión reafirma y fortalece las estructuras comunitarias y su relación con el mundo natural y los instintos animales.

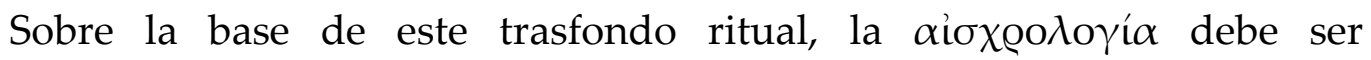
comprendida como un elemento constitutivo de esta subversión del orden social en el contexto de las ocasiones religiosas. ${ }^{57}$ En el yambo literario la

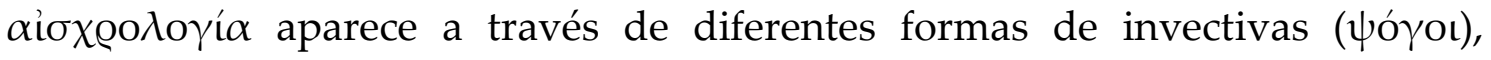

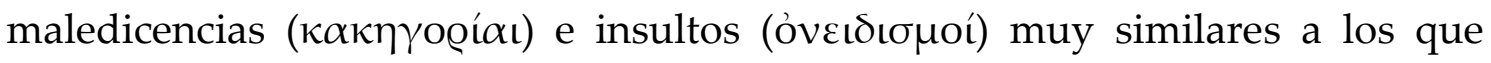
podrían haber sido los “insultos desde el puente" ( $\gamma \varepsilon \phi \cup \varrho ı \mu o ́ s)$ en el ritual eleusino; también aparecen burlas $(\chi \lambda \varepsilon \tilde{v} \alpha \iota)$ y bromas $(\sigma \kappa \omega \dot{\mu} \mu \mu \alpha \tau \alpha)$ que, por lo general, conllevan rasgos de obscenidad semejantes a aquellas con las que Yambe hizo reír a Deméter. La festividad del simposio y el consumo de vino pertenecen al ámbito de Dioniso, que en los yambos no solo se constituye como

celebraciones de las ménades. Disfrazado con el atuendo de la divinidad y con un vestido largo, es descubierto por las ménades, entre las que se encuentran su propia madre y sus dos hermanas, y lo sacrifican descuartizándolo con las manos. Véase Burkert (1983, págs. 195-97).

${ }^{56}$ Bremmer (1994, pág. 20): “Dionysus' divine relationship also display this tension between order and 'anti-order'. He was sometimes, understandably, connected with Aphrodite: in antiquity, too, wine and love went together. He was also connected with Artemis and it fits in with her marking of the boundaries of normality that she more than once supervised the restoration of order after Dionysiac disorder, as when she cured the madness of Proitos' daughters. It is rather surprising that he was even associated with Apollo, most clearly in Delphi where Dionysus 'ruled' three months in the winter and Apollo the rest of the year. Yet this relationship perhaps sums up best Dionysus' position in Greek society: society cannot live without a temporary relaxation of the social order, but order has to be restored."

${ }^{57}$ Brown (1997, pág. 41): “ $\alpha \grave{i} \chi \chi \varrho o \lambda o \gamma i ́ \alpha$ seems possible only when the normal rules of human intercourse are relaxed or suspended. In many cults, however, inversion provides more than licence for unusual behaviour; it stands as a symbolic event, representing the breakdown of society or the world as people know it." Bremmer (1994, pág. 21): "the great gods who went on foot, Demeter and Dionysus, are those with festivals in which the normal social order was temporarily dissolved, be it by the dominance of women or the prominence of wine and the phallus. (...) Evidently, a divinity's relationship to the social order was an important consideration for the Greeks in the (conscious or unconscious) construction of their pantheon." 
el contexto de ejecución sino también como motivo poético al que se hace referencia constantemente.

La función comunitaria del yambo literario, por lo tanto, podría aparecer en consonancia con el amplio contexto religioso del que se desprende. En Arquíloco e Hiponacte se manifiestan los distintos elementos que constituyen la $\alpha i \sigma \chi \varrho o \lambda o \gamma i ́ \alpha$ ritual a través de un registro lingüístico totalmente explícito. ${ }^{58} \mathrm{En}$ el yambo, a diferencia del resto de la poesía arcaica, la invectiva personal surge de manera directa, sin estilizaciones ni eufemismos, como puede evidenciarse

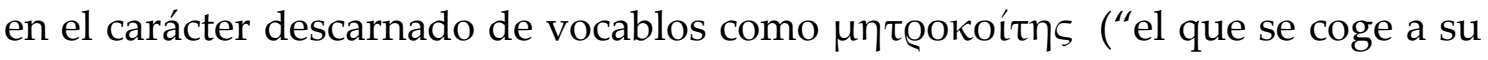
madre") con el que Hiponacte se dirige a Búpalo. ${ }^{59}$ Lo sexual aparece también de manera explícita: se mencionan los órganos genitales con términos vulgares empleados en el habla cotidiana y se describen situaciones abiertamente sexuales, que en otras formas poéticas solo son aludidas. Un ejemplo representativo de esto último lo constituye el fr. 42W de Arquíloco y el 24Dg de Hiponacte, en los que se describen de manera gráfica el acto sexual de la felación. ${ }^{60}$ También se pueden encontrar escenas con descripciones detalladamente escatológicas, como en el fr. 95Dg de Hiponacte, que narra las torturas físicas que sufre el narrador y sus consecuencias al ser intervenido en una sesión ritual para curar la impotencia. ${ }^{61}$ El fr. $120 \mathrm{~W}$ de Arquíloco nos presenta además una relación directa entre el ditirambo y la embriaguez del vino. ${ }^{62}$

\footnotetext{
${ }^{58}$ West (1974, pág. 25): "I suggest that we may recognize iambus most confidently in those types of subject matter for which elegiacs are never used: that is, in explicitly sexual poems, in invective which goes beyond the witty banter we found in elegy, and in certain other sorts of vulgarity. These, are, of course, the very elements that are especially associated with the iambic name."

${ }^{59}$ Hiponacte, fr. 20Dg; vid. inf. pág. 229 n. 86.

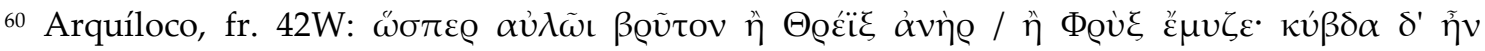

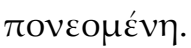

${ }^{61}$ Vid. inf. pág. 275.

${ }^{62}$ Vid. inf. pág. 69.
} 
La poesía yámbica de la Grecia arcaica, dentro del contexto también ritualizado del simposio, podría haber funcionado ella misma como una forma de inversión o suspensión momentánea del orden para purificar y reafirmar los

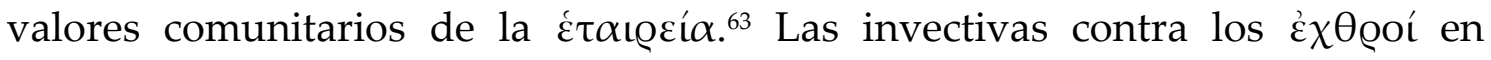
Arquíloco e Hiponacte y las múltiples escenas relativas al $\phi \alpha \varrho \mu \alpha \kappa o ́ s ~(" c h i v o$ expiatorio") podrían apuntar a esta dirección. ${ }^{64}$ En el período helenístico, aunque el estilo y la forma se han adaptado a un ámbito cultural más sofisticado; el yambo no constituye la recuperación de una pieza antigua a los efectos de su exhibición en el museo alejandrino. Por el contrario, la actualización que del género hace Calímaco parece estar motivada precisamente por ser la forma más adecuada para suspender transitoriamente el orden

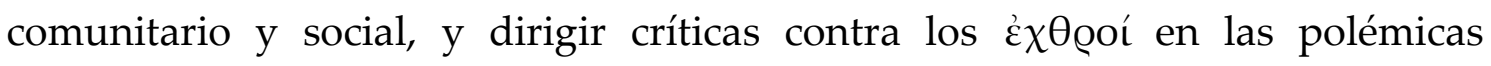
intelectuales de la Alejandría ptolemaica. El hecho de que su libro de Yambos no

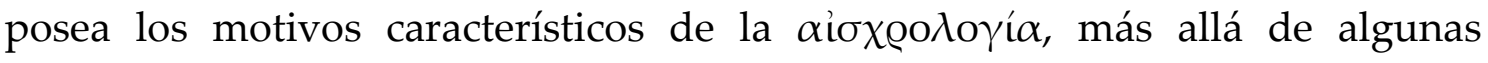
bromas e invectivas estereotipadas, parece sustentar la hipótesis de que la recuperación de esta forma poética se centra particularmente en su función polémica.

\section{PeRspectivas teóricas y MetOdológicas}

\subsection{ESTADO DE LA CUESTIÓN}

Dentro del marco de los estudios contemporáneos sobre la poesía griega antigua, dos corrientes críticas han adquirido relevancia interpretativa acerca de la naturaleza y la funcionalidad del 'yo' en las composiciones líricas. La primera entiende los textos como expresión personal del propio poeta. Desde esta

\footnotetext{
${ }^{63}$ La comedia probablemente cumplió la misma función en una escala mucho más amplia.

${ }^{64}$ Brown (1997, pág. 42): “The iambist is a protector of his community and by means of ľ $\alpha \mu \beta$ os repels any who threaten the stability of his world."
} 
perspectiva, el campo referencial que entra en juego en un poema remite siempre a la experiencia vivida por el poeta o a su reflexión íntima. Es necesario destacar, también, que esta concepción, al considerar la obra literaria y la experiencia vital del autor como unidad de sentido, postula una exégesis crítica tendiente a develar la poética a través de la biografía. La segunda corriente concibe el 'yo' como una construcción estereotipada o ficcional. De este modo, aquella primera persona, propia de la lírica, funcionaría como un artilugio poético convencional.

Bossi (1990, pág. 45) señala que para un relevamiento de esta polémica deberíamos retrotraernos hasta la primera mitad de s. XIX, más precisamente a los estudios sobre Arquíloco de Welcker (1844, págs. 1-7) y Müller (1875, págs. 215-48) que, si bien no descartaban la relación entre el contenido poético y la propia vida del poeta, sostenían que el yambo debía ser interpretado como elemento risible o jocoso ( $\gamma \varepsilon \lambda$ oĩov) dentro del marco festivo del ritual eleusino, poniendo reparos a los reduccionismos biográficos. A pesar de la modernidad de esta perspectiva, su incidencia en el ámbito académico no cobró relevancia sino hasta la segunda mitad de siglo XX.

En 1953 Snell (págs. 43-70) afirmaba que, en Grecia, los géneros poéticos habían florecido en sucesión cronológica, épica-lírica-drama, determinados por procesos históricos específicos. En esa dirección, entendeía el surgimiento de la lírica como el de un nuevo espíritu histórico contrapuesto al de la épica. La diferencia más importante entre los dos géneros era, para este autor, la emergencia de los poetas líricos como individuos que hablaban sobre ellos mismos, junto con las referencias al hic et nunc que otorgaban al presente inmediato un carácter ampliamente significativo. En ese sentido, proponía el concepto de "personal lyric" para "descubrir" el modo en que los poetas se pensaron como personalidades distintivas, los motivos por los cuales ellos hablaron de sí mismos, y los procesos que posibilitaron la conciencia de la 
propia individualidad. A partir de un análisis autobiográfico de los fragmentos líricos, el crítico alemán destacó la trascendencia del poeta que en primera persona manifestaba sus sentimientos y experiencias privadas, y lo enfrentó al aedo homérico, portavoz de la verdad inspirada por la Musa. Su estudio llega a la conclusión de que el "yo" de la lírica griega arcaica representa el nacimiento de la conciencia individual y del conocimiento de la propia individualidad en la poética occidental.

Una década más tarde, Dover, en su exposición sobre Arquíloco, recopilada en Entretiens sur l'Antiquité Classique (1964, págs. 183-212), manifestaba su escepticismo acerca de la deducción autobiográfica del 'yo' en la lírica griega arcaica. En primer lugar, sostenía que las composiciones de Arquíloco y de sus contemporáneos debían ser situadas en la etapa de transición entre la cultura preliteraria y la cultura literaria. Propuso entonces abordar la cuestión desde un análisis antropológico, utilizando como evidencia canciones provenientes de culturas prealfabéticas modernas, como las de Nueva Guinea, Hawai, las Islas Salomón y las comunidades del Sur de África. A partir de estas comparaciones, estableció un conjunto de características preliterarias compartidas entre las composiciones de estos pueblos y las de Arquíloco, Anacreonte y Alceo. Ellas son: a) se trata de canciones breves que expresan sentimientos; b) los sentimientos que una canción expresa no son necesariamente los de su compositor: este puede adoptar otra personalidad, individual o genérica; c) los hechos o situaciones que motivan los sentimientos expresados no son necesariamente reales; d) las canciones son compuestas en pequeñas comunidades, en las cuales cada uno conoce los asuntos de los demás. De estas evidencias, Dover dedujo que en ningún caso se puede afirmar una correspondencia inmediata entre lo expresado en un poema, la primera persona singular que lo expresa y la propia vida del poeta, ni siquiera se puede asegurar que los hechos que se narran hayan sucedido realmente. Por otro lado, 
trae como argumento para su hipótesis un pasaje de Retórica (1418.b.23-33) en el cual Aristóteles sostiene que, cuando una persona quiere acusar o injuriar a alguien, es necesario poner las palabras en boca de otro, para lo cual cita precisamente dos pasajes de Arquíloco. En el primero, según Aristóteles, el poeta hace hablar a un padre acerca de su hija (fr. 122W); en el segundo, al carpintero Carón (fr. 19W). ${ }^{65}$ Paralelamente, en su desarrollo argumentativo, Dover trae a cuento un fragmento de Anacreonte (fr. 40P) y otro de Alceo (fr. 10LP), en los que las 'personas' que hablan son mujeres. Por lo tanto, en ninguno de los textos la voz en primera persona se corresponde con la del poeta, como así tampoco los hechos que narran. Con estos argumentos Dover pretendía limitar el mecanicismo de la interpretación autobiográfica. Su análisis llega a la conclusión de que el poeta arcaico, al componer, podía otorgar al 'yo' un rol genérico, propio de las canciones preliterarias, y que la interpretación de esa primera persona dependía de las convenciones de la sociedad en que dichos poemas fueron compuestos.

En 1974, con la publicación del "Epodo de Colonia" de Arquíloco, el debate interpretativo se vuelve más explícito y queda manifiesto el quiebre de la dicotomía entre la crítica. ${ }^{66}$ Merkelbach (1974, pág. 113), uno de sus editores, relacionaba directamente los hechos narrados por la primera persona con la figura de Arquíloco, e interpretaba los avatares sexuales descriptos, el lenguaje obsceno y la soez ridiculización de las hijas de Licambes con un episodio personal de la vida del poeta. Merkelbach llevaba al extremo esta lectura y sostenía que ciertas injusticias sufridas por el poeta en su juventud habían influido en su carácter. ${ }^{67}$ De la misma manera, extiende su explicación

\footnotetext{
65 Para el pasaje de Retórica y los poemas de Arquíloco, véase pág. 131.

66 Para el "Epodo de Colonia”, véase pág. 153.

67 Específicamente, Merkelbach (1974, pág. 113) interpreta que a causa de que Arquíloco era hijo de una esclava, es decir un "bastardo" (vóӨos), pudo haber sufrido muchas injusticias desde pequeño que alteraron su carácter ("ein schwerer Psychopath") y lo llevaron de grande a
} 
biográfica del 'yo' a toda la obra yámbica de Arquíloco. Para la misma época, el otro editor del fragmento, West (1974, págs. 97-112; 1975, págs. 217-19), reclamaba, en evidente polémica con Merkelbach, una interpretación enmarcada en el contexto ritual del yambo. En ese ámbito, el autor destacaba la utilización por parte del poeta de topoi poético-rituales estereotipados, propios de los cultos populares de Deméter y Dioniso, que convivían en esa etapa con la emergencia de una poesía lírica más definida. Licambes y sus libidinosas hijas no serían sino "stock characters" ("personajes típicos"), pertenecientes a festividades tradicionales con fundamento ritual, quizás ya olvidado, y no personas reales contemporáneas de Arquíloco. ${ }^{68}$

La propuesta de West encuentra importantes ecos en el mundo académico. Hacia la misma época, Lefkowitz (1976, págs. 181-89; 1978, págs. 459-69; 2012, págs. 30-45) investigaba la errónea tendencia a interpretar como datos autobiográficos cualquier referencia que apareciera en los poemas. Por su parte, Nagy (1976, págs. 191-205; 1999), partiendo de la complementariedad

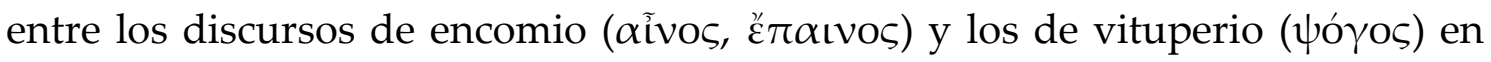
las sociedades arcaicas, sonstenía que el 'yo' poético desaparecía tras determinados recursos formales, como pueden ser considerados los personajes tipo que se dejan ver a partir del análisis de las raíces etimológicas de los nombres que se mencionan en la obra de Arquíloco. Sin embargo, no negaba la posibilidad de que asimismo la invectiva del yambo estuviera dirigida contra personas del propio entorno, del mismo modo que sucede, en sentido inverso, con el encomio dentro de la poética de Píndaro. En la misma línea interpretativa se sitúan Miralles \& Pòrtulas (1983; 1988), Carey (1986, págs. 60-7) y Rosen

vengarse a través de sus yambos: "Dass Archilochos nicht nur ein gläzender Dichter und kräftinger Mann gewesen ist, sondern auch ein schwerer Psychopath, konnte man immer wissen (...) Vermutlich hat er, selbst ein vóӨo , in seiner Junged viel Zurücksetzung ertragen müssen und ist dadurch auch in seinem Wesen geprägt worden: Was seine Mutter und er erlitten hatten, das mussten später andere büssen."

${ }^{68} \mathrm{Vid}$. sup. pág. 15. 
(1988, págs. 29-41); este último analiza particularmente los modos en que Hiponacte caracteriza en forma estereotipada a sus contrincantes Búpalo y Atenis, reconocidos escultores de la Antigüedad.

Una alternativa atractiva, que parte del análisis que realiza West sobre los nombres que aparecen en los poemas yámbicos pero se distancia en sus conclusiones, fue propuesta por Bonanno (1980, págs. 65-88; 1993, págs. 31-60).

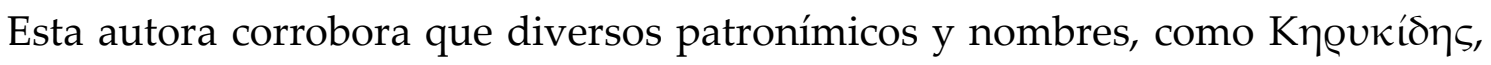

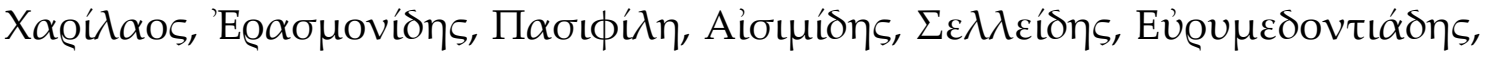

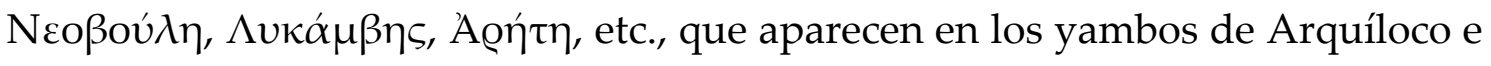
Hiponacte podrían ser "nombres parlantes" creados por los poetas para aludir a personas reales dentro de la comunidad, del mismo modo que Aristófanes empleó sobrenombres para satirizar a personajes históricos bien conocidos por el público ateniense. Para Bonanno, estos personajes "possono essere chiamati con un soprannome che allude non tanto al carattere di ciascuno, quanto alle note vicende che ne hanno rivelato il comportamento al resto della comunità" (1993, pág. 37). Esta propuesta de análisis tiene una clara incidencia sobre la cuestión de la interpretación de la primera persona que aparece en los poemas. Citando a Gentili, Bonanno sostiene que “è evidente che l'io locutore si identifica con la persona stessa del poeta" (1993, pág. 37), aunque considera que esa identificación no debe pensarse bajo criterios de "verdad/mentira", sino que, por tratarse de poesía, el "yo" debe ser considerado como un espejo deformado de la realidad.

A la disputa crítica que hemos comentado Rösler (1980; 1985, págs. 13144) le asigna un carácter "geográfico". Este autor entiende que las propuestas interpretativas, tanto las centradas en la persona individual del poeta reconocible a través de sus textos como las que apuntan a la persona poética separada de su identidad biográfica, derivan de tradiciones estéticas que también "si possono delimitare geograficamente" (1985, pág. 133). En un 
mismo grupo sitúa entonces a los críticos alemanes, Wilamowitz, Pfeiffer, Fränkel, y los citados Snell y Merkelbach, cuyas aproximaciones biográficas encontraban legitimación en los siguientes presupuestos: a) la lírica, en contraposición con la épica y el drama, resulta la "forma natural" más subjetiva, es decir, una autorrevelación casi monológica; b) la lírica griega arcaica emergió como nueva forma de expresión del individuo en su descubrimiento del propio "yo", y como reacción al "epos", en decadencia hacia el s. VII a. C. En otro grupo emplaza a la crítica angloamericana, particularmente a Dover y West, quienes habrían adoptado la teoría del New Criticism para sus investigaciones sobre la poética arcaica. Esta teoría, que surge de las concepciones de T. S. Eliot en Impersonal Theory of Poetry, fue sistematizada por Wellek y Warren en Theory of Literature (1948). Sus principales postulados son que: a) el arte impone cierto tipo de encuadre que desplaza la obra del mundo de la realidad; b) las características centrales de toda obra literaria se encuentran ya en los géneros tradicionales: lírica, épica y drama. Las referencias literarias, por ende, remiten siempre a un universo ficcional, razón por la cual, en la lírica "subjetiva", el 'yo' del poeta debe considerarse ficticio, un 'yo' estrictamente dramático.

Rösler plantea la necesidad de superar los escollos reduccionistas tanto de la interpretación del "yo poético" dominada por el aspecto biográfico (a la que denomina "Escila"), como de la despersonalización puramente ficcional (la correspondiente "Caribdis"), y postula comprender el problema a partir de un análisis "storico-funzionale". La función del poeta dentro de la sociedad arcaica es, para este crítico, lo que determina el vínculo que se establece entre su obra y su vida. Por ejemplo, en el caso de Alceo, el rol de expresar poéticamente los sucesos de la guerra civil contra los tiranos, dentro del ámbito del simposio, es lo que constituye su 'yo'. Esta contextualización histórica lo diferencia de Alcmán, que componía para los coros femeninos de Esparta dentro de la fiesta pública y ante un auditorio mucho más amplio, definiendo un 'yo' 
institucionalizado en relación directa al gobierno de la ciudad. En explícito debate con Rösler, Nagy (1996, págs. 1-25; 2004, págs. 26-48) replantea sus concepciones primeras y postula el concepto del "reenacting I", entre el "fictional I" y el "autobiographical I", cuya característica principal es la de conservar la idea de la presencia real de la persona del poeta representando sus composiciones ante un auditorio - un vago sentido de lo autobiográfico, pero observando las reglas del contexto dentro del cual la expresión poética toma lugar. ${ }^{69}$ La discusión no se ha acabado. Tesis doctorales como la de Lavigne (2005) demuestran que todavía puede progresarse en la dirección inaugurada por Dover, West y Nagy. Cada vez con más insistencia se deja escuchar la posibilidad de una performance rapsódica de las composiciones yámbicas y la contaminación temática con la épica, a partir de los certámenes públicos compartidos. Lavigne propone el concepto de "poet-persona" para analizar, dentro de la poesía yámbica, los procesos de enmascaramiento por parte del performer de la voz del poeta cuyas obras representa en escenarios públicos. Esta noción le permite desarrollar no solo el vínculo entre la perspectiva biográfica y la "persona loquens" dentro de un determinado poema, sino también abordar los procesos de transmisión y conservación de las composiciones orales a través de "performances secundarias". En relación a la poesía yámbica, un ejemplo emblemático en ese sentido, aunque en un contexto totalmente diferente, es la apropiación y reelaboración de la voz de Hiponacte por parte de Calímaco en los Yambos 1 y 13 (191 y 203Pf).

Al mismo tiempo, se observa en los últimos treinta años una tendencia a incorporar los aportes de la teoría narratológica (Chatman 1978, Genette 1980, Bal 1985) a los estudios clásicos en general; valgan como ejemplo los trabajos de

\footnotetext{
${ }^{69}$ Nagy (2004, pág. 27): “The idea of a reenacting I does two things. It retains the idea of the real presence of a speaking person that is vaguely implicit in the term autobiographical. But it recognizes, at the same time, that the self-expression as reflected in the auto- of autobiographical observes the rules of the medium within which the expression takes place."
} 
De Jong (1987). Basada en principios estructuralistas que conciben al texto como unidad autónoma, aislado de los procesos de producción y de su relación con el contexto, la narratología se centra en la descripción de distintos tipos de narradores (primarios, secundarios, internos, externos, cubiertos, descubiertos), los componentes de la fábula, y los elementos dentro del discurso que nos remiten a un auditorio o lector. Fácil de ver las limitaciones de este tipo de abordaje teórico: su análisis taxonómico del texto pretende postular un sistema que permita abordar producciones tan disímiles como la poesía lírica de la Grecia arcaica o la novela de siglo XX. La narratología "presupone que un número infinito de textos narrativos pueda ser descrito con el número finito de conceptos que contiene el sistema narrativo" (Bal, 1985, pág. 11). Desde esa perspectiva, el 'yo' es considerado un sujeto lingüístico que se abstrae de toda relación con la realidad. Con todas estas limitaciones, un estudio como el de Morrison (2007), centrado en los modos en que los narradores primarios en la poesía griega arcaica fueron modelos de los poetas helenísticos para desarrollar sus propios narradores, ofrece sin embargo un análisis eficaz para el estudio del 'yo' poético.

\subsection{LA ENUNCIACIÓN}

$\mathrm{Al}$ abordar los modos en que la primera persona se inscribe en la poesía yámbica de la Grecia arcaica y helenística, y en la búsqueda de sustentar la existencia de un proceso de enmascaramiento lingüístico del 'yo' en las formas de producción, transmisión y recepción de este género poético, nuestra perspectiva metodológica parte de las teorías que abordan la noción de sujeto dentro de un encuadre discursivo. Por esta razón, nos parece importante realizar una breve presentación de algunos conceptos del análisis del discurso que son fundamentales para nuestra investigación. 
En principio, es relevante destacar la noción de que el discurso es estructurado por la enunciación. Con sus postulados acerca del "aparato formal de la enunciación", Benveniste va a poder franquear la brecha entre lengua y habla, abierta por la teoría saussureana, y reubicará nuevamente al sujeto en el centro de la producción de significados discursivos. ${ }^{70}$ Para el análisis lingüístico, lengua y habla ya no se manifestarán como dos entidades autónomas sino como fenómenos constitutivos de un mismo proceso: la enunciación, acto individual de apropiación de la lengua, y el enunciado, en tanto manifestación discursiva particular. De este modo, el "aparato formal de la enunciación" se postula como una estructura lingüística virtual que se imprime en la materialidad del enunciado. Esta perspectiva implica la duplicidad en el estatuto del sujeto, como productor y como producto del discurso:

L'acte individuel d'appropriation de la langue introduit celui qui parle dans sa parole. C'est là une donnée constitutive de l'énonciation. La présence du locuteur à son énonciation fait que chaque instance de discours constitue un centre de référence interne. Cette situation va se manifester par un jeu de formes spécifiques dont la fonction est de mettre le locuteur en relation constante et nécessaire avec son énonciation. ${ }^{71}$

Se asume así un principio que va a ser fundamental para el análisis lingüístico: el sujeto, al mismo tiempo que enuncia, se inscribe en su enunciado. ${ }^{72}$ En consecuencia, este enfoque tiende a deslindar, por un lado, al

\footnotetext{
${ }^{70}$ Benveniste (1974, pág. 80): “L'énonciation est cette mise en fonctionnement de la langue par un acte individuel d'utilisation (...) cette manifestation de l'énonciation, n'est pas simplement la 'parole' (...) Il faut prendre garde à la condition spécifique de l'énonciation: c'est l'acte même de produire un énoncé et non le texte de l'énoncé qui est notre objet. Cet acte est le fait du locuteur qui mobilise la langue pour son compte. La relation du locuteur à la langue détermine les caracteres linguistiques de l'énonciation. On doit l'envisager comme le fait du locuteur, qui prend la langue pour instrument, et dans les caractères linguistiques qui marquent cette relation."

${ }^{71}$ Benveniste (1974, pág. 82).

72 Benveniste (1966, pág. 259) afirma: "Est ego qui dit ego", a lo que Coquet (1989, pág. 14) añade: "Est ego qui dit ego et qui se dit ego ou qu' on dit ego."
} 
sujeto real, empírico e histórico, del sujeto como construcción textual; y, por otro lado, dentro de la construcción textual, al sujeto como productor y producto de su discurso. Desde una visión más panorámica, esta duplicidad se hace extensiva a la distinción entre situación de comunicación e instancia de enunciación, ${ }^{73}$ sobre la que nos detendremos brevemente.

\subsection{LA INSTANCIA DE ENUNCIACIÓN}

La noción "instancia de enunciación" ha sido descripta como un sistema de coordenadas abstractas, de puntos de referencias, con respecto a los que se constituye toda enunciación. Estas coordenadas se organizan en tres categorías: persona, tiempo y espacio. El origo, o punto de origen de este sistema de referencias, se sitúa exactamente en el sincretismo personal, espacial y temporal, que inaugura la apropiación de la lengua y su puesta en funcionamiento a través del discurso, es decir, en el 'yo-aquí-ahora' de la enunciación.

En primer lugar, para las categorías que componen la subjetividad de la enunciación se puntualizan tres posiciones actanciales: enunciador, enunciatario y no-persona. La posición de enunciador aparece manifiesta en el enunciado a través de la deixis de primera persona singular, cuyo marcador lingüístico más representativo en español es el pronombre 'yo' (griego ẻ $\gamma \omega$ ). En reciprocidad solidaria al enunciador se ubica la posición de enunciatario, indicado por medio de la deixis de segunda persona, en particular por el pronombre 'tú' (griego oú). Finalmente, frente a las personas que participan de la instancia de enunciación se ubica la posición de aquellas entidades que no son susceptibles de tomar parte en el acto enunciativo y que por tal motivo Benveniste conceptualizó bajo el término de no-persona. La no-persona aparece en el discurso a través del nombre y de las marcas endofóricas (anáfora y

73 Maingueneau (2004, págs. 197-210). 
catáfora) de tercera persona, cuyo marcador lingüístico más representativo son los pronombres 'él-ella' (en griego, teniendo en cuenta también el género

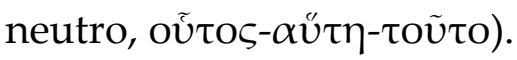

En segundo lugar, partiendo del 'aquí' y 'ahora' de la instancia de enunciación, el origo impone una referencia dimensional que permite localizar, espacial y temporalmente, los acontecimientos que se proyectan en el enunciado. Los procedimientos lingüísticos de referencia espacial y temporal son muy variados y su interpretación exige una delimitación pragmática del discurso. La proyección del espacio, por ejemplo, puede remitir a procesos estáticos o dinámicos que conllevan a espacializaciones posicionales, de puntos de referencia, de acercamiento o alejamiento, de distancias, etc. Por su parte, la proyección temporal es uno de los mecanismos más complejos de la enunciación, ya que implica la propia esencia temporal y aspectual del sistema verbal y el conjunto de las categorías temporales que el discurso presenta.

A raíz de que nuestra investigación se propone un análisis de la representación del 'yo' en el discurso poético, nuestro enfoque se centrará principalmente en las categorías de persona en la relación de comunicación intersubjetiva, aunque en algunas ocasiones será necesario hacer referencia al sincretismo espacial y temporal de la instancia de enunciación para analizar el modo en que estas categorías se proyectan sobre el enunciado.

\subsection{LA SITUACIÓN DE COMUNICACIÓN DEL YAMBO ARCAICO Y HELENÍSTICO}

El concepto de "situación de comunicación", por su parte, refiere al contexto y a las formas concretas de comunicación de un determinado discurso, y pone en consideración aspectos que pueden ser abordados desde distintas disciplinas: aspectos referidos por ejemplo al contexto histórico, social, cultural o religioso, al soporte físico de la comunicación, al tipo de género discursivo, etc. 
En este sentido, uno de los principales problemas que se presenta al abordar el análisis discursivo de la poesía yámbica de la Grecia arcaica y helenística, y de la poesía griega antigua en general, es que la situación de comunicación puede ser comprendida solamente a través de la transmisión escrita de esos mismos poemas, y, en muchos casos, como sucede con las producciones arcaicas, a través de transcripciones y ediciones tardías de textos cuya producción, ejecución y transmisión era de naturaleza oral. La imposibilidad de acceder a una situación de comunicación observable y de tener conocimiento directo de las ocasiones en que estos yambos fueron ejecutados, con sus rituales propios y sus significantes no verbales (piénsese, por ejemplo, en la importancia de la gestualidad y de la ostensión para la interpretación deíctica en una instancia de enunciación determinada), conlleva el desafío de realizar una reconstrucción de la situación de comunicación poética a partir de las marcas inscriptas en el enunciado y de la evaluación de los escasos testimonios antiguos que han sobrevivido hasta nuestros días. Particularmente, la poesía griega del período arcaico era, en esencia, una poesía de ocasión: cada poema fue compuesto para una festividad concreta y para un auditorio específico. Los poemas yámbicos, por lo tanto, exhiben muchas marcas de este proceso, como las referencias a determinadas características rituales del simposio o la apelación directa al auditorio, hasta el punto de que algunos poemas describen el propio contexto de ejecución pública y la situación de comunicación misma. ${ }^{74}$

La situación de comunicación de la poesía yámbica de la Grecia arcaica podría ser caracterizada brevemente de la siguiente manera: el poeta,

${ }^{74}$ Sobre la situación de comunicación en la poesía griega arcaica, véase Gentili (1996, págs. 71112). Específicamente para la descripción de la situación de comunicación desde una perspectiva de semiótica discursiva, véase Calame (1995, págs. 3-26). Calame estipula y caracteriza tres contextos para la poesía griega arcaica: el de la épica, el de la monodia y el de la poesía coral. En relación a las referencias "metasimpóticas" en los poemas griegos, véase Hobden (2013, págs. 22-65). 
acompañado por la música de la flauta ( $\alpha$ ủós), ejecuta en forma recitativa ( $\pi \alpha \varrho \alpha \kappa \alpha \tau \alpha \lambda \circ \gamma \eta ́)$ un poema relativamente breve compuesto por él mismo. El auditorio está constituido generalmente por un grupo que pertenece al mismo

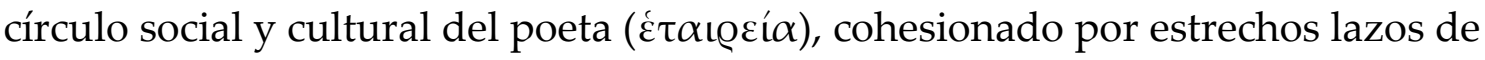
amistad y propósitos colectivos. Los miembros de estas comunidades se enfrentan también a los mismos contrincantes y enemigos ( $\dot{\chi} \chi 0$ ○oí), que ocupan una posición antagónica a los ideales comunes del grupo y son frecuentemente blancos de las críticas e invectivas en los yambos. La figura de un enemigo común contra quien encauzar la hostilidad funciona también como purga de los disensos internos y cohesión de los vínculos de $\phi \iota \lambda i ́ \alpha$.

El contexto particular de la situación de comunicación de la poesía yámbica arcaica es el ámbito del simposio masculino en ocasión de festividades privadas y públicas, pero restringido a un grupo selecto. Sus temas son bastante variables: abarcan desde reflexiones políticas y bélicas, bromas ocasionales contra alguno de los compañeros del simposio, parodias de la poesía épica, hasta narrativas sexuales con lenguaje explícito. El tono de este tipo de composiciones se sitúa comúnmente dentro del ámbito de lo serio-cómico

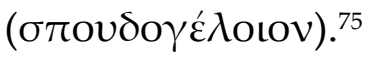

Esta descripción sucinta de la situación de comunicación pretende remarcar el carácter ocasional e inmediato de la poesía yámbica en relación a su contexto de ejecución, con una forma de ejecución oral y recepción aural, y definir fundamentalmente sus funciones dentro del simposio: lo risible, lo obsceno, la invectiva personal y ciertos aspectos de lo didáctico.

\subsection{LOS SUJETOS DEL DISCURSO POÉTICO}

Toda producción discursiva presupone la existencia de un sujeto productor, que puede inscribirse en su enunciado a través de la deixis de

${ }^{75}$ Gentili (1996, págs. 77-9, 243). 
primera persona $y$, en una perspectiva ampliada, de otros significantes que manifiestan su subjetividad. ${ }^{76}$ Frente a este sujeto productor, se sitúa el sujeto a quien se dirige el discurso, copartícipe solidario y necesario en todo acto de comunicación intersubjetiva. Así, y solamente en un principio, los sujetos del discurso se disponen en las posiciones actanciales de destinador y destinatario.

Al iniciar el análisis del discurso poético, conviene distinguir, por un lado, los sujetos que se sitúan en un espacio extralingüístico y, a raíz de esto, extradiscursivo o extratextual, es decir, el autor o el poeta y el lector o auditorio "reales", que pueden ser contextualizados social e históricamente; y, por otro lado, los sujetos que se sitúan dentro del espacio lingüístico. Estos últimos se desdoblan, en primer lugar, en sujetos intralingüísticos, pero extradiscursivos, actantes de la enunciación, denominados enunciador y enunciatario, y, en segundo lugar, en sujetos intralingüísticos e intradiscursivos, actantes del enunciado, denominados narrador y narratario o interlocutor e interlocutario, dependiendo del tipo de estructura comunicativa que se manifiesta en el discurso. Podríamos esquematizar estas distinciones de la siguiente manera:

${ }^{76}$ Para la perspectiva ampliada de la subjetividad en el discurso, el uso de subjetivemas evaluativos y afectivos, la axiologización y la modalización, véase Kerbrat-Orecchioni (1997, págs. 91-171). 


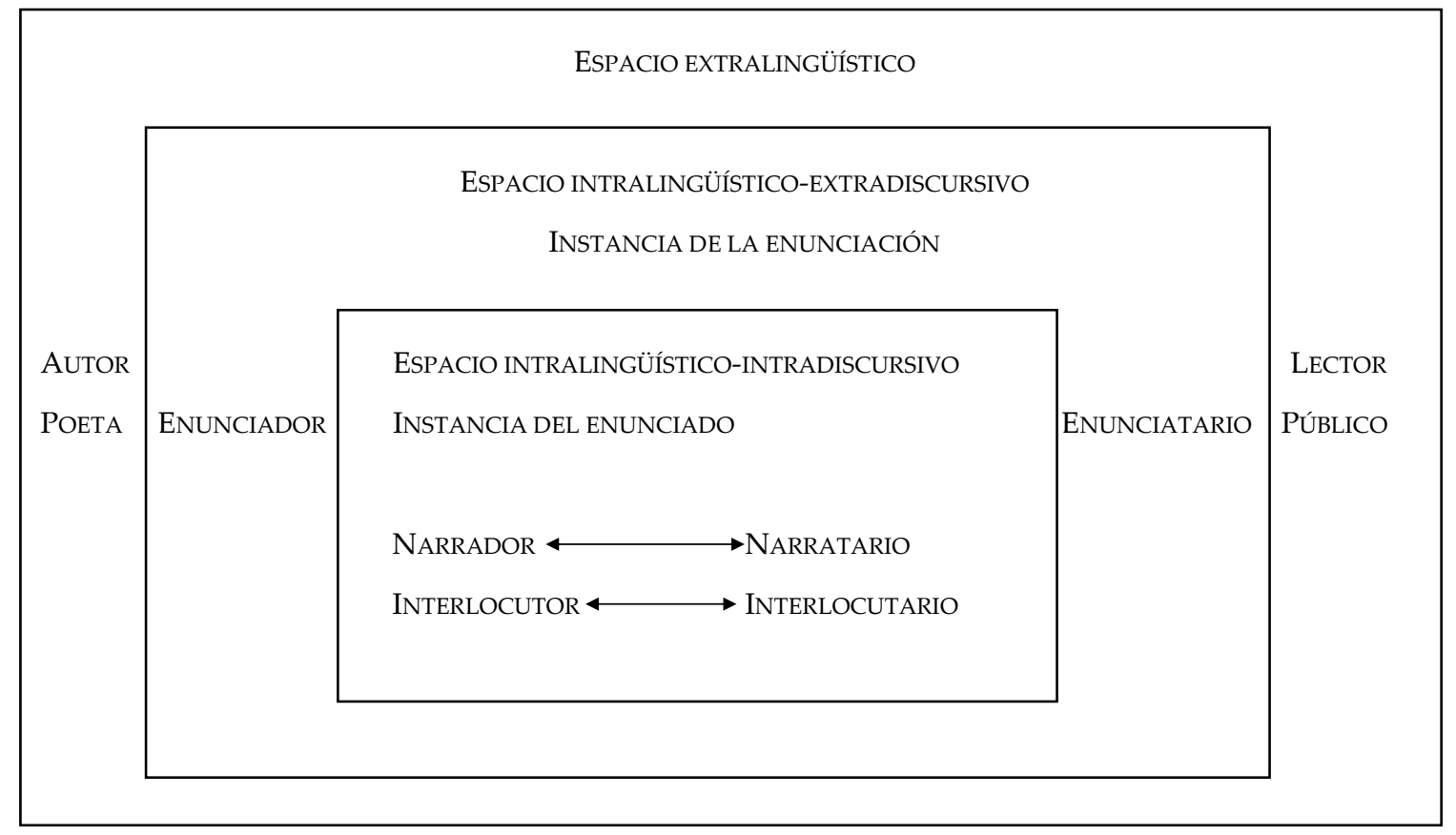

$\mathrm{Si}$ bien nuestra investigación tiene en cuenta a los sujetos extralingüísticos a raíz de consideraciones históricas y sociales que conciernen a las condiciones de producción y recepción del discurso poético, así como también a la naturaleza y el estatus particular del enunciador, del enunciatario, y de la situación concreta de enunciación, nuestro análisis discursivo se centra en los funcionamientos de los sujetos intralingüísticos a partir de la observación de determinados marcos enunciativos.

De este modo, la primera escisión del objeto de estudio tiende a separar al sujeto discursivo de cualquier otra caracterización que no se origine en y por el enunciado. La perspectiva descriptiva de los procesos enunciativos nos lleva a focalizar en el análisis lingüístico del sujeto verbal, dejando de lado cualquier enfoque que lo enmarque a priori dentro de conceptualizaciones externas al enunciado.

Sin embargo, el análisis de la instancia intralingüística, en su inmanencia, no impide que, partiendo de la observación y descripción de las propiedades intrínsecas al enunciado y a la enunciación, se busque caracterizar 
y dar cuenta de determinadas formas sociales históricas, instituciones y relaciones intersubjetivas, de las cuales el discurso es su reflejo. Pero el enfoque busca ir del análisis lingüístico al extralingüístico y no en sentido inverso.

En la instancia intralingüística es posible realizar una segunda escisión, por un lado, el sujeto intradiscursivo, es decir, aquel que aparece inscripto en el enunciado a través de la deixis personal; y, por otro lado, el sujeto extradiscursivo, que sitúa la instancia de comunicación entre enunciador y enunciatario.

\subsection{DEL ENUNCIADO A LA ENUNCIACIÓN}

El discurso implica un proceso pragmático a través del cual el enunciado revela las marcas del acto de su enunciación. Como hemos observado, estas marcas se dividen en tres categorías: persona, tiempo y espacio, considerando al sincretismo yo-aquí-ahora como origo o punto de fuga de las relaciones de persona, tiempo y espacio que se proyectan en el enunciado. ${ }^{77}$

Partiendo de las relaciones del tiempo verbal, Benveniste realiza una diferenciación entre dos planos enunciativos: histoire y discours. ${ }^{78}$ Desde su perspectiva, el récit historique se caracteriza por ser un modo de enunciación que narra acontecimientos pasados, hechos ocurridos en determinado momento del tiempo, sin ninguna intervención del locutor en su discurso. De esta manera, el modo de enunciación histórica se define como el modo de enunciación que excluye toda forma lingüística autobiographique, es decir, al no adoptar jamás el aparato formal del discurso no asume los índices de primera y segunda persona: 'yo'-'tú', ni los índices espaciales y temporales relacionados con el 'aquí' y 'ahora' de la enunciación. Benveniste señala además que en este modo

\footnotetext{
77 Para una perspectiva de la pragmática discursiva, véanse Levinson (1983) y Verschueren (2002). Para un estudio del ego como centro deíctico, véanse Lyons (1977, págs. 636-718) y Levinson (1983, págs. 61-73).

${ }^{78}$ Benveniste (1966, págs. 37-50).
} 
enunciativo solo se reconocen las formas de tercera persona y los tiempos verbales de aoristo, ${ }^{79}$ imperfecto y pluscuamperfecto. El presente queda excluido, a no ser la rara excepción de su empleo intemporal denominado “presente de definición". En contraposición, el modo enunciativo del discours presupone un locuteur y un allocutaire, por lo cual emplea los índices de primera y segunda persona y los tiempos verbales del presente y del futuro, excluidos de la histoire.

De acuerdo con el desarrollo de Benveniste, es posible considerar que esta distinción se basa en última instancia en un sistema referencial intrínseco al enunciado (histoire) y en uno que incluye además la propia enunciación (discours). ${ }^{80}$ Es decir, en tanto que las formas de la histoire se sustentan en un sistema de referencias internas al enunciado, que se organiza en torno a la tercera persona o "no-persona", a las marcas espacio-temporales del no-aquí y no-ahora de la enunciación, las formas del discours se sustentan en un sistema de referencias indisolublemente ligado a la instancia de enunciación, que se organiza en torno a índices de persona y a la deixis espacial y temporal del aquí y ahora.

Siguiendo el análisis de Benveniste sobre el carácter deíctico de los pronombres, Jakobson empleó el concepto de shifter (embrayeur) para examinar los modos en que estas categorías se articulan en el discurso. ${ }^{81}$ Desde esta

\footnotetext{
${ }^{79}$ Perfecto simple en español.

${ }^{80}$ Para un análisis de los conceptos de Benveniste, véase Simonin-Grumbach (1975, págs. 85121).

81 El concepto de shifter fue introducido por Jespersen (1922, pág. 123; 1924, págs. 83-6) y retomado por Jakobson en 1956, (1984, págs. 41-58), quien lo emplea en vinculación con las consideraciones acerca de la naturaleza deíctica de los pronombres propuestas por Benveniste (1966, págs. 251-66; 1974, págs. 195-230). Así, la categoría se identifica con los pronombres de primera y segunda persona, ya que remiten a la instancia de enunciación. Pero además Jespersen (1924, págs. 292-99) utiliza el término shifting aplicado al cambio de perspectiva ocasionado por el movimiento del discurso directo al discurso indirecto, es decir, la conmutación de un discurso en primera y segunda personas a un discurso en tercera persona. Para este tema, véase Fludernik (1991, págs. 193-230).
} 
perspectiva, lo que "conmuta" es el anclaje del discurso a la primera-segunda persona (yo-tú) o a la tercera (él/ella/ello), es decir, a las formas deícticas que refieren a la enunciación o a las formas fóricas del enunciado. Así, los shifters o deícticos se diferencian de los demás elementos lingüísticos porque su función es la de referir obligatoriamente a la persona, al tiempo o al espacio de la instancia de enunciación. ${ }^{82}$

Greimas y Courtés amplían estos conceptos y desarrollan su teoría actancial de la enunciación. ${ }^{83}$ De acuerdo con esta perspectiva, la enunciación es una instancia lingüística, presupuesta lógicamente por la existencia misma del enunciado, en donde se ejerce la competencia semiótica del sujeto. Esta instancia centrada en el yo-aquí-ahora es previa a cualquier articulación individual en un enunciado. ${ }^{84}$ La disyunción desde la enunciación hacia el enunciado se produce a través de procesos de desembrague (débrayage) que, al mismo tiempo que inauguran el enunciado, proyectan la instancia de enunciación misma. La teoría considera que este proceso consiste en disjuntar, en una primera etapa, la persona, el tiempo y el espacio de la enunciación en un no-yo, no-ahora y no-aquí, para proyectarlos en una segunda etapa sobre el discurso.

\footnotetext{
${ }^{82}$ Lyons (1977, pág. 637): "By deixis is meant the location and identification of persons, objects, events, processes and activities being talked about, or referred to, in relation to the spatiotemporal context created and sustained by the act of utterance and the participation in it, typically, of a single speaker and at least one addressee." Véase también Fillmore (1975, págs. 38-49, 70-85). Kerbrat-Orecchioni (1997, pág. 48): “los deícticos son las unidades lingüísticas cuyo funcionamiento semántico-referencial (selección en la codificación, interpretación en la decodificación) implica tomar consideración algunos de los elementos constitutivos de la situación de comunicación, a saber: el papel que desempeñan los actantes del enunciado en el proceso de la enunciación; la situación espacio-temporal del locutor y, eventualmente, del alocutario."

${ }^{83}$ Greimas (1966).

${ }^{84}$ Por esta razón considera que el ego, hic et nunc, son categorías semánticamente llenas pero semióticamente vacías, ya que solo la proyección fuera de la instancia de la enunciación hacia la del enunciado será la que les otorgue el contenido semiótico en tanto actantes y coordenadas espacio-temporales (Greimas \& Courtés, 1990, pág. 145).
} 
El desembrague actancial puede articularse en las categorías de persona o no-persona. A la primera forma le corresponden los morfemas personales 'yo' y 'tú' que denominan a los dos actantes de la enunciación (enunciador y enunciatario); a la no-persona le corresponden los actantes del enunciado. Partiendo de la instancia de la enunciación se pueden proyectar e instalar en el discurso a los actantes de la enunciación, o bien los actantes del enunciado. En el primer caso, se opera un desembrague enunciativo; en el segundo, un desembrague enuncivo.

De este modo, Greimas y Courtés, al igual que Benveniste, distinguen dos procesos y dos tipos de unidades discursivas: a través del desembrague enunciativo se instala en el discurso las formas de la enunciación enunciada (énonciation énoncée); en cambio, si el desembrague es enuncivo se inscriben las formas del enunciado enunciado u objetivado (énoncé énoncé). ${ }^{85}$

Estos procedimientos permiten comprender además el funcionamiento de los desembragues internos (de segundo o tercer grado), frecuentes en los discursos figurativos de carácter literario: partiendo de una estructura de diálogo, uno de los interlocutores puede realizar un desembrague de segundo grado al desarrollar una narración; y, a su vez, dentro de la narración, un actante del enunciado podrá realizar un nuevo desembrague (en este caso de tercer grado), para introducir, por ejemplo, un segundo diálogo. El retorno a la instancia de la enunciación primaria se produce por medio de procesos de embrague (embrayage). Así, el procedimiento de desembrague/embrague, utilizado por el enunciador como un componente de su estrategia, permite dar

\footnotetext{
${ }^{85}$ Greimas \& Courtés (1990, págs. 113-16); Courtés (1997, pág. 355): “Nos acogemos así a la enseñanza de É. Benveniste, quien distinguía el 'relato histórico' (o 'historia') y el 'discurso' (tomado, en este caso, en sentido restringido): la oposición enunciado vs. enunciación, subyacente a la pareja 'historia' vs 'discurso', se sustenta entonces, por ejemplo, en la categoría de la persona (el 'yo/tú' que depende del 'discurso', ya que el 'él' -o 'no persona' - es propio del 'relato'), pero también en la distribución de los tiempos verbales, etc."
} 
cuenta de la articulación del discurso figurativo en unidades discursivas tales como diálogos o narraciones.

Cuando se produce un desembrague enunciativo que instala en el discurso las formas de la enunciación enunciada (yo-tú), Greimas y Courtés emplean los conceptos de interlocutor/interlocutario" (interlocuteur/interlocutaire), si la estructura discursiva es una interlocución, y "narrador/narratario" (narrateur/narrataire), si se trata de un relato o narración. ${ }^{86}$ Estos términos tienden a diferenciar al enunciador y enunciatario de sus manifestaciones explícitas dentro del enunciado.

Podemos observar mejor la descripción de estos principios a partir de los siguientes esquemas:

Nivel ENUNCIATIVO

1. ENUNCIACIÓN ENUNCIADA

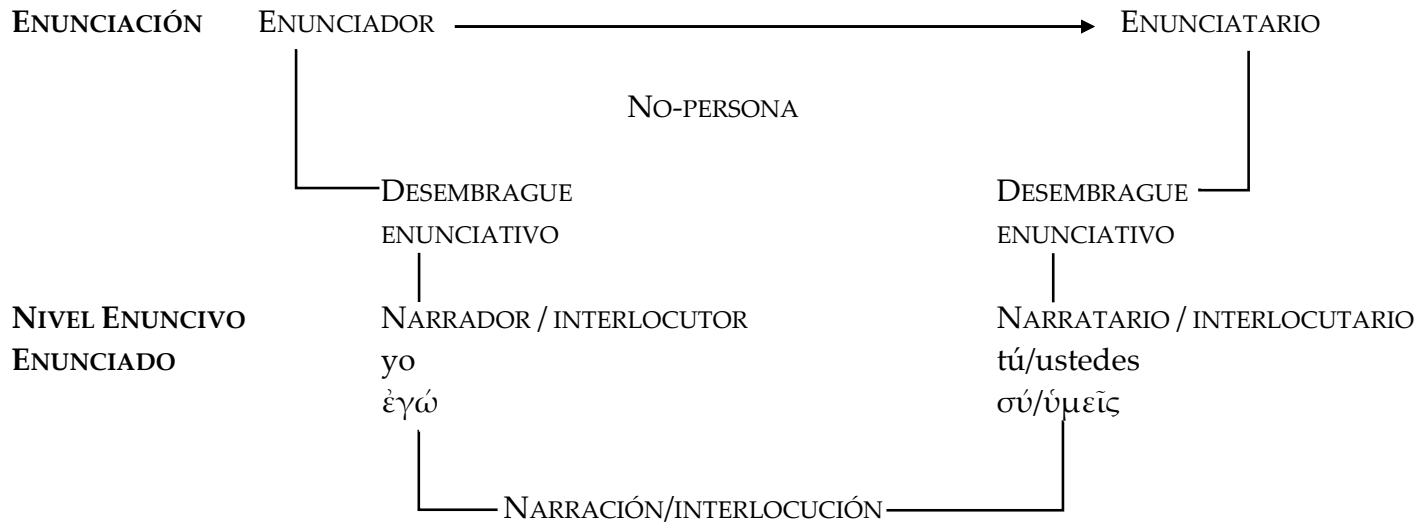

86 Greimas \& Courtés (1990, págs. 225, 272) toman los conceptos “interlocutor/interlocutario" y "narrador/narratario" de las respectivas teorizaciones de Ducrot (1984, págs. 251-77) y Genette (1989, págs. 270-321), y los utilizan para designar a los actantes de la enunciación enunciada cuando aparecen explícitamente instalados en el enunciado. 


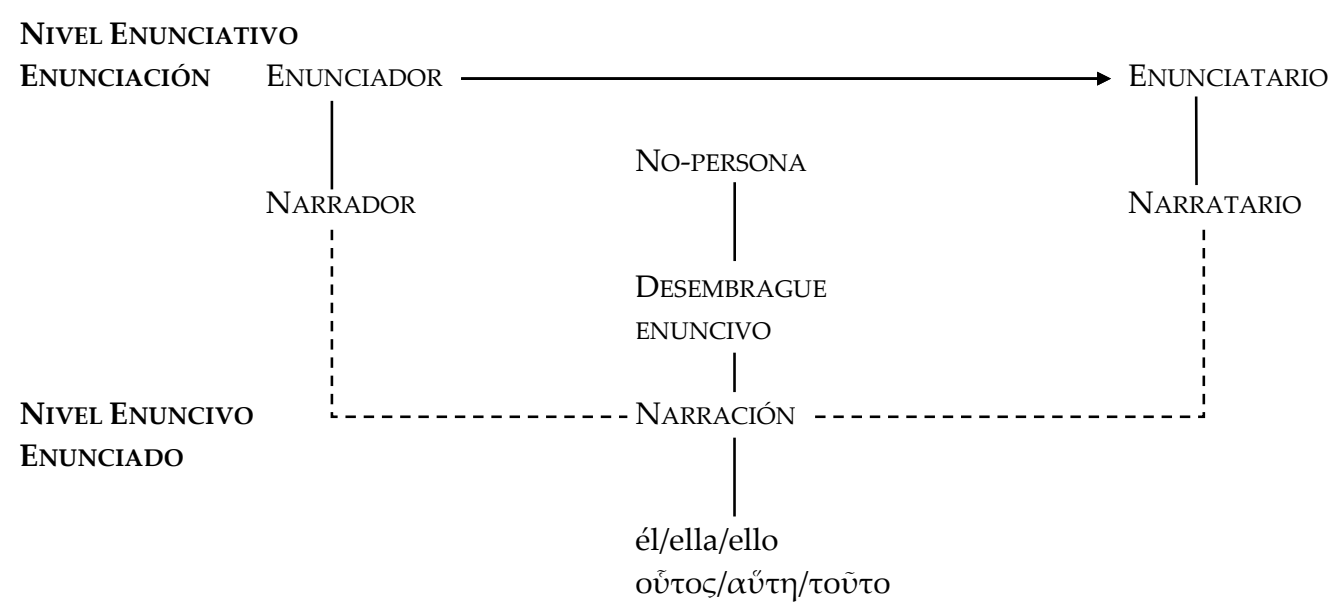

Los esquemas intentan representar los dos procedimientos y formas discursivas que postula la teoría. En el primero de ellos, mediante un desembrague de tipo enunciativo se instalan en el discurso las formas de la enunciación enunciada y, dependiendo del tipo de estructura, el 'yo' y el 'tú' pueden asumir los roles de interlocutor e interlocutario o de narrador y narratario. En el segundo, el desembrague es de tipo enuncivo e instala en el discurso las formas del enunciado objetivado. La única estructura que puede darse en este caso es la narrativa, ya que la interlocución presupone la inscripción deíctica de al menos uno de los actantes, en cambio la narración puede inscribir o no al narrador y/o al narratario: alguno de ellos aparece explícitamente, entonces deberíamos volver al primer esquema ya que se trata de una enunciación enunciada (narrador intradiegético, en términos de Genette); si el narrador y el narratario no se manifiestan en el discurso (narrador extradiegético), se presuponen como destinador y destinatario lógicos de la transmisión del relato, delegados directos del enunciador y el enunciatario, pero no aparecen marcados deícticamente en el nivel enuncivo, por esta razón el vínculo que los une a la narración se indica con una línea de puntos. 
El proceso de desembrague no es solamente actancial, también se producen simultáneamente desembragues temporales y espaciales. Ambos implican la disyunción entre el 'aquí' y 'ahora' de la instancia de enunciación y la espacialidad y temporalidad inscriptas en el enunciado. Para analizar la relación entre el tiempo y el espacio enunciativos y la complejidad de los diferentes planos temporales y espaciales enuncivos se puede establecer un sistema de referencias basado en la concomitancia y no-concomitancia que reflejan las distintas categorías gramaticales a partir de la localización de los eventos a través de la anterioridad, simultaneidad y posteridad, y de una topología orientada hacia el espacio tópico, heterotópico, utópico y paratópico. ${ }^{87}$ Del mismo modo que sucede con el proceso actancial, el desembrague temporal y espacial puede instalar en el discurso las formas de la enunciación enunciada o las del enunciado objetivado.

En el análisis del 'yo' de los poemas yámbicos, compuestos para la ocasión inmediata del simposio, la metodología expuesta posee la virtud y la capacidad de distinguir, por un lado, al sujeto extralingüístico (es decir, al poeta en tanto ser real, histórico, con un conjunto de experiencias y acontecimientos vividos, una forma de pensar y sentir, un determinado accionar, etc.), del sujeto lingüístico (el enunciador situado en una instancia particular de enunciación: el poema yámbico); y, por otro lado, dentro del plano lingüístico, también permite diferenciar al sujeto extradiscursivo (el enunciador yámbico) del sujeto intradiscursivo (narrador o interlocutor, según la estructura discursiva).

La primera distinción permite evitar caer en el reduccionismo autobiográfico y en la interpretación de la primera persona y de los acontecimientos que aparecen en los poemas como expresión testimonial por parte del poeta de sus propias vivencias y sentimientos. Entre el enunciador yámbico y la realidad histórica y biográfica del poeta puede existir una mayor o

${ }^{87}$ Greimas \& Courtés (1990, págs. 246-49). 
menor distancia. La segunda diferenciación otorga la posibilidad de no inferir mecánicamente que todo 'yo' inscripto en el enunciado poético remite de manera directa al enunciador yámbico. Al igual que en el caso anterior, entre el actante del nivel enunciativo y el actante del nivel enuncivo puede existir un grado de separación. ${ }^{88}$ Esta distancia se manifiesta, por ejemplo, cuando en el enunciado se asume una voz en primera persona cuya identidad se diferencia de la del propio enunciador. ${ }^{89}$ En este intersticio de carácter lingüístico que separa al enunciador yámbico del narrador o interlocutor inscripto en el enunciado poético es donde se despliegan y ejecutan las facultades de invención ficcional sobre la identidad del ' $y^{\prime}$ '.

Como contraparte a la posición de destinador se ubica el destinatario de la composición poética que, como sujeto, puede ser abordado a través de las mismas diferenciaciones. Por un lado, dentro del plano extralingüístico debemos considerar al público real e histórico que presenció la ejecución yámbica; por otro, al enunciatario, como representación lingüística de la instancia de recepción poética; finalmente, en el plano intradiscursivo, tenemos las posiciones actanciales del interlocutario o narratario. Del mismo modo que en el caso anterior es posible establecer una distancia entre el público real,

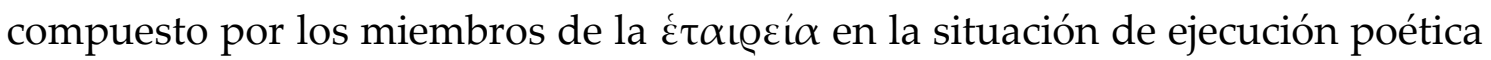
dentro del simposio, y el enunciatario, identificado desde nuestra perspectiva como un "auditorio yámbico", es decir, en tanto ser intralingüístico, un

\footnotetext{
${ }^{88}$ Calame (1995, pág. 7): “So, for example, the narrator installed in the discourse (...) is not necessarily the linguistic equivalent of the enunciator, nor is the narratee that of the enunciatee. This distance means that the uttered enunciation is to a certain extent independent of the actual production of discourse." Para las teorizaciones sobre estas distancias entre enunciador/enunciatario y narrador/narratario o interlocutor/interlocutario, véanse Genette (1989, págs. 270-321) y Ducrot (1984, págs. 251-77).

${ }^{89}$ Esta distancia puede observarse claramente en los ff. 19 y 22W de Arquíloco y en el Yambo 1 de Calímaco (vid. inf. págs. 131 y 292), y con una serie de graduaciones en las varias composiciones analizadas en este trabajo, como por ejemplo en el fr. 126Dg de Hiponacte, cuyo interlocutor se identifica con la voz de un aedo homérico (vid. inf. pág. 216).
} 
auditorio particular que aparece regido por determinaciones de tipo genérico en la decodificación de los poemas. ${ }^{90} \mathrm{Y}$, en igual medida, la misma distancia se manifiesta entre el enunciatario y el interlocutario o narratario, como es posible observar, por ejemplo, en varias composiciones de carácter apelativo en las que estas posiciones actanciales aparecen ocupadas por un actor individual, mientras que la función de enunciatario siempre es ejercida por el auditorio yámbico. ${ }^{91}$

Esta distinción entre el sujeto extra e intralingüístico nos obliga a considerar brevemente el principio de inmanencia y las posibilidades referenciales del lenguaje. El discurso, mediante procesos de "referenciación", construye sus referentes externos, es decir, evoca un mundo extralingüístico supuestamente aprehensible por medio del lenguaje. La "referenciación" crea la ilusión de que la comunicación lingüística es una transmisión de signos en cuyo interior existe algo de la naturaleza de los objetos a los cuales refieren. Por medio del sistema de deícticos personales, espaciales y temporales, y elementos que señalan la subjetividad y la exterioridad del lenguaje, el discurso entabla vínculos con el mundo empírico, adjudicando a lo que se enuncia un sentido de realidad o verdad referencial, pero que, en última instancia, no deja de ser una ilusión referencial o un efecto de veridicción.

Al mismo tiempo que produce la "referenciación", el discurso ejerce una "referencialización" que sustenta la estructura propia del enunciado. Los elementos anafóricos y catafóricos aseguran las relaciones referenciales hacia el

\footnotetext{
${ }^{90}$ Esta noción es próxima al concepto de "public générique", tal como lo define Maingueneau (2010, pág. 47).

${ }^{91}$ Maingueneau (2010, pág. 339): “Les énonciations proférées sur scène, on l'a vu, sont adressées à deux destinataires distincts: l'interlocuteur sur scène e le public. Le même discours doit donc agir sur l'interlocuteur immédiat et sur le destinataire indirect [...] En principe, les lois du discours concernent les seuls personnages. Mais elles doivent aussi, d'une certaine façon, être respectées à l'égard du spectateur." Si bien esta observación acerca del desdoblamiento de la instancia de recepción se refiere específicamente a la enunciación teatral, es también aplicable a a las composiciones apelativas de ejecución oral de la Grecia arcaica.
} 
interior del discurso, posibilitando no solo la coherencia y la cohesión textual sino también la autonomía y la inmanencia de un mundo ficcional, con sus propios actores y sus propios referentes intrínsecos..$^{92}$

De este modo, confrontamos con un doble proceder: por un lado, la "referenciación" mediante un movimiento hacia el afuera del discurso define la relación de significación semántica y figurativa en el nivel de la enunciación, por otro lado, la "referencialización", centrada en las relaciones internas del discurso, garantiza que la manifestación semántica se despliegue en una significación sintáctica, sustentando la cohesión y coherencia en el nivel del enunciado. Por lo tanto, es en las distancias manifiestas en el proceso de "referenciación" entre el sujeto empírico y el lingüístico, por un lado, y en el proceso de "referencialización" entre el sujeto extradiscursivo y el intradiscursivo, por otro, donde se ejecutan las posibilidades de invención ficcional del 'yo'.

El sujeto poético no es una realidad preexistente al acto de enunciación, sino que se constituye a través de su enunciado. El acto de enunciación implica una relación predicativa entre el 'yo' y lo que el 'yo' dice de sí mismo por medio de su enunciado, en consecuencia, el sujeto del discurso existe en tanto enuncia y se enuncia. Pero, obviamente, todo acto de comunicación es de naturaleza dialógica, el 'yo' predica de sí mismo ante un 'tú'. En este resquicio es posible discernir la composición semántica o semiótica del sujeto, ya que, al inscribirse en el enunciado, el 'yo' asume determinados roles y actitudes. Esto implica un proceso de ficcionalización del sujeto poético: ya sea como narrador o interlocutor, el 'yo' inscripto en el enunciado se posiciona como actor frente a su narratario o interlocutario..$^{93}$ En este sentido, y considerado en la inmanencia

92 Sobre los conceptos de "referenciación" y "referencialización", véase Greimas \& Courtés (1991, págs. 216-7).

${ }^{33}$ Greimas \& Courtés (1990, págs. 27-9) consideran que junto a la temporalización y la espacialización, la actorialización es uno de los componentes de la discursivización. Está 
lingüística, es posible hablar del 'yo' como un simulacro que cumple un determinado papel dentro de su enunciado. ${ }^{94}$

Si bien los actantes de enunciación (enunciador y enunciatario) presupuestos por el enunciado nos remiten a entidades exteriores al discurso, deben ser consideradas como simulacros formales que nunca se condicen con realidades fuera del lenguaje; son acontecimientos que nos reenvían operativamente a sujetos discursivos y no a seres reales. ${ }^{95}$

A raíz de estas conceptualizaciones, nuestra perspectiva de análisis consistirá en el estudio de los sujetos lingüísticos extradiscursivos (enunciador/enunciatario) e intradiscursivos (narrador/narratario e interlocutor/interlocutario), abordados desde la inmanencia de los textos poéticos. El sujeto extralingüístico (autor o poeta) queda excluido de nuestro enfoque, ya que su abordaje excede la perspectiva lingüística. Esto no significa, sin embargo, que la investigación se detenga en la observación y descripción de los elementos lingüísticos y de los sujetos de la enunciación y del enunciado, sino que solo partiendo de la inmanencia de los textos se podrá realizar un recorrido hacia la realidad individual, social, cultural e histórica del poeta, de la

basada, como las otras dos, en la realización de las operaciones de desembrague y embrague. El procedimiento de actorialización se caracteriza por reunir diferentes elementos de los componentes semántico y sintáctico para establecer a los actores del discurso. Estos dos componentes, sintáctico y semántico, llevan a cabo sus recorridos actancial y temático, en el plano discursivo, de manera autónoma; la reunión, término a término, de al menos un rol actancial y un rol temático es lo constitutivo de los actores.

${ }^{94}$ Calame (1995, pág. 15): "Semiotically speaking, the utterance of the enunciation creates its own world, just as the story creates its own fiction. (...) As it enunciates itself, the subject can play hide-and-seek with its psychosociological "reality"; it is capable de constructing itself in the text in eny way it wishes."

${ }^{95}$ La perspectiva de que el lenguaje y la realidad no tengan la misma naturaleza fundamenta el estatuto de autonomía del lenguaje en su estructura interna, expresado en el principio de inmanencia postulado por Hjelmslev (1972, 1974 y 1976). De acuerdo con este principio, se puede concebir que la producción y articulación de significación es un proceso que toma forma en un régimen interno al discurso. Fuera de ese régimen surge el dominio de lo exterior y, por ende, desaparece de la órbita de la investigación lingüística para situarse como objeto de investigación de disciplinas más propicias como la historia, la filosofía, la psicología, la sociología, la etnología, etc. 
cual los poemas son sus reflejos. Para poder observar las posibilidades de ficcionalización del 'yo' es importante no situar a priori una realidad biográfica o un evento externo como origen o causa del discurso poético.

\subsection{HIPÓTESIS}

Nuestra perspectiva de investigación nos lleva a sostener la hipótesis de un proceso de enmascaramiento del 'yo' en la producción, ejecución y transmisión de las composiciones yámbicas de la Grecia arcaica y helenística. Para poder llevar adelante el estudio de este proceso de enmascaramiento, postulamos el concepto de persona yámbica como un tipo de máscara enunciativa, particular de este género poético, que nos permite analizar el desembrague actancial y el desdoblamiento del sujeto lingüístico en el nivel enunciativo y enuncivo. A través del siguiente esquema es posible observar la funcionalidad de la persona yámbica:

\section{NiVEL ENUNCIATIVO}

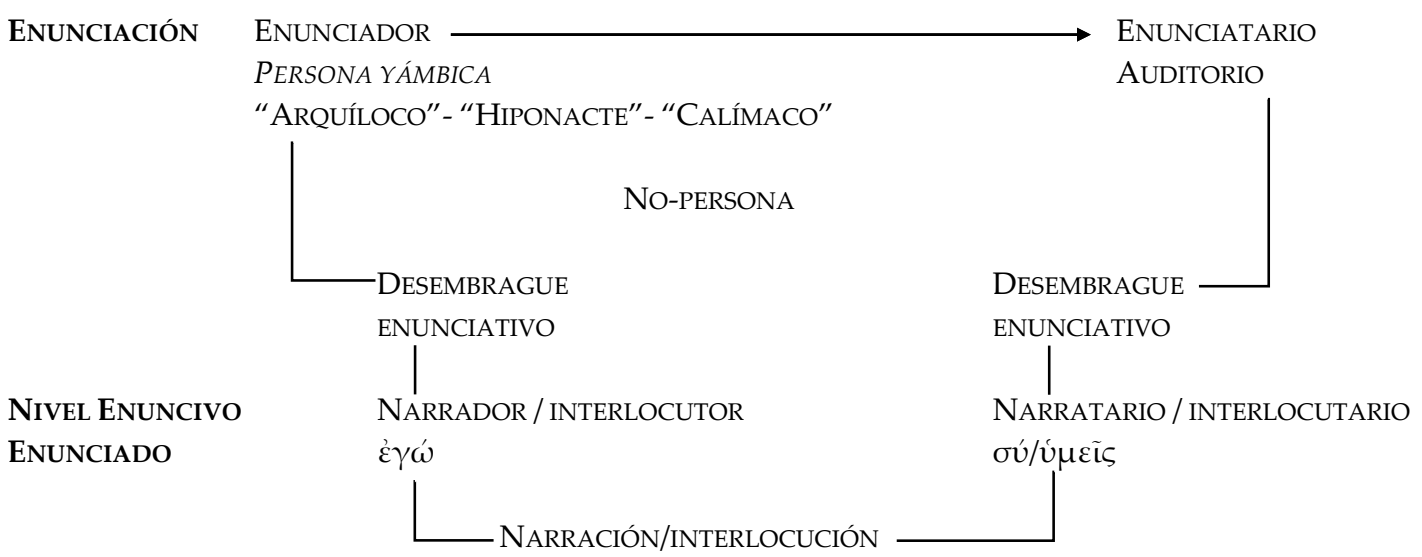

En la diferenciación entre el sujeto extralingüístico y lingüístico nos reservamos los nombres de Arquíloco, Hiponacte y Calímaco, para referirnos a los poetas históricos y reales a los que se les atribuyen los poemas, mientras que sus nombres entre comillas: "Arquíloco", "Hiponacte" y "Calímaco", serán empleados para referirnos al enunciador yámbico, es decir, propiamente a la 
persona yámbica. En tanto que utilizamos el término Auditorio para especificar al enunciatario.

Al estudiar los procesos de enmascaramiento del ' $\mathrm{yo}^{\prime}$ ', nuestra investigación se concentrará casi exclusivamente en los desembragues de tipo enunciativo, aquellos que instalan en el discurso poético las formas de la enunciación enunciada ('yo' y/o 'tú'). Como ya hemos observado, dependiendo del tipo de estructura que se inscriba en el enunciado (interlocución o narración), a los actantes del enunciado se los denominará interlocutor/interlocutario o narrador/narratario, respectivamente. Al estar frente a una enunciación enunciada, necesariamente al menos uno de estos actantes deberá aparecer explícitamente en el enunciado a través de la deixis personal pronominal o verbal. A raíz de esto, cuando el interlocutor o narrador se inscriba deícticamente en el enunciado se lo señalará con el pronombre $\dot{\varepsilon} \gamma \omega \dot{\omega}$, en caso de que se inscriba el interlocutario o narratario se indicará con el

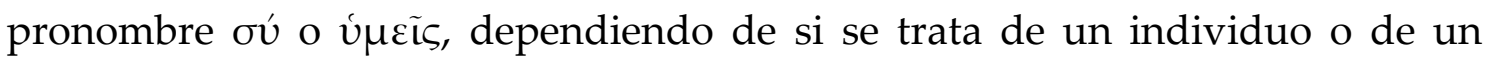
grupo. En algunos casos también puede aparecer un nombre en vocativo, esto se da particularmente en las apelaciones a un interlocutario en segunda persona singular.

Finalmente, para analizar los roles que la persona yámbica asume en el enunciado poético, empleamos la noción de "escenografía" (scénografia) postulada por Maingeneau ${ }^{96}$ Este autor aborda operativamente el estudio de la enunciación desde el concepto de scène d'énonciation y distingue hacia su interior tres planos complementarios a partir de los cuales se puede estudiar todo texto: en primer lugar, la "escena englobante" (scène englobante), que se corresponde con el tipo de discurso general dentro del cual se enmarca un texto, por ejemplo, un discurso religioso, político, literario, etc. Aunque esta caracterización es un poco laxa, permite sin embargo definir el estatus de los

${ }^{96}$ Maingueneau (2004, págs. 197-210; 2010, págs. 15-6). 
participantes en un cierto espacio pragmático. En segundo lugar, la "escena genérica" (scène générique), que remite a la ubicación de un texto dentro de un género discursivo particular, situado en un contexto histórico y cultural determinado. El género, en tanto dispositivo de comunicación y conjunto de normas, regula a partir de diversos parámetros, que van desde la finalidad del texto hasta los soportes materiales de la comunicación, la codificación textual, y estipula cierto grado de expectativa por parte del receptor. Por último, Maingueneau considera la "escenografía" (scénografia) como el plano donde el texto define las características de las posiciones actanciales y actoriales. Por lo tanto, no es con el marco escénico con lo que se relaciona directamente el receptor sino con la escenografía. ${ }^{97}$

El concepto de escenografía nos permite en principio agrupar las composiciones yámbicas en torno a los dos tipos de estructuras de comunicación que pueden manifestarse en el enunciado (interlocución o narración) y describir posteriormente el vertimiento actoral en cada una de las posiciones actanciales. De acuerdo con las composiciones semánticas que aparecen representadas en las diferentes escenografías es posible analizar las relaciones de identidad entre los actantes del enunciado y los de la enunciación.

\footnotetext{
${ }^{97}$ Maingueneau (2004, págs. 206-7): “La scénographie n’est pas simplement un cadre, un décor, comme si le discours survenait à l'intérieur d'un espace déjà construit et indépendant de ce discours, mais l'énonciation en se développant s'efforce de mettre progressivement en place son propre dispositif de parole. Le discours, par son déploiement même, prétend convaincre en instituant la scène d'énonciation qui le légitime. (...) La scénographie implique ainsi un processus en boucle. Dès son émergence, l'énonciation du texte suppose une certaine scène, laquelle, en fait, se valide progressivement à travers cette énonciation même. La scénographie apparaît ainsi à la fois comme ce dont vient le discours et ce qu'engendre ce discours; elle légitime un énoncé qui, en retour, doit la légitimer, doit établir que cette scénographie dont vient la parole est précisément la scénographie requise pour énoncer comme il convient, selon le cas, la politique, la philosophie, la science, ou pour prmouvoir telle marchandise."
} 


\section{ARQUÍLOCO}

\section{EL ENMASCARAMIENTO DEL 'YO' EN EL YAMBO DEL PERÍODO ARCAICO TEMPRANO}

La producción poética de Arquíloco de Paros ha sido datada hacia mediados de s. VII a. C. A pesar de que la cronología precisa de la vida de este poeta ha sido ampliamente discutida por la discrepancia de los testimonios antiguos, ${ }^{1}$ la información que transmiten dos fragmentos, la colonización de Tasos (antes del 650 a. C.) en la que participa su padre, Telesicles, y un epitafio de finales de s. VII a. C. dedicado a Glauco, ${ }^{2}$ uno de los personajes mencionados por Arquíloco, permiten situar razonablemente su florecimiento hacia el 660 a. C. ${ }^{3}$ En el fragmento 19W, hay una referencia a Giges, que reinó sobre Lidia entre el 687 y el 652 a. C., año en que Magnesia del Meandro fue destruida por los

\footnotetext{
${ }^{1}$ Para los diferentes argumentos de esta discusión, véase Jacoby (1941, págs. 97-109).

2 SEG 14.565; vid. inf. pág. 61 n. 25.

${ }^{3}$ Gentili (1996, pág. 374 n.12); Rankin (1977b, págs. 5-15).
} 
cimerios y acaba con la muerte del rey lidio. ${ }^{4}$ El contexto en que se menciona a Giges hace suponer que aún estaba vivo en el momento de la composición del yambo, sin embargo el hecho de que la referencia a este rey aparezca en boca de una persona loquens, el carpintero Caronte, no implica que este personaje, real o no, sea presentado necesariamente como una figura coetánea a la ejecución del poema. ${ }^{5}$ En el fragmento $122 \mathrm{~W}$, se hace referencia a un eclipse solar y es probable que Arquíloco se haya basado en un acontecimiento reciente. Entre los eclipses constatados en Paros durante el transcurso del s. VII a. C., se ha tomado como más factible el del 6 de abril del 648 a. C., aunque no se descarta tampoco el del 27 de junio del 660 a. C. ${ }^{6}$ Sin embargo, se presenta una situación similar a la del fr. 19W; en este yambo la mención del eclipse también aparece en boca de una persona loquens, un padre que habla acerca de su hija, por lo que este personaje tampoco tendría que ser necesariamente coetáneo a la ejecución original del poema. De cualquier manera, es indiscutible que la vida de Arquíloco transcurre entre la primera y la segunda mitad de s. VII a. C.

No todo lo escrito por Arquíloco es yambo; se conservan también composiciones en verso elegíaco (ff. 1-17W). Sin embargo fue por los poemas yámbicos que prontamente se volvió famoso. De hecho Horacio (Ars poetica 79) lo considera el inventor del Ł̌ $\alpha \beta \beta$ os aunque, como hemos visto en la introducción, este género tiene sus raíces en los cultos de Deméter y Dioniso. En relación a esto, Arquíloco y su familia aparecen en la antigua tradición biográfica estrechamente vinculados a la esfera religiosa de los ritos eleusinos. Pausanias (10.28.3), en su presentación del famoso pintor Polygnotos de Tasos, nos cuenta que este artista representó en los muros de la $\lambda \varepsilon ́ \sigma \chi \eta$ de los Cnidios,

\footnotetext{
${ }^{4}$ Arquíloco se refiere a la caída de Magnesia en el fr. 20W; vid. inf. pág. 58.

${ }^{5}$ Cf. Brown (1997, págs. 43-4).

${ }^{6}$ El eclipse del 660 a. C. fue parcial y Arquíloco parece aludir a uno total, por esta razón se considera más probable el del 648 a. C. Cf. Rankin (1977a, págs. 24-25).
} 
en Delfos, una imagen de la barca de Caronte en la cual aparecían las figuras de dos personas jóvenes identificadas como Tellis y Cleóbula. Pausanias señala

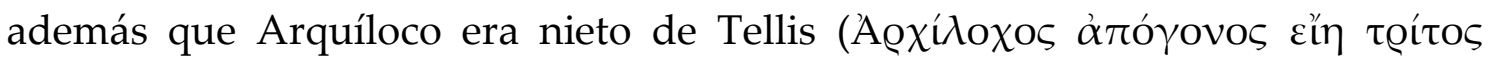

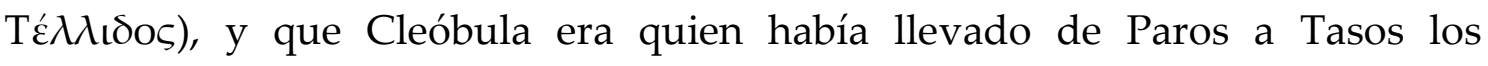

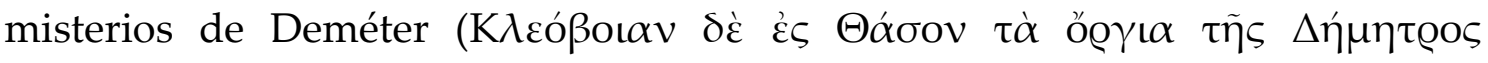

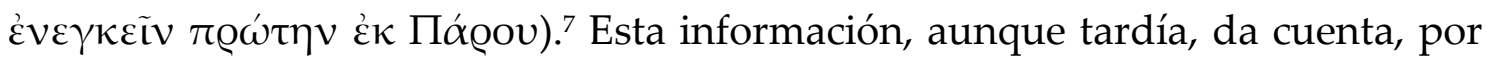
un lado, de la relación entre la familia de Arquíloco y el culto a Deméter y, por el otro, de la activa participación de esta familia en la colonización de Tasos. El

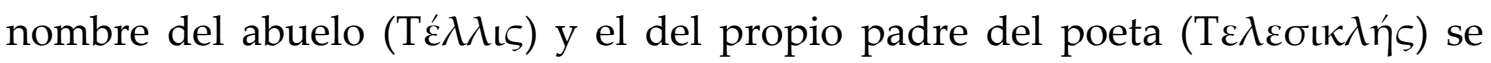
asocian con funciones religiosas del culto eleusino: $\tau \varepsilon \lambda \varepsilon \tau \eta ́$ refiere a los ritos de iniciación en los misterios de Deméter. ${ }^{8}$

El vínculo de Arquíloco con los cultos de Deméter podría confirmarse a partir de una composición destinada a la ejecución en el contexto de las festividades eleusinas:

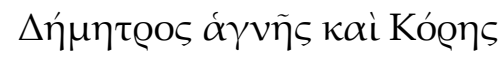

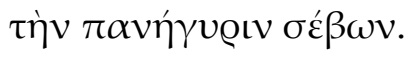

Arquíloco, fr. 322W9

celebrando el festival de la santa Deméter y Core.

Al transmitir este fragmento, Hefestión sugiere que pertenecen a los

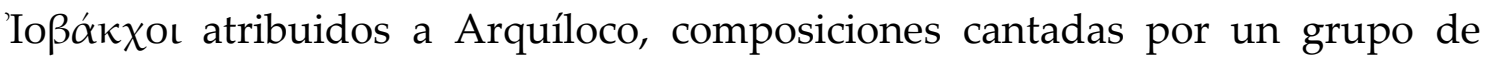

\footnotetext{
7 Para una estudio de $\lambda \varepsilon ́ \sigma \chi \eta$ de los Cnidios en Delfos y particularmente para Tellis y Cleóbula, véase Kerbic (1983, págs. 45-6). El nombre Telesicles como padre de Arquíloco aparece atestiguado en varias inscripciones del s. IV a. C.: en primer lugar, la "Inscripción de Dokimos" (CEG 2.674 Hansen = T 2 Gerber), hallada en Paros y publicada por Orlandos (1960, págs. 25556); en segundo lugar, Mnesiepis inscriptio E1 col. II 22 (SEG 15.517 = T 3 Gerber); $y$, en tercer lugar, Sosthenis inscriptio B col. IV 11 (IG XII 5 n. 445 + Suppl. pp. 212-14 Peek = T 4 Gerber). West (1974, pág. 24) sostiene que Tellis probablemente era una hipocorístico de Telesicles. Para las inscripciones véase particularmente Clay (2004).

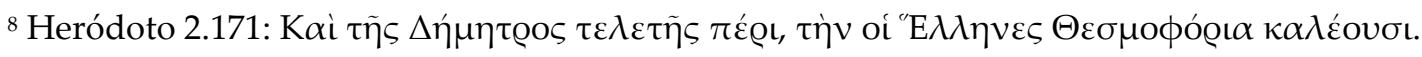

${ }^{9}$ Transmitido por Hefestión, Ench. met. 15.16 (pp. 52 Consbruch).
} 
personas instruidas por un director que iniciaba el canto con el grito: i $\omega$

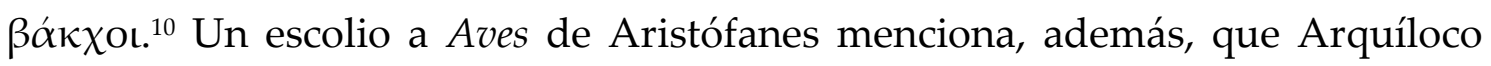
había ganado un premio por un himno a Deméter. ${ }^{11}$

Por otro lado, en relación a los cultos dionisíacos, en el fr. 120W Arquíloco se refiere a sí mismo como director ( $\left.\varepsilon^{\prime} \xi \alpha \varrho \chi 0 \varsigma\right)$ que sabe dar inicio, borracho, al ditirambo. ${ }^{12}$ En el fr. 194W se hace alusión a una $\beta \alpha \kappa \chi$ ín en un contexto vinculado a la bebida. Además, de acuerdo con la "Inscripción de Mnesiepes" (E1 col. III 15-57), tuvo un rol muy importante en la introducción del culto a Dioniso en Paros y sigue el patrón de la $\kappa \alpha \kappa o \xi \varepsilon v i ́ \alpha$ de estos rituales en diferentes regiones de Grecia. Aunque bastante fragmentario, el pasaje señala, además, que en ocasión de una festividad Arquíloco improvisó una canción, probablemente un ditirambo, del cual se citan algunos versos (fr. $251 \mathrm{~W}){ }^{13}$ pero los ciudadanos de la isla lo rechazaron por considerarlo

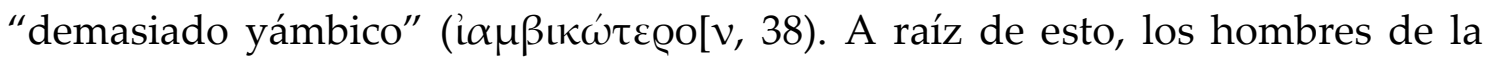

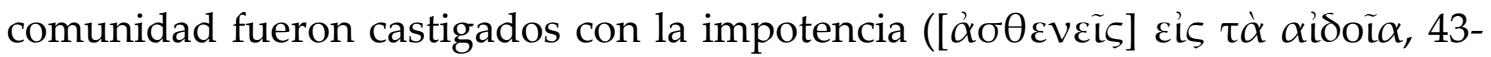
4). Tras enviar un emisario para consultar el oráculo de Delfos, el dios les comunicó que la enfermedad no se iría hasta que no honraran a Arquíloco. De este modo, Arquíloco y el yambo quedan asociados a la $\alpha i \sigma \chi \varrho o \lambda o \gamma i ́ \alpha$ dionisíaca.

La información transmitida por la propia obra del poeta y por las fuentes antiguas nos permite sostener que la producción yámbica de Arquíloco tiene

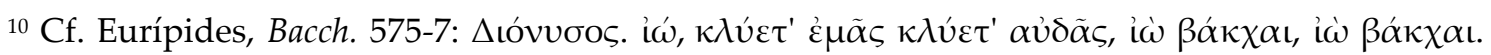

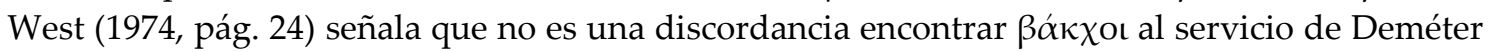
y Core ya que antes del s. IV a. C. esta palabra no se relacionaba necesariamente con Dionsio, simplemente refería a aquellos que habían atravesado algún tipo de purificación ritual. Por otro lado, West (1998, págs. 103-4) lo edita entre los fragmenta spuria debido a la violación de la ley de Porson en el dímetro yámbico.

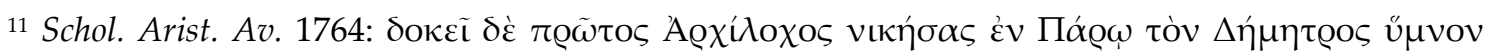

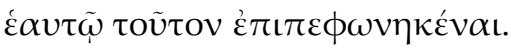

12 Vid. inf. pág. 69.

${ }^{13}$ Vid. inf. pág. 70. 
una estrecha vinculación con la esfera religiosa, sin embargo la sofisticación de su técnica integra sus composiciones a la emergencia de una forma poética claramente definida y que se constituye en relación dialéctica con otros géneros, particularmente con la amplia tradición de la épica.

En la definición del género yámbico, al igual que el elegíaco, parece ser fundamental el contexto de ejecución en la ocasión restringida del simposio y, en algunos casos, de la participación más abarcativa de las festividades comunitarias. Los yambos de Arquíloco incluyen una amplia variedad de temas: narrativas eróticas o bélicas, fábulas animales con función crítica o pedagógica, consideraciones sobre la propia actividad como poeta y como soldado, reflexiones de carácter general sobre la condición y el destino del hombre, bromas amistosas dirigidas contra compañeros e invectivas contra los enemigos del grupo comunitario. Pero esta heterogeneidad encuentra su conexión lógica en el ambiente y el espíritu del simposio masculino en donde el

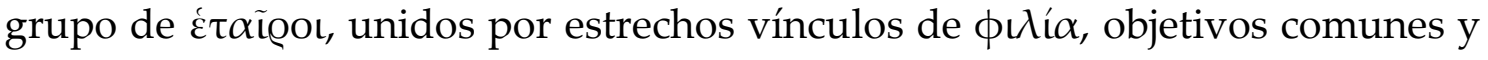
el mismo horizonte de expectativas, comparte las experiencias cotidianas y los temas de importancia para el grupo. En estas ocasiones festivas regidas por el vino compartido (Dioniso como divinidad tutelar), el yambo funciona a veces

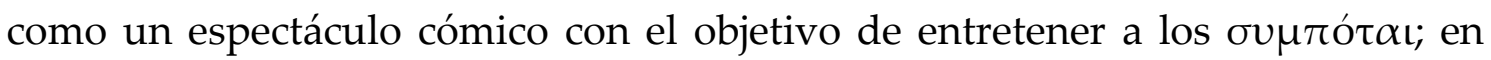
estos casos, las narrativas explícitamente sexuales, las invectivas y las ridiculizaciones en las que se introducen personajes con nombres parlantes (por ejemplo, Licambes y sus hijas), además de funcionar como entretenimiento, podrían enmascarar el ejercicio de difamación contra personas reales y coetáneas.

Para el corpus de Arquíloco seguimos el ordenamiento y el establecimiento de los textos en la edición canónica de West (1998): trímetros yámbicos (ff. 18-87W), tetrámetros trocaicos (ff. 88-167W), epodos (ff. 168204W), género incierto (ff. 205-95W), fragmentos de atribución dudosa o 
espurios (ff. 296-333W); y la de Gerber (1999) que sigue el ordenamiento de West. Además, hemos utilizado como consulta las ediciones tradicionales de Bergk (1882); Lasserre \& Bonnard (1958); Treu (1959-1968); Tarditi (1968); Diehl (1969) y Rodríguez Adrados (1990).

\section{ESTRUCTURA INTERLOCUTIVA}

Como hemos observado en la introducción, al estudiar los procesos de enmascaramiento del 'yo' en la yambografía, nuestra investigación se concentrará en los desembragues de tipo enunciativo, que instalan en el discurso poético las formas de la enunciación enunciada ('yo'-'tú'). En primer lugar, por lo tanto, dividiremos el corpus de cada poeta principalmente en dos secciones, que agrupan las composiciones yámbicas de acuerdo con la estructura de comunicación que se manifieste en el enunciado: interlocución o narración. En esta primera sección (1. ESTRUCTURA INTERLOCUTIVA) se reúnen los yambos que implican una situación dialógica y presuponen la existencia de dos posiciones actanciales: interlocutor e interlocutario. ${ }^{14}$ La segunda sección (2. ESTRUCTURA NARRATIVA) contiene aquellos poemas que postulan una situación narrativa y presuponen las posiciones actanciales de narrador y narratario. En segundo lugar, estas secciones se subdividen en diferentes escenografías que permiten describir el vertimiento actorial en cada una de las posiciones actanciales y las relaciones de identidad entre los actantes del enunciado y los de la enunciación.

${ }^{14}$ Tomo el concepto de "dialógico" en el sentido que le otorga Kerbrat-Orecchioni. Esta autora (1990, pág. 15) propone distinguir entre "interlocución dialogal", que se aplica a la interacción conversacional, e "interlocución dialógica", que se aplica a los discursos que no esperan respuesta pero que ponen en escena varias voces, es decir, que son polifónicos. 


\subsection{LA MÁSCARA AUTOBIOGRÁFICA}

Del corpus seleccionado de Arquíloco, al menos diez yambos (ff. 20, 114, $118-119,120,121,126,200,215,216$ y 296W) pueden ser agrupados a partir de una escenografía enunciativa similar: el 'yo' inscripto en el enunciado asume el rol de interlocutor y realiza una declaración de carácter personal ante su interlocutario. La identidad del interlocutor aparece en relación de concomitancia con la identidad del enunciador. En la misma dirección, en este grupo de fragmentos la identidad del interlocutario se manifiesta en correlación con la del enunciatario.

\section{FR. 20W}

El primer yambo de este grupo, el fr. 20, nos presenta un interlocutor que se lamenta por ciertos infortunios acaecidos a los habitantes de la isla de Tasos:

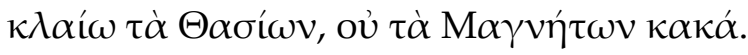

Arquíloco, fr. 20W 15

Lloro los males de los tasios, no los de los magnesios.

Los distintos textos que transmiten este trímetro lo hacen en referencia a la caída de Magnesia del Meandro durante las incursiones que las tribus cimerias llevaron adelante contra Lidia y algunas ciudades de Jonia hacia mediados del siglo VII a. C. ${ }^{16}$ En estas invasiones, el ejército cimerio derrotó al

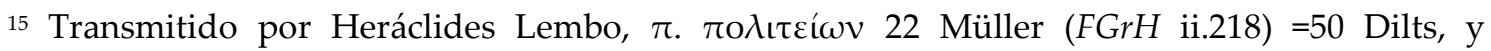
Estrabón 14.1.40.17-29. Vid. Ateneo 12.29, y Clemente de Alejandría, Stromata 1.21.131.7-8.

${ }^{16}$ Heráclides Lembo, la fuente más antigua (s. II a. C.), sostiene que los magnesios, por exceso

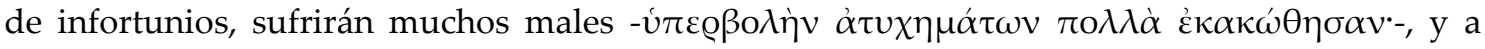
continuación cita el verso de Arquíloco. Estrabón atribuye la caída de Magnesia a los treres, a quienes identifica primero con una tribu tracia (1.3.18) y luego con una tribu cimeria (14.1.40); y en un tercer pasaje (13.4.8) señala que Calístenes ( FGrH 124 F 20) afirmaba que Sardes, capital de Lidia, había sido tomada primero por los cimerios y luego por los treres y los lícios - $\alpha \lambda \tilde{\omega} v \alpha$ เ

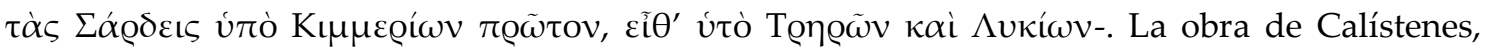
A $\lambda \varepsilon \xi \hat{\alpha} v \delta$ oov $\pi \varrho \alpha ́ \xi \varepsilon ı \varsigma$, data del siglo IV a. C. y puede haber sido una de las fuentes historiográficas más autorizadas en lo referente a las ciudades griegas arcaicas de Asia Menor. 
lidio y tomó parte de la ciudad de Sardes dando muerte al poderoso Giges. ${ }^{17}$ Probablemente el avance de ejércitos bárbaros sobre Lidia y la caída de importantes ciudades de la región como Sardes, Magnesia, Esmirna y Colofón, hayan impresionado fuertemente el mundo jónico de la época. Además del verso yámbico de Arquíloco, podemos encontrar testimonios de esta conmoción en las elegías de Calino, de Teognis y de la Teognidea. ${ }^{18}$ De acuerdo con Estrabón, la destrucción de Magnesia fue total, a tal punto que un año después los efesios, históricos enemigos de los magnesios, ocuparon el territorio y reconstruyeron la ciudad. ${ }^{19}$ A causa de su magnitud, la ruina de Magnesia pudo haberse convertido prontamente en proverbial, en tanto representaba el exterminio de un pueblo jónico por ejércitos bárbaros provenientes del norte del Mar Negro. ${ }^{20}$

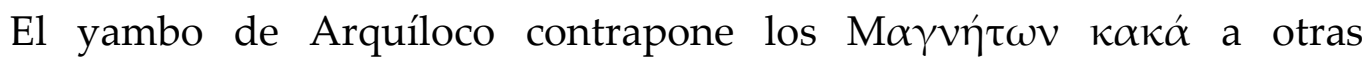
desventuras más cercanas en espacio y tiempo a la situación de enunciación

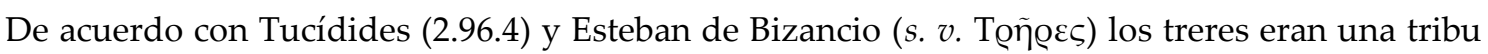

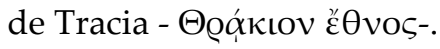

${ }^{17} \mathrm{El}$ fr. 19W de Arquíloco exhibe proverbialmente el poder y las riquezas de Giges. Acerca de estas incursiones bárbaras en Lidia, Heródoto, 1.15, afirma que Ardis, hijo de Giges y soberano de Sardes, luchaba contra los cimerios cuando estos tomaron la parte baja de la ciudad sin alcanzar la acrópolis. Jacoby (1941, págs. 104-6), tomando como fuente los anales babilonios de Asarhaddón y Asurbanipal que precisan la muerte de Giges en el año 652 a. C., considera que los M $\alpha \gamma v \eta \dot{\tau} \omega \nu \kappa \alpha \kappa \alpha ́$ a los que se refiere Arquíloco habrían ocurrido en torno a ese año. Por el contrario, Hudson-Williams (1910, pág. 262) los identifica con la sumisión de Magnesia a Lidia durante el reinado de Giges, es decir antes de las invasiones cimerias. También Hauvette (1905, págs. 28-31) y posteriormente Podlecki (1984, pág. 32) relacionan las desgracias de los magnesios con uno de los dos asedios llevados adelante por Lidia pero bajo el reinado de Candaules, predecesor de Giges.

${ }^{18}$ Calino fr. 5aW: "y ya las hordas de los feroces cimerios está en marcha", y 4W: "conduciendo a los treres"; vid. West (1998, pág. 21). Theognidea 603-4W: "Magnesia fue destruida por acciones como estas y por la desmesura -v́ßoı५-, / que ahora se derrama en nuestra sagrada ciudad"; y Teognis 1103-4W: "la desmesura -úßoıৎ- destruyó Magnesia, Colofón / y Esmirna. Sin duda, Cirno, también los destruirá a ustedes".

${ }^{19}$ Estrabón 14.1.40.17-29; vid. Ateneo 12.29.

${ }^{20}$ Aunque tardíamente y sin esclarecer demasiado cuáles fueron las razones de las desgracias de los magnesios, Juliano, Or. 7.210d-211a, refiere a $\tau \dot{\alpha}$ M $\alpha \gamma \nu \eta ́ \tau \omega \nu \kappa \alpha \kappa \alpha ́$ en forma proverbial, es decir el castigo sufrido por la desmesura de la ciudad; véase Tarditi (1959, pág. 118). 


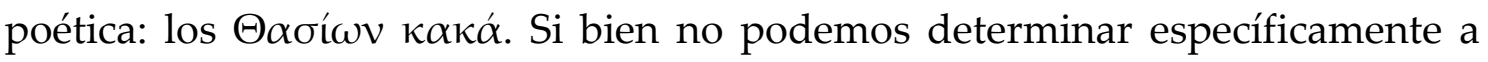
qué desgracias se refiere el poema, es posible relacionarlas con los avatares de la guerra por la colonización de la isla de Tasos que Paros llevó adelante contra los tracios, pueblo bárbaro como los cimerios. Acerca de la participación de Arquíloco en estos acontecimientos, por un lado fuentes antiguas testimonian que él y su familia estuvieron directamente vinculados con estas expediciones coloniales. ${ }^{21}$ Por otro, varias composiciones del poeta hacen referencia a la isla de Tasos y otras presentan al 'yo' inscripto en el enunciado participando militarmente contra los tracios..$^{22}$ Finalmente, hay un conjunto de fragmentos en los que el 'yo' se dirige en tono familiar a un tal Glauco, ${ }^{23}$ en uno de los cuales

${ }^{21}$ Enómao de Gádara (fr. 16.37-38 Hammerstaedt, ap. Eus. PE 6, 7, 8) y Esteban de Bizancio (s. v.

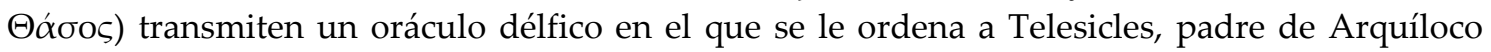
(Mnesiepes inscriptio E1 col. II 23 Clay), anunciar a los parios que debe fundar una colonia en la

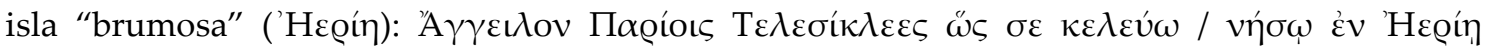

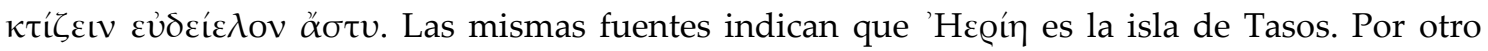
lado, Pausanias (10.28.3), como hemos visto anterirormente (vid. sup. pág. 54), dice que Polygnoto pintó en la $\lambda \varepsilon ́ \sigma \chi \eta$ de los Cnidios, en Delfos, la figura del abuelo de Arquíloco, Tellis, junto a Cleóbula, la sacerdotisa que llevó de Paros a Tasos el culto de Deméter. Para una discusión histórica y arqueológica sobre la colonización de Tasos por parte de los parios y con particular énfasis en los poemas y la cronología de Arquíloco, véanse Pouilloux (1954; 1964, págs. 3-27; 1986, págs. 114-24); Graham (1978, págs. 61-98; 2001, págs. 365-402); y Owen (2003, págs. 1-18). Para la relación entre la poesía de Arquíloco y las referencias a la colonización de Tasos, véanse además Gasparri (1982, págs. 33-41); Stella (1986, págs. 81-100); Aloni (2009, págs. 64-103).

${ }^{22}$ En los ff. 21 y $22 \mathrm{~W}$ se compara la isla con el espinazo de un asno y se dice que no es un lugar bello ni amable como otro ubicado en las costas del Siris; en 228W Tasos es llamada "ciudad tres veces miserable"; en 102W se anuncia que la miseria de todos los helenos se ha congregado en Tasos; en $5 \mathrm{~W}$ el 'yo' afirma que algún tracio se debe estar ufanando por poseer el escudo que él arrojó al huir rápidamente de la batalla; en los ff. 88 y $89 \mathrm{~W}$ se podrían estar enumerando diferentes frentes de batallas que Paros tuvo que afrontar durante esa época: en Naxos, en Tasos y en Toronea; en el fr. $91 \mathrm{~W}$ se suplica que la piedra de Tántalo no penda sobre la isla, probablemente en alusión a los sucesos bélicos en Tasos; en 93aW se narran los acontecimientos de una embajada enviada a los tracios que por algún motivo terminó con la muerte de los parios, en este fragmento a los tracios se los llama "perros".

${ }^{23}$ La aparición de Glauco, interlocutor privilegiado en los fragmentos de Arquíloco, se da en

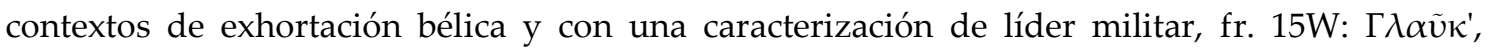

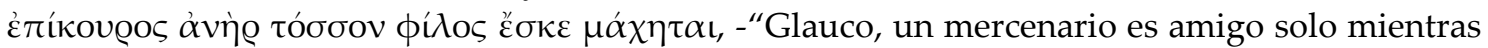

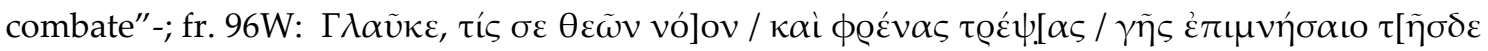

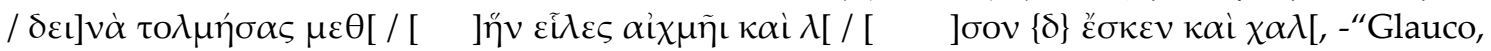
¿cuál de los dioses cambiando tu espíritu y tu corazón haría que de esta tierra te acordaras? ... 
se lo llama "hijo de Leptines". ${ }^{24}$ Una inscripción en un monumento de finales de siglo VII a. C., hallada en el ágora de Tasos y escrita en alfabeto pario, nos permite saber que Glauco, el hijo de Leptines, era una persona importante dentro de la aristocracia paria radicada en Tasos. ${ }^{25}$ Seguramente Arquíloco y Glauco eran parte del contingente militar pario que colonizó la isla de Tasos hacia mediados de siglo VII a. C. Más allá de las tradiciones posteriores que se basaron en la interpretación autobiográfica de los textos poéticos, ya sea con el fin de ensalzar al poeta o denostarlo, es indudable que la colonización de Tasos proporciona parte importante del contenido poético para los yambos de Arquíloco.

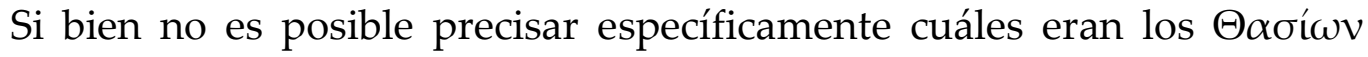
$\kappa \alpha \kappa \alpha ́$ a los que alude el fr. 20W, dada la comparación con Magnesia y su caída a manos de pueblos bárbaros, se puede sostener que las desgracias de los tasios se refieren directamente a las incursiones tracias que sufre esa ciudad. ${ }^{26}$

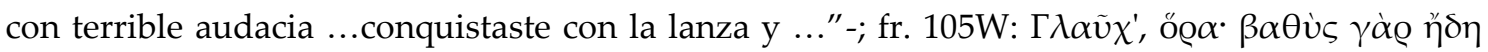

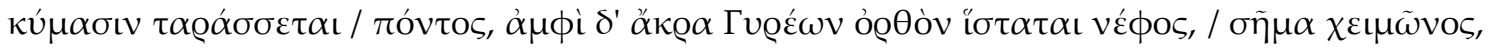

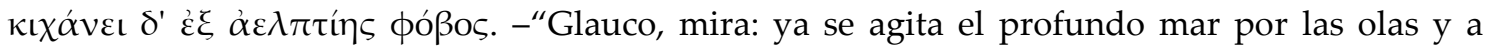
ambos lados de las cimas del Giras se levantan de frente las nubes, señal de tempestad, e inesperadamente nos alcanza el temor"-, al citar este fragmento, Heráclito, Alleg. Hom. 5.2, afirma que Arquíloco retrata con la imagen de la tormenta en el mar la guerra contra los tracios. Glauco también aparece como interlocutor en composiciones típicas del simposio de étaĩ@ol, en

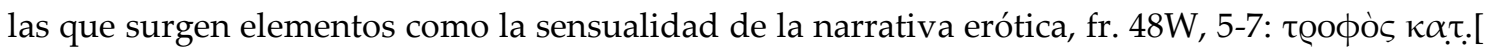

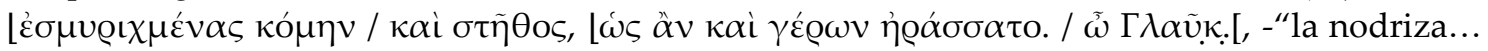
perfumados el pelo y los pechos, de tal modo que aun un viejo se habría enamorado. Glauco..."-; o la ridiculización amistosa y risible de uno de los compañeros a través de la

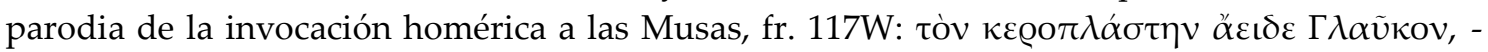
"Canta a Glauco, el delicado peluquero" -

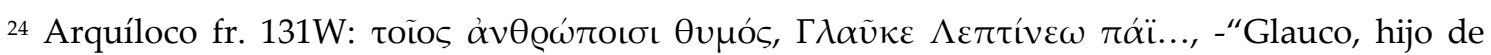
Leptines, el ánimo de los mortales..."-.

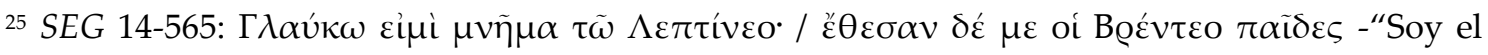
monumento a Glauco hijo de Leptines, / me erigieron los hijos de Brente"-; para esta inscripción en particular, véase Pouilloux (1955, págs. 73-86).

${ }^{26}$ Recordemos además que Estrabón, Tucídides y Esteban de Bizancio identifican a los treres con una tribu tracia (vid. sup. pág. 58 n. 16). 
El análisis discursivo nos permite determinar que el interlocutor aparece inscripto en el enunciado a través de la deixis de primera persona del verbo

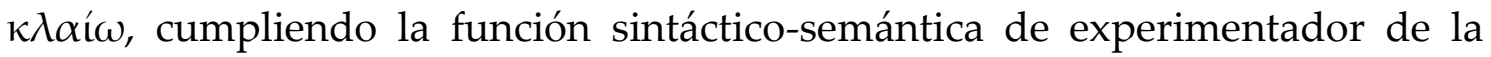
acción expresada por la predicación verbal. El interlocutario, por su parte, no se manifiesta explícitamente, pero puede presuponerse en forma implícita por reciprocidad solidaria con el interlocutor. De acuerdo con esta estructura de interlocución, podemos postular que existe una relación de concomitancia entre la identidad de los actantes del enunciado y la de los actantes de la enunciación -enunciador/enunciatario-. Es decir, a través de un desembrague de tipo enunciativo, "Arquíloco" se inscribe en el enunciado por medio de la deixis de primera persona del verbo $\kappa \lambda \alpha i ́ \omega$ expresando a su enunciatario el lamento que siente por los sucesos contemporáneos, cercanos en tiempo y espacio a la situación de enunciación. Sin embargo, esta primera persona no es un 'yo' que manifiesta un sentimiento individual e independiente del grupo comunitario, es en realidad un 'yo' representativo que encarna la voz de la comunidad de colonos parios, enunciando poéticamente aquello que cada uno de los miembros del auditorio podía llegar a sentir ante las desgracias de los tasios. ${ }^{27}$ De este modo, una de las características que nos presenta la persona yámbica "Arquíloco" dentro de sus yambos es un tipo de enmascaramiento con un procedimiento enunciativo autobiográfico para la formulación de sentimientos, juicios de valor y consideraciones sobre experiencias que afectan e inciden sobre la vida cotidiana de la comunidad de los hetaîroi.

${ }^{27}$ Fränkel (1993, pág. 479) considera que la poesía lírica griega arcaica no es un soliloquio Selbstgespräch-, sino una apelación a otros acerca de hechos importantes para todos dentro de una comunidad. De este modo, comprende al 'yo' no como un individuo sino como un "tipo" als Typos-. En este mismo sentido, Miralles \& Pòrtulas (1983, págs. 155-6) consideran que la primera persona de la poética de Arquíloco no es biográfica o individual, sino representativa de todo el grupo comunitario. Específicamente en relación al fr. 20W, Kantzios (2005, pág. 77) sostiene que el 'yo' sirve como la voz de la comunidad, ya que cualquiera dentro del auditorio podría identificarse con el "speaker" del poema. Véanse además Will (1969, pág. 88) y Miller (1994, págs. 22-3). 


\section{FR. 114W}

En el fr. $114 \mathrm{~W}$, un interlocutor en primera persona expresa su preferencia por un jefe militar cuyo aspecto físico y valores se diferencian bastante de los modelos que presenta la épica homérica:

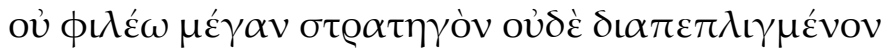

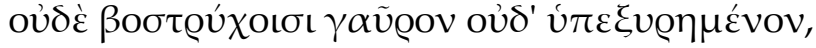

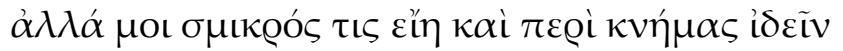

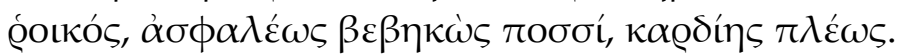

Arquíloco, fr. $114 W^{28}$

No quiero un general corpulento ni de largos trancos, que fanfarronee con sus rizos o se preocupe por afeitarse; el mío ha de ser uno morrudo y, a la vista, chueco de canillas, plantado con firmeza sobre sus pies, lleno de coraje.

Los versos en tetrámetros trocaicos de este yambo han sido citados, junto con los del fr. $5 \mathrm{~W}$, como uno de los ejemplos más significativos del cambio de mentalidad de la poesía mélica con respecto a los ideales épicos, y como una muestra del surgimiento de un 'yo' personal en la poesía griega arcaica. ${ }^{29}$

La composición se inicia con una negación en primera persona -oủ

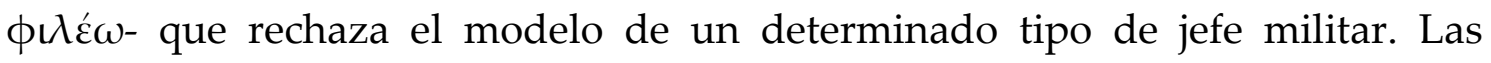
características de este general aparecen enumeradas en una secuencia simétrica encabezada cada una de ellas con la repetición de una negación enfática -oủঠè-.

\footnotetext{
${ }^{28}$ Los cuatro versos de esta composición no aparecen todos juntos en una única fuente, pero pueden ser reconstituidos fácilmente como unidad a partir de Dion Crisóstomo 33.17 y Galeno,

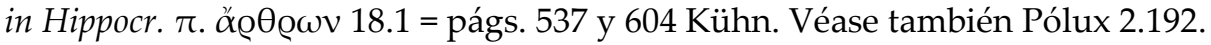

${ }^{29}$ Para las interpretaciones de este fragmento, véase especialmente Da Cunha Corrêa (2009, págs. 137-56). Ella analiza tres puntos de vista diferentes sobre el fragmento: en primer lugar, aquellos que lo leen como "anti-homérico", un ataque al ideario heroico de Homero (Schmid \& Sählin, Jaeger, Lesky y Fränkel); en segundo lugar, aquellos que consideran que el poema expresa una percepción heroica ya existente en la épica (Page, Stanford, Gelber y Russo); y, finalmente, aquellos que desvinculan el yambo de Arquíloco de la poesía homérica y lo interpretan como una crítica contra modelos heroicos vigentes en el contexto de producción poética (Hauvette, Fowler y Toohey). Por su parte, Duran (2000, págs. 201-4) presenta una

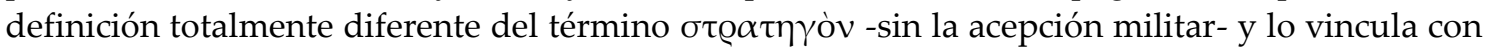
el ő́ $\chi \omega \nu$ "jefe del banquete" dentro del ámbito del simposio.
} 
El primer atributo que se desdeña es el de la altura $-\mu \varepsilon ́ \gamma \alpha \nu$-. Si bien en la épica el tamaño de los príncipes homéricos es una particularidad física que los distingue, ${ }^{30}$ no es suficiente para determinar el valor de un héroe. Del calidonio

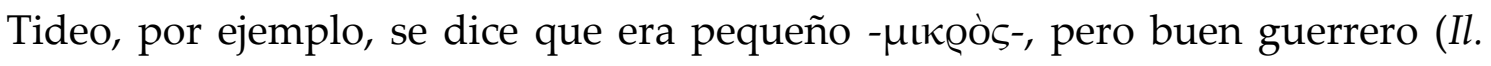
5.801). La segunda característica que se rechaza en el yambo es la de caminar

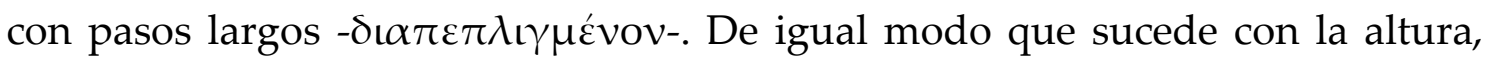
los héroes homéricos son retratados con esta manera de desplazarse. ${ }^{31}$ Sin embargo, el mismo Odiseo, que es una cabeza más bajo que Agamenón, recorre las filas de soldados con pasos ligeros y cortos como un carnero (Il. 3.196). El tercer atributo se refiere a la belleza exterior del general, pero se vincula directamente con la vanidad y el engreimiento, representados a través de la

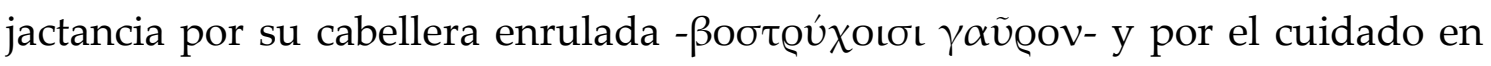

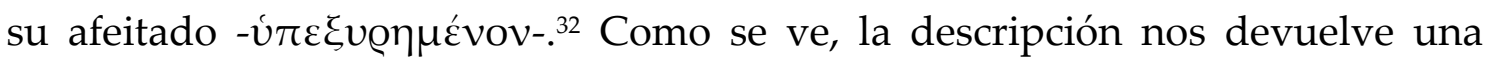
imagen de conjunto de un jefe militar vanidoso que se preocupa por su apariencia física y presume de su belleza.

En la segunda parte, el conector adversativo $\alpha \lambda \lambda \alpha \dot{\alpha}$ marca un giro en el poema mediante el cual se introducen en coordinación asindética las características del general que se prefiere. En un principio, estos atributos parecen construirse en forma diametralmente opuesta a los del jefe militar que

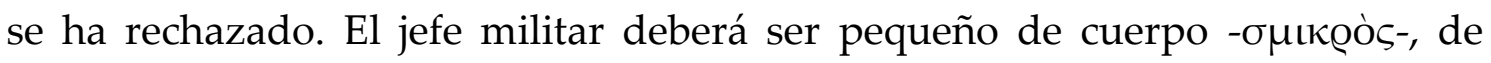
canillas chuecas $-\pi \varepsilon$ @i $\kappa v \eta ́ \mu \alpha \varsigma$ @ookós-, y plantado firmemente sobre sus pies. ${ }^{33}$

\footnotetext{
${ }^{30} \mathrm{Vid}$. Homero, Il. 3.167-70 y 6.263.

${ }^{31}$ Vid. Homero, Il. 15.686; Od. 9.450 y 11.539.

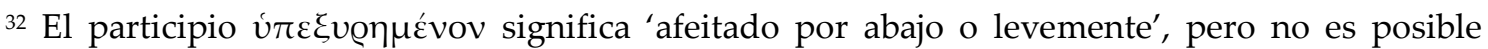
determinar si se refiere a los pelos de la cabeza o a la barba. Semónides fr. 10aW -kov@í $\alpha$ $\gamma \varepsilon v \varepsilon \iota^{\alpha} \delta \alpha-$, y muy posteriormente Luciano, Somnium 10, Dialogi mortuorum 9.4, Timon 20, Scytha 3 , hace referencia a llevar rasurada la barba.

${ }^{33}$ Galeno, op. cit., ejemplifica con los dos últimos versos del fragmento de Arquíloco la creencia

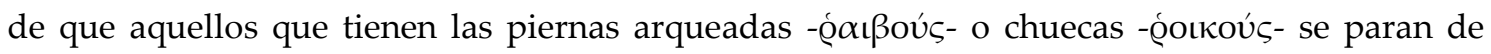
manera más firme y son más difíciles de tumbar que aquellos que las tienen perfectamente rectas.
} 
Pero, lo que se destaca realmente como valioso en el final del cuarto verso no es una característica física determinada, evidente a simple vista, sino una cualidad

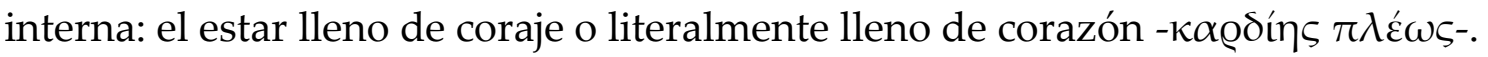

De este modo, la oposición entre los dos modelos se manifiesta en el aspecto físico, pero con el fin de exponer, en última instancia, la vanidad que ostenta el primero de ellos y el coraje que exhibe el segundo. El yambo de Arquíloco escinde entre el aspecto externo y las cualidades internas: es preferible un jefe militar pequeño, firme y con coraje, a uno alto, apuesto y vanidoso. Si bien el héroe homérico presenta por lo general una asociación entre lo externo y lo interno, entre la belleza y el valor, basada en el ideal del $\kappa \alpha \lambda$ ò

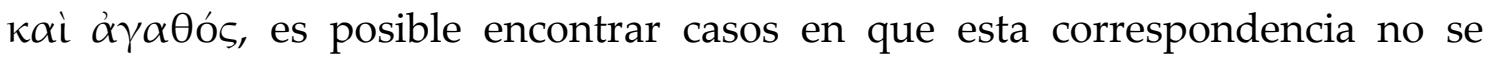

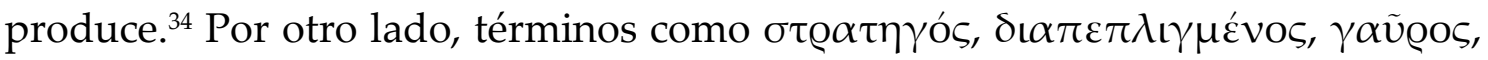

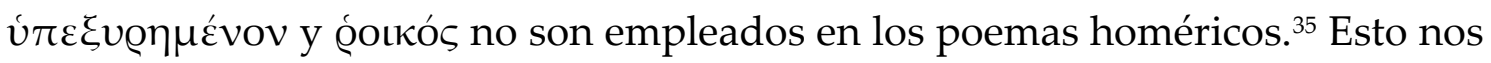
lleva a poner ciertos reparos a una lectura 'anti-homérica' del yambo de Arquíloco, en el sentido de que la separación entre la apariencia exterior y las cualidades interiores que presenta la composición haya buscado quebrar la "supuesta" correspondencia indisoluble de los héroes de Homero. ${ }^{36}$

Es más factible pensar en que la preferencia por un determinado jefe militar esté vinculada con la confrontación entre los modelos bélicos vigentes en

\footnotetext{
${ }^{34}$ Además del ya mencionado caso de Tideo (Il. 5.801), pequeño de tamaño pero buen guerrero, es posible citar otros ejemplos de la disociación entre el aspecto exterior y el valor interior en la épica homérica: Aquiles acusa a Agamenón de tener ojos de perro -кvvò ő $\mu \mu \alpha \tau \alpha$ - pero

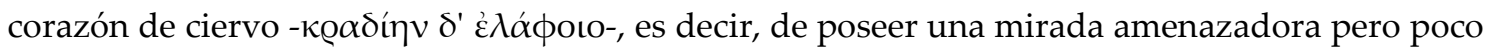
coraje (Il.1.225); Héctor le reprocha a Paris su cobardía diciéndole que a pesar de tener una bella

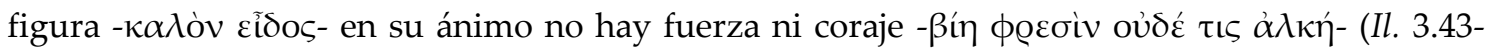

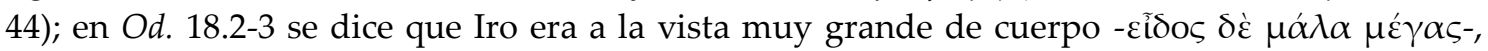

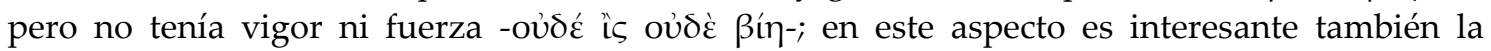
respuesta que Ulises da ante la provocación de Euríalo en Od. 8.166-77, en donde afirma que los dioses no dieron por entero a todos los hombres la noble figura, el valor de ánimo y la elocuencia, y concluye diciendo que un dios le otorgó a Euríalo una figura muy distinguida -

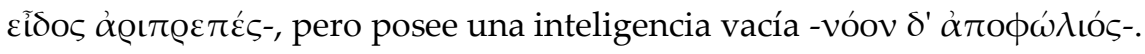

35 Vid. Scherer (1964, págs. 101-2); Page (1964, pág. 158).

36 Vid. Podlecki (1984, pág. 41).
} 
la tradición poética y la realidad del campo de batalla de mediados de siglo VII a. C. En este encuadre, la elección de un general menos vistoso, pero más eficaz y más acorde con las circunstancias de la guerra, que Arquíloco como soldado conocía muy bien, podría asociarse al surgimiento de las efectivas tácticas hoplíticas. Como es sabido, una de las bases de esta técnica era la formación en falanges cerradas en la que cada uno de los soldados tenía la misma importancia que aquel que se encontraba a su lado. La eficacia y el éxito de estas tropas no dependían del valor y del coraje individual sino de la uniformidad de las filas y de la coordinación en los movimientos. No importaba cuál era el riesgo que asumía el soldado hoplita, no importaba si la presión más fuerte del enemigo se ejercía directamente sobre su sector, debía mantenerse firme defendiendo su posición porque cualquier ruptura en la formación podía provocar el debilitamiento de la fila y el quiebre de la falange. ${ }^{37} \mathrm{Si}$ un soldado caía, su posición era inmediatamente ocupada por uno de sus compañeros. En este tipo de táctica, por lo tanto, los actos de arrojo individual no tenían ningún valor en particular, por el contrario, al igual que la cobardía y la huida, podían generar desorden entre los propios compañeros y dejar gravemente en riesgo la disposición de la fila. ${ }^{38}$ A diferencia de los príncipes homéricos, símiles de lo divino, los generales hoplitas no se diferenciaban demasiado del resto del ejército y su areté no dependía de la ejecución de grandes proezas heroicas que

\footnotetext{
${ }^{37}$ En sus retratos de las falanges hoplíticas, Tirteo encomia la actitud de mantenerse en primera línea sin ceder, plantado firmemente con los dos pies en la tierra; vid. ff. 10.31-32W (=11.21-22) y 12.15-17W. Vid. Da Cunha Corrêa (2009, págs. 152-4).

${ }^{38}$ Hanson (1989, pág. 36) nos da una imagen del enfrentamiento entre ejércitos de hoplitas y advierte sobre lo vital de mantener la cohesión de las filas en esta táctica bélica: "After the clash between the front ranks of armored infantry determined the direction of momentum and the one side made an inroad into the ranks of the other, battle degenerated into a massive, pushing contest as rank after rank struggled to solidify and increase local advantages until the entire enemy's formation was destroyed. Yet, if the defeated could somehow maintain enough cohesion, a fighting withdrawal of sorts was possible. A great number died only when there was a sudden collapse, a collective loss of nerve, when the abrupt disruption of the phalanx sent men trampling each other in mad panic to the rear, either in small groups or, worse, individually to save themselves from spear thrusts in the back."
} 
sirvieran para la gloria personal y la fama eterna, sino que su valor dependía de la capacidad para mantener el orden de las falanges y coordinar los movimientos tácticos, tratando de evitar cualquier acto que pudiera causar un quiebre en las filas. Su ejemplaridad consistía en mantenerse firme en el frente de la batalla, defendiendo su posición y arengando al resto de los compañeros para que no descuidaran sus posiciones.

Frente a la descripción realista de este general se encuentra el ideal del héroe épico, cuya máxima expresión la conocemos a través de los poemas homéricos, pero esto no significa que Arquíloco tuviera en mente a Homero en la oposición de los dos tipos de jefes militares ni que todos sus poemas deban ser considerados anti-homéricos. El ideal épico estaba presente en una tradición poética, tradición de la cual tanto Homero como Arquíloco participaban. En el yambo, a los valores aristocráticos y heroicos de este ideal, probablemente persistente en la ejecución de poemas épicos durante la época de Arquíloco, se le opone el realismo inmediato y despojado del nuevo soldado.

Como se puede constatar, el interlocutor se inscribe deícticamente en el

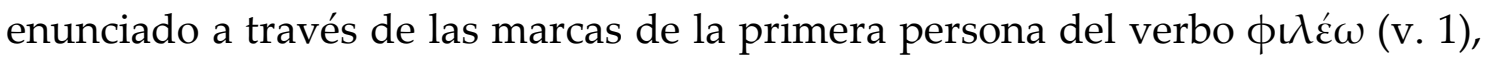
en la función de sujeto experimentador, y por el pronombre not (v. 2), funcionando como dativo posesivo o beneficiario. Por su parte, el interlocutario no aparece explícitamente en el enunciado, pero se presupone nuevamente en reciprocidad solidaria con el interlocutor. La identidad de estos actantes está en concomitancia con la del enunciador y la del enunciatario respectivamente. De este modo, "Arquíloco", en tanto persona yámbica, se dirige a su auditorio para manifestar la preferencia por un determinado tipo de jefe militar. Sin embargo, esta preferencia puede no ser interpretada como una expresión individual.

Por un lado, si consideramos la hipótesis de lectura del fragmento como una crítica realista contra la tradición poética que encomia el ideal épico, el yambo podría estar poniendo en perspectiva los valores heroicos y 
aristocráticos que esa tradición había construido. En el campo de batalla, la emergencia de la táctica hoplítica y el reclutamiento a gran escala de hombres provenientes de diferentes clases sociales trajeron consigo la democratización del ejército y situaron en un plano de igualdad a los generales con los soldados rasos. ${ }^{39}$ Así, bajo la luz de la organización militar hoplítica, la subversión del ideal épico por medio de la contraposición con un nuevo modelo de general podría implicar la revisión de los antiguos valores aristocráticos y otorgar voz a la emergencia de nuevos ideales. Ideales que, en última instancia, eran pregonados por las transformaciones que se venían dando en la incipiente configuración social de las ciudades-estados griegas, con el surgimiento de la tiranía y el fortalecimiento de una nobleza ligada al comercio que comenzaba a disputarle el poder a la antigua aristocracia hereditaria. En lo que respecta al jefe militar, es posible que la crítica del modelo épico y la elección de un general más acorde a la táctica hoplítica fuera un sentimiento compartido por el grupo comunitario de soldados que constituía el auditorio de los yambos de Arquíloco. Este hecho nos lleva a pensar nuevamente en que la primera persona que expresa el rechazo y la preferencia no es un 'yo' individual, sino un 'yo' representativo del grupo de hetaîroi.

\footnotetext{
${ }^{39}$ Hanson (1989, pág. 138) señala que el general tenía un "mandato" durante el transcurso de la guerra y, si sobrevivía, este cargo expiraba y volvía a ser un soldado raso: “The natural affinity in the classical Greek world between the general and his men derived from the shared knowledge that the commander was essentially little more than a hoplite who was stationed nearby on the right wing, the first to encounter the charge of the enemy, and a citizen who should surely serve as an ordinary soldier again once his tenure had expired." Al comparar el ethos épico y con el nuevo ideal que presenta el sistema hoplítico, Wheeler (1991, págs. 122-3) pone de manifiesto el proceso de democratización que trajo aparejado esta táctica: "The warrior code of the Iliad defined the Greek heroic ethos: an aristocracy of warrior princes in competition with each other for personal honor and eternal fame -both won in battle with great personal danger and without higher political goals. In apparent contrast, the hoplite phalanx emerged as the military representative of the polis. This mass infantry formation of files usually eight deep expanded the warrior function from the aristocracy to the middle class and by the fourth century at times also to the lower classes. Integrating aristocrats and shopkeepers, urban dwellers and farmers, the phalanx became (from one viewpoint) a conglomerate of 'interchangeable parts', in which all put aside personal distinction for the common good of the state. Here was military democracy in action."
} 


\section{FF. 120, 121, 126 Y $215 W$}

En cuatro fragmentos $(120,121,126$ y $215 \mathrm{~W})$, un interlocutor expresa ante el auditorio una reflexión que alude a su propia práctica como compositor de poesía. En el fr. 120W, esta primera persona afirma saber cómo dar inicio al ditirambo:

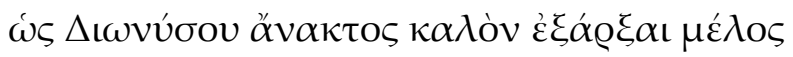

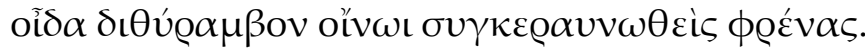

Arquíloco, fr. $120 \mathrm{~W}^{40}$

ya que sé dar inicio al hermoso canto del soberano Dioniso,

el ditirambo, cuando mi corazón ha sido fulminado por el vino.

En este yambo el interlocutor se presenta como alguien que sabe

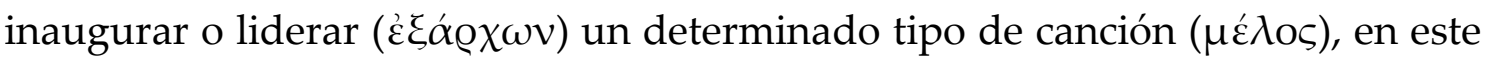
caso el ditirambo, cuya mención más antigua del término es precisamente la de este fragmento de Arquíloco. Este tipo de composición tiene un origen ritual dentro del culto de Dioniso. Aunque es difícil determinar cómo era su representación pública en el período arcaico, a partir de las pinturas vasculares de distintas regiones, cabría sostener que el ditirambo era ejecutado por un coro cuyos integrantes, coronados con hiedra, danzaban y cantaban acompañados por música de flauta. ${ }^{41}$ El propio flautista era quien instruía al coro y se constituía en $\dot{\varepsilon} \xi \alpha ́ \alpha \chi \omega \nu$ del ditirambo. Privitera (1957, págs. 95-110) ha sugerido que la apertura del ditirambo de la cual se enorgullece aquí “Arquíloco" podría estar relacionada con los restos de un poema que aparece en la "Inscripción de Mnesiepes":

O $\Delta$ เóvvбos $\sigma[$

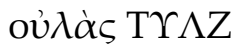

о̆ $\phi \alpha \kappa \varepsilon \varsigma \alpha$ [

\footnotetext{
40 Transmitido por Ateneo 14.24.

41 West (1992, págs. 16; 210-11).
} 
$\sigma \tilde{v} \kappa \alpha \mu \varepsilon \lambda[\llcorner\chi \varrho \alpha$

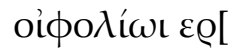

Arquíloco, fr. $251 \mathrm{~W}^{42}$

Dioniso...

cebada...

uvas en agraz...

higos dulces como la miel...

al cogedor...

Estaríamos aquí frente a los restos de un himno clético en honor a Dioniso, himno que funcionaría como preludio ( $\alpha v \alpha \beta o \lambda \eta ́)$ del canto coral. ${ }^{43}$ Este proemio, de ejecución monódica y tal vez repentizada, estaba a cargo el

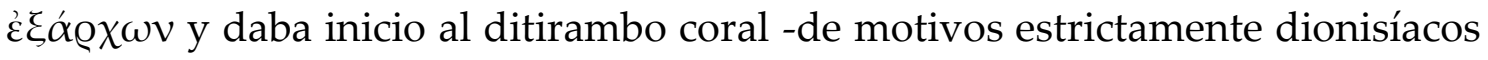
y tradicionales-, el cual él mismo se había encargado de instruir y que dirigiría a través de la ejecución de la flauta. ${ }^{44}$

El fr. 121W, también en tetrámetros, presenta la misma estructura enunciativa y temática:

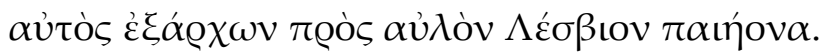

Arquíloco, fr. $121 \mathrm{~W}^{45}$

iniciando yo mismo, acompañado de la flauta, el peán lesbio.

${ }^{42}$ Transmitido por Mnesiepis inscriptio E1 col. III 31-35 Clay. La "Inscripción de Mnesiepes" fue realizada sobre dos mármoles hacia el siglo III a. C. Las piedras fueron encontradas en Paros en 1949 y pertenecían a un templo o recinto sagrado dedicado al culto heroico del poeta,

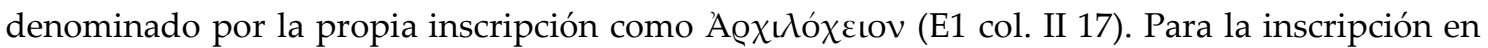
general y para una interpretación de este fragmento en particular, véase Clay (2004, págs. 1623).

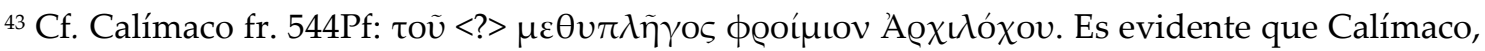
contemporáneo de Mnesiepes, tenía conocimiento del fr. 120W de Arquíloco; el término ф@ó́ptov (proemio) refuerza la hipótesis sobre la improvisación por parte del poeta de la

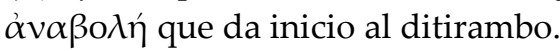

${ }^{44}$ Para un análisis del fr. 251W desde la hipótesis del ditirambo, véanse Müller (1985, págs. 99151), Zimmermann (1992, págs. 63-6) y Berranger (1992, págs. 175-85). Véanse además los análisis de Ieranò (1997, págs. 175-9) y Ornaghi (2009, pág. 162 ss.)

45 Transmitido por Ateneo 5.9-10. 
Nuevamente el interlocutor se presenta como $\dot{\varepsilon} \xi \alpha ́ \alpha \chi \omega v$, pero ya no del ditirambo sino del peán lesbio. Al igual que el ditirambo, el peán también es un canto coral de origen ritual, vinculado en este caso al culto de Apolo. Sus contextos y formas de ejecución eran bastante variados, podía consistir

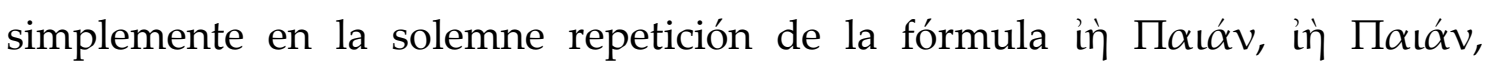
cantada al unísono en una ocasión privada, o en extensos y sofisticados cantos corales con acompañamiento de flauta o cítara para su presentación en festividades que involucraban a una comunidad entera, como podrían haber sido los de Píndaro. ${ }^{46}$

Es interesante advertir que los fragmentos 120 y $121 \mathrm{~W}$ remiten a la ejecución de composiciones que podrían implicar un auditorio y un contexto más amplio que el del yambo y el simposio, probablemente performances corales vinculadas a festividades públicas, al menos festividades ligadas al ámbito dionisíaco y apolíneo. ${ }^{47}$

Otro yambo en que el interlocutor manifiesta a su auditorio poseer un saber, que podría relacionarse con una determinada forma poética, es el fr. 126W:

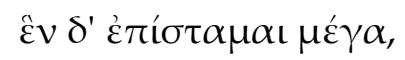

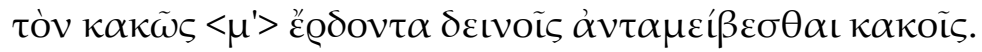

Arquíloco, fr. $126 \mathrm{~W}^{48}$

y una gran cosa conozco:

contestar con terribles males a quien me trata mal.

En este yambo, el interlocutor afirma conocer bien cómo corresponder con terribles males a quien obra mal con él. El fragmento se encuadra dentro de la tradición paremiológica griega de defender y ayudar a los amigos y atacar a

\footnotetext{
46 West (1992, págs. 15-6).

47 Aloni (2009, pág. 20).

48 Transmitido por Teófilo, ad Autolycum 2.37 (=pág. 94 G).
} 
los enemigos. ${ }^{49}$ Es posible pensar, por lo tanto, que la transposición de la formulación ética que postula el poema al campo de la poesía se corresponde

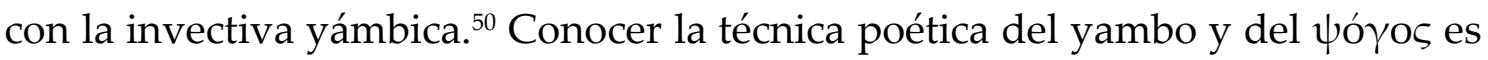
lo que le permite al interlocutor "contestar con terribles males."

Dentro de este grupo, se podría incluir también un trímetro yámbico en el cual el interlocutor enuncia que ya no le importan los yambos:

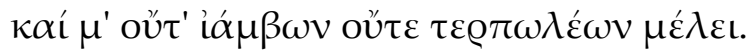

Arquíloco, fr. 215W 51

y no me importan ni yambos ni placeres.

El fragmento ha llegado hasta nosotros a través de una cita del gramático y escritor del siglo XII Johannes Tzetzes. En el contexto de la cita, Tzetzes compara el dolor de Aquiles por la muerte de Patroclo (Il. 24) con la pena que manifiesta Arquíloco por la pérdida de su cuñado en un naufragio. ${ }^{52}$ Con este

49 "Hacer el bien al amigo y el mal al enemigo" es una de las máximas que rigen el comportamiento del hombre griego arcaico, véase por ejemplo Arquíloco, fr. 23.14-5W:

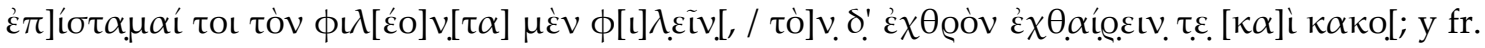

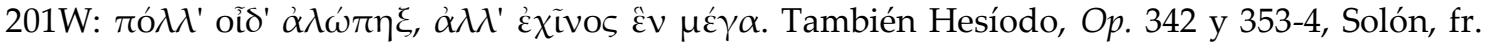
13.5, Teognis 869 W, Píndaro, P. 2.83. West (1997, pág. 500) remonta esta tradición hasta las culturas mesopotámicas.

${ }^{50}$ West (1974) afirma: "Invective was clearly regarded as the outstanding feature of the genre" (pág. 22); y unas páginas más adelante: "I suggest that we may recognize iambus most confidently in those types of subject matter for which elegiacs are never used: that is, in explicitly sexual poems, in invective which goes beyond the witty banter we found in elegy, and in certain other sorts of vulgarity" (pág. 24). Véase también Nagy (1976, págs. 194-6).

${ }^{51}$ Transmitido por Tzetzes, Alleg. Homer. 24.129.

${ }^{52}$ Inmediatamente a continuación del fr. 215W, Tzetzes transmite el fragmento elegíaco $11 \mathrm{~W}$ de Arquíloco, que aparece también en Plutarco (Quomodo adolesc. aud. poet. 12.33a-b). Al referir este fragmento, Plutarco, uno de los autores más citados por Tzetzes, confronta el rechazo de los placeres por parte de Aquiles ante la muerte de Patroclo con la posición que asume Arquíloco ante la pérdida del marido de su hermana. Sostiene que el poeta no fue "alabado" -où

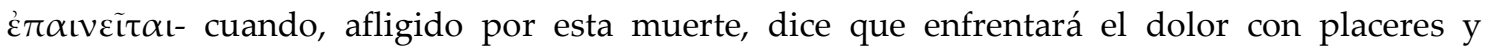
diversiones:

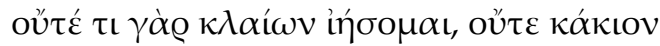

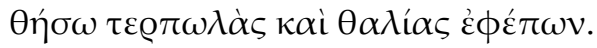


trímetro, Arquíloco estaría respondiendo a quienes le insistían en que dejase de lado sus sufrimientos y volviera a componer yambos. ${ }^{53}$

$\mathrm{Al}$ igual que el fr. $120 \mathrm{~W}$ con respecto a $\delta \imath \theta \dot{\rho} \alpha \mu \beta \mathrm{s}$, el fr. $215 \mathrm{~W}$ es el testimonio más antiguo que se tiene del término ǐ $\alpha \mu \beta o \varsigma$. Aunque su etimología no ha sido estipulada con precisión, en este poema podemos observar que en sus orígenes li $\alpha \mu \beta$ o hace referencia a un determinado tipo de poesía y no a un pie métrico en particular. Posteriormente, con el advenimiento del teatro, el término pasará a designar casi exclusivamente el trímetro yámbico, empleado en la tragedia y la comedia, pero, durante el período arcaico, es probable que bajo ese concepto se comprendieran no solamente las composiciones en trímetro sino también aquellas en tetrámetros trocaicos y las combinaciones epódicas. Dover (1964, pág. 189) ha señalado que Arquíloco podría haber utilizado el término para referirse a todas las formas poéticas en que compuso, puesto que

ya que ni lo remediaré llorando, ni lo pondré peor por dedicarme a placeres y festividades.

Es interesante la lectura que realiza Rotstein (2010, págs. 151-6) de los dos fragmentos en relación a la transmisión de Plutarco y la más tardía de Tzetzes. Para esta autora, Tzetzes no habría podido realizar una lectura de primera mano de la obra de Arquíloco, sino solo a través de comentarios o citas de otras obras. A raíz de esto es probable que haya interpretado el fr. 215W bajo la lectura que hace Plutarco del fr. 11W, es decir en vinculación con la pérdida del cuñado del poeta y en comparación con la pena de Aquiles por la muerte de Patroclo. El punto de conexión sería la palabra $\tau \varepsilon \varrho \pi \omega \lambda \eta$, que aparece en ambos fragmentos.

53 Tzetzes, Alleg. Homer. 24.125-29:

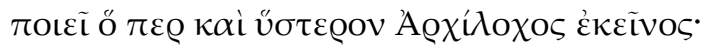

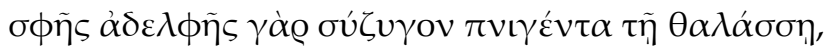

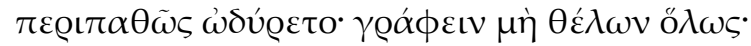

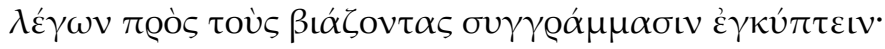

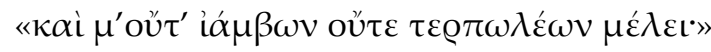

Él [Aquiles] hizo lo mismo que posteriormente Arquíloco, cuando el marido de su hermana se ahogó en el mar; profundamente apenado, sin deseos ya de componer, les dijo a quienes le exigían que se dedicara a sus composiciones: «...y no me importan ni los yambos ni los placeres.» 
lo determinante no habría sido el metro o el lenguaje sino el "tipo de ocasión" o el contexto social en que estos poemas eran ejecutados. ${ }^{54}$

En este fragmento, la palabra l’ $\alpha \mu \beta o \varsigma$ aparece en coordinación con

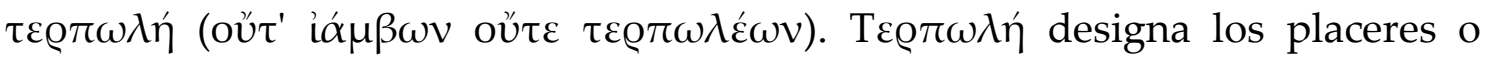
entretenimientos relacionados con reuniones de convivialidad ritual, tales como

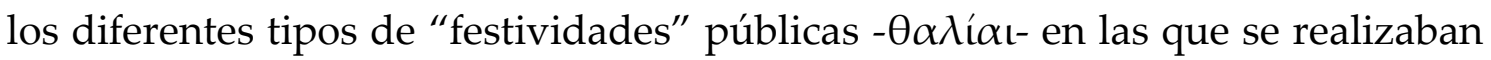
banquetes sacrificiales, ${ }^{55}$ o como el simposio, de carácter más restringido y privado. ${ }^{56}$ El disfrute en estas ocasiones habría consistido no solamente en la comida y la bebida, sino también en la música, la danza y la poesía. Por lo tanto, si $\tau \varepsilon \varrho \tau \omega \lambda \eta \dot{~ h a c e ~ r e f e r e n c i a ~ a ~ d e t e r m i n a d a s ~ o c a s i o n e s, ~ p a r t i c u l a r m e n t e ~ a l ~ p l a c e r ~}$ que proviene del banquete y del simposio, los Ł̌ $\alpha \mu \beta$ o tendrían que referir una determinada forma poética compatible con esos tipos de ocasiones. ${ }^{57}$ De este modo, a partir del fr. $215 \mathrm{~W}$ podríamos postular un contexto general para la ejecución de la poesía yámbica en la Grecia arcaica: la convivialidad pública o privada, y una función particular dentro de este contexto: el entretenimiento.

Como se ha observado, en estos fragmentos se manifiesta una reflexión por parte del interlocutor ya del saber ya del desinterés ocasional en la composición de un determinado tipo de poesía. Desde el punto de vista de la comunicación poética, en el fr. $120 \mathrm{~W}$ el interlocutor se inscribe en el enunciado

${ }^{54}$ La hipótesis de Dover produjo diferentes reacciones entre los investigadores, véanse West (1974, pág. 25), Bartol (1993, pág. 32), Brown (1997, págs. 48-9), Bowie (2001, págs. 2-3) y Kantzios (2005, pág. 4).

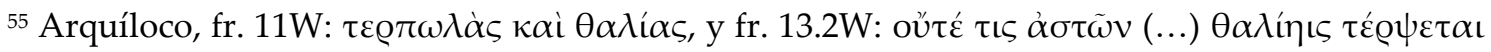
oủðè Tódıc. Véanse Schmitt-Pantel (1990, págs. 14-33) y Murray (1990, págs. 5-7).

${ }^{56}$ Homero, Od. 18.37; Hesíodo, Th. 206 y 917, Sc. 273; Theognidea 984 y 1068W; Sófocles, Aj. 1200 у 1202.

${ }^{57}$ West (1974, pág. 25) sostiene: “' $\alpha \mu \beta o$ are here something that goes with $\tau \varepsilon Q \pi \omega \lambda \alpha$ í, festivity (cf. $11.2 \tau \varepsilon \varrho \pi о \lambda \dot{\alpha} \varsigma \kappa \alpha \grave{i} \theta \alpha \lambda \hat{i} \alpha \varsigma$ ), and something that Archilochus might be taking an interest in if he were not grieving. They are surely more than just verses, they are an occasion. The poems of his that were known as iambi must have been so called because they were associated with such occasions." 
a través de la deixis de primera persona singular del verbo oĩ $\alpha$, ocupando la función sintáctico-semántica de sujeto experimentador; en el fr. 121W, por

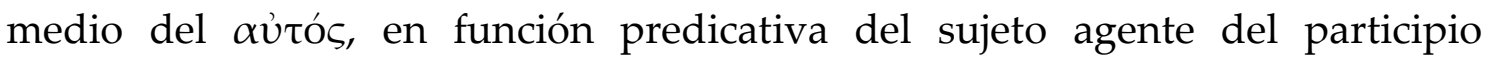
દ̇łó $\varrho \chi \omega v$; en el fr. 126W, a través de las marcas de primera persona del verbo

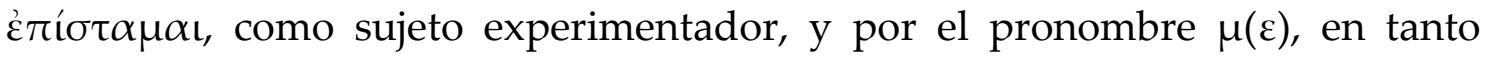

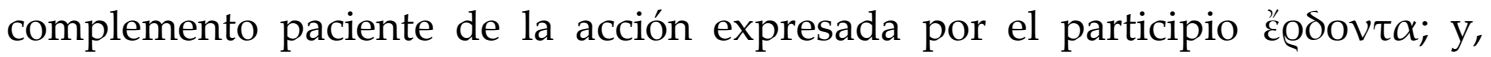
finalmente, en el fr. $215 \mathrm{~W}$, a través del pronombre $\mu(\mathrm{ol})$ funcionando como complemento experimentador en relación al verbo $\mu \varepsilon ́ \lambda \varepsilon$. La tematización por parte del interlocutor del propio quehacer poético dentro del poema, es decir la referencia metapoética, genera una fuerte focalización del 'yo': la identidad del interlocutor busca aparecer explícitamente en concomitancia con la identidad del enunciador. En la afirmación de su saber o de su desinterés momentáneo por la composición de determinadas formas poéticas, el 'yo' se define en estos yambos por la función que cumple dentro del grupo comunitario: la propia función de compositor. ${ }^{58}$

\section{FR. 118-119W}

Dentro del grupo de yambos que implican una expresión de carácter personal por parte del interlocutor ante el interlocutario-auditorio situamos los ff. 118 y $119 W$ :

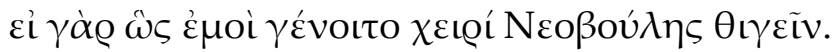

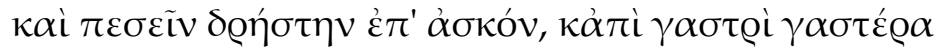

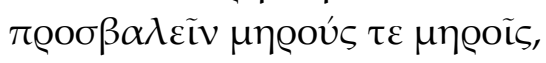

Arquíloco, ff. 118-119W59

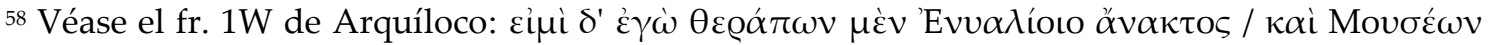

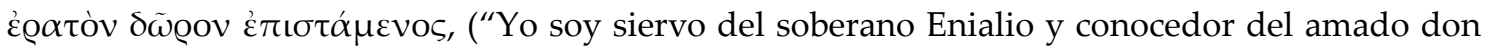
de las Musas"). En este poema en versos elegíacos, el 'yo' constituye su singularidad a partir de su relación con dos potencias divinas, las cuales definen las dos funciones que asume dentro del grupo comunitario: soldado y poeta.

${ }^{59}$ El fr. 118W ha sido transmitido por Plutarco, de E apud Delphi 5.386d; el 119W nos llega a través del Schol. Eur. Med. 679. Sigo aquí la unión de los fragmentos propuesta por Elmsly (1818, pág. 302) y continuada por la mayoría de los editores; para una fundamentación de esta unión,
} 
¡Si me fuera posible tocar con la mano a Neobule, así, y caer sobre su odre dispuesto a la tarea, y panza sobre panza apretar muslos contra muslos!

En este yambo, el interlocutor se inscribe en el enunciado a través de la deixis pronominal غ̇uoí, en la función de complemento beneficiario de la idea expresada por el predicado verbal. Como hemos visto con respecto a este primer grupo, la situación de comunicación poética se caracteriza por la concomitancia de identidad, por un lado, entre el interlocutor y el enunciador, y, por otro, entre el interlocutario y el enunciatario. Este desdoblamiento de las instancias de destinador y destinatario nos permite considerar en este yambo, por ejemplo, la modalización discursiva en dos niveles. En primer lugar, el enunciado aparece modalizado en función desiderativa. Esta modalización es atribuible a la figura del interlocutor, es él quien manifiesta a su interlocutario el deseo de tocar y acostarse con Neobule. Pero, en segundo lugar, si pensamos la comunicación a nivel enunciador-enunciatario, es posible sostener que, en última instancia, la expresión de deseo busca provocar la risa del auditorio. Esta modalización aparece en el nivel enunciativo y es atribuible, por lo tanto, al enunciador.

Dos elementos en el poema son de interés para examinar las modalizaciones que se producen en estos niveles. Primero, los textos sobre los que se basa la tradición biográfica del poeta transmiten que las familias de Arquíloco y de Neobule formalizaron un compromiso matrimonial entre ellos, pero que, a causa de algunas desavenencias, este pacto fue roto por el padre de la joven; ${ }^{60}$ sin embargo, es muy probable que Nعoßoú $\lambda \eta$ sea uno entre los

véase Degani \& Burzacchini (1977, pág. 28) con amplia documentación; también Bossi (1990, págs. 173-6).

${ }^{60}$ La tradición biográfica sobre la relación entre Arquíloco y Neobule, la hija de Licambes, puede reconstruirse a partir de diferentes fuentes antiguas, véanse por ejemplo Orígenes, Cont. Cels. 2.21K.; Dio Chrys., Or. 74.16; Anth. Pal. 7.69, 71, 351 y 352; Horacio, Epist. 1.19.30 y Epod. 
muchos nomina ficta que aparecen en los yambos de Arquíloco. ${ }^{61}$ El nombre podría traducirse como "aquella que tomó una nueva decisión" -la "decisión" quizás de no casarse con el poeta o de casarse con otro-. ${ }^{62}$ Más allá de que este nombre pudiera hacer referencia a alguna mujer dentro de la comunidad de Paros o de que fuera solamente una invención, sin ningún tipo de referente real, es evidente que si en el enunciado el interlocutor expresa su deseo de tocar y poseer a Neobule, en la enunciación, sin embargo, la intención es la de provocar la risa. Es decir, en el nivel enunciativo, "Arquíloco" en tanto persona yámbica asume ante su auditorio la máscara de un amante que expresa su deseo sexual por una mujer, máscara que se juega en el enunciado a través de la primera persona. El segundo elemento a destacar es la construcción paronomástica explícitamente sexual que aparece en los dos últimos versos del yambo y que podría constituir una parodia del estilo épico. ${ }^{63}$

6.11-14 con Ps. Acrón, Schol. ad loc. (=Test. 26 Gerber); Marcial 7.12.6; Ovidio, Ibis 53-4 y Schol. C ad loc. (=Test. 29 Gerber) e Ibis 521-4 y Schol. ad loc. (=Test. 31 Gerber); Eustacio, in Hom. Od. 11.277 (1684.45). En estos textos se dice que Licambes comprometió a su hija Neobule en casamiento con Arquíloco, ofreciéndole además la correspondiente dote. Pero, tiempo después, el padre de la joven rompió ese pacto y, en venganza, Arquíloco compuso poemas de invectiva - maledicum carmen scripsit- contra Licambes y sus hijas, haciendo que ellos se suicidaran. Sin embargo, como lo ha demostrado Lefkowitz (1976; 1981; 1991; 2012), estas tradiciones biográficas tomaban su información de los propios poemas y no de fuentes historiográficas. Con respecto a Arquíloco, esta autora demuestra que la información sobre su vida transmitida por detractores, como Critias, o por sus apologetas, como Mnesiepes, Sóstenes y Demeas, proceden de la lectura que ellos mismos realizaron de la obra del poeta y no de documentos históricos, conformando lo que ella denomina "fictional biographies": "all the biographical 'data' we have about Archilochus (and for that matter, about every other archaic poet) was generated from Archilochus' poetry by critical speculation, starting in the fifth century. This means, of course, that the details of Archilochus' life as they have come down to us, no matter how plausible they may sound, were invented long after the fact." (1976, pág. 182).

${ }^{61}$ Sobre los nomina ficta y nombres parlantes en la obra de Arquíloco, véase particularmente Bonanno (1980).

62 Van Sickle (1975, pág. 152): "We know that Archilochus shared the archaic alertness to the etymological fitness of names -'Neoboule' suits the kind of girl who changes her marriage plans." También, Degani (1977, pág. 42 n.64): “El nome [Neobule] designa evidentemente 'inconstanza.'"

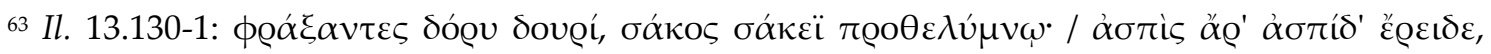

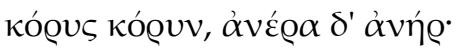


Por lo tanto, si Neobule es un nombre parlante que alude a una mujer real dentro de la comunidad de Paros o a un personaje dentro de un conjunto de personajes que conforman una narrativa en una suerte de entretenimiento tradicional, ${ }^{64}$ y si además existe una parodia del estilo épico, es posible afirmar entonces que el 'yo' aparece fuertemente caracterizado como personaje. ${ }^{65}$ Podría pensarse entonces que uno de los atributos de la persona yámbica "Arquíloco" es la caracterización del 'yo' basada en la comicidad y en lo explícitamente sexual. Además, en este yambo, la función de un 'yo' estereotipado podría vincularse con la invectiva personal, si detrás del nombre Neobule existiera un referente real, o simplemente con un entretenimiento, si Neobule fuera solamente el nombre de un personaje ficticio. ${ }^{66}$

\section{Fr. 216W}

Aunque es difícil reconstituir el contexto en que aparece el único verso que se ha conservado del fr. $216 \mathrm{~W}$, su estructura enunciativa es similar a la de los fragmentos que componen este grupo:

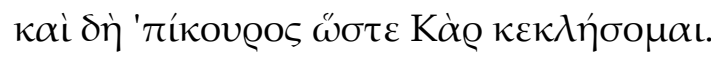

Arquíloco, fr. 216W67

y seguramente, como a un cario, seré llamado mercenario.

Se trasnmite en los escolios platónicos como explicación del proverbio “correr el riesgo cario". En efecto, en Laques 186e-187c, Sócrates indaga a Laques y a Nicias para saber cuál de los dos es mejor educador y si alguno de ellos

${ }^{64}$ West (1974, pág. 27).

${ }^{65}$ La caracterización del 'yo' como personaje se ve más claramente en los yambos que poseen una estructura narrativa. Véase al respecto el apartado correspondiente.

${ }^{66}$ En relación a esto, West afirma: "If Lycambes and his daughters were not real people, then Archilochus was playing a role. It was perhaps part of this role that he presented himself as a bastard, son of a slave-woman called Enipo (fr. 295); the name, with its connotatio of $\dot{\varepsilon} v ı \pi \alpha$, is suspiciously apt for an iambographer's mother" (1974, pág. 28).

${ }^{67}$ Transmitido por Schol. Plat. Lach. 187b y Schol. Plat. Euthyd. 285c. 


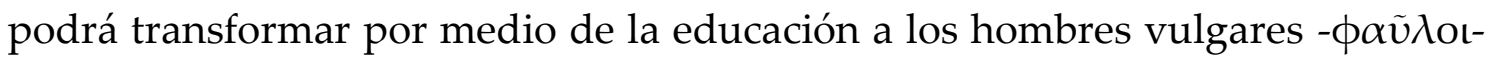
en personas bellas y de mérito - $\kappa \alpha \lambda$ oú $\tau \varepsilon \kappa \alpha ̉ \gamma \alpha \theta$ oí-. En el diálogo, Sócrates les advierte que si quisieran hacer un experimento no deberían realizarlo sobre sus hijos o los hijos de sus amigos sino sobre un cario, para no comenzar a aprender cerámica modelando un jarro, es decir, para tratar de no ponerse a practicar algo demasiado complejo, y, en caso de error, no sea perjudicial. En Eutidemo 285c, al discutir acerca de si la educación puede transformar a un hombre malvado en bueno, Sócrates se postula para que se realice la prueba sobre él mismo, "como si fuera un cario".

Los escolios a estos dos pasajes señalan que la expresión "el riesgo de los carios" es un proverbio acerca de aquellos que corren el mayor peligro, pues los guerreros carios fueron los primeros en recibir recompensas al formar parte de ejércitos extranjeros, es decir, en ser mercenarios; por este motivo, eran enviados al lugar más peligroso de la batalla. De acuerdo con Estrabón, 14.2.2728 , los carios, expertos en la guerra, vagaban por toda Grecia participando en

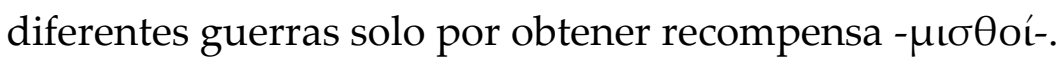

A partir de este verso, y en vinculación con el fr. 15W, la crítica ha construido una imagen de un Arquíloco mercenario. ${ }^{68}$ Sin embargo, la única línea de este fragmento que ha llegado hasta nuestros días no nos permite concluir que exista aquí una confesión por parte del poeta acerca de esta condición. El verbo en futuro expresa solamente la posibilidad de que lo llamen mercenario, pero no se puede saber por cuáles razones. Quizás estén vinculadas con los sucesos de su vida militar, pero no hay ningún indicio de que esto sea necesariamente de este modo. Al igual que lo que sucede en el fragmento analizado anteriormente, la primera persona de este yambo podría ser también la voz de un personaje, es decir, un 'yo' no-autobiográfico.

${ }^{68}$ Croiset (1913, pág. 191); Parke (1933, pág. 4); Privitera (1965, pág. 24); Rankin (1977, págs. 29, 40); Wheeler (1991, pág. 132). 
De cualquier manera, de acuerdo con la estructura enunciativa de este único verso, el interlocutor aparece inscripto deícticamente en el enunciado a través de las marcas de primera persona singular del verbo $\kappa \varepsilon \kappa \lambda \eta ́ \sigma o \mu \alpha \mathrm{l}$, en la función sintáctico-semántica de sujeto afectado. El interlocutario no se manifiesta explícitamente. Podríamos sostener que la identidad de ambos actantes entabla una relación de concomitancia con la identidad del enunciador y del enunciatario, respectivamente.

\section{FF. 200W Y 296W}

Dentro de este primer grupo de yambos, en el que se abordan composiciones con una estructura interlocutiva y que contienen una declaración que podría se considerada de carácter personal, es posible considerar también los ff. $200 \mathrm{~W}$ y $296 \mathrm{~W}$ :

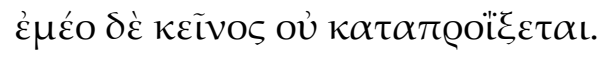

Arquíloco, fr. 200W69

él no se escapará de mí sin castigo.

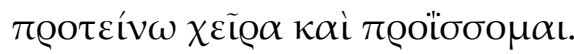

Arquíloco, fr. 296W 70

extiendo la mano y pido limosna.

Estos dos fragmentos han sido transmitidos por varios léxicos a

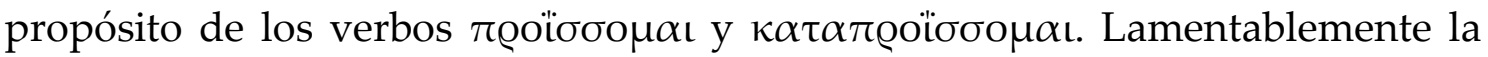

69 Los fragmentos aparecen como ejemplificación etimológica de $\pi \varrho 0 \ddot{\sigma} \sigma \sigma \mu \alpha \iota$ y

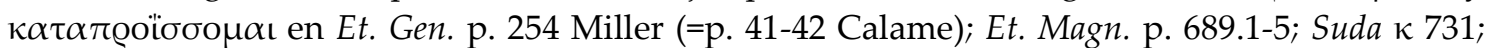

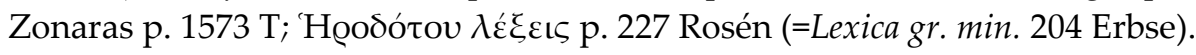

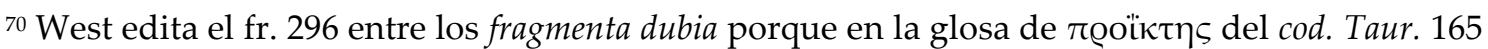

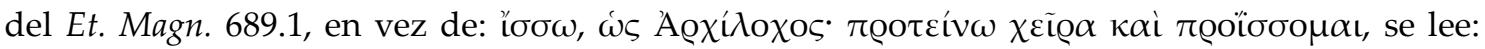

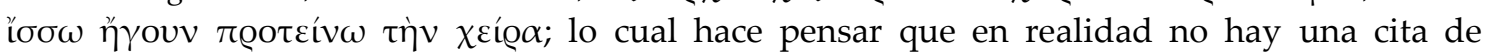

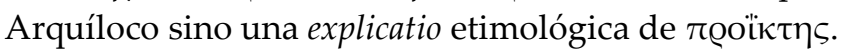


cita lexicográfica no nos permite reconstruir el contexto en que los versos fueron enunciados.

Desde el punto de la comunicación poética, sin embargo, es posible percibir que los fragmentos presentan algunas diferencias. Por ejemplo, el fr. 200W podría encuadrarse mejor dentro de una escena narrativa antes que interlocutiva. El narrador se manifiesta en el enunciado a través de la deixis pronominal દ̇ućo en la función sintáctico-semántica de complemento paciente

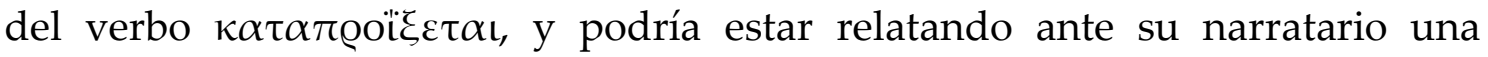

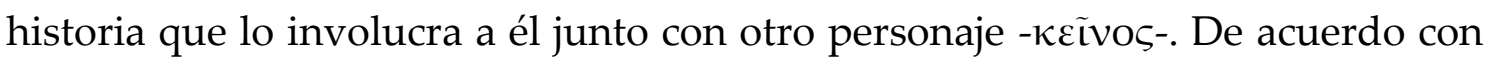
la estructura enunciativa, es posible postular además una relación de concomitancia entre las identidades del narrador y del narratario con las del enunciador y del enunciatario. Por su parte, el fr. 296W presenta una escena de interlocución. El interlocutor se manifiesta explícitamente en el enunciado a

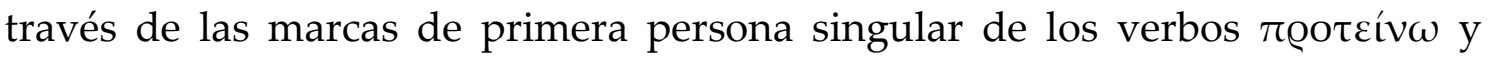
$\pi \varrho o i ̈ \sigma \sigma o \mu \alpha \mathrm{L}$, en la función de sujeto agente. $\mathrm{Al}$ igual que lo que sucede con el fragmento 200W, las identidades de estos actantes mantienen una concomitancia con las del enunciador y del enunciatario, respectivamente.

\section{CONCLUSIONES PARCIALES}

Los yambos analizados hasta el momento comparten una misma estructura de enunciación (a excepción del fr. 200W que, como hemos visto, presenta una escena narrativa), que podríamos esquematizar de la siguiente manera: 


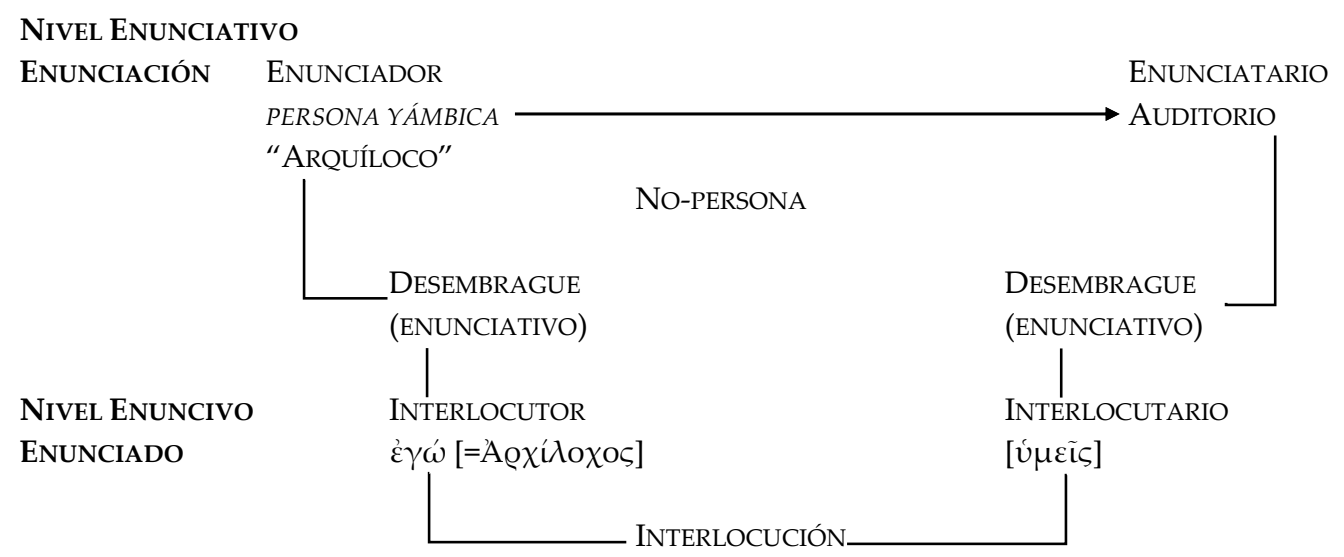

Hemos dividido el esquema en dos niveles: enunciativo y enuncivo. El primero se corresponde claramente con la instancia de enunciación, mientras que el segundo con la del enunciado. En el nivel enunciativo, por un lado, encontramos la relación de comunicación entre el enunciador y el enunciatario, posiciones actanciales que aparecen ocupadas por los actores "Arquíloco", en tanto persona yámbica, y por el Auditorio, entendido como representación del destinatario en la instancia de enunciación poética.

Por otro lado, el proceso de disyunción desde la instancia de enunciación hacia el enunciado se realiza a través de un desembrague de tipo enunciativo que instala en el discurso las formas de la enunciación enunciada. Dentro del nivel enuncivo, la posición actancial de interlocutor aparece ocupada en forma explícita por un elemento deíctico de primera persona singular, pronominal o verbal, que hemos consignado en forma representativa a través del pronombre $\varepsilon \gamma \gamma \omega$. Como se ha podido apreciar a través del examen de los fragmentos, la identidad de esta primera persona mantiene una relación de concomitancia con la identidad del enunciador, por esta razón el deíctico $\dot{\gamma} \gamma \omega \dot{\omega}$ se equipara con el

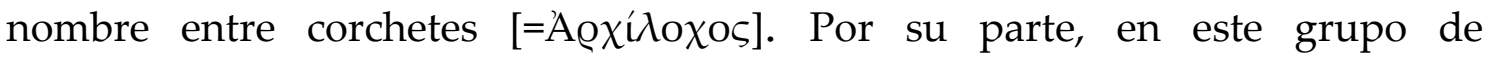
fragmentos, la posición de interlocutario no se manifiesta deícticamente en el enunciado, pero puede presuponerse por principio de reciprocidad solidaria con el interlocutor. Del mismo modo, la identidad de este interlocutario entabla 
una relación de concomitancia con la del enunciatario, a raíz de esto y por no manifestarse en forma explícita en el enunciado se consigna entre corchetes con

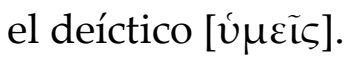

La escenografía enunciativa que nos presenta este grupo de yambos es, por lo tanto, la de un interlocutor en primera persona que puede ser identificado con el enunciador. ${ }^{71}$ Este interlocutor realiza manifestaciones de carácter personal (estados de ánimos, preferencias, deseos, juicios de valor, etc.) ante un interlocutario que no aparece deícticamente marcado en el enunciado y cuya identidad se corresponde con la del enunciatario. Las características de esta escenografía nos permiten pensar que uno de los atributos de la persona yámbica "Arquíloco", en tanto máscara enunciativa regida por el género yámbico de la Grecia arcaica, es la manifestación autobiográfica. Sin embargo, este 'yo' que, en superficie, o escenográficamente, aparece como autobiográfico, no se reduce meramente a la expresión de un pensamiento o sentimiento individual, sino que esconde en última instancia un 'yo' que puede ser representativo de la forma de sentir o pensar de un grupo comunitario (ff. $20 \mathrm{y}$ $114 W)$, un 'yo' que se define en relación a la función de compositor que cumple dentro de la propia comunidad (ff. 120, 121, 126 y 215W), o un 'yo' tipificado, construido como personaje frente a otros personajes (fr. 118-119W). ${ }^{72}$

\subsection{LA MÁSCARA APELATIVA}

Dentro del grupo grande de yambos de Arquíloco que poseen una estructura de interlocución, encontramos un conjunto de fragmentos (particularmente tetrámetros y epodos) que se caracterizan por presentar una

71 Para el concepto de "escenografía enunciativa", véase el desarrollo realizado en la introducción (vid. sup. pág. 49 ss.).

72 En cuanto a los ff. 200, 216 y 296W, al tener apenas un verso cada uno y aparecer como ejemplo de un proverbio o como explicación lexicográfica sin ninguna información referente a sus contextos, es difícil determinar claramente la naturaleza de la primera persona que contienen. 
escenografía apelativa: el interlocutor se dirige a una persona, a un grupo de personas o a una divinidad, empleando generalmente el vocativo y el verbo en imperativo, con el fin de solicitarles algo, criticarlos o burlarse de ellos.

A partir de esta instancia, la escenografía enunciativa de estos fragmentos presenta particularmente un desdoblamiento en la identidad del destinatario: mientras que, en el nivel enunciativo, el enunciatario sigue siendo el Auditorio al cual está destinada la comunicación poética, en el nivel enuncivo, el rol actancial de interlocutario aparece ocupado por el actor al cual se dirige la apelación. Por su parte, la identidad del interlocutor se encuentra en concomitancia con la del enunciador.

Este grupo puede dividirse en dos subgrupos de acuerdo con la naturaleza del interlocutario: en el primero de ellos (1.2.1) agrupamos a aquellos yambos cuyo interlocutario es un ser humano con un nombre histórico $y$ real o con un nombre ficticio o parlante; en el segundo (1.2.2) incluimos aquellas composiciones en que el interlocutor se dirige a una divinidad.

\subsubsection{INTERLOCUTARIOS HUMANOS}

Los yambos de este subgrupo presentan, como hemos dicho, una apelación a personas reales o a personajes ficticios. El interlocutor, por lo general, dirige una pregunta, un requirimiento o una crítica cómica que pone en evidencia los defectos del interlocutario. Si aparece en el texto, su nombre está en vocativo y el verbo de la apelación en imperativo.

\section{A ERXIAS}

El nombre Erxias aparece en forma apelativa en tres fragmentos: 88,89 y 110W.

\section{Fr. 88W}

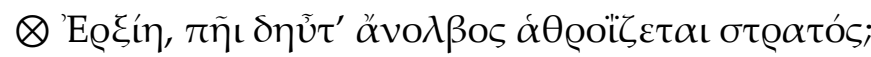


Erxias ¿dónde se reúne el infortunado ejército esta vez?

\section{Fr. 89W}

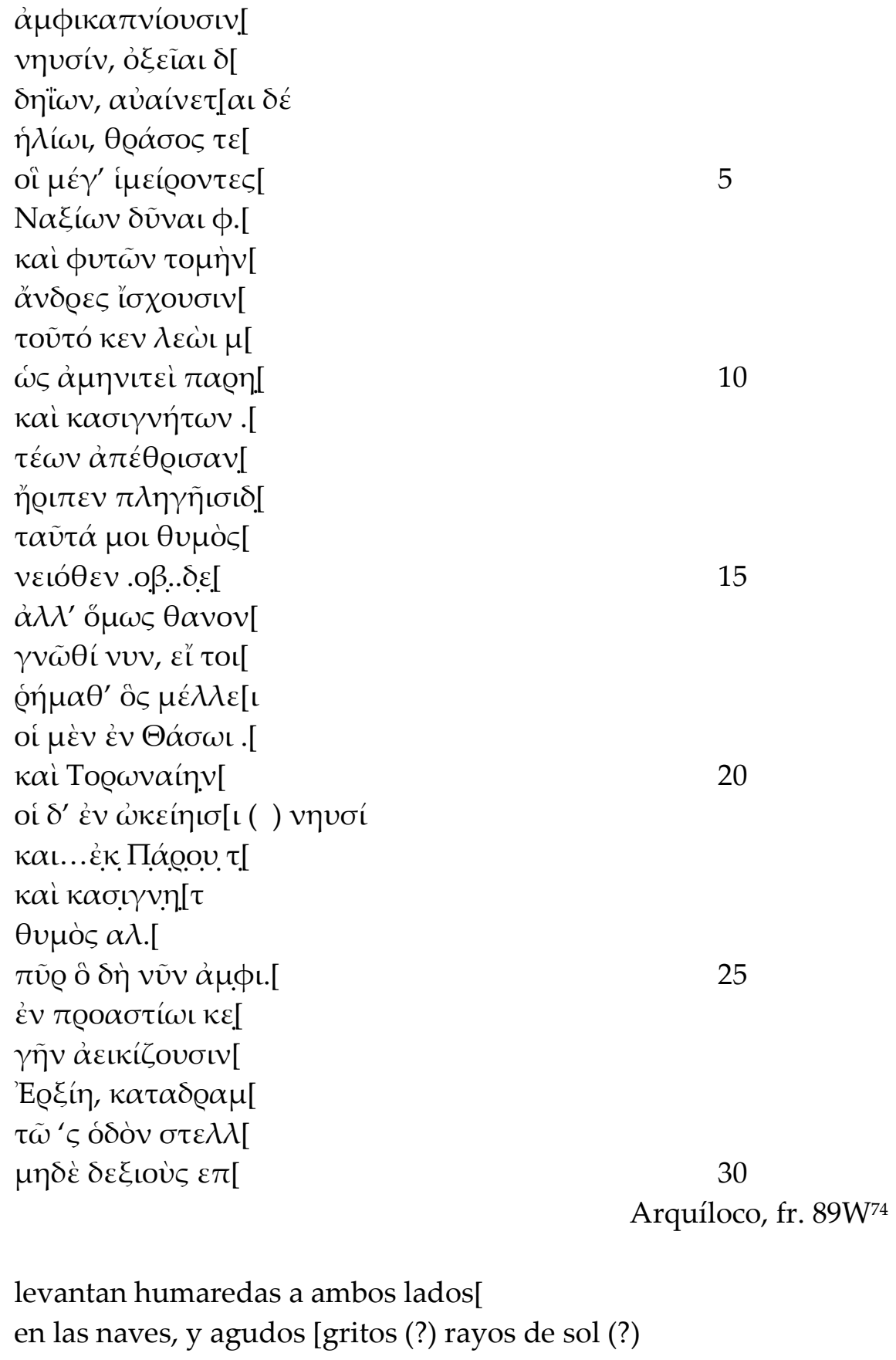

levantan humaredas a ambos lados[ en las naves, y agudos [gritos (?) rayos de sol (?)

73 Transmitido por Anónimo Ambrosiano, De re metr. (=Anecd. Varia Graeca pág. 223.2 Studemund).

${ }^{74}$ Transmitido por Mnesiepis inscriptio E2 col. I 15-44 Clay. 


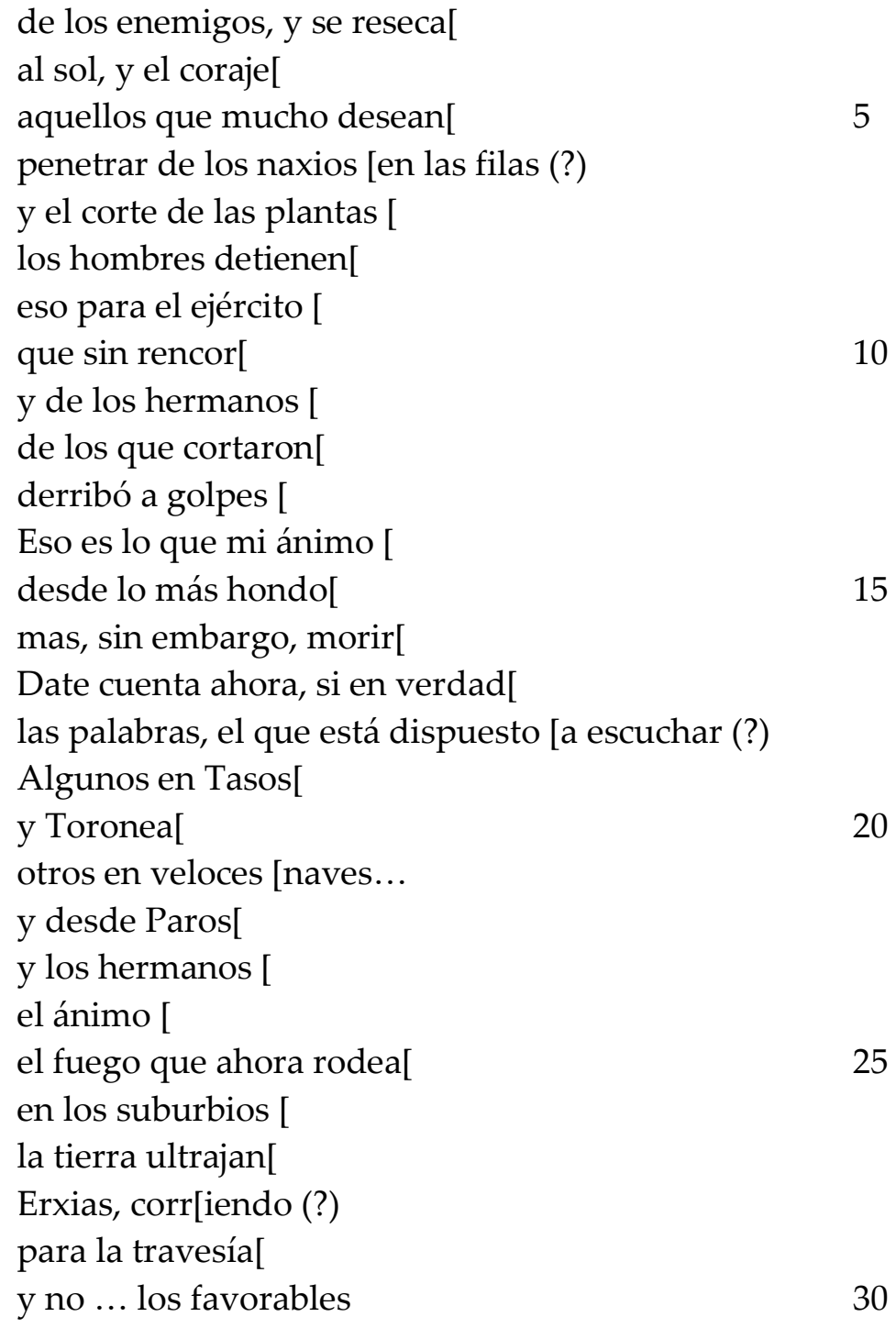

\section{Fr. 110W}

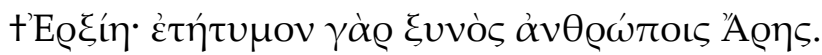

Arquíloco, fr. 110W75

Erxias, en verdad imparcial para todos los hombres es Ares. ${ }^{76}$

Los tres yambos son de temática bélica y probablemente se referían a las guerras que, hacia esa época, Paros mantenía con sus enemigos. El fr. 88W

\footnotetext{
${ }^{75}$ Transmitido por Clemente de Alejandría, Strom. 6.6.1

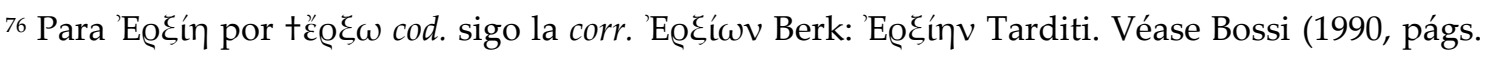
166-7).
} 
contiene una pregunta dirigida a Erxias sobre la reunión de un ejército, pero, al consistir en la cita de un único verso con el fin de dar un ejemplo del tetrámetro trocaico, su contexto no nos ha sido transmitido. ${ }^{77}$ Por su parte, el fr. $89 \mathrm{~W}$ se encuentra en la "Inscripción de Mnesiepes", como prueba de la participación de de Arquíloco en los conflictos contra los naxios y de su heroísmo. ${ }^{78}$ Lamentablemente la piedra sobre la que se halla la citada inscripción está muy erosionada y es prácticamente imposible realizar una lectura de corrido del texto. La primera parte se compone de una narrativa con verbo en tercera persona y en presente histórico y aoristo, que estaría retratando los sucesos de un enfrentamiento entre los ejércitos de Paros y de Naxos. El verbo

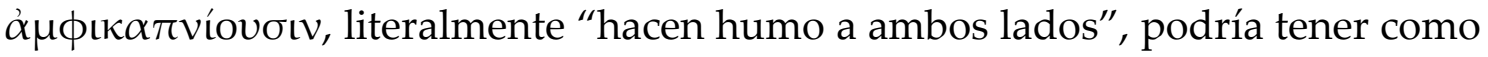
sujeto a "los enemigos", posiblemente "los naxios" (vv. 3 y 6). El segundo verso

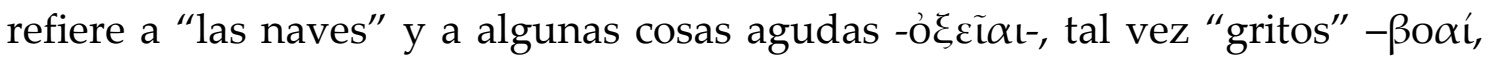

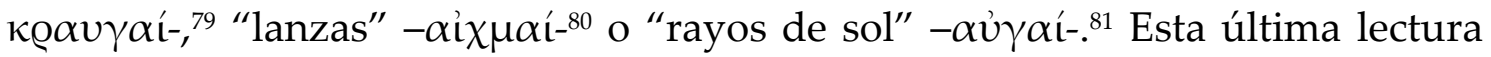

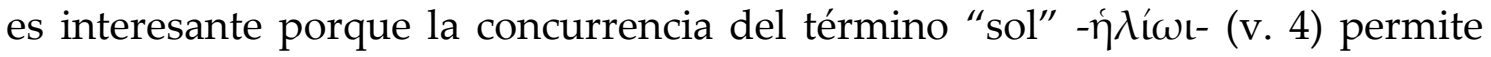
vincular este yambo con el 107W:

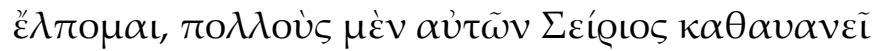

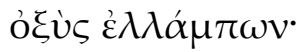

Arquíloco, fr. 107W 82

77 En el Anónimo Ambrosiano, De re metr. (=Anecd. Varia Graeca pág. 223.2 Studemund) solamente se dice que "el troqueo lleva este nombre a causa de su ritmo apresurado; por ello

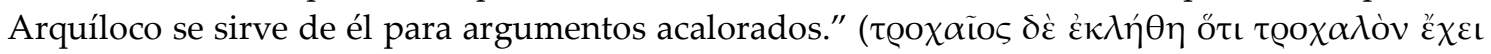

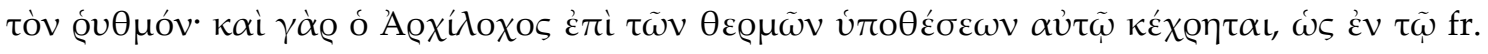
88).

${ }^{78} \mathrm{Al}$ citar el fr. 89W, la Mnesiepis inscriptio (E2 col. I 4-5 Clay) hace referencia explícita a la guerra contra Naxos como contexto de este yambo. Para una síntesis detallada de las diferentes interpretaciones de este fragmento, véase Da Cunha Corrêa (2009, págs. 195-209).

${ }^{79}$ Peek (1955, pág. 32).

${ }^{80}$ Lasserre \& Bonnard (1958).

${ }^{81}$ Kontoleon (1952, pág. 85).

82 Transmitido por Plutarco, Quaest. conv. 3.10.2.658b. 
a muchos de ellos, espero, los resecará Sirio con su agudo fulgor.

Una interpretación posible de estos versos sería que los agudos rayos del sol resecan los cuerpos de los enemigos. En los versos siguientes podría leerse algo así como "coraje [y audacia no faltan] a aquellos que mucho desean [penetrar en las filas] de naxios" (vv. 4-6), con la intención quizás de destruir las

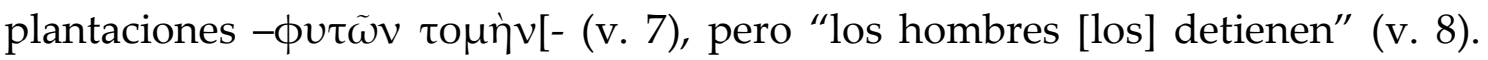
West (1974, pág. 126) se pregunta si aquellos llenos de coraje y audacia no estaría aludiendo a los más jóvenes del ejército de Paros -véot-, que están ansiosos por entrar en Naxos y destruir sus cultivos, aunque los mayores no se lo permiten. Tarditi (1958, pág. 41) considera que, si fuera posible localizar este acontecimiento en Tasos, se trataría entonces de los parios y los tasios que desean penetrar las falanges de los naxios y defender los cultivos. Es evidente que esta parte del fragmento puede ser interpretado de diferentes maneras si se considera como invasores a los parios o a los naxios, aunque los vv. 19-22 y 2527 inclinan a pensar que sería Tasos la ciudad que está siendo atacada.

Los versos que siguen presentan muchas dificultades para su lectura y no es posible recuperar el sentido del texto: se menciona al "ejército" o la "tropa" ( $\lambda \varepsilon \dot{\omega} \mathrm{l})$ (v. 9), "sin ira" o "rencor" (v. 10), "de los hermanos" (v. 11), "de los que cortaron" (v. 12), y “derribó a golpes" (v. 13).

En el v. 14, la aparición de la primera persona en presente interrumpe la narrativa en tercera persona de pretérito y parece iniciarse una percepción personal del narrador sobre esos acontecimientos: "esas cosas es lo que mi ánimo... desde lo más hondo..." En los vv. 17-18 se introduce una exhortación en segunda persona singular del imperativo: "Date cuenta ahora, si en verdad... palabras, el que está dispuesto [a escuchar (?)]” De la narración se pasa entonces a una estructura de interlocución, y es posible considerar que el destinatario de esta exhortación sea el mismo Erxias invocado en el v. 28. En los 
vv. 19-22 se habla de dos grupos distintos: "unos en Tasos... y Toronea..., y otros en veloces [naves]... desde Paros..." West (1974, pág. 126) conjetura la posibilidad de que se hable aquí de caídos en batallas sucedidas en Tasos y en Toronea, y de otros que han muerto en las naves. Tarditi (1958, pág. 42) sugiere que podría tratarse de una invasión militar de Toronea, aliada de Naxos, contra Tasos, y que aquí se estaría haciendo mención al desplazamiento de tropas, mientras Lasserre \& Bonnard (1958, pág. 26) interpretan que una parte del ejército pario estaría sitiada en Tasos por los naxios y que la otra parte, en la cual estaría el poeta, necesitaría refuerzos, por eso le pide socorro a Erxias para que ayude a liberar a los asediados. Por su parte Treu (1959, pág. 211) sugiere que algunos hombres pueden haber partido para Toronea, dejando en apuros a los "hermanos" en Tasos. Por último, Campbell (1982, pág. 138) sitúa el yambo en Paros y sostiene que Arquíloco estaría pidiéndole ayuda a Erxias, que se encontraba en Tasos, ante la invasión de los naxios.

El carácter fragmentario de la "Inscripción de Mnesiepes" y la falta de documentación acerca de las batallas que debió afrontar Paros hacia esa época hacen imposible precisar el sentido del texto. Es probable que la expansión de Paros hacia el norte haya representado una amenaza para las ciudades de la península de Cálcide, como Toronea, ya que Tasos era un punto estratégico para la entrada marítima al continente. Esta expansión colonizadora también podría haber sido una preocupación para Naxos, vecina e histórica rival de Paros, que aprovechando la ocasión del conflicto se habría aliado con Toronea. ${ }^{83}$

En los versos siguientes se vuelve a aludir a "los hermanos" y al

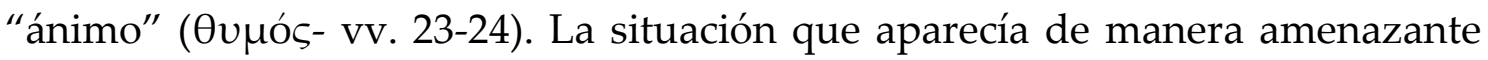
en la primera parte del fragmento se vuelve crítica hacia el final: el humo del v. 1 es "fuego que ahora $\operatorname{rod}[\mathrm{ea}] \ldots$ los suburbios ..." (vv. 25-26), y son probablemente los enemigos quienes "ultrajan la tierra..." (v. 27).

${ }^{3}$ Véanse Podlecki (1974, pág. 3) y Da Cunha Corrêa (2009, págs. 205-6). 
Finalmente, en el v. 28 se realiza la apelación a Erxias, quizás para que vengan o vayan apresuradamente, literalmente "vengan corrien[do" -

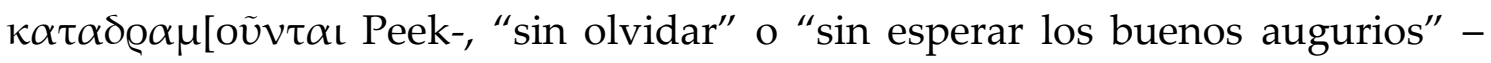
$\mu \eta \delta \dot{\varepsilon} \delta \varepsilon \xi$ เoùs $\varepsilon \pi[$ (v. 30)-.

En el fr. 110W vuelve a aparecer el nombre de Erxias. Al citar este verso, Clemente de Alejandría señala que Arquíloco realiza una adaptación de

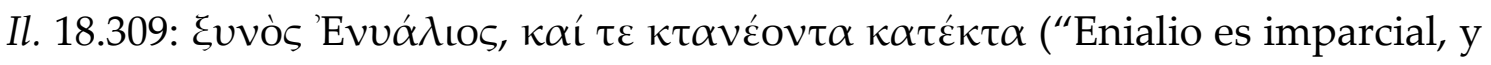
mata también a quien mata"). El tetrámetro trocaico debe ser comprendido como un proverbio o una máxima que contiene un saber de carácter general acerca de la ecuanimidad de Ares, dios de la guerra, común a todos en el campo de batalla.

A diferencia de otros nombres que aparecen en los yambos de Arquíloco, como Glauco o Pericles, no hay evidencia de que Erxias haya sido una persona real. West (1974, pág. 126) cree que la pregunta del fr. 88W y la invocación del fr. 89W serían más adecuadas si estuvieran dirigidas a un dios, y que el nombre Erxias podría ser el título de una divinidad: "Defensor", de č@ $\omega^{\prime}$ / عío $\omega_{\omega}$ "el que hace o impide". ${ }^{84}$ Señala también que Heródoto (6.98) lo consigna como uno de los títulos de Darío. Y afirma además que, finalizado el poema, la "Inscripción de Mnesiepes" nos habla de una plegaria dirigida a los dioses. ${ }^{85}$ Bossi (1990, págs. 149-50) se opone a la interpretación de West, pues considera que ninguno de los argumentos prueba que Erxias sea el apelativo de un dios, y repara que al final del poema se habla de "dioses" - $\theta \varepsilon$ ó́-, y no de un dios en particular. Sostiene por otra parte que todos los nombres compuestos por 'EQ $\xi$ - designan siempre a hombres, no a divinidades. Para este autor Erxias podría ser un sobrenombre, probablemente un "nombre parlante" empleado

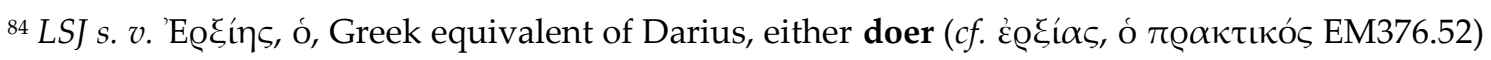

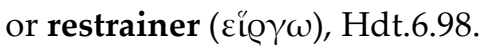

${ }^{85}$ Mnesiepis inscriptio E2 col. I 45-47 Clay.
} 
para calificar a un general del ejército pario y compañero del poeta. Si esta hipótesis es válida, entonces es posible considerar que detrás de los nombres parlantes que aparecen en el corpus de Arquíloco exista una persona real e histórica, contemporánea del poeta a la cual se esté haciendo referencia.

Desde el punto de vista de la comunicación poética, en estos tres yambos se presenta una estructura de interlocución. El interlocutor se inscribe en el enunciado solamente en el fr. $89 \mathrm{~W}$ a través de la deixis del pronombre $\mu$ oı (v. 14), probablemente en la función de complemento experimentador de la idea verbal. El interlocutario, por su parte, se inscribe en los tres poemas a través del nombre en vocativo apelativo 'Ẹł́n y, en el fr. $89.17 \mathrm{~W}$, por medio de la deixis verbal en segunda persona del imperativo $\gamma v \tilde{\omega} \theta$ í.

\section{A Glauco}

Hemos visto anteriormente que dentro del corpus de Arquíloco, Glauco es uno de los interlocutores más frecuentes. ${ }^{86} \mathrm{Su}$ nombre aparece en al menos seis fragmentos: 15, 48, 96, 105-106, 117, 131-132W. ${ }^{87}$ Por sus escenografías apelativas, nos interesan aquí específicamente los ff. 96, 105-106 y 131-132W:

\section{Fr. 96W}

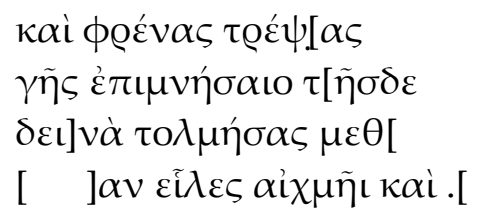

Arquíloco, fr. 96W 88

\footnotetext{
${ }^{86}$ Vid. sup. pág. 60 n. 23.

${ }^{87} \mathrm{El}$ fr. 15W es un verso elegíaco; el 48W es un fragmento papiráceo de 32 líneas (P.Oxy. $3211 \mathrm{fr}$. 1.a), muy deteriorado, que apenas conserva los restos de una palabra por línea y cuya reconstrucción textual es muy discutida; el fr. 117W será analizado más adelante.

88 Transmitido por Sosthenis inscriptio A IVa 8-13 Clay. La "Inscripción de Sóstenes" fue preservada en tres bloques de mármol pario y data del s. I a. C. Es muy probable que estas

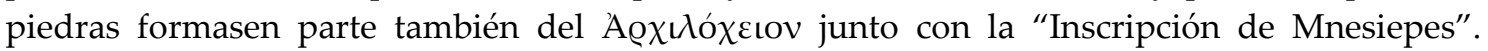
Sóstenes realizó un extracto o un resumen de la obra de Demeas, un cronista o historiador de
} 
Glauco, ¿cuál de los dioses cambiando tu espíritu

y tu corazón (pudiera hacer)

que de esta tierra te acordaras? ...

con terrible audacia...

...conquistaste con la lanza y...

Antes de citar estos versos que constituyen el fr. 96W, la "Inscripción de Sóstenes" parecería indicar que están dirigido a Glauco porque había partido hacia Tasos mientras en la batalla vencían los enemigos. ${ }^{89}$ No es posible saber quiénes son esos enemigos ni de qué batalla se trata, tampoco se puede saber por qué Glauco decide retirarse hacia Tasos. Es necesario tener en cuenta, sin embargo, que la intención de Sóstenes, y la de Demeas mismo, es la de presentar una narrativa que ponga de manifiesto, a través de los hechos y de la obra, el coraje y patriotismo de Arquíloco. ${ }^{90}$ Al igual que Mnesiepes, Sóstenes pretende dejar por escrito dentro del recinto sagrado testimonios que

mediados de s. III a. C., sobre Arquíloco y Paros. De acuerdo con Sóstenes (Bloque A I Clay), Demeas habría establecido una cronología para los hechos y las composiciones de Arquíloco ordenándolos a partir de los arcontes de Paros. Esta inscripción conserva los ff. 7, 7a, 93a, 94-98 y 192W. Para la Sosthenis inscriptio véase Clay (2004).

89 Sosthenis inscriptio A IVa 6-8 Clay: ö $\iota$ $\delta \dot{\varepsilon} \Gamma \lambda \alpha \tilde{v}[\kappa o \varsigma$ $\kappa \varrho \alpha \tau \eta \sigma[\alpha \dot{\alpha} \nu \tau \omega \nu$

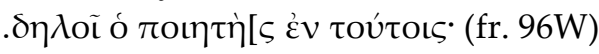

90 Sóstenes, descendiente de una familia aristocrática de Paros, señala el propósito de su inscripción por medio de un epigrama funerario que representa el diálogo entre Arquíloco y un peregrino que pasa frente a su tumba:

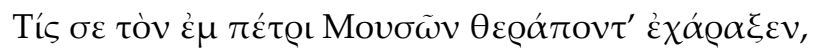

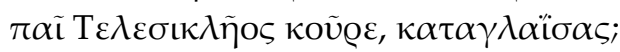

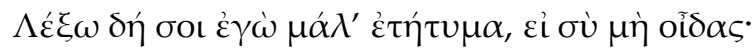

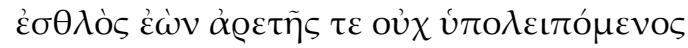

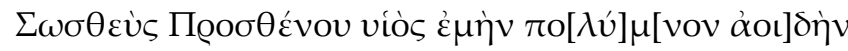

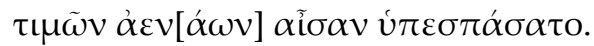

Sosthenis inscriptio B VII 12-17 Clay.

(Peregrino) ¿Quién te cinceló en la piedra como el siervo de las Musas, joven hijo de Telesicles, glorificándote?

(Arquíloco) Te diré ciertamente la verdad, si no la sabes: un noble no carente de virtud.

Sosteo (es decir, Sóstenes), hijo de Próstenes, de mi canto de muchos temas extrajo una parte de los honores que fluyen constantemente. 
demuestren "la piedad y [devoción] de Arquíloco por su patria" (A I, 3-4 Clay). De este modo, la narración de hechos biográficos se va intercalando con poemas que parecen testimoniar esos hechos, pero la única fuente para la escritura biográfica de Arquíloco, y de los poetas griegos en general, era su propia obra. ${ }^{91}$

El yambo no parece implicar un reproche o una censura contra Glauco por haberse marchado, seguramente junto con su tropa, abandonando al ejército en medio de una batalla, sino más bien una súplica. El interlocutor lo exhorta a cambiar su determinación y a acordarse de "esa tierra" y de los actos heroicos que él había realizado para conquistarla. ${ }^{92}$ En este sentido, es posible considerar que se tratase quizás de alguna colonia sobre el continente, cercana a Tasos, y dentro del territorio ocupado por los tracios.

\title{
FF. 105-106W
}

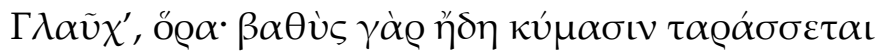

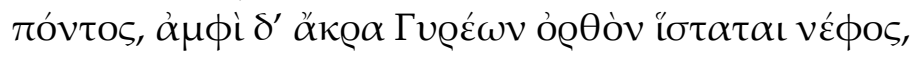

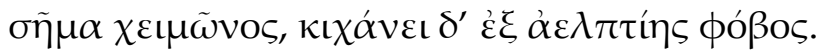

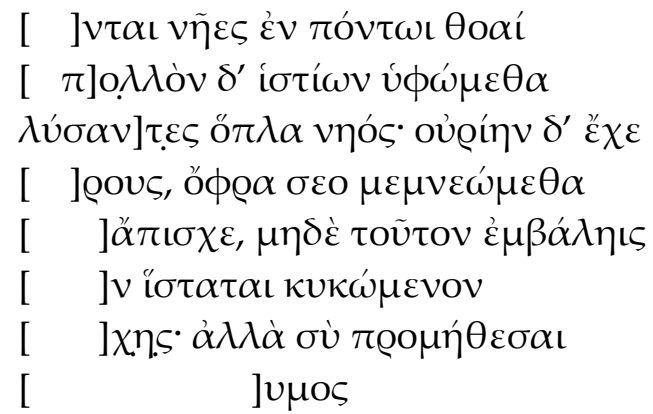

Arquíloco, fr. 105W

Arquíloco, fr. 106W93

\begin{abstract}
91 Sobre este tema véanse Lefkowitz (2012, págs. 30-7) y Kivilo (2010, págs. 87-119).
92 Da Cunha Corrêa entrevé en este fragmento la estructura de una plegaria con una secuencia determinada, semejante a las dirigidas a los dioses en solicitud de auxilio o para la concesión de alguna gracia: la invocación a la divinidad, las ofrendas realizadas anteriormente por el suplicante o los servicios prestados, y finalmente el pedido realizado en esta ocasión. Esto la lleva a interpretar el fragmento en sentido paródico: "No caso, Arquíloco teria adaptado a forma tradicional, possivelmente com efeito paródico, pois a sua prece seria laica, dirigida a Glauco, um mortal" (2009, pág. 234).

${ }^{93}$ El fr. 105W ha sido transmitido por Heráclito, Alleg. Hom. 5.3 y el fr. 106W por el P. Lit. Lond. 54 ed. Milne. Sigo los argumentos de Rodríguez Adrados (1955, págs. 106-10) para la unión de
\end{abstract}


Glauco, mira: por las olas se agita ya el profundo mar

y alrededor de las cimas del Giras recta se levanta una nube, señal de tempestad, e inesperadamente nos alcanza el temor.

...] en el mar las veloces naves

...] repleguemos la mayoría de las velas

... aflojando] las jarcias de la nave; pero obtén un viento favorable

...] para que nos acordemos de ti

...] aparta, y no precipites este

...] se levanta turbulento

...] mas tú sé precavido...

Al transmitir el fr. 105W, Heráclito señala que los versos contienen una $\alpha \lambda \lambda \eta \gamma$ oeí $\alpha$ en la cual Arquíloco representaba la guerra contra los tracios a través de la imagen de una nave en la tempestad. ${ }^{94}$ Esta sería la primera aparición de lo que posteriormente ha sido conocida como "la alegoría de la nave del Estado", una imagen con una larga tradición dentro de la literatura occidental. ${ }^{95}$ Mediante esta imagen Arquíloco habría tratado de transmitir a sus compañeros de armas la impresión amenazante de alguna incursión contra los tracios por la colonización de Tasos. El interlocutor se dirige a Glauco a través de la forma imperativa del verbo de percepción (ó@ó $\omega$ ) "mira, Glauco", e

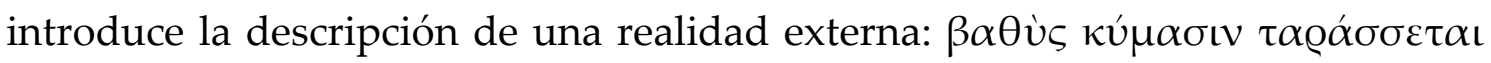

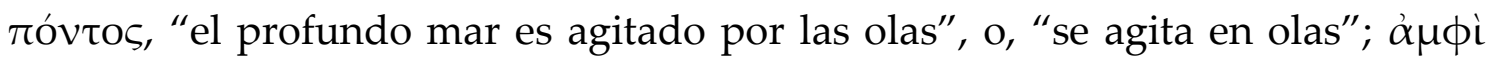

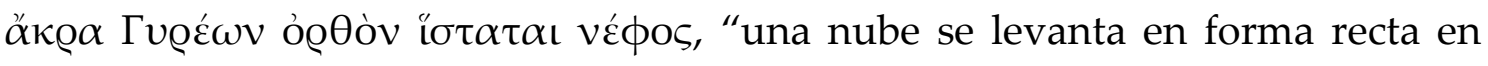

los fragmentos, propuesta por Crönert en la edición de Diehl (ff. 56 y 56A D), véanse también West (1974, págs. 128-9) y Gentili (1996, págs. 435-9). De opinión opuesta son Wood (1966, págs. 228-33) y Boserup (1966, págs. 28-38); véanse también los argumentos de Bossi (1990, págs. 1601) y Da Cunha Corrêa (2009, págs. 311-7).

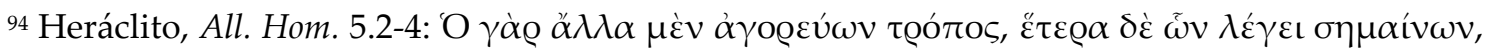

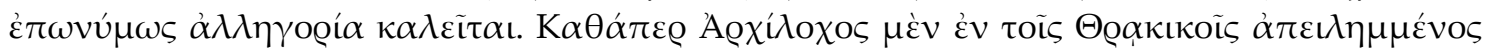

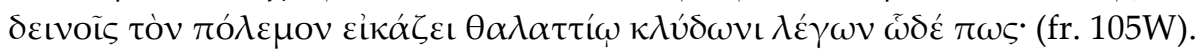

${ }^{95}$ La alegoría de Arquíloco aparece posteriormente en obras como las de Alceo (ff. 6, 7, 208V), Horacio (Carm. 1.14) y Dante (Pg. 6.77). Para un recorrido de esta imagen en la literatura antigua véase Gerlach (1937, págs. 127-39). 
torno a las cimas del monte Giras". ${ }^{96}$ Sandbach (1942, págs. 63-5), a partir de

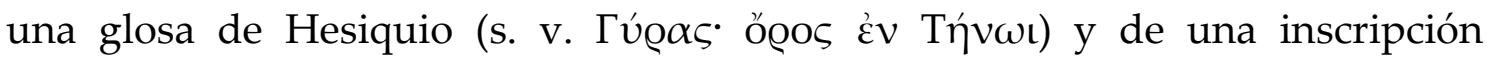

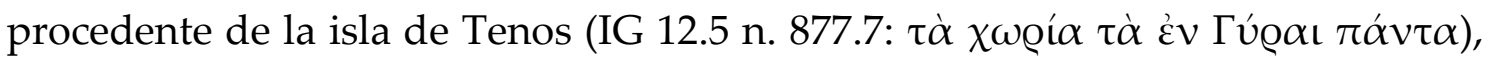

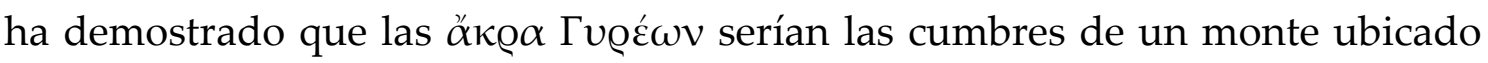
geográficamente en esa isla, a unas 15 millas marinas al norte de Paros y en la ruta de navegación hacia Tasos. ${ }^{97}$ De este modo, el mar agitado y las nubes cubriendo las montañas de Tenos, visibles desde Paros, constituirían las señales de una tempestad $-\sigma \tilde{\eta} \mu \alpha \chi \varepsilon \varepsilon \mu \tilde{\omega} v o \varsigma$ - que se aproxima desde el norte y que, en su inminencia, provoca repentino фóßos en la tripulación.

En el fr. 106W, la alegoría adquiere un tono más dramático. El interlocutor exhorta a Glauco, seguramente la persona con la autoridad necesaria para ordenar los recaudos y evitar un posible naufragio: $\pi 0 \lambda \lambda$ òv

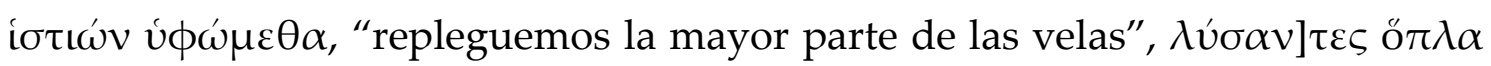

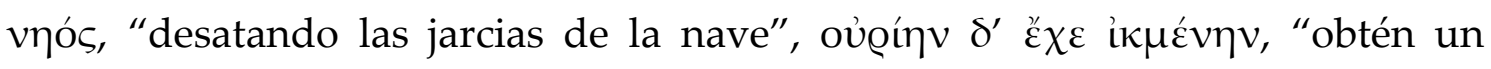

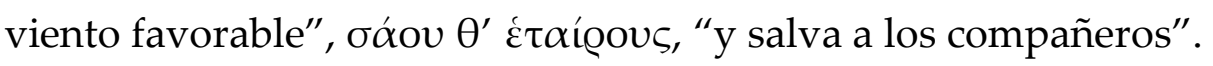

De este modo, la alegoría entablaría una correspondencia entre dos realidades: la primera, explícita en el poema, una realidad sensible, delimitada y organizada por la vista; la segunda, una realidad implícita, no denotada en los versos, pero que cada uno de los miembros de la hetería conocía y podía formular: los acontecimientos de una guerra inminente. De allí la perentoria exhortación a quien podría ser uno de los generales del ejército para que prevea el riesgo y tome las decisiones correctas.

\section{FF. 131-132W}

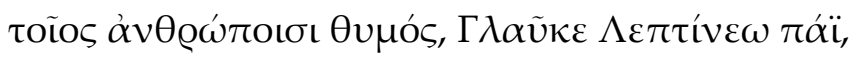

\footnotetext{
${ }^{96}$ Gentili (1996, págs. 405-39) analiza la "alegoría de la nave" en Alceo y Arquíloco y muestra, tomando como punto de partida la épica, el funcionamiento de semas metafóricos tales como "olas/soldados", "tempestad/guerra", "nubes/tropas avanzando", "nave/hetería", etc.

${ }^{97}$ Clay (1982, págs. 201-4)
} 


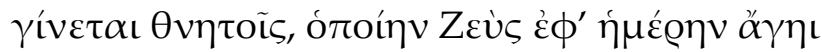

Arquíloco, fr. 131W

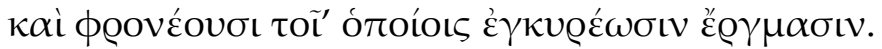

Arquíloco, fr. $132 W^{98}$

Glauco, hijo de Leptines, el ánimo de los mortales se dispone de acuerdo con el día que Zeus les envía y sus pensamientos de acuerdo con las obras que realizan.

En los ff. 131-132W, el interlocutor transmite a Glauco un saber general y tradicional acerca de cómo varía el estado de ánimo y la forma de pensar de los hombres de acuerdo con la disposición divina y de los hechos cotidianos que deben afrontar. Además de por Estobeo, los versos del fr. 130W han sido transmitidos por varios autores en relación con $O d$. 18.136-37, donde Odiseo, bajo el disfraz de mendigo, alecciona a uno de los pretendientes, Anfínomo, sobre la endeblez del destino humano y su subordinación a los designios de

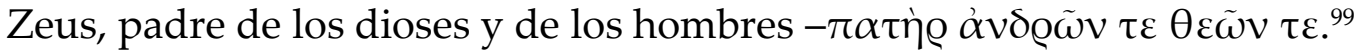

Una inscripción encontrada en Tasos, que data de fines de s. VII a. C., ha permitido saber, a partir del patronímico Leptineo, que Glauco era una persona real:

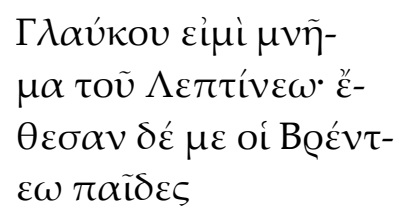

Soy el monumento de Glauco, hijo de Leptines.

\footnotetext{
${ }_{98}$ El fr. $131 \mathrm{~W}$ ha sido transmitido por Estobeo 1.1 .18 y el fr. 132W por Ps. Plat., Eryxias 397e. La unión de estos fragmentos ha sido propuesta por Jacobs y aceptada por la mayoría de los editores; véase West (1998, pág. 52).

${ }_{99}$ Ps. Plut. de vita et poesi Hom. 7.424.24 Bernardakis; Sext. Emp. adv. math. 7.127; Diog. Laert. 9.71; Teon, Progymn. 62.22 Spengel; Syrianus in Hermog. 1.30.24 Rabe.

${ }^{100}$ La inscripción fue publicada por Pouilloux (1955, págs. 73-86); véanse también Marcaccini (2001, págs. 32-61) y Clay (2004, págs. 67-9).
} 
Me erigieron los

hijos de Brentes.

El hecho de que el cenotafio que contenía la inscripción estuviera ubicado en el ágora de Tasos demuestra también que Glauco era un personaje relevante dentro de la aristocracia de la isla hacia mediados de s. VII a. C. Muy probablemente, como hemos visto en relación a los ff. 105-106W, Glauco haya sido un jefe militar con un rol preponderante en las guerras coloniales frente a los tracios.

En cuanto a la comunicación poética, según hemos señalado, estos fragmentos presentan una estructura de interlocución apelativa. El interlocutor se manifiesta inscripto deícticamente solo en los ff. 105-106W, a través de las marcas de primera persona plural de los verbos $v \phi \omega ́ \mu \varepsilon \theta \alpha$ (v. 5) y $\mu \varepsilon \mu \nu \varepsilon \omega ́ \omega \varepsilon \theta \alpha$ (v. 7), en ambos casos funcionando como sujeto agente. Por su parte, el interlocutario se manifiesta en el fr. $96 \mathrm{~W}$ por medio de la deixis pronominal $\sigma \varepsilon$

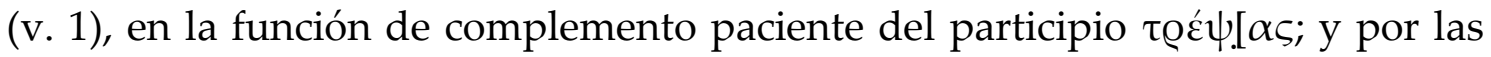

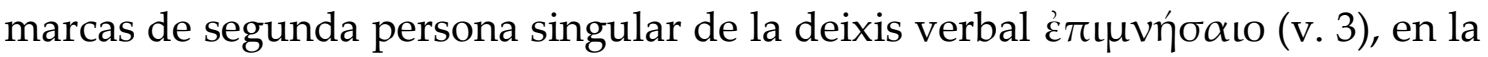
función de sujeto experimentador, y عĩ $\varepsilon \varsigma$ (v. 5), como sujeto agente. En los ff. 105-106W, el interlocutario se inscribe deícticamente en el enunciado por medio de la deixis pronominal $\sigma \varepsilon o$ (v. 7), en la función de complemento paciente del verbo $\mu \varepsilon \mu \nu \varepsilon \omega ́ \omega \varepsilon \theta \alpha$, y por $\sigma u ́$ (v. 10), como sujeto agente del verbo $\pi \varrho 0 \mu \eta ́ \theta \varepsilon \sigma \alpha \mathrm{l}$; también se manifiesta por medio de la deixis de la segunda

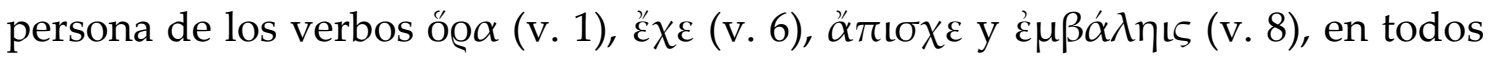
los casos funcionando como sujeto agente. Por último, en los ff. 131-132W ni el interlocutor ni el interlocutario aparecen en el enunciado a través de la deixis personal.

En los tres yambos, la identidad del interlocutario está explícitamente

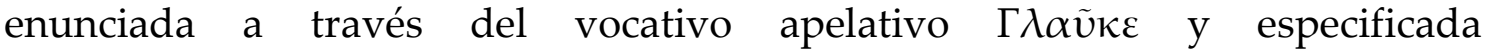
particularmente en los ff. 131-132W por medio del patronímico $\Lambda \varepsilon \pi \tau i ́ v \varepsilon \omega$. Esto 
implica un desdoblamiento de la instancia de recepción: Glauco ocupa, dentro del nivel enuncivo, la posición actancial de interlocutario, en tanto que el Auditorio ocupa en el nivel enunciativo la posición de enunciatario.

\section{A Pericles}

\section{Fr. 124W}

Al igual que Erxias y Glauco, Pericles también parece haber sido contemporáneo y amigo de Arquíloco. Si bien el nombre de Pericles no aparece en el fr. 124, la fuente que lo transmite sostiene que en este yambo el poeta se estaría dirigiendo a él:

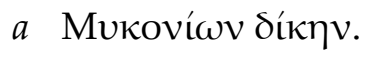

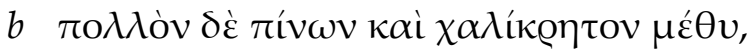

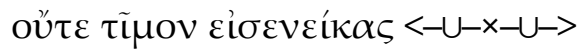

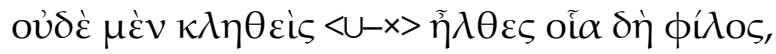

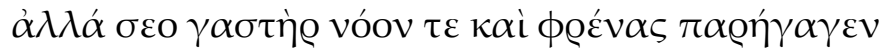

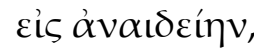

Arquíloco, fr. 124W 101

a ... a la manera de los de Miconos.

$b$... aunque tú bebes vino abundante y puro, ni pagaste tu parte $[\ldots$

ni viniste invitado, como corresponde a un amigo; por el contrario, tu vientre desvió tu espíritu y tu mente por el camino de la desvergüienza [...

De acuerdo con Ateneo, en este yambo Arquíloco compara a Pericles con los miconios, famosos por su codicia y tacañería, ${ }^{102}$ ya que este tenía la

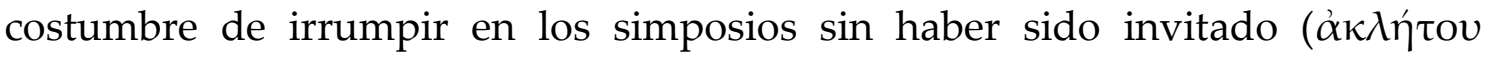

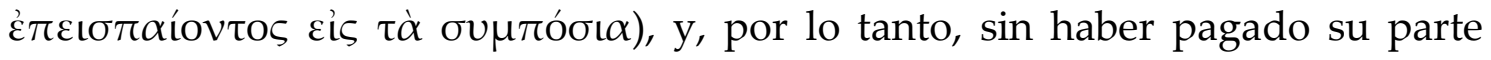

${ }^{101}$ Transmitido por Ateneo 1.13-14.

102 En el mismo pasaje, Ateneo señala que los habitantes de Micono tenían la reputación de codiciosos y avaros a causa de su pobreza, ya que ellos vivían en una isla miserable. 
correspondiente. El nombre de Pericles también aparece en el fragmento elegíaco 13W, conocido como "Elegía a Pericles", 103 en que el interlocutor, dirigiéndose a él por su nombre y llamándolo "amigo" ( $\tilde{\omega} \phi i ́ \lambda \varepsilon)$, le aconseja aceptar la mutabilidad de la fortuna dispuesta por los dioses y soportar con fortaleza las penas por los compañeros muertos en un naufragio.

Arístides (Or. 46) también nombra a Pericles. Al hablar del oráculo dado por Apolo al asesino de Arquíloco, Arístides afirma que el dios honró al poeta y lo llamó "sirviente de las Musas", razón por la cual deducía que, aun cuando estaba muy involucrado en la invectiva, no calumniaba a los mejores y más distinguidos de los griegos, sino que insultaba a Licambes, a Carilao, a cierto

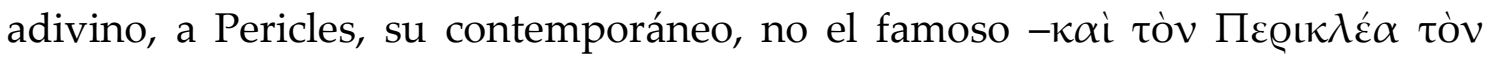

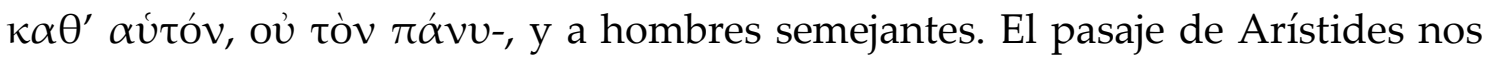
informa, por lo tanto, que Pericles también era una persona real.

\section{A CARILAO y Cericidas}

\section{FF. 167, 168 Y 185-187W}

En el pasaje que acabamos de comentar, Arístides, junto con la mención de Pericles y Licambes como víctimas de los yambos de Arquíloco, nombra también a un tal Carilao, que también es mencionado por Ateneo. En efecto, en Deipn. 10.8, al hablar de la gula del rey Tíos de Paflagonia, Ateneo recuerda que

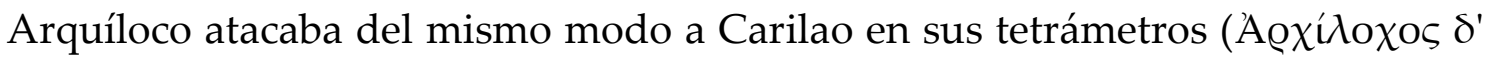

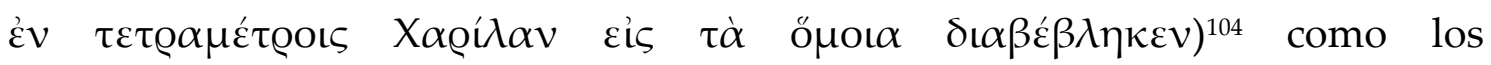
comediógrafos a Cleónimo y Pisandro. Del yambo de Arquíloco, editado como el fr. 167W, únicamente nos queda el testimonio de Ateneo; sin embargo, es probable que este autor estuviera aludiendo en realidad a un poema en estrofa

\footnotetext{
103 Transmitido por Estobeo 4.56.30.

104 El acusativo X $\alpha$ @íl $\alpha v$ es una forma contracta del nombre X $\alpha \varrho i ́ \lambda \alpha o \varsigma$.
} 
epódica, editado como el fr. 168W y en el cual también aparece el nombre Carilao, y no a una composición diferente, escrita en tetrámetros:105

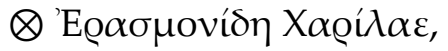

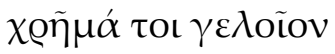

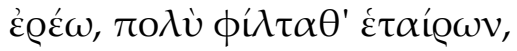
$\tau \varepsilon \dot{\varepsilon} \mathrm{\psi} \varepsilon \alpha \mathrm{L} \delta^{\prime} \dot{\alpha} \kappa o u ́ \omega \nu$.

Arquíloco, fr. 168W106

Carilao, hijo de Erasmón, algo cómico

voy a contarte, el más querido de mis compañeros,

y disfrutarás al oírlo.

Hefestión transmite este poema como ejemplo de que Arquíloco había sido el primero en emplear la combinación epódica de metros. A diferencia de Erxias y Glauco, no hay testimonios antiguos que confirmen que Carilao haya sido una persona real y contemporánea al poeta. Al contrario, es muy probable

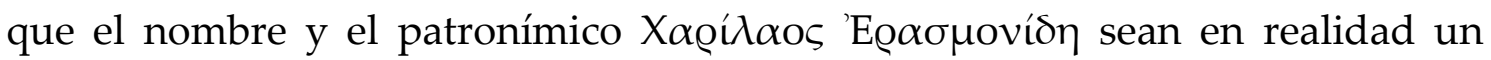

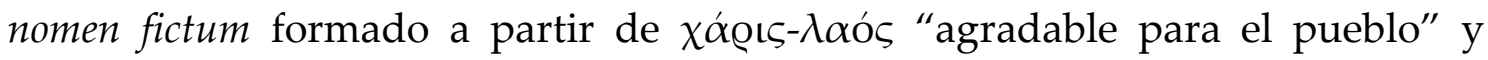
descendiente del "deseable" 'Ẹáo $\mu \omega v$, al cual se apela de manera casi redundante con el epíteto $\pi \mathrm{o} \lambda \dot{v} \phi i ́ \lambda \tau \alpha \theta^{\prime} \varepsilon \dot{\tau} \alpha \hat{i} \varrho \omega v .{ }^{107}$

Los ff. 185-187W, por su parte, transmiten una fábula sobre un mono y una zorra, y también tienen como destinatario un interlocutario con nombre parlante:

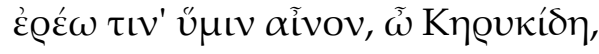

105 “È quanto mai probablie, dunque, che la testimonianza di Ateneo (e quella di Eliano VH 1,27, Aristide Or. 46 y Eustazio ad Hom. ı 310) risalga proprio al fr. 168.", Bossi (1990, págs. 186-7).

${ }^{106}$ Este fragmento ha sido transmitido por Hefestión, Ench. met.15.1-3 (idem 8.7).

107 Hefestión (Ench. met. 15.7) señala que Cratino se equivocaba en su comedia Los Arquílocos

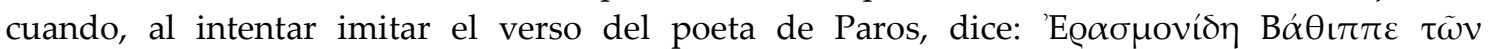
$\grave{\alpha} \omega \varrho o \lambda \varepsilon i ́ \omega \nu$ (fr. 10K), ya que no reproduce fielmente el metro de Arquíloco. Más allá del reparo métrico que motiva a Hefestión, lo interesante de su referencia es que Cratino también habría querido introducir en su obra el juego de palabras de su predecesor yámbico a partir del patronímico 'E@ $\alpha \sigma \mu o v i ́ \delta \eta$. 
$\dot{\alpha} \chi v v \mu \varepsilon \dot{v} \eta \eta \sigma \kappa v \tau \alpha \dot{\lambda} \lambda \eta$

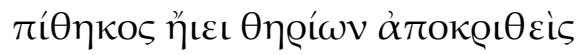

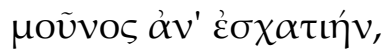

$\tau \tilde{\omega} \iota \delta^{\prime} \tilde{\alpha} \varrho^{\prime} \dot{\alpha} \lambda \omega \pi \eta \xi \kappa \varepsilon \varrho \delta \alpha \lambda \tilde{\eta} \sigma v v \eta \dot{v \tau \varepsilon \tau о,}$

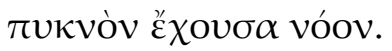

Arquíloco, fr. 185W ${ }^{108}$

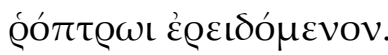

Arquíloco, fr. 186W109

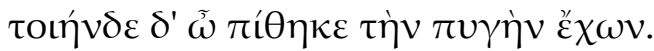

Arquíloco, fr. 187W 110

Les contaré una fábula, Cericidas,

lamentable vara de mensajes:

un mono, separado de los demás animales,

se dirigía solo a un lugar extremo,

pero la astuta zorra se encontró con él,

animal de perspicaz inteligencia.

(...)

pisando el palito

(...)

¡Mono! ¿Con semejante culo...?

La fábula esópica de "El mono elegido rey y la zorra" (81 Perry) nos permite reconstruir el argumento de este poema. En ella se cuenta que, en una reunión de animales, el mono, luego de danzar y ganar la aprobación de los demás, fue elegido rey. Pero la zorra, envidiosa de la situación, condujo al mono hasta una trampa con un pedazo de carne, con la excusa de haber encontrado un tesoro que, en vez de quedárselo, había guardado como obsequio para su dignidad real. Con este engaño lo animó para que lo tomase.

${ }^{108}$ El fr. 185W ha sido transmitido por Herenio Filón De diversis verborum significationibus pág. 142 Palmieri.

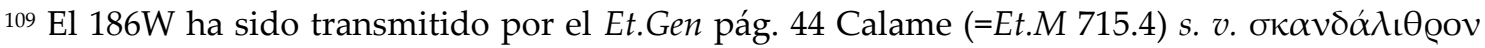
"muelle de una trampa", en la definición se dice que Arquíloco llama a este muelle @ót tøov y cita el fr. 186W. Véase también Schol. Arist. Ach. 687.

${ }^{110}$ El fr. 187W ha sido transmitido por el Schol. Arist. Ach. 119-20. En el pasaje de Acarnienses,

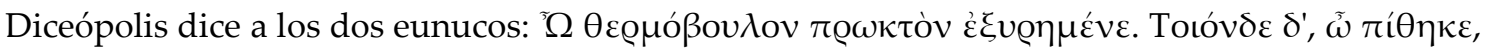

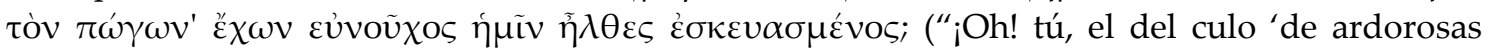
determinaciones' rasurado, ¿y tú, mono, con semejante barba vienes vestido de eunuco?”); el

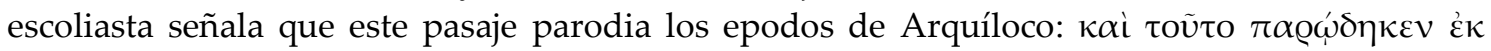

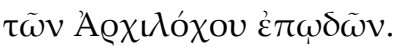


Sin pensar, el mono se lanzó sobre la carne y quedó atrapado. Al acusar a la zorra de haberle tendido una trampa, ella le respondió: “¡Mono! ¿Tú, con

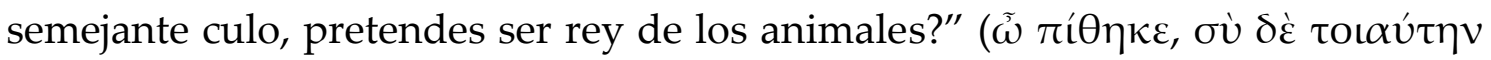

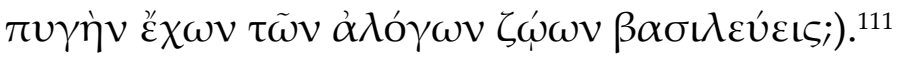

En el poema de Arquíloco, el interlocutor se dirige a un tal Cericidas

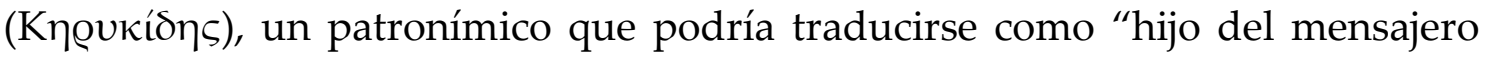
$(\kappa \tilde{\eta} \varrho v \xi)$ ". Si tenemos en cuenta que la expresión "triste vara de mensajes"

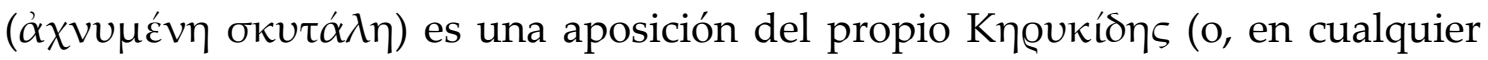
caso, del sujeto de $\dot{\varepsilon} \varrho \varepsilon ́(\omega),{ }^{112}$ entonces es posible afirmar que Cericidas es un nombre parlante dentro de un juego de palabras mayor. Probablemente con el nombre Cericidas se hiciera alusión a algún personaje histórico y real cuya identidad, obviamente, el auditorio podía develar. Aunque el contexto del poema se ha perdido completamente, es posible suponer que a través de esta fábula Arquíloco se estuviera burlando de las aspiraciones políticas de algún miembro de la aristocracia de Paros.

\section{A Licambes}

\section{FF. 172-181W}

Dentro de la obra de Arquíloco, hay un conjunto importante de fragmentos que se erigen en invectiva, en estrofa epódica, contra un tal Licambes: ${ }^{113}$

\footnotetext{
111 Para $\pi v \gamma \eta \dot{v}$ por $\psi v \chi \eta ́ v$ o $v \chi \chi \eta ́ v$ y para la fábula en relación con el epodo de Arquíloco, sigo en general la interpretación de Van Dijk (1997, págs. 144-7).

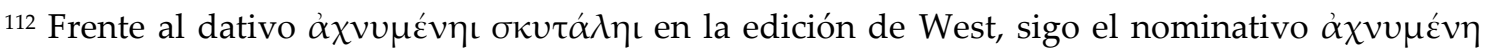

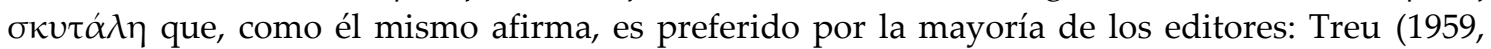
pág. 228), Tarditi (1968, pág. 164), Campbell (1982, pág. 130), Gerber (1999, pág. 200). Es

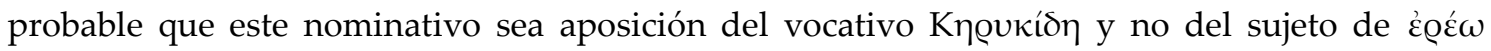
como lo considera Stephanie West (1988, págs. 42-8).

113 Para este grupo de fragmentos, véanse West (1974, págs. 132-4) y Bossi (1990, págs. 187-206); particularmente para la relación entre este grupo de fragmentos y la fábula 1 Perry de Esopo, véase Van Dijk (1997, págs. 138-44).
} 


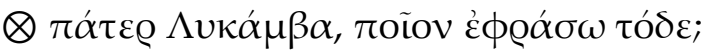

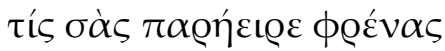

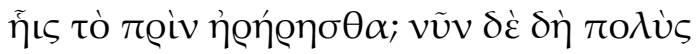

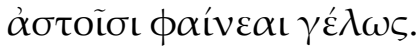

Arquíloco, fr. 172W $\mathrm{W}^{114}$

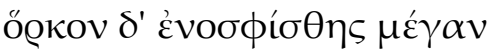

$\alpha ٌ \lambda \alpha \varsigma \tau \varepsilon \kappa \alpha i ̀ ~ \tau \varrho \alpha ́ \pi \varepsilon \zeta \alpha \nu$.

Arquíloco, fr. 173W 115

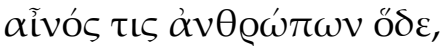

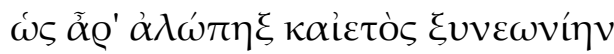

है $\mu \varepsilon เ \xi \alpha v$,

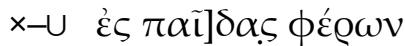

Arquíloco, fr. 174W 116

[ $\quad \delta \alpha \tilde{\mathrm{i}}] \tau \alpha \delta^{\prime}$. oú $\kappa \alpha \lambda \dot{\eta} \nu \dot{\varepsilon} \pi[\mathrm{i}$

$\omega ̋ \mathrm{Q} \mu \eta \sigma \alpha v \alpha \dot{\alpha} \pi] \tilde{\eta} v \varepsilon \varsigma \delta \dot{o}$

$\times-\cup-x] \cdot \gamma \tilde{\eta}[\varsigma] \dot{\varepsilon} \phi^{\prime} \dot{v} \psi \eta \eta \hat{\omega} \iota \pi[\alpha \dot{\alpha} \gamma \omega \iota$

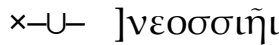

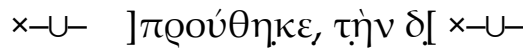

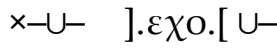

$\times-\mathrm{U}-\quad] \alpha \delta \varepsilon_{. .}[\mathrm{U} \mathrm{U}-\mathrm{x}-\mathrm{U}-$

$\times-\cup-x] \phi \omega \lambda \alpha \dot{\alpha}[\delta-$

Arquíloco, fr. 175W $W^{117}$

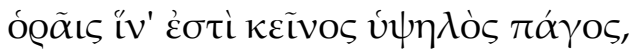

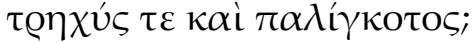

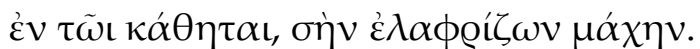

Arquíloco, fr. 176W ${ }^{118}$

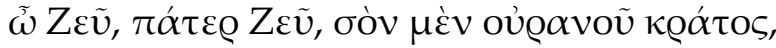

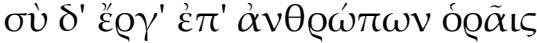

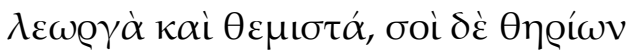

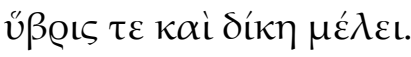

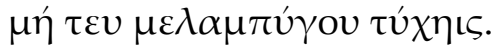

Arquíloco, fr. 177W119

Arquíloco, fr. 178W120

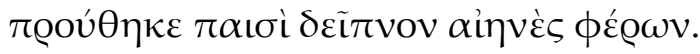

Arquíloco, fr. 179W $\mathrm{W}^{121}$

${ }^{114}$ Transmitido por el Schol. Herm. Rhet. 7.820.27 Walz.

115 Transmitido por Orígenes, contra Celsum 2.21 (1.314 Borret).

116 Transmitido por Herenio Filón, de diversis verborum significationibus pág. 142 Palmieri.

117 Transmitido por P.Oxy. 22.1325 fr. 1 Lobel.

118 Transmitido por Ático, fr. 2 (=pág. 41 des Places).

119 Transmitido por Estobeo 1.3.34.

${ }^{120}$ Transmitido por Porfirio, Quaest. Hom. ad Il. pág. 275.1 Schrader (Il. 24.315).

${ }^{121}$ Transmitido por Et.M 32.26, s. v. aìvés. 


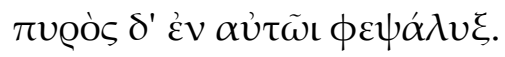

Arquíloco, fr. 180W 122

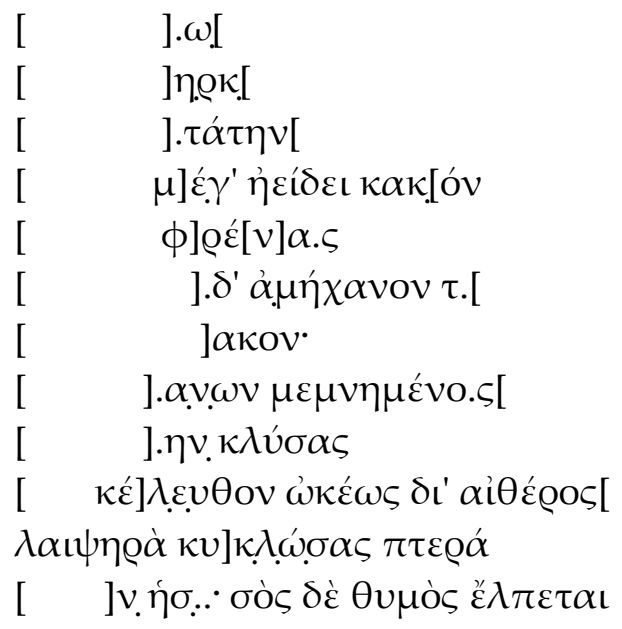

Arquíloco, fr. 181W $\mathrm{W}^{123}$

Padre Licambes ¿qué clase de maquinaciones son estas?

¿Quién hizo desvariar tu razón,

que antes era tu firme apoyo? Ahora en verdad grande es

tu ridículo a los ojos de los conciudadanos.

(...)

Fuiste infiel a un solemne juramento, a la sal y a la mesa

(...)

Cierta fábula que los hombres cuentan dice así: que la zorra y el águila trabaron alianza

(...)

...a sus hijos llevando y sobre el nada bello banquete se lanzaron los dos polluelos implumes... sobre una elevada colina de la tierra

... para la nidada ... puso delante y a esta...

... oculta al acecho.

(...)

¡Zeus, padre Zeus! Tuyo es el dominio del cielo, tú las obras de los hombres contemplas, villanas e ilícitas, y a tu cuidado están la insolencia y la justicia de los animales

(...)

... no te vayas a encontrar con un águila de negra cola.

(...)

Presentó a sus hijos el maldito banquete que les llevaba...

(...)

... y en él había una brasa de fuego

$(\ldots)$

“¿Ves dónde está aquella elevada colina

122 Transmitido por Schol. Arist. Ach. 278 (=pág. 48 Wilson).

${ }^{123}$ Transmitido por P.Oxy. 22.2316 Lobel. 
escarpada y amenazante? En ella está posada. Buscando ventaja en la lucha contigo."

(...)

... nefasta era su sabiduría... /... su corazón... ... irremediable... /... pensando en...

... tras anegar la... /... su camino velozmente a través del éter con circular movimiento de sus ligeras alas...

... pero tu corazón alimenta esperanzas...

Nuevamente es una fábula de Esopo (1 Perry) la que nos da la clave para comprender el argumento de un yambo de Arquíloco: un águila y una zorra que se hicieron muy amigas decidieron vivir una cerca de otra, porque creían que la vecindad consolidaría esa amistad. El águila subió a un árbol de gran altura e hizo allí su nido, mientras que la zorra se metió en un arbusto cercano al árbol y tuvo allí sus crías. Cierto día en que la zorra se había ido a buscar alimento, el águila, que se había quedado sin comida, descendió hasta el arbusto, arrebató las crías de la zorra y se las devoró junto a sus polluelos. Cuando la zorra regresó y se dio cuenta de lo que el águila había hecho, sintió mucho dolor, no tanto por la muerte de sus crías sino por la impotencia que le generaba ser un animal terrestre y no poder perseguir al águila para vengarse. Por tanto, apartada a cierta distancia, maldecía a su enemiga, que es el único recurso que les queda a los impotentes y débiles. Pero no pasó mucho tiempo para que el águila pagara por traicionar la amistad. Un día en que unos individuos estaban realizando el sacrificio de una cabra en un campo cercano, el águila se precipitó sobre el altar y robó un trozo de víscera todavía incandescente y lo llevó hasta lo alto de su árbol, pero el viento hizo que una pequeña llama se iniciara entre las ramas del nido. A causa del incendio las crías del águila cayeron a tierra, ya que todavía no les habían salido plumas 
para volar, y la zorra, que se encontraba observando todo, corrió hasta el pie del árbol y devoró a los polluelos ante los ojos del águila. ${ }^{124}$

Si bien el contexto de la fábula de Arquíloco no se ha conservado, la imagen del águila probablemente hace alusión a Licambes, al menos es lo que se puede deducir, en primer lugar, de la explícita apelación del fr. 172W que inicia el epodo, y de la acusación de haber quebrantado un juramento que nos transmite el fr. 173W. ${ }^{125}$ En segundo lugar, tenemos el testimonio de Filóstrato, quien afirma que Arquíloco utilizó la fábula contra Licambes. ${ }^{126}$ Ambos fragmentos podrían haber servido para sustentar la antigua tradición biográfica del compromiso nupcial entre Arquíloco y Neobule, una de las hijas de Licambes. ${ }^{127}$ Nos referimos al pacto que, de acuerdo con esta tradición, fue roto por el propio Licambes, provocando la ira de Arquíloco, que comenzó a atacar con sus invectivas yámbicas a las hijas de aquel, de tal modo que la deshonra que recayó sobre ellas hizo que se ahorcaran y que posteriormente también lo hiciera el propio Licambes.

A pesar de que desconocemos el contexto del epodo, aun así es posible detectar algunos paralelismos entre la fábula del águila y la zorra y la tradición

${ }^{124}$ La fábula de Arquíloco difiere en algunos puntos de la transmitida por Esopo: por un lado,

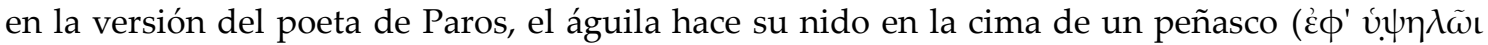

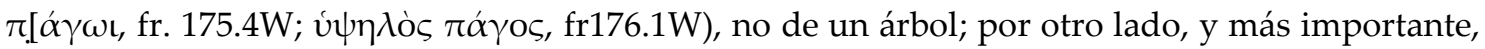
la fábula de Arquíloco tiene una dimensión religiosa, observable en la súplica que la zorra le dirige a Zeus (fr. 177W), que la versión esópica no posee.

${ }^{125} \mathrm{Al}$ transmitir el fr. 173W, Orígenes, Contra Celsum 2.21, deja explícito que este fragmento está dirigido contra Licambes. En ese pasaje el autor señala que la historia de los griegos y de los bárbaros está llena de ejemplos de hombres que conspiraron contra compañeros con los que han compartido la sal y la mesa, y que esto es lo que reprocha el poeta yámbico de Paros a

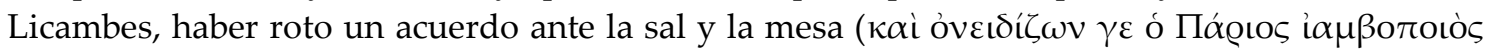

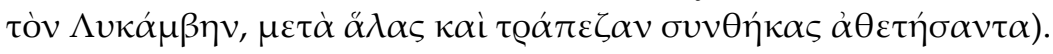

126 Filóstrato, Imagines 1.3 (2.298 Kayser), señala que aunque Homero y Hesíodo se interesaron en la fábula, y también Arquíloco contra Licambes, sin embargo, todos los aspectos de los seres

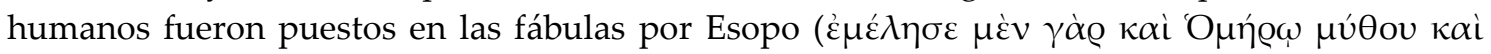

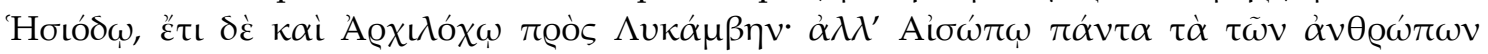
$\dot{\varepsilon} \kappa \mu \varepsilon \mu \hat{v} \theta \omega \tau \alpha \mathrm{\iota})$.

${ }^{127}$ Vid. sup. pág. 76 n. 60. 
biográfica del poeta: se produce un pacto entre el águila-Licambes y la zorraArquíloco, ese pacto sellado con un juramento es traicionado por parte del águila-Licambes, ante lo cual la zorra-Arquíloco ruega a Zeus por venganza; ${ }^{128}$ la zorra-Arquíloco termina devorando a las crías del águila-Licambes ante su propia vista. La función del epodo contra Licambes es poner de manifiesto que aquel que ha perjurado, que ha roto un juramento, no puede escapar a la justicia porque es Zeus quien sanciona inevitablemente la pena que deberá cumplir el que ha cometido la traición.

La fábula en sí misma es un mecanismo fundamental para el enmascaramiento del "yo" dentro de la poesía didáctica, así como también de la poesía de invectiva y, en ese sentido, debe ser considerada como un atributo legitimado por el género poético para la persona yámbica "Arquíloco".

Se imponen algunas aclaraciones acerca del nombre de Licambes. West

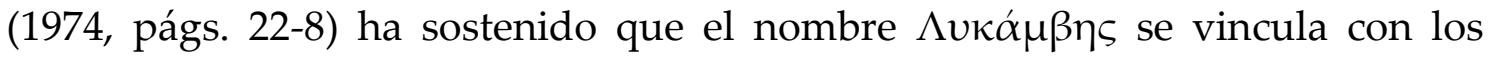
cultos de Dioniso y de Deméter, ya que el formante $-\alpha \mu \beta$ - puede ser asociado

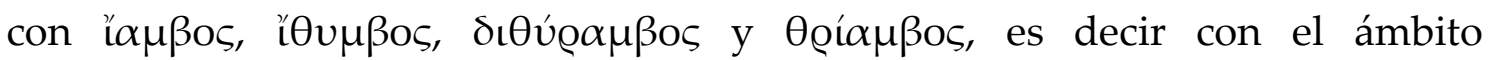
dionisíaco. E, igualmente, el nombre comparte su raíz con 'I $\alpha \mu \beta \eta$, la mítica esclava del rey Céleo. ${ }^{129}$ Es necesario recordar, además, que el nombre utilizado por Deméter durante el transcurso de tiempo en que aparece bajo la máscara de anciana, es decir antes de que se manifieste como divinidad frente a los presentes en el palacio, es $\Delta \omega \omega^{130}$ que remite a su cualidad de dispensadora de dones y que podría traducirse como "la dadora" o "la generosa".

${ }^{128}$ Un juramento significaba poner de testigos a los dioses, por lo tanto, su ruptura era una violación sumamente grave del código religioso, social y moral griegos, y se esperaba que las divinidades hicieran efectivo el castigo. La imputación de violación del juramento por parte de Licambes se manifiesta de manera explícita en el fr. 173W, y la súplica que la zorra dirige a Zeus en el fr. 177W podría haber contenido también el pedido de venganza. Véase además el análisis del fr. 197W (vid. inf. pág. 119)

${ }^{129} \mathrm{Vid}$. sup. pág. 5.

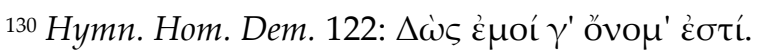


Significativamente, en el fr. 57W de Arquíloco podría aparecer el patronímico

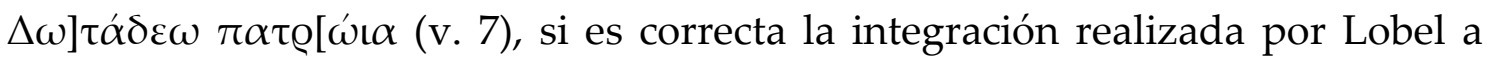

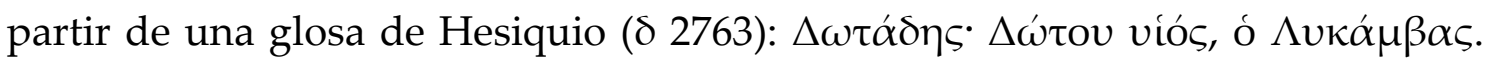
De este modo, el patronímico Dotades referido a Licambes vendría a situar a este personaje también dentro del ámbito eleusino. ${ }^{131}$

Además del vínculo con la esfera religiosa de Dioniso y Deméter, el mismo nombre $\Lambda v \kappa \alpha ́ \alpha \beta \eta \varsigma$ parece ser en sí mismo un nombre parlante

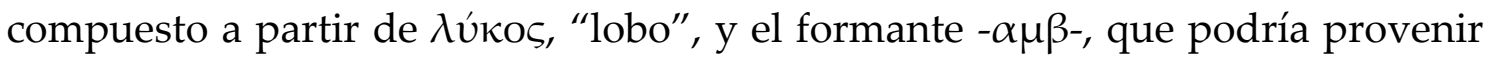

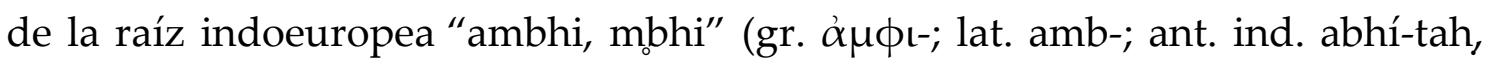
Pokorny, 1969, pág. 34) presente en palabras castellanas como "ambular", y que podría referirse a la forma de andar del lobo, a su deambular acechante: "el paso del lobo", ${ }^{132}$ y tal vez podríamos postular la hipótesis de un determinado tipo de movimientos y pasos dentro de una danza o festividad ritual, o de un personaje dentro de esa danza o festividad: "el lobo yámbico".

131 Bonanno (1980, págs. 81-2), por el contrario, no considera que $\Delta \omega \tau \alpha \dot{\delta} \delta\rceil \varsigma$ pueda ser

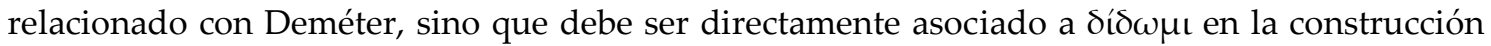

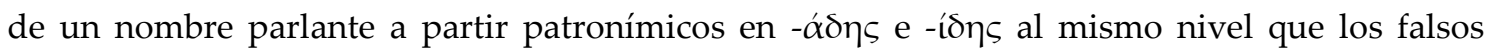

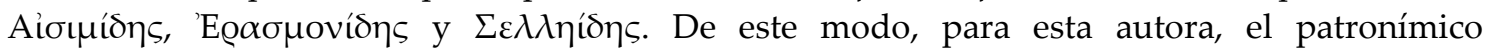
$\Delta \omega \tau \alpha ́ \delta \eta \varsigma$ referido a Licambes sería un incisivo sarcasmo en alusión a que él es "hijo", "pertenece a la raza de $\Delta \omega \dot{\tau} \eta \varsigma^{\prime}$, en la acepción de aquellos que "dan" a sus hijas en dote o en matrimonio.

132 Pickard-Cambridge (1966, pág. 15) tradujo el nombre $\Lambda v \kappa \alpha ́ \mu \beta \eta \varsigma$ como "wolf's gait". Sobre los posibles significados de este nombre, además de West (1974, págs. 22-8), véanse también Nagy (1976, pág. 198), Miralles \& Pòrtulas (1983, págs. 53-60) y Miralles (1986, págs. 11-26). 


\section{A NeObUle}

\section{FF. 188-192W}

Otro grupo de fragmentos, compuestos también en estrofas epódicas (ff. 188-192W), ${ }^{133}$ presenta invectivas dirigidas contra Neobule, una de las hijas de Licambes:

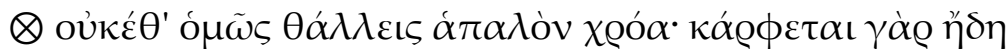

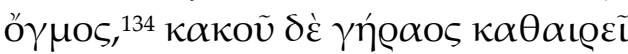

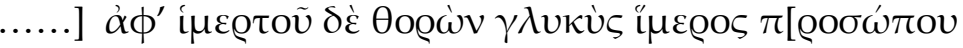
..] $\kappa \varepsilon v^{*} \tilde{\eta} \gamma \dot{\alpha} \varrho \pi \mathrm{o} \lambda \lambda \dot{\alpha} \delta \dot{\eta} \sigma^{\prime} \dot{\varepsilon} \pi \tilde{\eta} \iota \xi \varepsilon v$

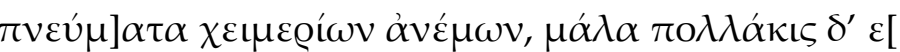

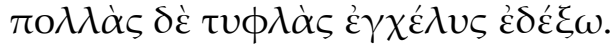

Arquíloco, fr. 189W $\mathrm{W}^{136}$

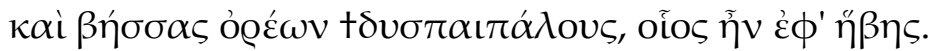

Arquíloco, fr. 190W $\mathrm{W}^{137}$

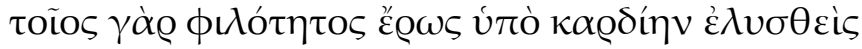

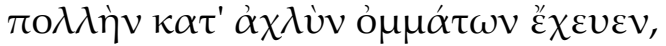

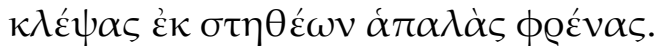

Arquíloco, fr. 191W $\mathrm{W}^{138}$

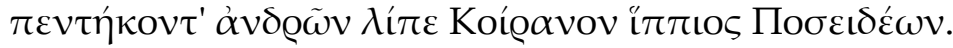

Arquíloco, fr. 192W $\mathrm{W}^{139}$

${ }^{133}$ Estos fragmentos poseen la siguiente estructura métrica: tetrámetro dactílico-itifálico-trímetro yámbico cataléctico; vid. Hefestión, Ench. met. 6.3; Atilio Fortunaciano, Gramm. Lat. 6.298.6. Para la unión de estos cuatro fragmentos, véase West (1974, págs. 134-5).

134 Sigo aquí la lectura en nominativo singular ő $\gamma \mu \circ$ s frente a la sustitución en dativo plural postulada por Snell (1944, págs. 282-92) y seguida por West. La discusión textual radica en si se debe leer aquí ö $\gamma \mu \circ \varsigma$ en referencia al sexo femenino, o debería entenderse ö $\gamma \mu$ o $\varsigma$ en alusión a las arrugas del rostro. Para una discusión de los diferentes argumentos, véase Brown (1995, págs. 29-34).

${ }^{135}$ Los vv. 1 y 2 de este fragmento han sido transmitidos por Hefestión, Ench. met. 6.3 y 5.3, respectivamente, y se completa con el P. Colon. 7511 36-40 Merkelbach-West; vid. Atilio Fortunaciano, Gramm. Lat. 6.298.6 Keil.

136 Transmitido por Ateneo 7.53-54.

${ }^{137}$ Transmitido por Hefestión, Ench. met. 15.8 (pág. 50 Consbruch).

138 Transmitido por Estobeo 4.20.43.

139 Transmitido por Plutarco, Sollert. anim. 36.984f. 
Tu delicada piel no reverdece como antes, pues ya se te está secando el surco y (los efectos) de la maldita vejez te alcanzan.

El dulce encanto que brotaba de tu delicioso rostro (se ha ido).

¡Cuántas ráfagas has debido soportar

de vientos invernales! ¡Con cuánta frecuencia...!

(...)

y muchas anguilas ciegas acogiste.

(...)

y los abruptos valles de los montes, tal como era yo en mi juventud.

(...)

Tal fue el deseo sexual que tras envolver mi corazón

derramó sobre mis ojos espesa niebla,

luego de arrebatar de mi pecho los débiles sentidos.

(...)

De entre cincuenta hombres, Poseidón Hipio dejó con vida a

Cérano.

En el fr. 188W, el interlocutor expresa con irónica crudeza el deterioro físico de la hija de Licambes, deterioro que podría atribuirse a su envejecimiento natural o a la lascivia y promiscuidad de la joven. ${ }^{140}$ En el 189W,

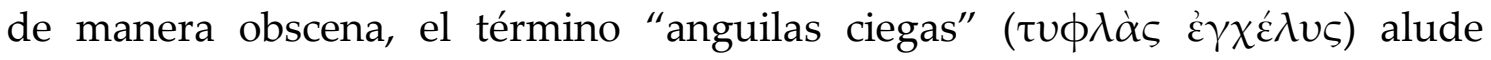
metafóricamente a "los penes" que Neobule habría "recibido" dentro de su cuerpo. ${ }^{141}$ Igualmente, la primera parte del fr. 190W, "profundos valles de los

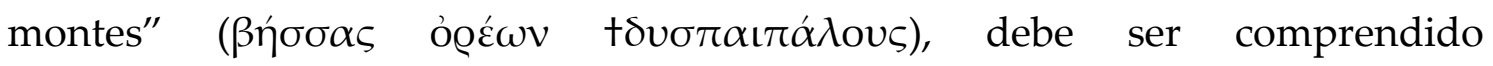
metafóricamente en referencia a las curvas del cuerpo de una mujer. ${ }^{142} \mathrm{Y}$ la parte final de ese verso podría estar funcionando como concatenación entre la imagen de las "anguilas ciegas" del fr. 189W con el contenido del fr. 191W, ya

\footnotetext{
${ }^{140}$ Henrichs (1980, págs. 7-27). Más adelante, al analizar el "Primer Epodo de Colonia" (ff. 196 y 196aW), ampliaremos el tema de la relación entre la promiscuidad de Neobule y su deterioro físico.

${ }^{141}$ Schneidewin (1839, pág. 193): “Tv $\phi \lambda \grave{\alpha} \varsigma \dot{\varepsilon} \gamma \chi \varepsilon ́ \lambda v \alpha \varsigma$ intellige membra virilia, quae receperat Neobule". Posteriormente, Gerber (1973, págs. 105-9) y West (1974, pág. 134) sustentarán la

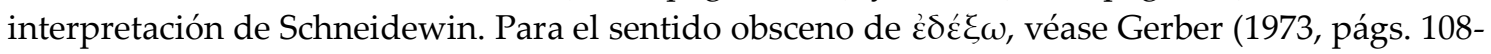
9).

142 "Archilochus is not recalling the delights of mountain walking, a most un-Greek pastime; the rocky glens are those of the woman's body", West (1974, pág. 134).
} 
que el hombre parece decir que su interlocutora en realidad no era tan atractiva ni deseable, sino que él había perdido el juicio porque, al igual que otros, estaba ciego por el deseo sexual de la juventud. ${ }^{143}$

Por último, el fr. 192W hace referencia a una historia que menciona Plutarco al citar este fragmento, y que ya también había sido transmitida por Demeas en la "Inscripción de Sóstenes."144 De acuerdo con la versión de Demeas, una nave que volvía desde Mileto llevando embajadores se hundió en el estrecho que hay entre Naxos y Paros y solo se salvó uno de ellos, llamado Cérano, gracias a la ayuda de un delfín que lo transportó a una cueva, donde habitó hasta que pudo regresar. La cueva de su refugio recibió el nombre de Ceraneon y fue consagrada a Poseidón Hipio. Aunque de difícil interpretación dentro del contexto, si es correcta la ubicación de este fragmento junto con los anteriores, se podría especular que el hombre está siendo irónico con Neobule, ya que finalmente él, al igual que Cérano, pudo salvarse de aquella que tantas “anguilas ciegas” había guardado dentro de sí.

Si esta lectura es correcta y si su destinataria es efectivamente Neobule, como todos los críticos han sostenido, entonces este epodo constituye una durísima invectiva contra la hija de Licambes. De acuerdo con la leyenda, Neobule estaba comprometida en casamiento con el poeta. Pero el nombre Neoßoú $\lambda \eta$, como hemos visto anteriormente, también podría ser un nomen fictum: "aquella que tomó una nueva decisión", o más poéticamente "La tornadiza", "La inconstante."145

\footnotetext{
143 "191 would come well after this: 'for such was the desire for sex that blinded me and robbed me of my wits'", West (1974, pág. 135); véase también Henderson (1976, pág. 161).

${ }^{144}$ Cf. SEG 15.518; A I 7-19.

145 Vid. sup. pág. 76.
} 


\section{CONCLUSIONES PARCIALES}

Como hemos tratado de demostrar, los yambos que hemos integrado en el grupo analizado presentan todos ellos una estructura enunciativa con una escenografía apelativa cuya posición actancial de interlocutario aparece ocupada o bien por un nombre real que refiere a una persona histórica y contermporánea del poeta (Erxias, Glauco y Pericles), o bien por un nombre ficticio, probablemente parlante (Carilao, Cericidas, Licambes y Neobule). Podríamos esquematizar esta escenografía de la siguiente manera:

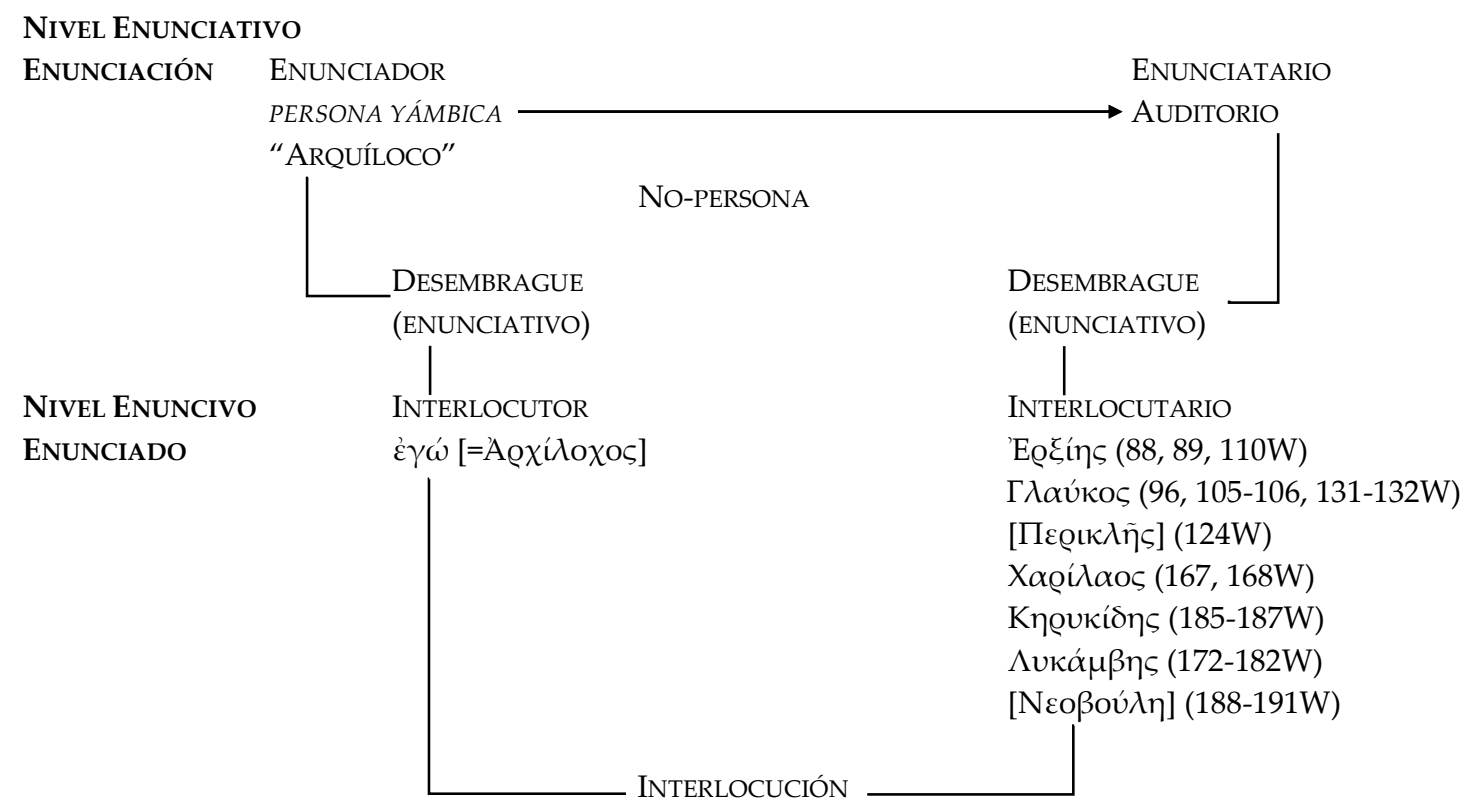

El esquema nos indica que la disyunción desde la instancia de enunciación hacia el enunciado se produce a través de un desembrague de tipo enunciativo que va a instalar en el discurso las formas de la enunciación enunciada.

El interlocutor se inscribe deícticamente en el enunciado a través de un pronombre únicamente en el fr. $89 \mathrm{~W}, \mu \mathrm{ol}$ (v. 15), cumpliendo probablemente la función de dativo posesivo; y a través de las formas verbales v́$\phi \omega ́ \mu \varepsilon \theta \alpha$,

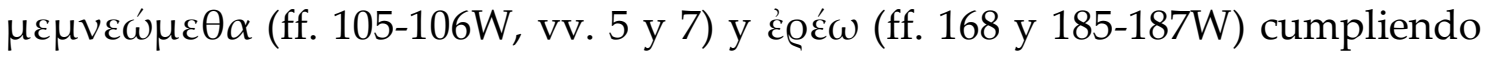


en todos los casos la función de sujeto agente; y también por medio de $\tilde{\eta} v$ (ff. 188-191W), cumpliendo la función de sujeto afectado.

Por su parte, los interlocutarios se inscriben deícticamente en el enunciado de la siguiente manera: Erxias a través de la deixis verbal $\gamma v \tilde{\omega} \theta i ́$ (fr. 89, v. 18), en la función sintáctico-semántica de sujeto expermientador. Glauco en el fr. 96W por medio del pronombre $\sigma \varepsilon$ (v. 1), en la función de complemento

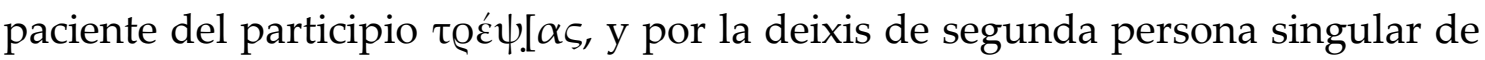

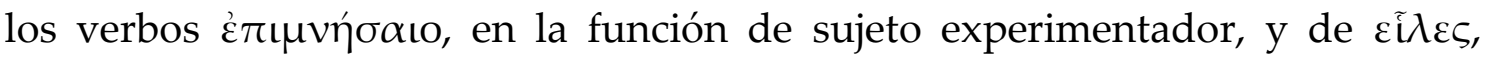
como sujeto agente; y en los ff. 105-106W a través de los pronombres $\sigma \varepsilon \mathrm{o}$ (v. 7), como complemento paciente del verbo $\mu \varepsilon \mu \nu \varepsilon \omega ́ \omega \varepsilon \theta \alpha$, y de $\sigma \dot{v}$ (v. 10), como sujeto agente del verbo $\pi \varrho o \mu \eta ́ \theta \varepsilon \sigma \alpha$; también aparece inscripto por medio de la

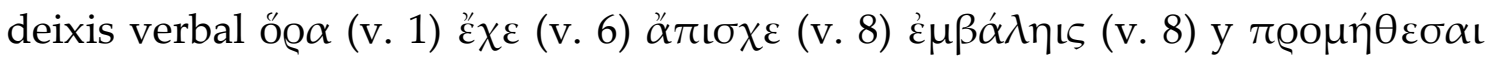
(v. 10), en todos los casos funcionando como sujeto agente. En el fr. 124W, Pericles se inscribe mediante la deixis de segunda persona singular del verbo $\tilde{\eta} \lambda \theta \varepsilon \varsigma$ (v. 4), en la función de sujeto agente, y por el pronombre $\sigma \varepsilon \mathrm{o}(\mathrm{v} .5)$, como

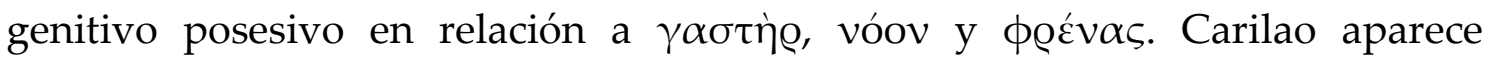
señalado deícticamente en el fr. $168 \mathrm{~W}$ por medio del pronombre $\tau$ oı (v. 2) en la función de complemento paciente del verbo $\varepsilon$ @éc $\omega$, y en las marcas de segunda

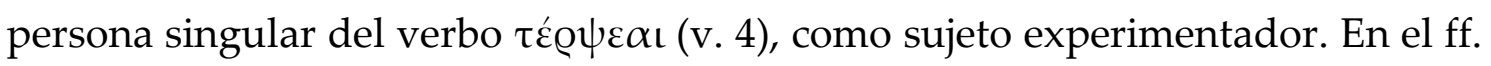
185W, Cericidas se inscribe en el enunciado por medio de la deixis pronominal

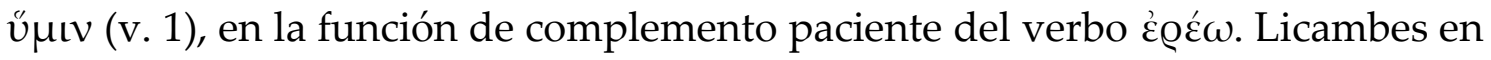

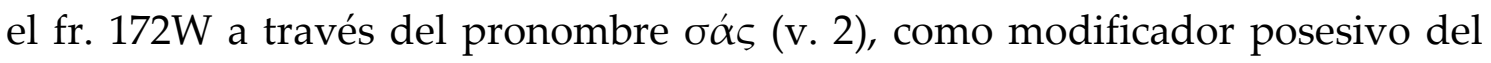
sustantivo $\phi \varrho \varepsilon ́ v \alpha \varsigma$, y por las marcas de segunda persona singular de los verbos

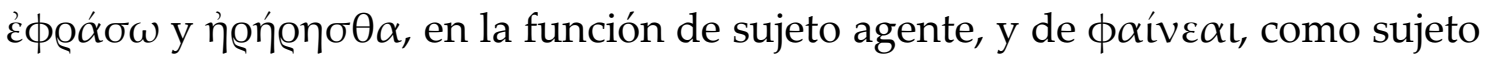
afectado; también aparece deícticamente en el fr. 173W por medio de las marcas

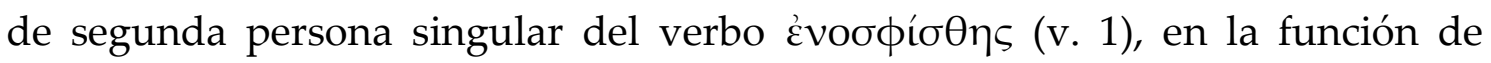
sujeto agente. En último lugar, Neobule se inscribe en el fr. 188W a través del verbo $\theta \alpha \dot{\alpha} \lambda \lambda \varepsilon\llcorner\varsigma$ (v. 1), en la función sintáctico-semántica de sujeto afectado, y 
por el pronombre $\sigma \varepsilon(\mathrm{v} .4)$, como complemento paciente de la acción expresada por el verbo $\dot{\varepsilon} \pi \tilde{\eta} \iota \xi \varepsilon v$; y en el fr. $189 \mathrm{~W}$, por medio de la deixis de segunda persona del verbo $\dot{\varepsilon} \delta \varepsilon ́ \xi \omega$ (v. 1), funcionando como sujeto agente.

El esquema nos muestra también un desdoblamiento de la instancia de recepción. En primer lugar, en el nivel enuncivo, la deixis en segunda persona singular nos marca al interlocutario al cual se dirige la apelación; en segundo lugar, en el nivel enunciativo, aparece de manera implícita el enunciatario, es decir el Auditorio al cual se dirige la representación poética. ${ }^{146}$ Esto nos lleva a considerar que, si es posible postular una concomitancia entre la identidad del interlocutor y la del enunciador, esta relación no se mantiene entre el interlocutario y el enunciatario.

Ante este desdoblamiento, es necesario señalar también que el contenido proposicional de cada uno de estos yambos conlleva dos fuerzas ilocutorias diferentes: una dirigida al interlocutario y otra al enunciatario. La primera es, por ejemplo, aquella que se desarrolla en las apelaciones bélicas destinadas a Erxias o a Glauco, en la amonestación risible pero amistosa contra Pericles, en la narración de una fábula o de una historia a Carilao y a Cericidas, o en la invectiva contra Licambes y Neobule. La segunda es aquella que conlleva el poema en su formulación y ejecución oral frente al auditorio en el contexto del simposio. Así, por ejemplo, la punzante invectiva dirigida contra Neobule puede contener en su ejecución pública una fuerza ilocutoria tendiente a generar la risa del auditorio.

\footnotetext{
146 "Les énonciations proférées sur scène, on l'a vu, sont adressées à deux destinataires distincts: l'interlocuteur sur scène e le public. Le même discours doit donc agir sur l'interlocuteur immédiat et sur le destinataire indirect [...] En principe, les lois du discours concernent les seuls personnages. Mais elles doivent aussi, d'une certaine façon, être respectées à l'égard du spectateur", Maingueneau (2010, pág. 339). Si bien esta observación acerca del desdoblamiento de la instancia de recepción se refiere específicamente a la enunciación teatral, es también aplicable a las composiciones apelativas de ejecución oral de la Grecia arcaica.
} 
Por último, los interlocutarios además de estar marcados deíctimante en el enunciado se inscriben de manera apelativa a través de los nombres en

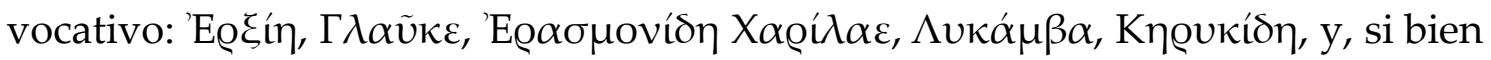
ni Pericles ni Neobule aparecen en los restos que se han conservado de los ff. 124 W y 188-191W, es muy probable, de acuerdo con los testimonios, que estos nombres también se hallaran apelativamente en esos yambos. ${ }^{147}$

El empleo de nombres parlantes también es una forma de enmascaramiento del 'yo', un dispositivo utilizado por la persona yámbica "Arquíloco" con la intención de generar un efecto cómico o de atenuar la tensión de la invectiva a través de lo risible. En la poesía yámbica arcaica, al igual que posteriormente en la comedia ática, ${ }^{148}$ es posible encontrar nombres reales como los de Erxias, Glauco y Pericles junto a sobrenombres y nombres parlantes como Carilao, Cericidas, Licambes y Neobule. Mediante estos nombres, el poeta yámbico alude a una característica negativa y risible, pública y privada, de aquella persona contra la cual dirige sus bromas de simposio o

${ }^{147} \mathrm{Al}$ introducir el fr. 124W, Ateneo 1.13-14 dice explícitamente que Arquíloco en este yambo se

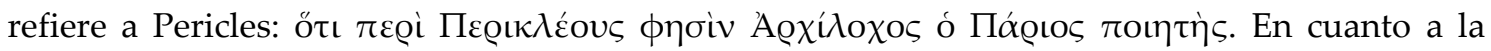
mujer contra la cual se dirige la invectiva en los ff. 188-191W, el fr. 188W (vv. 36-40) está precedido en el P. Colon. 7511 del fr. 196aW (vv. 1-35), donde aparece explícitamente el nombre Neoßoú $\lambda \eta[v$ (v. 24), por lo cual los editores Merkelbach \& West (1974, pág. 111) señalan: “Es ist ein Spottlied auf eine Frau, wohl Neobule". En ambos casos, la estructura apelativa en segunda persona singular nos lleva a pensar que, al igual que en el resto de los fragmentos de este grupo, los nombres de Pericles y Neobule habrían aparecido en vocativo en estos yambos.

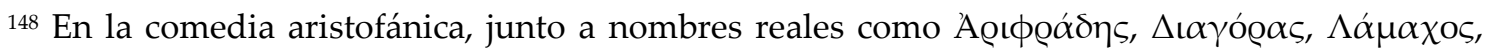
encontramos otros que, desvirtuados mediante sustituciones y trasposiciones como $\Lambda \alpha ́ \beta \eta \varsigma /$

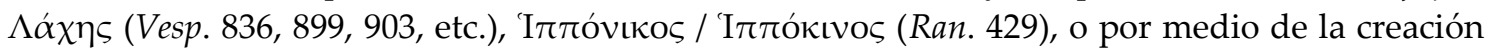
de un seudónimo $K \lambda \varepsilon \dot{\varepsilon} \omega \nu / \Pi \alpha \phi \lambda \alpha \gamma \omega \dot{ }$ / (Eq. 54, 65, etc.), sirven para caricaturizar y ridiculizar a determinados personajes dentro del ambiente político de la Atenas de la segunda mitad de s. V a. C. Seguramente el empleo de sobrenombres o nombres parlantes en la comedia ática haya sido el producto de los intentos de limitar la libertad de los comediógrafos en sus sátiras políticas, que llevaron al dictamen de dos $\psi \eta \phi i ́ \sigma \mu \alpha \tau \alpha$ durante ese período: el primero el de

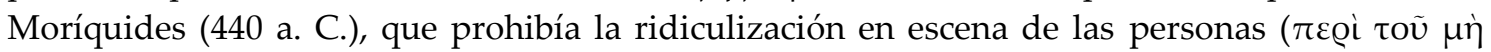
$\kappa \omega \mu \omega \delta \varepsilon i v$; vid. Schol. Arist. Ach. 67); el segundo el de Siracosio (415 a. C.), que prohibía las

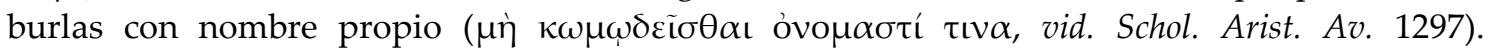
También es necesario recordar que Aristófanes fue acusado judicialmente por Cleón de haber ofendido a los magistrados y de haber difamado a la ciudad ante extranjeros en Babilonios (vid. Schol. Arist. Ach. 378). 
sus invectivas más violentas. Que el corpus yámbico de Arquíloco, al igual que el de Hiponacte, contenga una gran cantidad de nombres parlantes como el de Licambes, Neobule o su madre Anfimedo, no implica que ellos refieran a personajes puramente imaginarios, a "stock characters" en el sentido en que lo propone West, ${ }^{149}$ sino que estos nombres podrían haber sido creados ad hoc por el poeta con el fin de aludir satíricamente a personas históricas y reales del entorno comunitario de Paros. Un buen ejemplo de esto parece ser el fr. 115W:

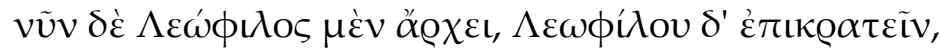

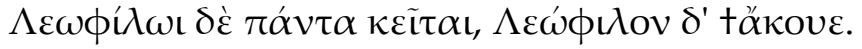

Arquíloco, fr. 115W 150

Ahora gobierna Leófilo, el poder es de Leófilo, todo recae sobre Leófilo, escucha (el nombre?) Leófilo.

Este fragmento de Arquíloco es citado en un texto atribuido a Herodiano como ejemplo de políptoton, una figura retórica consistente en el empleo de la misma palabra declinada en sus diferentes casos dentro de unos pocos versos. El nombre compuesto por los vocablos $\lambda \varepsilon \omega ́ \varsigma$ y $\phi i ́ \lambda o s$ significa “amigo del pueblo", por lo tanto, es posible que el yambo escondiera bajo este nombre parlante una sátira política contra algún demagogo coterráneo del poeta.

\subsubsection{INTERLOCUTARIOS DIVINOS}

Reunimos en un mismo grupo a tres poemas de Arquíloco que poseen una estructura enunciativa de interlocución y que se caracterizan también por presentar una escenografía de poesía petitoria a un dios. La divinidad invocada

\footnotetext{
149 West (1974, pág. 27) sostiene: “The possibility I am suggesting is that Lycambes and his libidinous daughters were not living contemporaries of Archilochus but stock characters in a traditional entertainment with some (perhaps forgotten) ritual basis".

150 Transmitido por Pseudo-Herodiano, De figuris (Rhet. Gr. 8.598.16 Walz). Para los problemas de crítica textual de este fragmento, véase la discusión en West (1974, págs. 130-1)

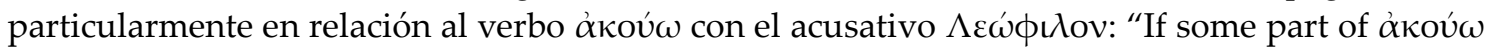
is correct, and has $\Lambda \varepsilon \omega ́ \phi \iota \lambda o v$ as its object, the sense will be 'hear the name Leophilus'".
} 
por el interlocutor aparece en vocativo y el verbo de la apelación se construye en imperativo:

\section{A Apolo}

\section{FR. 26W}

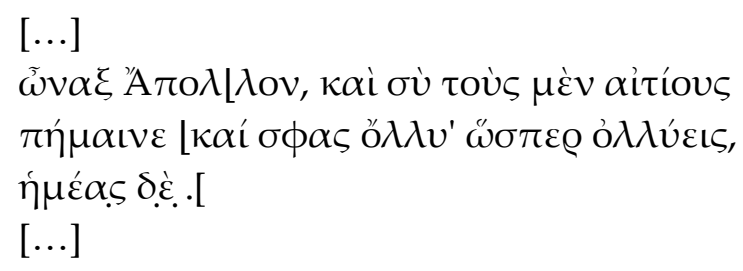

Soberano Apolo, castiga tú a los culpables, destrúyelos como tú lo haces, pero a nosotros...

En el yambo que constituye en fr. 26W, el interlocutor invoca a Apolo para solicitar probablemente la destrucción de sus enemigos. Lo conocemos a partir de una cita de Macrobio, en Saturnalia 1.17.9-10, donde expone una relación paretimológica entre el nombre Apolo (Aтó $\lambda \lambda \omega v$ ) y el verbo "destruir" ( $\alpha \dot{\pi} \hat{\lambda} \lambda \nu \mu \mathrm{l})$ : el dios habría obtenido ese nombre a raíz de que destruye a los seres vivos $(\dot{\alpha} \pi \pi \mathrm{o} \lambda \hat{v} v \tau \alpha \tau \dot{\alpha} \zeta \tilde{\omega} \alpha)$, cuando envía las pestes que se producen por el excesivo calor. Las pestes suelen representarse como flechas arrojadas por Apolo contra los humanos, como sucede en el ejemplo más representativo, el del castigo de la divinidad contra los aqueos por el rapto de Criseida y el rechazo de Agamenón de aceptar la recompensa ofrecida por el sacerdote Crises para su liberación (Il. 1.43-53).

151 El fragmento ha sido transmitido por P.Oxy. 2310 fr. 1 col. 2, sin embargo, el texto deteriorado del papiro únicamente se ha podido completar en las líneas 5 y 6 gracias a Macrobio, Sat. 1.17.9-10. 


\section{A Hefesto}

\section{FR. 108W}

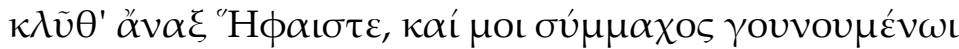

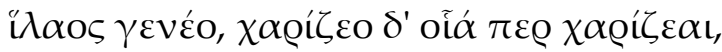

Arquíloco, fr. 108W $\mathrm{W}^{152}$

Escúchame, soberano Hefesto, y sé tú mi aliado propicio, te lo suplico de rodillas: concédeme aquellos (favores) que sueles conceder

En este caso es Plutarco el que trasmite el fragmento. Señala que cuando los poetas emplean nombres de divinidades lo hacen a veces con la intención de dirgirse ellos mismos a un dios en particular (podría interpretarse, por lo tanto, en función apelativa), y otras veces emplean el nombre para referirse a ciertos atributos de esos dioses (podría considerarse como un uso metonímico del nombre). Plutarco ejemplifica estos dos empleos con poemas de Arquíloco, para el primero cita los tetrámetros del fr. 108W, y para el segundo, los versos elegíacos del fr. $9 \mathrm{~W} .{ }^{153}$

Por otro lado, en la poesía griega arcaica y clásica, la solicitud de la alianza - $\sigma u \mu \mu \alpha \chi$ í $\alpha$ - es un tópico bastante extendido. ${ }^{154}$

152 Transmitido por Plutarco, Quomodo adolesc. aud. poet. 6.23a.

${ }_{153}$ Al transmitir el fr. 9W, Plutarco dice que al lamentarse por la muerte del marido de su hermana en un naufragio, sin haber gozado de los ritos funerarios, Arquíloco manifiesta que estos ritos le habrían permitido sobrellevar el desastre con mayor moderación. Plutarco transmite también que, en este fragmento, la purificación por el fuego funerario aparece indicada a través del nombre de Hefesto: "si Hefesto hubiera cubierto entre puras vestiduras la

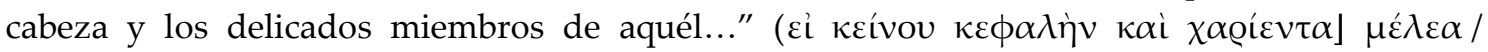

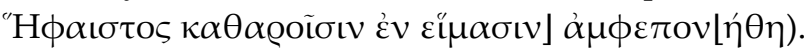

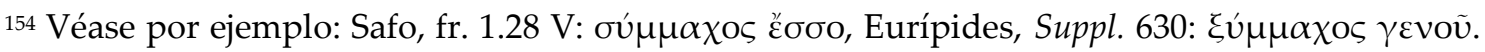

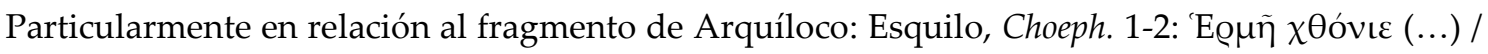

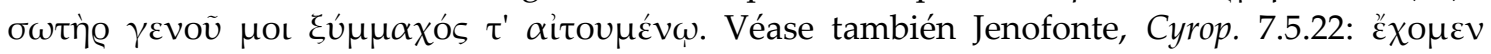

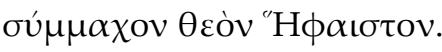




\section{A Zeus}

\section{Fr. 197W}

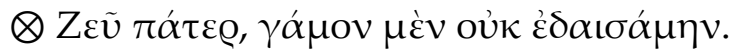

Padre Zeus, no celebré el banquete nupcial.

Lamentablemente este verso es citado por Hefestión en un texto de métrica antigua, como ejemplo de trímetro trocaico cataléctico, sin ninguna información acerca del contenido del poema que lo contenía. Sin embargo, la apelación dirigida a Zeus puede relacionarse fácilmente con el infructuoso compromiso de casamiento con Neobule que hemos ya comentado. Estaría el interlocutor poniendo de testigo a Zeus por no haberse cumplido el acuerdo de boda entre él y una de las hijas de Licambes. ${ }^{156}$ Parece evidente que el poema constituía una plegaria dirigida a la divinidad solicitándole tal vez un acto de justicia reparador, en particular a causa de que el acuerdo habría sido sellado a través de un juramento. ${ }^{157}$

\section{CONCLUSIONES PARCIALES}

Como hemos visto, los últimos tres yambos (ff. 26, 108 y 197W) poseen estructuras y escenografías enunciativas similares, que podríamos esquematizar de la siguiente manera:

\footnotetext{
${ }^{155}$ Transmitido por Hefestión, Ench. met. 6.2 (pág. 18 Consbruch).

156 Vid. sup. pág. 76 n. 60.

${ }^{157}$ Vid. sup. pág. 107 n. 128. La temática de la plegaria en la poesía yámbica será desarrollada en detalle dentro del corpus de Hiponacte (vid. inf. pág. 199).
} 


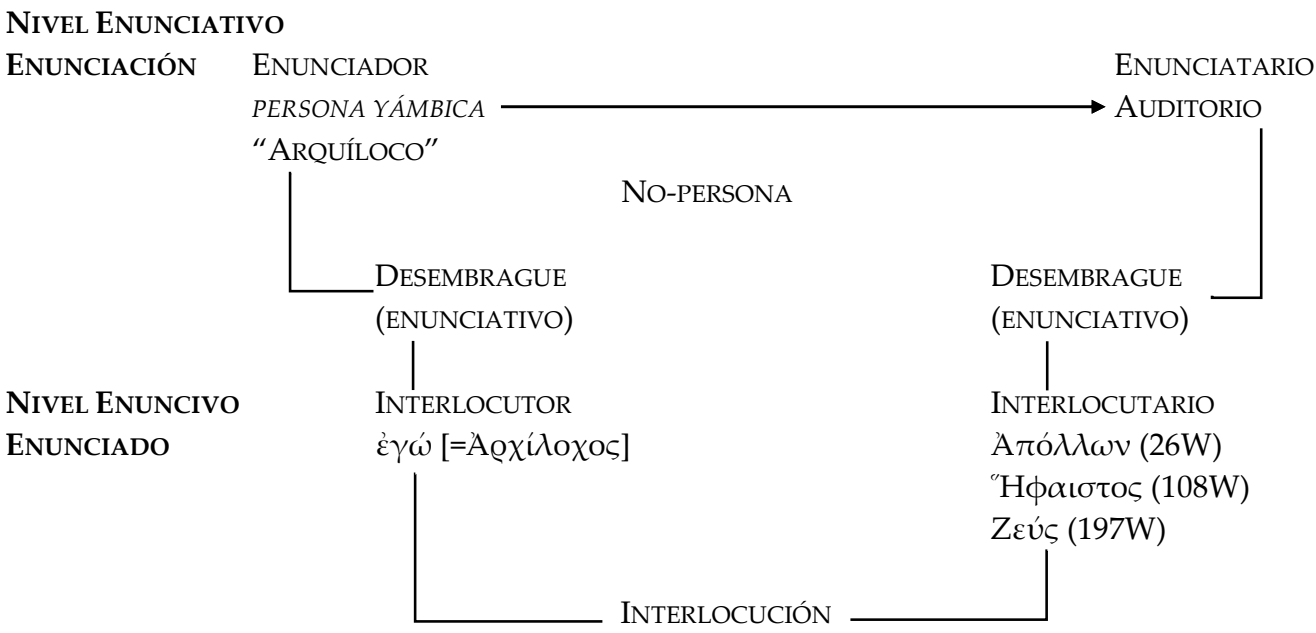

El esquema nos muestra que el proceso de disyunción desde la instancia de enunciación hacia la del enunciado se realiza a través de un desembrague de tipo enunciativo que instaura en el discurso las formas de la enunciación enunciada. El discurso toma la forma de una interlocución en la que el interlocutor aparece inscripto deícticamente en el enunciado del fr. 26W por

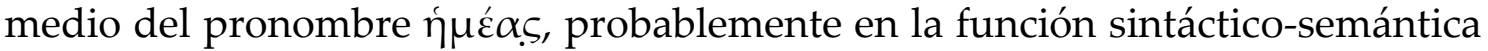
de complemento paciente de algún verbo en activa que no se ha conservado en el papiro; en el del fr. 108W, a través de la deixis pronominal $\mu \mathrm{o}$, funcionando

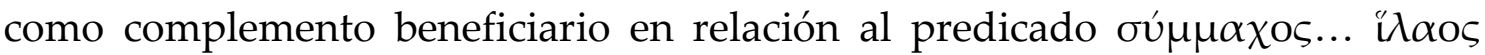

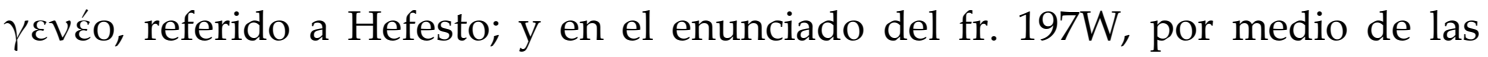
marcas de primera persona singular del verbo $\dot{\varepsilon} \delta \alpha \sigma \alpha ́ \mu \eta \nu$, como sujeto agente. Por su parte, el interlocutario se inscribe deícticamente en el enunciado del fr. $26 \mathrm{~W}$ a través del pronombre $\sigma u ́$, en la función de sujeto agente de los verbos

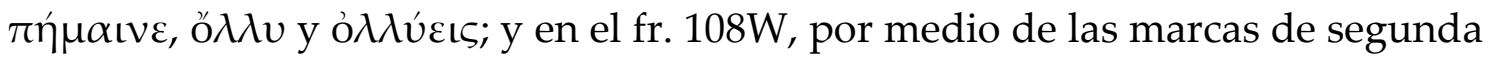
persona singular de los verbos $\kappa \lambda \tilde{v} \theta(\iota), \gamma \varepsilon v \varepsilon \dot{o}, \chi \alpha \varrho i ́ \zeta \varepsilon$ y $\chi \alpha \varrho i ́ \zeta \varepsilon \alpha \iota$, cumpliendo en todos los casos la función sintáctico-semántica de sujeto agente; en el fr. 197W, el interlocutario no se manifiesta deícticamente en el enunciado.

Es necesario distinguir que, si los marcadores deícticos en primera persona, aquellos que refieren al interlocutor, constituyen una deixis ad oculos, es decir, un sistema deíctico que señala exofóricamente o extratextualmente hacia 
una realidad que se manifiesta ante los sentidos del auditorio en la instancia de la ejecución poética oral; en cambio, los marcadores de segunda persona que instauran en el enunciado al interlocutario, conforman una deixis am Phantasma, ya que el sistema deíctico de segunda persona se organiza detrás de la imagen mental de la divinidad que se convoca en el aquí y ahora de la performancia poética. Por lo tanto, es posible afirmar que, en estos yambos, si existe una relación de concomitancia entre la identidad del interlocutor y la del enunciador, esta concomitancia no se da entre el interlocutario (Apolo, Hefesto y Zeus) y el enunciatario (Auditorio). ${ }^{158}$

Para finalizar, es importante recalcar que, dentro de los yambos de estructura apelativa, la máscara del suplicante es un atributo legitimado por el género que caracteriza a la persona yámbica "Arquíloco".

\subsection{LA MÁSCARA DEL AEDO HOMÉRICO}

Dentro de las composiciones de estructura apelatitiva, podemos destacar también dos yambos en que el locutor podría estar emulando de manera paródica la voz del aedo homérico:

\section{FR. 117W}

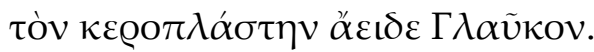

Arquíloco, fr. 117W 159

Canta a Glauco, el que arregla su pelo en forma de cuerno.

Este fragmento, particularmente, contiene una alusión paródica de la

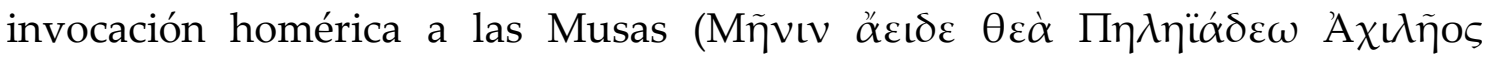

${ }^{158}$ El desdoblamiento de la instancia de recepción es particularmente evidente en la escena teatral, pero es indistintamente aplicable a la ejecución de la poesía oral; véase Maingueneau (2010, págs. 339-40).

159 Transmitido por Schol. (b)T Hom. Il. 24.81. 


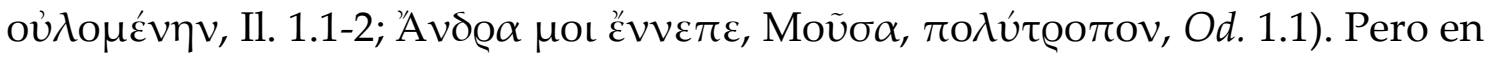
este caso, el poeta yámbico no le estaría solicitando a la Musa que le cante acerca de la cólera de Aquiles ni del hábil Odiseo, sino de Glauco, “aquél que cuidadosamente arregla su pelo en forma de cuerno". Glauco, hijo de Leptines, como hemos visto, era probablemente un general pario o tasio ligado al círculo íntimo del poeta, un hombre valeroso pero un tanto vanidoso de su aspecto físico. ${ }^{160}$

\section{FR. 25W}

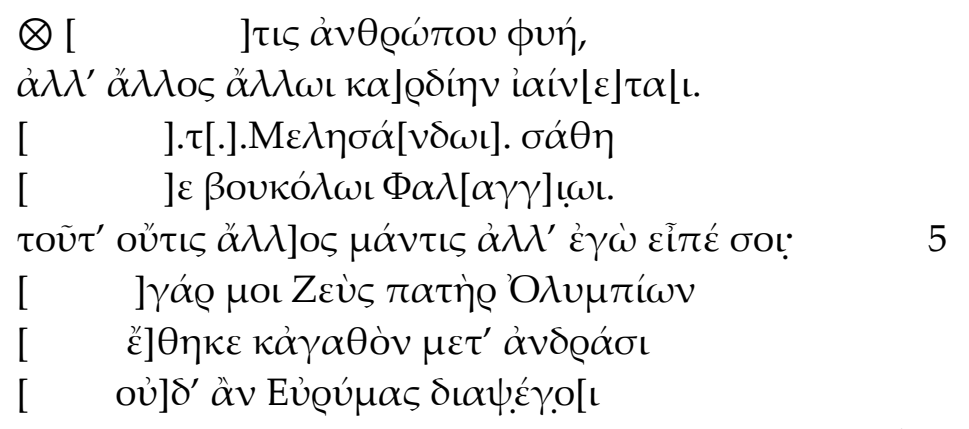

[...] la naturaleza del hombre, sino que cada uno calienta su corazón con algo distinto. ...] la verga para Melesa[ndro] ...] para el boyero Fal[ang]io.

Eso ningún otro adivino, sino yo, te lo dijo: pues Zeus, padre de los Olímpicos, me hizo... y bueno entre los hombres y ni siquiera Eurimas podría criticar[me].

Las fuentes que citan este fragmento señalan un paralelo entre su

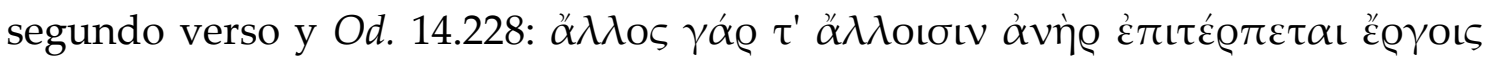

$160 \mathrm{Vid}$. sup. pág. 91. Es probable que el fr. 114W, en que el interlocutor manifiesta su preferencia por un jefe militar pequeño pero plantado firmemente sobre sus pies, antes que uno corpulento y vanidoso que se jacta de sus rizos, también estuviera haciendo referencia a Glauco (vid. sup. pág. 63).

${ }^{161}$ Este fragmento ha sido transmitido y citado por diversas fuentes, de manera directa nos llega a través del P.Oxy. 2310 fr. 4 Lobel. 
("cada hombre disfruta con un trabajo diferente"). ${ }^{162}$ Pero, además de la similitud de los versos, es interesante observar que existen ciertas resonancias entre el pasaje completo de Odisea y el yambo de Arquíloco. En primer lugar, las palabras del verso homérico aparecen en boca de Odiseo, arribado recientemente a Ítaca disfrazado de mendigo, y forma parte de sus falsos relatos cretenses. En ese contexto, Odiseo le cuenta al porquero Eumeo que su padre

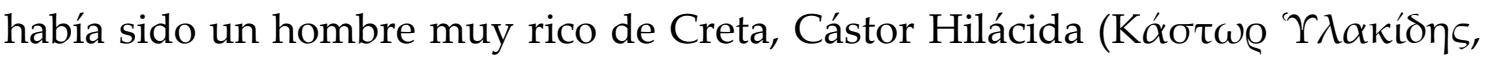
Od. 14.204), y su madre una de las esclavas de este. Significativamente, de acuerdo con el testimonio de Critias, Arquíloco habría afirmado en alguno de sus fragmentos que él también era hijo de una esclava llamada Enipo ('Evıtoũs

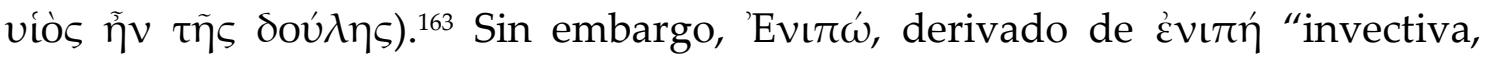
injuria, ultraje", podría ser también un nombre parlante creado a propósito por el poeta para atribuirse una progenie cómica en relación a su vocación yámbica: "soy hijo de la esclava Injuria". Tal vez, como sugiere West, en este mismo fragmento podría haber aparecido esa afirmación. ${ }^{164}$

En segundo lugar, Sexto Empírico cita el verso homérico y el análogo de Arquíloco para mostrar las divergencias que hay entre los hombres según los deseos particulares de cada uno, y los comenta explicando que mientras unos aspiran a la fama, otros buscan la riqueza, otros la salud, y otros el placer, ${ }^{165}$ pero es evidente que, si existe algún tipo de alusión por parte del poeta

\footnotetext{
162 Schol. ad Hom. Od. 14.228; Sexto Empírico, Adv. math. 11.44; Clemente de Alejandría, Strom. 6.7.3-5.

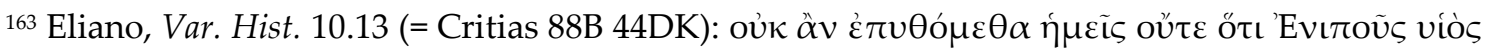

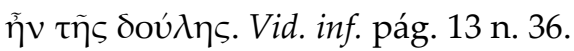

164 West: "the name [Enipo], with its connotation of $\dot{\varepsilon} v \imath \pi \alpha$, is suspiciously apt for an iambographer's mother. [...] If 6 began $\tau$ òv $\pi \alpha \tau \dot{\varepsilon} \mathrm{\rho} \alpha$, it is a possibility that Archilochus' chosen illustration of the variety of men's tastes was father's love for a slave-girl, Enipo, which resulted in the birth of the poet. We know that Archilochus told of this somewhere." (1974, pág. $28 \mathrm{y}$ 122).

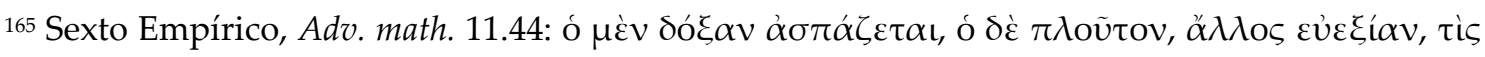

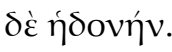


yámbico, es una alusión paródica de la voz del aedo homérico. En el pasaje de Odisea, al contarle sus falsos avatares a Eumeo, Odiseo resalta que a pesar de ser hijo de una esclava tomó por esposa a una mujer de una familia rica y distinguida, y que su pasión no era el trabajo, ni la casa, ni criar hijos ilustres, sino la guerra; antes de embarcarse hacia Troya con el rey cretense Idomeneo, él ya había comandado sus tropas nueve veces en distintas expediciones a

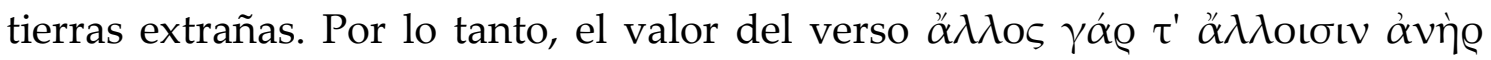

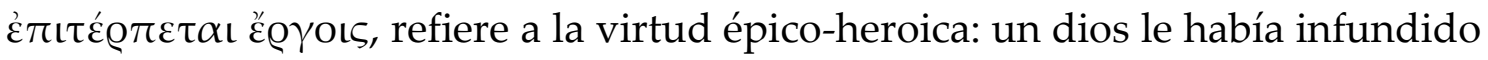
en su pecho el placer por la guerra (Od. 14.227). En cambio en Arquíloco, el

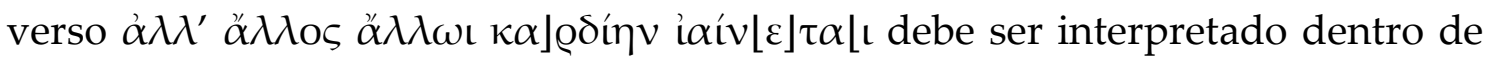
un contexto obsceno, ya que el placer de cada uno tiene que ver con las diferentes inclinaciones sexuales de los personajes que se mencionan: la verga para Melesandro, (alguna otra cosa) para el boyero Falangio, y, en los versos 58, el mismo interlocutor podría estar declarando su propia inclinación ante el interlocutario.

En tercer lugar, en el verso 8 se nombra a un tal Eurimas. Este Eurimas, héroe de Óleno en Etolia, fue muerto de un puñetazo por Pólux al tratar de enemistarlo con su hermano Cástor hablando maliciosamente de él. ${ }^{166}$ Tal vez también fuera el padre del adivino Télemo Eurímidas, quien le vaticinó a Polifemo en su juventud que un tal Odiseo lo dejaría ciego. ${ }^{167}$ Es posible que, en el yambo de Arquíloco, Eurimas apareciera representando el papel de un

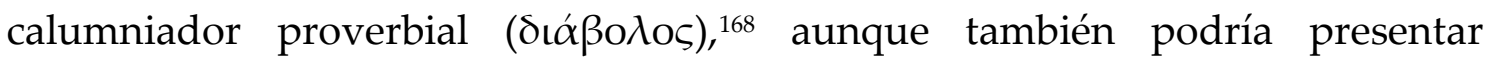
resonancias del vaticinio del pasaje de Odisea, ya que el cíclope recuerda el presagio que realizó el hijo de Eurimas en el mismo momento en que Odiseo se

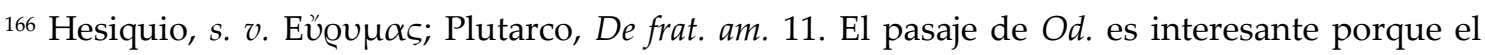
cíclope devela el vaticinio justo en el momento en que Ulises, ya en la nave con sus compañeros, le descubra su verdadero nombre.

${ }^{167}$ Homero, Od. 9.509 y Schol. ad locum.

168 West (1974, pág. 122).
} 
quita la máscara del seudónimo que había utilizado, "Nadie", 169 un verdadero nombre parlante yámbico, y revela su verdadero nombre.

Por último, tal vez se trate de un hecho más fortuito, debemos recordar que en los falsos relatos cretenses Odiseo llama a su padre con el nombre de Cástor, lo que coincide con el de uno de los Dioscuros a los que quiso enemistar Eurimas con sus calumnias.

\section{CONCLUSIONES PARCIALES}

La estructura enunciativa de estos últimos dos fragmentos es exactamente igual a la de los yambos con apelaciones dirigidas a humanos o a divinidades; es más, el interlocutario del fr. 25W es humano, mientras que el del fr. 117W es claramente una divinidad. Sin embargo, en estos dos fragmentos varía la escenografía de enunciación, ya que presentan de manera paródica la voz del aedo homérico. Podemos esquematizar la estructura enuncivoenunciativa de estos dos yambos de la siguiente manera:

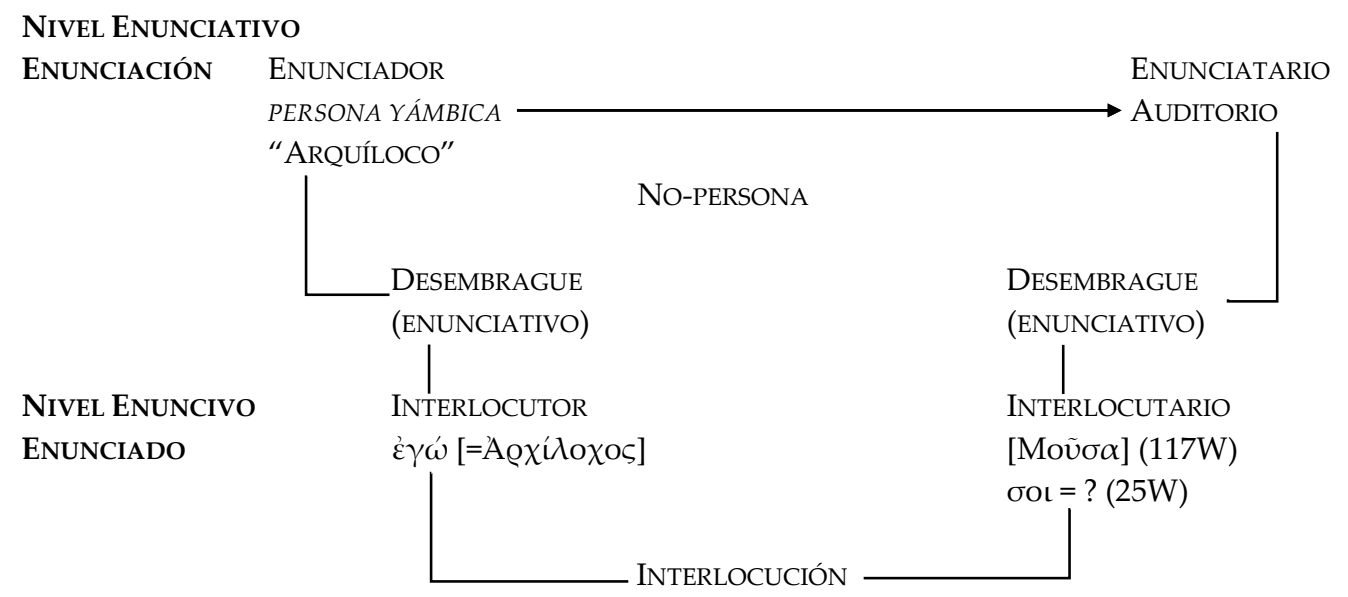

El esquema nos muestra que, en el fr. 25W, el interlocutor aparece señalado deícticamente por los pronombres $\dot{\varepsilon} \gamma \omega \dot{\omega}$ (v. 5), en la función sintácticosemántica de sujeto agente del verbo عĩ̄ov (elidido), y por $\mu$ oı (v. 6), como complemento receptor de la acción expresada por el verbo ह̌] $\theta \eta \kappa \varepsilon$. El

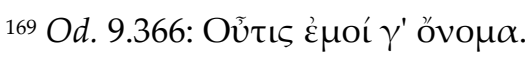


interlocutario, por su parte, aparece marcado deícticamente por el pronombre бol (v. 5), en la función de receptor del verbo عĩTć.

En el fr. 117W el interlocutor no se manifiesta deícticamente, pero se presupone en solidaridad recíproca con el interlocutario, señalado a través de las marcas de segunda persona singular del verbo ő́ $\varepsilon \_\varepsilon$ en la función sintáctica de sujeto agente.

Como hemos observado, aunque la identidad del interlocutor no aparece explícita en ninguno de los dos yambos, sin embargo, es posible sostener que la persona yámbica "Arquíloco" asume aquí la máscara del aedo homérico de manera paródica, seguramente con la función de entretenimiento dentro del simposio, caricaturizando amistosamente a Glauco o desvirtuando una frase proverbial a través de un contenido obsceno. Por su parte, la identidad del interlocutario tampoco aparece de manera explícita dentro del enunciado de los yambos, pero la parodia de la invocación homérica nos permite sostener que en el fr. 117W el interlocutario es la Musa; y el contenido del fr. 25W ( $\alpha \dot{\alpha} \theta \varrho \omega ́ \pi$ ov

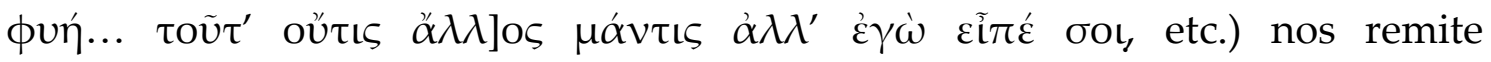
claramente a un interlocutario de carácter humano.

Para concluir, podemos sostener que la máscara paródica del aedo homérico también es uno de los atributos legitimados por el género que caracteriza a la persona yámbica "Arquíloco".

\subsection{A sí MISMO}

\section{FR. 128W}

Un yambo realmente interesante para nuestro análisis es el fr. 128W. En este tetrámetro, el interlocutor exhorta a su propio corazón como si fuera un interlocutario humano: 


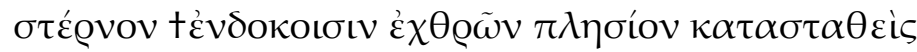

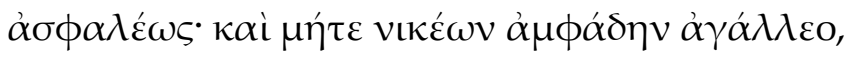

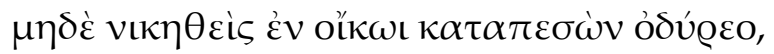

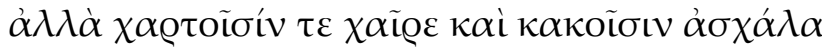

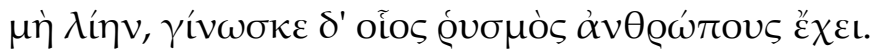

Arquíloco, fr. 128W170

¡Corazón, corazón, por inmensas penas arrastrado!

¡Emerge! Y con resistencia defiéndete, oponiendo el pecho

y parándote firme ante las emboscadas de los enemigos.

No te jactes ante todos, si vences,

ni, vencido, te lamentes en casa abatido.

Por las cosas alegres, alégrate, y por las desgracias, aflíjete,

pero no demasiado: ¡comprende qué tipo de cadencia rige al

hombre!

En estos versos en tetrámetros trocaicos, el interlocutor exhorta a su Өvuós a no dejarse ahogar por las penas que lo arrastran y lo incita a emerger de las profundidades oponiendo resistencia a las embestidas de los enemigos. ${ }^{171}$ Significativamente, este yambo de Arquíloco nos trae una nueva resonancia de la épica homérica y, en particular, del mismo Odiseo hablándole a su propio corazón. En Od. 20.18-21, luego de haberse acostado y sin poder dormir por las risas de sus siervas que salen a reunirse con los pretendientes, Odiseo duda en saltar inmediatamente y matarlas en ese mismo instante o dejar que se acuesten por última con ellos. Este debate interno se representa con la imponente imagen en la que se compara el arrebato del corazón con una perra que comienza a ladrar, cuidando de sus cachorros, y se dispone a atacar ante la presencia de una persona extraña. Pero Odiseo, en su astucia, increpa a su corazón golpeándose en el pecho:

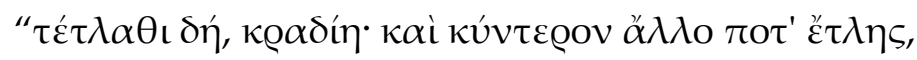

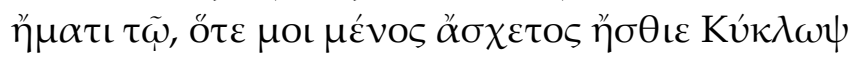

170 Transmitido por Estobeo, 3.20.28.

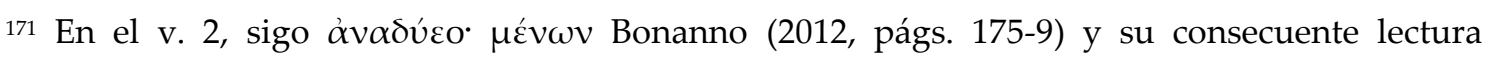
marítima de los primeros versos. 


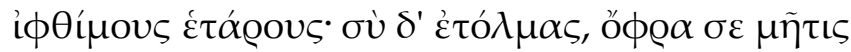

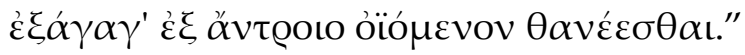

Odisea $20.18-20$

“Calla ya, corazón, que otras cosas más duras sufriste

como el día que el cíclope, de fuerza sin par, devoraba

mis valientes amigos: tú allí te aguantaste y, al cabo,

con la muerte a la vista, mi ardid te sacó de la cueva."172

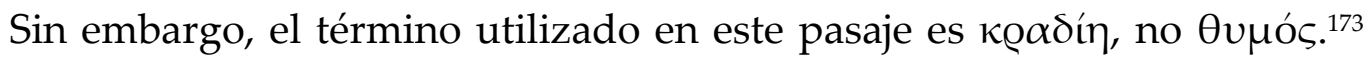

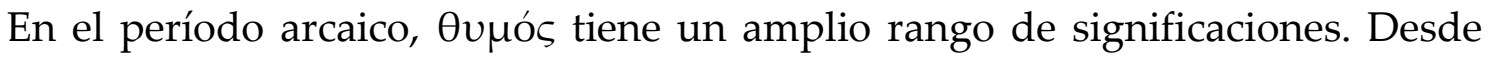
Homero aparece con el significado de "alma" o "corazón" en tanto principio de vida y se vincula con tres dominios: las emociones, la voluntad y el intelecto. Bajo estos tres dominios se agrupan acepciones tan variadas como vida, espíritu, pensamiento, discernimiento, temperamento, voluntad, deseo, coraje, valor, ira. ${ }^{174}$ Esta polisemia dentro de los tres campos semánticos parece desplegarse a lo largo del yambo de Arquíloco por medio de las exhortaciones dirigidas al Өvuós. En el primer verso, la exhortación al corazón concierne al

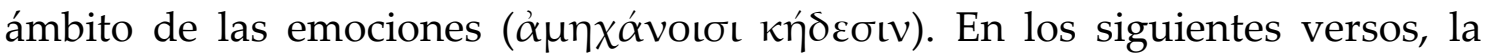
imagen militar constituye una exhortación al coraje y a la voluntad para

172 Traducción de José Pabón (1993).

${ }^{173}$ En varios pasajes de Ilíada (11.403, 17.90, 18.5, 20.343, 21.53, 21,552 y 22.98) y en otros tantos de Odisea (5.298, 355, 407 y 464), el narrador homérico nos dice que los personajes les hablan a

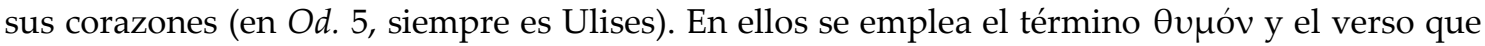

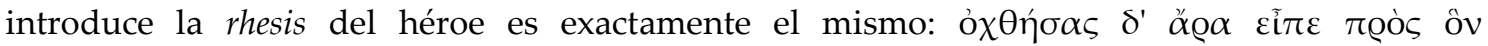

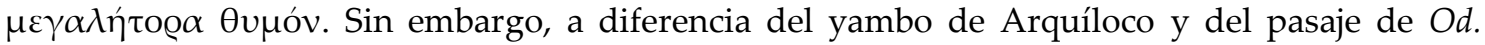
20.18-20, ninguno de los personajes exhorta a su corazón en segunda persona, sino que ellos se lamentan de las adversidades a través de un monólogo interior en primera persona. Por lo

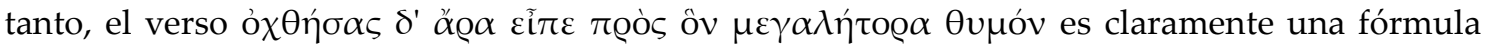
introductoria de un discurso interno, y no una apelación al propio corazón.

174 Chantraine y LSJ, s. $v$. $\theta v \mu$ ós. Para los tres ámbitos significación del término $\theta v \mu o ́ s$ en Homero, véase Böhme (1929, págs. 68-83), quien considera que los límites que lo separaban de

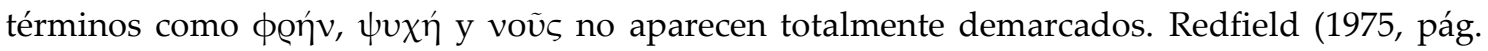
173) considera el $\theta v \mu o ́ \varsigma$ como el órgano donde se asienta la "affective life -of passions, whishes, hopes and inclinations", pero también de "the whole practical consciousness, from instant rage and pain to deliberation on the basis of lessons laboriously learned." En una perspectiva similar, Darcus (1977, págs. 178-82) señala: "In Homer the thumos is an organ of emotion, intellect, and will with no special emphasis on any of these activities". 


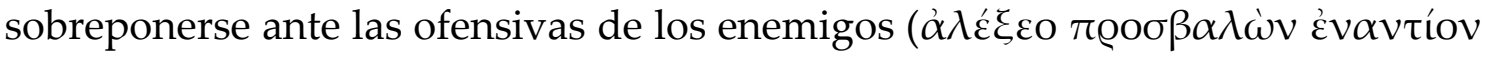

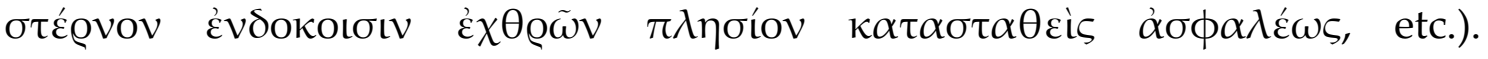

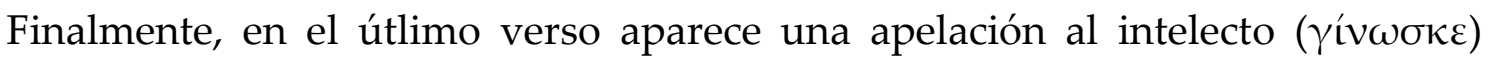
para mantener la mesura ante los vaivenes que rigen al hombre. Del mismo modo que la imagen marina del poema parece desplazarse desde la agitación catastrófica de las olas que todo lo arrastran a una resistencia firme ante los embates, para llegar finalmente a una oscilación permanente pero comprensible, la exhortación al $\theta v \mu$ ós se mueve de manera lineal desde el sentimiento de catástrofe a la comprensión de los vaivenes del hombre. ${ }^{175}$

Tanto en el pasaje de Odisea como en el yambo de Arquíloco se produce

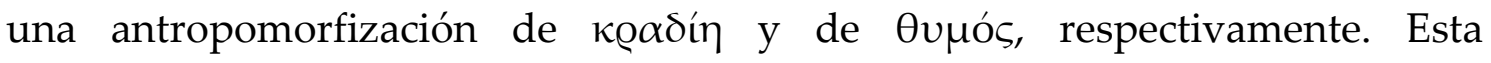
antropomorfización permite exhortar a estos órganos, en que se asientan el coraje, la voluntad y el pensamiento, como si fueran interlocutarios humanos. Si bien ambas obras están vinculadas a partir de la $\tau \lambda \eta \mu o \sigma u ́ v \eta$ (resistencia ante la adversidad), sin embargo cuando Odiseo incita a su к@ $\alpha \delta i ́ n$ a sobreponerse ante la deshonra de sus criadas y compara estas desgracias con peores soportadas en el pasado, no hay incertidumbres en sus palabras, es como si supiera de antemano que atravesar estas desgracias lo conducirá a alcanzar un objetivo final y permanente, una felicidad inmutable; en cambio, en el yambo de Arquíloco no existe esa certidumbre, el @vouós que rige al hombre marca exactamente la mutabilidad constante de su destino, por esta razón exhora a su $\theta v \mu o ́ s$ a que comprenda esa cadencia en la cual a veces se sale vencedor y otras vencido. ${ }^{176}$

El esquema enunciativo del yambo de Arquíloco es exactamente igual al del resto de este grupo, aunque como hemos visto se modifica la escenografía ya que el interlocutor se dirige a un interlocutario que es su propio $\theta v \mu o ́ s:$

\footnotetext{
175 Felson Rubin (1981, págs. 1-8).

176 Kirkwood (1974, pág. 36).
} 


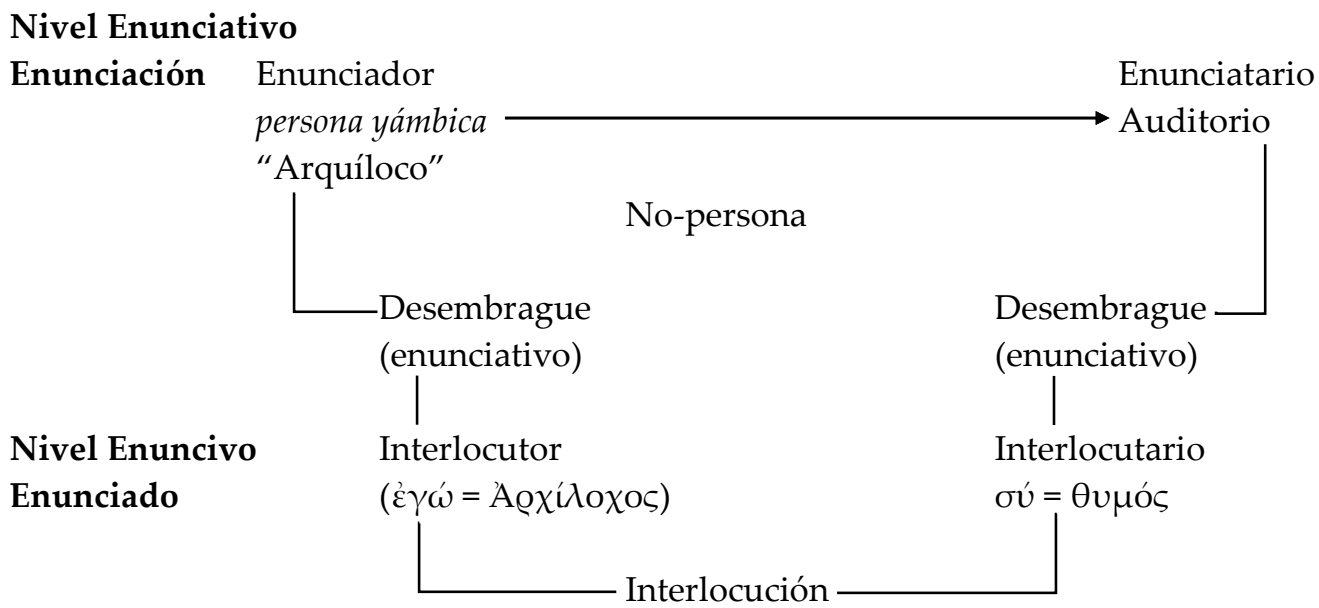

En el esquema se puede observar que en el nivel enuncivo el interlocutor no aparece inscripto deícticamente en el enunciado, pero se presupone en reciprocidad solidaria con el interlocutario. Este último, obviamente, se inscribe

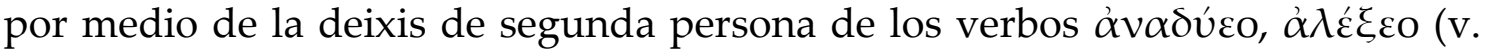

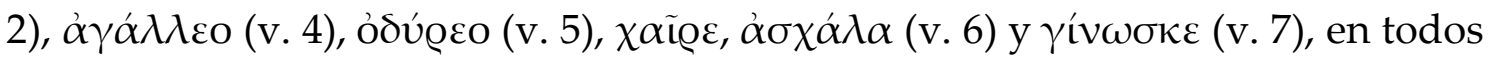
los casos cumpliendo la función sintáctico-semántica de sujeto agente.

El interlocutario aparece explicitado en el enunciado a través del vocativo $\theta v \mu \varepsilon ́$ (v. 1). Lo cual implica una relación de no concomitancia entre la identidad de este y la del enunciatario. Por su parte, si bien el yambo no transmite cuál es la identidad del interlocutor, es posible sostener una relación de concomitancia entre este y el enunciador, es decir, la persona yámbica "Arquíloco".

Por otro lado, la antropomorfización permite que la exhortación pase de tener un destinatario particular a uno de carácter más general. En cierta forma, al dirigirse a su propio $\theta v \mu o ́ s$, se produce por medio de una sinécdoque un desdoblamiento del " $\mathrm{yo}^{\prime}$, en tanto la identidad de ese "yo" ocupa las posiciones actanciales de interlocutor y de interlocutario. Pero, además, a lo largo del

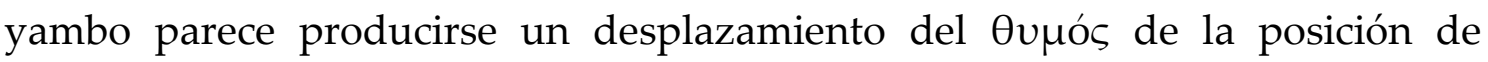
interlocutario, por el surgimiento de un actor con un carácter más general, el 
auditorio en la instancia de enunciación poética. De este modo, la persona yámbica "Arquíloco" comienza el poema exhortando a su propio corazón para poco a poco dirigir esa exhortación a su auditorio.

\subsection{LA MÁSCARA DEL OTRO}

Fr. 19W

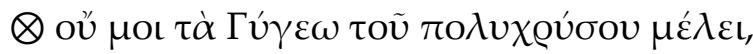

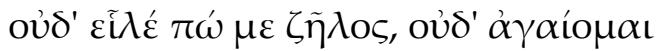

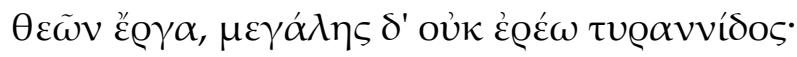

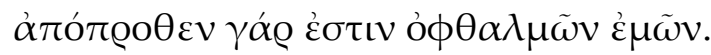

Arquíloco, fr. $19 \mathrm{~W}^{177}$

No me interesa la (fortuna) del muy rico Giges, ni jamás se apoderó de mi la envidia, ni ansío las obras de los dioses, y tampoco deseo la poderosa tiranía; muy lejos está de mis ojos.

El primer verso de este trímetro ha sido citado por Aristóteles en Retórica 1418.b.23-32, un pasaje clave para comprender el funcionamiento de la persona yámbica en relación a una de las características más destacadas de este género poético: la invectiva. Al discutir acerca del "carácter" -ท̃Өos- de los argumentos que se esgrimen en una deliberación o en un juicio, Aristóteles señala que, debido a que hablar acerca de uno mismo puede provocar envidia y controversia o parecer palabrería excesiva, y hablar acerca de otro puede ser interpretado como una ofensa o grosería, es conveniente que, cuando una de las partes intente acusar o censurar a la otra, lo haga poniendo las palabras en boca

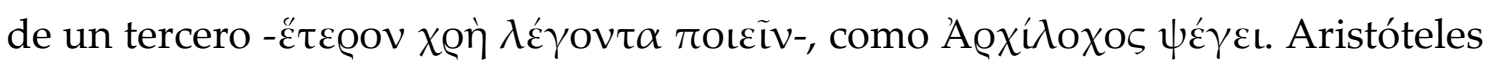

177 Este fragmento ha sido transmitido y mencionado por diversas fuentes, véanse en particular Plutarco, De tranqu. animi 10.470b-c; Aristóteles, Rhetorica 1218.b.23 y escolio ad. loc.; Et.Gud

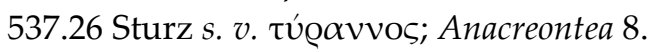


ilustra estas observaciones precisamete con dos composiciones del poeta de Paros (los que serán los ff. 122W y 19W):

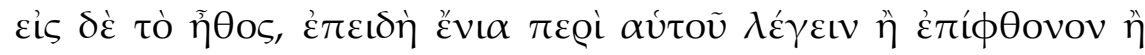

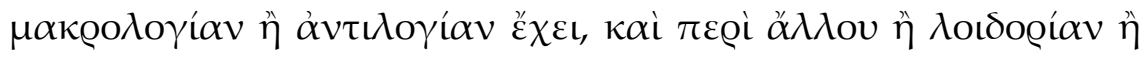

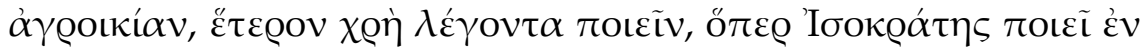

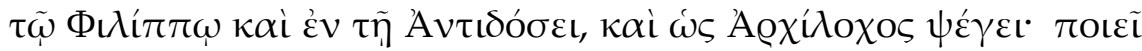

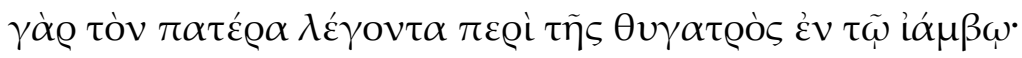

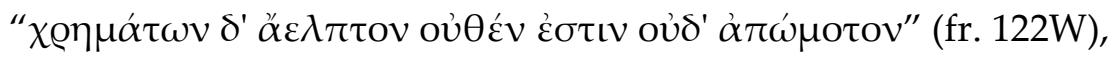

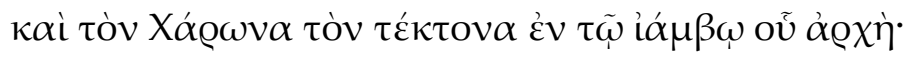

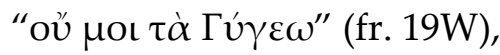

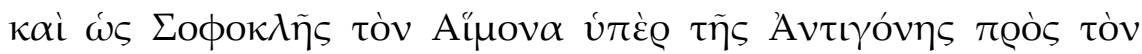

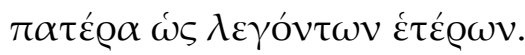

Aristóteles, Rhetorica 1418.b.23-32

En lo que respecta al talante, como decir cosas de uno mismo puede dar lugar a envidia o a prolijidad o a contradicción $y$, decirlas de otro, a injurias y a asperezas, es útil representar que es otra persona la que habla. Así lo hace Isócrates en el Filipo y en la Antídosis y éste es también el medio de que se sirve Arquíloco para sus censuras; como en aquel yambo en que, en efecto, hace que sea el padre quien diga de su hija:

En asuntos de dinero, nada hay inesperado ni que se rehúse por un juramento;

y como <lo que hace decir $>$ al carpintero Caronte, en el yambo que comienza:

No a mí los <dominios $>$ de Giges...

$<$ Otro ejemplo es lo que dice> Hemón, según Sófocles, a su padre en favor de Antígona, como si fueran otros quienes lo dijesen. ${ }^{178}$

De acuerdo con Aristóteles, en el fr. 122W Arquíloco hace hablar a un padre acerca de su propia hija, y en el fr. 19W el que habla es el carpintero

178 Traducción de Quintín Racionero (1994). 
Caronte. Es decir, en ambos casos las marcas de la primera persona inscriptas en el enunciado no remitirían a "Arquíloco" en tanto enunciador, sino a Caronte o a un padre, respectivamente. Otra información importante que nos revela Aristóteles en estas pocas líneas es la indicación de que el yambo, refiriéndose particularmente al fr. 19W, comienza con los versos que cita $(\dot{\varepsilon} v \tau \tilde{\omega}$

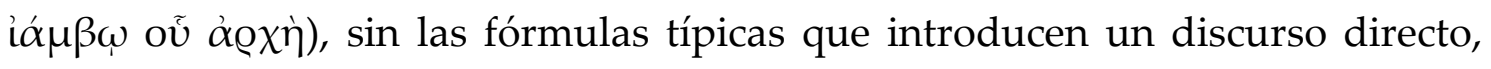
según se registran en la elegía y en la épica. ${ }^{179}$ Esta innovación en el modo de comenzar las composiciones, sin indicar que se trata de las palabras de otro, lleva a considerar que posiblemente otros fragmentos yámbicos de Arquíloco también pueden contener una primera persona que remita a una máscara como la de Caronte y no a la voz del poeta. ${ }^{180}$

Haciendo gala de una actitud de total desprendimiento, este carpintero afirma no tener interés por las riquezas de Giges, el famoso rey de Lidia, ${ }^{181}$ ni sentir envidia, ni ansiar las obras de los dioses, ni tampoco la tiranía poderosa. La austeridad que manifiestan las palabras de Caronte parece reproducir la sabiduría tradicional habitualmente expresada en proverbios o máximas. ${ }^{182}$ Sin embargo, su falta de ambición de poder y bienes materiales, rayana en la candidez, también puede ser comprendida de manera irónica. Vox (1998, págs. 113-8) ha demostrado que el fragmento tiene una estrecha relación con las enseñanzas que transmite Hesíodo en Trabajos y días, y que este vínculo debe entenderse como un contrapunto irónico de la sabiduría tradicional.

El discurso mimético en clave irónica permite postular un total distanciamiento entre la voz de Caronte, el interlocutor, y la de la persona

\footnotetext{
179 Acerca de las fórmulas introductorias o de finalización de un discurso referido en forma directa, véanse Edwards (1970, págs. 1-36), Olson (1994, págs. 141-51) y Beck (2008, págs. 16283).

180 Sobre esta hipótesis, véase Tsagarakis (1977, págs. 32 y 79-81).

${ }^{181}$ Nótese que significativamente vuelve a aparecer en una composición de Arquíloco una alusión al reinado de Giges (vid. sup. pág. 59 n. 17).

${ }^{182}$ El mismo tema aparece en el fr. 19P de Anacreonte (PMG 361).
} 
yámbica "Arquíloco", el enunciador. Si el carpintero asume como propia la enseñanza sobre la austeridad y la moderación, es porque "Arquíloco" hace oír esa voz ante su auditorio para ridiculizarla.

Lamentablemente no ha sido posible conocer quién es la persona contra

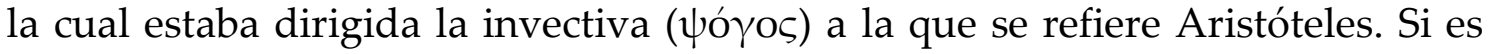
posible argumentar a favor de pensar que se trata de una ironía contra una forma de pensar ingenua y sencilla, el blanco de las críticas podría ser el propio Caronte o la persona real que se enmascara detrás de este personaje. ${ }^{183} \mathrm{O}$ tal vez se trate de una crítica velada contra alguien rico y poderoso, protegido por los dioses, algún tipo de pequeño Giges local. Siguiendo la interpretación que propone Vox de relacionar con Hesíodo, quizá Caronte esté dirigiendo sus críticas a otro carpintero, tal como podría deducirse de Trabajos y días 25-6, un pasaje que habría tenido su origen en un proverbio tradicional: $\kappa \alpha i ̀ ~ \kappa \varepsilon \varrho \alpha \mu \varepsilon u ̄ \varsigma$

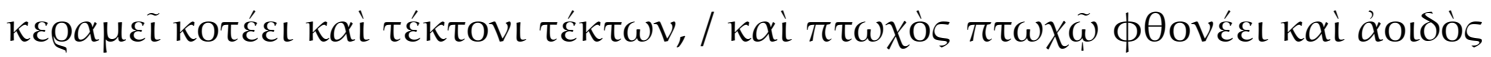
$\grave{\alpha} \operatorname{ot} \delta \tilde{\omega}$ ("el alfarero siente rencor por el alfarero y el carpintero por el carpintero, el mendigo envidia al mendigo y el aedo al aedo"). ${ }^{184}$ Esta lectura del fragmento nos conduciría a postular que la invectiva podría estar dirigida contra otro poeta.

\section{FR. 122W}

El primer verso del fr. $122 \mathrm{~W}$, como acabos de comentar, es citado por Aristóteles como ejemplo de invectiva a través del procedimiento de hacer hablar a otra persona. Del resto de este yambo, escrito en tetrámetros, conocemos lo siguiente:

183 Plutarco, De tranq. animi 10.470c afirma que el carpintero era un ciudadano de Tasos, sin embargo es posible que el nombre Caronte $(X \alpha ́ \varrho \omega v)$ haya sido utilizado en alusión al mítico barquero del Hades, o que tal vez sea un nombre parlante a partir de $\chi \alpha ́ \varrho \omega v$, forma poética de $\chi \alpha \varrho 0 \pi$ ó $\varsigma$ "de mirada brillante" y utilizado como epíteto de animales.

184 West (1978) señala la posibilidad de que estos versos provengan de un proverbio tradicional; cf. Verdenius (1982, pág. 28) 


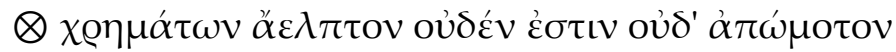

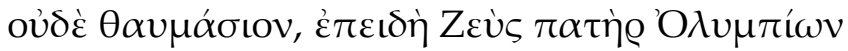

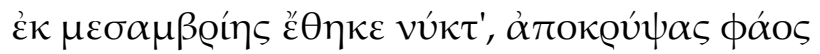

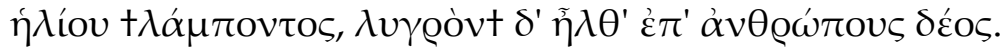

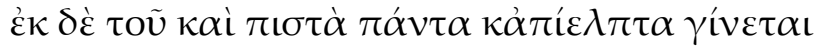

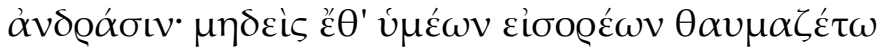

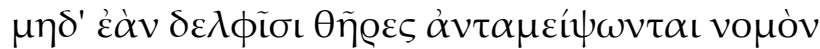

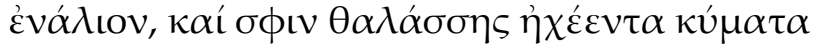

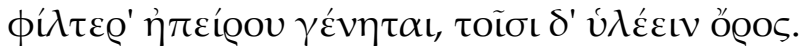

[

Aอ] $\chi \eta v \alpha \kappa \tau i ́ \delta \eta \varsigma$

10

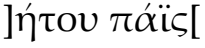

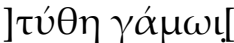

].. $\alpha ! v \varepsilon \varepsilon . .[$

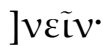

]

$\dot{\alpha} v] \delta \varrho \alpha ́ \sigma \iota v \cdot$

].[].[]

Arquíloco, fr. 122 West $^{185}$

Ningún hecho es inesperado, ni que pueda jurarse imposible, ni asombroso, desde que Zeus, padre de los Olímpicos,

el mediodía transformó en noche, luego de ocultar la luz del sol mientras resplandecía, y desde que el lúgubre temor [alcanzó a los mortales.

Desde entonces todo resulta creíble y esperable para los hombres. ¡Qué ya ninguno de ustedes se asombre ni siquiera al ver que las fieras intercambian con los delfines los dominios marinos y que a unos las resonantes olas del mar les resultan más agradables que la tierra firme, y a los otros el [boscoso monte!

$\begin{array}{ll}{[} & \text { Ar]quenáctida } \\ {[} & \text { ]el hijo de[ } \\ {[} & \text { ]para la boda[ } \\ {[} & ] \ldots[ \\ {[} & ] \ldots \\ {[} & ] \ldots \\ {[} & \text { ] a los hombres } \\ {[} & \text { ]... }\end{array}$

De acuerdo con el estagirita, en este poema Arquíloco hace hablar a un padre acerca de su propia hija. ${ }^{186}$ En búsqueda de atribuir una identidad a los

${ }^{185} \mathrm{El}$ fragmento ha sido transmitido por Estobeo, 4.46.10, al cual se le sumó posteriormente el P.Oxy. 2313 fr. 1.a. 
actores involucrados en el poema, la información que aporta Aristóteles ha sido interpretada de diversas maneras. Lasserre, por ejemplo, considera que la persona loquens sería el propio padre del poeta, quien estaría reprendiendo la excesiva manifestación de dolor de su hija, la hermana de Arquíloco, por la muerte de su marido en un naufragio. ${ }^{187}$ De acuerdo con esta lectura, el poeta estaría utilizando este artilugio para evitar que su propia recriminación,

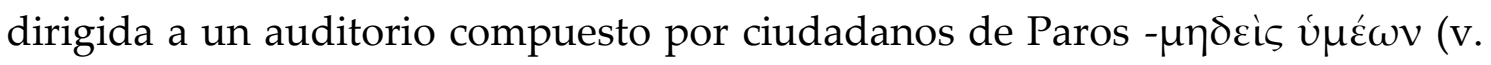
6.)-, sea considerada una confrontación directa y puedan recriminarle su soberbia y falta de civismo. Tras el descubrimiento del P.Oxy. 2313 fr. 1.a, y en

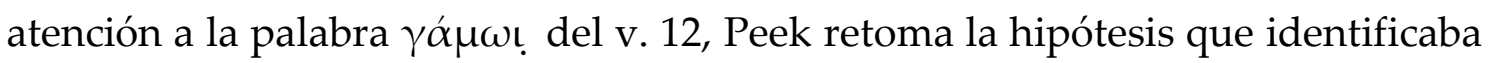
al padre y a la hija, siguiendo la indicación de Aristóteles, con Licambes y Neobule. ${ }^{188}$ La lectura de Peek se vincula nuevamente con las historias

186 Un comentario al pasaje de Aristóteles, Comm. in Aristot. Graeca 21, 2.255.31, nos transmite dos interpretaciones acerca del poema de Arquíloco: en la primera, el escoliasta señala que se

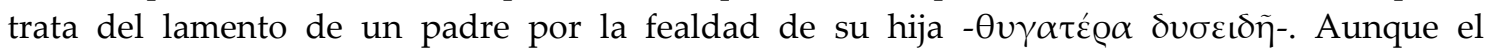
comentario no lo explicita, el lamento podría deberse a la falta de pretendientes; en la segunda, el escoliasta sostiene que el padre le está respondiendo a un pretendiente que le reprocha la falta de dote que no pierda las esperanzas de recibir alguna, ya que hasta lo más inesperado puede suceder.

187 La lectura de Lasserre (1947, págs. 1-7) se apoya principalmente en dos argumentos: en

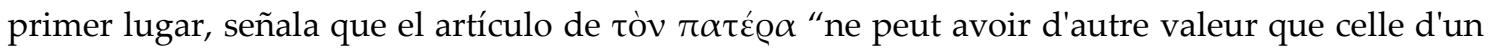
possessif", es decir, al tratarse de un sustantivo de parentesco, Aristóteles estaría enfatizando que Arquíloco hace hablar "al/a su" padre. En segundo lugar, considera que las circunstancias por las cuales la hija se lamenta se enuncian en los ff. 8-13W, donde, de acuerdo con la fuente que los trasmite (Plutarco, Quom. adolesc. aud. poet. deb. 23b.5 y 33a.11), el propio poeta se aflige "llorando al marido de la hermana, desaparecido en el mar, sin haber recibido la sepultura acostumbrada"; unas líneas más adelante agrega: "Arquíloco (...) afligido por la muerte en el mar del marido de su hermana..." Sin embargo, este último argumento parece difícil de sostener, ya que los pasajes citados por Plutarco son elegías, no yambos, por lo cual, más allá de las similitudes temáticas compartidas entre ambas formas poéticas, es evidente el carácter invectivo del fr. 122W. En la búsqueda de conciliar la cuestión, Lasserre (1947, pág. 2) interpreta

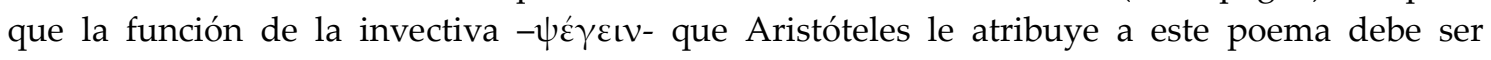
entendida, meramente, como la violenta severidad con la que el padre se dirige a su hija.

188 Esta hipótesis ya había sido postulada por Immisch (1890, págs. 198-203); desarrollada posteriormente por Jurenka (1900, pág. 13); Hauvette (1905, pág. 75); Fränkel (1924, pág. 81); Friedländer (1929, pág. 379). Véanse también Peek (1956, pág. 2); Treu (1968, pág. 146); Rodríguez Adrados (1976, pág. 212). La apelación en vocativo del primer verso del fr. 172W de

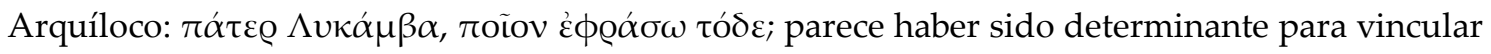
al padre al que se refiere Aristóteles con Licambes. 
transmitidas por la tradición antigua sobre la conflictiva relación que supuestamente Arquíloco mantuvo con los licámbidas, particularmente

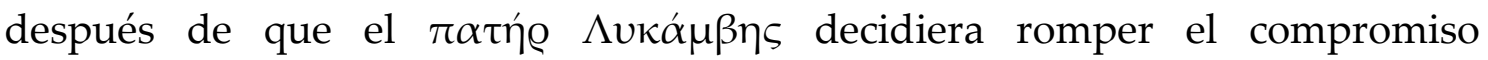
matrimonial entre el poeta y una de sus hijas, Neobule. ${ }^{189}$ La aparición del fr. 196aW de Arquíloco, publicado en 1974 como el "Epodo de Colonia", trajo consigo una nueva interpretación, ya que en ese poema un narrador en primera persona relata un encuentro erótico con la hija menor de Licambes. Por lo tanto,

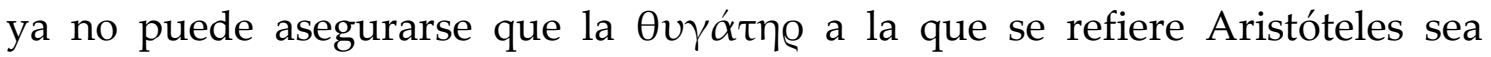
Neobule, sino que podría tratarse igualmente de su hermana menor. ${ }^{190}$ Si este fuera el caso, Licambes podría estar hablando tal vez sobre la conducta sexual de su hija más pequeña, seducida en el fr. 196aW, en lo que sería nuevamente una violenta invectiva contra esta familia. De cualquier modo, la falta de datos certeros conduce a la necesidad, como aconseja Bossi (1990, pág. 179), de "rinunciare del tutto a un'identificazione".

\section{CONCLUSIONES PARCIALES}

La información transmitida por Aristóteles acerca de quiénes son los que hablan en los yambos citados (información que, además, ha sido recuperada únicamente por esta fuente), nos resulta primordial a los efectos de nuestro estudio. Sin ella se podría cometer el error de referenciar directamente la deixis de primera persona a la figura del poeta, interpretando los fragmentos como

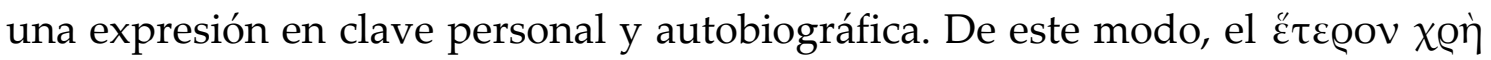

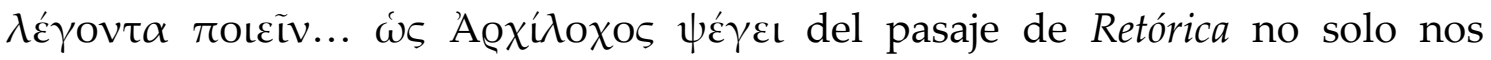
advierte de la existencia de personae loquentes en estas composiciones, sino que también nos previene de explicar mecánicamente como autorreferenciales todas

189 Vid. sup. pág. 106 n. 127. Con la aparición del P.Oxy. 2313 y de su unión al fr. 122W, Treu (1959, pág. 223) sostuvo que la ruptura del compromiso de matrimonio - $\gamma \alpha \dot{\alpha} \mu \omega \mathrm{l}$ (v. 12)- se habría

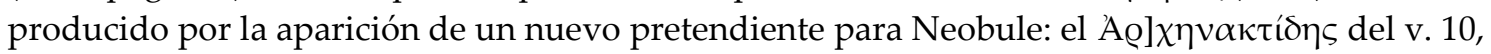
preferido por ella, o por Licambes, antes que el poeta.

${ }^{190}$ Rankin (1977a, pág. 27; 1977b, págs. 5-15). 
las manifestaciones en primera persona que aparecen en el corpus yámbico de Arquíloco. Este ha sido, por otro lado, un procedimiento crítico que ha gozado de un extenso recorrido desde la antigüedad hasta nuestros días, y que ha impuesto una línea de interpretación autobiográfica y personal de la poesía lírica, elegíaca y yámbica de la Grecia arcaica.

Aunque presentan algunas diferencias, los yambos 19W y $122 \mathrm{~W}$ pueden ser analizados bajo una misma estructura de enunciación que podríamos esquematizar de la siguiente manera:

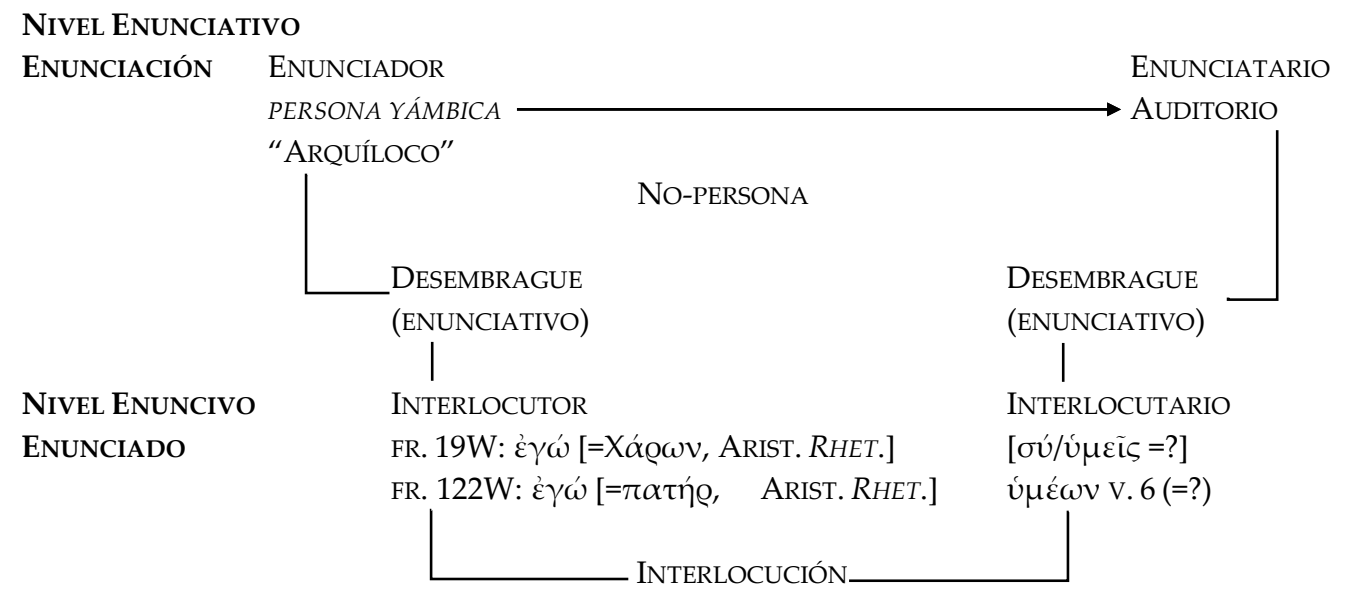

Aunque la escenografía de ambos yambos es idéntica, hay algunas diferencias en la forma de apertura discursiva. El fr. 19W se inicia con un desembrague de tipo enunciativo que instala en el discurso las formas de la enunciación enunciada. En este yambo, el interlocutor se inscribe deícticamente en el enunciado a través de los pronombres $\mu \mathrm{ol}$ (v. 1), en la función sintáctico-

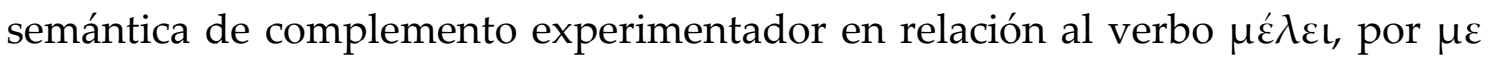
(v. 2), como complemento paciente del verbo $\varepsilon \tilde{i} \lambda \dot{\varepsilon}$, y por $\dot{\varepsilon} \mu \tilde{\omega} \nu$ (v. 4), como modificador determinante indicando al poseedor de ỏ $\phi \theta \alpha \lambda \mu \tilde{\omega} v$; y también por

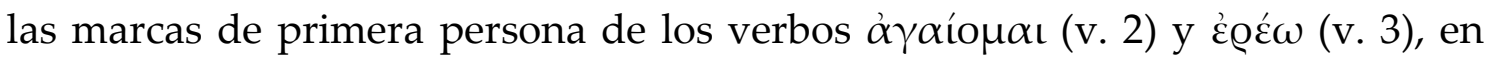
ambos casos cumpliendo la función de sujeto experimentador. En este yambo, el interlocutario no aparece explícitamente en el enunciado. 
Por su parte, el fr. $122 \mathrm{~W}$ comienza en realidad con un desembrague de tipo enuncivo que inaugura en el discurso las formas del enunciado referido (vv. 1-5). Pero en el v. 6 se inicia un nuevo enunciado, esta vez por medio de un desembrague enunciativo que, ahora sí, inscribe en el discurso a los actantes de la enunciación enunciada. En este caso el interlocutor no aparece marcado deícticamente en el texto, pero se presupone implícitamente en el discurso por solidaridad recíproca con el interlocutario, inscripto a través de la deixis

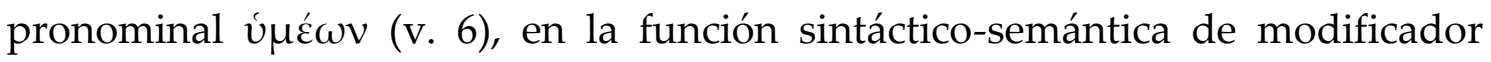
determinante indicando la totalidad o pertenencia que restringe al pronombre indefinido $\mu \eta \delta \varepsilon$ ćs.

Como ya se ha observado, para un lector moderno la identidad de estos interlocutores no es recuperable sino a partir de la información aportada por Aristóteles. ${ }^{191}$ Por un lado, este aporte es fundamental para determinar que la identidad de los interlocutores, Caronte y ese padre, aparecen en ambos casos en relación de no concomitancia con la identidad del enunciador, es decir con la persona yámbica "Arquíloco"; por otro, también nos permite indagar acerca de la función de invectiva que Aristóteles le atribuye a estos yambos. Con respecto a esto, los textos de los poemas no parecen contener ningún elemento que remita

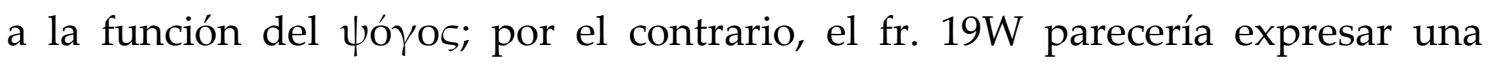
actitud de total desprendimiento frente a la vanidad de la riqueza y del poder, y el tono del fr. $122 \mathrm{~W}$ tiene, por su parte, la sobriedad característica de la lamentación y de la justificación reflexiva de acontecimientos inverosímiles por

${ }_{191}$ Probablemente Aristóteles conocía el texto completo de estos yambos, y si se considera que Horacio, Ep. 2.68: haec ubi locutus ferator Alfius, podría estar imitando a Arquíloco, se puede sostener la hipótesis de que hacia el final de los poemas la identidad de ambos interlocutores era revelada. De cualquier modo, la forma de comunicación poética en el período arcaico era muy diferente a la de la época de Horacio. La ejecución oral del yambo ante un reducido auditorio de amigos en el contexto del simposio arcaico seguramente no requería hacer explícita la identidad de las personae loquentes para comprender de quiénes se trataba; es más probable que la explicitación de los nombres fuera una información redundante e innecesaria y quitara efectividad a la revelación. De manera diferente sucede con la poesía escrita, ya que se vale de otros recursos discursivos para que la máscara sea develada por los lectores. 
causa de la intervención divina. Sin embargo, en tanto actos ilocutorios, las expresiones de desprendimiento y de lamentación reflexiva pertenecen al nivel enuncivo, a la interlocución, es decir, estas actitudes con respecto a los discursos deben ser atribuidas a Caronte y a ese padre. En el plano enunciativo, en el plano de comunicación entre la persona yámbica "Arquíloco" y su auditorio, parece evidente que se produce otro tipo de acto ilocutorio o que la constatación de lo enunciado (como sucede con la ironía) genera un efecto perlocutorio totalmente diferente a lo que podría esperarse en una lectura literal

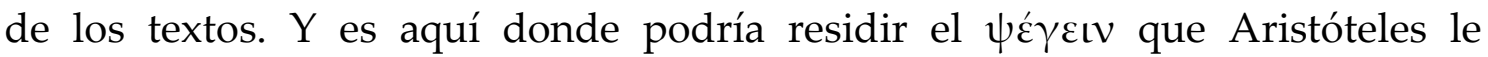
atribuye a estos yambos. ${ }^{192}$

Además, es lógico suponer que el auditorio-enunciatario era capaz de distinguir en la instancia de la ejecución poética los diferentes planos discursivos, y podía interpretar la presencia de una determinada persona loquens sin la necesidad de que su identidad apareciera explícitamente revelada en el texto. Esto nos lleva a considerar, entonces, que el empleo de una máscara como la de Caronte o la de ese padre era un dispositivo enunciativo legitimado por el género yámbico del período arcaico y uno de los atributos utilizados por la persona yámbica “Arquíloco" con el fin de realizar la invectiva poética.

192 En relación al "Himno a Afrodita" (fr. 1 Voigt) de Safo, Calame (1995, págs. 12-4) advierte que el investigador moderno, al trabajar con "textos escritos" de la poesía griega arcaica y sin la presencia de situaciones enunciativas observables, corre el riesgo de reducir su análisis del enunciado al "acto ilocutorio" y perder de vista los "efectos perlocutorios"; lo cual significa, en cierta forma, perder de vista que la poesía de este período es una poesía de ocasión, una poesía cuya significación depende del contexto pragmático de producción y ejecución. 


\section{ESTRUCTURA NARRATIVA}

En esta segunda sección, como hemos observado en la introducción, se agrupan las composiciones yámbicas que postulan una situación narrativa y presuponen las posiciones actanciales de narrador y narratario. Al analizar los procesos de enmascaramiento del 'yo', se reúnen aquí únicamente los yambos que presentan desembragues de tipo enunciativo, es decir, que instalan en el discurso poético las formas de la enunciación enunciada ('yo'-'tú'). Y, del mismo modo que se ha procedido en la sección anterior, también se realiza aquí una subdivisión en diferentes escenografías para describir el vertimiento actorial en cada una de las posiciones actanciales y las relaciones de identidad entre los actantes del enunciado y los de la enunciación.

\subsection{LAS HIJAS DE LICAMBES}

FR. 23W

$$
\begin{aligned}
& {[\quad] . .[} \\
& \text { [ ] ]...[ } \\
& \text { [ ] ]...[ ].[ ] } \\
& \text { [ ].....[ ]..[ ]......... } \\
& \text { [ ] ].....[ ]..[].... } \gamma \dot{\alpha} Q . \dot{\varepsilon} Q \gamma \mu \alpha \tau[ \\
& \text { [ ]..... ] ]......... } 1 \alpha_{\alpha} . . \omega[
\end{aligned}
$$

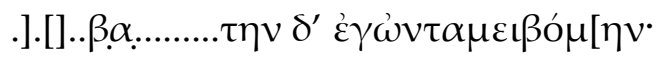

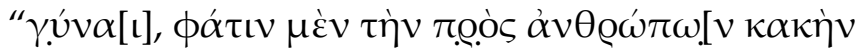

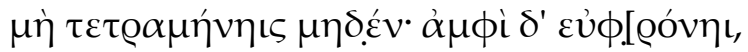

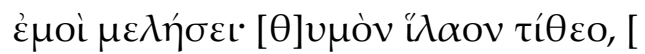

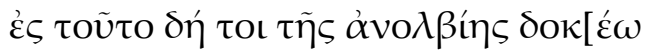

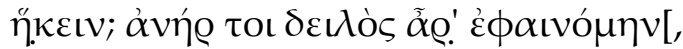

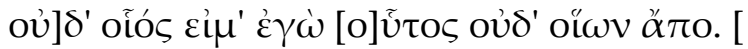

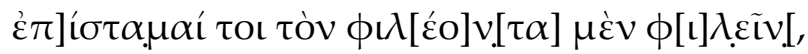

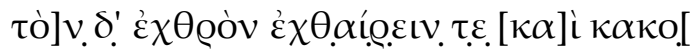

$$
\begin{aligned}
& \mu v ́] \mathrm{Q} \mu \eta \xi \text {. } \lambda \text {. }
\end{aligned}
$$

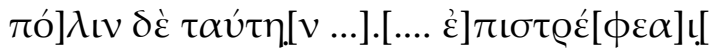

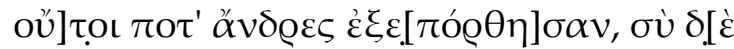

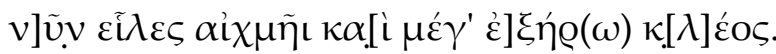

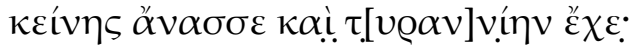




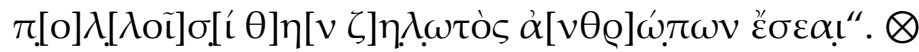

Arquíloco, fr. 23W ${ }^{193}$

$[\ldots]$

...acciones

5

$[\ldots]$

... y a ella le respondí:

“Mujer, por los rumores maliciosos de la gente

no temas: al anochecer

será mi preocupación. Vuelve propicio tu ánimo,

¿a tal grado de infortunio te parezco haber llegado?

Seguramente aparenté ser un hombre miserable, no como yo soy, ni aquellos de quienes desciendo.

En verdad sé querer al que me quiere

y odiar y maltratar al enemigo

como la hormiga. En estas palabras está ahora la verdad.

Y esta ciudad que recorres

jamás los hombres la saquearon antes, pero tú

ahora la has tomado con la lanza y has alcanzado gran fama.

Sé soberana de ella y ejerce la tiranía:

ciertamente para muchos de los hombres serás envidiable."

El poema presenta un diálogo entre un hombre y una mujer, narrado en primera persona. La parte legible del fragmento se inicia en el momento en que el hombre le responde a la mujer con una fórmula introductoria del discurso

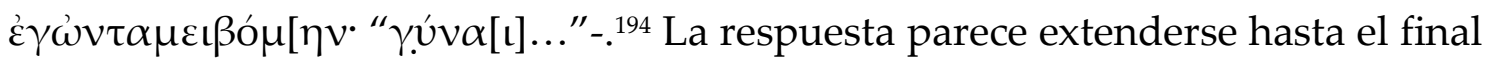
del poema, por lo cual nada se ha preservado del encuadre narrativo ni de las palabras de la mujer que motivan la respuesta del hombre.

De lo que nos transmite el texto, se pueden inferir, sin embargo, algunas cuestiones de la situación del diálogo. En primer lugar, el hombre trata de

193 Transmitido por P.Oxy. 2310 fr. 1, col. 1, 1-21 Lobel-Roberts. El papiro contiene los fragmentos 23-29W de Arquíloco. Para las discusiones de crítica textual, como así también para los debates acerca de la autoría de los poemas y la subdivisión de los mismos, véase Bossi (1990: 88-114).

${ }^{194}$ La estructura de la composición en forma de diálogo narrado, articulado a través de fórmulas que inician o finalizan los discursos de cada uno de los interlocutores recuerda al "Epodo de

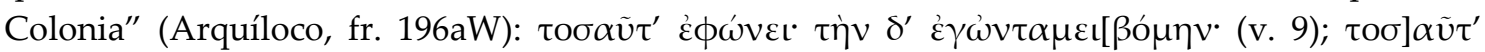

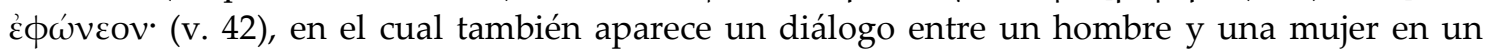
contexto de seducción erótica (vid. inf. pág. 153). 
tranquilizar a la mujer por los rumores malvados que se han suscitado o que podrían suscitarse entre la gente (vv. 8-9). Si bien no queda demasiado claro, estos rumores parecen referirse a cierto comportamiento del hombre (vv. 11-12), aunque también podrían relacionarse con el comportamiento de ella o el de ambos. Lo cierto es que la mujer no se encuentra para nada tranquila con la situación, ante lo cual el hombre le asegura que él mismo al "anochecer" se hará cargo del asunto (v. 10). ${ }^{195}$ Por algún motivo que no queda demasiado claro, el hombre le afirma a su interlocutora que tiene una opinión errónea acerca de él y que no se corresponde con quien él realmente es, ni con aquellos de quienes desciende.

A partir del v. 16, parece producirse un cambio estilístico y temático, el poema se acerca más al tono épico. El hombre se dirige a la mujer como si ella fuera una conquistadora que ha sometido a una ciudad nunca antes arrasada, y el mérito parece ser únicamente de ella y de su lanza, por lo cual ha alcanzado gran fama (vv. 18-19). Él le aconseja a su interlocutora que se ejerza la tiranía sobre esa ciudad y se convierta en envidia de los hombres (vv. 20-21). Ciertamente, es difícil conciliar la imagen de la mujer que ha realizado una hazaña bélica, tal vez dirigiendo un gran ejército, con aquella de la primera parte, temerosa de lo que puedan llegar a decir los demás acerca de ella. ${ }^{196}$

Esto ha llevado a algunos críticos a proponer distintas interpretaciones del fragmento. La más drástica ha sido directamente omitir la lectura de la palabra $\gamma u ̛ v \alpha[\iota]$ en el v. 8 y proponer otras integraciones. ${ }^{197}$ Una menos radical,

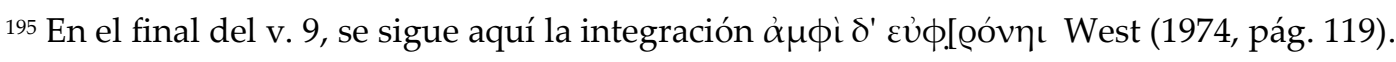

196 En ed. pr., Lobel \& Roberts (1954, pág. 3) señalan que no hay ningún tipo de indicio que pueda indicar una división del fragmento.

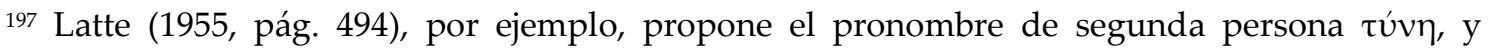
sostiene que si uno acepta la integración $\gamma u ̛ v \alpha[\iota]$ de Lobel "dann gerät man in unüberwindliche Schwierigkeiten, denn 19 ff. kann der Angeredete nur ein Mann sein"; vid. Giannini (1958, pág. 60). Por su parte, Steffen (1961, pág. 21) considera la integración del infinitivo фũvat. Tarditi

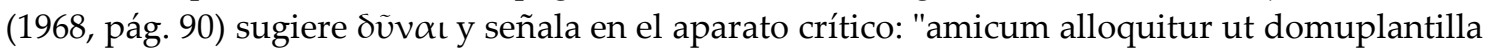
inviem ingrediatur, aut -si $\gamma] \cup ́ v \alpha[\iota$ legas- eum reprehendit cum timeat, quasi foemina, vulgi 
aunque también sobre la base de la eliminación de la figura femenina, fue postulada por Page, para quien, sorprendentemente, el vocativo $\gamma u ́ v \alpha[\iota]$ podría estar dirigido a un hombre y sería empleado por el interlocutor para burlarse sobre la falta de virilidad de su interlocutario. ${ }^{198}$ Otra propuesta es la de Rodríguez Adrados, que mantiene el vocativo femenino y propone entender que la ciudad conquistada que aparece en los vv. 17-21 tenga un sentido

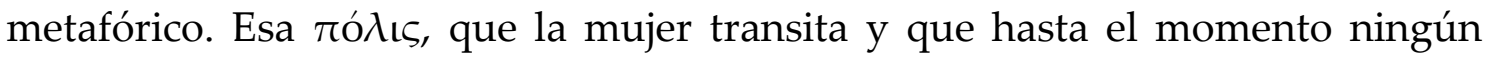
hombre ha arrasado, sería el propio poeta, el cual además la exhorta para que sea su soberana y ejerza el dominio sobre él. En este caso, el yambo tendría un sentido erótico construido a partir de una imagen bélica. ${ }^{199}$ Para West, la lectura de Rodríguez Adrados aclararía todas las dificultades interpretativas que parece manifestar el poema:

It is Archilochus whose defences she has broken through. He was never conquered by men, at the period of his life when that was most liable to happen, but she has succeeded where they failed. Let her now enter into her domain, and take advantage of her victory. There are many who will envy her. ${ }^{200}$

rumores". Sin embargo, la lectura $\gamma u ́ v \alpha[\iota]$ parece poco discutible, en sustento véanse Peek (1955-1956, pág. 192); Treu (1959, pág. 179); Kamerbeek (1961, pág. 10); West (1974, pág. 119); Stoessl (1976, pág. 257); Bossi (1990, pág. 99).

198 Page (1961, pág. 69), quien cita Esquilo, $A g$. 1625, donde el corifeo, con el término $\gamma u ́ v \alpha$ เ, se podría estar dirigiendo a Egisto y no solo a Clitemnestra, ya que unas líneas más adelante (1643)

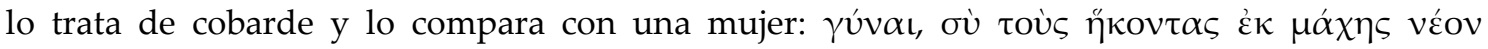

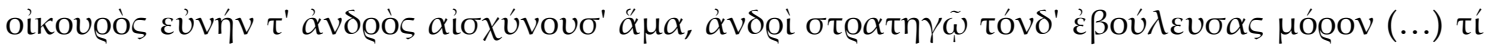

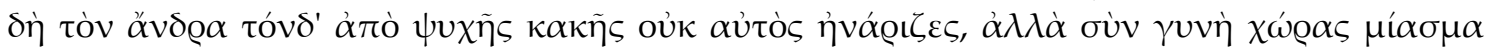

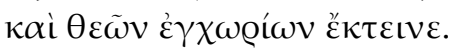

199 Rodríguez Adrados (1956, pág. 40); este autor cita como posible paralelo Teognis 951W:

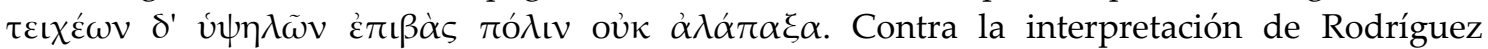
Adrados véase Kamerbeek (1961, pág. 11): “D'ailleurs, d'après l'avis de l'éminent érudit espagnol, les villes dont il s'agit dans les vers suivants doivent être prises dans un sens métaphorique: il s'agirait de conquêtes sur le terrain érotique. Mais Archiloque n'est pas un poète de basse époque. Il est libidineux, obscène même à ses heures, mais jamais poète ne fut plus exempt de mièvrerie et d'autre part, de gongorisme que lui."

200 West (1974, pág. 119). 


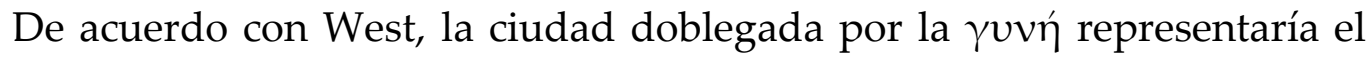
sometimiento amoroso del propio poeta. Sin embargo, parece poco convincente que expresiones bastante concretas como "has tomado la ciudad con la lanza y

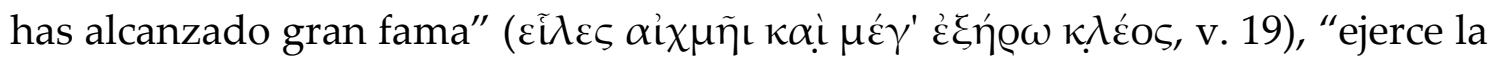

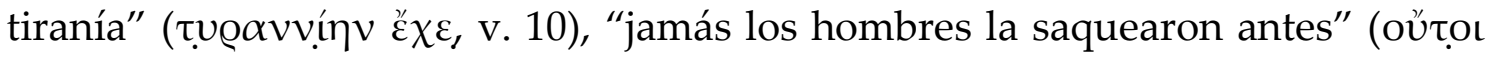

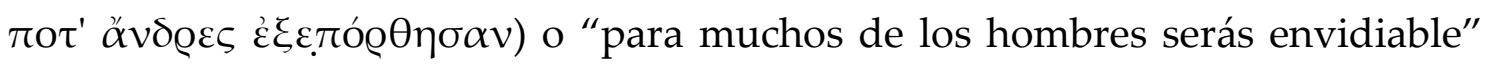

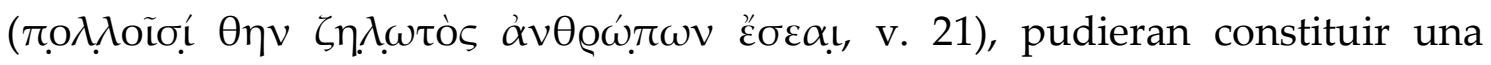
figuración de la conquista amorosa. Ante esto, West señala que es característico de la dicción poética de la Grecia arcaica que las frases tradicionales puedan ser empleadas para expresar un concepto básico, aun cuando esas palabras no sean lo suficientemente apropiadas para el contexto. De acuerdo con esto, por ejemplo, sugiere que en la primera frase tal vez la única palabra que podría

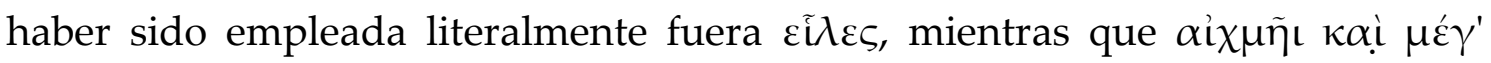

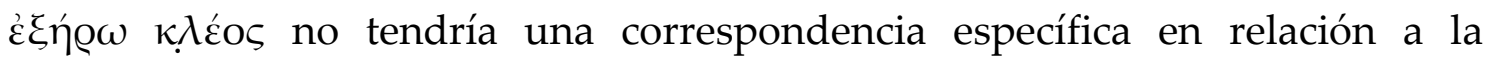
temática de conquista erótica. ${ }^{201}$ Sin embargo, en el fr. 96W de Arquíloco la

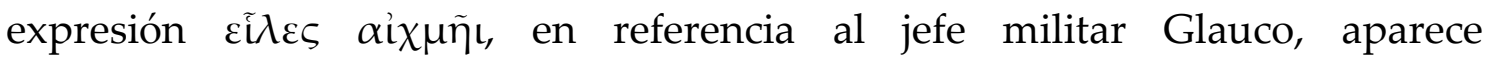
específicamente dentro de un contexto de temática específicamente bélica. ${ }^{202} \mathrm{El}$ problema del fr. $23 \mathrm{~W}$ reside la dificultad de adecuar la temática bélica a una interlocutora femenina; una interpretación metafórica solucionaría el problema.

Una interpretación diferente ha propuesto Bowie. ${ }^{203}$ Aunque argumenta a favor del diálogo de conquista amorosa, considera que la rhesis que el hombre le dirige a la mujer concluye en el v. 16, y que los vv. 17-21 constituyen, en realidad, una exhortación en clave épica mediante la cual la mujer incita al hombre para que tome coraje y la posea, ya que ha conquistado una "ciudad"

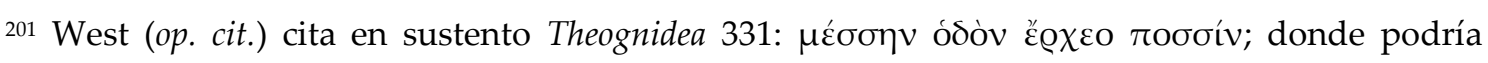
producirse el mismo fenómeno dentro de una metáfora.

202 Vid. sup. pág. 91.

${ }^{203}$ Bowie (2001, pág. 12).
} 
que nadie ha saqueado jamás, y que disfrute de este modo de la envidia de todos los hombres. Lo interesante de la lectura de Bowie es que, manteniendo la imagen bélica, muchas de las incongruencias entre las dos esferas que forman la alegoría encuentran significación, sin forzar ni la presencia de la mujer ni la metáfora erótico-militar. ${ }^{204}$

No ha faltado tampoco la interpretación enteramente literal, que

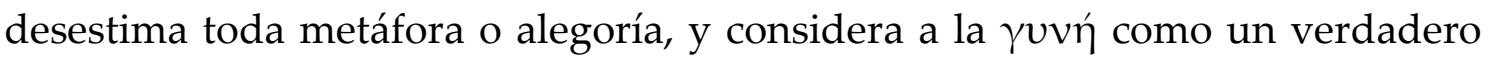
conquistador militar, y la exhortación bélica como tal. Uno de sus defensores es Peek (1955, pág. 200), quien sugirió que esta mujer podría haber sido una princesa de Asia Menor semejante a Artemisia. En la misma dirección, Kamerbeek (1961) señala que no existe un conocimiento certero sobre la historia de Grecia y de Asia Menor del siglo VII a. C. que nos permita rechazar de plano esta posibilidad. De acuerdo con Kamerbeek, nada se sabe de Artemisia, ni de la esposa de Candaules, ni del destacado rol que desempeñaron las mujeres en los enfrentamientos legendarios entre Mileto y Naxos, en los cuales Paros estuvo a favor de Mileto, como para "l'élimination trop précipitée d'une femme qui aurait été sur le point d'être rendue à l'histoire". ${ }^{205}$ Esta lectura lleva a Strauss Clay (1986, pág. 11) a postular una hipótesis bastante atractiva: “I suggest that the woman of frag. 23 is the wife of Candaules and the speaker none other than Gyges." La historia del rey lidio Candaules y de su esposa, y

${ }^{204}$ Una objeción a la lectura de Bowie puede radicar en el hecho de que el P.Oxy. 2310 no presenta ningún elemento que permita distinguir un cambio de interlocutor, como por ejemplo las típicas fórmulas empleadas por Arquíloco para señalar el fin o comienzo de un discurso, vid. fr. 196a, 42W, etc.

${ }^{205}$ Kamerbeek (1961, págs. 14-15) va un poco más allá con su hipótesis: “Nous ne nous dissimulons pas l'objection grave à laquelle l'interprétation que nous avons mise devant le lecteur est sujette. Pour l'accepter dans ses grandes lignes il faudra croire qu'à un moment donné de sa carrière de soldat et d'aventurier Archiloque a été l'allié ou le conseiller ou l'associé d'une femme-tyran à l'esprit de conquête. Rien de tout cela ne nous est connu d'ailleurs." Sobre la hipótesis de la referencia a una mujer "tirana" en este yambo de Arquíloco véanse también Treu (1959, pág. 183); Kirkwood (1974, pág. 29); Stoessl (1976, pág. 259); y Bossi (1990, pág. 100). 
del advenimiento al poder de Giges, uno de los oficiales de mayor confianza del rey, es transmitida por Heródoto 1.8.1-12.2.

De acuerdo con el relato de Heródoto, Candaules, jactándose de la belleza de su mujer, le propone a Giges, para que él mismo la juzgue, que al anochecer se esconda detrás de la puerta del dormitorio. Luego de que ella ingrese y se desvista dejando sus ropas junto a un asiento, él podrá contemplarla desnuda, pero deberá retirarse mientras ella se dirige a la cama, sin que advierta su presencia. Ante la insistencia de Candaules, Giges accede a la propuesta. Pero en el momento en que ella se encamina a la cama, repentinamente se da vuelta y ve cómo Giges sale de la habitación. Alarmada, acude a su marido que yace acostado sobre la cama, y al ver su rostro se da cuenta inmediatamente de su complicidad. Heródoto señala aquí que, entre los lidios, el hecho de ser contemplado desnudo supone una gran deshonra. Al día siguiente, sin decir nada de lo sucedido, la mujer decide vengarse. Hace llamar a Giges, y con los más fieles de sus servidores lo obliga a confesar lo que había tramado Candaules. Luego de su confesión, ella le da dos alternativas: o mata a Candaules, se casa con ella, y se convierte en el nuevo rey de Lidia, o afronta inmediatamente la muerte. Esa misma noche, Giges, oculto detrás de la misma puerta que le había permitido ver la desnudez de la mujer del rey, esperó a que Candaules se durmiera y lo asesinó. Posteriormente, su soberanía sobre el reino de Lidia fue ratificada por un oráculo de Delfos. Lo más interesante es que, luego del relato, el propio Heródoto afirma: “Arquíloco de Paros, que vivió en esa misma época, mencionó a Giges en un trímetro yámbico."206 En su

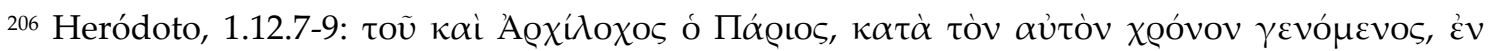

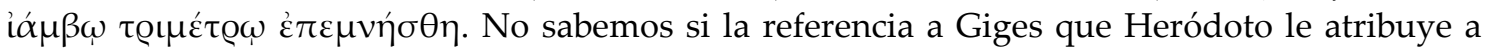
Arquíloco es la del fragmento 19W, como parece afirmarlo el versificador del siglo II d. C., Juba, Rufinus de Metris Terenti, GL VI, 563: "cum de Archilocho Pario referret, qui Gygae fabulam

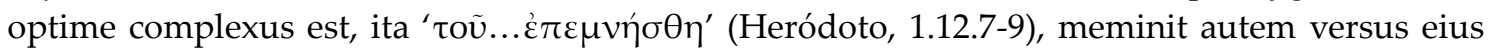

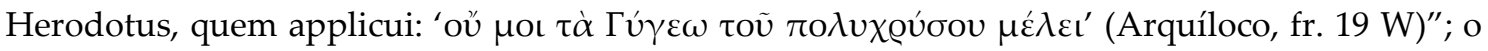
si existió otra composición en trímetros yámbicos que tratara sobre el tema, como podría ser el fr. $23 \mathrm{~W}$. 
argumentación a favor de la relación entre la historia del asesinato de Candaules y el fr. 23W de Arquíloco, Strauss Clay trae a cuento, además, la

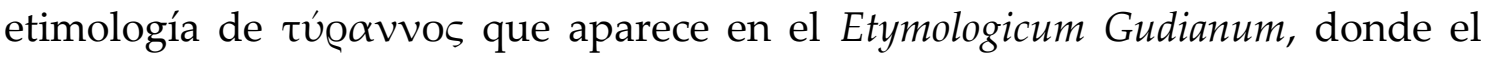
término "tirano" se vincula directamente con Giges y se cita a Arquíloco como el primero en emplearlo. ${ }^{207}$ De este modo, el poema de Arquíloco estaría representando la respuesta que Giges le da a la esposa de Candaules luego de que este le confesara haberla espiado desnuda por sugerencia del propio rey y de que ella le impusiera elegir entre matar a Candaules o morir.

El cambio de tono que se produce entre los vv 8-16 y 17-21 del trímetro de Arquíloco podría explicarse por la tensión de la situación y la delicada posición de Giges. Su interlocutor es una mujer poderosa cuyo honor ha sido mancillado y que desea vengarse. Es probable, si esta lectura es correcta, que en el discurso previo a la intervención de Giges, la reina le reprochara la gran deshonra que él junto con su marido le habían infligido y que a causa de eso su reputación estaba comprometida. Por lo cual, Giges se dirigiría primeramente a confortarla y a despreocuparla por los rumores de la gente. La vida de Giges

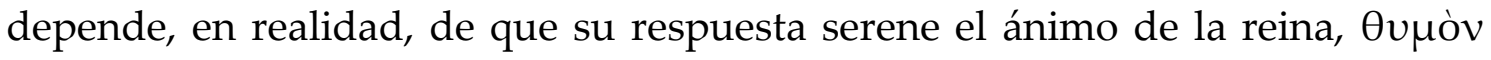

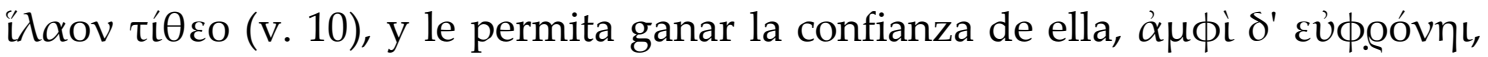

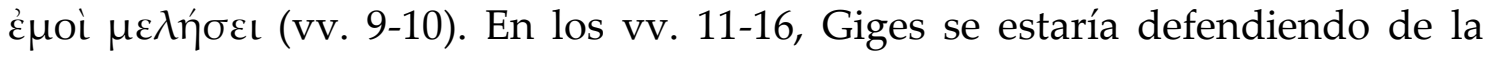
opinión que se tiene de él, quizás por prestarse a las intrigas de Candaules; su procedencia es noble, lo que manifestaría también que él es digno de convertirse en soberano de los lidios. Finalmente, en los vv. 17-21, su discurso migra desde una actitud defensiva y de justificación, a una disposición mucho más osada. Astutamente, Giges invierte la propuesta que la reina le habría

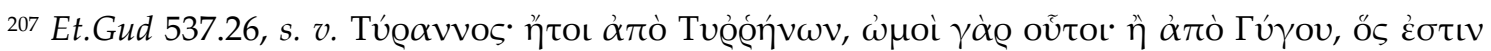

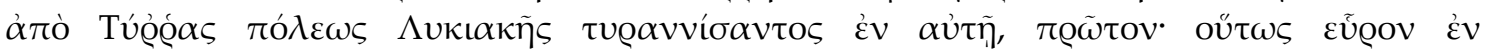

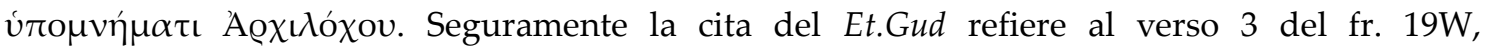

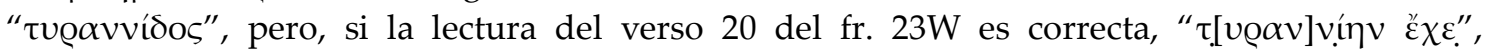
entonces no habría que desestimar la hipótesis de Strauss Clay. 
hecho momentos antes: no es él quien debe convertirse en soberano y ejercer la tiranía sino ella, porque ha sido ella quien ha conquistado una ciudad que ningún hombre hasta el momento ha podido arrasar, y debe ser ella quien disfrute de la envidia de los hombres.

No por atractiva la interpretación de Strauss Clay está libre de interrogantes que no encuentran una fácil resolución. Uno de los más significativos es que, si Arquíloco compuso un trímetro yámbico cuyo tema es ni más ni menos que el diálogo que mantuvieron Giges y la mujer de Candaules antes del asesinato de este último, ¿cómo es que un yambo de tanta repercusión en cuanto a su tema pudo pasar casi inadvertido a través de toda la antigüedad griega y latina? Parece bastante improbable que si ese había sido realmente su contenido no hubiera sido citado por alguna fuente, ni tampoco exista ningún testimonio que dé cuenta de él. Otro interrogante, de no menor importancia, tiene que ver con ilación argumentativa de la propuesta Strauss Clay. Heródoto refiere que entre los lidios ser contemplado desnudo implica una gran vejación, a partir de lo cual Strauss Clay presupone que en el yambo de Arquíloco la esposa de Candaules estaría preocupada por los malvados rumores que la gente podría proferir sobre su persona, lo cual le permite interpretar los vv. 8-9 como un intento por parte de Giges de tranquilizarla. Ciertamente los rumores difamatorios tenían gran importancia en la sanción social que los miembros de pequeñas comunidades, como las de Asia o de la Grecia arcaica, ejercían sobre las conductas individuales. ${ }^{208}$ Sin embargo, parece haber al menos una

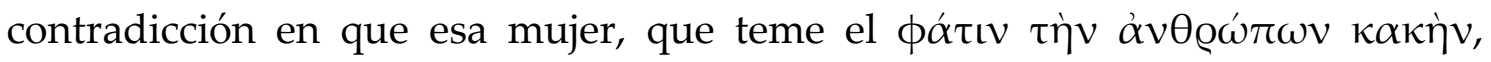
tenga por el contrario en muy poca estima lo que pueda decirse acerca de su complicidad en el asesinato de su esposo, el rey, y acerca del inminente casamiento con el asesino, que, como atestigua Heródoto, hizo que los lidios se

${ }^{208}$ En relación a este tema, véanse Detienne (1973, págs. 16-27); Nagy (1999, págs. 222-42); Gentili (1996, págs. 241-55); Cairns (1993, págs. 1-47). 
levantaran en armas contra los nuevos soberanos, que consideraron intolerable la muerte de Candaules. ${ }^{209}$ Ello no solo suscitó rumores de la comunidad lidia de la época, sino que levantó una ignominiosa fama sobre ella trascendiendo todas las fronteras territoriales y temporales hasta el día de hoy. Finalmente, un último interrogante surge en atención a la exhortación que Giges le estaría

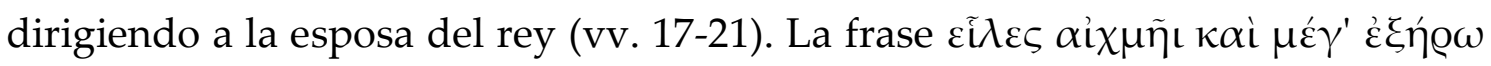
$\lambda$ ćos (v. 19) es mucho más propicia para un triunfo bélico en el campo de batalla que para la perpetración de un asesinato a traición y con un puñal

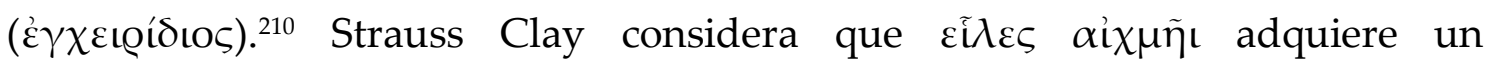
significado especial, si se tiene en cuenta que en el momento del diálogo los interlocutores están en presencia de los hombres de confianza de la reina

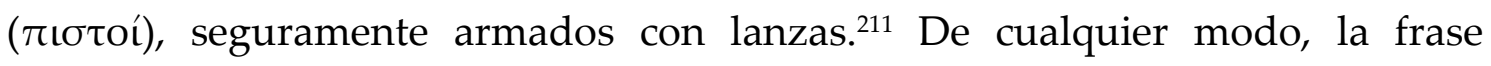
expresada por una persona innoble y de menor rango no podría haber sido entendida por la reina como algo dicho en forma sincera. Es evidente que las expresiones "conquistar con la lanza", que en Arquíloco y en Heródoto remiten al triunfo en la guerra, ${ }^{212}$ y "alcanzar gran fama", dado lo que se ha expuesto acerca del rumor, necesariamente deberían haber sido comprendidas como un sarcasmo si se refieren a los actos que trama la mujer de Candaules, lo cual podría haber complicado aún más la delicada situación de Giges.

Como hemos creído demostrar, la forma de interpretar el contenido de este yambo ha generado muchas controversias. Particularmente, porque la composición presenta dos núcleos discursivos muy diferentes en cuanto al tema y al estilo. La primera parte se asemeja mucho al diálogo de conquista sexual,

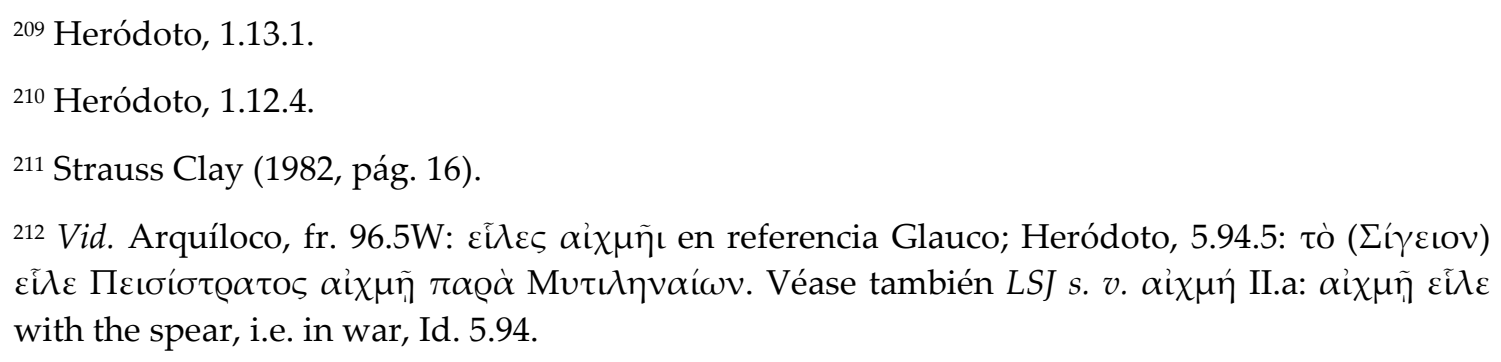

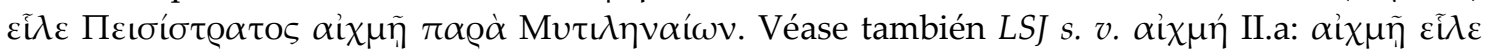
with the spear, i.e. in war, Id. 5.94. 
similar al del "Epodo de Colonia", y la segunda parte, por el contrario, es una exhortación épica idéntica a los yambos bélicos en tetrámtetros.

Las diferentes interpretaciones han puesto en juego también discusiones acerca de la identidad de los interlocutores, que es tema central de nuestro estudio. Por ejemplo, hay quienes interepretan biográficamente el poema y refieren la primera persona masculina que aparece en los primeros versos a la figura del poeta. Así, Lasserre (1956) considera que todo el fragmento es un relato mediante el cual Arquíloco le informa a un amigo, que ha regresado recientemente a Paros, qué fue lo que le sucedió con Neobule mientras este se encontraba fuera de la isla. ${ }^{213}$ Sorprendentemente, West, a pesar de su propuesta de la presencia de "stock characters" en la yambografía de Arquíloco, ${ }^{214}$ en este caso en particular, afirma que la primera persona remite al

${ }^{213}$ Lasserre, sin embargo, considera que los ff. 23 y $24 \mathrm{~W}$ pertenecen a una misma composición (1956, págs. 229-31): “Archiloque rapporte à quelqu'un d'autre la fière réponse qu'il a donnée à celle qui s'inquiétait de sa misère et lui en faisait reproche [...] Les vers 26 à 33 sont consacrés à un épisode connexe à l'entretien avec la $\gamma v v \eta$ : ils doivent exposer la cause des infortunes d'Archiloque. Comme son ami, Archiloque avait cherché fortune sur les routes de la mer (v. 29):

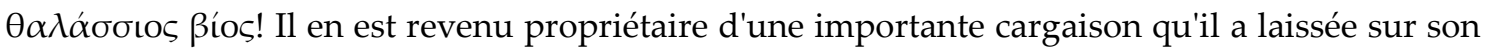
bateau. Son arrivée à Paros, et peut-être aussi l'argent qu'il a gagné, vont lui permettre de célébrer ses noces (vv. 27 et 28). Du coup la situation s'éclaire: la femme à qui s'adresse la óñoıs est Néoboulé." También sostiene (1957, pág. 52): “L'iambe, sous les dehors d'une lettre ou d'un discours, s'adresse à un ami du poète dont le nom nous demeure malheureusement inconnu. Cet ami vient de rentrer à Paros après avoir couru les mers et s'y être, à ce qu'il semble, passablement enrichi (v. 22-25). Archiloque, en revanche, rentré quelque temps avant lui d'un voyage analogue, se plaint d'avoir perdu après son arrivée au port la cargaison qui constituait tout son avoir (v. 29-33). Or il devait à son retour s'unir à Néoboulé 'en des noces déjà

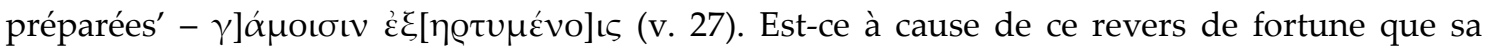
fiancée décidera de rompre ses engagements? L'iambe ne le laisse pas voir, et sans doute la rupture n'a-t-elle pas encore eu lieu au moment où le poète confie à son ami ses difficultés Mais la première partie du fragment nous apprend que Néoboulé s'était alarmée déjà avant le retour d'Archiloque de propos malveillants qu'on faisait courir sur son compte et qu'elle lui reprochait sa misère et sa faiblesse. Les premiers vers conservés, qui son aussi les plus lisibles, évoquent, en effet, ce double reproche dans la réponse que le poète avait faite aux plaintes de sa fiancée et qu'il rapporte fidèlement à son ami (v. 8-21)" En la misma línea de interpretación, véase Tsagarakis (1977, págs. 35-7).

${ }^{214}$ Sobre la hipótesis de West acerca de los "stock characters"; vid. sup. pág. 116 n. 149 . 
poeta Arquíloco. ${ }^{215}$ Por el contrario, para Strauss Clay, de acuerdo con su hipótesis de que se trata de una narración histórica, el "yo" que aparece en la composición no se correspondería con la persona del poeta sino con Giges, antes de dar muerte a Candaules. Por su parte, Bowie sostiene la premisa de que la narrativa podría haber sido un elemento tan importante como la invectiva en la definición del género yámbico y remarca las similitudes entre el narrador y las características eróticas del fr. $23 \mathrm{~W}$ con las del "Epodo de Colonia." En este sentido, si bien no se pronuncia sobre la identidad ficcional o biográfica de esa primera persona, señala que en ambas composiciones la narrativa y la invectiva deben haber funcionado para denigrar a los participantes, particularmente si las mujeres a las que se hace refierencia eran las hijas de Licambes. ${ }^{216}$

Es oportuno, por lo tanto, antes de continuar con la descripción discursiva de este fragmento, pasar al análisis del "Epodo de Colonia", composición en que la relación amorosa con una de las hijas de Licambes centra toda la atención.

215 West (1974, págs. 118-9): “The narrator (whom I shall assume to be Archilochus rather than some assumed character) says that he replied 'Madam', etc. [...] From the reply that she receives it may be inferred (i) that she is angry ( $\theta v \mu$ òv i $\lambda \alpha$ ov $\tau \imath \theta \varepsilon$ ó), (ii) that she has formed the

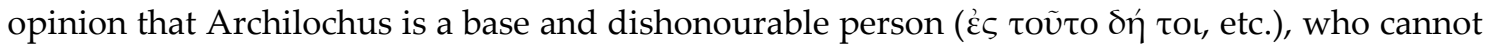

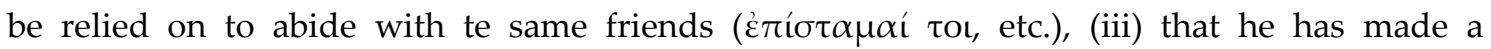
declaration which se regards as untrustworthy ( $\left.\lambda o ́ \gamma \omega v v v \tau \tilde{\omega} \delta^{\prime} \dot{\alpha} \lambda \eta \theta \varepsilon i ́ \eta \eta \dot{\eta} \varrho \alpha . ..\right)$, (iv) that se is afraid of evil rumours, whether those already current about Archilochus or those likely to arise about herself (...) Suppose, first, that Archilochus is engaged in seducing some Amazon of the Aegean whose conquests and existence have by some mischance failed to leave any echo in the records of history, despite her sensational brush with one of the most famous of Greek poets."

${ }^{216}$ Bowie (2001, pág. 14): “Now the purpose of such sexual narrative may have been partly to discredit the participants, especially if some of the girls involved are daughters of Lycambes, a conjecture often made but not so far shown to be correct. But if that is their purpose it is important that the manner in which Archilochus attempts this is to narrate actions that are discreditable." 


\section{FF. 38 Y 196-196AW}

Nuestra argumentación a favor de que el fr. $23 \mathrm{~W}$ es un yambo erótico con carácter invectivo proviene de la confrontación con otros fragmentos compuestos en trímetro yámbico (38W) y en epodos (196 y 196aW). Los ff. 38 y 196W, concretamente, consta cada uno de un solo verso y tras la edición del fr. 196aW, "Epodo de Colonia", han sido considerados como partes de la misma composición, tanto por la estructura métrica (hemiepes dactílico y dímetro yámbico, que únicamente se da en estos fragmentos de Arquíloco), como por sus afinidades temáticas. ${ }^{217}$ De este modo, el verso del fr. 196W sería parte de una apelación dirigida a un amigo $(\tilde{\omega} \tau \alpha \tilde{\varrho} \varrho \varepsilon),{ }^{218}$ a quien le habría de contar el diálogo y el encuentro erótico que mantuvo con aquella a quien se denomina en el fr. 38W como "la superior (físicamente)" o "la más joven" de las hijas de Licambes: ${ }^{219}$

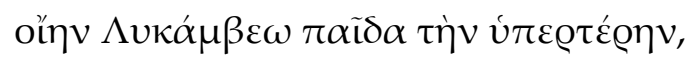

Arquíloco, fr. $38 \mathrm{~W}^{220}$

217 West (1975, pág. 217; 1978, págs. 44-8). Sobre la posible pertenencia del fr. 38W al “Epodo de Colonia", Merkelbach \& West (1974, pág. 102) señalan: "Archilochos ist dabei, die jüngere Schwester der Neobule zu verführen. Sie befindet sich auf einer Wiese, vielleicht im heiligen Bezirk der Hera; vermutlich wollte sie Blumen sammeln. Sie ist wohl noch sehr Jung. Zu fr. 38,

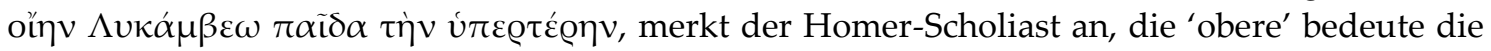
jüngere. Der Vers könte also bedeuten: "[Ich traf] die jüngere Tochter des Lykambes allein [an]."

${ }_{218} \mathrm{Al}$ igual que en otras composiciones narrativas de Arquíloco, como el fr. 13W, dirigido a Pericles, y el fr. 168W, dirigido a Carilao.

219 Bowie (2001, pág. 17) también considera los dos fragmentos como parte de una misma composición, en la cual se evidencia un encuadre narrativo que tiene como fin contar un relato erótico a uno de sus compañeros y con una intención de invectiva contra las hijas de Licambes. Como se ha observado, Bowie señala la similitud entre la estructura narrativa y la función de invectiva del "Epodo de Colonia" y el fr. 23W; vid. sup. pág. 152.

${ }^{220}$ Transmitido por Schol. A Hom. Il. 11.786, donde se afirma que Aquiles es "superior en

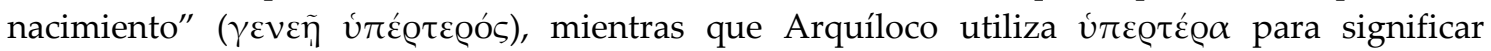

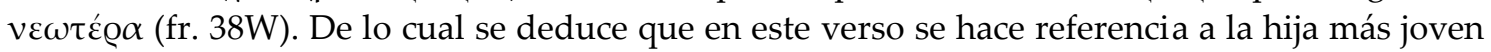
de Licambes. Sin embargo, el escoliasta ha interpretado de manera incorrecta el término

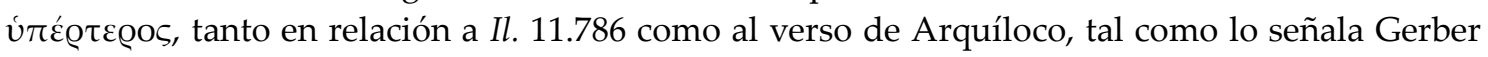

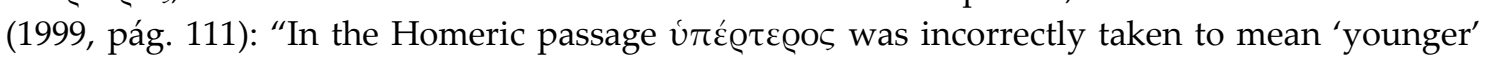




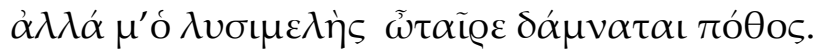

Arquíloco, fr. 196W 221

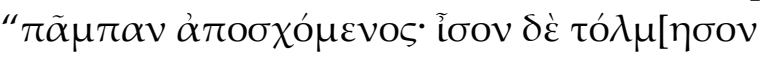

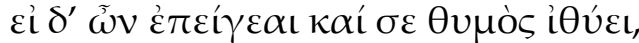

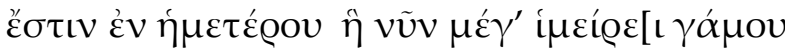

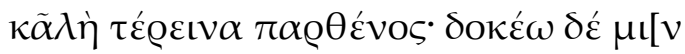

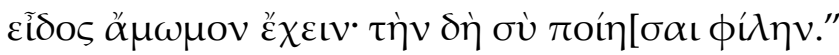

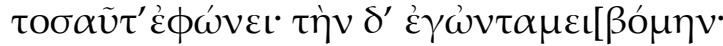

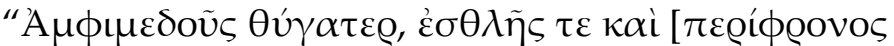

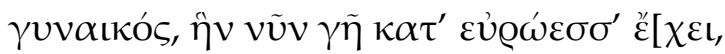

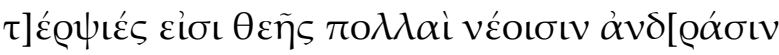

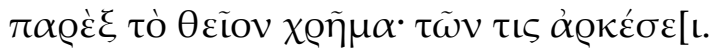

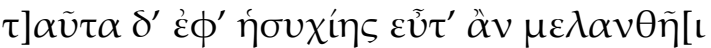

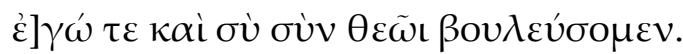

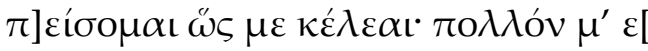

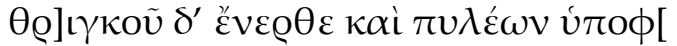

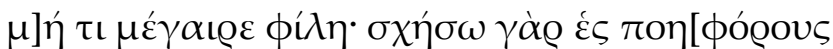

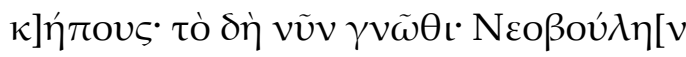

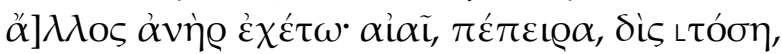

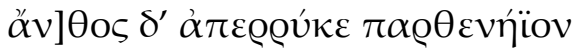

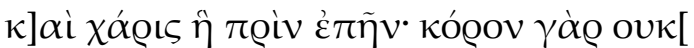

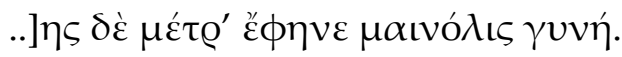

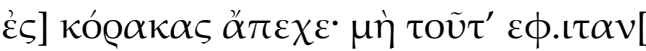

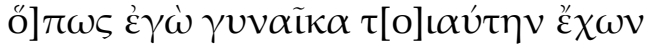

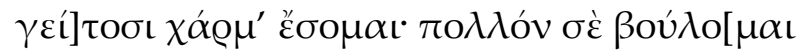

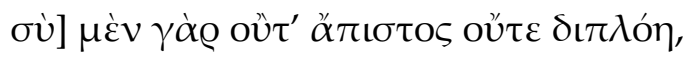

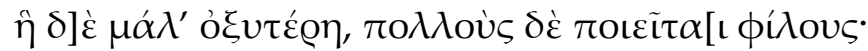

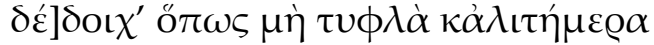

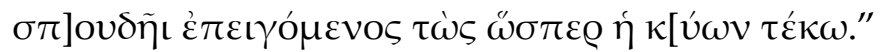

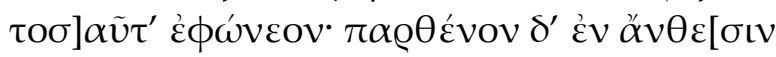

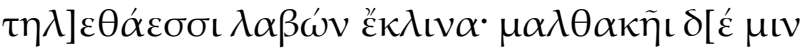

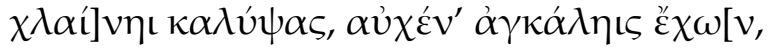

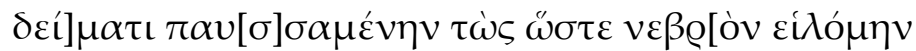

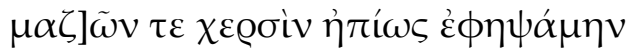

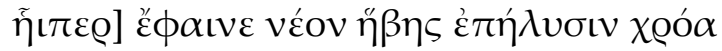

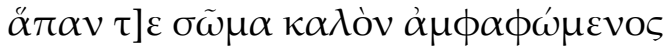

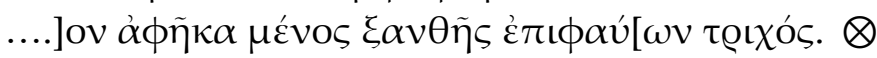

Arquíloco, fr. 196aW

and Archilochus was cited, also incorreclty, in support. Archilochus meant physically or morally superior." Particularmente sobre este tema, véase Bossi (1990, págs. 121-23).

${ }^{221}$ Este fragmento ha sido transmitido por Hefestión, Ench. met. 50.14-7, para ejemplificar el

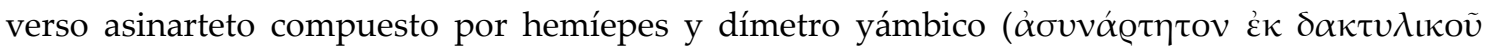

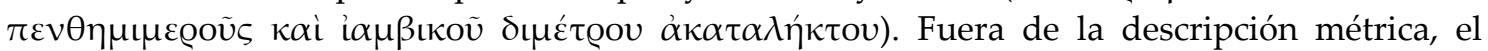
texto de Hefestión no preserva ninguna otra información acerca del contenido del fragmento. 
[encontré (?)] a la mejor hija de Licambes, sola.

(...)

pero a mí, amigo, me somete el deseo que afloja los miembros.

(...)

“...absteniéndote por completo e igualmente aguántate.

Pero si estás apurado y te oprime la pasión,

hay en nuestra casa una que siente gran deseo de casarse,

joven hermosa y tierna. $\mathrm{Y}$ considero que

tiene una belleza inmaculada. Haz que ella sea tu amiga."

Estas cosas decía, y yo le respondí:

"Hija de Anfimedo, noble y [prudente

mujer, a quien ahora la húmeda tierra cubre,

placeres de la diosa hay muchos para los hombres jóvenes

aparte del divino asunto. Cualquiera de ellos será suficiente.

Pero estas cosas con calma, cuando se vuelva negro [...

tú y yo con un dios lo decidiremos.

Obedeceré como me ordenes. Mucho me [excita el deseo (?).

Debajo del cercado y de las puertas [que me precipite

no rehúses, amiga, pues atracaré en el herboso

jardín, ten presente eso ahora mismo. ¡A Neóbule que otro

hombre la posea! ¡Ay!, demasiado madura está, te dobla (en edad),

la flor de su doncellez ha desaparecido

y el encanto que antes poseía, pues saciedad [no tuvo. (?)

Ya ha exhibido la medida su [vigor (?)] esa enloquecida mujer

¡A pártala a los cuervos! Que eso no [...

Que yo, por tener semejante mujer,

no me convierta en regodeo de los vecinos. Mucho más te prefiero,

pues tú no eres infiel ni tienes doblez,

en tanto que ella es inestable y hace amigos a muchos;

tengo miedo que (hijos) ciegos y prematuros,

apurado por el ansia, tal como una perra, engendre."

Así le decía, y tomando a la joven, entre las incipientes flores la recosté. Luego de cubrirla con mi suave

manto, mientras rodeaba su cuello con mis brazos,

por el temor detenida como un cervatillo la tomé

y dulcemente toqué con mis manos sus pechos,

en donde] revelaba la fresca piel, encanto de juventud,

y sintiendo [todo] su hermoso cuerpo,

eyaculé mi [blan]co vigor mientras rozaba su rubio [vello. (?)

A semejanza del yambo $23 \mathrm{~W}$, el fragmento $196 \mathrm{aW}$ nos presenta un diálogo entre un hombre y una mujer. Sin embargo, el tema y los motivos del epodo, recurrentes en la tradición épica y lírica, tienen claramente las 
características de un relato de seducción y de conquista sexual.222 Este fragmento, el más extenso que se ha conservado de Arquíloco, es muy importante para comprender los procesos de enmascaramiento del "yo" en la invectiva yámbica del poeta de Paros. Por este motivo es necesario realizar un análisis minucioso de las figuraciones poéticas de este fragmento.

Los versos 1 a 5 preservan la parte final del discurso que la joven le dirige al narrador. Este discurso parece contener una respuesta negativa por parte de la muchacha ante una propuesta, probablemente sexual, realizada por el narrador. El participio aoristo de $\alpha \dot{\alpha} \varepsilon \dot{\chi} \omega($ v. 1) implica específicamente la abstención sexual, ${ }^{223}$ y en el mismo sentido debe entenderse la integración del

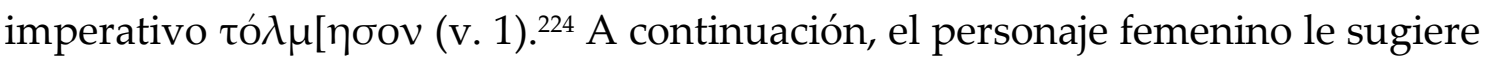
al interlocutor que, si se encuentra "apurado" por la pasión, se haga amigo de

${ }^{222}$ La estructura del epodo contiene estrechas reminiscencias del encuentro entre Zeus y Hera en el monte Ida (vid. Il. 14.312-51). El epodo presenta, además, motivos recurrentes en la tradición poética arcaica vinculados con la pubertad femenina y el despertar sexual, ámbito dominado particularmente por Afrodita. Del mismo modo, el escenario bucólico en el que acontece el diálogo, un prado florido ( $\varepsilon v \not ̉ v \theta \varepsilon[\sigma \iota v \tau \eta \lambda] \varepsilon \theta \alpha ́ \varepsilon \sigma \sigma \mathrm{l}$, vv. 28-9) al cual la joven podría haber ido para juntar flores, también es típico de los encuentros amorosos (vid. Od. 5.474, 6.85; Hesíodo, Theog. 194; 279; fr. 26 M-W; Cypria 4B; Hymn. Hom. Aphr. 5.53; Hymn. Hom. Dem. 2.5; Safo, ff. 2.9, 104 y 105; Theognidea 1249; Íbico, fr. 286; Anacreonte, fr. 60P (PMG 402); Píndaro, Pyth. 9.20. Merkelbach \& West (1974, pág. 102), siguiendo Anth. Pal. 7.351, señalan que la escena podría haber tenido lugar en el templo de Hera. El reverdecer del prado silvestre en temporada de primavera o verano, situado en ocasiones junto a una fuente de agua donde las jóvenes se bañan, simboliza la etapa de juventud y virginidad en que ellas descubren su sexualidad y comienzan a predisponerse para la unión física y matrimonial. En estas incursiones, las jóvenes están acompañadas y protegidas por las ninfas y las gracias. Sobre estos temas véase Henderson (1976, pág. 163).

${ }^{223}$ Vid. Il. 14.206; Aristófanes, Lys. 163. Véase además Henderson (1991, pág. 161).

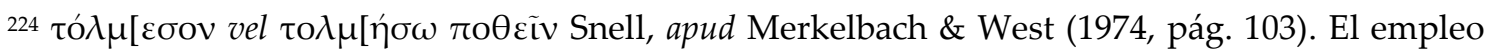

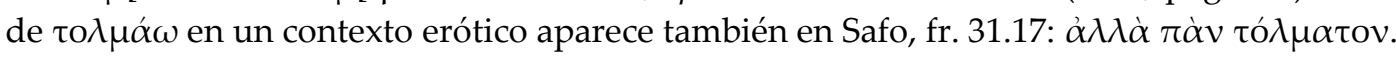


una mujer que habita con ella ( $\dot{v} v \hat{\eta} \mu \varepsilon \tau \varepsilon \dot{\varrho} \varrho 0 v$, v. 3), ${ }^{225}$ a quien considera hermosa

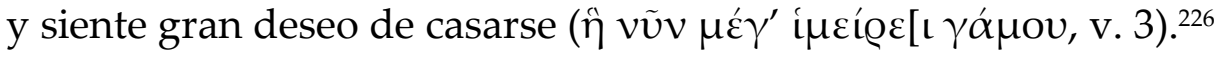

De acuerdo con estas palabras de la muchacha, es probable que en los versos que iniciaban el epodo el joven hubiera intendado seducirla, tal vez hablándole de casamiento, para luego pedir tener un encuentro sexual en ese mismo instante. ${ }^{227}$ De ese modo, la respuesta de la joven sería que aún no tiene edad para casarse, negándose así a la propuesta realizada por el muchacho. ${ }^{228}$

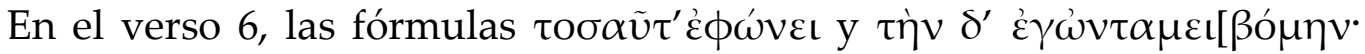
clausuran el discurso de la joven y dan paso a la intervención del interlocutor masculino. Este se dirige a la muchacha apelando al nombre de su madre "hija

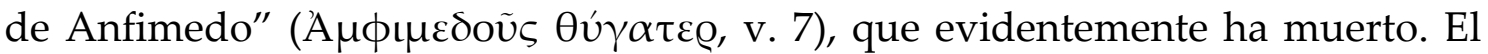
recuerdo de la madre podría no ser gratuito, ya que en la tradición griega antigua es ella quien debe vigilar la pubertad de la hija y aconsejarla hasta el momento de su matrimonio. ${ }^{229}$ Por ende, el hecho de que Anfimedo esté muerta

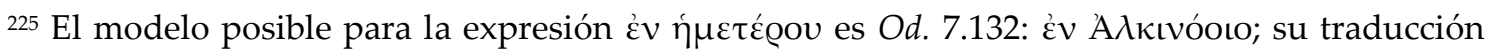
literal sería "dentro de/en nuestra casa." Vid. también Od. 2.55, 7.301, 8.39, 15.513; Hymn. Hom. Herm. 370; Heródoto, 1.35.4 y 7.8.1; y las observaciones de Slings (1987, pág. 32) a este verso.

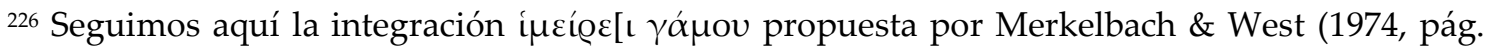

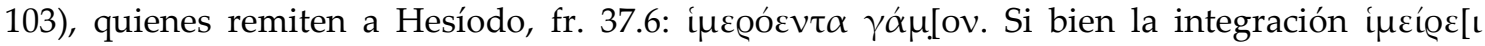
$\lambda \varepsilon ́ \chi \varepsilon 0 \varsigma$, Ebert \& Luppe (1975, pág. 226), realza más lo erótico, como ellos afirman, también convierte lo sexual en algo demasiado explícito. Por otro lado, el suplemento $\gamma \alpha \dot{\mu} \mu o v$ posee el valor de referir implícitamente al acto sexual que conlleva el matrimonio y de remitir a la tradición biográfica antigua sobre la frustrada boda entre el poeta y Neobule.

${ }^{227}$ La lectura de una propuesta sexual por parte del narrador en los versos que iniciaban el poema ha sido sostenida por la mayoría de los investigadores. La suposición de una promesa nupcial dentro del acto de seducción ha sido planteada primeramente por West (1975, pág. 218): "Archilochus will have described how lovely she looked, how he was overcome with desire for her, and how he began to talk to her of marriage and to suggest an immediate sampling of Cypris' gifts."

${ }^{228}$ Henderson (1976, págs. 167-9) señala que, dado el contexto tradicional de seducción, el rechazo de la joven podría tener cierto rasgo de moderación y prudencia. Ella estaría negándose firmemente al deseo del narrador porque considera, o finge considerar, que el matrimonio es un requisito previo para consumar el acto sexual.

229 Véanse por ejemplo los consejos que Atenea le da a Nausícaa bajo la figura de la hija de Dimante (Od. 6.25). Además, es posible apreciar una similitud entre el inicio de la intervención del interlocutor en el fr. $23 \mathrm{~W}$ y el de este epodo, en ambos casos podría tratarse de una captatio 
nos indica, por un lado, que la joven carece de la protección materna y de sus consejos, y, por otro lado, que el joven, al nombrarla, podría estar buscando una contraposición entre la mujer que yace muerta debajo de la húmeda tierra (ịv

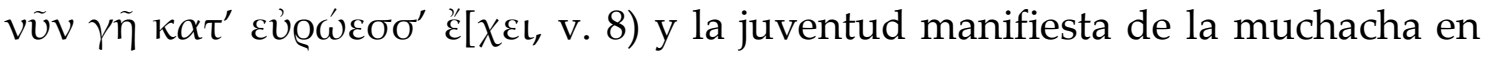
medio del prado silvestre que crece sobre la superficie de la tierra y que constituye el ámbito del diálogo. De acuerdo con esto, el epíteto que califica a

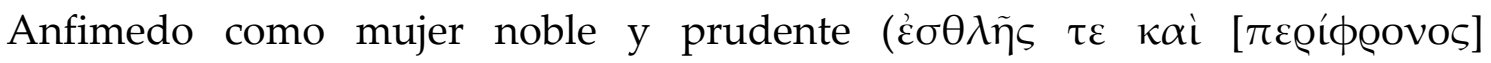
juvaıkós, vv. 7-8) podría conllevar cierta ironía en el nivel de la enunciación poética, ironía que el auditorio podría decodificar, pero no en el nivel enuncivo. Lo que el joven le estaría sugiriendo a la muchacha, en una suerte de invitación al carpe diem, es que se olvide de los prudentes consejos que le dio su madre sobre el sexo y sobre esperar hasta el matrimonio, y disfrute de los placeres inmediatos que le presenta la vida a quienes todavía viven.

En los versos siguientes parecería confirmarse esta hipótesis: aquellos

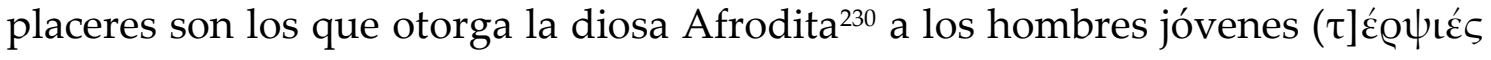

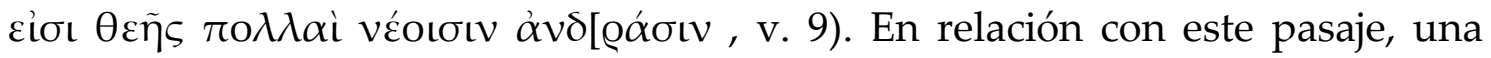
glosa de Hesiquio (Lex. $\pi$ 839) ha permitido resolver a qué refiere la frase $\pi \alpha \varrho \dot{\varepsilon} \xi$

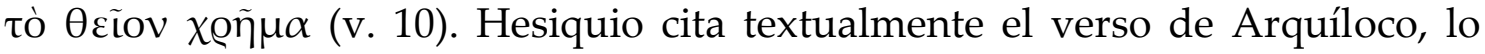
cual permite inferir que su información se fundamenta en algún comentario al

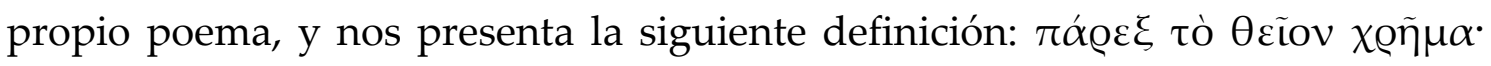

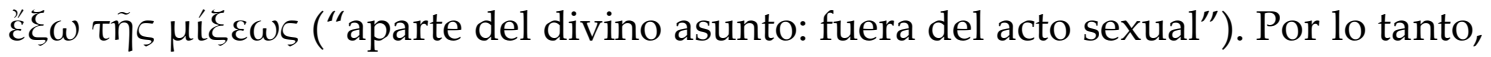

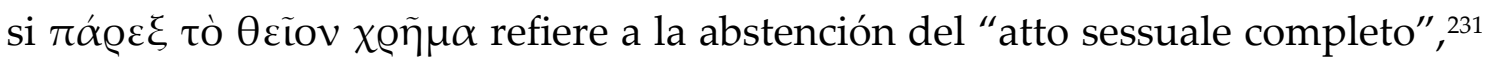
entonces los placeres a los cuales alude el interlocutor tendrían que ver con el encuentro sexual evitando que la eyaculación se produzca dentro de la vagina

benevolentiae con el fin de aplacar el ánimo de sus interlocutoras y lograr de este modo la predisposición que necesita el interlocutor; vid. Degani (1974, pág. 117).

230 West (1975, pág. 218); Slings (1987, pág. 36); Gerber (1999, pág. 215) fundamentan la referencia a Afrodita en este verso.

${ }^{231}$ Degani (1975, pág. 229). 
de la mujer -coitus interruptus-, o bien, descartando directamente la penetración

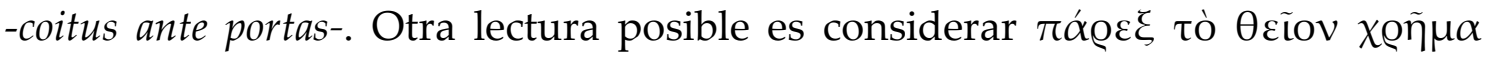
como el acto sexual entendido fuera del matrimonio. ${ }^{232}$ De acuerdo con esta interpretación, el interlocutor podría estar diciéndole a la muchacha que son muchos los placeres de la diosa para los hombres jóvenes, además del acto sexual consumado dentro el matrimonio; entre estos placeres debería suponerse también el coito en su totalidad pero 'fuera' o, en nuestro caso, 'antes' de la celebración ritual del matrimonio y de su promulgación pública.

De cualquier manera, está claro que el protagonista descarta por el momento el "asunto divino", ya que declara conformarse con cualquiera de los

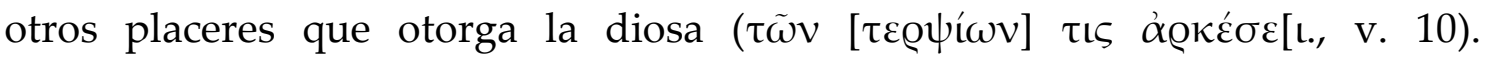
Siguiendo esta lectura, el joven le proponía decidir entre los dos "aquellas cosas" referentes a un futuro casamiento. Aquí el poema se torna ambiguo, ya que si $\tau \alpha \tilde{v} \tau \alpha$ (v. 11) refiere a cuestiones concernientes con un posible matrimonio, el joven le dice que estas cosas lo decidirán con la ayuda de un

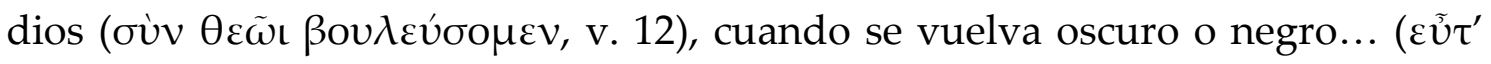

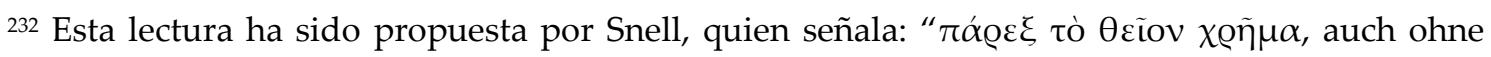
kultische Hochzeit"; vid. Merkelbach \& West (1974, pág. 105), seguida luego por Koenen (1974, pág. 499) y Henderson (1976, págs. 171-2). A favor de esta lectura es posible citar además Od. 6.285-8. El pasaje homérico cuenta que Nausícaa, luego del encuentro con Odiseo a orillas del río, decide conducirlo al palacio de su padre, el rey Alcínoo, pero le pide que antes de llegar al pueblo se esconda en el bosque de Atenea, aledaño a la villa, hasta que ella y sus sirvientas hayan realizado el trayecto que las separa del palacio. Nausícaa teme las murmuraciones que la gente pudiera realizar al verla llegar sola con un extranjero, porque, como le dice a Odiseo, ella misma odiaría a una mujer que teniendo padre y madre se mezclase con hombres antes de

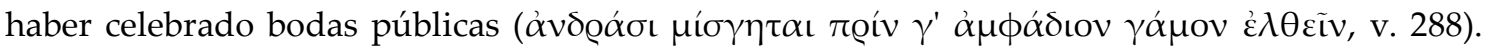

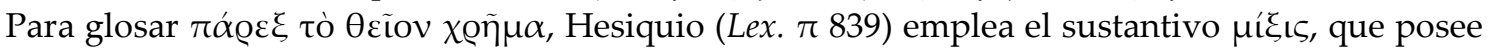
la misma raíz del verbo $\mu$ í $\gamma \eta \tau \alpha \iota$ que aparece en el pasaje homérico. En ambos casos la referencia es al coito. El episodio del diálogo entre Odiseo y Nausícaa, por otro lado, es muy interesante para la confrontación con el poema de Arquíloco. Particularmente porque ambos relatos presentan el encuentro entre el héroe y una joven en la edad de su despertar sexual y en un contexto típico de seducción amorosa. El rasgo erótico, por lo tanto, es uno de los elementos centrales de ambos episodios. Sin embargo, es evidente que el $\tilde{\eta} \theta$ o $\varsigma$ de cada uno de ellos es completamente diferente. Mientras en la épica prima la moderación de Odiseo y la prudencia de Nausícaa, en el epodo de Arquíloco se produce lo contrario, el narrador busca la satisfacción inmediata y la joven actúa contraviniendo la prudencia que podría haberle aconsejado su propia madre antes de morir, prudencia que Nausícaa predica. 
àv $\mu \varepsilon \lambda \alpha v \theta \tilde{\eta}[\mathrm{l}, \mathrm{v} .11)$. Es difícil interpretar a qué se estaría refiriendo con "oscuro" o "negro", ya que falta el final del v. 11. Para esta laguna se han

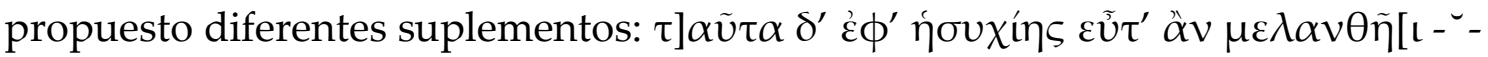
. Se ha considerado, por ejemplo, que la oscuridad podría referir a un momento inmediatamente posterior al coloquio entre los jóvenes, es decir, "cuando el día se vuelva oscuro", "cuando llegue la noche", momento apropiado para la deliberación y el consejo. ${ }^{233}$ Sin embargo, se ha objetado que no tiene demasiado sentido que el joven le propusiera a la muchacha deliberar acerca de un posible casamiento esa misma noche, lo más razonable dado el encuadre del poema, sería la postergación de la decisión por un lapso de tiempo mayor. En la editio princeps, Merkelbach \& West (1974, pág. 105) habían sugerido عũ̃' àv

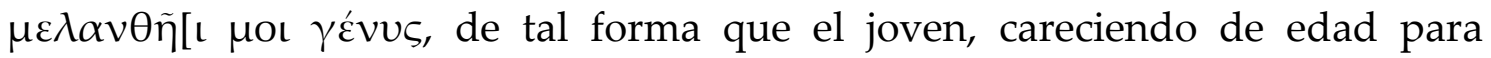
contraer matrimonio, le estaría proponiendo a la muchacha postergar esta decisión hasta que sus mejillas "se oscurezcan por el surgimiento de la barba." 234 Sin embargo, habría que objetar aquí que si el joven es imberbe y no lo suficientemente adulto aún como para contraer matrimonio con su

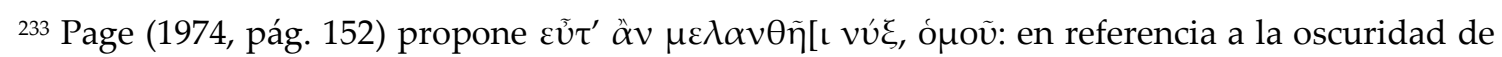
la noche. Van Sickle (1975, pág. 133), particularmente en referencia al oscurecimiento de la luz

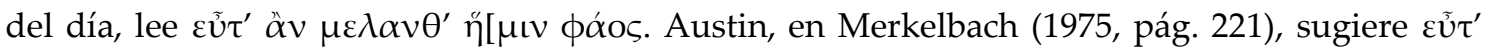

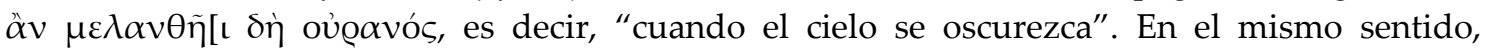

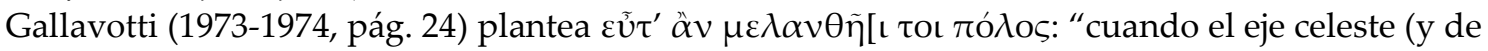
allí el cielo) se vuelva oscuro". En la misma revista, Marzullo (1973-1974, pág. 74) propone eṽ̃

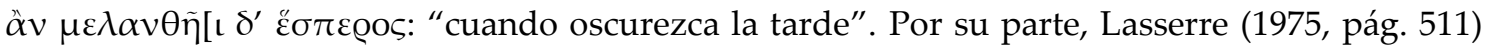
señala: "la tranquillité, le silence sont évidemment liés à la nuit" y propone $\varepsilon \tilde{v} \tau^{\prime} \alpha \ddot{\alpha} \nu \mu \varepsilon \lambda \alpha v \theta \tilde{\eta}[\iota$

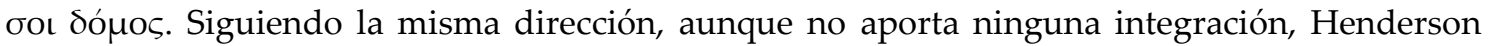
(1976, págs. 171, 179) entiende también que la oscuridad se refiere al anochecer y cita como

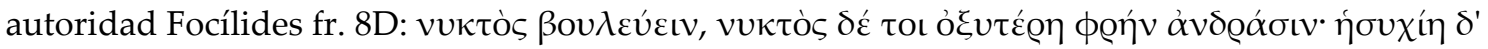

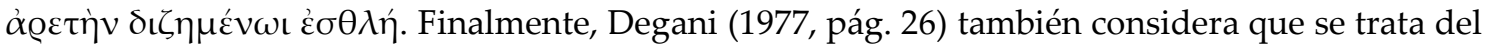

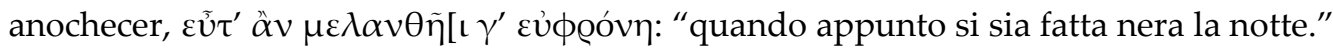

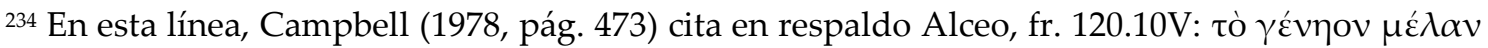
$\varepsilon \check{\mu} \mu \varepsilon v \alpha$, cuyo escolio al verso 5 afirma que allí se ironiza sobre un hombre que se casó antes de que le saliera la barba. También cita Píndaro, Ol.1.67-9, donde se refiere que Pélope, cuando sus mejillas comenzaron a ennegrecerse por la barba, decidió aceptar el desafío impuesto de

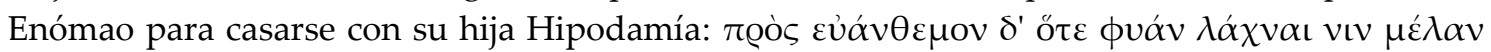

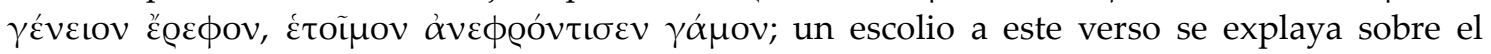

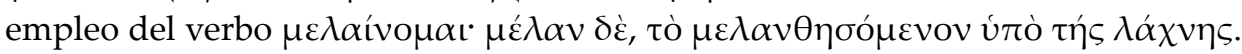


interlocutora, entonces tampoco habría de serlo para casarse con aquella mujer que ella le sugiere. La insinuación de un posible matrimonio entre el joven y otra mujer, Neobule, y el explícito rechazo por parte de él aparecen manifiestos a lo largo de todo el poema. ${ }^{235}$

Otros han interpretado que en realidad es la muchacha la que aún es demasiado joven y no está en condiciones de contraer matrimonio. En ese caso,

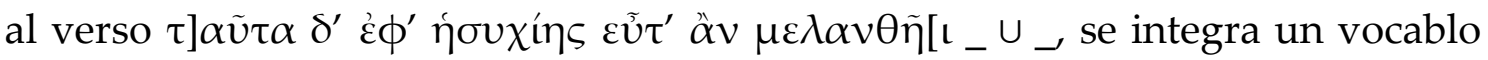
relacionado con la maduración de la uva, en sentido literal o metafórico. ${ }^{236}$

Como puede observarse, existen diferentes propuestas de integración para el final del v. 11, y con ellas se habilitan diversas interpretaciones acerca del significado del pasaje. Sin embargo, es posible sintetizar que, debido a la consecución entre $\beta o v \lambda \varepsilon v ́ \sigma o \mu \varepsilon v$ y la cláusula temporal, la referencia a aquello que es necesario que se vuelva oscuro o negro para que puedan debatir sobre un posible matrimonio es una condición que se enmarca en un tiempo futuro. Este futuro será inmediato si se vincula el oscurecimiento con la caída del sol y el anochecer, o un futuro más distante si se piensa el oscurecimiento en forma metafórica al desarrollo físico de alguno de los jóvenes.

${ }^{235} \mathrm{Vid}$. vv. 2-4 y 15-27.

${ }^{236}$ En esta línea de lectura, Ebert \& Luppe (1975, págs. 227-8) han realizado la siguiente

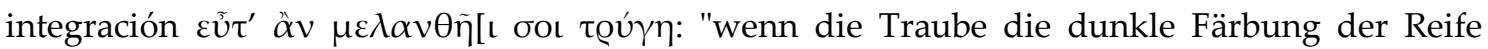
angenommen hat", por lo cual se sobreentiende en sentido metafórico de que la joven no ha madurado aún físicamente lo suficiente. En sustento citan a Filodemo, Anth. Pal. 5.124, donde se nombra a una tal Lisidice como pronta a iniciar un gran fuego, a pesar de que su flor no ha salido aún del capullo, ni las uvas, productoras del virginal encanto, se han oscurecido todavía:

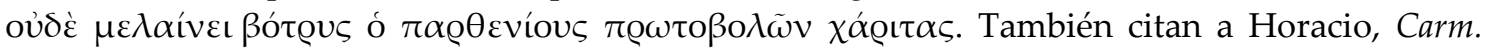
2.5.9-12: tolle cupidinem / inmitis uvae: iam tibi lividos / distinguet autumnus racemos / purpureo varius colore. Siguiendo a Ebert \& Luppe, Slings (1975, pág. 170) señala que en

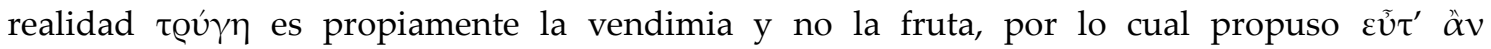
$\mu \varepsilon \lambda \alpha v \theta \tilde{\eta}[\iota$ бol $\beta o ́ \tau \varrho v \varsigma$, en donde las uvas podrían referir metafóricamente a los pezones de la muchacha, es decir, cuando la joven haya crecido y esté lo suficientemente desarrollada como para poder contraer matrimonio. Burkert, en Merkelbach (1975, pág. 221), había sugerido con anterioridad la posibilidad de una referencia a la maduración de las uvas pero en un sentido

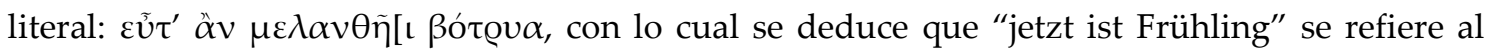
momento en que se produce el diálogo, sin embargo ßót@va implica la transposición de un vocablo helenístico. 
En el verso siguiente, el joven declara a la muchacha que obedecerá a

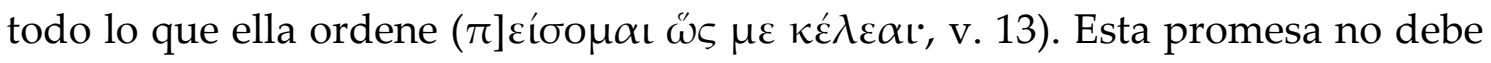
entenderse en relación a la deliberación acerca de un futuro matrimonio, sino vinculada probablemente al modo de realizar el acto sexual en ese mismo instante. El joven parece decirle a su interlocutora que aceptará y respetará lo que ella le ordene en cuanto a la consumación total del acto, al coitus interruptus o al coitus ante portas. ${ }^{237}$

Los vv. 13-16 parecen ser una estrategia del joven para ganar la confianza de su interlocutora con el fin de disuadirla a que acepte realizar el acto sexual. En el v. 13 le dice que acatará lo que ella decida, y en los vv. 13-16, además de manifestar el gran deseo que siente por estar con ella ("mucho me excita el deseo. No rehuses, amiga, que me precipite debajo de la cerca y de las puertas"), ${ }^{238}$ el joven también la tranquiliza con respecto a su eyaculación, (“atracaré en el herboso jardín, desde ya ten presente eso"). ${ }^{239}$

${ }^{237}$ Es interesante la integración de Koenen (1974, pág. 472) para final del v. 13: $\left.\pi\right] \varepsilon i ́ \sigma o \mu \alpha \iota ~ \omega ̆ \varsigma \mu \varepsilon$

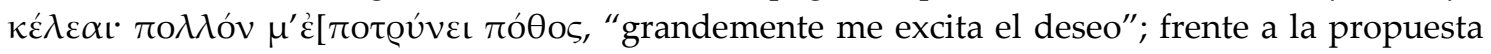

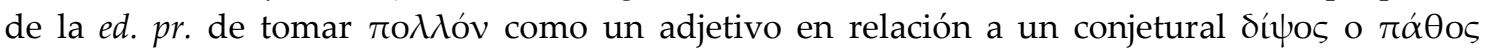

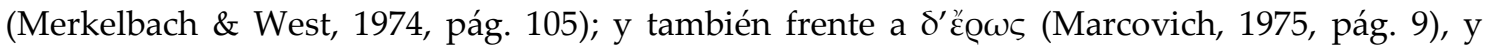

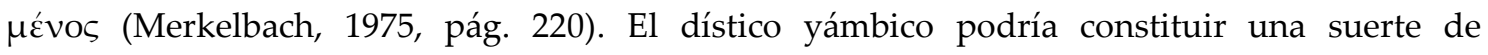
comentario del hemiepes, en una estructura asindética de las formas pronominales $\mu \varepsilon$ (o $\mu \varepsilon \ldots$

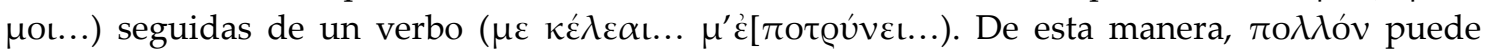
aparecer en función adverbial o adjetival. Por la forma adjetival se decide Slings (1987, pág. 38),

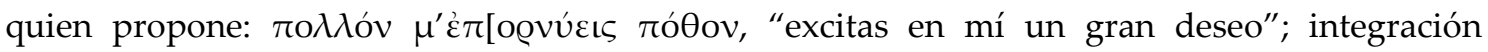
seguida en la edición de Gerber (1999, pág. 214).

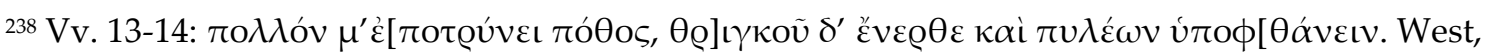

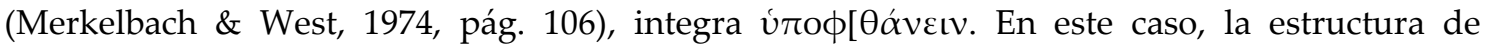

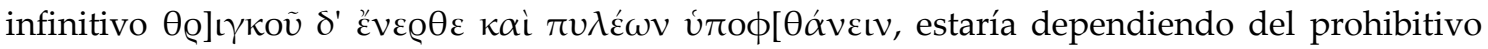

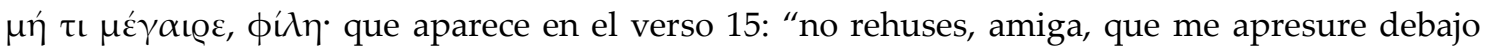
del cercado y de las puertas." Slings (1987, pág. 39) señala, sin embargo, que el verbo

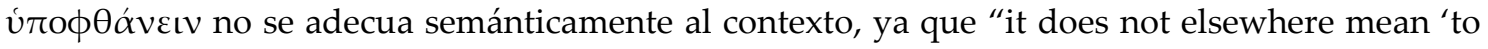
be first', but 'to be earlier'", por lo cual propone el suplemento v́ $\pi \circ \phi[\lambda \hat{v} \sigma \alpha \mathrm{L}$, que, por su sentido figurado de "eyacular", podría relacionarse muy bien con la metáfora sexual que constiuirían las imágenes del cercado y de las puertas. E igualmente Latacz (1992, pág. 12), quien sostiene: "das Wort gehörte zum individuellen poetischen Sprachschatz des Archilochos". Sin embargo, el compuesto úro- $\phi \lambda u ́ \varepsilon ı v$ no está atestiguado en ninguna otra parte, y parece bastante difícil pretender defenderlo con el $\alpha \dot{\alpha} \varepsilon \dot{\phi} \phi v \sigma \alpha v$ del fr. $45 \mathrm{~W}$ de Arquíloco, como lo intenta Slings, o citando el $\check{\varepsilon} \phi \lambda v \sigma \varepsilon$ que presentan los epigramas alejandrinos de Dioscórides y de Meleagro 
Es muy probable que los versos 14 a 16 constituyan una referencia

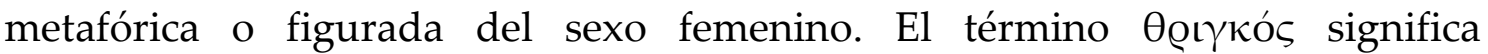
"albardilla, cercado superior de piedras de un muro";240 Merkelbach \& West (1974, pág. 106) lo definen como “Wölbungsbogen" y explican el sentido metafórico del vocablo: "bezieht sich metaphorisch auf den Knochen über der Scham des Mädchens", es decir el mons veneris.. ${ }^{241}$ Para $\pi u ́ \lambda \alpha \iota$ es posible remitirnos a Aristófanes (Lys. 1163), donde el nombre de la ciudad disputada por espartanos y atenienses, Пúגos, dispara un juego de palabras con doble

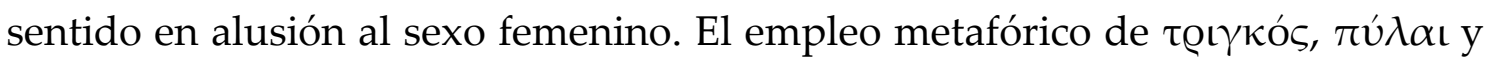
de su sinónimo $\theta v ́ \varrho \alpha$ en un contexto erótico-obsceno aparece en distintos textos de la antigüedad..$^{242}$

Sin embargo, tampoco se puede rechazar el empleo literal de los términos, como referencia directa al lugar en que se desarrolla el encuentro entre los jóvenes. ${ }^{243}$ La lectura literal se fundamenta principalmente en el

(Anth. Pal. 7.351 y 352), donde las hijas de Licambes desmienten haberse encontrado a solas con el poeta y lo acusan de ensañarse contra ellas.

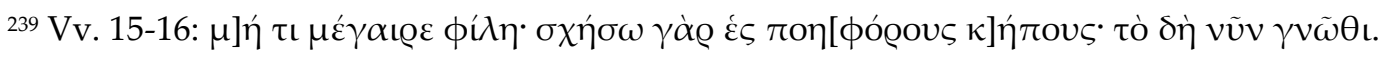

${ }^{240}$ LSJ s. v. Ө̣ırкós.

${ }^{241}$ Ebert \& Luppe (1975, pág. 229) traducen Ө̣ı $\gamma$ kó como "Gewölbebogen", y van un poco más allá con la metáfora, para ellos esta "bezeichnet (...) insgesamt den Bogen, den Schenkel und Schamgegend bilden." La mayoría de los investigadores que han analizado y traducido el epodo avalan la lectura erótica de los términos: Barigazzi (1973-1974, pág. 8); Casanova (1976, pág. 33); Gallavotti (1973-1974, pág. 24); Marcovich (1975, pág. 7); Montanari (1973-1974, pág. 93); Sisti (1975, pág. 227); Stoessl (1976, pág. 250); Van Sickle (1975, pág. 140); Henderson (1976, pág. 170); Zanetto (1985, pág. 36 n. 8); Slings (1987, pág. 38); Latacz (1992, pág. 7); Günther (1996, pág. 65); West (1997, pág. 500); Gerber (1999, pág. 215); Suárez de la Torre (2002, pág. 174 n. 115).

${ }^{242}$ Es posible remitirse, por ejemplo, a Arquíloco, fr. 47W: Өv@é $\omega v$ (aunque no en sentido metafórico); Hiponacte, fr. 95.2Dg: $\pi v \gamma \varepsilon \tilde{\omega} v \alpha$ (deformación cómica sobre $\pi v \lambda \varepsilon \tilde{\omega} v \alpha$ );

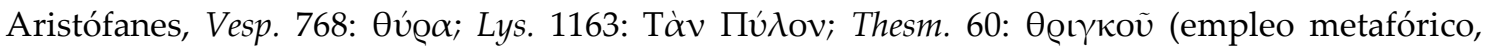

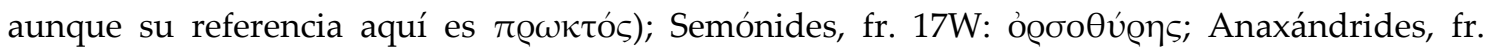

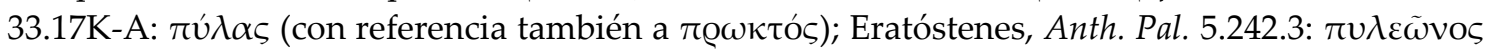

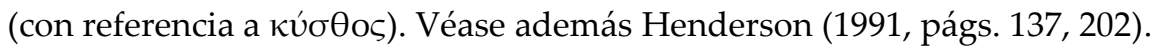

${ }^{243}$ De este parcecer son Cataudella (1974, pág. 35); Lasserre (1975, págs. 511-12), quien, apoyándose en Alcifrón, Epist. 4.10.2, considera que el cercado, las puertas y los jardines "appartiennent à l'équipement des maisons de rendez-vous."; Treu (1976, pág. 116) afirma que 
epigrama alejandrino de Dioscórides (Anth. Pal. 7.351), en el que se representa a las hijas de Licambes hablando desde sus tumbas y jurando que jamás se encontraron con Arquíloco, ni en las calles ni en el gran templo de Hera. ${ }^{244}$

La figuración erótica termina con una imagen mediante la cual el joven intentaría tranquilizar a su interlocutora: “atracaré en el herboso jardín, desde

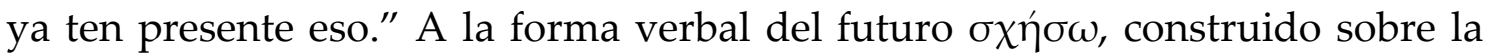
raíz del aoristo, se le debe atribuir el valor de una acción momentánea, frente al futuro $\varepsilon \xi \omega$, construido sobre el presente, con valor durativo. ${ }^{245}$ De acuerdo con

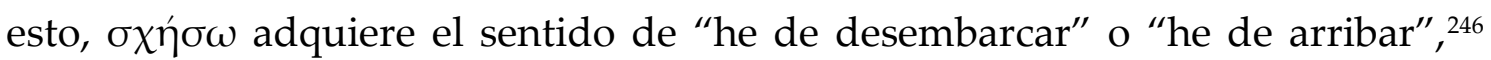
que en el contexto del epodo podría constituir una metáfora de la eyaculación del joven. ${ }^{247}$ Dentro de la continuidad de la imagen, el "herboso jardín" destaca,

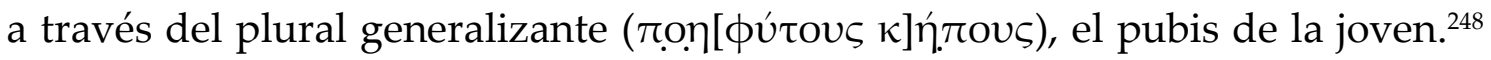

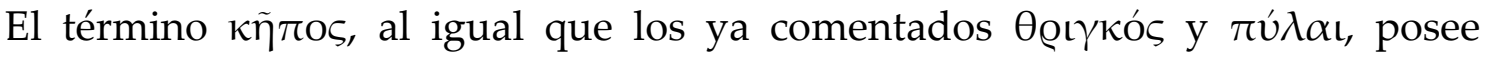

“die Erwähnung von Thrinkos und Toren kann, wörtlich genommen, nur auf ein vieltoriges Bauwerk gemünzt sein, auf eine Mauer also, wohl auf die Stadtmauer von Paros."; Gentili (1982, pág. 18), por su parte, considera que la literalidad de los términos debe entenderse en referencia a un santuario, "luogo privilegiato, nel ristretto mondo della societa greca, per gli innamoramenti, per i primi approcci tra adolescenti, per le proposte di matrimonio."

${ }^{244}$ Vid. inf. el análisis de los ff. 34-38W (pág. 176).

${ }^{245}$ Kühner \& Gerth (1898, pág. 170): “Nur in den (im Aktivum seltenen) Fällen einer doppelten Futurbildung tritt eine Scheidung der Aktionen ein. Die aus dem Aoriststamme gebildeten Futura werden dann in momentanem Sinne, die aus dem Präsensstamme gebildeten in

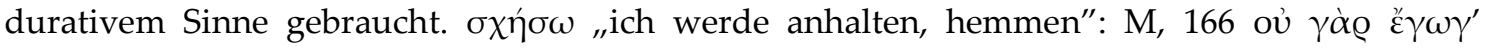

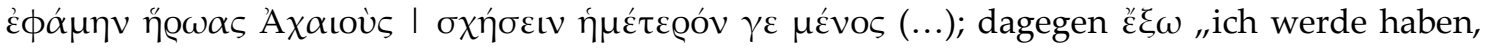

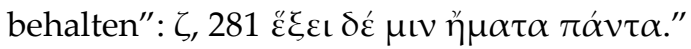

${ }^{246} \mathrm{Vid} . \mathrm{LS}{ }^{9}$ s. $v$. $\check{\varepsilon} \chi \omega$ A.II.8, que registra las acepciones "hold or keep in a certain direction (...);

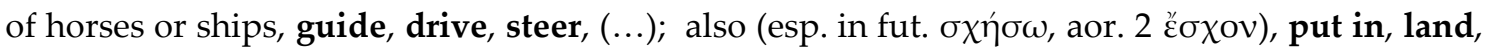

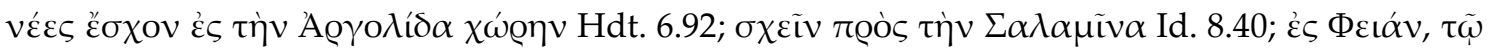

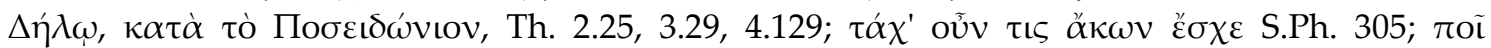

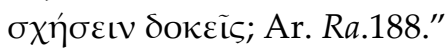

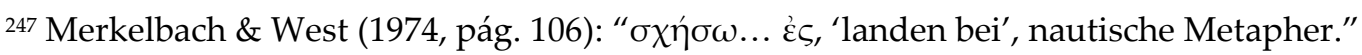

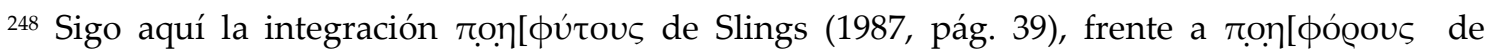
Merkelbach \& West (1974, pág. 106). A favor de este suplemento se puede confrontar no

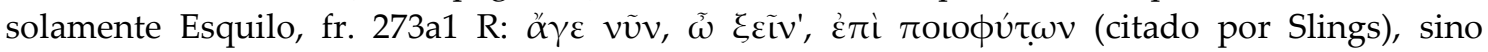

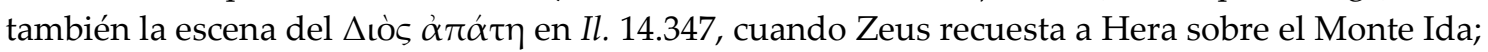

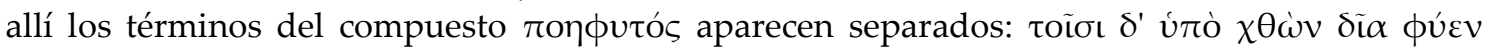

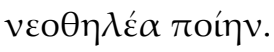


también cierta tradición en su figuración erótica, particularmente en este caso del mons veneris. ${ }^{249}$ Sin embargo, en una lectura literal, los $\kappa \tilde{\eta} \pi$ o podrían referirse a jardines anexos al santuario de Hera, ya que en los vv. 42-3 se indica que el joven toma a la muchacha y la recuesta sobre esplendorosas flores. ${ }^{250}$

Una lectura literal sin duda simplificaría las connotaciones eróticas y sexuales tradicionalmente presentes en la épica y la lírica, y particularmente en la tradición yámbica. El diálogo entre los jóvenes tiene lugar en un prado florido, como se evidencia hacia el final del poema, y el escenario podría haber sido las cercanías al santuario de Hera, con sus puertas, sus muros y sus jardines, pero también la descripción comparte el valor simbólico arraigado en la tradición poética de los encuentros amatorios, las conquistas sexuales, los raptos y las violaciones. Es posible, por lo tanto, que todo el pasaje desarrolle una imagen bucólica con doble sentido, en la que se conjugan la virginidad de la muchacha, su despertar sexual, el reverdecer de la primavera en un prado

\footnotetext{
${ }^{249}$ Sobre el carácter metafórico de $\kappa \tilde{\eta} \pi \mathrm{ou}$ se ha citado al comediógrafo del siglo V a. C., Arquipo,

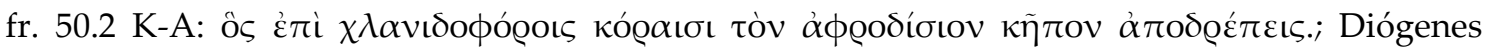
Laertius, Vit. phil. 2.116, citando a Teodoro de Cirene, siglo IV a. C., contra Estilpón de Mégara:

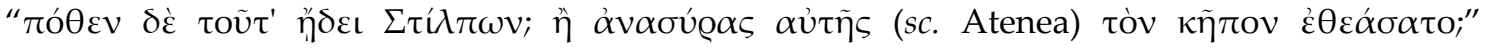

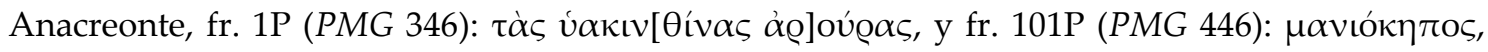

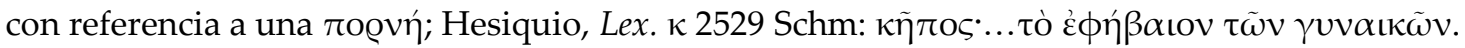

250 Para una lectura literal del pasaje, podemos considerar Safo, fr. 2, donde, a pesar de no emplear el término $\kappa \tilde{\eta} \pi \mathrm{s}$ sino $\lambda \varepsilon \dot{\mu} \mu \omega \nu$ (v. 9), se describe el templo de Afrodita en Lesbos

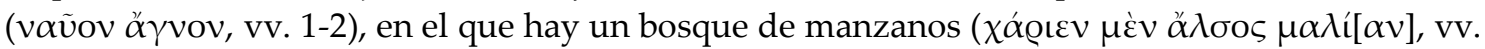

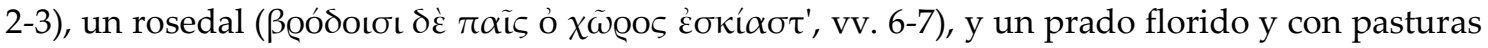

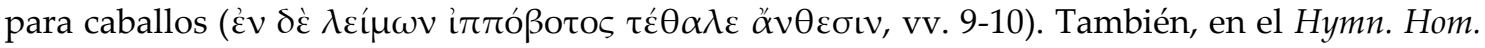
Aphr. 5.58-66 se narra el ungimiento de Afrodita en su altar de Pafos, Chipre. La diosa posee allí

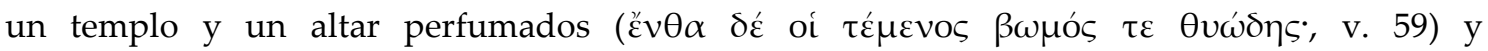
resplandecientes puertas ( $\phi \alpha \varepsilon \imath v \alpha ́ \varsigma \theta v ́ \varrho \alpha \varsigma$, v. 60). En el mismo himno se cuenta que Afrodita, luego de abandonar el perfumado huerto ( $\varepsilon \dot{v} \omega \dot{\delta} \eta \varsigma \kappa \tilde{\pi} \pi \mathrm{s}, \mathrm{v} .66)$, se dirigió a Troya. Además, Pausanias, Graeciae descriptio 2.17.2, al describir el templo de Hera en Samos señala la presencia

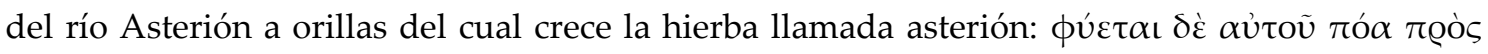

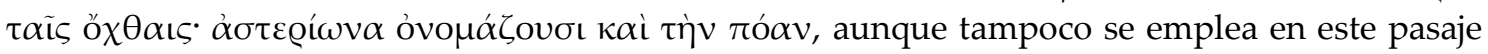

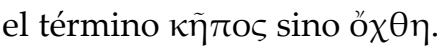


silvestre, el inminente deseo del joven y eufemismos al coitus interruptus o ante portas. $^{251}$

El mismo verso 16 continúa con una expresión perentoria “ten presente

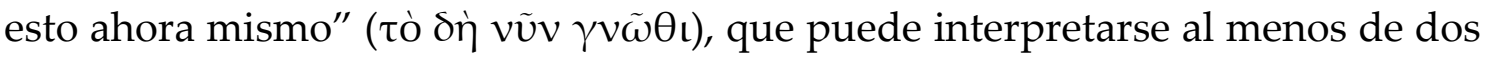
maneras diferentes. La primera entiende la expresión como una manifestación concluyente acerca de la promesa del coitus interruptus o del coitus ante portas. ${ }^{252}$ La segunda interpretación considera que la frase, en vez de concluir lo que el joven le ha dicho recientemente, en realidad inicia de manera tajante una

${ }^{251}$ Marcovich (1975, pág. 12) considera que aquí se podría estar empleando una metáfora para aludir al acto sexual por medio de la acción de remar: "if the man's sexual action is metaphorically envisaged as a 'rowing process' (...) then 'the final landing or lighting' must imply 'ejaculation', and this will take place upon the girl's mons Veneris. It seems clear to me that coitus interruptus is meant." Del mismo modo, Merkelbach (1975, pág. 220) señala: "Der

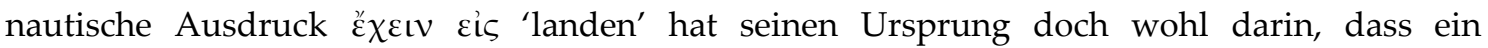
Landepflock eingeschlagen und das Schiff daran befestigt wird; an dem Pflock wird das Schiff festgehalten, mit dem Land verbunden. Mir scheint die metaphorische Anwendung dieses Ausdrucks für den Sexualakt nicht zu der Hypothese zu passen, dass nur ein coitus interruptus vollzogen worden sei." En la misma línea de interpretación se encuentra también Slings (1975, pág. 170), aunque para este autor $\sigma \chi \eta ் \sigma \omega$ "apart from 'to land' it can also mean 'to stear one's course' [obj. $\nu \tilde{\eta} \alpha(\varsigma): \kappa 91, \lambda 70$; (pseudo-) intransitive $\gamma$ 182]. The form $\sigma \chi \eta \dot{ } \sigma \omega$ rather than $\varepsilon \check{\xi} \xi \omega$ is chosen because Archilochus promises to change the direction of his member (cf. K.-G. 1 170; $\lambda$ 70). Consequently, there is no objection at all to the theory of a coitus interruptus." West (1975, pág. 218) se inclina también por una lectura metafórica: "He (Archilochus) treats her tenderly, and keeps his promise that it will be a coitus interruptus (15f.; 35. The second passage only has point in relation to the first)." Finalmente, Degani (1977, pág. 22) considera que es absurdo no entender la expresión en sentido sexual, pero para él "Il testo non parla né di penetrazione, dunque di stupro, né di manovre che facciano pensare all'onanismo: la preoccupazione del seduttore -e della sedotta- non è tanto di evitare un'eventuale 'gravidanza prematrimoniale' (Marcovich 1975: 14), ma semmai di non compromettere la verginità. Si tratterà dunque di coitus ante portas, puittosto che di pratiche per cosí dire malthusiane."

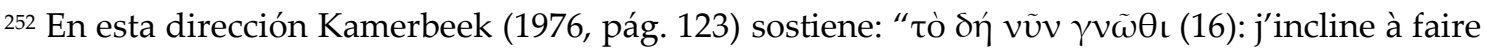
se rapporter cette petite phrase à ce qui précède, non à ce qui suit. Avant d'aborder son algarade farouche contre Néobulé il résume sa préférence et ses intentions à l'égard de la jeune fille en une formule saisissante"; también Van Sickle (1975, pág. 140): "In other words, the lover will obey the girl's wish to avoid complete union now; in turn he asks her not to 'make a big thing of it' if he does do something that comes close but stops short (and which is a far cry from wedding). His final emphasis, to de nun gnōthi (16), appears almost to throw the words of her final suggestion at her $-t \bar{e} n$ dè su poiē $[s a i$ (5)- for he does refuse her proposal and insist on her herself". En esta misma línea, las ediciones de West (1998, pág. 77) y de Gerber (1999, pág. 212)

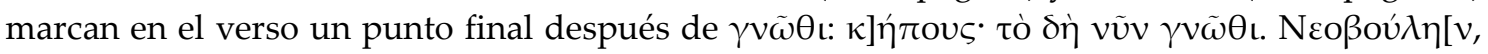
lo cual obliga a relacionar la frase con lo que precede y no con el texto que continúa. 
invectiva contra Neobule, la mujer ofrecida por la muchacha para que él tome por esposa. ${ }^{253}$

La aparición del nombre "Neobule" en el v. 16, por un lado, ha permitido confirmar que el epodo, descubierto y editado en 1974, pertenecía al ciclo de los poemas centrados en la figura de Licambes y de sus hijas. Por otro lado, ha

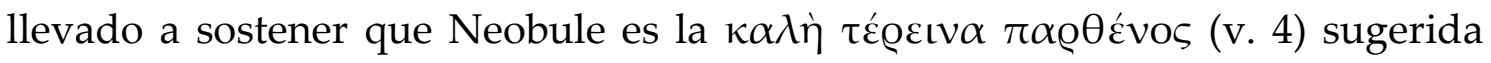
por la muchacha al protagonista para saciar su deseo sexual; por lo tanto, estas

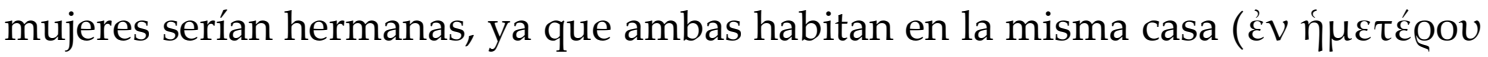
v. 3). ${ }^{254}$

En este punto, el joven inicia una vehemente invectiva contra la figura de Neobule que se extenderá hasta el final de su rhesis (v. 27). El ataque se centra particularmente en el deterioro físico de Neobule que, de acuerdo con el epodo y las creencias de la época, habría sido ocasionado por su lascivia y promiscuidad. ${ }^{255}$ El insulto es devastador: “¡Ay!, demasiado madura está, te

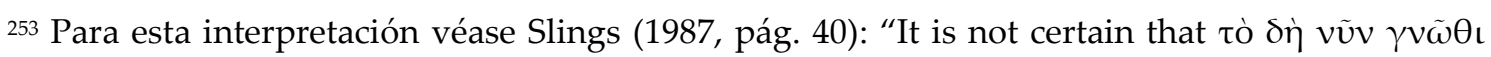
refers to the following words, but it is at least likely that it does. 'Know this (now)' as a conclusion of the promise made in the previous lines, is rather feeble to my taste." También, Nicolosi (2007, pág. 207): "Più che concludere quanto appena detto, il tò con l'imperativo sarà da riferire a ciò che segue, cioè alla risposta articolata con cui il poeta rifiuta i suggerimenti relativi a Neobule e ribadisce il proprio interesse nei confronti dell'inerlocutrice".

${ }^{254}$ De acuerdo con esta lectura, parece más apropiada la integración de Lloyd-Jones, en

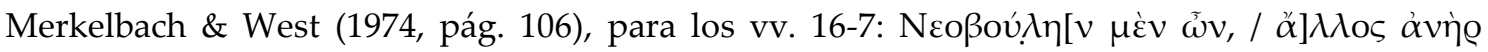

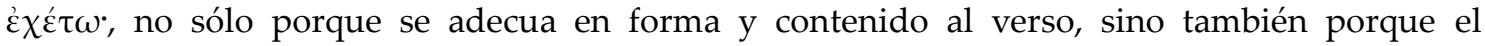
suplemento $\mu \dot{\varepsilon} v \tilde{\omega} v$ permite recuperar la proposición que la muchacha realiza al joven en el v.

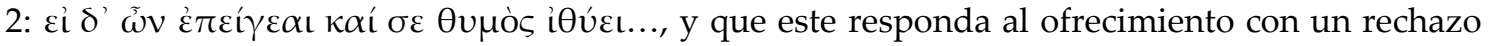
terminante. A partir de esta reconstrucción, los vv. 16-7 deberían interpretarse de la siguiente manera: “Ahora, ten por seguro esto: ¡Con Neobule / que otro hombre se case!” o “¡A Neobule / que otro hombre la posea!"

${ }^{255} \mathrm{El}$ marchitarse de la juventud femenina a causa de excesos sexuales es un tema que aparece ya en Hesíodo, fr. $132 \mathrm{M}-\mathrm{W}$, fragmento transmitido en la definición de "lujuria" de la Suda $\mu$

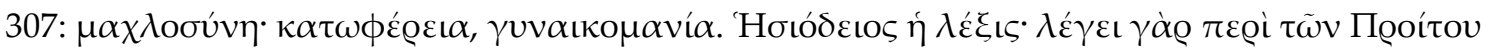

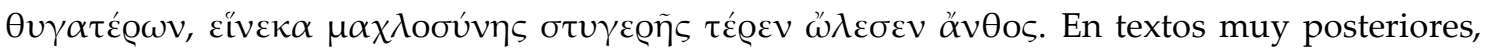
particularmente cristianos, $\pi \alpha \varrho \tau \varepsilon v i ́ \alpha \varsigma \alpha ̋ v \theta 0 \varsigma$ tiene el significado de flos virginitatis; vid. Longo, Daphnis et Chloe 3.23.2.4; Juan Crisóstomo, De paenit. 49.296.13; De sanctis Bernice et Prosdoce 50.636.6; Quod regulares feminae viris cohabitare non debeant 1.24; Expositiones in psalmos 55.202.11; In adorationem venerandae crucis 62.750.10; Anfiloquio, In occursum domini 2.28-9; Hesiquio, In 


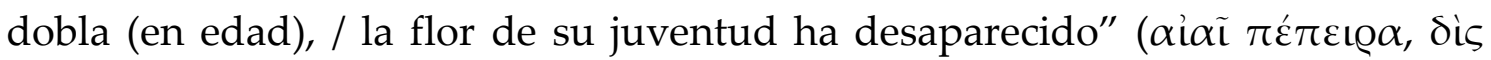

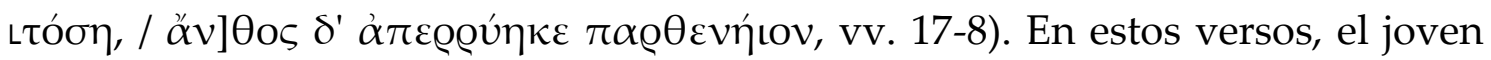

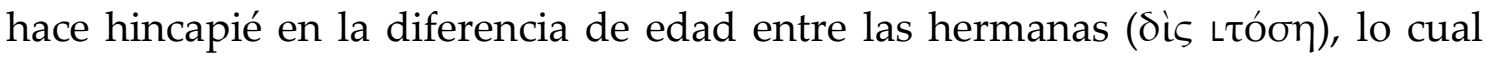
podría indicar que mientras la hija más pequeña de Anfimedo está en el inicio de la pubertad, Neobule transitaría ya el final de su juventud. ${ }^{256}$ La edad le permitirá subrayar los contrastes físicos y morales entre ambas mujeres, en torno a los que se va a ir construyendo el escarnio de Neobule y el elogio de su hermana.

En primer lugar, el término $\pi \varepsilon ́ \pi \varepsilon \iota \alpha$ refiere a la fruta pasada, blanda y en estado de descomposición, y era empleado figurativamente para insultar a las mujeres. ${ }^{257}$ Más que indicar la ancianidad, $\pi \varepsilon ́ \pi \varepsilon\llcorner\varrho \alpha$ alude a cierto decaimiento y deterioro de la belleza femenina, producto de los excesos sexuales. $^{258}$

En segundo lugar, la expresión "la flor de su juventud ha desaparecido"

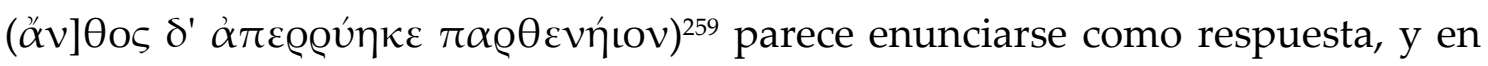

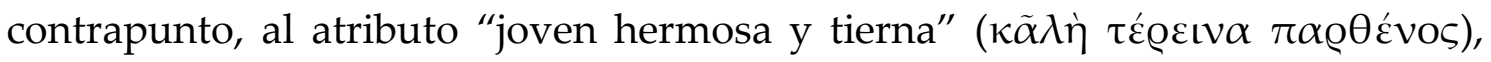

sanctum Antonium 8.1.7; Libanio, Progymnasmata 11.17.4.8. Sobre este tipo de creencias en la Grecia arcaica, véase Henrichs (1980).

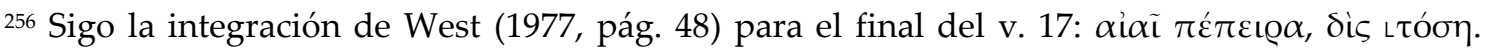

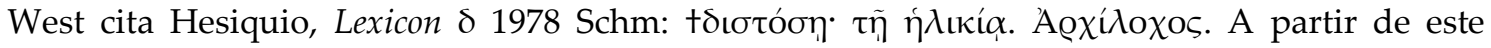
suplemento, West concluye: "Neobule will be in her late twenties, still advertised as a $\kappa \alpha \lambda \eta \dot{\eta}$

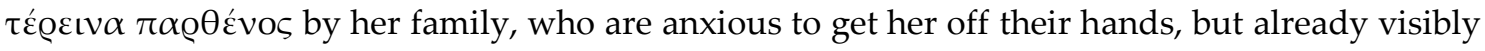
past her prime."

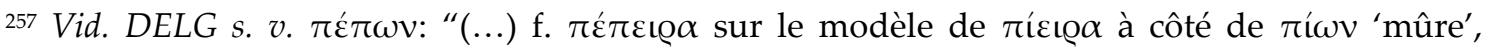
quelquefois 'vieille', dit souvent de femmes (Anacr., Ar.), 'molle' (Hp., S.)".

258 En el fr. 89P (PMG 432) de Anacreonte, una mujer le reprocha a un hombre que su deterioro

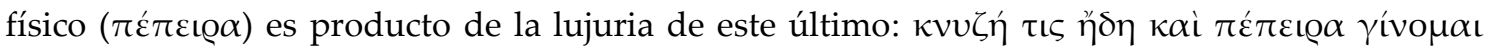

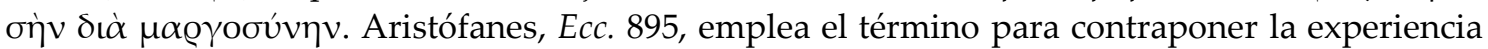

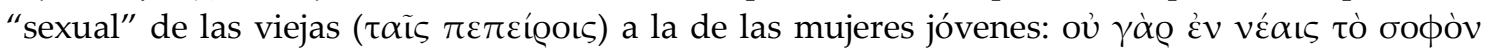

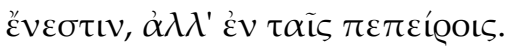

259 Vid. Hymn. Hom. Dem. 2.108: kov@íiov åvӨos. Slings (1987, pág. 41) señala que la expresión

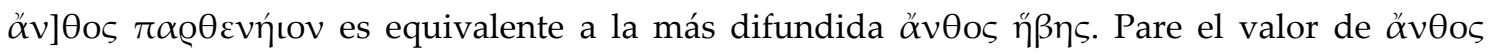
$\eta\rceil ß \eta \varsigma$, Slings cita Homero, Il. 13.484; Hesíodo, Theog. 998; Hymn. Hom. Herm. 4.375; Solón, fr. 25.1W; Tirteo, fr. 10.88W; Theognidea 1007W; Simónides, fr. 8.6. 
que la hermana menor pronuncia elogiosamente sobre Neobule en el v. 4. El joven no niega que alguna vez Neobule haya sido una mujer muy bella, sino que remarca que la pérdida del encanto y la hermosura que antes poseía se ha debido a su conducta sexual, como puede apreciarse en los vv. 19-20. ${ }^{260}$

En tercer lugar, en los vv. 20-23 el protagonista expresa abiertamente su rechazo por Neobule y su repulsión ante la idea de contraer matrimonio con ella; teme volverse el hazmerreír de los vecinos por tener como esposa a una mujer que se hace "amiga de muchos." ${ }^{261}$ Al mismo tiempo que realiza la invectiva contra Neobule, el joven elogia por medio de la lítote a su interlocutaria. Ella representa lo contrario de su hermana. Mientras Neobule aparece como una mujer ya marchita, adúltera e infiel, su hermana es joven, sincera y sin dobleces. Inmediatamente, el joven manifiesta de manera explícita su preferencia por la menor de las hijas de Anfimedo.

Finalmente, concluye su rhesis con lo que podría ser un antiguo proverbio: "temo -dice el joven a la muchacha- engendrar hijos ciegos y prematuros, acuciado por su ansia, tal como lo hace la perra." La suposición de que la perra presurosa engendra cachorros prematuros y ciegos parece provenir de alguna creencia popular que podría remontarse hasta las civilizaciones mesopotámicas, más de mil años antes de la época de Arquíloco. ${ }^{262}$ Dentro de la

${ }^{260}$ El lenguaje empleado por el joven, con fuerte carácter invectivo, no deja lugar a dudas sobre

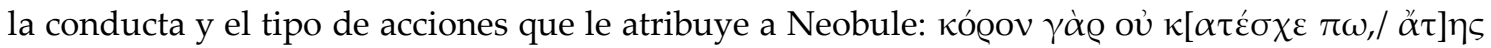

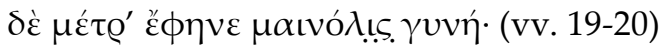

${ }^{261}$ Los vv. 20-23 del epodo recuerdan los consejos matrimoniales que Hesíodo le da a su hermano Perses, a quien le recomienda casarse con una joven virgen que haya vivido siempre cerca de su casa, y que antes de tomarla por esposa preste mucha atención a su entorno, no vaya a ser cosa que contraiga matrimonio con una mujer que sea el regodeo de los vecinos: $\pi \alpha \alpha^{2} \tau \alpha$

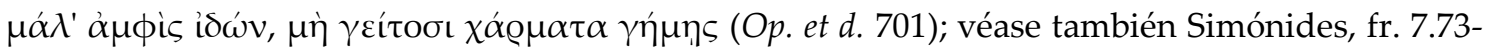
4 y $108-11$ W.

262 El proverbio aparece en un mensaje enviado por Šamši-Adad I, rey de los asirios, coetáneo y rival de Hammurabi de Babilonia, a su hijo Yasmah-Addu, soberano de Mari. Al enterarse del modo en que su hijo despliega estratégicamente sus tropas para enfrentar al enemigo, ŠamšiAdad I le recomienda prudencia, recordándole que "la perra presurosa engendra crías ciegas" 
cultura griega, la fábula 251 (Hsr) de Esopo cuenta que cierta vez la perra y la cerda discutían acerca de cuál de ellas era la más fecunda. La perra sostenía que ella era la más rápida de todos los cuadrúpedos en parir, a lo cual la cerda le replica que, al decir eso, reconoce entonces que engendra crías ciegas: $\alpha \lambda \lambda^{\prime}$

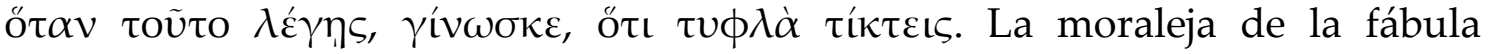
sostiene que las cosas no deben ser juzgadas por la rapidez con que se hacen, sino por su perfección. De manera similar, el proverbio aparece en Aristófanes, Pax 1078, aunque quien engendra crías ciegas no es ya la perra sino el jilguero:

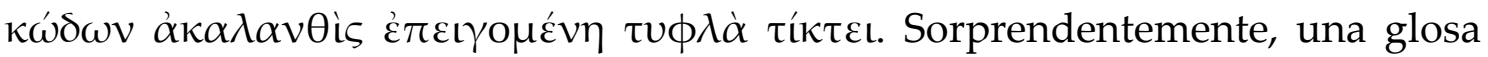
de Hesiquio define $\alpha \kappa \alpha \lambda \alpha v \theta i ́ s$ como "la perra rápida; también un pájaro pequeño." ${ }^{263}$ Casi mil años después, el proverbio vuelve a aparecer con una explicación que refiere a "las equivocaciones a causa de la prisa." ${ }^{264}$ En el epodo, la proverbial perra sería el propio protagonista, y no Neobule como se ha querido leer, ${ }^{265}$ y aquello que podría conducirlo a cometer una equivocación, si

(kalbatum ina šu-tebu/pu-ri-ša huppudūtim ūlid). Acerca del derrotero de este proverbio, véanse Moran (1978), Bremmer (1980) y West (1997, pág. 500).

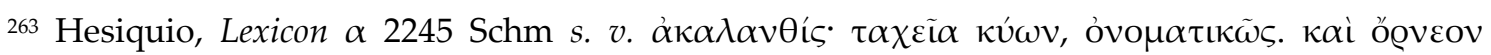

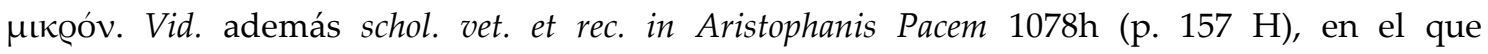
explícitamente se dice que la expresión de Aristófanes hace referencia a un proverbio:

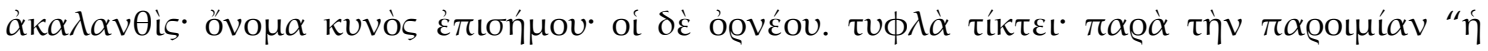
$\kappa u ́ \omega \nu ~ \sigma \tau \varepsilon v ́ \delta о v \sigma \alpha \tau u \phi \lambda \dot{\alpha} \tau i ́ k \tau \varepsilon \iota . "$ En este escolio también se afirma que el proverbio no tiene sentido, por ser una parodia de la oscuridad de las respuestas oraculares con el fin de alcanzar un efecto cómico, ya que ninguno de los seres vivos, tampoco la perra presurosa en el trabajo de

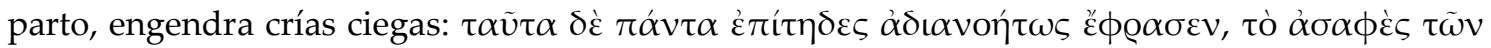

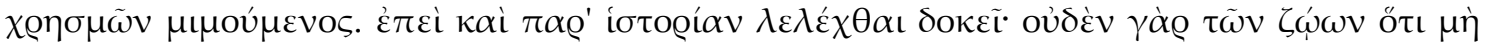

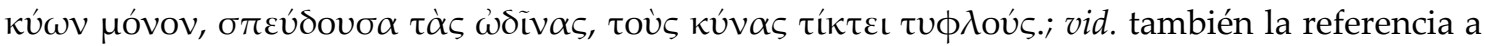

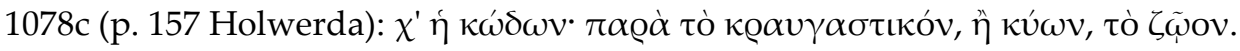

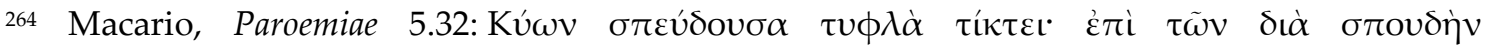
$\alpha \dot{\alpha} \alpha \varrho \tau \alpha \nu \operatorname{vov}_{\tau} \omega \nu$.

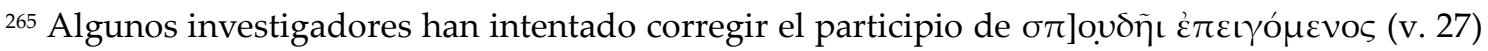
para que refiera a Neobule y no al interlocutor y, de este modo, hacer coincidir la premura de la perra con el carácter adúltero de esa joven. En ed. pr., Gronewald, por ejemplo, corrige

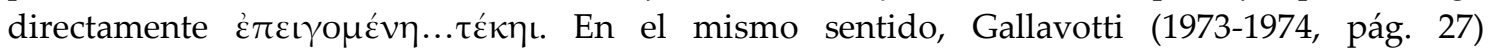
enmienda $\dot{\varepsilon} \pi \varepsilon \nmid \gamma 0 \mu \varepsilon \dot{v}\langle\eta \eta>\varsigma$. Koenen, en Markelbach (1975, pág. 221), integra una iota al

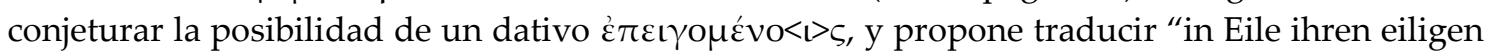
Freunden". Sin embargo, de acuerdo con Merkelbach \& West (1974, pág. 108), quienes exponen los argumentos a favor y en contra de estas correcciones, el papiro no presenta ningún 


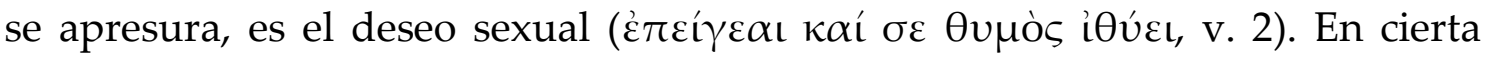
forma, el proverbio de la perra y las crías ciegas viene a ser una respuesta a la cuestión planteada en la primera parte del epodo por la muchacha: si lo oprime el deseo y desea realizar el acto sexual en forma completa, entonces debería hacerse amigo de su hermana, que está deseosa de casarse. El rechazo de esta posibilidad motiva la invectiva contra Neobule, invectiva que no se centra únicamente en la ofensa directa, sino que se instituye como proverbio dentro de la comunidad masculina del simposio: quien se case con ella parirá cachorros

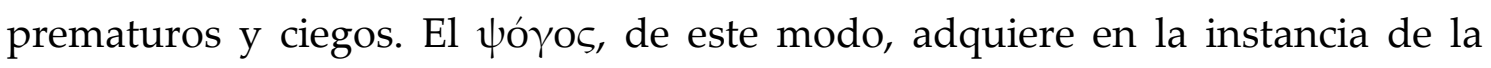
ejecución poética una dimensión y una contundencia mucho mayores que el insulto particularizado.

Los versos finales del epodo (28-35) rememoran los hechos que supuestamente sucedieron entre ellos luego de esa conversación. El joven toma a la muchacha, la recuesta entre las flores y mientras pasa su brazo alrededor de su cuello la cubre con un manto. De esta manera, el poema pasa del nivel de la interlocución al nivel de la narración y sitúa al narratario directamente en la descripción del acto sexual: "puse dulcemente mis manos sobre sus senos... y sintiendo todo su cuerpo eyaculé mi blanco vigor".

Este pasaje final evoca el ya citado encuentro entre Zeus y Hera en el Monte Ida. La transcripción del texto de Ilíada nos permitirá apreciar muchos puntos de contacto con el epodo de Arquíloco:

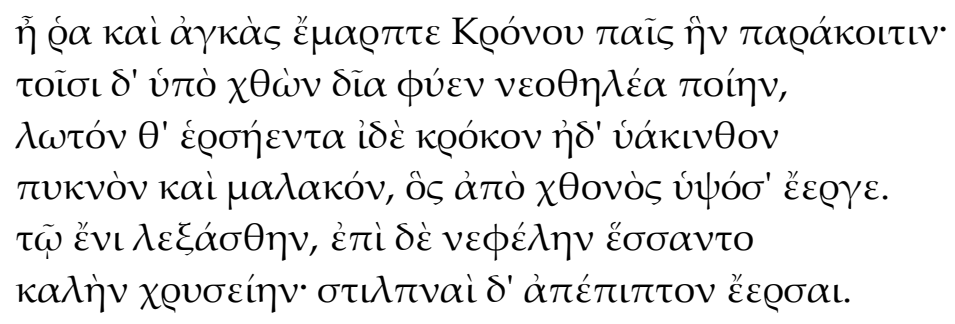

Homero, Ilíada 14.346-51

problema desde el punto de vista paleográfico que requiera un supplementum o additio, y el texto tampoco presenta problemas que puedan requerir una emendatio. 
“Dijo, y el hijo de Crono estrechó a su esposa en los brazos.

Bajo ellos la divina tierra hacía crecer blanda yerba,

loto lleno de rocío, azafrán y jacinto

espeso y mullido, que ascendía y los protegía del suelo.

En este tapiz se tendieron, tapados con una nube

bella, áurea, que destilaba nítidas gotas de rocío."266

En efecto, varios son los puntos a destacar entre los dos textos. En primer lugar, en ambos se narra un encuentro erótico en un prado silvestre. En segundo lugar, la secuencia de acciones realizada por Zeus y por el joven en el momento previo del coito es muy similar. Por útlimo, en ambos pasajes se destaca que el hombre cubre a la mujer en el instante de realizar el acto sexual, el joven con un manto y Zeus con una nube. ${ }^{267}$

266 Traducción de Emilio Crespo (2006, pág. 283).

${ }^{267}$ La acción de cubrirse con un manto en el momento de realizar el acto sexual puede estar destinada a proteger la desnudez de los amantes ante la mirada de algún extraño. Esto parece claro en los versos que preceden al pasaje homérico; allí, Zeus le promete a Hera, ante su temor de ser vista por los demás dioses, que la cubrirá con una nube tan densa que ni siquiera el sol

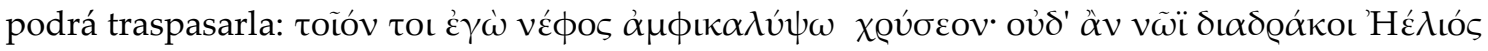
$\pi \varepsilon Q$. Vid. también Odyssea 11.243-4, donde se describe el encuentro entre Posidón y Tiro, y cómo

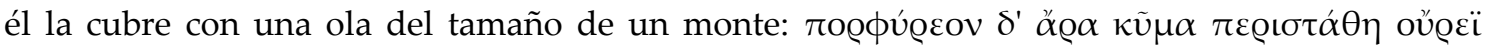

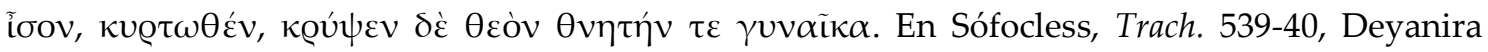
señala, en referencia a ella misma y a Yole, que ahora serán dos las que esperen el abrazo de

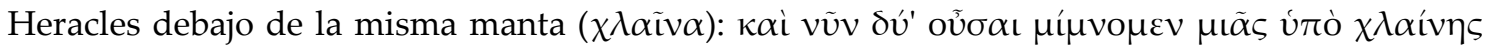
vं $\alpha \gamma \kappa \alpha \dot{\alpha} \iota \sigma \mu \alpha$. En Eurípides, fr. $603.4 \mathrm{~N}$, también se alude al hecho de compartir la misma

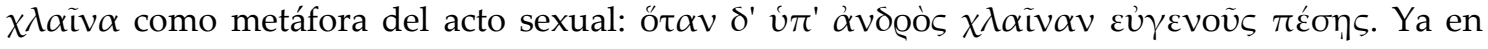
época helenística, Asclepíades, Anth. Pal. 5.169, expresa que una de las cosas más gratas es que

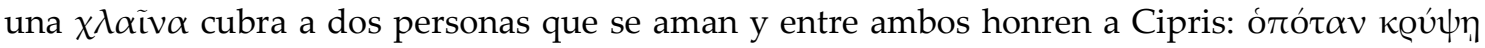

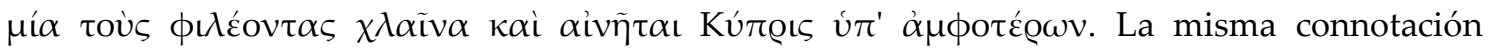
erótica de $\chi \lambda \alpha \tilde{i} v \alpha$ aparece en Teócrito, Idyllia 18.19; en este caso quienes yacen bajo la misma

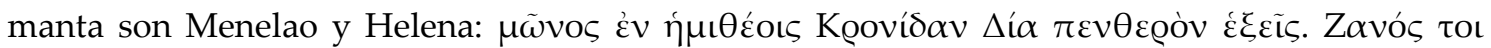

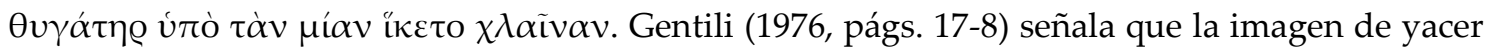
bajo la misma $\chi \lambda \alpha \tilde{i} v \alpha$ "-un'espressione che rispecchiava verisimilmente una consuetudine sociale- diviene, a partire almeno dal V sec. in poi, una figura metaforica del rapporto sessuale." Para Slings (1987, pág. 46), el gesto de cubrir a la amante no sería "a sign of tenderness but of taking possession sexually." Sobre este tema, véase particularmente Arrigoni (1983). 
Como se ha señalado anteriormente, el escenario natural y silvestre es un tópico para el encuentro sexual de los amantes en la poesía griega. ${ }^{268}$ En relación a esto, es notable el carácter idealizado del encuentro entre Zeus y Hera en el Monte Ida, con su blanda hierba, sus flores de loto, azafrán y jacinto, y la nube cargada de rocío cubriéndolos, frente a la descripción mucho más despojada y realista que nos presenta el epodo. Las diferencias entre ambas descripciones podrían radicar en la reelaboración que realiza cada género de un mismo motivo para las ocasiones en que la poesía épica y el yambo eran ejecutados. Así, lo determinante podría ser la función de encomio de los valores aristocráticos que distingue a la épica (sobre todo si se trata de divinidades), frente al carácter invectivo de la poesía yámbica.

Dentro de este escenario silvestre, en el epodo, el narrador compara a la joven con un cervatillo que, ante la acechanza de un cazador o predador, se queda inmóvil por causa del temor. ${ }^{269}$ La imagen del cervatillo podría ser

268 Véase, por ejemplo, Hesíodo, Theog. 278, donde Posidón se acuesta con Medusa en un suave

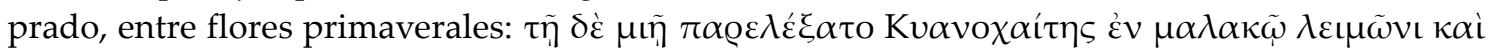

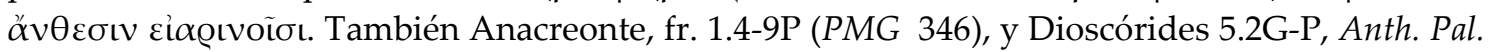
5.55 .

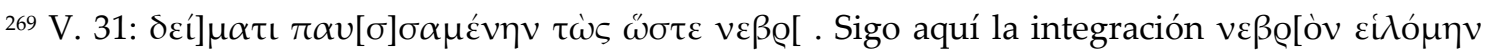
Page, en Merkelbach \& West (1974, pág. 110), que representa la escena sexual bajo la imagen de un cazador o de un depredador que acecha a su presa. El verso podría parafrasearse de la siguiente manera: "la he tomado $o$ la he atrapado como a un cervatillo asustado." Por su parte,

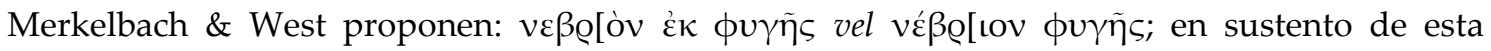

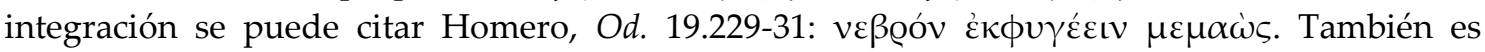
atractivo el suplemento $v \varepsilon \beta \mathrm{Q}[o ̀ v ~ \beta \lambda \eta ́ \mu \varepsilon v o v$ de Gentili, en Degani (1974, pág. 120). De acuerdo con Gentili, la joven aparecería inmóvil y temerosa como un cervatillo derribado o herido; en

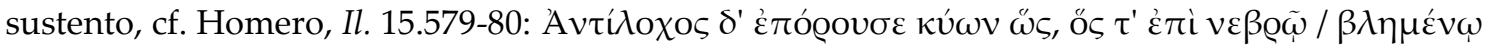

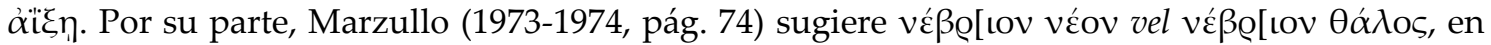
referencia a la vulnerabilidad del pequeño ciervo: Anareonte, fr. 66P (PMG 408). Marcovich

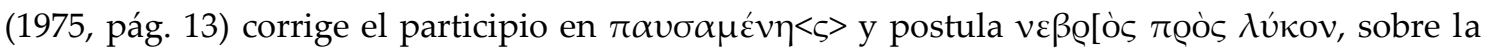
imagen de un lobo y su presa. Koenen, en Merkelbach (1975, pág. 221), postula vé $\beta \mathrm{Q}[ı v$ $\tau \varrho \varepsilon ́ \mu \varepsilon เ v$, la joven sería comparada con un cervatillo que tiembla por el temor. Al igual que Page, también se ha propuesto la integración de un aoristo o de un imperfecto indicativo en coordinación $(\tau \varepsilon)$ con $\dot{\phi} \phi \eta \psi \alpha ́ \mu \eta \nu$ (v. 32). Van Sickle, en Degani (1974, pág. 120), sugiere vعß@[òv $\theta \varepsilon \lambda \gamma o ́ \mu \eta v$ vel $v \varepsilon \beta \mathrm{Q}[\dot{v} v \theta \varepsilon \lambda \xi \alpha ́ \alpha \eta \eta$, que debería entenderse como el engaño del joven sobre la

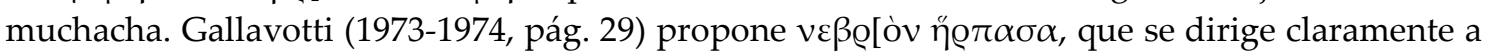
la comparación de la conquista sexual con una escena de caza; en sustento, véase Homero, $\mathrm{Il}$.

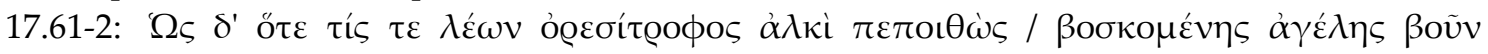


también un lugar común dentro de la poesía arcaica para simbolizar la parálisis provocada por el miedo que infunden los enemigos. ${ }^{270}$ En el epodo, el temor de la joven, tal como lo deja traslucir el narrador, parece ser producto de la inocencia de su edad y la falta de experiencia sexual. ${ }^{271}$

En esa instancia, el narrador prosigue detallando cómo sucedieron los hechos del encuentro sexual. Él tocó con sus manos los pechos de la muchacha,

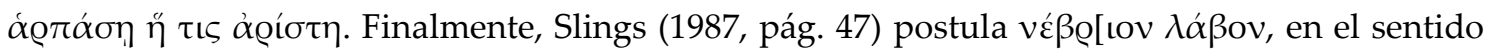
también de "tomar" o "agarrar."

$270 \mathrm{Vid}$. Homero, Il. 4.243-5, donde Agamenón, recorriendo el frente de combate y arengando a las tropas, compara a los cobardes con cervatillos que al cansarse de huir se quedan impávidos:

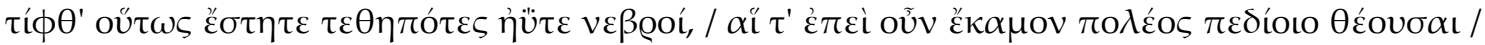

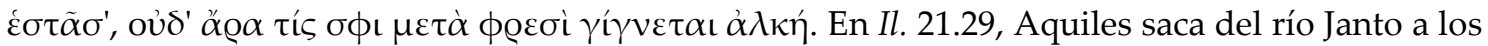

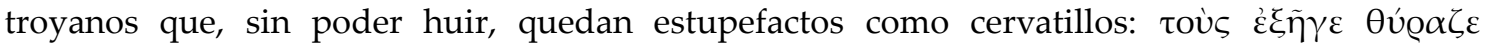

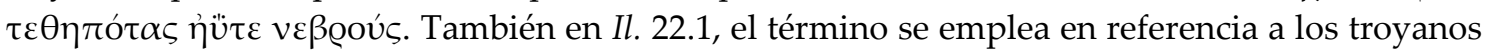
que temerosos se encierran dentro de los muros ante el acecho de los aqueos: ' $\Omega \varsigma$ oî $\mu \varepsilon \dot{\varepsilon} v \kappa \alpha \tau \dot{\alpha}$

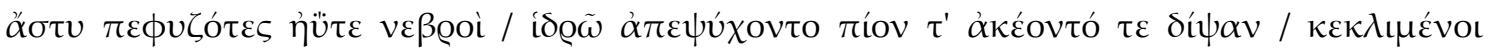

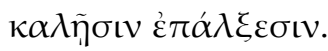

${ }^{271}$ Vid. Anacreonte, fr. 66P (PMG 408), donde probablemente el término veßoó sea empleado para comparar a una joven temerosa con un cervatillo que se ha perdido en el bosque: $\alpha \gamma \alpha v \omega \tilde{\omega} \varsigma$

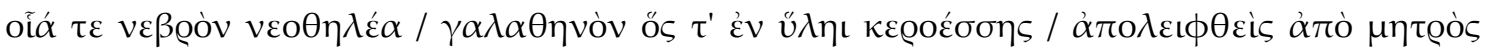
$\varepsilon \dot{\pi} \tau o \eta ́ \theta \eta$. También, Theognidea 949 y 1278, donde la imagen del león y el cervatillo, su presa,

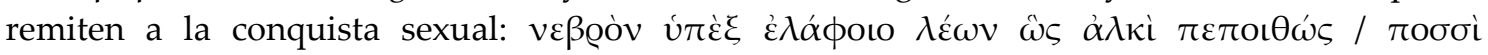

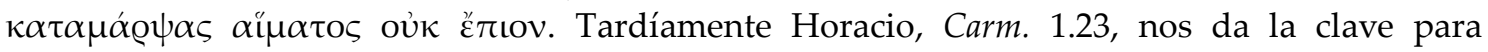
interpretar la imagen del cervatillo como símbolo del temor provocado en la iniciación sexual femenina en general y en el epodo de Arquíloco en particular. En la oda horaciana, una joven llamada Chloe es comparada con un cervatillo temeroso que se ha perdido en el bosque y está en búsqueda de su madre. Ese temor, afirma la voz en primera persona, hace que rehúya de él, pero él no es ni un tigre ni un león que esté persiguiéndola para devorarla, sino que lo único que quiere es que deje de seguir a su madre porque ya tiene edad suficiente para seguir a un hombre:

Vitas inuleo me similis, Chloe, quaerenti pavidam montibus aviis matrem non sine vano aurarum et siluae metu. nam seu mobilibus veris inhorruit adventus foliis seu virides rubum dimovere lacertae, et corde et genibus tremit. atqui non ego te tigris ut aspera Gaetulusve leo frangere persequor: tandem desine matrem tempestiva sequi viro. 
la fresca piel, encanto de la juventud. ${ }^{272} \mathrm{Y}$, por último, el narrador finaliza el epodo contando cómo concluyó el episodio. Abrazando a la joven hija de Anfimedo, él expulsa su "blanco vigor." ${ }^{773}$ Queda claro aquí que el joven cumple con la promesa de evitar el acto sexual completo, y de "atracar en el herboso jardín" o eyacular fuera de la vagina de la joven, tal como lo manifiesta la frase "tocando el rubio [cabello]", frase que debe ser interpretada en

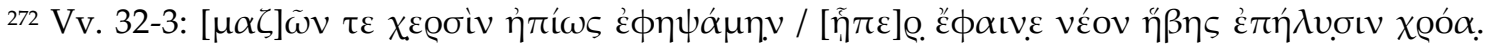

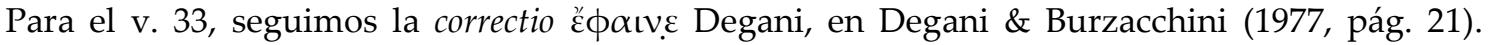

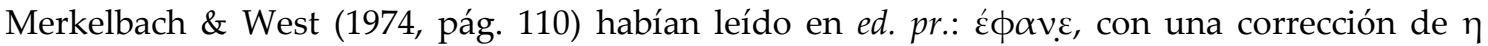
sobre la $\alpha$ en el propio papiro, por lo cual dedujeron que debería leerse $\varepsilon \phi \eta v \varepsilon$, "Vorher stand

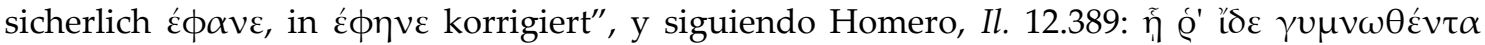

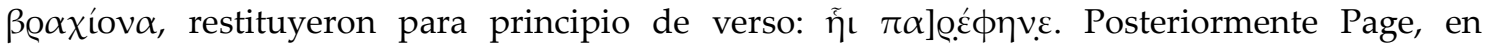
Merkelbach (1975, pág. 221), separa en forma diferente las palabras e integra $\tilde{\eta} \iota \pi \varepsilon] \varrho$ é

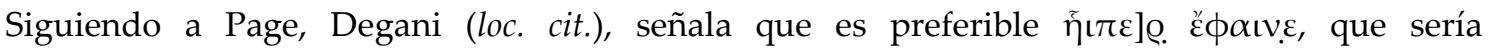
paleográficamente aceptable. Vid. Hagedorn, en Van Sickle (1975, pág. 875 n. 33): “.é $\phi \alpha \iota v e$ with $\eta$ above $\alpha \mathrm{t}$ in pap." Por otro lado, seguimos aquí la interpretación propuesta por Burzacchini

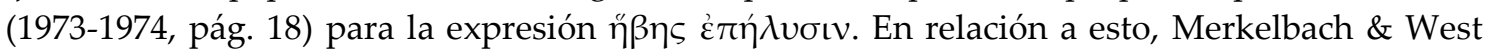
(1974, pág. 110) señalaban: "غ̇สń $\lambda v \sigma \iota v$ ist rätselhaft"; West postula la hipótesis de considerar la

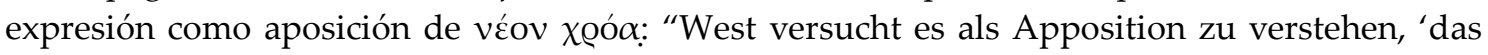
Aufkommen (der Jugend).'" Siguiendo también esta lectura, Slings (1987, pág. 48) señala: "'the fresh skin, the approach of her prime', perhaps implies that the girl's breasts are not yet fully

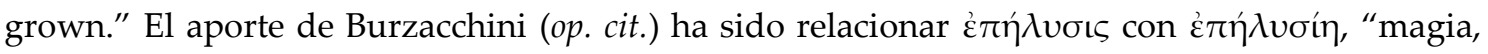

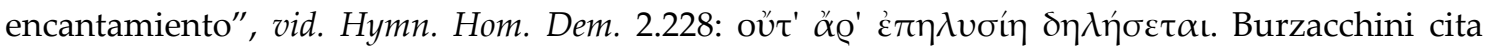

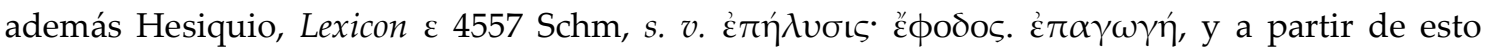
concluye: "non è azzardato supporre che il locus classicus da cui dipende Esichio sia proprio il v. 50 del nuovo Archiloco, dove si dice che la più giovane sorella di Neobule, sotto l'incalzante azione del protagonista, fa vedere 'la fresca pelle, incanto di giovenezza.'"

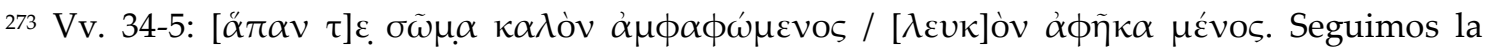
integración de West para inicio del v. $34 \stackrel{\alpha}{\pi} \alpha \nu \tau$ ] $]$. Entre las muchas propuestas para la laguna

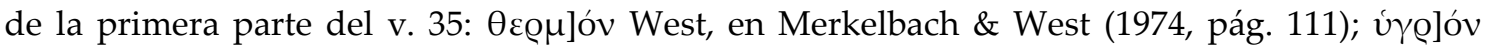

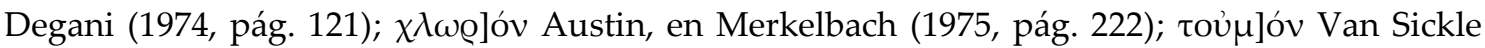

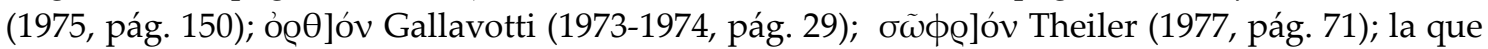
nos parece más apropiada de seguir es $\lambda \varepsilon v \kappa]$ jóv Merkelbach, en Merkelbach \& West (1974, pág.

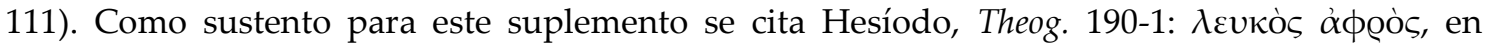

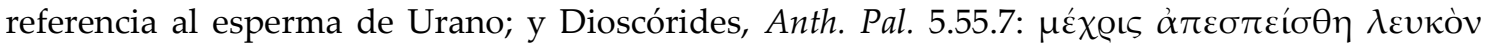

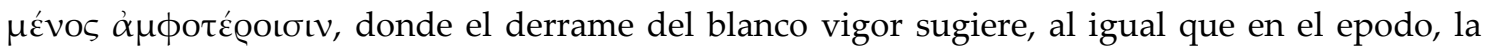
conclusión del coito. Posteriormente, Koenen (1978, pág. 200) confirma la integración de Merkelbach con una referencia a $\lambda \varepsilon v \kappa o ̀ v ~ \sigma \pi \varepsilon ́ \varrho \mu \alpha$ que aparece en una cita tardía: Clemente de

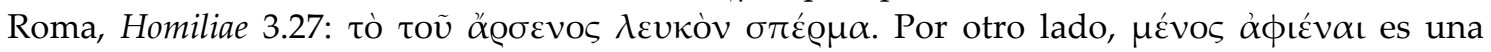
expresión formular de la épica homérica para referirse a la pérdida del vigor vital a causa de

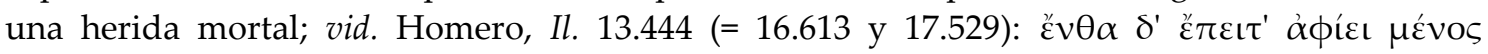

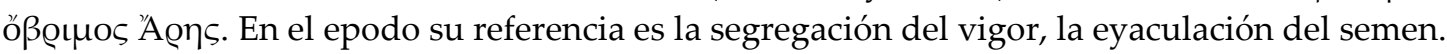


referencia al vello púbico y en una clara alusión al coitus interruptus o coitus ante portas. ${ }^{274}$

\section{FF. 34-37 Y 47W}

Hay una serie de trímetros yámbicos que presentan una estructura narrativa y una temática que también permitiría enmarcarlos dentro del tópico erótico. En primer lugar, los ff. 34-37W que, aunque de tradición indirecta y transmitidos por diferentes fuentes, podrían ser vinculados a la conducta licenciosa de las hijas de Licambes. Se presentan aquí conjeturalmente como un conjunto temático a partir de una hipótesis sugerida por el propio West: ${ }^{275}$

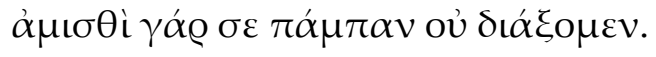

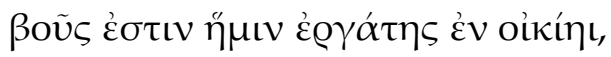

Arquíloco, fr. $34 \mathrm{~W}^{276}$

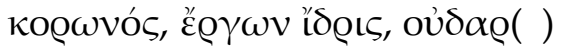

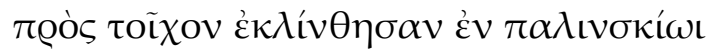

Arquíloco, fr. 35W277

Arquíloco, fr. 36W278

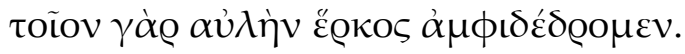

Arquíloco, fr. 37W279

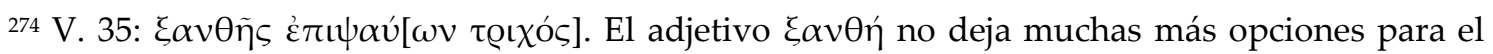
suplemento de final de verso que la referencia al cabello o al vello púbico de la muchacha.

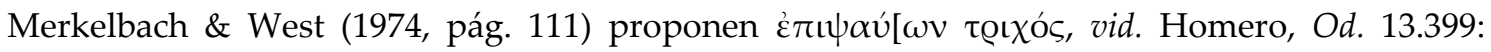

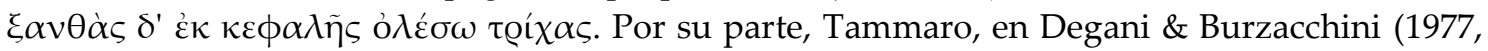

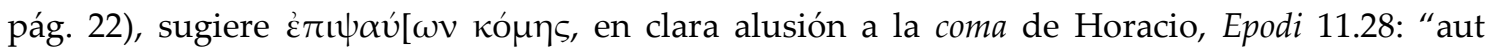
teretis pueri longam renodantis comam."

275 West (1974, pág. 123).

276 Transmitido por Apolonio Díscolo, de adverb. (Gramm. Gr. 2.1.1.161).

277 Transmitido por Et.Gen (p. 35 Calame), Et.Gud (col. 339.30 Sturz), y Et.M 530.28, s. v.

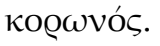

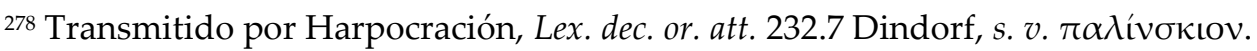

279 Transmitido por Porfirio, Quaest. Hom. ad Od. pág. 134 Schrader (Il. 9.90), que glosa la palabra $\pi \varepsilon \varrho \iota \varepsilon \varepsilon \tilde{v} v$ ("correr alrededor" / "ceñir, rodear"), afirmando que, de acuerdo con Doroteo de Ascalón, una suerte de cercado o tejado ( $\kappa \lambda$ í́øıv) rodeaba la casa de Laertes, y en el centro mismo se ubicaba la vivienda, y que Arquíloco quiere significar excactamente lo mismo en uno

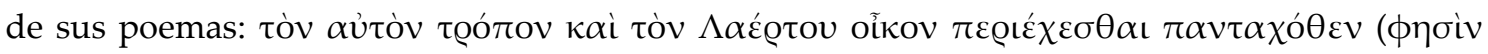

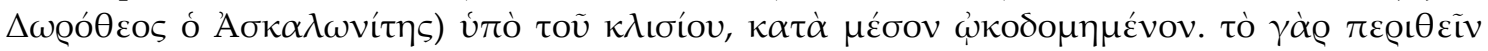

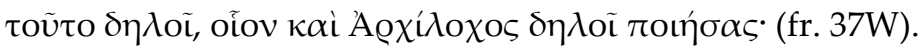


de ningún modo te cruzaremos gratis

(...)

Un buey trabajador tenemos en nuestra casa, orgulloso, conocedor de las labores y no...

(...)

Contra el muro se recostaron, a la sombra

(...)

Tal cerco rodea el patio.

Si la hipótesis de West es correcta, deberíamos considerar que los poemas constituyen una narrativa en la cual el narrador esta contando hechos relacionados con la conducta libidinosa de las hijas de Licambes. En el fr. 34W, estas dos mujeres le habrían demandado al narrador una "tarifa" por

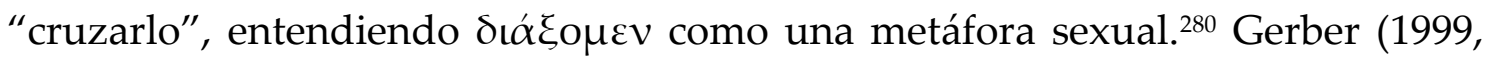

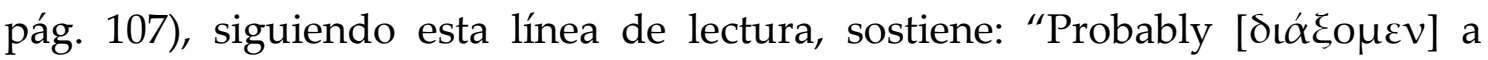
metaphor for sexual intercourse, perhaps placed in the mouths of the daughters of Lycambes." 281

En el fr. 35W, por su parte, podría continuarse el sentido metafórico. El significado de este fragmento podría ser similar al de la conclusión de la fábula 215 (Perry) de Esopo. Allí se cuenta que las perdices y las avispas llegaron un día sedientas hasta donde se hallaba un labrador. A cambio de agua, las primeras le prometieron cavar las vides para que los racimos crecieran más hermosos, y las avispas le ofrecieron mantener alejados a los ladrones con sus aguijones. El labrador les respondió: "Pero si yo ya tengo un par de bueyes que sin prometerme nada lo hacen todo, mejor es que les dé de beber a ellos en vez de a ustedes." ${ }^{\prime 282}$ Probablemente, en el yambo de Arquíloco, la figura del buey refiera a un hombre. Así, en la lectura de una narrativa erótica, las mujeres

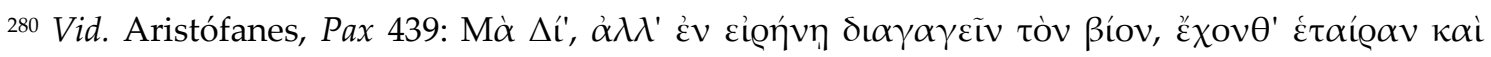

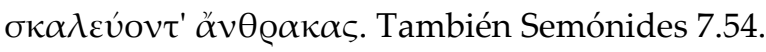

${ }^{281} \mathrm{Vid}$. además el excelente artículo de Gerber (1989, págs. 99-103) sobre este fragmento.

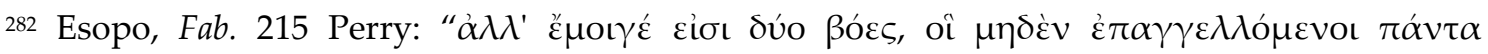

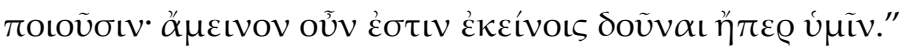


podrían estar diciéndole al narrador que si él quiere tener sexo con ellas deberá pagar, porque ellas ya poseen un hombre altivo y experto en esas labores, por lo que no tendrían necesidad de él. ${ }^{283}$

Los ff. 36-37W podrían situar el recinto de Hera como el escenario donde se produce el encuentro entre el narrador y las jóvenes. Como ya se ha observado en relación al "Epodo de Colonia", 284 un epigrama de Dioscórides (Anth. Pal. 7.351) retrata a las hijas de Licambes hablando desde sus tumbas y jurando que jamás deshonraron la virginidad, ni a sus padres ni a Paros, y que nunca se encontraron con Arquíloco, ni en las calles ni en el gran templo de

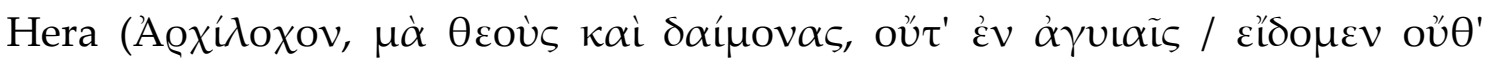

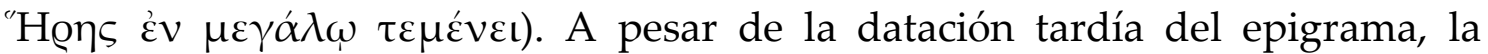
relevancia que se le otorga a los lugares en que supuestamente habrían ocurrido los hechos es muy significativa. Es posible que Dioscórides haya tomado la referencia al templo de Hera de este trímetro yámbico o, tal vez, del “Epodo de Colonia." 285 Ello nos lleva también a considerar que si los fragmentos 36-37W

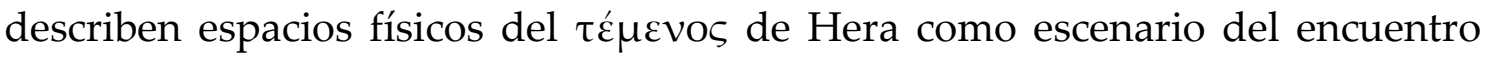
entre el narrador y las hijas de Licambes, entonces deberíamos aceptar que el "cercado" y las "puertas" a las que se hace referencia en el "Epodo de Colonia" no tendrían un significado figurado, como lo pretenden la mayoría de los

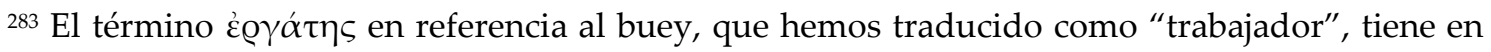
Arquíloco una connotación claramente sexual. Eustacio, in Hom. Il. 23.775, dice que Arquíloco hablaba abusivamente de una "prostituta barata" ( $\chi \alpha \lambda \kappa \iota \delta i \tau \iota \varsigma)$ tratándola de "gorda" ( $\pi \alpha \chi \varepsilon \tilde{\imath} \alpha \nu)$

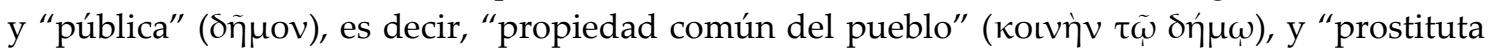

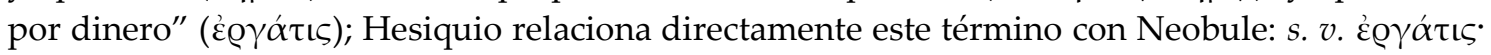

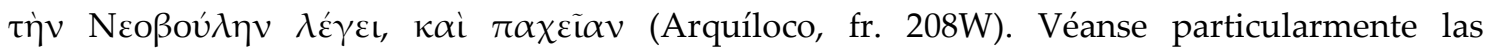
consideraciones de Lehnus (1980, pág. 171) y Bossi (1990, págs. 216-9) sobre este tema.

${ }^{284}$ Vid. sup. pág. 164.

285 Vid. West (1974, pág. 123).
} 
investigadores, sino que precisarían el lugar en que se desarrollaron el o los encuentros. ${ }^{286}$

El fr. 47W, por último, nos presenta una estructura narrativa en la que el narrador relata que unas jóvenes lo expulsan a golpes de palos de las puertas, probablemente, del santuario de Hera:

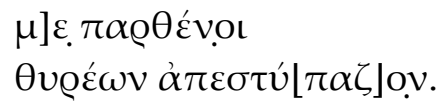

Arquíloco, fr. 47W287

...las muchachas

de las puertas me echaron a palos.

Los versos han llegado a nosotros como ilustración de un comentario del siglo II d. C. sobre el significado de la palabra $\sigma \tau v \pi \alpha ́ \zeta \varepsilon \iota$ en alguno de los poetas cómicos. El comentarista afirma que, de acuerdo con el gramático Amonio,

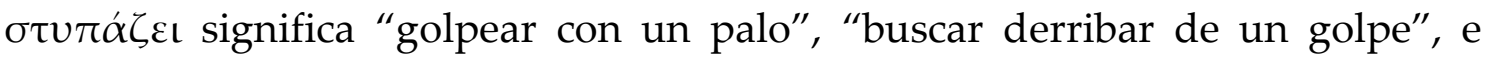
ilustra esta definición recurriendo al compuesto $\alpha \dot{\pi} \pi \sigma \tau v \pi \alpha ́ \zeta \zeta \omega$ que aparece en la

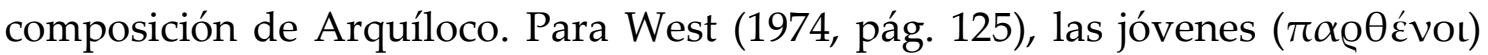

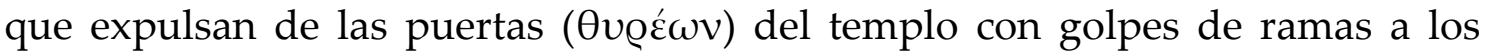
hombres, en este caso particular al narrador, podrían ser sacerdotisas de Hera: "perhaps virgin priestesses of Hera driving the miscreants away from the temple with sticks." Nuevamente, al igual que en las composiciones analizadas

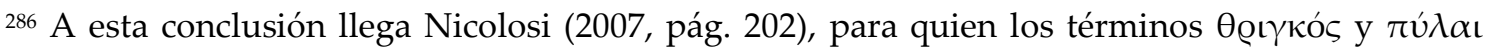
del "Epodo de Colonia refieren "ad un luogo ben preciso, il tempio di Era." Cf. Merkelbach \& West (1974, pág. 106), quienes abogan por el sentido figurado de estos términos: "14 Ө̣ı $\gamma \kappa o ́ \varsigma$ 'Wölbungsbogen' bezieht sich metaphorisch auf den Knochen über der Scham des Mädchens.

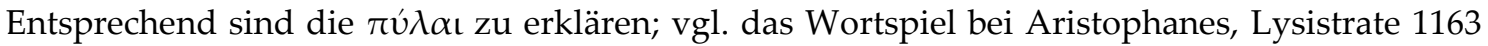
$\tau \dot{\alpha} v$ Пúxov."

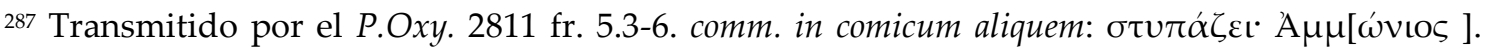

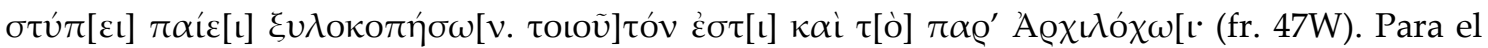
primer verso, sigo la integración $\mu] \varepsilon \pi \alpha \varrho \theta \varepsilon ́ v o r$ Bossi (1990, pág. 140), frente a $\sigma] \varepsilon \pi \alpha \varrho \theta \varepsilon ́ v o \iota$ West (1998, pág. 20), ya que considero, como afirma Bossi, que en este fragmento "si sarà trattato, probabilmente, delle $\Lambda v \kappa \alpha \mu \beta i ́ \delta \varepsilon \varsigma$ (...) Archiloco avrà parlato in prima persona," de manera semejante a lo que sucede con las otras composiciones en que aparecen las hijas de Licambes. 
dentro de este grupo, se vuelve a hacer referencia al $\tau \varepsilon \dot{\mu} \mu \varepsilon v o \varsigma$ de Hera como escenario del encuentro entre el narrador y las jóvenes hijas de Licambes. ${ }^{288}$

\section{CONCLUSIONES PARCIALES}

Las composiciones analizadas en este grupo de yambos presentan una estructura enunciativa de carácter narrativo. En cierta forma, la narración es en sí misma una escenografía de enunciación, ya que se presenta ante el auditorio a un narrador que va a contar los encuentros eróticos que mantuvo con las hijas de Licambes. Podemos esquematizar la estructura enuncivo-enunciativa de estos dos yambos de la siguiente manera:

\footnotetext{
${ }^{288}$ Koenen (1974, pág. 506) considera que el motivo de la violación en cercanías de un santuario podría haberse convertido en un tópico de la comedia griega, se apoya en relatos míticos como la violación de Auge, sacerdotisa de Atenea, por Heracles, en el santuario de la diosa (contada por Eurípides en Auge y parodiada por Menandro en Heros); la violación de Filomela por Tereo durante las dionisíacas (contada por Sófocles en Tereus y parodiada por Aristófanes al comienzo de Aves); la deshonra de Casandra y la profanación de Atenea por Áyax Oileo en el templo de la diosa; y en diferentes cultos durante los períodos preclásico y clásico como los de Deméter, Dioniso, Ártemis o Adonis. A partir de esto, Koenen relaciona el sustrato ritual que podría contener la violación en los mitos con el epodo de Arquíloco y concluye que "ein solches Ritual mag den Hintergrund für die hier berichtete Verführung -wahrscheinlich im heiligen Hain der Hera- gebildet haben." En el mismo sentido, Degani (1977, pág. 38) afirma que los mitos griegos dan testimonio de escenas de seducción, raptos y violaciones en los templos, y que estos se constituían como explicación de ciertas celebraciones rituales. Señala además que los santuarios representaban, en el estrecho mundo de la sociedad griega, "il luogo ideale per molti incontri, amori, rapimenti e seduzioni." Por otro lado, hemos desarrollado la similitud temática y formal de estas composiciones de encuentros eróticos con la escena entre Hera y Zeus en el episodio

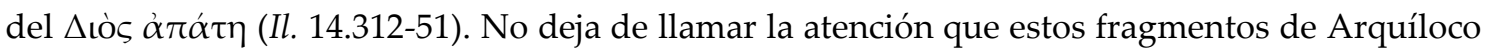
tengan como escenario el propio $\tau \varepsilon ́ \mu \varepsilon v o \varsigma$ de esa diosa, en un encuentro erótico atravesado igualmente por el engaño.
} 


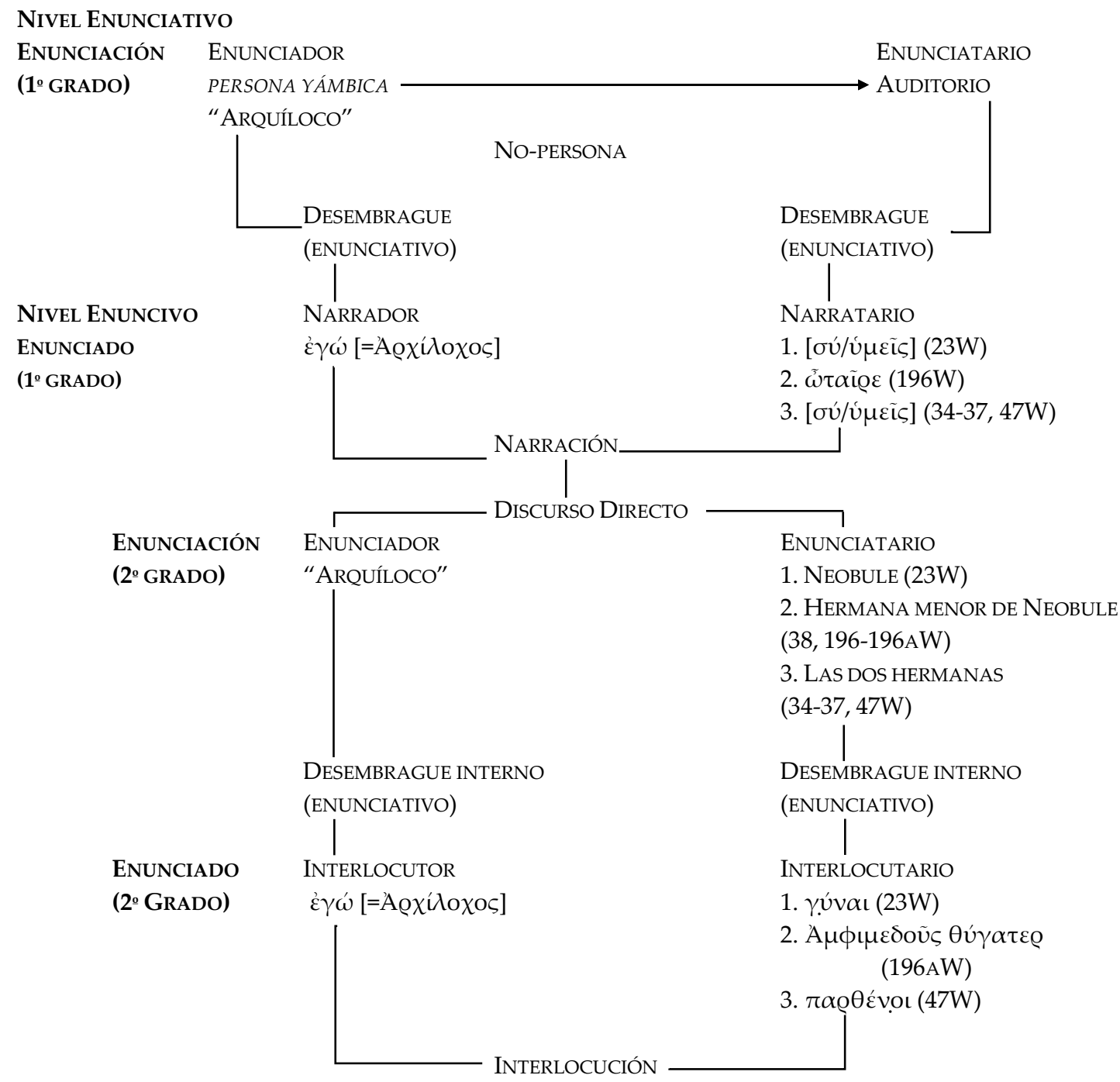

El esquema representa las dos instancias de comunicación en las distintas composiciones. La primera, que aparece indicada como de $1^{\underline{o}}$ grado, muestra los actantes y actores en la instancia de comunicación poética. De este modo, se puede apreciar que el proceso de disyunción desde la enunciación hacia la del enunciado se produce a través de un desembrague enunciativo que instala en el discurso las formas de la enunciación enunciada.

Dentro del nivel enuncivo de $1^{\underline{o}}$ grado, el enunciado adquiere la forma de una escenografía narrativa. La posición actancial de narrador aparece ocupada de manera explícita por un elemento deíctico de primera persona singular, pronominal o verbal, que hemos consignado en forma representativa a través del pronombre $\dot{\varepsilon} \gamma \omega \dot{\omega}$. Como se ha podido apreciar a través del análisis de los 
fragmentos, la identidad de esta primera persona mantiene una relación de concomitancia con la identidad del enunciador, por esta razón el deíctico ẻ $\gamma \omega \dot{\omega}$ se

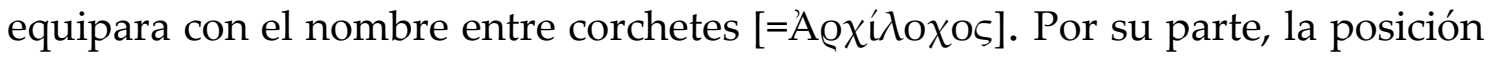
actancial de narratario aparece ocupada de manera explícita únicamente en el

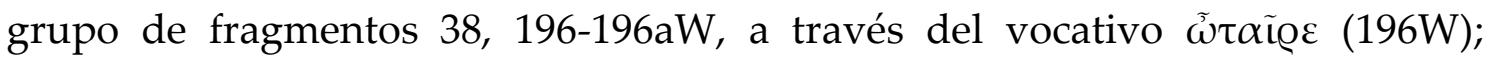
mientras que en los ff. 23W, 34-37W y $47 \mathrm{~W}$ el narratario no se manifiesta deícticamente en el enunciado, aunque puede presuponerse por principio de reciprocidad solidaria con el interlocutor. En tanto la identidad de este narratario es desconocida, se consignan entre corchetes el deíctico de segunda persona singular $\sigma u ́$ y ú $u \varepsilon \tilde{\iota} \varsigma$, ya que esta posición actancial podría estar ocupada por un sujeto singular, como en el caso del fr.196W, o por un sujeto plural en relación de concomitancia con el Auditorio.

En el fr 23W, el narrador se inscribe deícticamente en el enunciado a través del pronombre $\dot{\varepsilon} \gamma \omega \dot{\omega}(\mathrm{v} .7)$ en la función sintáctico-semántica de sujeto agente del verbo $\alpha \mu \varepsilon \iota \beta o ́ \mu \eta v$. Por su parte, el narratario no aparece marcado deícticamente.

En el grupo de fragmentos 38, 196-196aW, el narrador aparece inscripto por medio de la deixis pronominal $\mu \varepsilon(196 \mathrm{~W})$, en la función de complemento

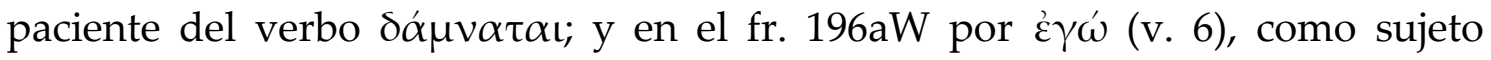
agente del verbo $\alpha \dot{\mu} \varepsilon\llcorner\beta o ́ \mu \eta v, y$ también por las marcas de primera persona

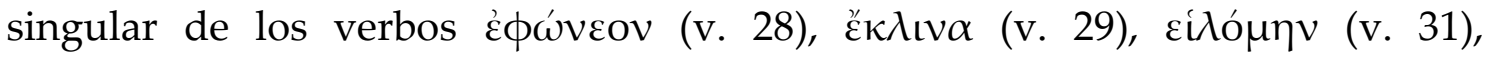

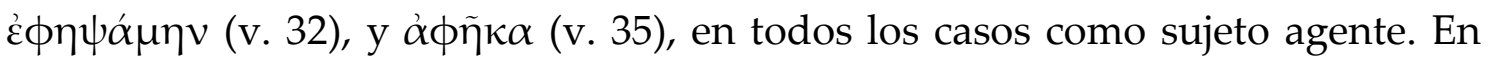
este grupo de fragmentos, el narratario no aparece marcado deícticamente, pero sí, como hemos visto, a través de la apelación en vocativo $\tilde{\omega} \tau \alpha \tilde{\varrho} \varrho \varepsilon(196 \mathrm{~W})$.

Por último, en los ff. $34-37$ y $47 \mathrm{~W}$, el narrador se manifiesta únicamente por medio de la deixis pronominal $\mu \varepsilon$. $(47 \mathrm{~W})$, funcionando como complemento paciente del verbo $\alpha \dot{\tau} \varepsilon \sigma \tau u ́ \pi \alpha \zeta o v$. En tanto que el narratario tampoco se halla deícticamente en el enunciado. 
Dentro de esta instancia de comunicación, la posición actancial de objeto aparace ocupada por la narración del encuentro que el narrador mantuvo con las hijas de Licambes. Si en el encuentro se produce un diálogo, entonces se introduce en la narración un discurso referido en forma directa mediante un verbum dicendi, lo cual inaugura una nueva situación de comunicación, indicada en el esquema como de $2^{\circ}$ grado. Por lo tanto, la introducción de un discurso directo produce una disociación de dos situaciones de enunciación autónomas: la primaria o de $1^{\text {o }}$ grado, situación original de la comunicación del yambo, y la secundaria o de $2^{\underline{o}}$ grado, situación comunicativa que se inaugura dentro del enunciado de $1^{\mathrm{o}}$ grado. Cada una de estas instancias enunciativas tiene su propio marco de enunciación, sus propios actantes, y sus propias referencias espaciales y temporales. ${ }^{289}$

Pero para que estos dos dominios enunciativos coexistan es necesario que se produzca un desembrague interno que permita desacoplar el sistema de referencias de la enunciación de $1^{\mathrm{o}}$ grado, ligado al enunciador primario, y establecer un nuevo sistema de referencias propio de la enunciación de $2^{\underline{o}}$

\footnotetext{
289 Maingueneau (2010, págs. 182-3) señala que mediante el discurso directo se establecen dos situaciones de enunciación con dominios enunciativos autónomos, con sus propias personas, deícticos y marcas de subjetividad: "La caractéristique linguistique essentielle du DD est la dissociation entre les deux situations d'énonciation, citante et citée, qui fait coexister deux domaines énonciatifs autonomes: chacun conserve son JE, son TU, ses repérages déictiques, ses marques de subjectivité propres. (...) Alors que les déictiques du discours citant sont directement interprétables grâce à leur situation d'énonciation, ceux du discours cité ne peuvent l'être qu'à partir des indications fournies par ce discours citant." Los dos dominios enunciativos podrían describirse de la siguiente manera: un enunciador de primer grado $\left(E_{1}\right)$ dirige un enunciado, cuya modalidad discursiva produce un efecto de objetividad, a un enunciatario $\left(\mathrm{e}_{1}\right)$ en una situación de enunciación $\left(\mathrm{S}_{1}\right)$, anclada en el tiempo $\left(\mathrm{T}_{1}\right)$ y el lugar $\left(\mathrm{L}_{1}\right)$ de la instancia enunciativa primaria. Dentro de este enunciado, $\mathrm{E}_{1}$ introduce por medio del discurso directo una situación de enunciación de segundo grado $\left(\mathrm{S}_{2}\right)$, en la que un nuevo enunciador $\left(\mathrm{E}_{2}\right)$ dirige un enunciado a un nuevo enunciatario $\left(\mathrm{e}_{2}\right)$, en el $\mathrm{T}_{2}$ y L $\mathrm{L}_{2}$ propio de la instancia enunciativa secundaria. Esta nueva situación de enunciación se manifiesta bajo una modalidad subjetiva, ya que el discurso presenta las marcas de los actantes de la enunciación que, al estar inscriptos en el enunciado y al tratarse de una estructura de interlocución, analizamos nuevamente bajo los conceptos de interlocutor e interlocutario.
} 
grado. Este desembrague interno es de tipo enunciativo porque vuelve a instalar en el enunciado de $2^{o}$ grado las formas de la enunciación enunciada.

Dentro de la enunciación de $2^{\underline{o}}$ grado, la posición actancial de enunciador vuelve a estar ocupada por "Arquíloco" en todos los fragmentos y la posición de enunciatario es ocupada en el fr. 23W por Neobule, en los ff. 38, 196-196aW por la hermana de Neobule, y en los ff. 34-37, 47W por las dos jóvenes juntas.

En el nivel enuncivo de $2^{\underline{o}}$ grado del fr. $23 \mathrm{~W}$, el interlocutor se inscribe por medio de la deixis pronominal غ̇uoì (v. 10), en la función de complemento experimentador del verbo $\mu \varepsilon \lambda \eta ́ \sigma \varepsilon \mathrm{L}$, y por $\dot{\varepsilon} \gamma \hat{\omega}$ (v. 13), como sujeto afectado del

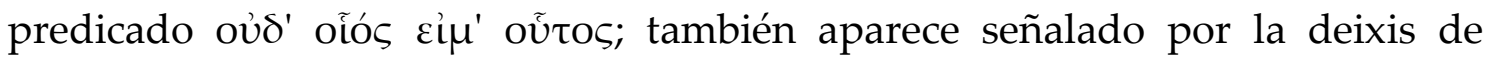

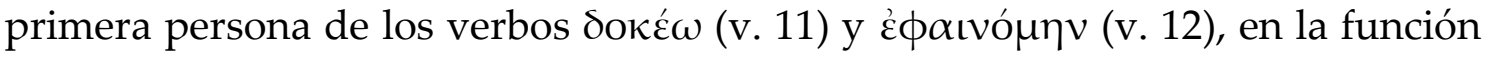

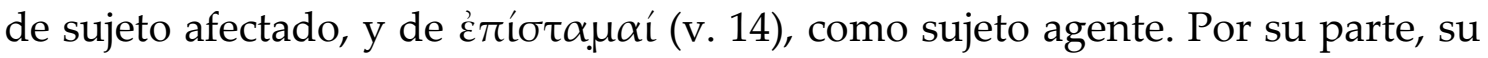
interlocutaria se manifiesta inscripta en el enunciado de $2^{\underline{o}}$ grado a través de la

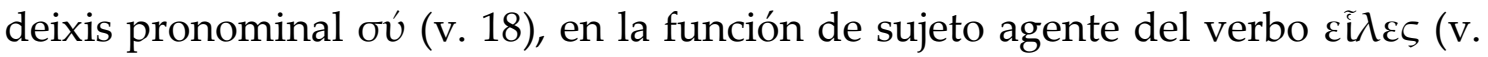

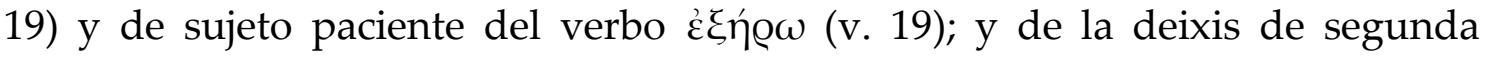

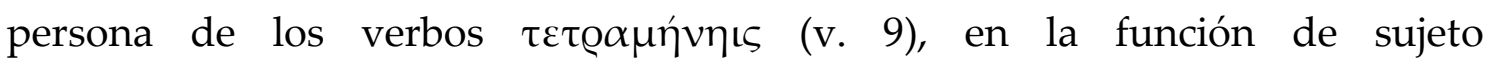

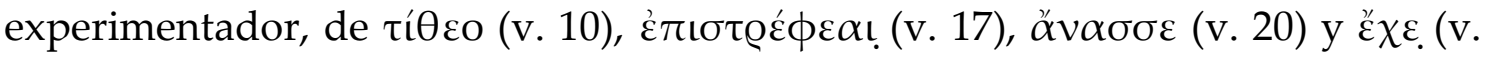

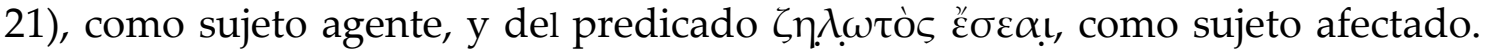
En este fragmento se hace alusión únicamente a la identidad de la interlocutaria por medio del vocativo apelativo $\gamma u ̛ v \alpha ı ~(v .8)$.

En el grupo de fragmentos 38, 196-196aW, el interlocutor se inscribe únicamente en el fr. 196aW a partir de la deixis pronominal $\dot{\varepsilon} \gamma \omega \dot{\omega}$ en dos oportunidades (vv. 12 y 22), en el primero, funcionando junto a $\sigma v ́$ en referencia deíctica al interlocutario como sujeto agente del verbo $\beta o v \lambda \varepsilon v ́ \sigma o \mu \varepsilon v$, en el

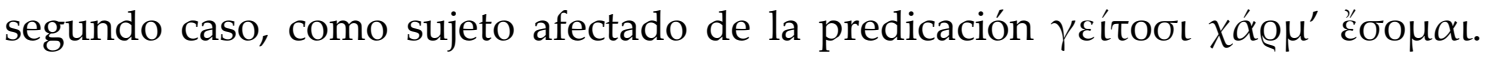
También aparece inscripto deícticamente por el pronombre $\mu \varepsilon$ (v. 13) en dos ocasiones, en la primera como complemento paciente del verbo $\kappa \varepsilon ́ \lambda \varepsilon \alpha \mathrm{l}$, y en la

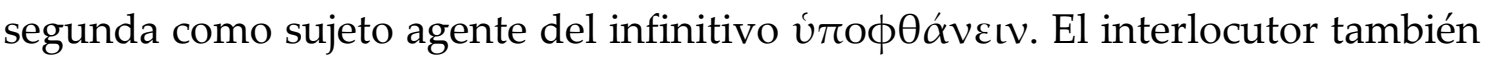


se manifiesta a través de las marcas de primera persona singular de los verbos

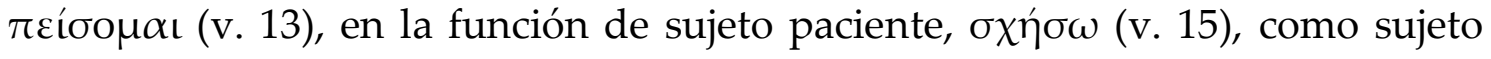

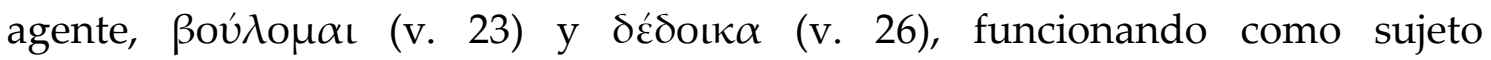
experimentador, y de $\tau \dot{\varepsilon} \kappa \omega$ (v. 27), como sujeto paciente. Por su parte, la interlocutaria aparece inscripta a través de la deixis pronominal oú (vv. 12 y 24), en el primer caso, como hemos visto, funcionando junto con $\dot{\varepsilon} \gamma \omega \dot{~ c o m o ~ s u j e t o ~}$ agente del verbo $\beta o v \lambda \varepsilon v ́ \sigma o \mu \varepsilon v$, y en el segundo, funcionando como sujeto del

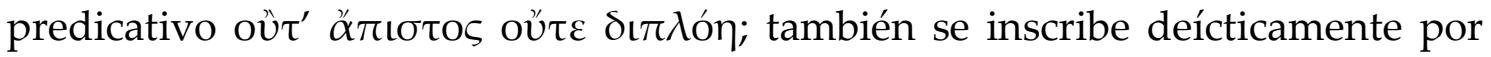
medio del pronombre $\sigma \varepsilon ́$ (v. 23), como complemento paciente del verbo

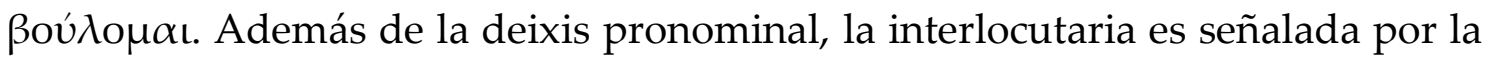

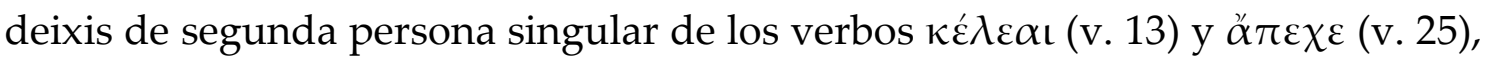

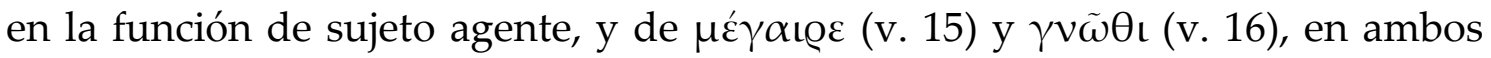
casos como sujeto experimentador. En cuanto a la identidad de los actantes en este grupo de fragmentos, únicamente aparece de manera explícita la interlocutora a través del vocativo apelativo A $\mu \phi \mu \varepsilon \delta о \tilde{v} \varsigma$ $\theta \dot{\gamma} \gamma \alpha \varepsilon Q$ (v. 7).

Finalmente, del último grupo de fragmentos, $34-37$ y $47 \mathrm{~W}$, se ha conservado únicamente la rhesis que las jóvenes le dirigen a "Arquíloco", y por lo tanto son ellas en realidad las que están ocupando la posición actancial de interlocutoras, en tanto que "Arquíloco" se inscribe en el enunciado como interlocutario. De este modo, las interlocutoras se manifiestan deícticamente en el enunciado por medio de las marcas de la primera persona plural del verbo

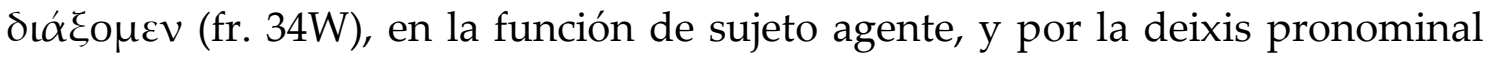
$\eta ̋$ que el interlocutario, "Arquíloco", aparece señalado por la deixis pronominal

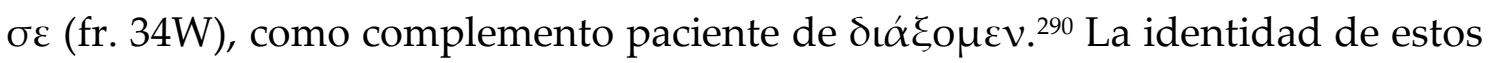

290 De cualquier modo, y observando que las funciones actanciales de interlocutor e interlocutario son intercambiables en toda situación de interlocución, para el análisis nos interesa únicamente las funciones actanciales que refieran a un "yo" considerado como una de las variantes de la persona yámbica "Arquíloco". 
actantes no aparece de manera explícita dentro de la interlocución, pero en la narración, el narrador refiere a estas interlocutoras como $\pi \alpha \varrho \theta \varepsilon ́ v$ oı (fr. 47W).

La escenografía enunciativa que nos presenta el grupo de yambos analizado en este apartado es, por lo tanto, la de un narrador en primera persona que se dirige a su narratario, el cual puede aparecer en segunda persona singular, como en el fr. 196W. De este modo, "Arquíloco", en tanto persona yámbica, asume en la instancia de ejecución poética la voz de un narrador que va a contar a un amigo los acontecimientos de sus encuentros con las hijas de Licambes. Dentro de esta esta narración se introducen, por medio de discursos referidos en forma directa, las conversaciones que este narrador mantuvo con las jóvenes, representadas en el análisis como estructuras interlocutivas.

Por último, es necesario hacer nuevamente una breve referencia a los nombres parlantes. En el fr. 196aW, además de aparecer nuevamente el nombre Neobule, cuya significación ya se ha visto, el interlocutor se dirige a la menor de las hermanas por medio del nombre de su madre, Anfimedo (A $\mu \phi \mu \varepsilon \delta o \tilde{s}$ Өv́ $\gamma \alpha \tau \varepsilon Q)$, "noble y prudente mujer, a quien ahora la húmeda tierra cubre" (vv.

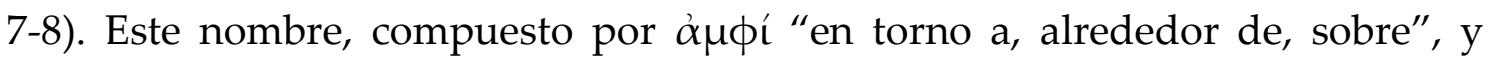
$\mu \varepsilon ́ \delta \omega$ "cuidar, proteger, regir", podría ser también un nomen fictum creado por el poeta con una intención sarcástica: Anfimedo, es decir aquella que "protege del entorno", yace muerta en el momento en que se produce el encuentro; su hija menor está ahora por tanto indefensa. ${ }^{291}$

\subsection{BÉLICOS}

El último grupo a analizar se caracteriza por presentar una escenografía narrativa en la que el narrador se manifiesta deícticamente en primera persona,

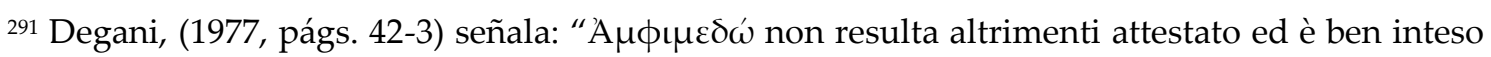
da Koenen 500 como «colei che tutt'intorno si preocupa», epiteto dunque che si addice perfettamente ad una «umsichtige Frau»." 
y por una temática que se vincula con acontecimientos bélicos en los que pudo haber estado involucrado el poeta. Aunque las narrativas bélicas son abundantes en los yambos de Arquíloco, particularmente en los tetrámetros, sin embargo suelen estar en tercera persona; la primera persona únicamente está presente en los ff. 98-99, 146 y 101W:

FF. 98-99W

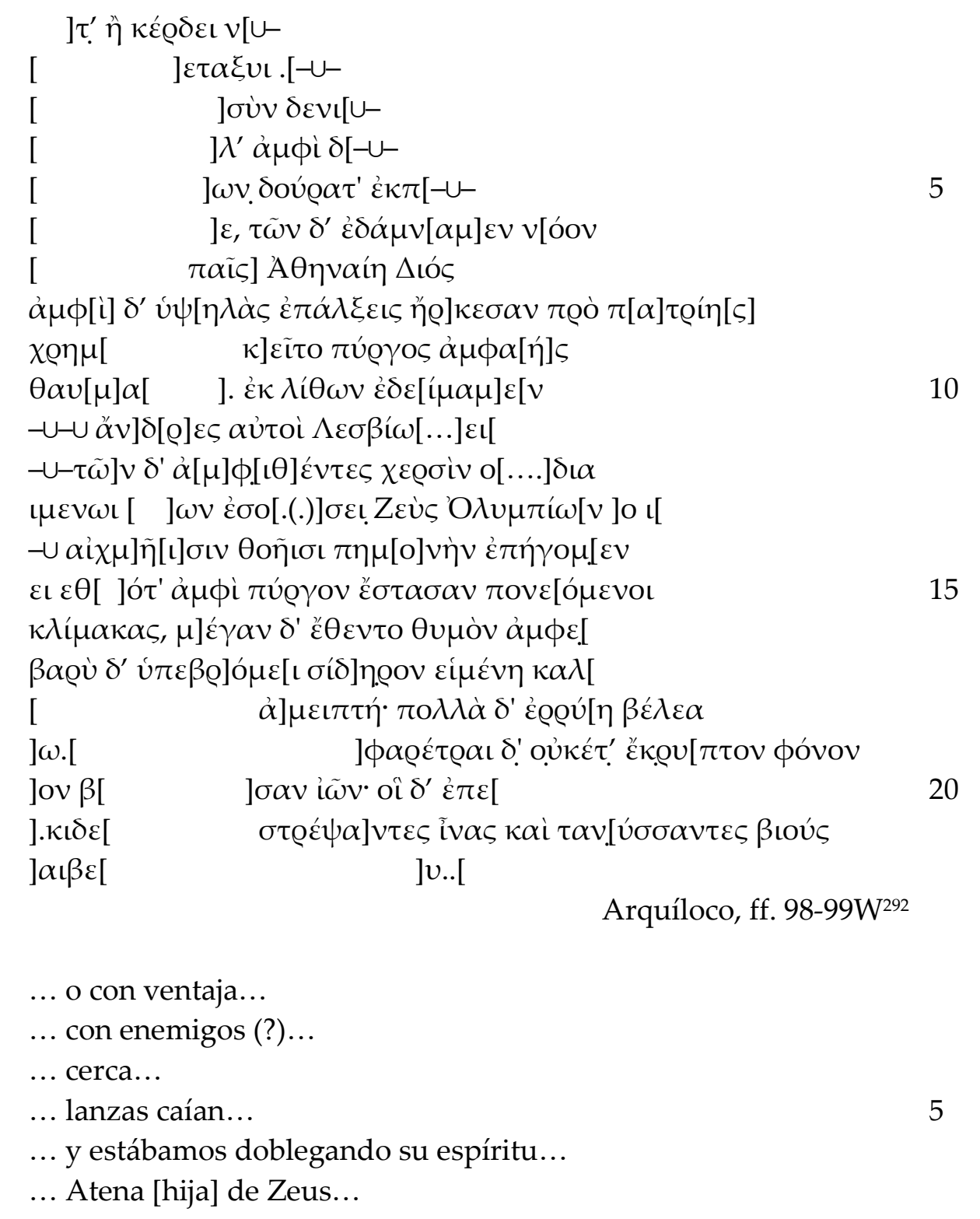

${ }^{292}$ Transmitido por Sosthenis Inscriptio A col. IVa 42-58 (vv. 1-17) y por P.Oxy. 2313 fr. 3a (vv. 1217) y $3 b$ (vv. 18-21). 
y alrededor de altas fortificaciones resistieron en defensa de su patria

... había una torre visible desde todos los lados...

maravilla (?)... de piedras construimos...

... los mismos hombres de Lesbos...

... poniendo en sus manos...

... Zeus, de los Olímpicos...

... con veloces dardos, infligíamos dolor...

... a ambos lados de la torre levantaron con esfuerzo

[escalas], y tomando mucho coraje...

...y rugía, revestida de [pesado] hierro...

...cambiable; (?) y cayeron muchos [proyectiles]

...y las aljabas ya no ocultaban la muerte...

...de las flechas; pero ellos...

...habiendo retorcido las tripas y estirados los arcos...

Esta composición nos enfrenta a una vívida narrativa bélica acerca del asedio a una ciudad amurallada. La escena podría recomponerse del siguiente modo: los tasios y sus aliados los parios estarían defendiéndose de un ataque enemigo dentro de la ciudadela de Tasos. En el v. 5, las "largas lanzas"

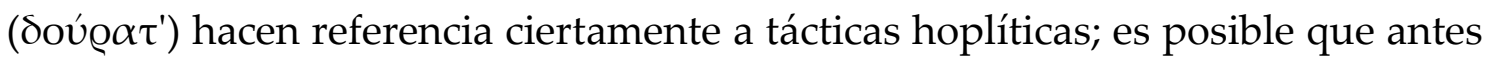
del asedio haya habido un enfrentamiento entre los dos ejércitos (descripto tal vez en la primera parte perdida del yambo). Probablemente en ese primer enfrentamiento, los tasios y los parios habrían sido superados por sus enemigos y obligados entonces a protegerse dentro la ciudad. En cambio desde los muros

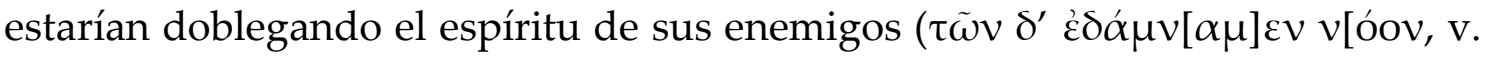
$6)$.

En el v. 8 se produce el cambio de la primera persona a la tercera:

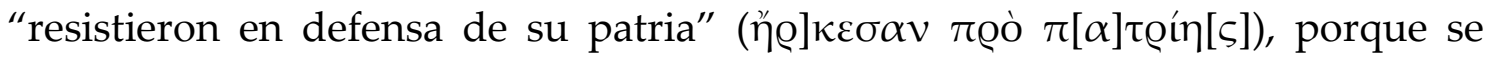
estaría haciendo referencia únicamente a los colonos tasios. El v. 9 alude a una torre de piedra, visible desde todos lados, que probablemente los parios y los

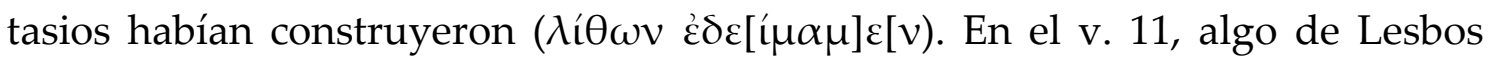
aparece en escena $(\Lambda \varepsilon \sigma \beta i ́ \omega[)$. Se ha propuesto entender la referencia como parte 


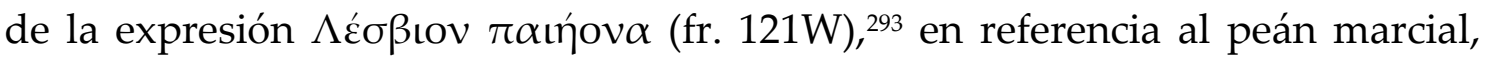
pero un peán sería un tanto prematuro en este contexto. ${ }^{294}$ Podría tratarse de la mención de una táctica característica de los lesbios o de algún tipo de arma que usaran, tal vez las mismas armas que en el verso siguiente "toman en sus manos" (Da Cunha Corrêa, 2009, pág. 245). Alrededor de esta torre, los enemigos levantaron con mucho esfuerzo escaleras para trepar el muro (v. 14), pero la lucha es desigual: los sitiados arrojan lanzas, dardos, proyectiles y flechas sobre sus enemigos causando muchas muertes. Es posible pensar que la táctica hoplítica, concebida para la batalla en campo abierto, con escudos y lanzas de gran tamaño y peso para el enfrentamiento entre falanges, haya resultado ineficaz en el rápido ascenso a las murallas de una ciudad fortificada. $^{295}$

Todo lleva a pensar que el escenario de disputa de este yambo sean los conflictos bélicos entre parios y tracios por la colonización y soberanía de Tasos. ${ }^{296}$

\section{Fr. 146W}

Otro yambo de la misma estructura narrativa y temática bélica en que el narrador se inscribe en primera persona dentro de su relato lo constituye este breve fragmento proveniente también del P.Oxy. 2313:

$$
\begin{aligned}
& \text { [ ] } \sigma \alpha[ \\
& \text { [ ] } \mu \eta[ \\
& \text { [ ] } \mu \phi \alpha[ \\
& \text { [ ] ] } \\
& \text { [ ] } \pi \varrho 0 \sigma \beta \alpha \lambda o ́ v \tau \varepsilon[\varsigma .] \sigma[
\end{aligned}
$$

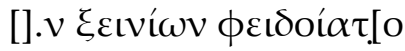

${ }^{293}$ Hiller von Gaertringen (1900, pág. 21).

${ }^{294}$ West (1974, pág. 128) y Slings (1986, pág. 3).

${ }^{295}$ La guerra del Peloponeso puso en evidencia las dificultades de las tácticas hoplíticas en el asedio de ciudades amuralladas; vid. Ober (1991, pág. 180).

296 Cf. págs. 60 y 93. 


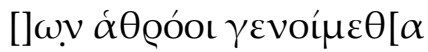

[ ] $\sigma\rceil \varsigma \tau \varepsilon \dot{\chi \varepsilon \varepsilon \sigma \iota v ~ \pi \varepsilon \phi Q[] ~}$

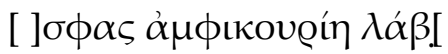

Arquíloco, fr. 146W297

$\cdots$

$\cdots$

$\cdots$

... golpeando contra...

5

... se ahorraban los presentes de hospitalidad

... estábamos reunidos

... con las armas [protegidos (?)]

... sometidos a un cerco (?)...

Aunque demasiado fragmentado como para lograr captar una imagen clara de su sentido, este yambo, al igual que los ff. 98-99W, parece abordar la temática del asedio a una ciudad; muy probablemente se trate nuevamente de los Tasos. En esta oportunidad el narrador también se ubica entre los sitiados.

\section{Fr. 101W}

Finalmente, el último fragmento que nos presenta una narrativa bélica en primera persona ha sido transmitido por Plutarco hacia el s. I d. C.:

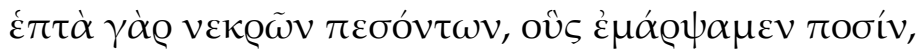

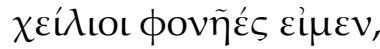

Arquíloco, fr. 101W 298

Siete cadáveres yacen por tierra, de los que atrapamos a la carrera. ¡Mil somos los asesinos!

Plutarco cita los versos de Arquíloco para ilustrar la conducta de aquellos que participaron del multitudinario asesinato del emperador romano Galba y de sus hombres de confianza: Pisón, Vinio y Lacón; pero también, para poner de manifiesto la cobardía y la bajeza de todos aquellos que, sin participar

297 Transmitido por P.Oxy. 2313 fr. 13.

298 Transmitido por Plutarco, Galba 27.9. 
en estos hecho,s manchaban sus manos y espadas con sangre para congraciarse con el nuevo emperador, Otón, y recibir de él una recompensa.

Aunque desvirtuado por el propio contexto de la narrativa de Plutarco, es probable que en el yambo de Arquíloco se esté ironizando sobre el asesinato por la espalda de aquellos que, al huir de la batalla, son alcanzados en la carrera por sus enemigos. El término $\chi \varepsilon$ ćlıı es claramente una hipérbole para enfatizar la superioridad numérica de los que han dado muerte a siete enemigos. Del mismo modo que el fragmeto elegíaco $5 \mathrm{~W}$ pone en cuestionamiento el ideal épico que sanciona el acto de arrojar el escudo como un hecho cobarde e innoble, ${ }^{299}$ en sentido contrario, en este yambo se podría estar cuestionando el heroísmo de matar a los enemigos de esa manera.

\section{CONCLUSIONES PARCIALES}

Las tres últimas composiciones, como se ha podido apreciar, presentan una estructura enunciativa de carácter narrativo sobre acontecimientos bélicos. La escenografía es la de un narrador en primera persona que relata ante su auditorio acontecimientos en los que él tomó parte. Podemos representar la estructura de estos fragmentos de la siguiente manera:

NiVEL ENUNCIATIVO

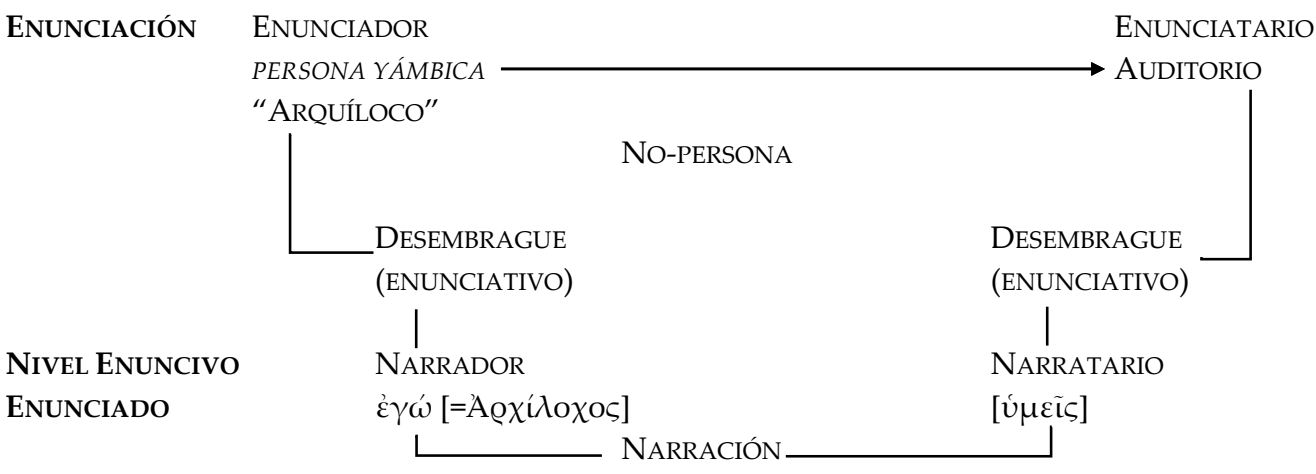

El esquema nos muestra que la disyunción de la instancia de la enunciación a la del enunciado se produce a través de un desembrague de tipo 
enunciativo que instala en el discurso las formas de la enunciación enunciada. El narrador se inscribe deícticamente en los ff. 98-99W por medio de las marcas de primera persona plural de los verbos $\varepsilon \delta \alpha ́ \alpha \nu[\alpha \mu] \varepsilon v(\mathrm{v} .6), \varepsilon \dot{\varepsilon} \delta[\dot{i} \mu \alpha \mu] \varepsilon[v(\mathrm{v}$. 10) y غ̇ंท́㇒ semánticamente como sujeto agente. En el fr. 146W, el narrador se manifiesta por medio de las marcas de primera persona plural del predicado $\alpha$ @oóoı $\gamma \varepsilon v o u ́ \mu \varepsilon \theta[\alpha$ (v. 7), en la función de sujeto afectado. Por último, en el fr. 101W, el narrador aparece deícticamente por medio de las marcas de primera persona

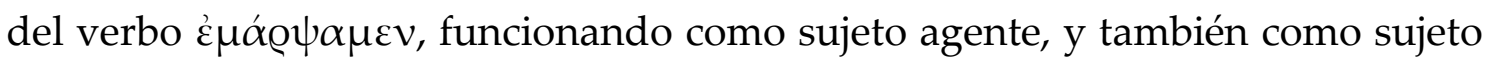

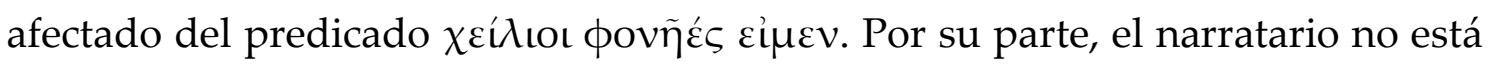
inscripto deícticamente en ninguno de los fragmentos.

La estructura es muy simple desde el punto de vista de la comunicación poética, por lo cual es posible pensar que las identidades del narrador y las del narratario mantienen una relación de concomitancia con las del enunciador y el enunciatario, respectivamente. De este modo, la persona yámbica "Arquíloco" estaría ubicándose en la posición actancial de narrador, en tanto que la de narratario estaría ocupada por el Auditorio en la instancia de ejecución poética, auditorio que como hemos visto estaba constituido por los mismos soldados que podían haber participado de esas mismas acciones militares. De este modo, la persona yámbica en esta ocasión funciona como una máscara narrativa que permite formular en palabras poéticas acontecimientos que todos los miembros de esa comunidad conocían y de los cuales probablemente muchos de ellos habían participado.

Por último, un hecho interesante para señalar es que al menos en dos de esas composiciones (ff. 98-99 y 101W), si bien el narrador participa de los hechos narrados y parece pertenecer al ejército que predomina en la batalla, su relato manifiesta cierto extrañamiento. Este narrador no se jacta del triunfo, sino que su voz toma distancia ante la crudeza de los sucesos. Si esta línea de 
interpretación es correcta, en los ff. 98-99W, el narrador parece enfatizar cómo en una posición estratégica superior ellos, los sitiados, inflingen gran dolor con

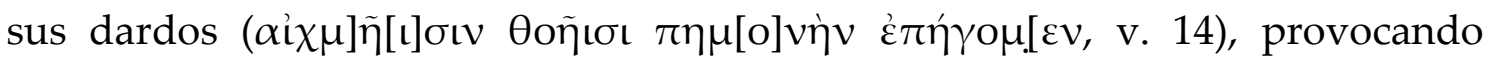
muchas muertes entre los sitiadores que con mucho esfuerzo y coraje intentan

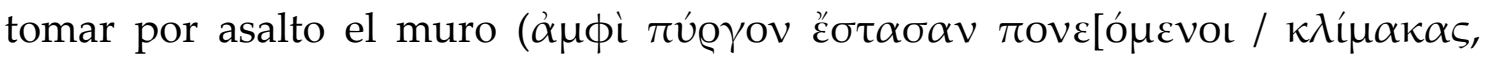

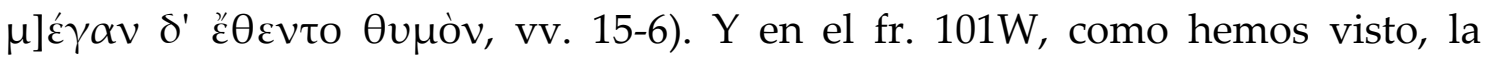
distancia se produce ironizando sobre el supuesto heroísmo de dar muerte a unos pocos enemigos que huyen derrotados de la batalla. ${ }^{300}$

${ }^{300}$ Es posible observar también este distanciamiento en el fr. 102W, donde la voz poética afirma:

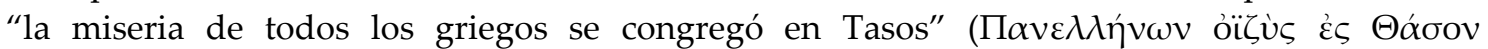
$\sigma v v \varepsilon ́ \delta \varrho \alpha \mu \varepsilon v)$, probablemente en referencia a las calamidades ocasionadas por las guerras en la isla durante ese período, de las cuales participaron mercenarios provenientes de distintas regiones, cf. además fr. 15W. 


\title{
$\underline{3}$ \\ HIPONACTE
}

\author{
EL ENMASCARAMIENTO DEL 'YO' EN EL YAMBO DEL \\ PERÍODO ARCAICO TARDÍO
}

La tradición biográfica conserva pocos detalles sobre la vida de Hiponacte. El Marmor Parium (ep. 42) sitúa la vida del poeta en torno a la caída de Creso y la conquista de Sardes por parte de Ciro, hacia el 546 a. C. Esta fecha es corroborada por Plinio el Viejo, Hist. nat. 36.11, quien postula la existencia de Hiponacte y de los escultores Búpalo y Atenis alrededor de la Olimpíada 60 (540-537 a. C.). A su vez, Proclo, Chrest. 7 (ap. Focio, Bibl. 239), data la madurez del poeta en época de Darío (522-486 a. C.). La Suda ( 588 Adler) transmite que era de Éfeso, hijo de Píteas y Protide, y que debió exiliarse a causa de la tiranía de Atenágoras y Comas, y se radicó en Clazómenas.

A partir de sus poemas y de diferentes testimonios, se sabe que compuso yambos contra dos escultores, Búpalo y Atenis. Plinio establece la cronología de estos artistas con algunos datos que fueron corroborados posteriormente. 
Habrían sido hijos de Arquermo, nietos de Miccíades y biznietos de un célebre escultor de Quíos, llamado Melas. Una estatua que data del 550 a. C. contiene en su base los nombres de Arquermo y Miccíades. Estos datos nos permiten establecer la producción de Hiponacte hacia la segunda mitad de s. VI a. C.

Del mismo modo que sucede con la yambografía de Arquíloco, una de las funciones destacadas de las composiciones del poeta de Éfeso es la invectiva y el retrato denigrante de un conjunto de víctimas que aparecen con nombre propio. Es difícil, sin embargo, determinar si esos nombres refieren a personas reales o si son ficticios. De cualquier manera, las descripciones y los hechos que se narran tienden a representar gráficamente a estos personajes como seres degradados social y moralmente. A raíz de esto, es posible que el objetivo haya

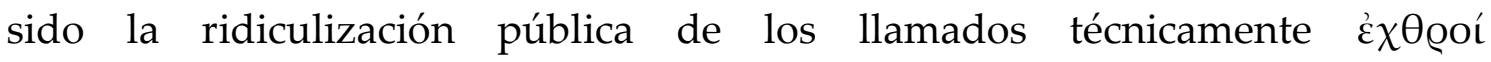
("enemigos") del grupo comunitario y, al mismo tiempo, podría haber obrado su yambo como entretenimiento en el contexto del simposio masculino. Debemos recordar, como hemos visto en la introducción, que la $\alpha i \sigma \chi \varrho o \lambda o \gamma i ́ \alpha$ ritual de la que se desprende tiene igualmente esta doble finalidad.

En Hiponacte, al igual que en Arquíloco, los yambos se caracterizan por la invectiva, el vituperio y la crítica. En última instancia, la finalidad de este

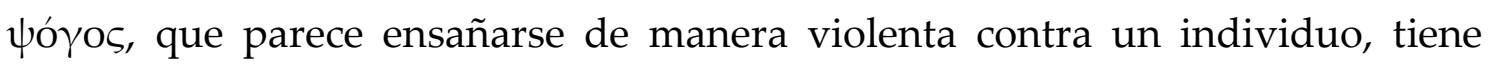
como objetivo estrechar los vínculos entre los miembros que forman parte de la comunidad a la que pertenece el poeta, ya que a través de las invectivas y de las críticas dirgidas contra los $\varepsilon \chi \chi \emptyset$ @oí se pone en evidencia todo aquello que es condenado y despreciado por el grupo de "amigos". ${ }^{1}$

Para el corpus yámbico de Hiponacte hemos seguido el establecimiento de los textos y la numeración de la exhaustiva edición de Degani (1991), en conjunto con la tercera edición de West (1998). Hemos consultado además las

\footnotetext{
${ }^{1}$ Brown (1997, pág. 87): “These social concerns seem to lie close to the cultic roots of ' $\alpha \mu \beta$ os; the poet's invective sought to support the traditional structure of community to which he belonged."
} 
ediciones tradicionales de Schneidewin (1839); Bergk (1882); Masson (1962); Rodríguez Adrados (1990) y Gerber (1999).

\section{ESTRUCTURA INTERLOCUTIVA}

Como hemos señalado en la introducción, hemos procedido con Hiponacte, del mismo modo que con Arquíloco, el dividiendo los yambos a estudiar en dos grandes grupos, de acuerdo con la estructura de comunicación inscripta en el enunciado. Así, en esta primera parte se agrupan los poemas que manifiestan una estructura interlocutiva en la que se evidencien las posiciones actanciales de interlocutor y/o interlocutario. Asimismo, se proponen diferentes escenografías para estudiar el vertimiento actorial en esas posiciones y las relaciones de identidad entre los actantes del nivel enuncivo y del nivel enunciativo.

\subsection{LA MÁSCARA AUTOBIOGRÁFICA}

A diferencia de lo que sucede en Arquíloco (ff. 20, 114, 118-119, 120, 121, 126, 200, 215, 216 y 296W), en el corpus de Hiponacte encontramos únicamente dos casos que podrían ser agrupados bajo la escenografía de una máscara autobiográfica, ff. 120 y 194Dg, es decir un 'yo' inscripto en el enunciado que asume el rol de interlocutor y realiza una declaración de carácter personal ante un interlocutario cuya identidad se asocia con la del auditorio en la instancia de ejecución poética. Sin embargo, es necesario reparar en que la autoría de estas composiciones ha sido muy discutida. La atribución a Hiponacte del fr. 120Dg es objetada por tratarse de una posible contaminación con un yambo de Arquíloco. Por su parte, el fr. 194Dg es un epodo proveniente de un papiro que conserva poemas atribuidos indudablemente a Arquíloco y que presenta además similitudes temáticas y de contenido con los epodos de este poeta. De 
cualquier modo, incluimos aquí el análisis de estos yambos porque, atendiendo a estas discusiones, sin embargo tanto West como Degani los han editado, aun con reservas, en el corpus hiponacteo.

\section{FR. 120DG:}

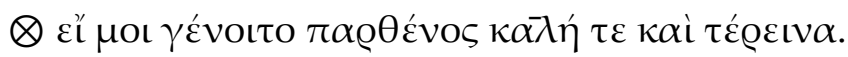

$$
\text { Hiponacte, fr. } 120 \mathrm{Dg}^{2}
$$

¡Ay, si una joven bella y tierna fuera para mí!

Este verso, que Hefestión cita junto al fr. 188.2W de Arquíloco y el 429P de Anacretonte como ejemplos de tetrámetros yámbicos catalécticos (curiosamente el único de su tipo en Hiponacte), probablemente sea algún tipo de contaminación de dos composiciones de Arquíloco que refieren a Neobule:

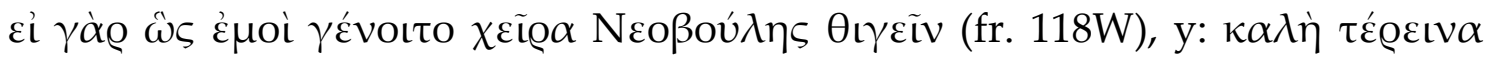
$\pi \alpha \varrho \theta \varepsilon ́ v o \varsigma$ (fr. 196aW). ${ }^{3}$

\section{Fr. 194DG}

$$
\begin{aligned}
& \cdot[ \\
& \eta[ \\
& \pi .[\quad] v[\ldots] . . .[
\end{aligned}
$$

$\kappa v ́ \mu[\alpha \tau \iota] \pi \lambda \alpha[\zeta o ́ \mu] \varepsilon v o \varsigma^{\circ}$

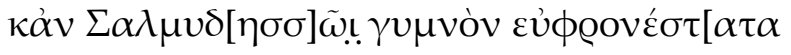

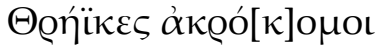

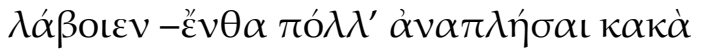

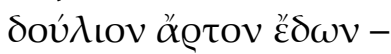

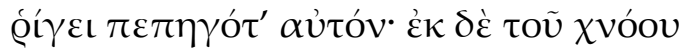

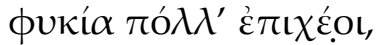

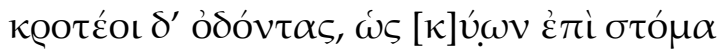

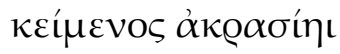

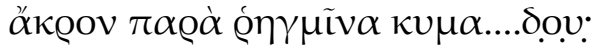

$\tau \alpha \tilde{v} \tau^{\prime} \dot{\varepsilon} \theta \varepsilon \dot{\lambda} \lambda \mu^{\prime} \alpha^{\alpha} v i \delta \varepsilon \tilde{v} v$,

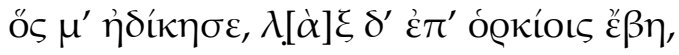

\footnotetext{
${ }^{2}$ Transmitido por Hefestión, Ench. met. 5.3 (pág. 16.16 Consbruch); cf. Schol. Arist. Pl. 253.

${ }^{3}$ Cf. Gerber (1999, pág. 451).
} 


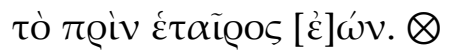

Hiponacte, fr. $194 \mathrm{Dg}^{4}$

... arrastrado por el oleaje

y que en Salmideso, desnudo, muy amablemente

los tracios de pelo recogido en lo alto

lo reciban (allí podrá hartarse de desgracias sin fin,

comiendo pan de esclavo)

duro de frío; y que, al salir de la espuma,

le cuelguen muchas algas

y le castañeen los dientes, mientras yace,

como un perro, sobre su rostro, sin fuerzas,

a la orilla de la playa, olas...

De este modo quisiera verlo,

a él, que me ofendió y pisoteó nuestros juramentos,

cuando antes era mi amigo.

En este yambo, el interlocutor expresa el deseo de que alguien, que

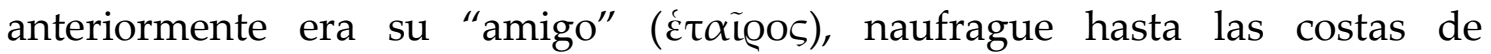
Salmideso, y los tracios lo tomen como esclavo por haber pisoteado unos

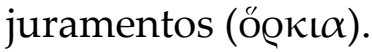

Es notable la similitud de este epodo con algunos de Arquíloco, particularmente por la alusión a los temas de la antigua amistad y la traición de los juramentos, lo cual recuerda a la acusación de perjurio contra Licambes y la falta de lealtad del águila con su amiga, la zorra, en el epodo contra Licambes (ff. 172-181W), ${ }^{5}$ pero también por la referencia a Tracia, tan temida y odiada a causa de los sucesos de las guerras de colonización de Tasos.

Degani (1991, pág. 168) lo ha editado entre los Fragm. Dubia, en razón de las objeciones acerca de su autoría. ${ }^{6}$ Por ello consideramos que, como sucede

\footnotetext{
4 Transmitido por P. Argent. 3a 1-16 Reitzenstein.

${ }^{5}$ Vid. sup. pág. 102.

${ }^{6}$ Los ff. 194-196Dg pertenecen al P. Argent. 3, editado por Reitzenstein en 1899. Más conocido como "Epodos de Estrasburgo", a los fragmentos que aparecen en este papiro se ha dedicado con ahínco la crítica para establecer su autoría. Para un estudio completo del "Epodo de Estrasburgo", véase Nicolosi (2007). Algunos atribuyen las composiciones a Arquíloco debido a ciertas similitudes con los epodos de Horacio, fuertemente influenciado por el poeta de Paros;
} 
con el anterior, no puede ser considerado con certeza como la expresión de un deseo personal por parte del interlocutor en un poema de Hiponacte.

\section{CONCLUSIONES PARCIALES}

Del corpus yámbico de Hiponacte, solamente dos fragmentos con estructura de interlocución podrían ser analizados bajo la escenografía enunciativa de un 'yo' identificado con "Hiponacte" que, inscripto en el enunciado, asume la posición de interlocutor para realizar una declaración de carácter personal (en ambos fragmentos, la expresión de un deseo) ante un interlocutario identificado con el auditorio en la instancia de ejecución poética.

Sin embargo, la autoría de estas dos composiciones epódicas es de alguna manera dudosa, por lo cual, como ya expresamos, no pueden ser considerados como datos confiables de los cuales extraer conclusiones acerca de las manifestaciones personales en los yambos de Hiponacte que pudieran remitir a una lectura autobiográfica.

\subsection{LA MÁSCARA DEL SUPLICANTE}

En cambio, encontramos que dentro de las composiciones que poseen una estructura de interlocución y están adjudicadas sin duda a Hiponacte, al menos siete presentan una escenografía de poesía petitoria y pueden ser consideradas por ello dentro de un mismo grupo: ff. 10, 42, 43, 47, 48, 49, 120 y 208Dg. En estos yambos, un interlocutor en primera persona se dirige a una divinidad para solicitarle ayuda o bienes materiales, o para reclamarle no haber

cf. Fraenkel (1957, págs. 27-36) Kirkwood (1961, págs. 267-82). Otros a Hiponacte, particularmente por la mención de I $\pi \pi \tilde{\omega} v \alpha[\xi$ en 196.4Dg; cf. Perrotta (1938, págs. 3-41) y (1939, págs. 177-88); Masson (1946-1947, págs. 8-27) y (1951, págs. 427-42). Otros, consideran que el fr. 194Dg pertenece a Arquíloco y el 196Dg a Hiponacte; cf. Degani \& Burzacchini (1977, págs. 3342). Por último, hay quienes directamente sostienen que son una imitación helenística de los poetas arcaicos; cf. Coppola (1929, págs. 155-68). Para un recorrido de las diferentes posturas con indicaciones bibliográficas, véase el app. cr. a los fragmentos en Degani (1991, págs. 168-75). 
cumplido con dichos pedidos. En algunos casos, el destinatario de la solicitud o el reproche no es propiamente una divinidad sino un actor desconocido.

Estas composiciones siguen las estructuras formulares de las plegarias, que se caracterizan por poseer: 1) una invocación en vocativo, con los epítetos propios de la deidad a la cual se dirige el suplicante, 2) la hypomnesis, en la que se mencionan las honras o los vínculos que ligan a quien realiza el pedido con esa divinidad en particular y que justifican la petición, y 3) la expresión de la demanda o la súplica. ${ }^{7}$ Un ejemplo paradigmático de este tipo de plegarias se encuentra en el primer canto de Ilíada, donde Crises, luego de invocar a Apolo, le pide que castigue a los dánaos a causa de la deshonra que ha sufrido por parte de Agamenón, al no respetar el acuerdo de los príncipes aqueos y no aceptar el rescate para la liberación de su hija Criseida:

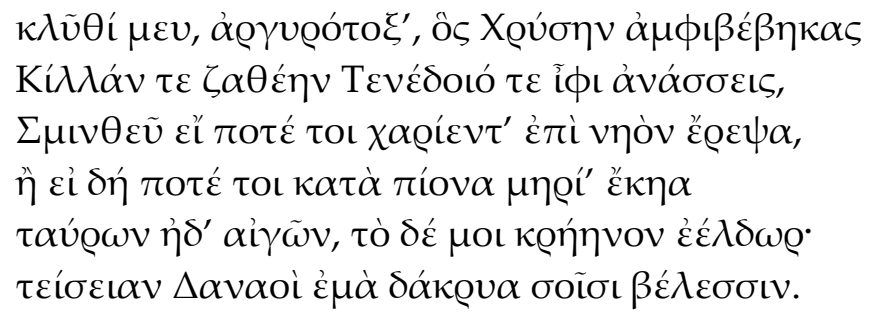

Homero, Ilíada 1.37-42

\begin{abstract}
“¡Óyeme, oh tú, el de argénteo arco, que proteges Crisa y la muy divina Cila, y sobre Ténedos imperas con tu fuerza, oh Esminteo! Si alguna vez he techado tu amable templo o si alguna vez he quemado en tu honor pingües muslos de toros y de cabras, cúmpleme ahora este deseo: que paguen los dánaos mis lágrimas con tus dardos."
\end{abstract}

En los yambos de Hiponacte, la comicidad paródica de estas fórmulas petitorias se revela claramente en el contraste grotesco que se produce entre la invocación grandilocuente que realiza el suplicante y la trivialidad de aquello que le solicita, en la mayoría de los casos bienes materiales y cotidianos, como

\footnotetext{
7 Para la estructura de la poesía petitoria, véase particularmente Race (1992, págs. 13-38).

8 Traducción de Emilio Crespo (2006, pág. 104).
} 
vestimenta, calzado y dinero, o el auxilio por parte del dios ante situaciones un tanto ridículas. El carácter irrisorio del pedido, junto con la discordancia respecto del destinatario divino, ubican al interlocutor en la posición de un mendigo, privado de los bienes básicos para su subsistencia, antes que en la de un digno suplicante al modo tradicional.

Entre las divinidades a las que se dirigen las súplicas, se encuentra Hermes en cuatro ocasiones (ff. 10, 42, 43 y 208Dg), y Zeus (fr. 47Dg) y Atenea (fr. 49Dg), cada uno en una ocasión.

\section{A Hermes}

\section{FR. 42DG}

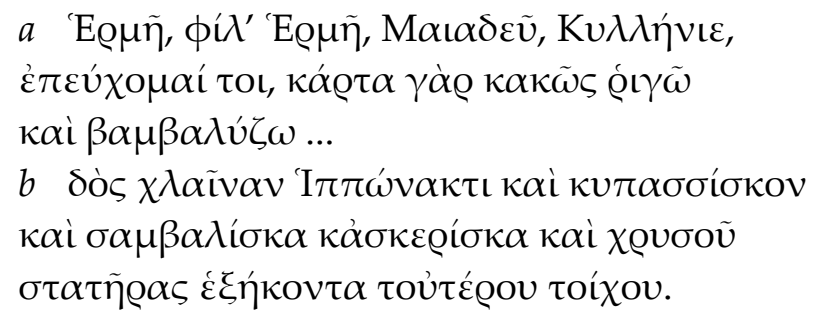

a Hermes, querido Hermes, cachorro de Maya, Cilenio, te suplico, ya que tirito mucho y de mal modo y castañeo los dientes...

$b$ dale un manto a Hiponacte y una capita, sandalitas, zapatillitas y sesenta estateres de oro del otro lado.

Refiriendo los orígenes de la comedia y de la parodia, Polemón de

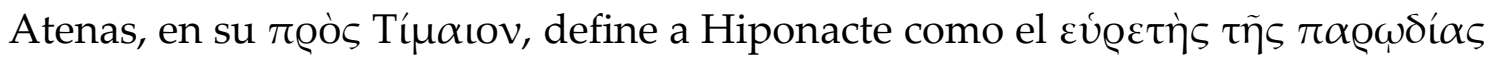
("descubridor de la parodia"). ${ }^{10}$ Polemón remite particularmente a un

\footnotetext{
${ }^{9}$ Transmitido por Tzetzes, ad Lyc. 855 (pág. 277.10 - 278.2 Scheer).

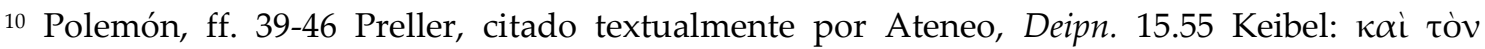

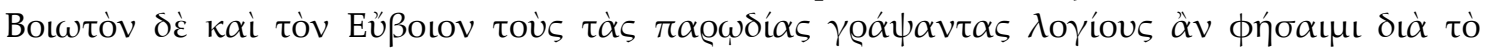

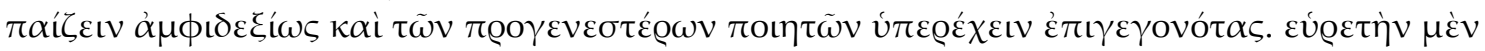

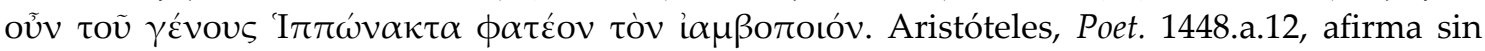
embargo que el fundador de la parodia fue Hegemón de Tasos (s. V. a. C.), pero podría estar
} 
fragmento en hexámetros $(126 \mathrm{Dg})$ en que Hiponacte estaría parodiando la Odisea; ${ }^{11}$ sin embargo, es claro que su consideración puede aplicarse a muchas otras composiciones del poeta yámbico, entre ellas el fragmento "A Hermes" que acabamos de citar.

Precisamente, en este fr. 42Dg, Hiponacte altera cómicamente las estructuras formulares de la poesía petitoria de la plegaria para generar, en principio, un efecto cómico. Por un lado, la invocación en tono elevado dirigida

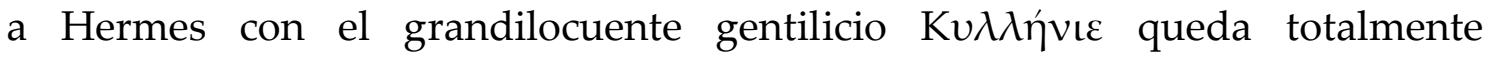
desvirtuada con la introducción del término M $\alpha \_\alpha \delta \varepsilon \tilde{v}$, que, en apariencia, estaría imitando los patronímicos y matronímicos de tradición épica, como el

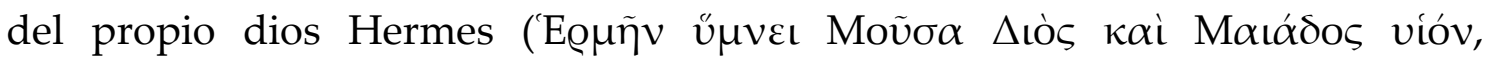

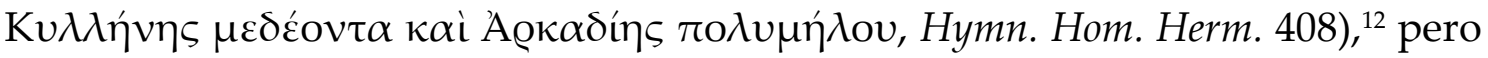

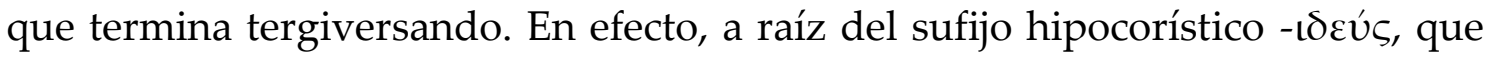
combina a la vez marcas de patronímico y diminutivo, ${ }^{13}$ y es utilizado casi exclusivamente para las crías de los animales, ${ }^{14}$ se genera un efecto cómico: el dios recibe el trato de "pichón" o "cachorro" de Maya.

Por otro lado, aun valiéndose de una expresión formal típica para este

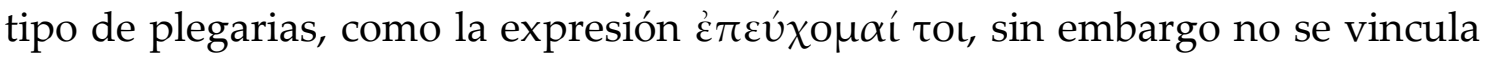
el ruego con ninguna hypomnesis que recuerde algún tipo de honra o vínculo

considerando a Hegemón como el primero en formalizar la parodia en tanto género, que posteriormente disfrutó de sus propios certámenes. A raíz de esto, es posible pensar que los poetas anteriores a esta formalización empleaban la parodia de manera marginal, sin estimarlo un modo poético autónomo. Posiblemente Polemón, conociendo el pasaje de Aristóteles y en respuesta a él, haya postulado deliberadamente el fr. $126 \mathrm{Dg}$ de Hiponacte como inicio de la parodia; cf. Degani (2002, págs. 187-8). Para el fr. 126Dg, vid. inf. pág. 216.

${ }^{11}$ Vid. inf. pág. 216.

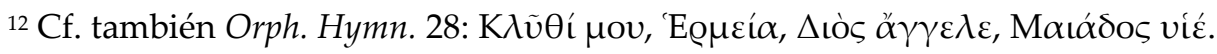

13 Para la combinación de formantes - $-\delta$ - $\varepsilon u ́ \varsigma$, Chantraine (1933, pág. 363): "le sens de dépendence, d'appartenence, et en même temps la valeur diminutive de la finale $t \delta$ - et la

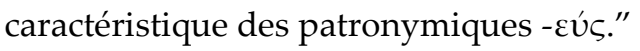

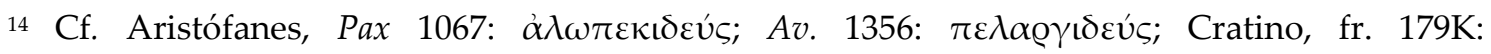

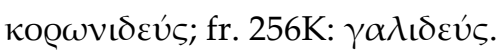


recíproco entre el suplicante y la divinidad, que funcione como captatio benevolentiae para que Hermes le conceda lo que le pide. La única justificación para el reclamo la encontramos en cambio en algo mucho más personal y

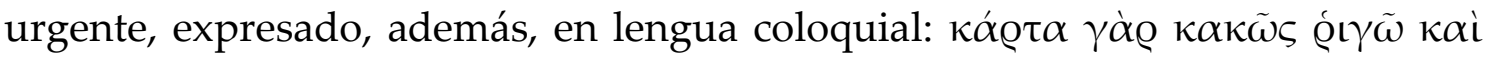
$\beta \alpha \mu \beta \alpha \lambda u ́ \zeta \omega .{ }^{15}$ La petición, por su parte, expresada en el $\delta o ́ \varsigma \mu \mathrm{ol}^{16}$ se vale del empleo de diminutivos, que tienen por finalidad empequeñecer aquello que se

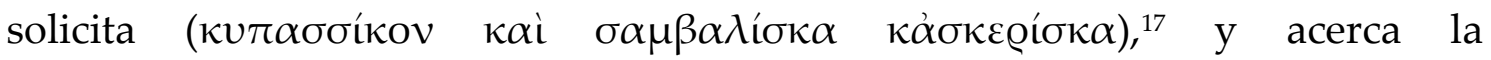
caracterización del suplicante a la de un mendigo antes que a uno al modo

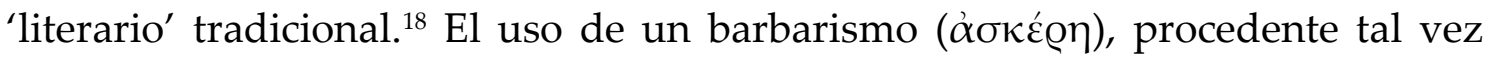
del habla popular lidia, ${ }^{19}$ va en el mismo sentido.

Por último, no pasa inadvertido el contraste entre, por un lado, las vestimentas y el calzado del suplicante, necesarios para paliar el frío, y, por el otro, las sesenta monedas de oro que se le piden a Hermes, lo que también evidentemente tiene un efecto cómico. El final del verso 6 ha recibido disímiles

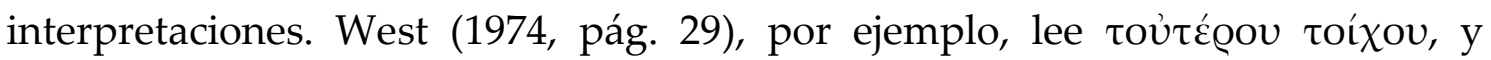
considera que significa: "the 'other wall' of someone else's house". Si esto es así, debería entenderse que el suplicante es un ladrón que le estaría solicitando a Hermes un robo ventajoso de la casa de alguna persona. Se trata de una interpretación atractiva, que añadiría comicidad al reclamo. Sin embargo, Degani (2004, pág. 106) rechaza la hipótesis de West de plano, y señala que en

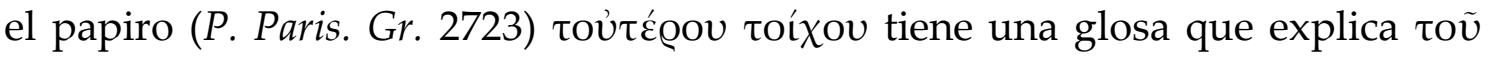

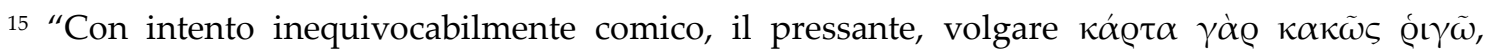
l'ineffabile $\beta \alpha \mu \beta \alpha \lambda \dot{\zeta} \zeta \omega$ (la pittoresca voce onomatopeica che richiama il realistico particolare dei denti che ‘battono'[...]).” Degani (2002, pág. 189).

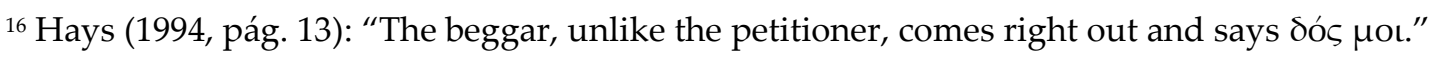

17 Procedimiento popular característico de los pedidos entre familiares o amigos, constatado en cartas privadas, o propio de los "pedigüeños" que aparecen frecuentemente parodiados en la comedia; cf. García Teijeiro (1989, págs. 233-4).

18 García Teijeiro (1983, pág. 277): "Sin duda, Hiponacte imita la manera de hablar de los mendigos profesionales, y consigue así un efecto especial en su parodia."

${ }^{19}$ Cf. Masson (1962, pág. 125). 


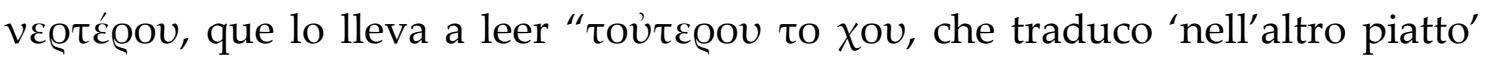
(della bilancia), e non 'dalla tasca di un altro', 'da un'altra casa." De acuerdo con Degani, el suplicante sería un mendigo que estaría pidiéndole al dios que le otorgue sesenta monedas de oro del platillo más cargado, tal vez en alusión a balancear su situación miserable. ${ }^{20}$

De cualquier manera, sea un ladrón o un mendigo, en este fragmento la parodia a la poesía petitoria se construye a partir de una voz fuertemente caracterizada como un actor de las clases más bajas con elementos propios de la picaresca. Este mismo actor se repite, como veremos, en varias composiciones.

\section{Fr. 43DG}

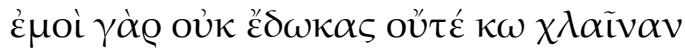

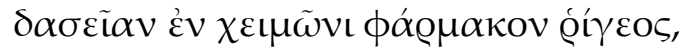

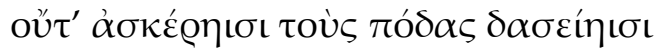

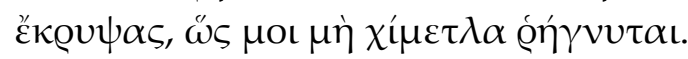

pues no me diste nunca un manto grueso, remedio contra el tiritar del invierno, ni me cubriste los pies con zapatillas abrigadas, para que no se me agrieten los sabañones.

Es indudable que este fragmento también es parte de una parodia a la poesía petitoria, aunque se hayan perdido los versos iniciales, que debían de contener la invocación a la divinidad y, tal vez, los versos finales. Es posible, además, que en este yambo el suplicante se esté dirigiendo nuevamente a Hermes, como se desprende de la coincidencia entre los bienes que se reclaman

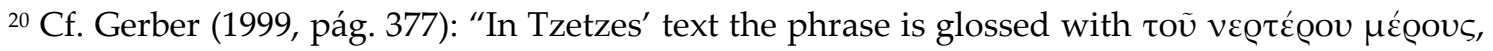
"the lower part" (of the scales?). If this is correct, Hipponax is in effect asking that his accounts be balanced. Or does he hope to dig through to the other side of a wall and steal the objects?"

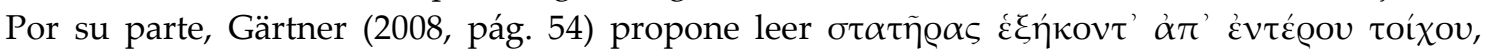
entendiendo que "Der Dichter bittet um sechzig Goldmünzen 'vom Bauch bzw. Eingeweide (Inneren) der Wand."“

${ }^{21}$ Transmitido por Tzetzes, ad Lyc. 855 (pág. 277.10-278.2 Scheer)
} 
en el fr. 42Dg, anteriormente comentado, y los que aquí se le solicitan ( $\chi \lambda \alpha \tilde{\imath} v \alpha$,

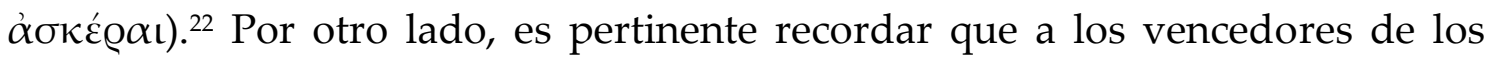
juegos en honor a Hermes en Pelene se les daba como premio precisamente una $\chi \lambda \alpha \tilde{\mathrm{\imath}} \nu \alpha \delta \alpha \sigma \varepsilon \tilde{\varepsilon} \alpha{ }^{23}$

Otra vez estamos ante la presencia de alguien más cercano a la condición de mendigo que a la de digno suplicante: este actor reclama a la divinidad no haberle otorgado bienes materiales útiles para aliviar su acuciante situación. La comicidad surge de su desfachatez y falta de vergüenza ( $\alpha i \delta \omega \varsigma)$, manifiesta al dirigir su reclamo, lo que debía de verse como una característica típica de esta clase de personaje. En $O d$. 17.350, cuando Odiseo llega disfrazado de mendigo a Ítaca, recibe de parte de Telémaco un poco de pan, por intermedio de Eumeo; Telémaco le ordena que se acerque al palacio para que pida entre los pretendientes, ya que "no es bueno que un mendigo muestre vergüenza." 24

\section{FR. 10DG}

En la misma línea temática que las composiciones anteriores existe un yambo del cual se ha conservado una sola línea:

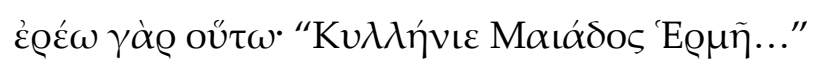

Hiponacte, fr. $10 \operatorname{Dg}^{25}$

...diré así: “¡Cilenio, hijo de Maya, Hermes...!”

Aunque claramente el verso constituye parte de la invocación a la divinidad, la estructura enunciativa de esta composición presenta, en términos

\footnotetext{
${ }^{22}$ Schneidewin (1839, pág. 210) postula la unión de los ff. 42 y 43Dg.

${ }^{23}$ Cf. Degani (1991, pág. 64): "poeta lepide ad "Eo $\mu \alpha \iota \alpha$ adludere, quae Pellenae in urbe Achaiae

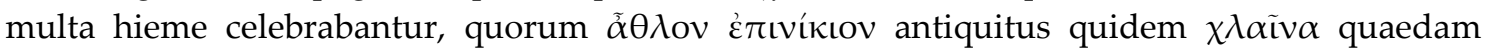
$\pi \alpha \chi \varepsilon \tilde{\alpha} \alpha$ eademque magni pretii fuit (scoll. Pind. Ol. 9,98a-99b et Nem. 10,44 ab al.)"

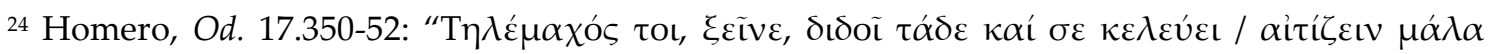

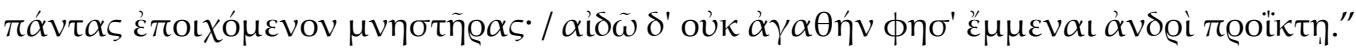

${ }^{25}$ Transmitido por Prisciano, De metr. Ter. 3.426.16-24 Keil, a partir de una cita de Heliodoro.
} 
de los intereses de nuestra investigación, la particularidad de que el enunciado

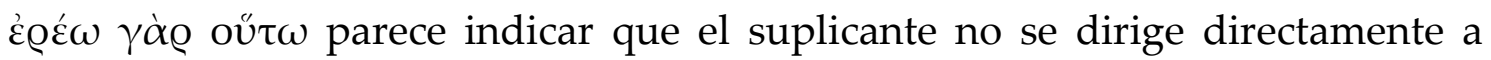
Hermes, como en el fr. 42Dg. Lamentablemente Prisciano, citando a Heliodoro, retoma este único verso de la composición como ejemplificación de las modificaciones que Hiponacte realizaba sobre el coliambo, razón por la cual no se ha conservado el contexto, y ello nos impide saber quién era el interlocutario de estas palabras. El actor que va a realizar la súplica podría estar dirigiéndose a otro actor, a sí mismo por medio de un monólogo interior, al auditorio, o inclusivo al propio Hermes. A diferencia del fragmento anterior, el matronímico del dios aparece en grado cero, sin el diminutivo hipocorístico.

\section{FR.208DG}

Dentro de la estructura de interlocución, el último fragmento de nuestro grupo que está dirigido a Hermes es un yambo del cual se ha conservado el verso que precisamente iniciaba la invocación a la divinidad:

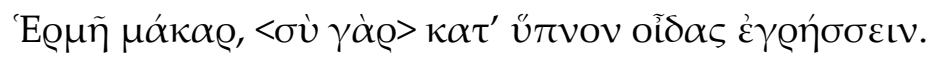

Hiponacte, fr. 208Dg26

¡Bienaventurado Hermes! ¡Tú que sabes despertar al soñoliento...!

Ciertamente Hermes infunde el sueño y despierta a los hombres con su caduceo, ${ }^{27}$ pero aquí la invocación podría también relacionarse específicamente con alguno de los atributos de la divinidad, tal como aparecen en el Hymn. Hom. Herm. 13-15: "de muchos recursos, saqueador, ladrón de vacas, guía de los sueños, espía de la noche, vigilante de las puertas." ${ }^{28}$ Es dable vincularlo, a la

\footnotetext{
${ }^{26}$ Transmitido por Mario Plotio, Ars gramm. 3.4 (6.523.10-17 Keil).

${ }^{27}$ Cf. fr. 79Dg (vid. inf. pág. 263).

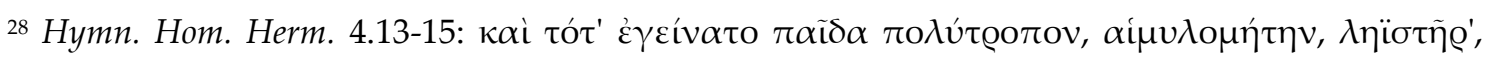

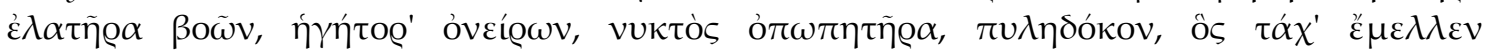

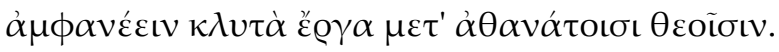


luz de los otros fragmentos, con su función de protector de los ladrones. ${ }^{29}$ A raíz del robo de las vacas, el mismo día de su nacimiento, Apolo lo llamó “jefe de los

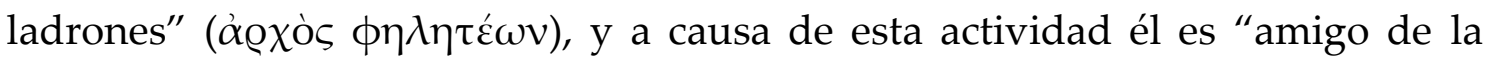

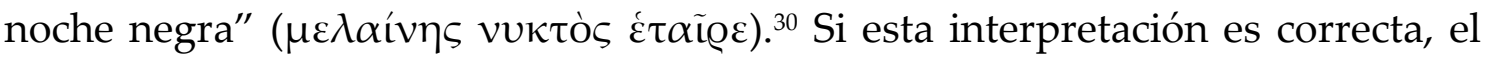
interlocutor en este yambo podría ser un ladrón, y bajo esta investidura también se podrían considerar, según hemos visto, las plegarias dirigidas a Hermes que hemos visto en los yambos anteriores.

Obviamente todas las invocaciones de este tenor no dejan de tener una intencionalidad paródica para lograr un efecto humorístico y suscitar la risa en el auditorio: Hermes sabe despertar al soñoliento no para otra cosa sino para que vaya a robar. A diferencia de Zeus y Atenea, divinidades a las que el suplicante de Hiponacte también dirige sus plegarias, el temperamento y carácter de Hermes, asociado a la figura del trickster, lo convierten en una deidad particularmente acorde a la burla y la ridiculización del género yámbico. ${ }^{31}$

${ }^{29}$ Cf. fr. 2Dg (vid. inf. pág. 246).

${ }^{30}$ Hymn. Hom. Herm. 4.290-94, 67, 578. Véase además Càssola (1994, págs. 153-73).

${ }^{31}$ Kerényi (1956, págs. 173-91) introduce el término trickster en el campo de la mitología griega para analizar algunos aspectos de la personalidad de Hermes y Prometeo. Acerca del primero señala: "The phallus is Trickster's double and alter ego. Hermes too is often represented either by the phallus alone, set up as a 'Kyllenic image', or by the ithyphallic herm, the erect phallus and pillar bearing the god's head. (...) One possibility, then, that characterized the trickster was the fact that he could be represented by the phallus. Like every other trickster, Hermes, too, operates outside the fixed bounds of custom and law. I have described his field of operations as a 'no man's land, a sealed off, Hermetic region between the fixed bounds of property, where finding and thieving are still possible." Brelich (1976, págs. 105-18) analiza la figura del trickster, asociada a Hermes en la comedia aristofánica y la define de la siguiente manera: "oltre che ingannatori -del resto molto spesso a loro volta ingannati- questi personaggi sono sempre frossolani e comici; sotto lo stimolo di un eterna e insaziabile fame e di un appetito sessuale senza limiti, essi passano dall'una all'altra delle loro avventure fantastiche e grottesche, violando continuamente le norme di condotta cui si conforma l'esistenza dei popoli stessi che ne raccontano le storie (...) Proprio ridendo della grossolana comicità di quelle avventure, la comunità primitiva sanziona la superiorità di un'esistenza piegata a norme e a valori riconosciuti, rispetto al caotico mondo delle origini." En relación a Hermes y la figura del trickster en los yambos de Arquíloco e Hiponacte, véase Miralles \& Pòrtulas (1983, págs. 11-50). 


\section{A ZEUS}

Zeus es otra de las divinidades a la que se dirige el interlocutor de Hiponacte:

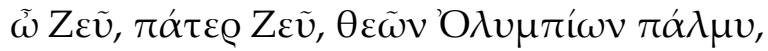

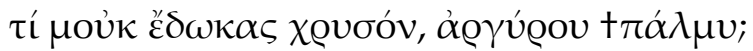

Hiponacte, fr. $47 \mathrm{Dg}^{32}$

¡Zeus, padre Zeus, sultán de los dioses olímpicos! ¿Por qué no me concediste oro, sultán de la plata?

Estos versos coliámbicos parecen constituir una lamentación o un reclamo dirigido a Zeus, antes que una plegaria como en los casos anteriores. Sin embargo, es posible ver que la invocación a la divinidad y el reclamo mismo funcionan como una hypomnesis, pero en sentido inverso, ya que no recuerda vínculos recíprocos pasados sino la ausencia de ellos, y, en ese sentido, permite suponer que en los versos siguientes se produciría también la súplica. La parodia se genera, nuevamente, por la colisión entre la formalidad solemne de la plegaria y la banalidad de aquello que se le reclama a Zeus.

Por otro lado, el término $\pi \alpha ́ \lambda \mu v \varsigma_{,}^{33}$ que tradujimos aquí como "sultán", es una voz lidia que equivale al griego $\beta \alpha \sigma \iota \lambda \varepsilon u ́ s,{ }^{34}$ lo cual podría estar manifestando el carácter extranjero del hablante, tal vez un esclavo que suplica

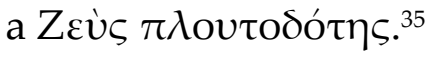

\section{A Atenea}

El fr. 49Dg nos enfrenta a una nueva situación de súplica, dirigida esta vez a la diosa Atenea:

\footnotetext{
32 Transmitido por Tzetzes, ad Lyc. 690 (pág. 227.25-27 Scheer).

${ }^{33} \mathrm{El}$ término $\pi \alpha ́ \alpha \lambda \mu \nu \varsigma$ también aparece en los ff. 1, 7 y 72Dg.

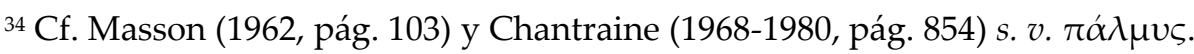

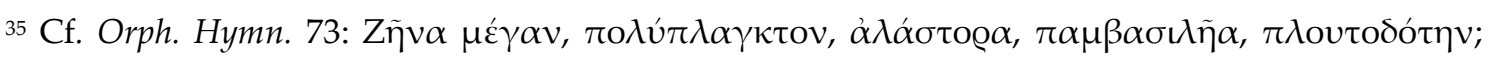

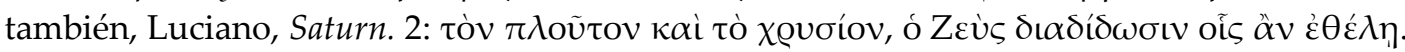




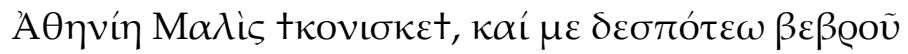

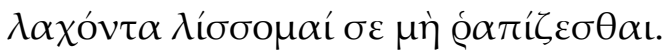

Hiponacte, fr. $49 \mathrm{Dg}^{36}$

jAtenea Málide, ayúdame! Te suplico, ya que me ha tocado un amo idiota, que no me lleve yo los palazos.

El interlocutor en este yambo, al igual que el mendigo y el ladrón, es un actor que pertenece a los estratos sociales más bajos, probablemente sea un esclavo. El suplicante se dirige a la diosa con el epíteto M $\alpha \lambda$ ís, que Hesiquio $(\mu$

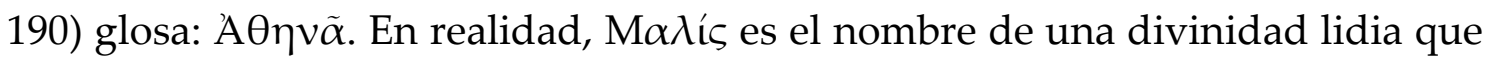
era identificada con Atenea. El adjetivo $\beta \varepsilon \beta$ @ós también es conocido por una

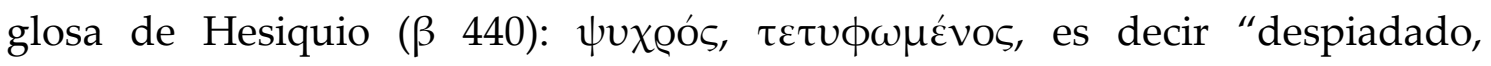
insensible" o "demente." Este término aparece únicamente en estas dos fuentes y es probable que sea una voz jonia o lidia de uso coloquial. ${ }^{37}$

\section{A UN INTERLOCUTARIO NO IDENTIFICADO}

El mismo motivo de lamento y súplica aunados encontramos en el fr. $48 \mathrm{Dg}$, aunque aquí el interlocutario puede no ser necesariamente una divinidad:

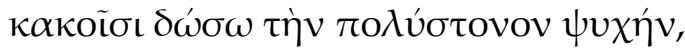

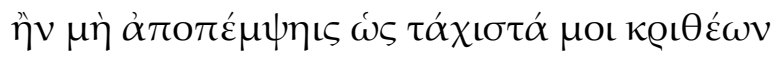

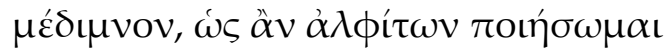

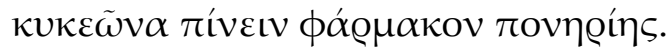

a mal fin entregaré mi penosa alma si no me envías cuanto antes una medida de cebada, para que haga de su harina un brebaje, y beba el remedio contra la miseria.

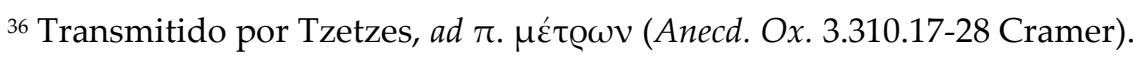

${ }^{37}$ Cf. Degani (2004, pág. 126) y Suárez de la Torre (1987, pág. 122).

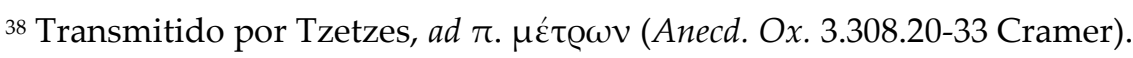


El interlocutor solicita a un actor no identificado en el fragmento conservado una medida de cebada para prepararse el $\kappa v \kappa \varepsilon \omega ́ \omega v$, remedio contra la miseria. Amenaza además con suicidarse si su interlocutario no le da con

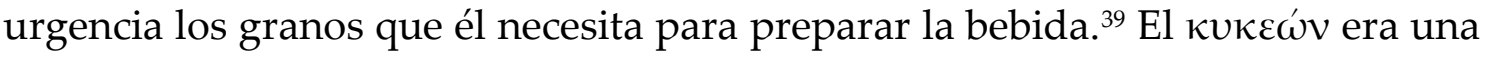
bebida hecha a base de harina de cebada mezclada con un líquido (agua, miel, aceite o vino), el que hacía variar la consistencia y el uso del brebaje. En Il. 11.632-43 aparece como un alimento reconstituyente, a base de cebada, miel, vino y queso. ${ }^{40}$ En $O d .10 .233$, Circe también utiliza esta mezcla, pero le agrega los $\phi \alpha ́ \varrho \mu \alpha \kappa \alpha$ que transformarán a los compañeros de Odiseo en cerdos; recordemos que Odiseo se libra porque lleva un antídoto que precisamente le ha dado el dios Hermes.

Tradicionalmente se ha supuesto que el actor de este yambo, a causa de

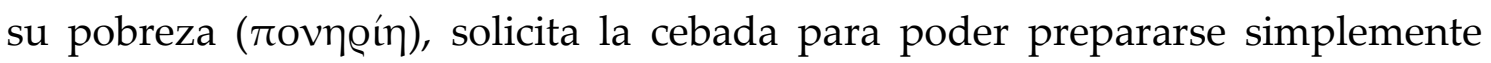
una comida y saciar así su hambre. ${ }^{41}$ Pero, si pensamos que el $\kappa v \kappa \varepsilon \omega ́ v$ también era utilizado en la antigüedad con fines medicinales, el pedido podría estar vinculado más bien con la idea de un $\phi \alpha ́ \varrho \mu \alpha \kappa o v .{ }^{42}$ Como bebida ritual, por ejemplo, el $\kappa \cup \kappa \varepsilon \omega ́ v$ tenía una función prominente en los misterios eleusinos. En el Hymn. Hom. Dem. 198-211, como ya hemos observado en la introducción, ${ }^{43}$ se menciona que, luego de que Yambe lograra reanimar el corazón de Deméter

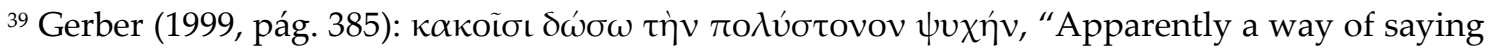
that he will lose all hope and commit suicide."

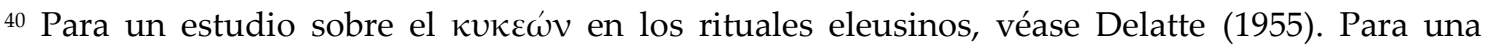
mirada científica sobre la preparación y composición de la bebida, véanse Webster, Perrine \& Ruck (2000).

${ }^{41}$ Cf. Roscher (1888, pág. 523). Como hemos visto, en el fr. 43Dg el interlocutor reclama a Hermes no haberle concedido nunca un manto grueso como remedio contra el tiritar provocado

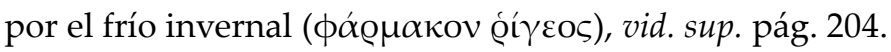

${ }^{42}$ Como bebida terapéutica aparece en reiteradas ocasiones en el Corpus hippocraticum, variando su composición de acuerdo a la enfermedad que se pretende tratar. Notablemente, en Aristófanes, Pax 712, Hermes le recomienda a Trigeo que beba $\kappa v \kappa \varepsilon \omega ́ v v$ para prevenir algún daño al acostarse con Opora.

${ }^{43} \mathrm{Vid}$. sup. pág. 5.
} 
incitándola a reír, la diosa pone fin al duelo y al ayuno que se había impuesto por el rapto de su hija Perséfone. Ella rechaza, sin embargo, una copa de vino que le ofrece Metanira, porque no le era lícito beber alcohol, y pide a cambio que le preparen una mezcla de agua, harina de cebada y poleo, es decir, un $\kappa \cup \kappa \varepsilon \omega ́ v .{ }^{44}$ Luego de que se lo trajeran así preparado, la augusta Deo inauguró el rito. ${ }^{45}$ La escena del Himno Homérico contiene la etiología de tres elementos centrales en los ritos eleusinos: el ayuno y el duelo, la $\alpha$ í $\chi \varrho o \lambda o \gamma$ í $\alpha$ y la bebida

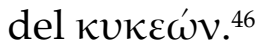

Probablemente el papel de Yambe en la interrupción del duelo de Deméter constituya también una suerte de $\alpha$ ľ̃ıov de la poesía yámbica. El nombre de la sirvienta del rey Celeo y las bromas y burlas $(\chi \lambda \varepsilon \dot{n} \eta[. ..] \pi 0 \lambda \lambda \dot{\alpha}$ $\pi \alpha \varrho \alpha \sigma \kappa \omega ́ \pi \tau o v \sigma \alpha$, Hymn. Hom. Dem. vv. 202-3) con las que ella hace reír a la diosa, aun disfrazada de anciana, parecen tener una conexión con la función cómica de la poesía yámbica. En esta función catártica de movilizar a la risa, el ritual eleusino comparte con la poesía yámbica elementos como la

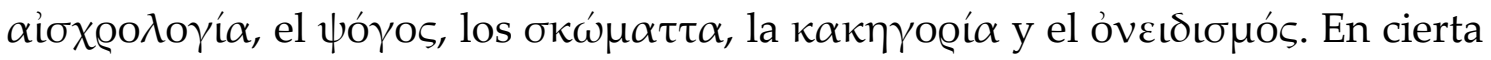
forma, a través de la legitimación de las $\chi \lambda \varepsilon \tilde{v} \alpha \iota$ de Yambe, la divinidad también

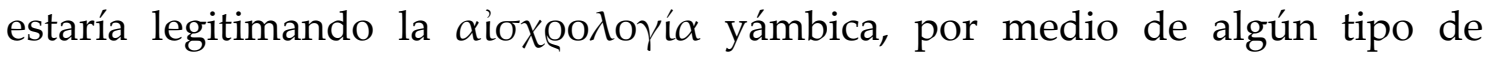
sanción religiosa.

A partir de lo narrado en el mito de Yambe, Rosen (1987) considera que la mención del $\kappa \cup \kappa \varepsilon \omega ́ v$ en el fr. 48Dg de Hiponacte podría estar refiriendo, de

${ }^{44}$ Por esta razón el $\kappa v \kappa \varepsilon \omega ́ v$ en el ritual eleusino se prepara sin alcohol.

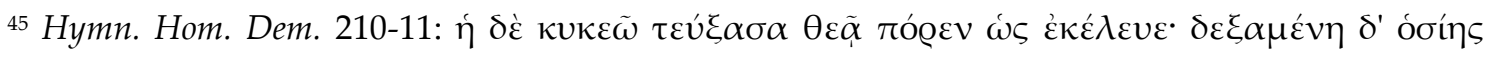

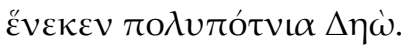

${ }^{46}$ Richardson (1974, págs. 22-3, 211-17) documenta la aparición de estos elementos en el ritual eleusino; véase también Foley (1993, págs. 45-8). La procesión a Eleusis incluía el insulto y la

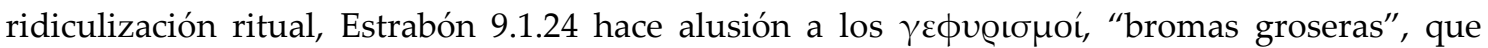
hacían hombres y mujeres enmascarados desde el puente sobre el río Cefiso a los iniciados en el

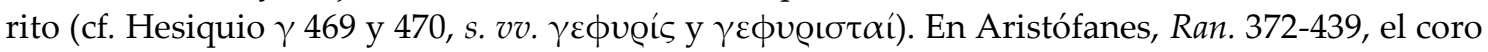

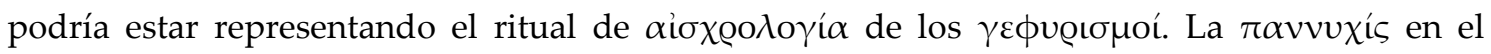

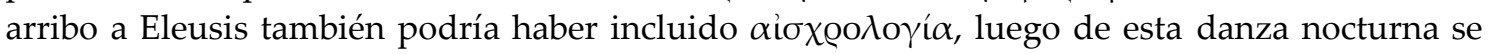

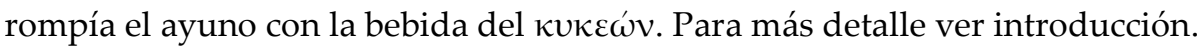


manera polisémica, no solamente al brebaje en tanto comida sino también como bebida ritual eleusina. ${ }^{47}$ De acuerdo con su argumentación, al igual que Deméter sufre la rovๆ@í $\alpha$ de manera doble, por la pérdida de su hija y por las burlas que momentáneamente le está dirigiendo Yambe, en la composición de Hiponacte se podría estar haciendo alusión no solamente a los sufrimientos a causa de la situación apremiante de la persona loquens, sino también a raíz de las invectivas que recibe de sus enemigos ( $\dot{\chi} \chi \theta$ @oí), de tal modo que desea preparar rápidamente el $\kappa v \kappa \varepsilon \omega ́ \omega v$ para saciar su hambre, es decir, finalizar con el ayuno, pero también para terminar con la malevolencia de los enemigos.

Es altamente probable que en este fragmento se estén poniendo en juego diversos niveles connotativos en relación al término $\kappa v \kappa \varepsilon \omega ́ \omega v$ (como alimento y como bebida ritual) que deben tenerse en cuenta para una interpretación del yambo y de su vinculación con el culto eleusino. ${ }^{48}$ Esos diferentes niveles de significación pondrían de manifiesto la relación intrínseca entre la invectiva ritual y la saciedad del hambre, aspectos destacados de los rituales asociados con Deméter.

\section{CONCLUSIONES PARCIALES}

Desde el punto de vista discursivo, en las composiciones analizadas es posible observar una escenografía enunciativa similar, que podríamos esquematizar de la siguiente manera:

\footnotetext{
${ }^{47}$ Rosen (1987, pág. 420): "If, then, he is actually reenacting on one level Demeter-Iambe scene of

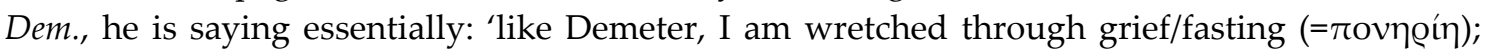

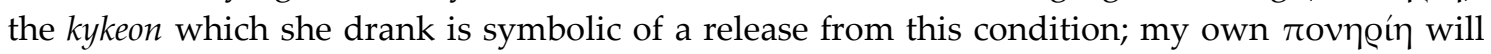
be relieved by participation in this symbolic act.'"
}

${ }^{48}$ Cf. Degani \& Burzacchini (1977, págs. 61-3). 


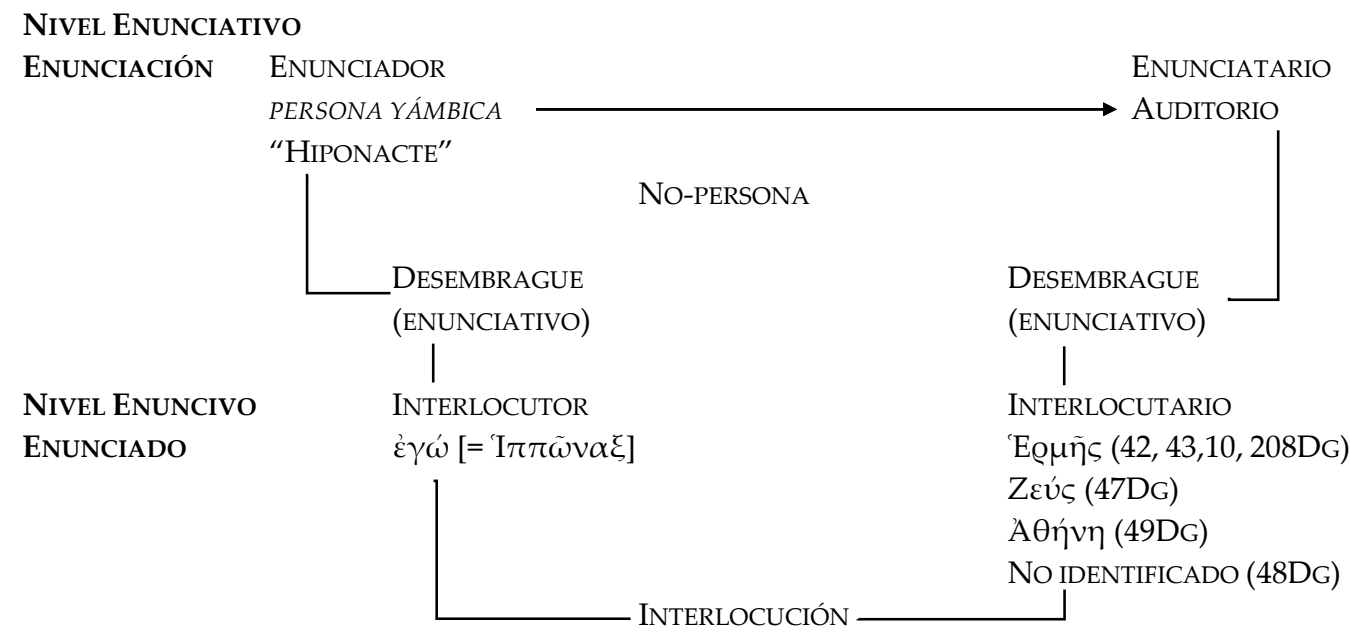

En el esquema propuesto se puede observar que el proceso de disyunción desde la instancia de enunciación hacia la del enunciado se produce a partir de un desembrague de tipo enunciativo que instaura en el discurso las formas de la enunciación enunciada. El interlocutor y el interlocutario se inscriben a través de la deixis pronominal y verbal de la siguiente manera:

Fr. 42. Interlocutor: por medio de la deixis de primera persona de los verbos

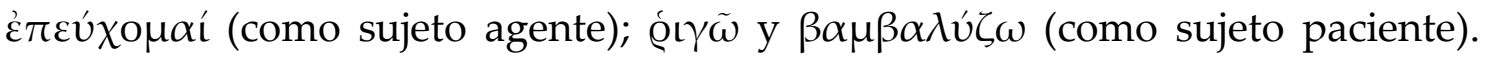
Interlocutario: por medio del pronombre toı en la función de complemento

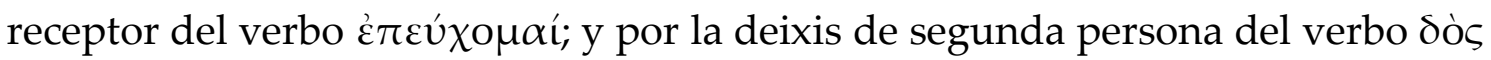
(como sujeto agente).

Fr. 43. Interlocutor: por medio del pronombre غ̇uoì (como complemento

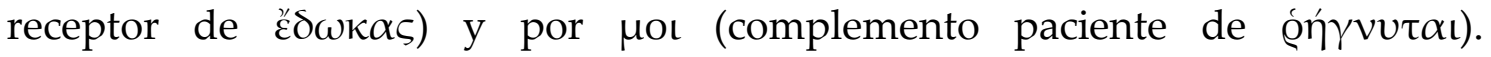

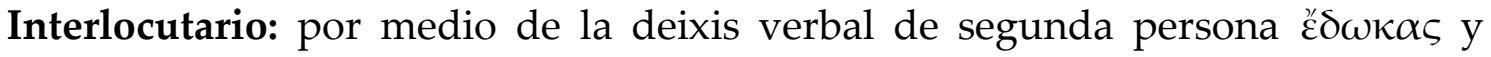

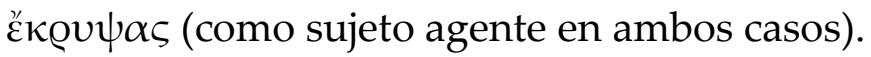

Fr. 10. Interlocutor: a través de $\dot{\varrho} \varrho \varepsilon ́ \omega$ (como sujeto agente). Interlocutario: no aparece señalado deícticamente, pero se presupone en reciprocidad solidaria con el interlocutor.

Fr. 208. Interlocutor: no aparece señalado deícticamente. Interlocutario: a través de la deixis de segunda persona del verbo oĩ $\delta \varsigma$, y probablemente también a través de su sujeto sintáctico $<\sigma u ̀>$ en la función semántica de agente.

Fr. 47. Interlocutor: a través de la deixis pronominal $\mu(\mathrm{ol})$, en la función

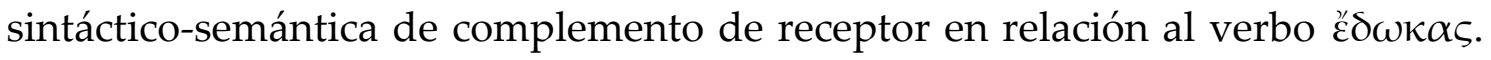


Interlocutario: por medio de las marcas de segunda persona singular del verbo $\varepsilon \Leftarrow \delta \omega \kappa \alpha$, en la función de sujeto agente.

Fr. 49. Interlocutor: a través de la deixis pronominal $\mu \varepsilon$, en la función sintáctico-

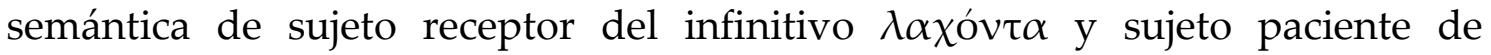

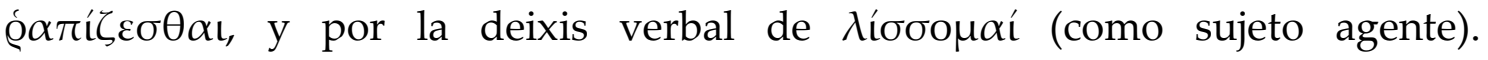
Interlocutario: a través del pronombre $\sigma \varepsilon$ (como complemento paciente de

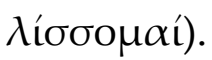

Fr. 48. Interlocutor: por los verbos $\delta \omega \sigma \omega$ y $\pi$ oıฑ́ $\sigma \omega \mu \alpha \iota$ (como sujeto agente), y por el pronombre $\mu \mathrm{ol}$ (como complemento receptor de $\dot{\alpha} \pi \mathrm{\sigma} \pi \dot{\varepsilon} \mu \psi \eta \iota \varsigma$ ). Interlocutario: a través de la deixis de segunda persona del verbo $\alpha \dot{\pi} \pi \dot{\varepsilon} \mu \psi \eta \iota \varsigma$ (como sujeto agente).

La identidad de este interlocutor, tematizado como el suplicante que dirige la plegaria a la divinidad, es recuperable a través de la aparición del nombre propio I $\pi \pi \omega \dot{v} \alpha \kappa \tau \iota$ en el fr. $42.4 \mathrm{Dg}$ que funciona como complemento beneficiario -dativus commodi- del verbo dòs. Esta forma particular de sphragís, ${ }^{49}$ implica un desdoblamiento del sujeto de la enunciación, ya que este no solo aparece inscripto en primera persona ocupando la posición actancial de interlocutor, sino que también aparece en tercera persona a través del nombre propio ocupando la posición de beneficiario. De este modo, retóricamente, por medio de una enálage de persona el interlocutor-suplicante busca deliberadamente disociarse del beneficiario. En este caso, la enálage permite que una posición sintáctico-semántica como la de beneficiario, que debería estar ocupada por una categoría gramatical en primera persona refiriendo

\footnotetext{
${ }^{49}$ La introducción del nombre propio en la poesía oral de la Grecia arcaica es un procedimiento poético analizado bajo el concepto de sphragis ("sello o firma"). Cf. Hesíodo, Theog. 22; Theognidea v. 22; Alcmán, ff. 17, 39 y 95b; Adesp. mel. 953 Page; Safo, ff. 1, 20 y 94 Voigt. Para la sphragis y sus distintas funciones desde el período arcaico hasta época helenística, véanse Kranz (1961, págs. 1-46); Adrados (1976, pág. 132); Calame (1995, págs. 48-50).
} 
deícticamente al enunciador, sufra un desplazamiento y pase a estar ocupada por un nombre propio, es decir, por una categoría de tercera persona. ${ }^{50}$

Por su parte, la identidad del interlocutario, como es propio de estas estructuras formulares, aparece explícitamente indicada en el enunciado

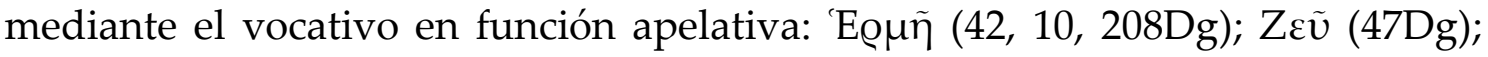

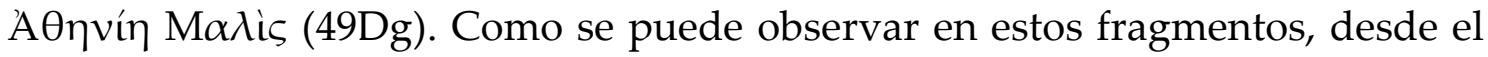
punto de vista del destinatario, la identidad del interlocutario mantiene una relación de no-concomitancia con la del enunciatario. Estamos por lo tanto frente a un destinatario desdoblado: en el nivel enuncivo la identidad del interlocutario refiere a la divinidad, mientras que en el nivel enunciativo la identidad del enunciatario es el auditorio. ${ }^{51}$ Al tratarse particularmente de una divinidad, las marcas de segunda persona deben ser consideradas deixis am Phantasma. ${ }^{52}$

Por último, la repetición de determinadas estructuras enunciativas en el corpus de Hiponacte y la disposición y caracterización de la primera y segunda personas que aparecen en el enunciado, permiten postular un vertimiento actorial más o menos estereotipado en determinadas posiciones actanciales. En este caso en particular, por ser una parodia de la poesía petitoria o postulatoria, el caso más evidente es el de la divinidad en la posición actancial de

50 Kerbrat-Orecchioni (1997, págs. 81-6) define la enálage como un fenómeno retórico que consiste en emplear en el discurso las categorías de persona, tiempo y espacio con un valor sintáctico o gramatical desplazado respecto de su valor en el plano de la lengua. Esta autora señala que las enálages más frecuente son las de número, por ejemplo, el uso del "nosotros" mayestático o el de modestia en lugar del "yo"; y la de persona, el empleo de la tercera en lugar de la primera: "«él»= «yo» (en la boca o en la pluma de César, de Cicerón, etc.) empleos que reflejan diversos mecanismos de idenificación/distanciamiento. (...) A pesar de ese «él» bajo el cual César disimula su status de escritor, todos los lectores $-\mathrm{y}$ son entonces las informaciones extralingüísticas las que permiten la identificación de este truco discursivo cuya «extraordinaria fuerza política» ha mostrado bien Butor- saben bien de quién se trata."

${ }^{51}$ Vid. sup. pág. 38 ss. y pág. 46 n. 91.

52 Para el concepto de "deixis am Phantasma" frente a "deixis ad Oculos" y "anaphoric or textual deixis", véase Bühler (1990, págs. 136-46). Para el desarrollo de estos conceptos en relación particularmente con la lírica griega arcaica, véase Felson (2004, págs. 253-63). 
interlocutario, aquel a quien se dirige la súplica. Del mismo modo, la posición de interlocutor, caracterizada semánticamente por ser la del suplicante, parece en cada ocasión estar ocupada por un mismo actor, la persona yámbica "Hiponacte".

Por último, nos parece interesante señalar que las características enunciativas de la plegaria a los dioses, con sus artilugios discursivos, las enálages, el uso de diminutivos y registros lingüísticos populares, fueron importantes en la recepción que los yambos de Hiponacte tuvieron en el período helenístico, ya que poseían el tono adecuado para solicitar a los Ptolomeos bienes de poco valor..$^{53}$

\subsection{LA MÁSCARA DEL AEDO HOMÉRICO}

Dentro de las composiciones que presentan estructuras de interlocución, consideraremos el fr. $126 \mathrm{Dg}$ de manera diferenciada. Aunque aquí el interlocutario es también una divinidad, este yambo presenta sin embargo una escenografía particular: la misma invocación a las Musas con que se inicia la épica homérica. Lo que se parodia en este caso ya no es el carácter del interlocutor como suplicante, como en los ejemplos anteriores, sino como aedo homérico:

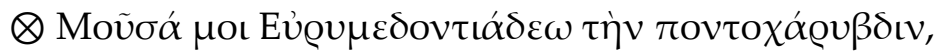

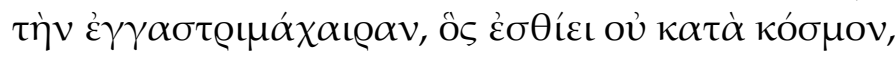

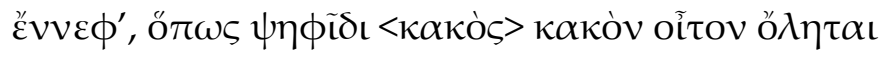

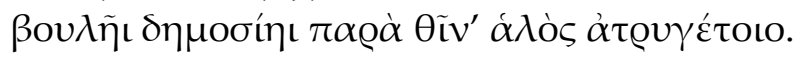

Hiponacte, fr. $126 \mathrm{Dg}^{54}$

¡Musa! Cuéntame acerca del Eurimedontiada, la Caribdis tragamares, la panza-con-cuchillos, que devora ordinariamente, dime el modo en que con (funesto) voto final funesto sufrirá, por decisión popular a la orilla del mar estéril.

\footnotetext{
${ }^{53}$ Para este tema, véase Hays (1994, págs. 11-26).

${ }^{54}$ Transmitido por Ateneo, Deipn. 15.698b.
} 
Manifiestamente, a través del empleo del hexámetro dactílico, este yambo imita el inicio de los poemas homéricos y parodia el uso de epítetos compuestos, patronímicos, y, fundamentalmente, la voz y la estructura enunciativa del aedo en su invocación a la Musa para que cuente una historia acerca de los héroes épicos. ${ }^{55}$

En efecto, el interlocutor se dirige a la Musa para que cante sobre

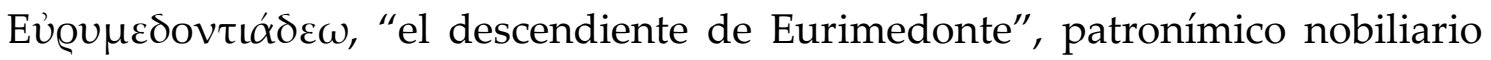
con timbre épico y reminiscencias míticas, que podría traducirse literalmente como "aquél que gobierna ampliamente o a lo lejos." Es muy difícil determinar cuál es el significado implicado aquí, pero la mención del mar en los versos finales del fragmento podría indicar que el nombre remite, tal vez de manera cómica, a la esfera de Posidón. ${ }^{56}$

Los epítetos claramente emulan los compuestos homéricos:

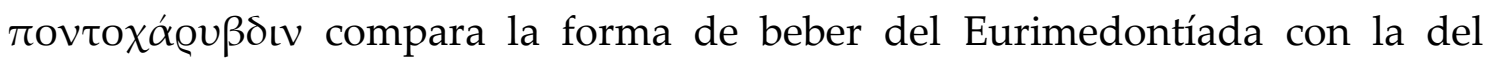
famoso remolino que engulle grandes cantidades de agua por día (Od. 12.104:

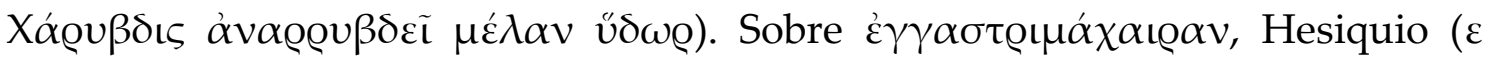

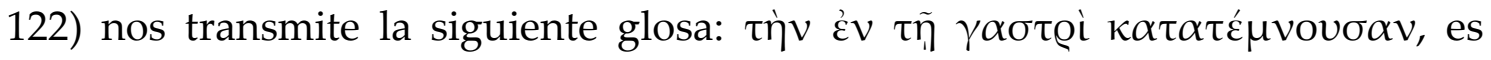
decir, este personaje devora de tal forma que no se toma el trabajo de cortar aquello que come; la función de cuchillo la cumple su propio estómago.

La invocación, construida sobre la caracterización del antihéroe y sobre la condena que merece, concluye en el cuarto verso con el auspicio de una

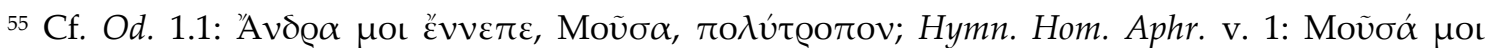

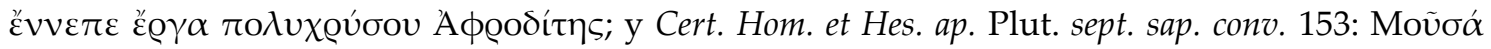

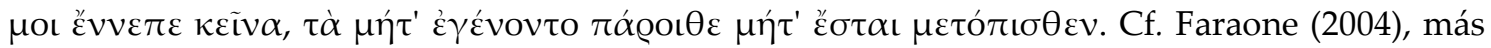
que una parodia de la poesía épica, ve en este yambo una suerte de conjuro o de encantamiento en hexámetros, compuesto para acompañar al $\phi \alpha \varrho \mu \alpha \kappa o ́ \varsigma$ en los rituales de expulsión o exterminio de $\delta \alpha i ́ \mu o v \varepsilon \varsigma$ que amenazan a la comunidad.

${ }^{56}$ En Il. 4.228 Eủov $\mu \varepsilon ́ \delta \omega v$ es uno de los escuderos de Agamenón; en 8.114 y 11.620 aparece como escudero de Néstor; en $\mathrm{Od}$. 7.58 es el nombre de uno de los reyes de los gigantes, cuya hija, Peribea, se unió con Posidón y concibió a Nausítoo, primer rey de los feacios; en Píndaro, $\mathrm{Ol}$.

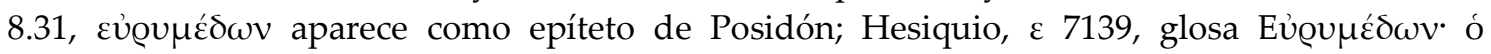

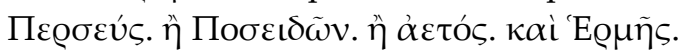


muerte a través del juicio popular, una condena destinada a la víctima expiatoria ( $\phi \alpha \varrho \mu \alpha \kappa o ́ \varsigma)$ con el fin de purificar a la comunidad de la contaminación que se extiende de manera amenazante.

Aunque el tema del $\phi \alpha \varrho \mu \alpha \kappa o ́ \varsigma$ excede en gran medida la perspectiva de análisis aquí planteada y, por otro lado, no es el objetivo de este trabajo, sin embargo, no es irrelevante revisar ligeramente un pasaje del escritor bizantino Tzetzes porque, en su Chil. 5.728-58, al describir el ritual de purificación, cita precisamente varios pasajes de Hiponacte:

El pharmakós era una antigua forma de purificación. Si una desgracia, como el hambre, la peste o alguna otra plaga, azotaba una ciudad por causa de la ira divina, conducían al hombre más deforme de todos como sacrificio para purificar y curar los males. Luego de disponer el sacrificio en el lugar adecuado, colocaban en la mano de la víctima queso, pan de cebada e higos secos, y después de golpearlo siete veces en el pene con escilas, ramas de higuera y otras plantas agrestes, finalmente lo quemaban con madera silvestre y dispersaban sus cenizas en el viento hacia el mar para purificación, como he dicho, de las plagas de la ciudad. Creo que Licofrón transmite esto acerca de las mujeres locrias, diciendo algo así, aunque no recuerdo bien sus versos [...] Pero Hiponacte describe mejor esta costumbre:

"Purificar la ciudad y recibir golpes de ramas de higuera."

Y en otro lugar de su primer libro de yambos dice:

(fr. 26Dg)

“golpeándolo y azotándolo en un prado con ramas de higuera

y de escila como si fuera una víctima expiatoria."

Y nuevamente en otro lugar dice palabra por palabra:

"hay que convertirlo en víctima expiatoria"

“y ponerle en sus manos higos secos, pan de cebada

y queso, como a una víctima expiatoria"

"porque hace tiempo que esperan por ellos boquiabiertos sosteniendo ramas de higueras, como lo hacen para las víctimas expiatorias"

Y en algún lugar del mismo libro de yambos también dice: 
"que de hambre se quede seco y que expulsado como víctima expiatoria se le golpee siete veces la verga"

$(\text { fr. 30 })^{57}$

Es posible que Tzetzes, en su descripción del citado ritual, se haya basado en los propios poemas de Hiponacte y en lo que recuerda de Licofrón. Sin embargo, es improbable que el ritual concluyera con la ejecución del $\phi \alpha Q \mu \alpha \kappa o ́ \varsigma$, como afirma Tzetzes. Quizás sí hayan existido, dentro de la tradición oral, relatos que concluyeran con el sacrificio de la víctima expiatoria, pero estos sacrificios no se habrían llevado a cabo efectivamente en las reales ceremonias rituales. ${ }^{58}$

A través de la parodia de la poesía épica, el fr. 126Dg podría constituir

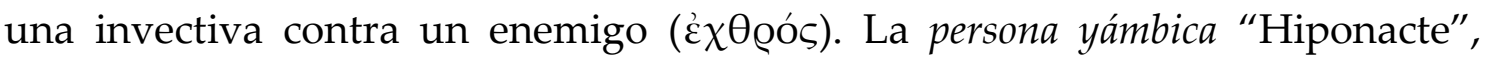
asumiendo la voz del aedo homérico, estaría invocando a la Musa no para que

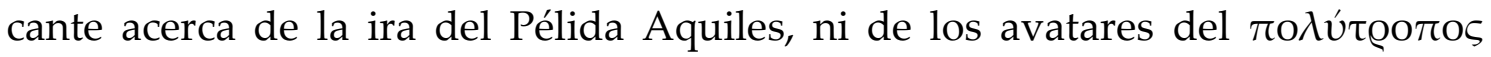
Odiseo, sino sobre el funesto final que sufrirá el Eurimedontíada, nombre que, de acuerdo con su significado, podría funcionar como apelativo para el hijo de

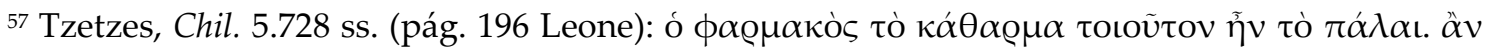

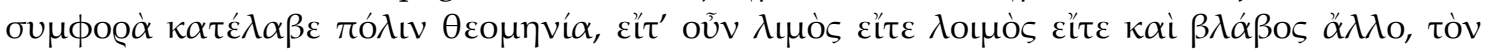

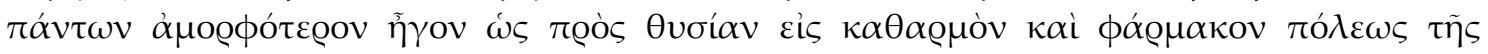

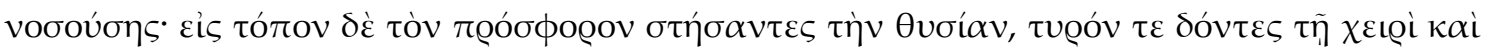

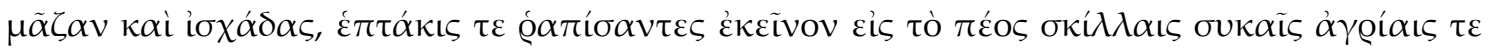

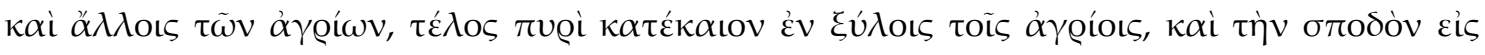

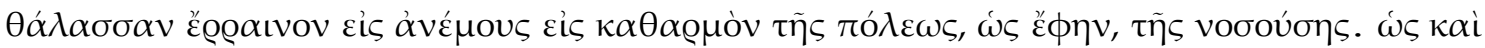

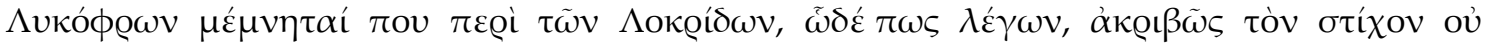

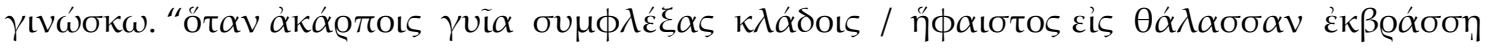

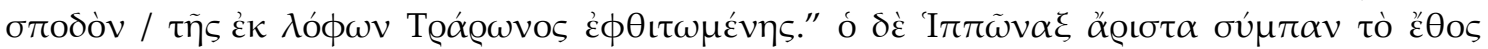

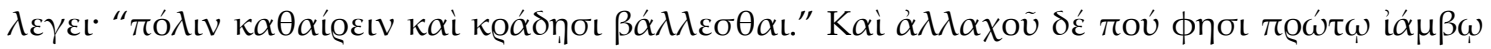

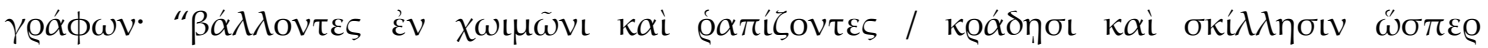

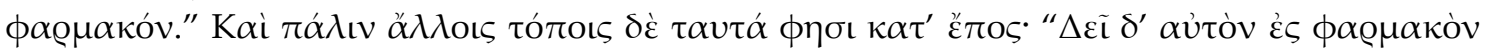

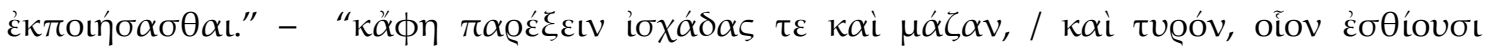

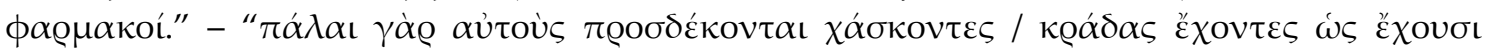

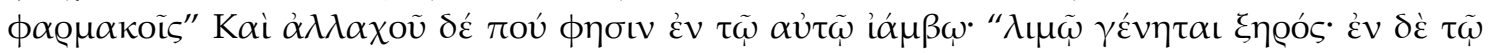

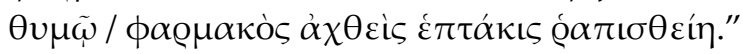

${ }^{58}$ Para el desarrollo completo y significado ritual, véase Burkert (2007, págs. 114-17). Para un análisis en relación al pasaje de Tzetzes y las composiciones de Hiponacte, véanse Bremmer (1983, págs. 299-320) y Hughes (1991, págs. 139-65). 
una persona poderosa, tal vez algún gobernante cuyo apetito insaciable y hábitos alimenticios amenaza con devorar todo a su paso (imagen que podría tener también una implicancia política). ${ }^{59}$ El hijo de Eurimedonte, como el ser

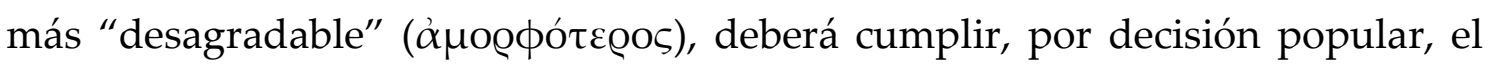

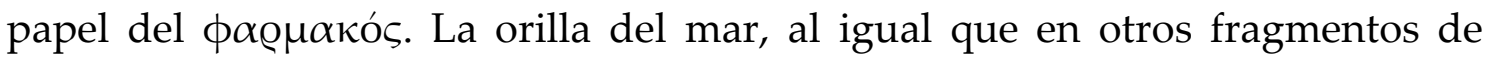
Hiponacte, $^{60}$ es el sitio destinado para la expiación ritual, y la expresión

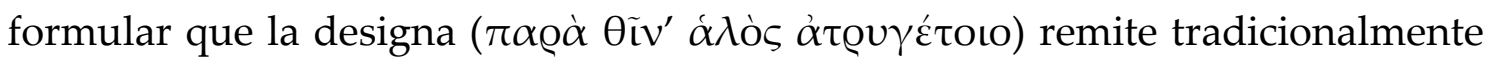
al carácter purificador del mar. ${ }^{61}$

De este modo, utilizando diferentes niveles de connotación tales como la parodia de la invocación a las Musas y los ritos de purificación de la comunidad, el yambo de Hiponacte constituye una invectiva humorística en la

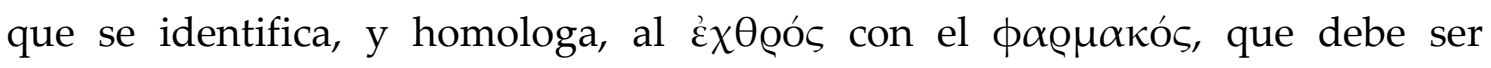
erradicado por completo para expiación de la ciudad.

\section{CONCLUSIONES PARCIALES}

Discursivamente, el fr. 126Dg posee una estructura enunciativa idéntica a los yambos que parodian la poesía petitoria; la única diferencia radica en la escenografía que se presenta. Mientras que en el grupo precedente se establece, dentro del plano enuncivo, una interlocución entre la máscara de un suplicante y una divinidad con el fin de obtener su favor, en este caso la interlocución se plantea entre la máscara de un aedo homérico y la Musa, a la que se le solicita le cuente una historia acerca de un personaje. Podríamos esquematizar la estructura enuncivo-enunciativa del fr. 126Dg de la siguiente manera:

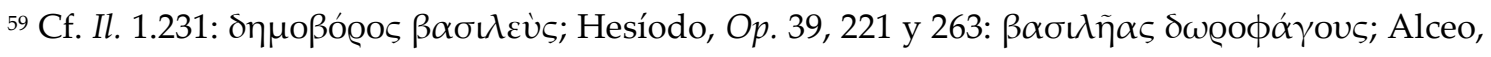

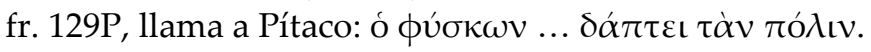

${ }^{60}$ Cf. West (1974, pág. 148): “Death on seashore (fr. 118E, cf. 103. 7, 115)”, en la edición Degani (1991), ff. 130, 106.7 y 194, respectivamente.

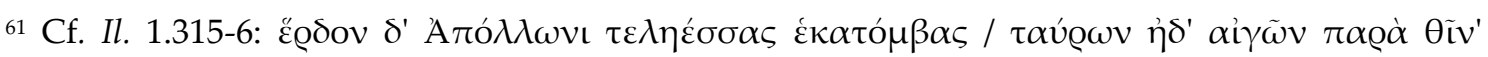

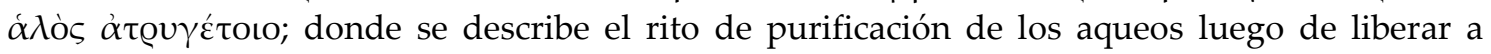
Criseida. También, Od. 2.370.
} 


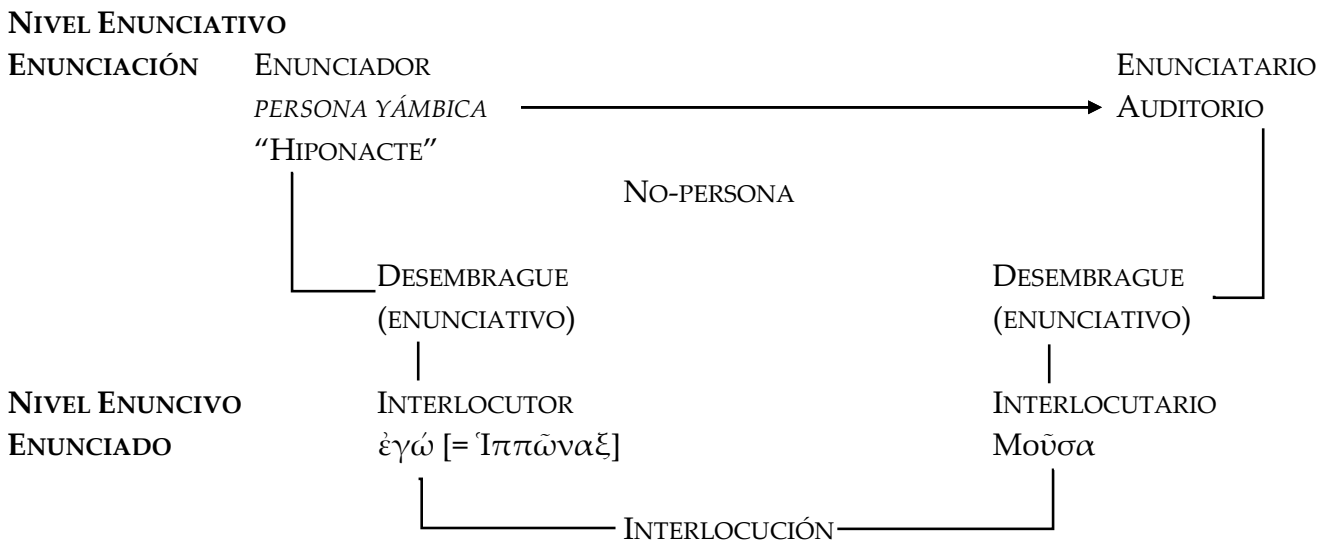

El interlocutor aparece inscripto en el enunciado a través de la deixis pronominal $\mu \mathrm{ol}$, en la función sintáctico-semántica de complemento receptor de

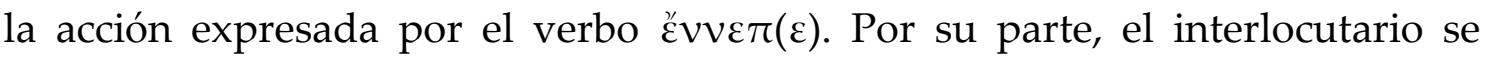
manifiesta deícticamente a través de las marcas de segunda persona del verbo $\varepsilon ̌ v \vee \varepsilon \pi(\varepsilon)$, en función de sujeto agente.

La identidad del interlocutario se explicita en la invocación apelativa $($ Moṽ $\sigma \alpha)$, por lo cual existe una relación de no-concomitancia entre el interlocutario y el enunciatario. Nuevamente se produce un desdoblamiento en la instancia de recepción: en el nivel enuncivo la identidad del interlocutario refiere a la divinidad, mientras que en el nivel enunciativo la identidad del enunciatario es el auditorio. Del mismo modo que en la parodia de la poesía petitoria, las marcas de segunda persona deben ser consideradas deixis am Phantasma.

Por su parte, la identidad del interlocutor no aparece de manera explícita en el discurso poético, pero es posible afirmar que el actor que ocupa esta posición actancial mantiene una relación de concomitancia con la identidad del enunciador, es decir, la persona yámbica "Hiponacte" adopta la máscara de un aedo homérico de manera paródica.

Es posible sostener, finalmente, que la máscara del aedo homérico en la parodia de la poesía épica, al igual que la del suplicante, es una determinación 
poética regida por el género yámbico, un recurso legitimado genéricamente, que caracteriza a la persona "Hiponacte".

\subsection{LA MÁSCARA DEL INJURIADOR}

En vinculación con la temática anterior hay un conjunto de yambos, muy fragmentarios, que presentan una estructura de interlocución y repiten la

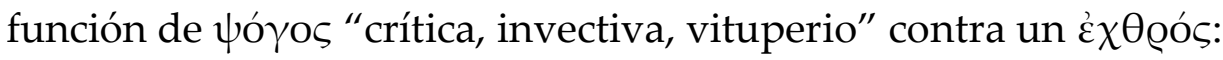

\section{CONTRA SANO}

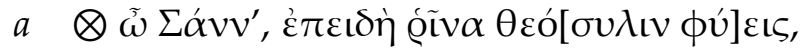

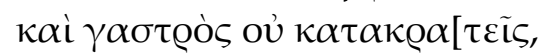

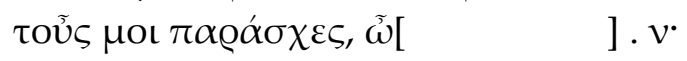

Hiponacte, fr. $129 \mathrm{Dg}^{62}$

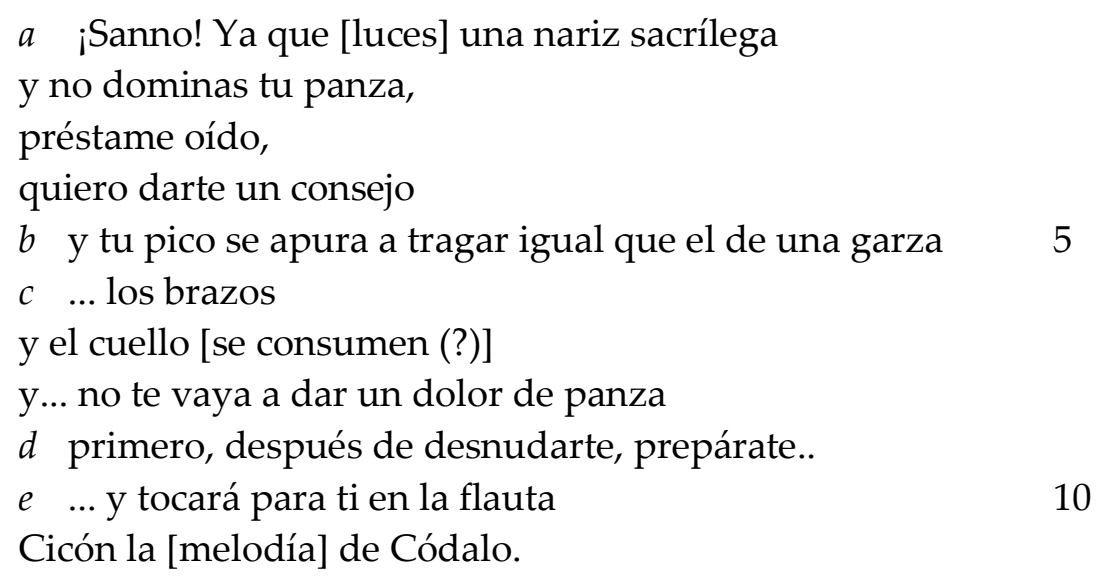

Este epodo, formado por trímetros y dímetros yámbicos, presenta un ataque en tono burlesco contra un tal Sano. El papiro que lo contiene, P.Oxy. 
2176, junto con otros veintitrés fragmentos, presenta también un conjunto de comentarios o hypomnema: la compilación está seguida de diferentes tipos de exégesis y observaciones. De acuerdo con estos comentarios, el nombre Sano sería muy apropiado para invectivas, ya que deriva del griego ó́ $v v \alpha \varsigma$ ("cabra salvaje"). Estos comentarios reproducen, además, un pasaje del Tœòs

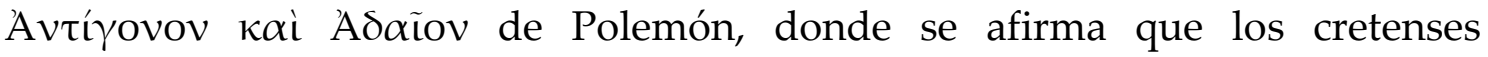
consideraban a las cabras salvajes animales tontos, y por esta razón el nombre ¿ávvos era utilizado habitualmente como apodo para denominar a los estúpidos. $^{63}$ Aristófanes de Bizancio confirma, en una glosa, que Sano significaba efectivamente "tonto". ${ }^{64}$ Por otro lado, el nombre aparece también

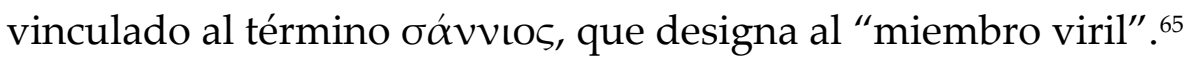

Al igual que en el fr. $126 \mathrm{Dg}$, en este yambo Sano es ridiculizado por su voracidad desmedida. Aparece caricaturizado como un ser dominado por su vientre y se compara su forma de tragar con la de una garza; ${ }^{66}$ podría estar haciéndose una alusión también a su falta de piedad religiosa, ${ }^{67}$ y no es desacertado pensar que bajo esta imagen de gula subyace una crítica burlesca por su excesivo apetito sexual. ${ }^{68}$

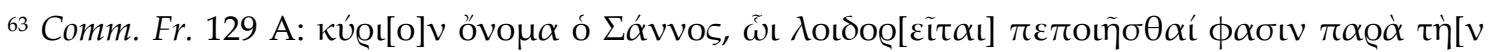

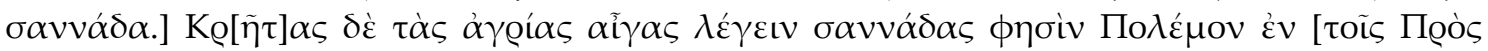

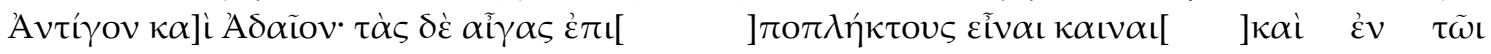

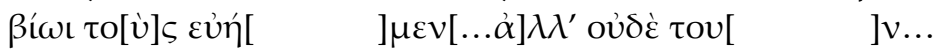

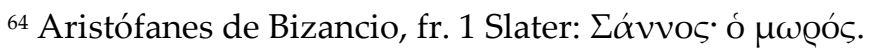

${ }^{65} \mathrm{Cf}$. Éupolis, fr. 471 y testimonio ad loc. Sobre este significado, véase particularmente Masson (1962, pág. 166).

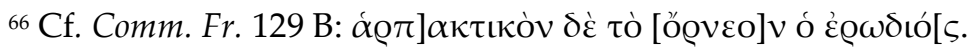

${ }^{67}$ Aunque no se puede determinar claramente cuál es el significado de "nariz sacrílega" en el fragmento, en el comentario al P.Oxy. 2176 se consigna junto a @ĩv $\alpha \theta \varepsilon o ́[\sigma u \lambda ı v$ (Comm. Fr. 129

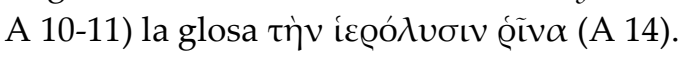

${ }^{68}$ West (1974, pág. 143): "What a sacrilegious nose may be, I cannot think, and it is surely more likely that lechery and gluttony are being mentioned in parallel, as so often." Cf. Degani (2004 , pág. 110). 
Según los citados comentarios, en los vv. 6-11 se estarían describiendo los síntomas de una enfermedad. El interlocutor le dice a Sano que sus brazos y su nuca están consumidos a pesar de que sigue comiendo, y, en consecuencia, le da el siguiente consejo: que se desvista y haga ejercicios antes de tomar el medicamento ( $\phi \alpha ́ \varrho \mu \alpha \kappa o v)$, porque de ese modo tendrá efecto más rápido y se extenderá por todo el cuerpo. ${ }^{69}$ Siempre de acuerdo con los comentaristas, debe entenderse que el consejo apunta a que Sano haga gimnasia, desnudo, al ritmo de la música de la flauta, antes de beber el remedio; Cicón interpretará para él la melodía de Códalo. Este último personaje es un adivino cuyos ritos adivinatorios aparecen parodiados en varios fragmentos de Hiponacte. ${ }^{70}$ Una glosa de Hesiquio referida a su persona señala que era hijo de Amitaón y que no profetizaba nada auspicioso. ${ }^{71}$ Códalo es mencionado también en otro fragmento de Hiponacte, ${ }^{72}$ aunque de atribución dudosa y extremadamente breve, pues tan solo se conservan dos palabras: "el quenix de Códalo", refiriéndose a un dicho popular. El quenix era una medida de capacidad de aproximadamente un litro, aunque se supone que el recipiente que utilizaba Códalo para sí era mayor, lo que explicaría el significado de la frase. Si, además, tomamos en consideración lo expresado por Ateneo acerca de que los flautistas griegos llevaban nombres frigios, apropiados para esclavos, y entre sus ejemplos menciona: “y en Hiponacte Cicón, Códalo y Babis, que inspiró el proverbio que se dice de aquellos cuya forma de tocar la flauta siempre empeora «toca peor que Babis»", ${ }^{73}$ podría suponerse que lo que estos versos de

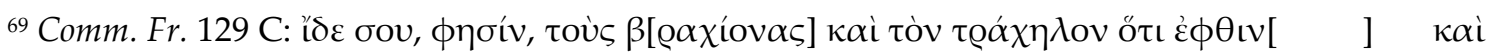

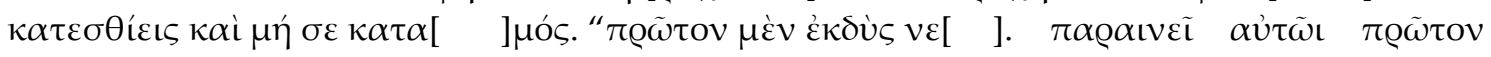

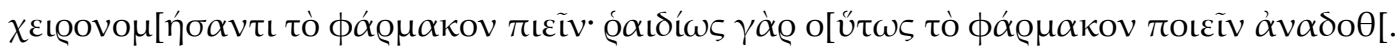

${ }^{70}$ Cf. ff. 3, 78 y $105 \mathrm{Dg}$.

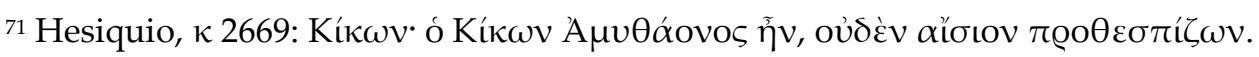

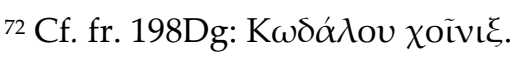


Hiponacte insinúan es que tanto la forma de interpretar de Cicón como la propia composición de Códalo eran muy deficientes, lo que daría lugar a otro giro cómico.

Con respecto a la curiosa expresión del pimer verso conservado del fragmento, Slings (1987, pág. 84) trata de desentrañas su significado: Sano sería "one who steals food from altars,"74 y por esa razón se dice que su nariz es "sacrílega", en tanto le sirve de guía para encontrar las víctimas sacrificiales.

\section{CONTRA BÚPALO y ATENIS}

Dentro de las composiciones con estructura interlocutiva, la figura del $\grave{\varepsilon} \chi \bigoplus$ @ós se reitera encarnada en los hermanos Búpalo y Atenis, en tres yambos muy fragmentarios (ff. 17, 18 y $70 \mathrm{Dg}$ ):

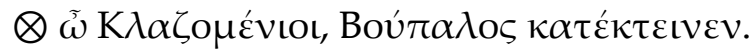

Hiponacte, fr. $17 \mathrm{Dg}^{75}$

¡Clazomenios, Búpalo mató...!

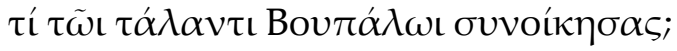

Hiponacte, fr. $18 \mathrm{Dg}^{76}$

¿Por qué conviviste con ese desdichado de Búpalo?

$\otimes{ }^{\prime} \Omega \theta \eta v \iota \kappa v[$

$\dot{\varepsilon} \pi^{\prime} \tilde{\eta} \iota \sigma \varepsilon \pi[$

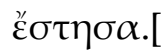

Hiponacte, fr. $70 \operatorname{Dg}^{77}$

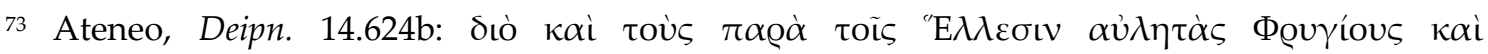

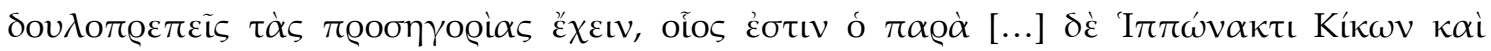

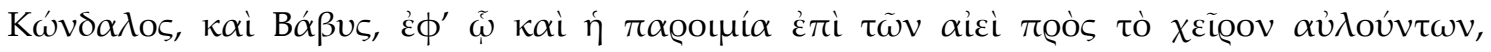

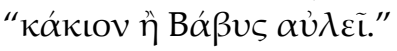

${ }^{74}$ También, Degani (2002, págs. 271-6).

75 Transmitido por Mario Plotio, Ars gramm. 3.4 (6.522.15-20 Keil), a partir de una cita de Juba.

${ }^{76}$ Transmitido por Querobosco, ad Theod. 4.1.268.32-34 Hilgard.

77 Transmitido por P.Oxy. 2174 col. II fr. 1.11-13.
} 
¡Atenis!...

sobre la que te...

coloqué...

Como se puede fácilmente apreciar, el carácter fragmentario de estos yambos y la absoluta falta de información del resto del poema que los contiene, dado los contextos en que se los cita -aparecen como ejemplos de métrica o del uso particular de algunos términos-, torna prácticamente imposible realizar una interpretación que no sea aventurada. Sin embargo, si los consideramos en relación a otros fragmentos, y particularmente dentro de la leyenda biográfica que la antigüedad creó acerca de la confrontación entre el poeta y los hermanos Búpalo y Atenis, estos pocos versos podrían alcanzar algún sentido. ${ }^{78} \mathrm{El}$ antagonismo entre ambos y la persona yámbica "Hiponacte" forjó una historia legendaria muy semejante a la ya comentada entre otro yambógrafo, Arquíloco, y los licámbidas. ${ }^{79}$

En efecto, Plinio el Viejo registra una versión de esta leyenda en un pasaje de su Historia Natural. Al describir los inicios de la escultura en mármol en Grecia, refiere que los primeros en ser famosos en este arte fueron, por un lado, los cretenses Dipoinos y Esquilis, y, por otro, una familia de escultores de Quíos. Sobre esta familia, señala que en la isla Quíos habitó el escultor Melas, a quien le sucedió su hijo Micciades y su nieto Arquermo; los hijos de este último, Búpalo y Atenis, muy famosos en este arte, fueron contemporáneos del poeta Hiponacte, que sin duda vivió en la Olimpíada sexagésima (540 a. C.). Plinio

${ }^{78} \mathrm{El}$ nombre Atenis aparece solamente en el fr. 70Dg. El nombre Búpalo, además de en los ff. 17 y $18 \mathrm{Dg}$, aparece también en los ff. 19, 20, 77, 79, 86, 98, 121-122Dg, en todas las ocasiones dentro de contextos de invectiva personal y con temáticas erótico-sexuales; a estas composiciones hay que agregar los ff. 1, 2 y $3 \mathrm{Dg}$, ya que según las fuentes que los transmiten afirman que asimismo referían a Búpalo.

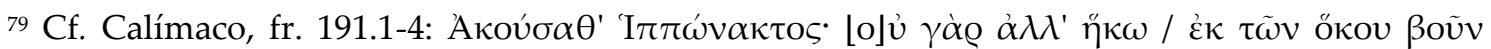

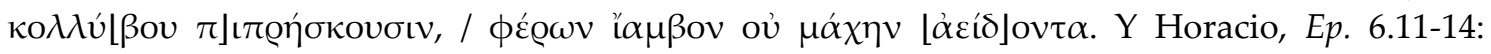
"cave cave, namque in malos asperrimus / parata tollo cornua, / qualis Lycambae spretus infido gener / aut acer hostis Bupalo". 
agrega además que Hiponacte era notablemente feo ${ }^{80} \mathrm{y}$, a causa de esta circunstancia, ambos artistas, en forma de broma, decidieron exponer una escultura de su persona, cómica -afirma- por la imagen de su lascivia ("imaginem lascivia iocosam"), con la intención de ridiculizarlo ante "ridentium circulis." Hiponacte, indignado, destiló sobre ellos la amargura de sus versos, hasta tal punto que, algunos creen, provocó que se ahorcaran por desesperación. Pero Plinio considera que esto es falso, ya que ellos habrían esculpido después muchas estatuas en las islas cercanas, como por ejemplo en Delos, e hicieron que Quíos no solo fuera famosa por sus viñedos, sino también por sus obras. ${ }^{81}$

Otra fuente mucho más tardía, la $S u d a$, repite el relato de la tradición: además de informar que Hiponacte era hijo de Piteas y de Protis, que tuvo que radicarse en Clazomenes porque los tiranos Atenágoras y Comas lo desterraron de Éfeso, afirma que escribió contra los escultores Búpalo y Atenis porque ellos hicieron una estatua que lo ridiculizaba. ${ }^{82}$

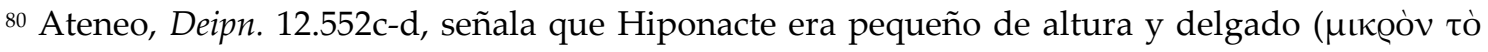
$\sigma \tilde{\omega} \mu \alpha, \dot{\alpha} \lambda \lambda \dot{\alpha} \kappa \alpha \grave{i} \lambda \varepsilon \pi \tau$ tóv); Eliano, Var. Hist. 10.6, transmite lo mismo pero agrega además que

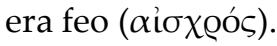

${ }^{81}$ Plinio, Nat. hist. 36.4.11-12: "fuerat in Chio insula Melas scalptor, dein filius eius Micciades ac deinde nepos Archermus, cuius filii Bupalus et Athenis vel clarissimi in ea scientia fuere Hipponactis poetae aetate, quem certum est LX olympiade fuisse [...]Hipponacti notabilis foeditas voltus erat; quam ob rem imaginem eius lascivia iocosam hi proposuere ridentium circulis, quod Hipponax indignatus destrinxit amaritudinem carminum in tantum, ut credatur aliquis ad laqueum eos conpulisse. quod falsum est. conplura enim in finitimis insulis simulacra postea fecere, sicut in Delo, quibus subiecerunt carmen non vitibus tantum censeri Chion, sed et operibus Archermi filiorum. Cf. Pseudo Acronis Schol. Horat. Ep. 6.14: Bupalum pictorem fuisse apud Clazomenas, civitatem Asia. hic Hipponactem quendam poetam deformem pro risu pinxit". También, Schol. [Гb] Horat. Ep. 6.14: "Hipponax scilicet, qui poeta erat eloquentissimus, foeda et vitiosa facie. hunc Bupalus pictor in Panatheneaeis pictum proposuit, ut risum moveret populo". De cualquier modo, los dos escolios al Epodo 6 de Horacio son de poca validez testimonial, ya que mezclan las leyendas en torno a Arquíloco y Licambes con la de Hiponacte y Búpalo, y además da por sentado que Búpalo era un pintor y no un escultor.

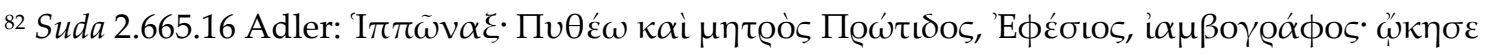

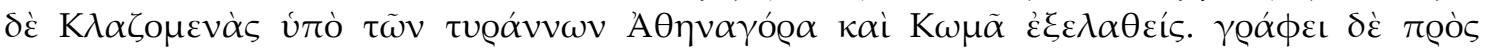

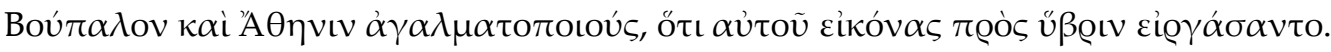


A confirmar al menos la veracidad de la existencia histórica de tales personajes viene una inscripción hallada en la base de una escultura datada hacia el 550 a. C., en cercanías del templo de Artemisa en Delos, donde aparece

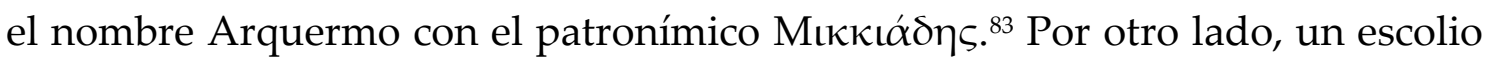

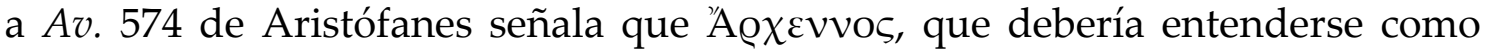
Arquermo, padre de Búpalo y Atenis, fue el primero en representar a la diosa Nike con alas, y menciona como fuente a Caristión de Pérgamo (s. II a. C.). ${ }^{84}$ Todos estos datos parecen atestiguar que tanto el escultor Arquermo como sus hijos fueron personas reales que vivieron hacia mediados de s. VI a. C. Sin embargo, al igual que la relación que presenta el nombre Sano con respecto a las cabras, Boú $\pi \alpha \lambda$ os podría esconder una alusión al toro o al buey. En esa dirección, Rosen considera que su pronunciación podría sonar en el auditorio como "falo de buey" (ßoũ $\varsigma-\phi \alpha \lambda \lambda$ ó $)$ o simplemente "gran falo." 85 Vale decir que la etimología de algunos de los nombres podría explicar en gran medida el

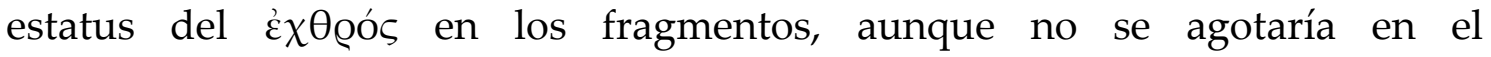
procedimiento el significado de las burlas. Como hemos visto, Búpalo puede ser un nombre parlante y al mismo tiempo haber designado a una persona real, lo que daría por tierra con la posibilidad de que lo haya inventado el poeta ad hoc. En segundo lugar, el nombre Atenis en el fr. $70 \mathrm{Dg}$, que no posee ningún significado per se, demostraría que aquellos a quienes atacó Hiponacte eran los famosos escultores hijos de Arquermo, lo que elimina la hipótesis de una invención de estos nombres por parte del poeta.

\footnotetext{
${ }^{83}$ I.Delos 9; cf. Masson (1962, pág. 13); Degani (1991, pág. 2); D’Accunto (2007, págs. 227-68).

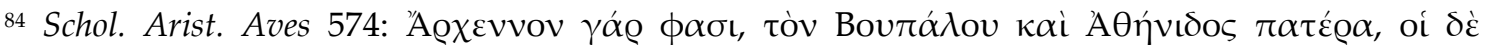

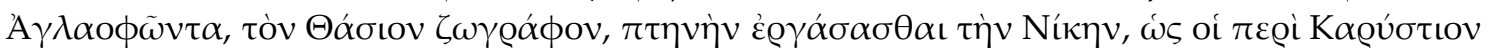

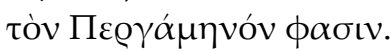

85 Rosen (1988, pág. 32): “I would suggest that the key to Boupalos' status in the Hipponactean iambos lies in his name, which can be heard as a play on the elements Bov- ("bull-like") and $\pi \alpha \lambda$ o $\left(=\phi \alpha \lambda \lambda\right.$ ó $\left._{)}\right)$. So divided, the name could be etymologized as either "Bull-Dick" or perhaps, simply, "Big-Dick."
} 
Una solución intermedia podría ser que Hiponacte, en su invectiva contra los hermanos se valió de la etimología de uno de los nombres, o más probablemente de la homofonía entre Boú $\pi \alpha \lambda$ os y $\beta$ oú $\phi \alpha \lambda \lambda$ os. Su estatus de $\varepsilon \chi \chi \bigoplus$ ¿ós en el ámbito de lo sexual parece corroborar esta hipótesis; distintos fragmentos lo sitúan en esta posición, como por ejemplo el fr. $18 \mathrm{Dg}$, en el que un interlocutor reprocha a una mujer por "cohabitar" con Búpalo. Seguramente el reproche esté dirigido a haber tenido relaciones sexuales con él, por lo cual

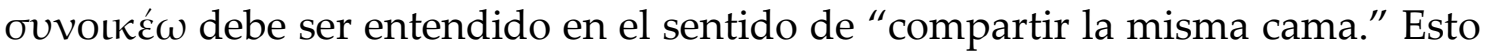

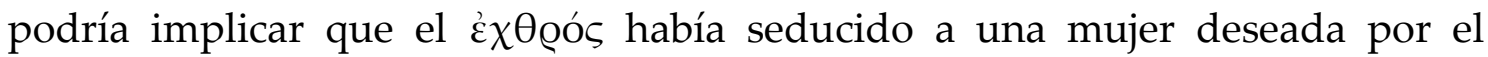
interlocutor. En otras composiciones, Búpalo es acusado de mantener relaciones incestuosas con su madre. En el fr. 20Dg, dentro de un contexto de fuerte invectiva y al mismo tiempo de gran comicidad, se lo llama de manera vulgar

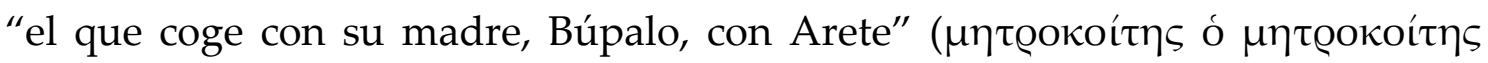

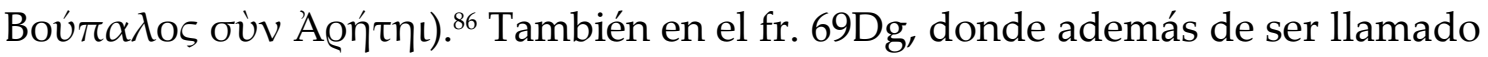
"odiado por los dioses", se menciona la realización del acto incestuoso mientras su madre duerme. ${ }^{87}$

Todo ello ha llevado a considerar que Búpalo mantenía una relación incestuosa con su madre (Arete) y que esta era la razón por la que Hiponacte lo acusaba públicamente. Sin embargo, es posible que estas acusaciones deban

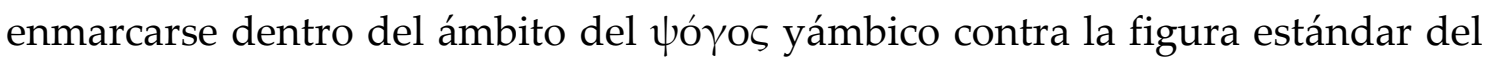

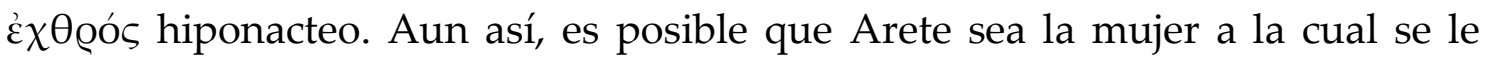

\footnotetext{
${ }^{86}$ Fr. 20Dg: "con esto engaña a los hijos de Eritras / Búpalo, el que coge con su madre, con Arete,

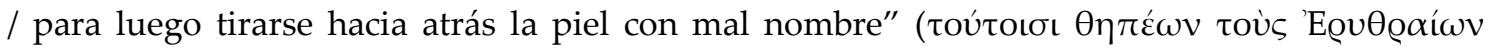

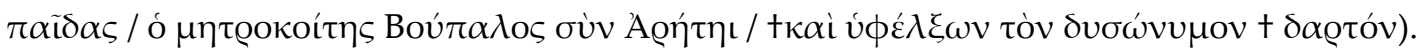

${ }^{87}$ Fr. 69.7-8Dg: "a ese, odiado por los dioses, / que mientras su madre dormía le saqueaba el

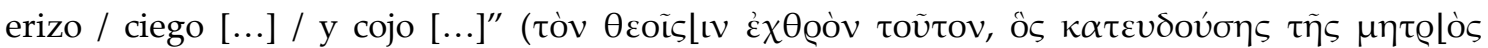

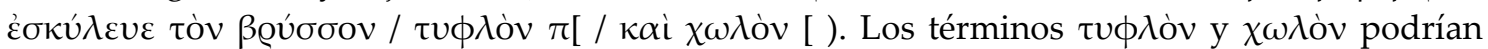
remitir a los estigmas típicos de los castigos por las relaciones incestuosas, ejemplos por excelencia son los de Edipo y Télefo, a los que se podría agregar la leyenda en torno a Licurgo y el intento, estando ebrio, de someter sexualmente a su propia madre" (Higino, Fab. 132); cf. Miralles \& Pòrtulas (1988, págs. 54-7).
} 
reprueba haber cohabitado con Búpalo en el fr. 18Dg. Ella, como veremos más adelante, también aparece en otras composiciones como partenaire sexual de "Hiponacte", y es aquí donde podría hallarse la explicación de la rivalidad con Búpalo. ${ }^{88}$

\title{
CONTRA Mimnes
}

Si en los yambos anteriores "Hiponacte" lanza sus invectivas contra los escultores Búpalo y Atenis, en el fr. 39Dg el blanco de sus críticas se dirige también a un artista, el pintor Mimnes:

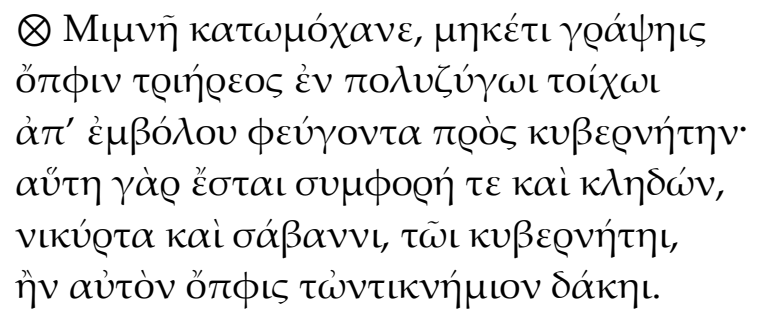

Hiponacte, fr. 39Dg89

\begin{abstract}
¡Mimnes! ¡Boquiabierto! Deja de pintar ya
la serpiente que desde el espolón huye hacia el piloto en el costado del trirreme con muchos bancos; ya que será a la vez mal presagio y desgracia -jesclavo hijo de esclavos!- para el piloto: si la serpiente le muerde la canilla.
\end{abstract}

En este yambo, como lo confirma Tzetzes, los coliambos están dirigidos

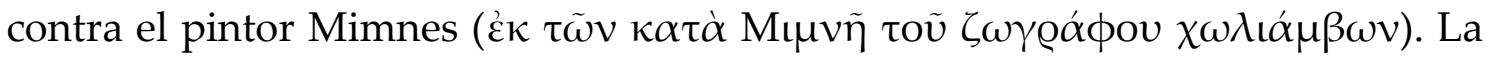
crítica se centra particularmente en la incompetencia del artista. Mimnes pinta, en el lateral de una embarcación de guerra, una serpiente en la dirección contraria a la que debería ir, esto es, la cola partiendo del timonel, ubicado en la popa, y su cabeza dirigida hacia la proa, ya que se espera que la ferocidad de la

\footnotetext{
88 Vid. inf. pág. 255.

${ }^{89}$ Transmitido por Tzetzes, ad Antehom. 168.
} 
serpiente sea vista atacando a los enemigos y no huyendo de ellos. ${ }^{90}$ De acuerdo con Fränkel, la serpiente simbolizaría la "mordida" mortal contra la nave enemiga. ${ }^{91}$ La crítica que se desprende del yambo es evidente, pero no menos lo es la comicidad e ironía con la que se lleva adelante esta crítica. La dirección que le da Mimnes a la serpiente implica un mal presagio para la flota de guerra, encarnada aquí en el piloto que dirige la nave: no solo será un mal presagio, sino una desgracia para el piloto si la serpiente realmente le muerde la pierna.

Por otro lado, al igual que en otros yambos, la comicidad de este fragmento se provoca a través del recurrente empleo de vocablos compuestos, tal vez sorprendentes para el auditorio, como $\kappa \alpha \tau \omega \mu$ ó $\chi \alpha \nu \varepsilon$, literalmente "boca abierta hasta los hombros", que podría basarse en el $\kappa \alpha \kappa o \mu \eta ́ \chi \alpha \nu \varepsilon$ con el cual Penélope insulta a Antínoo en Od. 16.418. La misma función le cabría a los

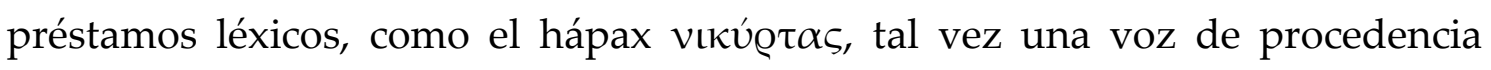

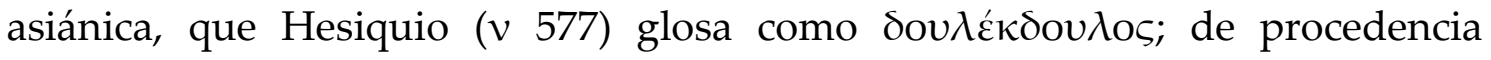
asiánica también sería el hápax ó́ß $\alpha v v ı s$, un insulto de la misma índole que

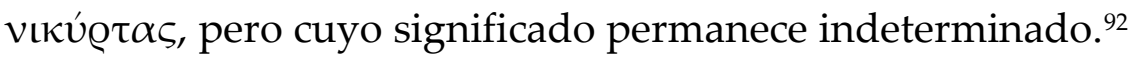

Si en los yambos anteriores el juicio contra los escultores Búpalo y Atenis era de índole ética, porque la crítica que ellos habrían plasmado en la representación del yambógrafo también podría haber sido ética, el juicio contra Mimnes, en cambio, es puramente estético; "Hiponacte" lo ataca haber equivocado la imagen en su obra de arte, no por su conducta.

\section{CONTRA CRITIAS}

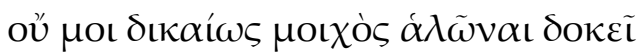

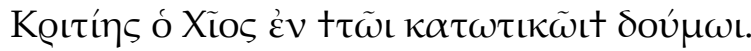

\footnotetext{
${ }^{90}$ Cf. también Brink (1851, págs. 727-30); Masson (1962, pág. 121).

${ }^{91}$ Fränkel (1968, pág. 249).

92 Para los préstamos léxicos en Hiponacte, véanse particularmente Degani (2004, págs. 123-30); Suárez de la Torre (1987, págs. 113-39); Bonati (2013, págs. 29-46).
} 
No me parece justo haber sorprendido como adúltero a Critias de Quíos en esa casa de mujeres.

Al igual que la mayoría de los fragmentos de Hiponacte, estos versos nos llegan como ejemplificación métrica, por lo que carecemos de toda información relativa al contexto. Aun así, como en otras ocasiones, es posible reponer o conjeturar acerca de su significado. Podemos observar que el interlocutor censura como injusta ( de Quíos en una situación de adulterio, en un lugar donde las mujeres ejercerían la prostitución. $^{94}$ La exposición de este hecho frente al interlocutario/auditorio, más que un desagravio, debería ser considerado como una crítica sarcástica contra la conducta de Critias, ya que la divulgación pública del hecho conllevaría una reprobación risible por parte del interlocutario.

Una diferencia con los fragmentos analizados anteriormente es que en este caso la invectiva no está dirigida en segunda persona contra el interlocutario, sino contra un personaje que constituye la no-persona en la instancia de la enunciación.

\section{CONTRA INTERLOCUTARIOS NO IDENTIFICADOS}

Como es de esperar a causa de la naturaleza oral de la poesía arcaica, la mala conservación de los papiros y la limitación que supone la transmisión

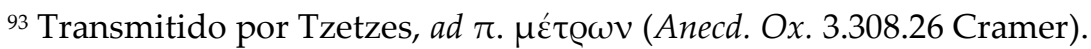

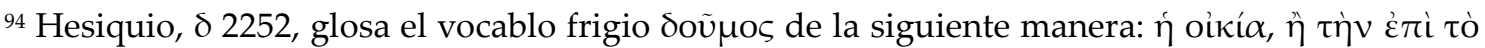

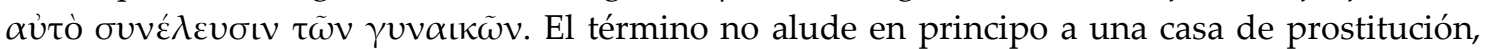
podría simplemente ser el lugar de reunión de un $\theta$ í $\alpha \sigma o s$, pero en el yambo de Hiponacte este término expresa irónicamente que las actividades de estas mujeres no eran precisamente religiosas. Para $\dagger \tau \tilde{\omega} \iota \kappa \alpha \tau \omega \tau \iota \kappa \tilde{\omega} \iota t$ (corrupto para la mayoría de los editores), West propone leer el adjetivo $\kappa \alpha \tau \omega \hat{\gamma} \varepsilon \omega \iota \tau \tilde{\omega}$ "subterránea", que podría realzar el carácter clandestino de la casa.
} 
indirecta, hay un conjunto de fragmentos en los que la identidad del interlocutario al que se dirige la invectiva se ha perdido.

FR. 33DG

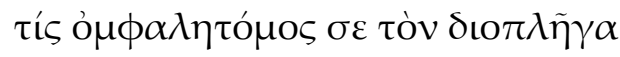

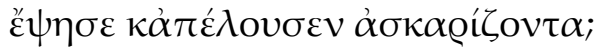

Hiponacte, fr. 33Dg95

A ti, fulminado por Zeus, ¿qué cortaombligos

te refregó y te lavó mientras pataleabas?

Este fragmento, que ha sido transmitido a propósito del significado del verbo $\dot{\alpha} \sigma \kappa \alpha \varrho i \zeta \varepsilon \iota v$, es sumamente interesante para certificar que la invectiva yámbica de Hiponacte se mueve de manera casi estereotipada siempre dentro del terreno de lo risible ( $\gamma \varepsilon \lambda$ oĩov). Es difícil determinar si el objetivo es realizar una crítica contra alguien e insultarlo o simplemente hacer reír, aunque probablemente los dos objetivos valgan por igual.

Se observa nuevamente el uso de la lengua popular, en el compuesto

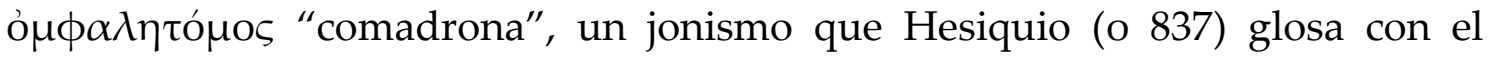
término $\mu \alpha \tilde{i} \alpha{ }^{96}$ y el empleo de palabras compuestas que remiten a formas épicas, como el hápax $\delta\left\llcorner \_\pi \lambda \tilde{\eta} \gamma \alpha\right.$, que podría estar formado a partir de $\Delta$ เóৎ-

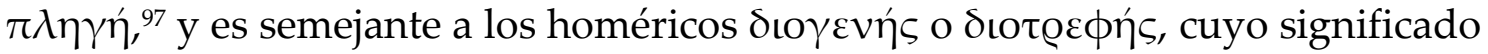
es equivalente al ático , "aquel que ha sido golpeado por el rayo de Zeus." 98

\section{Fr. 190DG}

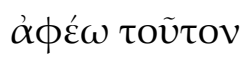

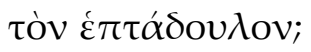

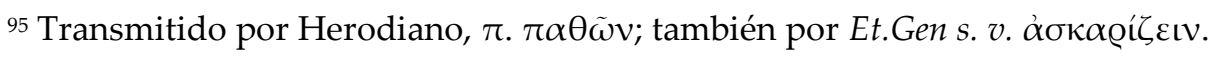

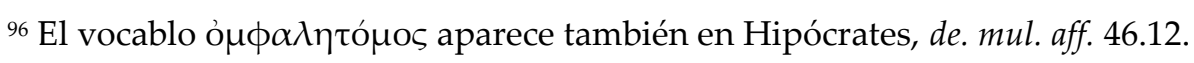

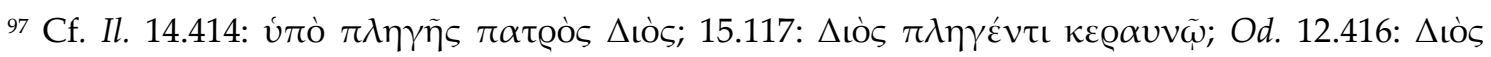

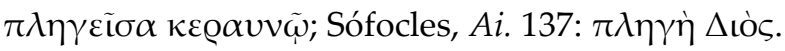

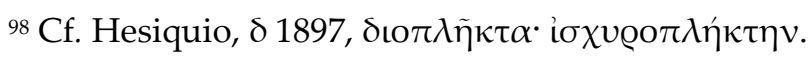


¿Voy a dejar libre

a ese requetesclavo?

En este yambo, cuya atribución a Hiponacte es dudosa, ${ }^{100}$ la invectiva no se dirige propiamente contra el interlocutario, sino contra un tercero, al igual que Critias en el fr. 41Dg. Eustacio (in Hom. Od. 5.306), quien cita el fragmento, señala que con el término $\varepsilon \pi \tau \alpha ́ x \delta o u \lambda o \varsigma$ (literalemente "siete veces esclavo")

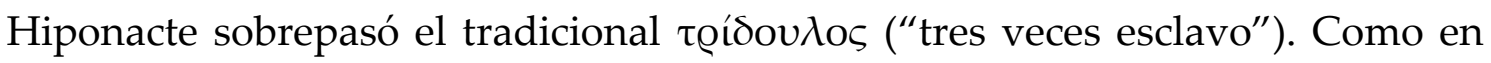
todos los casos, la exageración está al servicio de la sorpresa del auditorio ante un neologismo que asegura un efecto cómico.

\section{CONCLUSIONES PARCIALES}

$\mathrm{Al}$ igual que los grupos analizados anteriormente, la invectiva personal posee una estructura enunciativa de interlocución. Sin embargo, la escenografía aquí es la de un interlocutor que dirige una crítica contra un actor en particular. En la mayoría de los casos, este actor ocupa la posición actancial de interlocutario, por lo que la invectiva en segunda persona aparece de manera dramática y contundente. En otros casos (ff. 17, 18, 41 y 190Dg), la invectiva está dirigida contra la no-persona en la instancia de la enunciación poética. La esquematización para la estructura enuncivo-enunciativa de estos fragmentos podría ser la siguiente:

${ }_{99}$ Transmitido por Suetonio, de blasph. 63 Taillardat y también por Eustacio, in Hom. Il. 8.488 (2.623.9 van der Valk), también en in Hom. Od. 5.306 (1542. 49 van der Valk).

100 Degani (1991, pág. 165) lo edita entre los Fragm. Dubia porque la misma frase aparece en

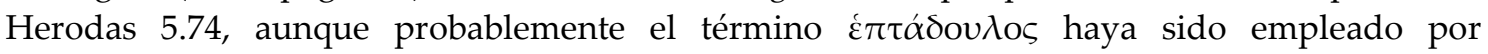
Hiponacte. 


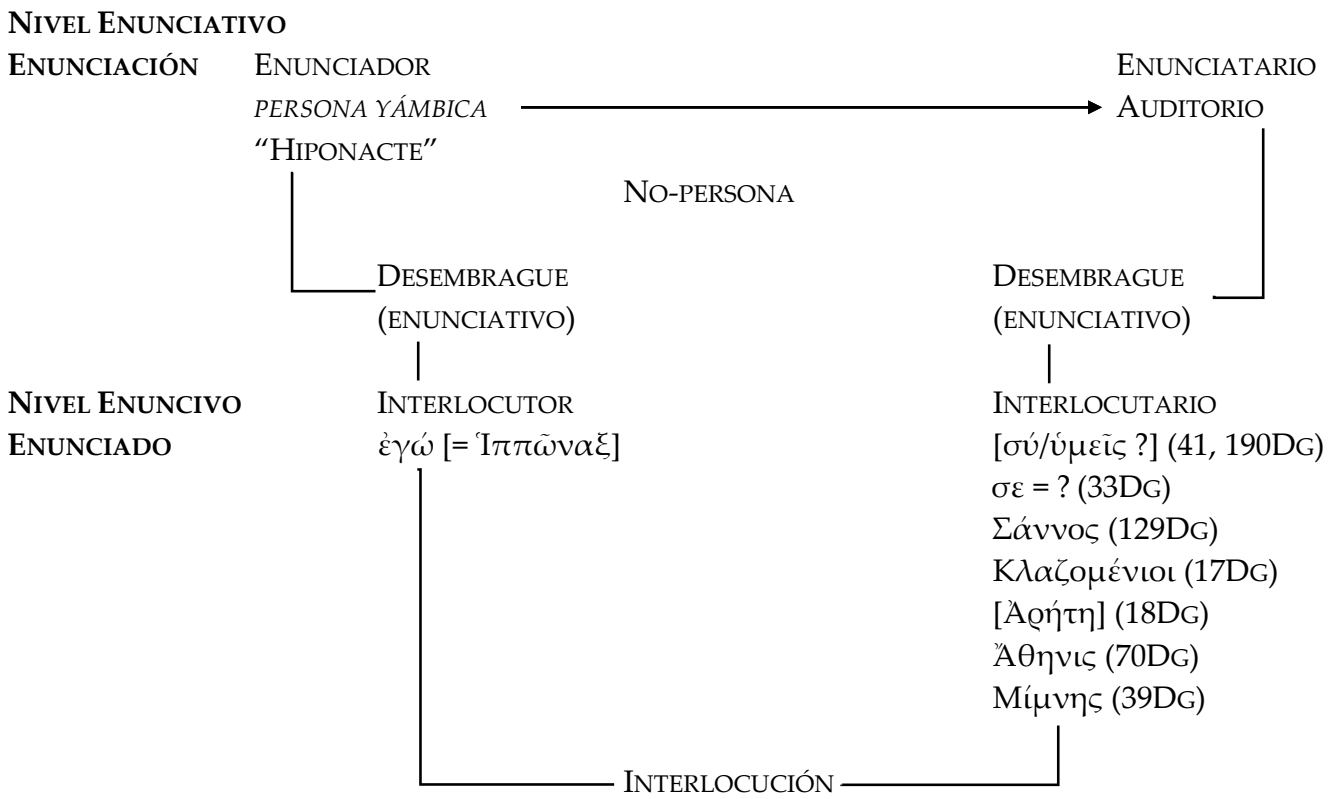

Como podemos observar en el esquema, el proceso de desembrague enunciativo instala en el discurso poético las formas de la enunciación enunciada. En estos casos el interlocutor y el interlocutario se inscriben en el enunciado a través de la deixis pronominal y verbal de la siguiente manera:

Fr. 129. Interlocutor: $\mu$ o v. 3 (complemento receptor de $\pi \alpha \varrho \alpha ́ \sigma \chi \varepsilon \varsigma$ ); y por la deixis de primera persona del verbo $\theta \varepsilon \dot{\varepsilon}[\lambda \omega$ v. 4 (sujeto agente). Interlocutario: $\sigma o \iota$ v. 5 (poseedor con respecto a tò $\chi \varepsilon \tilde{i} \lambda o s$ ); $\sigma \varepsilon$ v. 8 (complemento paciente de

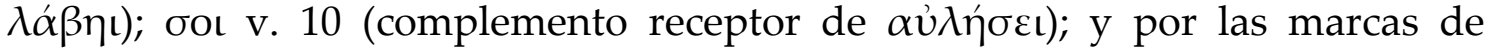
segunda persona de los verbos $\phi u ́] \varepsilon ı \varsigma$ v. 1 (sujeto poseedor); $\kappa \alpha \tau \alpha \kappa \varrho \alpha[\tau \varepsilon \tilde{\iota} \varsigma$ v. 2 (sujeto posicionador); ع̋ $\phi \iota \sigma \alpha \iota$ v. 7 (sujeto paciente); $\pi \alpha \varrho \alpha ́ \sigma \chi \varepsilon \varsigma$ v. 3,

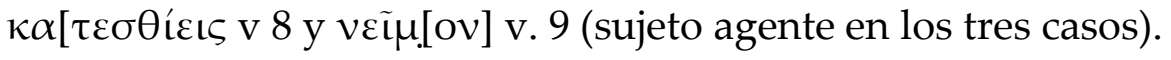

Fr. 17. Interlocutor: ninguna. Interlocutario: ninguna.

Fr. 18. Interlocutor: ninguna. Interlocutario: a través de la deixis de segunda

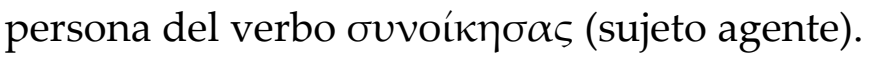

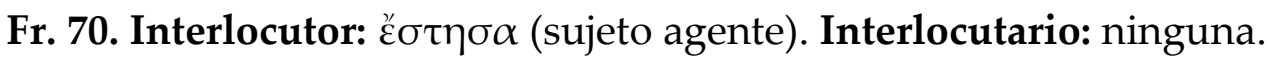

Fr. 39. Interlocutor: ninguna. Interlocutario: $\gamma \varrho \alpha ́ \psi \eta \iota \varsigma$ (sujeto agente).

Fr. 41. Interlocutor: $\mu \mathrm{ol}$ (complemento experimentador de Interlocutario: ninguna. 
Fr. 33. Interlocutor: ninguna. Interlocutario: $\sigma \varepsilon$ (como complemento paciente de $\varepsilon \dot{\psi} \eta \sigma \varepsilon$ y $\alpha \dot{\alpha} \hat{\varepsilon} \lambda \circ v \sigma \varepsilon v)$.

Fr. 190. Interlocutor: $\alpha \dot{\phi} \hat{\varepsilon} \omega$ (como sujeto agente). Interlocutario: ninguna.

Se repite como en ocasiones antes comentadas que la identidad del interlocutario puede aparecer de manera explícita en el enunciado a través del

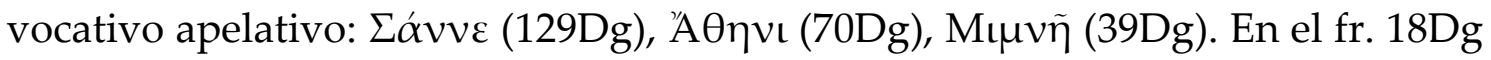
la identidad del interlocutario no aparece explícitamente, pero es posible

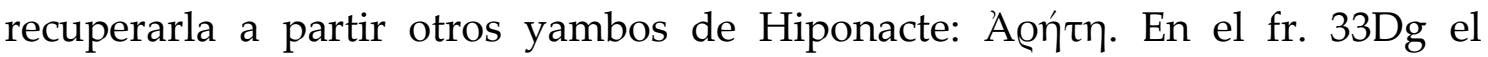
interlocutario aparece marcado deícticamente pero su identidad no se hace explícita ( $\sigma \varepsilon=$ ?). Por lo tanto, en todos estos casos es posible sostener que las identidades de estos interlocutarios establecen una relación de noconcomitancia con la del enunciatario-auditorio. Lo cual implica que en estas composiciones de tipo apelativas también se produce un desdoblamiento de la instancia de recepción, por un lado, la identidad del interlocutario y, por otro, la del enunciatario.

El fr. 17Dg se diferencia de estas consideraciones ya que el vocativo

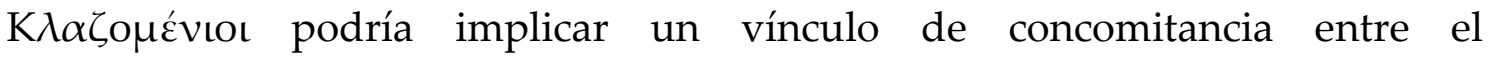
interlocutario y el enunciatario-auditorio. Por último, en los ff. 41 y 190Dg el interlocutario no se manifiesta deícticamente como así tampoco su identidad, por lo cual no es posible determinar si existe una relación de concomitancia o de no-concomitancia entre este actante y el enunciatario-auditorio [ $\sigma \dot{v} / \hat{v} \mu \varepsilon \tilde{\iota} \varsigma$ ?].

Por su parte, la identidad del interlocutor no está explicitada en el enunciado de ninguno de los fragmentos. Aun así, el hecho de que ciertas posiciones actanciales dentro de estructuras enunciativas similares, como la del interlocutor en las parodias de la poesía petitoria o en los yambos de invectiva personal, tengan un vertimiento actorial repetitivo y estereotipado en sus caracterizaciones, con la misma actitud y disposición frente a su interlocutario, 
permite suponer que la identidad de ese interlocutor es la misma cada vez que se manifiesta. Es razonable asumir que el interlocutor que dirige una acusación contra Búpalo ante los clazomenios sea el mismo que le reprocha a Arete haber convivido con él ante un auditorio compuesto también por habitantes de Clazomenes. Esto nos lleva a sostener que la identidad de interlocutor entabla una relación de concomitancia con la del enunciador "Hiponacte".

\subsection{LA MÁSCARA DEL PÚGIL CÓMICO}

Nos ocuparemos, en lo que sigue, de una serie de yambos del corpus hiponacteo que reproducen una figura que hemos denominado "el púgil cómico". En las escenografías de estas composiciones, el actor que asume la posición de interlocutor participa de episodios de combate, estereotipados en sus desarrollos, que apuntan a situaciones ridículas y cómicas.

\section{FF. 121 Y 122DG}

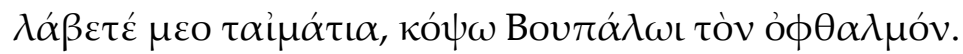

Hiponacte, fr. $121 \operatorname{Dg}^{101}$

¡Ténganme la ropa! Golpearé a Búpalo en el ojo.

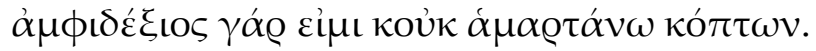

ambidiestro soy y no fallo cuando golpeo.

Hiponacte, fr. $122 \mathrm{Dg}^{102}$

Dos alusiones del comediógrafo Aristófanes referidas a Hiponacte confirman la imagen que se desprende de los fragmentos citados, esto es, la del púgil cómico. En la primera de ellas, Lys. 360-1, el jefe del coro de los viejos, de

${ }_{101}$ Transmitido por Suda 1.487.10 Adler.

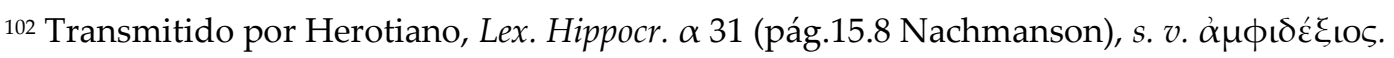


manera amenazante, compara el trato que deberían darles a las ancianas para hacerlas callar con los golpes que Hiponacte propinó a Búpalo:

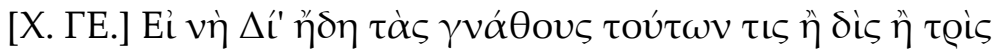

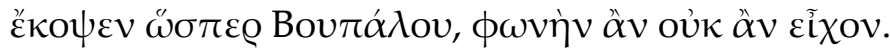

Aristófanes, Lys. 360-1

[CORIFEO] Por Zeus, si alguien les hubiera dado dos o tres golpes en la mandíbula, como le sucedió a Búpalo, ya no tendrían ni un hilo de voz. ${ }^{103}$

El verbo кó $\tau \tau \omega$, utilizado por Aristófanes, tiene una resonancia particular en la obra de Hiponacte. ${ }^{104}$ Es posible que la mera mención de Búpalo en la comedia de Aristófanes fuera suficiente para que el auditorio recordara no solo las peleas entre el poeta y el escultor, sino también toda la tradición poética que esta confrontación representaba.

En Ran. 659, Aristófanes menciona a Hiponacte por su nombre en un contexto en que los yambos del poeta arcaico se asocian deliberadamente con una situación de dolor y sufrimiento físico, sin perder la perspectiva cómica. En efecto, Dioniso, habiendo convenido con Éaco padecer algunos tormentos para probarle que es una divinidad y por lo tanto no padece dolor alguno, sin embargo, manifiesta muy poca tolerancia al sufrimiento, a tal punto que cada vez que Éaco lo tortura hace lo imposible por contenerse y no delatarse. Jantias, el criado de Dioniso, al advertir que su amo se queja de dolor, se apresura a avisar a Éaco la situación, pero Dioniso intenta esconder sus lamentos con la excusa de estar simplemente recitando un verso de Hiponacte, que acababa de venirle a la memoria:

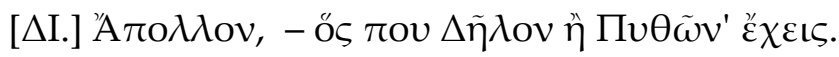

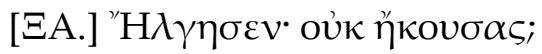

103 Traducción de Claudia Fernández (2008, pág. 97).

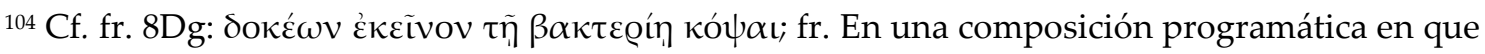
la herencia de Hiponacte es abiertamente reclamada, Herodas, Mim. 8.60, alude a este

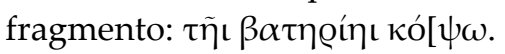




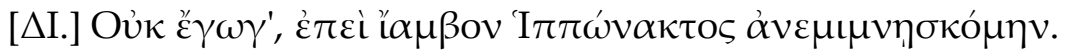

Aristófanes, Ran. 659-61.

[DIONISO] ¡A Apolo! ...que habitas en algún lugar de Delos o Pito.

[JANTIAS] Le dolió. ¿No escuchaste?

[DIONISO] ¿A mí? No. Lo que pasa es que recordaba un yambo de Hiponacte.

A causa del dolor que padece al ser golpeado por Éaco, Dioniso grita “¡Apolo!” y para disimular su sufrimiento continúa rápidamente recitando un verso que comienza con el nombre de esta divinidad, y que supuestamente pertenecía a Hiponacte. ${ }^{105}$ Es dable suponer que, tratándose de una comedia, de cara a una escena en que los personajes se golpean y expresan dolor, la evocación de un verso de Hiponacte con el fin de disimular los gritos de Dioniso haya sido no solamente oportuna sino también eficaz para provocar la risa del auditorio. Probablemente este último asociara inmediatamente la alusión a Hiponacte con toda una tradición poética ligada a la comicidad generada a través de invectivas, acusaciones, golpes y exclamaciones de dolor.

Fr. 193DG

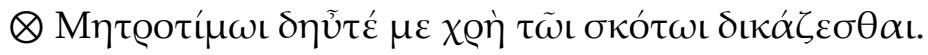

Hiponacte, fr. $193 \operatorname{Dg}^{106}$

De nuevo tengo que pleitear contra el sombrío Metrotimo.

Este yambo también podría enmarcarse dentro de la temática pugilística. "Hiponacte" anuncia a su interlocutario que deberá pelearse nuevamente con

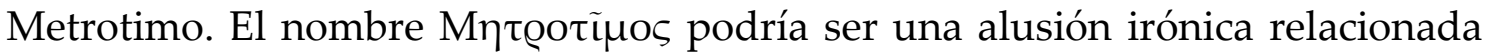

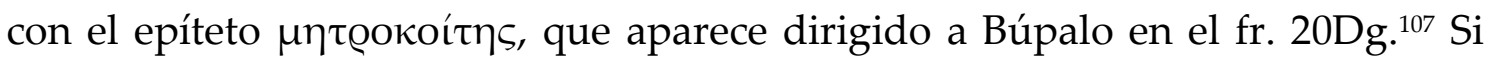

\footnotetext{
${ }^{105}$ El Schol. Arist. Ran. 661 atribuye el verso al yambógrafo Ananio.

106 Transmitido por Hefestión, Ench. met. 6.2 (pág. 18.16 Consbruch).

107 Vid. sup. pág. 229 y n. 86.
} 
esta lectura es correcta, una vez más "Hiponacte" estaría utilizando un nombre parlante para embestir contra su adversario más destacado: “el que estima a su madre".

Además de la comicidad propia que se desprende de las situaciones de pelea, el lenguaje aporta lo suyo para acrecentar el humorismo del yambo: en primer lugar, el empleo, como hemos visto, de un apodo construido a partir de un compuesto, similar a los epítetos que aparecen en la épica. En segundo lugar, también ligado a la invectiva yámbica, el empleo del término okótos, que en Ilíada y en teatro refieren siempre a la oscuridad de la muerte, ${ }^{108}$ en tanto aquí es utilizado para caracterizar a Metrotimo; aunque su significado en el yambo es incierto, seguramente aluda al carácter lúgubre o tenebroso del personaje. ${ }^{109}$ El mismo término aparece también en otro fragmento de

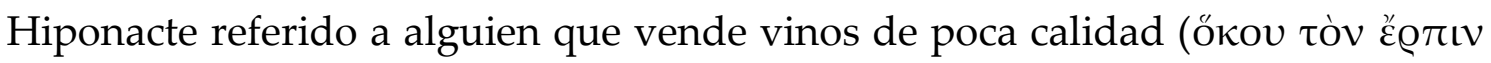

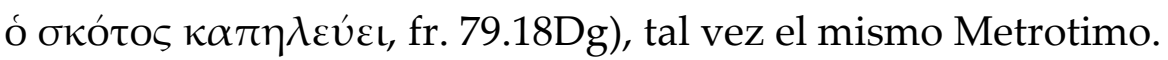

\section{FR. 196DG}

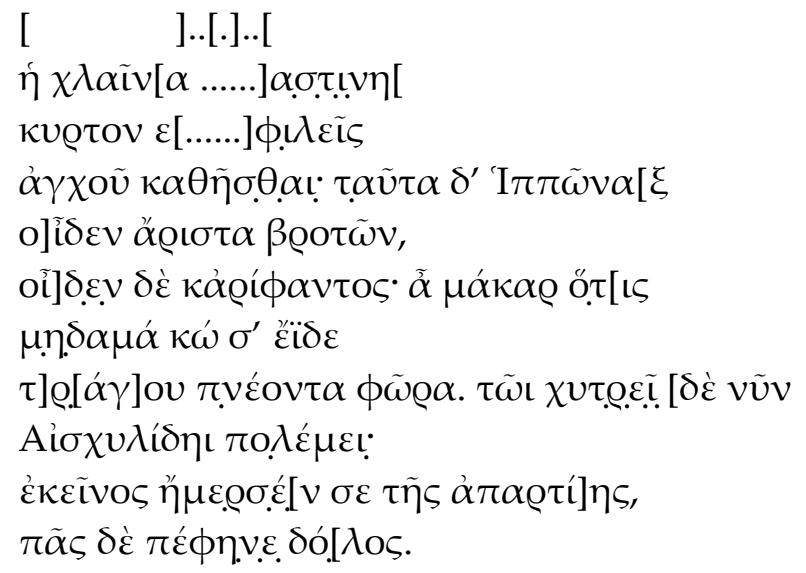

${ }^{108}$ El término okótos refiere particularmente a la oscuridad de la muerte cuando se apropia de

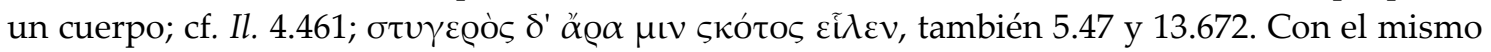

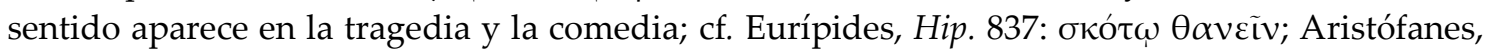

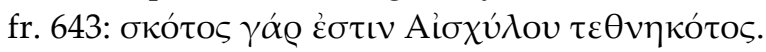

109 Gerber (1999, pág. 415 n. 8): “The meaning of бкótos is uncertain (West renders it as 'bastard'), but Latin tenebrio, describing one who works under cover of darkness, is a close parallel." 
Hiponacte, fr. $196 \operatorname{Dg}^{110}$

...

El manto...

encorvado (?)... te gusta

sentarte cerca; pero eso Hiponacte

es quien mejor lo sabe de los mortales

y lo sabe también Arifanto -jAh, bienaventurado aquel

que nunca te vio,

ladrón, que hueles como una cabra!- Y ahora

peléate con el alfarero Esquilides:

aquél te quitó [tus enseres]

10

pero se ha develado todo el engaño...

Este yambo, que forma parte de los denominados "Epodos de Estrasburgo", 111 integra en último lugar la lista de composiciones con escenografías enunciativas con "el púgil cómico".

El fragmento nos presenta en sus primeras líneas una acusación dirigida contra un ladrón ( $\phi \tilde{\omega} \varrho \alpha, v .8)$, lo que nos lleva a suponer que se trata de la delación pública de un robo. Es posible que el objeto robado sea el manto nombrado en el segundo verso ( $\eta \hat{\chi} \chi \lambda \alpha \tilde{\mathrm{iv}}\left[\alpha\right.$, v. 2). ${ }^{112}$ Los siguientes (vv. 3-4) referirían la metodología utilizada por el ladrón en sus hurtos, tal vez señalando: "te gusta sentarte encorvado cerca de la víctima."113 Todos estos hechos, continúa el yambo, son conocidos por "Hiponacte" y también por Arifanto. Para West (1974, pág. 146) ellos dos "are people who know all about the thief, probably having suffered from him. It is this that prompts the

${ }^{110}$ Transmitido por P. Argent. 3b 2 Reitzenstein.

${ }^{111}$ Vid. sup. pág. 197 (fr. 194Dg).

112 El robo del manto por arrebato es un motivo frecuente en Aristófanes: Av. 498 y 1490; Pax 731; Eccl. 544. Véase también la alusión al robo del manto en el Yambo I (fr. 191.30Pf) de Calímaco, aunque allí se trata de un $\tau \varrho i ́ \beta \omega v$ y no de una $\chi \lambda \alpha \tilde{v} v \alpha ;$ vid. inf. pág. 298 ss.1.2 El enjambre de eruditos (vv. 6-31)

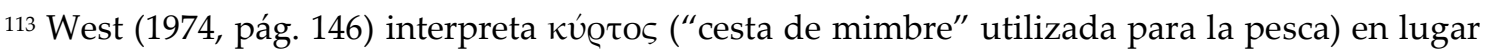

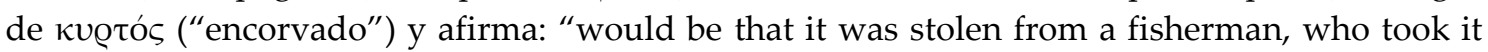

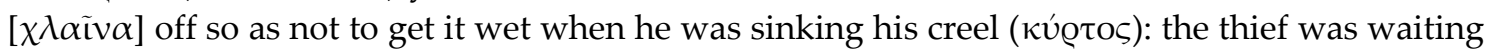
his chance nearby." 


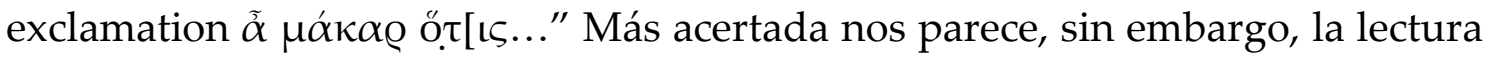
de Degani (2007, pág. 158), quien sugiere que tanto "Hiponacte" como Arifanto serían en realidad testigos presenciales del robo y lo habrían delatado. La parte final del fragmento es de muy difícil interpretación. Es posible que el ladrón, ya desenmascarado, deba pelearse con el alfarero Esquilides, probablemente un damnificado que se ha quedado con sus muebles y enseres en venganza por el robo. ${ }^{114}$ Es posible también, si nos guiamos por los ff. 1-2Dg, que el ladrón sea el mismo Búpalo. ${ }^{115}$

Aunque el fragmento trata de la delación de un robo, podría enmarcarse de cualquier modo dentro de las composiciones que contienen una reyerta callejera por motivos innobles y sin ninguna honra. Los motivos de estas riñas, sus personajes y la descripción de sus acciones, se ubican en el extremo opuesto al heroísmo y la nobleza que definen el ந̃̄os de la poesía épica; sin embargo, la figura del púgil cómico parece ser una reminiscencia del libro 18 de Odisea, en donde se narra que el mendigo Iro, devorador y bebedor sin mesura, pretende expulsar de las puertas del palacio de Ítaca a Odiseo, que oculta su identidad bajo el aspecto de un miserable vagabundo. El pugilato entre estos dos personajes degradados en su condición social constituye inmediatamente una forma de divertimento para los pretendientes, que los rodean para observar la pelea y le ofrecen al vencedor a modo de premio una tripa de cabra asada.

Lo que parece acaparar la atención del auditorio dentro del contexto del simposio arcaico es, sobre todo, el humor de estos yambos.

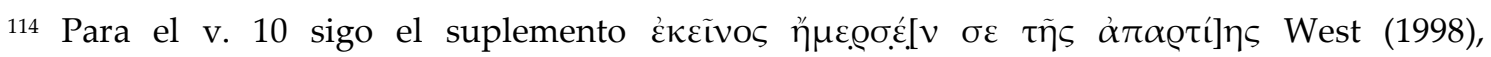
considerado "plausibile, seppur audace" por Degani (2007, pág. 158).

115 Vid. inf. pág. 246.
} 


\section{CONCLUSIONES PARCIALES}

Los yambos agrupados dentro de la escenografía "de pugilato cómico" presentan, al igual que los fragmentos analizados en esta primera parte, una estructura de interlocución. Es posible esquematizar los procesos enuncivoenunciativos de estas composiciones la siguiente manera:

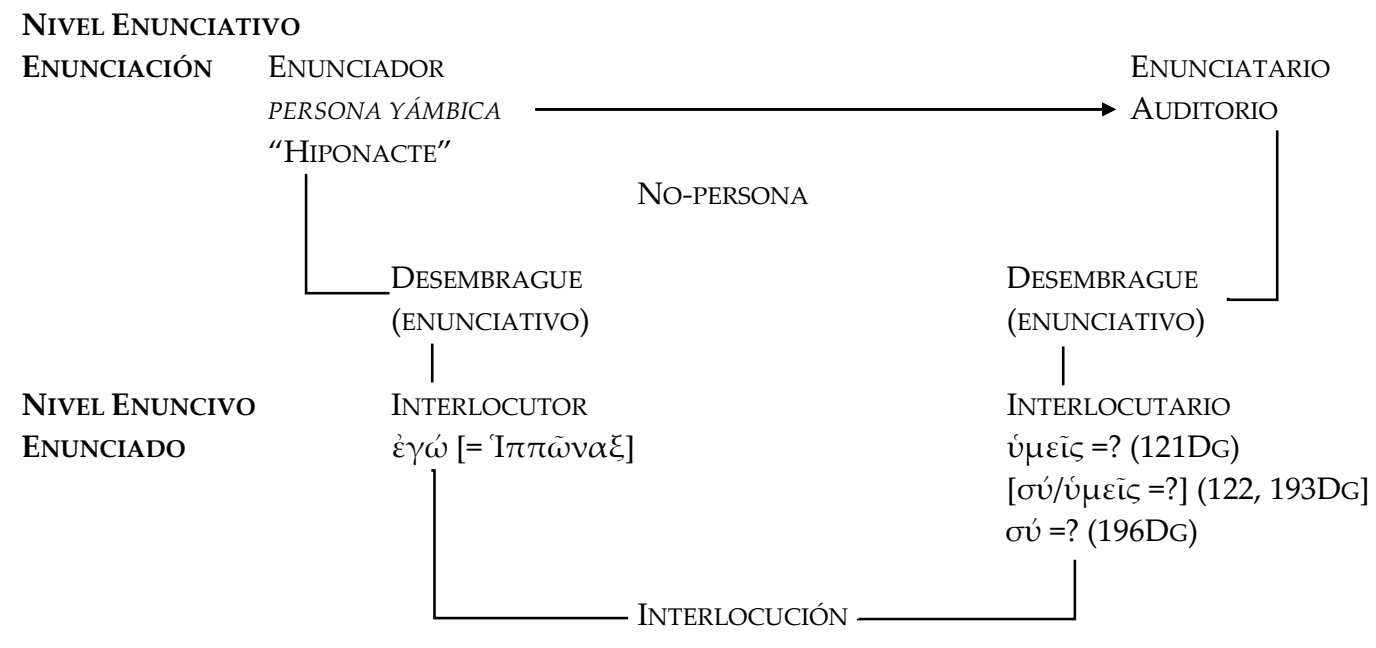

Por medio del desembrague enunciativo se instala en el discurso poético las formas de la enunciación enunciada. En estos casos el interlocutor y el interlocutario se inscriben en el enunciado a través de la deixis pronominal y verbal de la siguiente manera:

Fr. 121. Interlocutor: a través del pronombre posesivo $\mu \varepsilon o$ y de las marcas de primera persona singular del verbo kó $\psi \omega$ (como sujeto agente). Interlocutario: a través de las marcas de segunda persona plural del verbo $\lambda \dot{\alpha} \beta \varepsilon \tau \varepsilon$ (como de sujeto agente).

Fr. 122. Interlocutor: a partir de las marcas de primera persona de los verbos

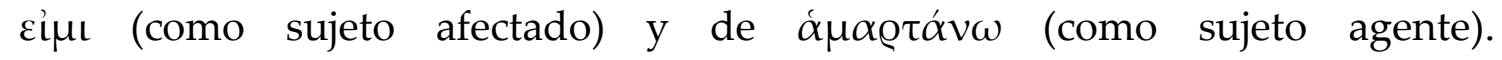
Interlocutario: ninguna.

Fr. 193. Interlocutor: $\mu \varepsilon$ (como sujeto agente del infinitivo $\measuredangle \kappa \alpha ́ \zeta \varepsilon \sigma \theta \alpha \iota)$. Interlocutario: ninguna. 
Fr. 196. Interlocutor: ninguna. Interlocutario: a través de las marcas de segunda

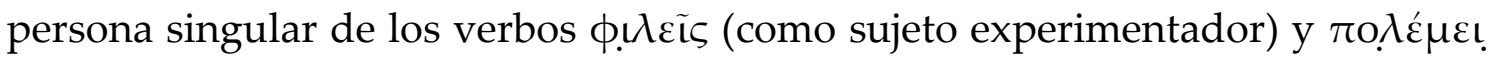
(como sujeto agente); y por la deixis pronominal $\sigma \varepsilon \mathrm{v} .7$ (complemento paciente

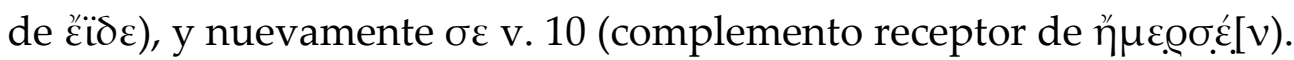

La identidad del interlocutor aparece de manera explícita únicamente en el fr. 196Dg con la mención del nombre $\operatorname{I} \pi \pi \tilde{\omega} v \alpha[\xi$. Nuevamente aquí la sphragis implica una enálage de persona que produce un desdoblamiento del sujeto de la enunciación, ya que este no solo aparece inscripto en primera persona ocupando la posición actancial de interlocutor, sino también aparece en tercera persona a través del nombre propio en nominativo funcionando como sujeto experimentador del verbo o]ĩðcv. Probablemente este recurso de disociación se emplee aquí para focalizar parte del enunciado ante el interlocutario: "pero eso Hiponacte es quien mejor lo sabe de los mortales."

En el resto de los fragmentos la identidad del interlocutor no se puede determinar, pero es posible que este actante establezca una relación de concomitancia con el enunciador "Hiponacte" en tanto máscara yámbica que le permite asumir el rol estereotipado de púgil cómico.

Por su parte, la identidad del interlocutario es más variable y problemática, en primer lugar, a causa de la propia naturaleza oral de la poesía yámbica arcaica, ya que en la instancia de ejecución probablemente no era necesario explicitar a quién se estaba dirigiendo el interlocutor; y, en segundo lugar, por el carácter fragmentario de los textos, que no sabemos si este interlocutario era nombrado en algún otro pasaje de los mismos.

De cualquier modo, en el fr. 196Dg el interlocutario aparece marcado deícticamente en segunda persona singular oú =?, lo cual demuestra que la identidad de este actante mantiene una relación de no-concomitancia con la del enunciatario-auditorio. En el fr. 121Dg la deixis de segunda persona plural $\hat{v} \mu \varepsilon \tilde{\iota} \varsigma=$ ? podría dar la pauta de que la identidad de este actante se corresponde 
en este caso con la del enunciatario-auditorio. Por último, en los ff. 122 y 193Dg el interlocutario no aparece deícticamente, por lo cual este actante podría estar ocupado tanto por una segunda persona singular como así también por una

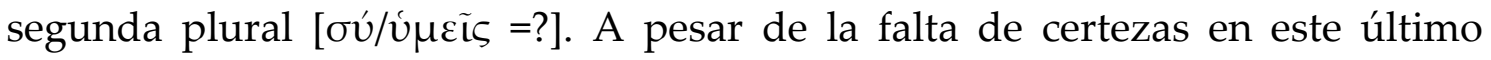
punto, la situación de comunicación del yambo arcaico, es decir la ejecución de un poema breve con acompañamiento de la flauta frente a un auditorio reducido, compuesto por un círculo de compañeros del poeta, dentro del contexto del simposio, nos permite postular que enunciados como "ambidiestro soy y no fallo cuando golpeo" o "De nuevo tengo que pleitear contra el sombrío Metrotimo", poseen en última instancia un interlocutor semejante al de “¡Ténganme la ropa! Golpearé a Búpalo en el ojo.”116 Por esta razón, es posible concluir que en estos fragmentos la identidad del interlocutario aparece en relación de concomitancia con la del enunciatario-auditorio.

\section{ESTRUCTURA NARRATIVA}

En esta sección agrupamos aquellas composiciones del cuerpo hiponacteo que presentan en el enunciado una estructura narrativa y en las que se evidencie la presencia de las posiciones actanciales de narrador y/o narratario. Igualmente, como hemos venido trabajando, reagrupamos los yambos en relación a la similitud de las escenografías que estos presentan.

116 Calame (1995, págs. 33-4): “The enunciatee of this type of poetry generally corresponds to a circle of intimate friends of the enunciator: such a group may have an institutional character, as did Sappho's circle in Lesbos, or be brought together on the occasion of a banquet or symposium, as in the case of the iambic performance." 


\subsection{PAROdia DE LA PLEgaria}

Dentro de los yambos de Hiponacte que reflejan en su enunciado una estructura narrativa, es posible encontrar dos fragmentos (ff. 1-2 y 44Dg) que presentan una situación de súplica o reclamo a una divinidad de manera cómica. La semejanza en el carácter paródico de estas composiciones con aquellas que hemos analizado en la sección de estructura interlocutiva (1.2. LA MÁSCARA DEL SUPLICANTE), ${ }^{117}$ nos permite postular aquí una escenografía similar, a la que hemos denominado "Parodia de la plegaria". Sin embargo, es necesario tener presente que en este caso estamos frente a una forma de comunicación narrativa, no interlocutiva.

\section{A HerMes}

Dentro de esta escenografía, en el fr. 1-2Dg el narrador relata la solicitud de ayuda de un actor desconocido al dios Hermes:

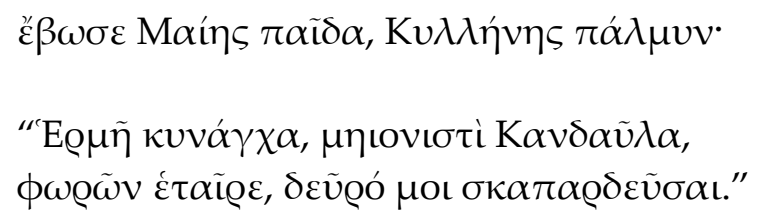

Hiponacte, fr. 2Dg ${ }^{119}$

Clamó al hijo de Maya, sultán de Cilene: “iHermes ahorcaperros, Candaules para los meonios, compañero de los ladrones, ven a ayudarme a tirar de la soga."

Como testimonio de que Hermes es hijo de Maya y de Zeus, Tzetzes (Lyc. 219) acude al ejemplo de Hiponacte que constituye este fr. 1Dg, indicando,

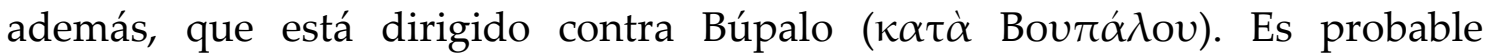
entonces que el narrador esté refiriendo ante el auditorio parte de una plegaria

\footnotetext{
117 Vid. sup. pág. 199.

118 Transmitido por Tzetzes, Lyc. 219 (pág. 102.16-22 Scheer).

119 Transmitido por Tzetzes, Chil. 1.147 (pág. 547 Leone). La reunión de ambos fragmentos fue propuesta por Schneidewin (1839, pág. 49).
} 
del propio Búpalo a Hermes. Este pasaje es muy similar al primer verso del fr. $42 \mathrm{Dg}$, y emplea del término lidio $\pi \alpha ́ \alpha \lambda \mu \nu$, que también está utilizado en el fr. $47 \mathrm{Dg}$, pero en referencia a Zeus.

El fr. 2Dg transmite la tradicional invocación a la divinidad y aquello que el suplicante le solicita. La invocación se vuelve cómica a partir del uso del epíteto kuvá $\gamma \chi \alpha$ "ahorcaperros", otro de los compuestos a los que nos tiene acostumbrados Hiponacte: $\kappa u ́ \omega v-\not ̌ \gamma \chi \eta \varsigma$, relacionado con Hermes en tanto

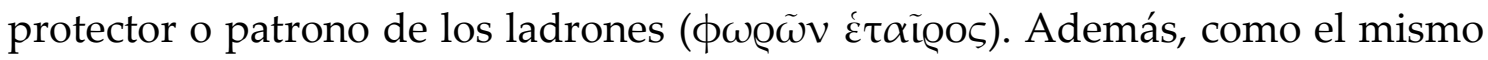
fragmento parecería manifestarlo, sería una traducción de la voz lidia

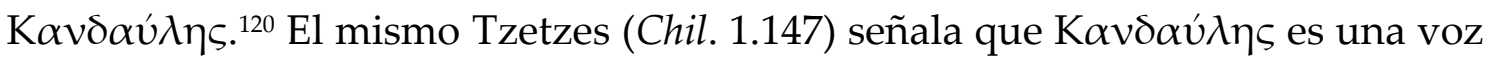

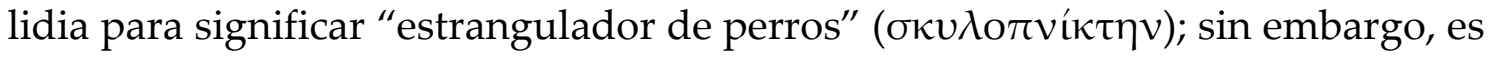
posible que el término K $\alpha v \delta \alpha u ́ \lambda \eta \varsigma$ no tenga propiamente el significado que Tzetzes le atribuye, y haya en cambio algún proceso de sincretismo entre la divinidad griega y alguna divinidad asiánica, tal vez un dios al que le sacrificaban perros. ${ }^{121}$

En la última línea del fragmento, el narrador nos transmite lo que Búpalo le estaría solicitando a Hermes: $\delta \varepsilon \tilde{v} \varrho o ́ ~ \mu o เ ~ \sigma \kappa \alpha \pi \alpha \varrho \delta \varepsilon \tilde{v} \sigma \alpha \iota$. El significado de la expresión y particularmente del verbo $\sigma \kappa \alpha \pi \varepsilon \varrho \delta \varepsilon v ́ \omega$ ha sido muy discutido.

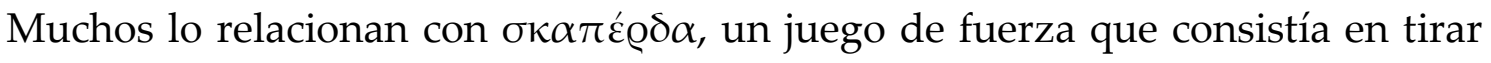
de una soga, similar a los que se juegan hoy en día; sin embargo, en este caso, solamente lo jugaban dos oponentes ubicados de espaldas, cada uno de ellos atado por el extremo de la soga a la altura del pecho. La soga atravesaba un agujero en un pilar de madera a una altura mayor que la de los contendientes.

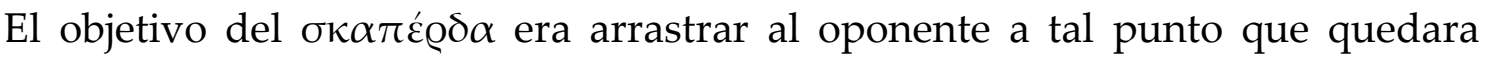

${ }^{120} \mathrm{~K} \alpha v \delta \alpha u ́ \lambda \eta \varsigma$ es también el nombre del último rey de la dinastía Heráclida, destronado por Giges (c. 680 a. C.); cf. Arquíloco, fr. 23W.

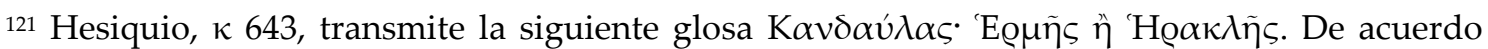
con Masson (1962, pág. 105), la divinidad asiánica *kan-daules podría ser "un dieu-loup (...), probablement un dieu de la guerre, auquel on sacrifiait des chiens." Véase también Ianovitz (1970). 
colgando de espaldas al pilar. ${ }^{122}$ Hay también quienes consideran que podría

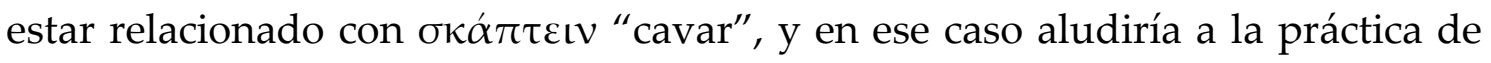
los ladrones de excavar agujeros para pasar al otro lado del muro de una casa. ${ }^{123}$

Si se acepta la primera interpretación, el pedido debe entenderse de manera metafórica "ayúdame a tirar de la soga", es decir "échame una mano"; por el contrario, si se sigue la segunda interpretación, entonces debe comprenderse de manera literal "ayúdame a cavar." De cualquier modo, Búpalo está solicitando a Hermes, en tanto protector de los ladrones, que lo ayude con algún tipo de robo.

\section{EL DIOS DE LA RIQUEZA}

Si bien este yambo no contiene propiamente la narración de la invocación a una divinidad con un fin petitorio, es posible considerarlo dentro de esta categoría porque en cierta forma el narrador presenta de manera satírica la actitud poco favorable que ha tenido el dios de la Riqueza para con él. La escena aparece enfatizada a partir de un discurso referido en estilo directo, en el cual el narrador hace hablar a esa divinidad en primera persona, aunque, como él mismo lo anticipa a su narratario, son palabras que el dios de la Riqueza jamás le dirigió:

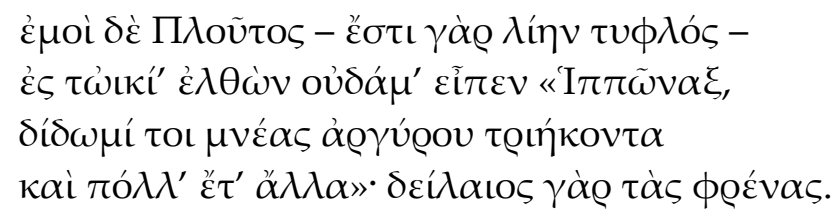

Hiponacte, fr. $44 \operatorname{Dg}^{124}$

A mí, Riqueza -como está del todo ciego-, jamás, luego de venir a casa, dijo: “Hiponacte, te entrego treinta monedas de plata y también muchas otras cosas más". ¡Qué mezquino es de sentimientos!

${ }^{122}$ Cf. Pólux, Onom. 9.116 (vol. 2, pág. 179 Bethe), y Hesiquio o 854.

123 Para ambas conjeturas véase Degani (1991, pág. 25).

124 Transmitido por Tzetzes, ad Ar. Pl. 87 (pág. 30b.1 Massa Positano). 
Esta es la primera referencia literaria de la ceguera del dios de la Riqueza, tema que, como señala Tzetzes al transmitir el fragmento, será ampliamente explotado por Aristófanes en Pluto. Al igual que Crémilo al inicio de la comedia, "Hiponacte" se queja aquí porque el dios jamás llegó hasta su casa para hacerlo rico. En este yambo, como en la mayoría de las composiciones de Hiponacte que parodian la poesía petitoria, el narrador aparece como un mendigo que se lamenta por sus carencias materiales.

\section{CONCLUSIONES PARCIALES}

Dentro de un encuadre narrativo, las escenografías de poesía petitoria que presentan los ff. 1-2 y 44Dg son idénticas, sin embargo, hay una diferencia en el proceso de disyunción que se da desde la instancia de enunciación hacia el enunciado. Por esta razón, es necesario distinguir en este caso particular las dos composiciones a partir de dos esquemas diferentes: 


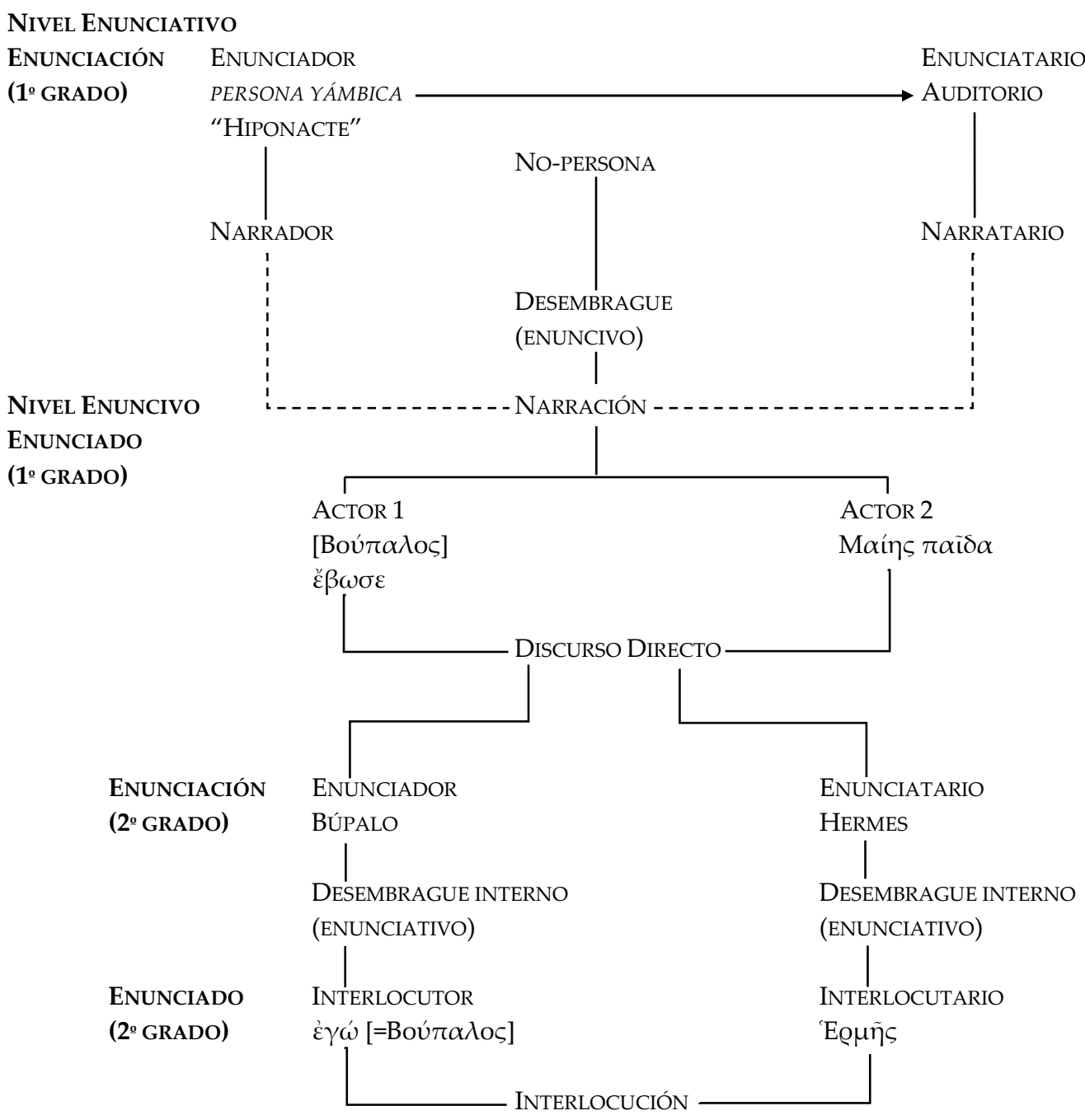

A diferencia de los yambos analizados anteriormente, en esta composición se puede apreciar que el proceso de disyunción desde la instancia de la enunciación primaria hacia el enunciado primario se produce a través de un desembrague de tipo enuncivo que inscribe en el discurso poético las formas del enunciado referido. ${ }^{125}$ Es decir, ni el narrador ni el narratario aparecen en este caso inscriptos en el enunciado, pero se presuponene en tanto destinador y

125 Greimas y Courtés (1990, págs. 113-4). 
destinatario de la narración y se remiten a los actantes enunciador y enunciatario, respectivamente. ${ }^{126}$

Dentro del nivel enuncivo, las marcas de tercera persona del verbo $\varepsilon ̋ \omega \sigma \varepsilon$ instalan directamente en el enunciado a la no-persona de la enunciación. La narración involucra dos actores, en primer lugar, como hemos argumentado en el análisis, [Boú $\pi \alpha \lambda$ $\alpha$ ] que aparecería en nominativo cumpliendo la función sintáctico-semántica de sujeto agente del verbo ع̋ $\beta \omega \sigma \varepsilon$; en segundo lugar, el otro actor es Maíns $\pi \alpha \tilde{i} \delta \alpha$ (Hermes) que aparece en acusativo funcionando como complemento receptor del predicado verbal.

El verbo $\check{\beta} \beta \omega \sigma \varepsilon$ introduce un discurso directo que inaugura una nueva situación de comunicación. Pero para que estos dos dominios enunciativos coexistan es necesario que se produzca un desembrague interno que permita desacoplar el sistema de referencias de la enunciación de $1^{\text {o }}$ grado, ligada al enunciador primario, y establecer un nuevo sistema de referencias propio de la enunciación de $2^{o}$ grado, con sus propios actores y actantes. En este caso el desembrague interno es de tipo enunciativo ya que instala las formas discursivas de la enunciación enunciada. De este modo, Búpalo y Hermes, que en la instancia primaria de enunciación constituían la no-persona, en la instancia secundaria pasan a tener el estatuto de "persona".

La enunciación de $2^{\underline{o}}$ grado se presenta como una estructura de interlocución entre Búpalo y Hermes en una escenografía de poesía petitoria. El interlocutor aparece marcado deícticamente por el pronombre $\mu \mathrm{ol}$ en la función de complemento beneficiario, en tanto que el interlocutario, si bien no aparece señalado por deixis de persona, se presupone en reciprocidad solidaria a todo acto de comunicación intersubjetiva.

${ }^{126} \mathrm{Al}$ no aparecer inscriptos deícticamente en el enunciado, situamos al narrador y al narratario en el nivel enunciativo y no en el nivel enuncivo, y establecemos sus vínculos en tanto destinador y destinatario de la narración a través de líneas discontinuas. 
En cuanto a las identidades de los actantes y actores de la interlocución y la narración, partiendo de lo más evidente, se puede observar que el interlocutario se manifiesta explícitamente a través del vocativo apelativo

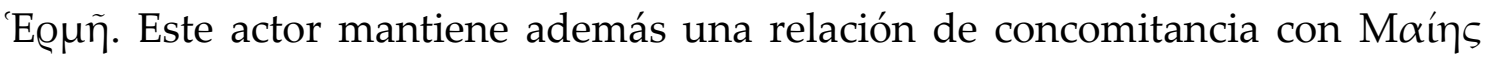
$\pi \alpha \tilde{i} \delta \alpha$, complemento receptor del verbo $\varepsilon \beta \omega \sigma \varepsilon$ en el plano de la narración, pero esta correspondencia no se hace extensiva al narratario, identificado con el auditorio en el nivel de la enunciación poética.

Por su parte, como hemos visto, la identidad del interlocutor no se revela explícitamente en la interlocución, pero es posible establecer una relación de concomitancia entre este interlocutor y el Actor 1, sujeto agente del verbo $\varepsilon \Leftarrow \beta \omega \sigma \varepsilon$ en el plano de la narración. Finalmente, y al igual que en el caso anterior, la relación de identidad que se establece entre este actor y el narrador es, obviamente, de no-concomitancia. 


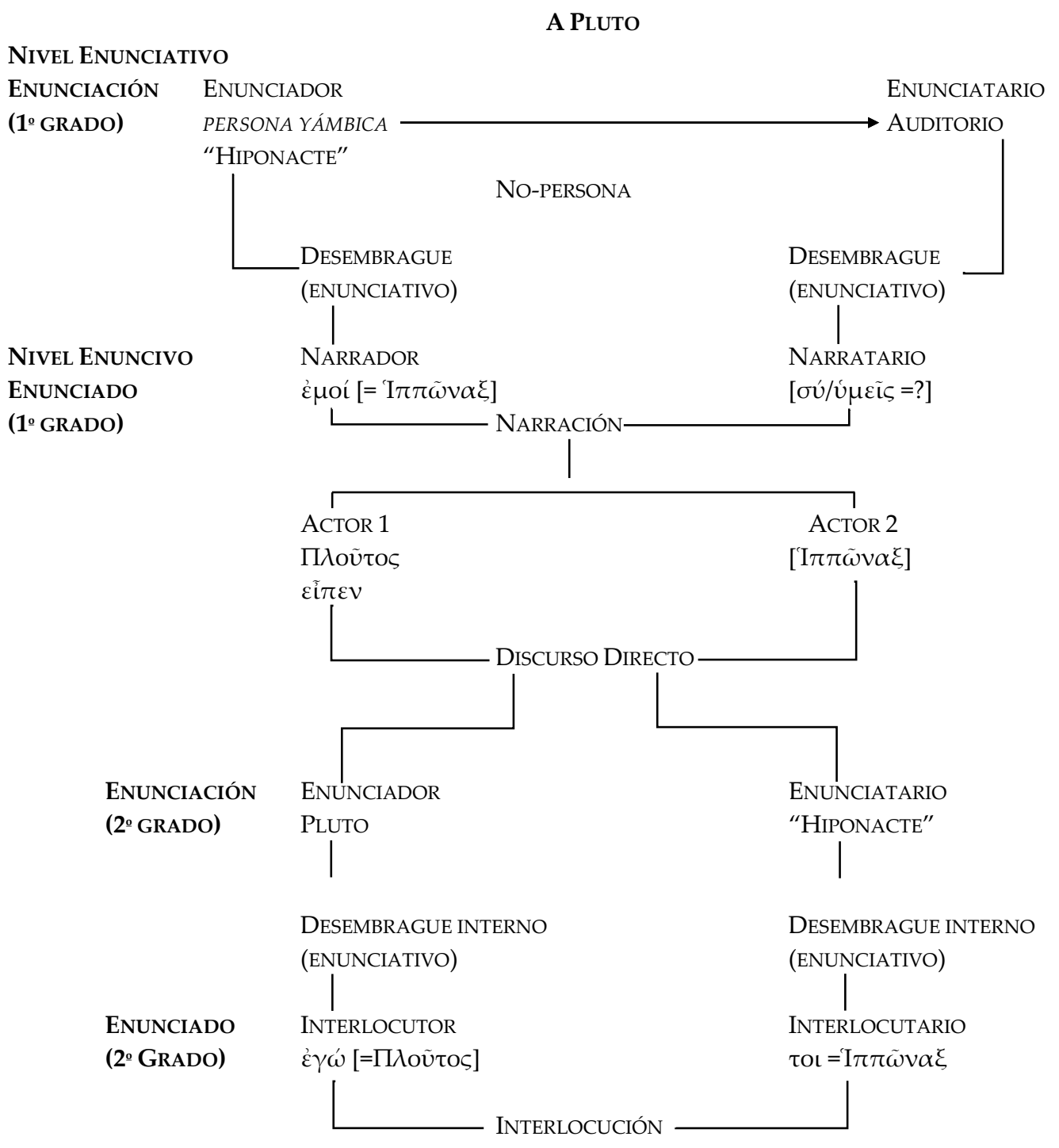

A diferencia del fragmento anterior, en este yambo se puede observar que el proceso de disyunción desde la instancia de enunciación de $1^{\text {o }}$ grado hacia el enunciado se produce por medio de un desembrague enunciativo, instalando en el discurso las formas de la enunciación enunciada. En este caso el narrador se inscribe deícticamente en el enunciado primario a través de la deixis pronominal غ̇uoí en la función sintáctico-semántica de complemento

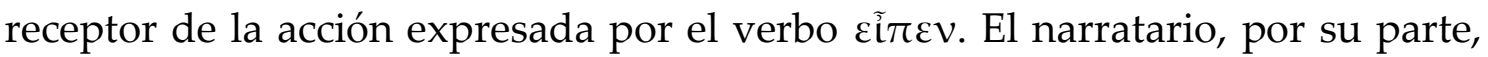
no aparece marcado deícticamente, pero se presupone en reciprocidad solidaria

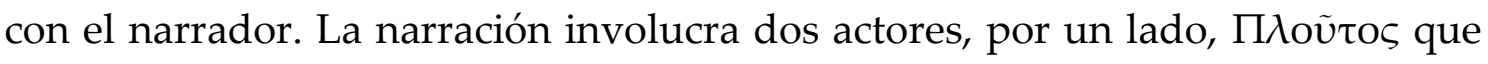
aparece en nominativo cumpliendo la función sintáctico-semántica de sujeto 
agente del verbo $\varepsilon \tilde{\tau} \pi \varepsilon v$; por otro lado, [I $\operatorname{I} \pi \tilde{\omega} v \alpha \xi]$ que aparece, como se ha indicado, a través del pronombre èmoí.

El verbo عĩ $\varepsilon \varepsilon v$ en tanto verbum dicendi introduce un discurso referido en estilo directo que inaugura una nueva instancia de enunciación. Nuevamente se produce un desembrague interno de tipo enunciativo que presenta el simulacro de una nueva situación de comunicación en $2^{\underline{o}}$ grado. Esta enunciación secundaria tiene una estructura interlocutiva, en la que interlocutor aparece marcado deícticamente por el verbo $\delta i ́ \delta \omega \mu \mathrm{l}$, en la función sintácticosemántica de sujeto agente, en tanto que el interlocutario se inscribe en el enunciado secundario a través del pronombre toı como complemento receptor de $\delta i ́ \delta \omega \mu$.

En cuanto a las identidades, se puede observar dentro del enunciado de $2^{\underline{o}}$ grado que la posición actancial de interlocutario aparece de manera explícita

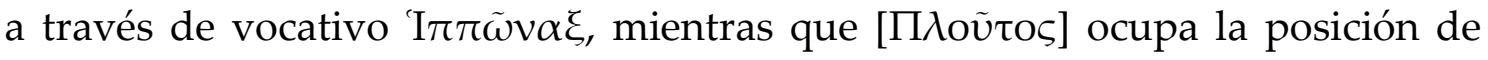
interlocutor. Por lo tanto, la relación de concomitancia en este caso se da entre el narrador y el interlocutario (=I $\pi \pi \tilde{\omega} \nu \alpha \xi)$.

Es necesario señalar, sin embargo, que el mismo narrador aclara a su narratario que la escena del encuentro con Pluto jamás sucedió, es decir que la interlocución que él presenta es en cierta forma idílica para el suplicante. El hecho mismo de no haber sucedido, al igual que la alusión a la ceguera de Pluto, realzan la ironía del yambo.

Como se ha podido observar en estos dos últimos fragmentos, la máscara paródica del suplicante es un atributo empleado por la persona yámbica “Hiponacte" con el objetivo de realizar una crítica humorística contra el $\varepsilon \chi \theta \varrho o ́ \varsigma$ (fr. 1-2Dg). Dentro de la narrativa, este personaje estaría dirigiendo una súplica a Hermes para que lo ayude a salir de una situación comprometida, tal vez en ocasión de un robo. Esta máscara también es empleada por "Hiponacte" para poner de manifiesto cómicamente la indiferencia de Pluto para con él. 


\subsection{NARRATIVAS SEXUALES}

Tres fragmentos pueden ser agrupados dentro de una escenografía que tiene como temática la narrativa sexual o erótica, y los tres presentan como partenaire del narrador a una mujer llamada Arete:

\section{ARETE}

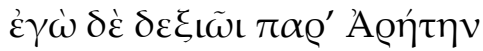

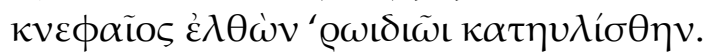

Hiponacte, fr. $23 \operatorname{Dg}^{127}$

y yo, tras llegar en la oscuridad con la garza

a la derecha, me alojé en casa de Arete.

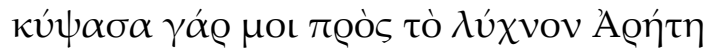

Hiponacte, fr. $24 \operatorname{Dg}^{128}$

en cuatro patas junto al candil Arete me...

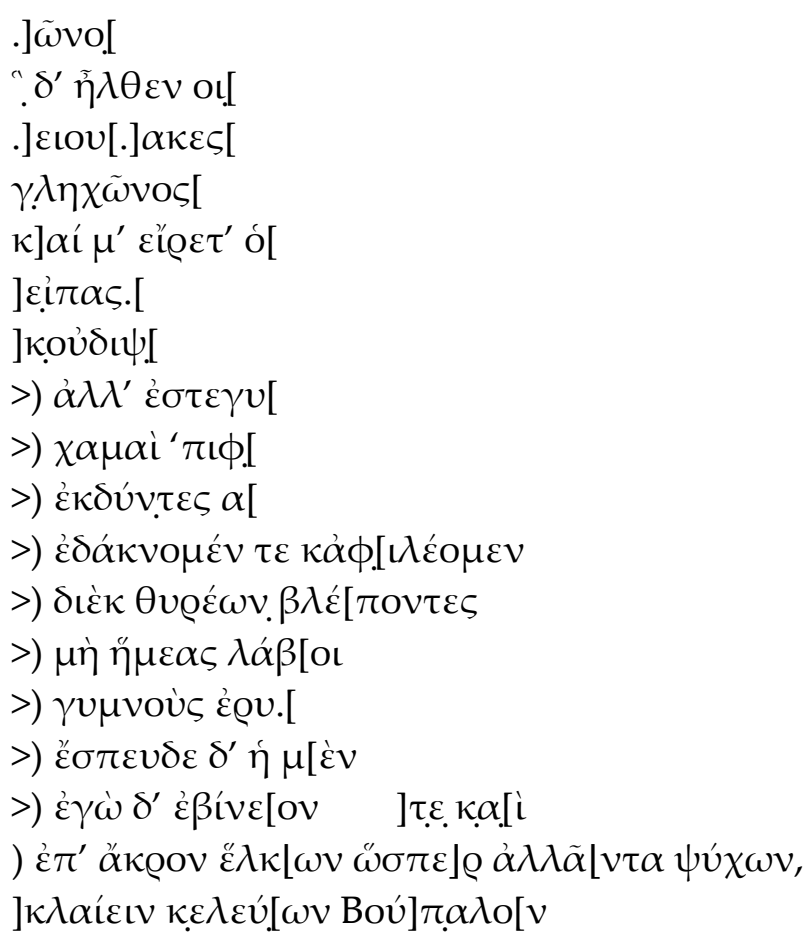

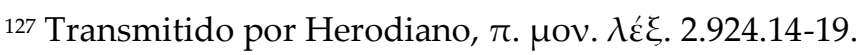

${ }^{128}$ Transmitido por Et.G $\lambda 156$ Adler-Alpers (pág. 36 Calame). 


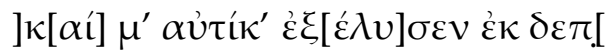

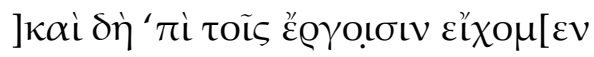

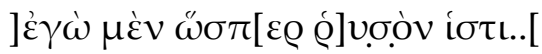

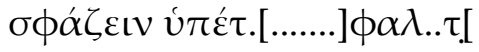

Hiponacte, fr. $86 \operatorname{Dg}^{129}$

..

...llegó...

... remedio (?)

de (su) poleo... ${ }^{130}$

y me preguntó el...

diciendo...

...y no...

sino...

en el suelo...

luego de quitarnos la ropa...

nos mordíamos y nos besábamos,

mientras mirábamos a través de la puerta...

no nos fuera a atrapar...

desnudos...

ella se apresuraba...

y yo (me la) cogía... y ...

y arrastraba hasta la punta (el prepucio?) como frotando una morcilla...

... mandé a la mierda a Búpalo...

e inmediatamente me apartó...

continuábamos con los movimientos...

yo... como una vela plegada...

degollar..

Búpalo aparece vinculado a Arete en varios yambos de Hiponacte. Particularmente en el fr. 20Dg se lo llama "el que coge con su madre" ( llevado a pensar que ella era la madre de Búpalo y, por ende, también la de Atenis. En el fr. 69Dg también es acusado de "saquear el erizo a su madre mientras ella duerme."131 Dada la incriminación de incesto, es posible que el

129 Transmitido por P.Oxy. 2174 fr. 16 col. 2.

${ }^{130}$ De acuerdo con Aristófanes, Lys. 89, es probable que $\gamma \lambda \eta \dot{\eta} \chi \omega \nu$ (át. $\beta \lambda \eta \dot{\chi} \chi \omega \nu$ ) refiera aquí al vello púbico; véase Henderson (1991, pág. 135).

${ }^{131}$ Vid. sup. pág. 229 n. 87. 
nombre Arete tuviera alguna relación con la reina de los feacios, la esposa de Alcínoo. En Od. 7.53-68 se dice que Arete desciende de los mismos padres que engendraron al rey Alcínoo y se detalla esa genealogía: Posidón tuvo a Nausítoo con Peribea, hija de Eurimedonte, rey de los gigantes; Nausítoo, rey de los feacios, tuvo dos hijos, Rexénor y Alcínoo; el primero murió joven y dejó una hija, Arete, con la cual se casó Alcínoo. Por lo tanto, la relación de parentesco entre los esposos es de tío paterno y sobrina. ${ }^{132}$ Es curioso además que nuevamente se vuelva sobre el pasaje de $O d$. 7, al cual se alude en el fr.

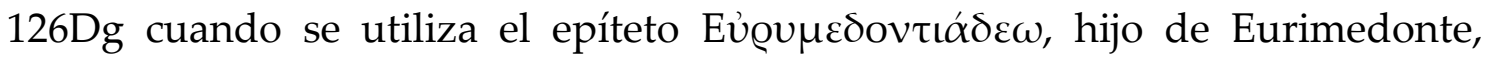
probablemente referido a Búpalo. ${ }^{133}$

Sin embargo, no sería tampoco desacertado pensar que, a pesar de la

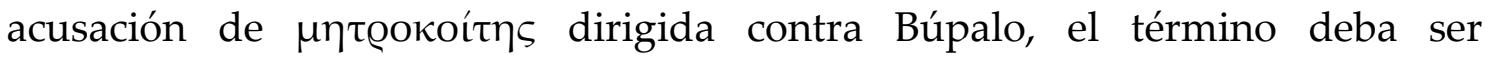
comprendido como un insulto sin más dentro de una situación de difamación escenificada a partir de distintos pasajes de Odisea. Es decir, no importa si realmente Búpalo se acostaba con su madre o no, lo importante es que

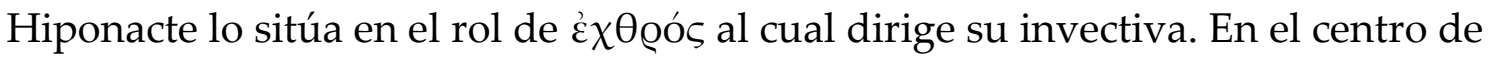
la disputa de estos dos contrincantes sexuales se ubica Arete. Es a esta mujer a quien se le reprocha haber "convivido" con Búpalo en el fr. 18Dg. ${ }^{134}$

En el fr. 23Dg, el narrador cuenta haber llegado en medio de la oscuridad, con la garza a la derecha (es decir, de manera auspiciosa ya que la garza era considerada un augurio favorable), seguramente para pasar la noche con Arete. Una vez más recurre a la alusión paródica de la épica homérica: en Il. 10.274-76, correspondiente al pasaje conocido como "Dolonía", Odiseo y

${ }^{132}$ Cf. Schol. Hom. Od. 7.54 (= Hesíodo, fr. 222), donde se dice que Hesíodo tomó a Arete por

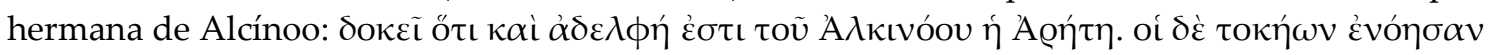

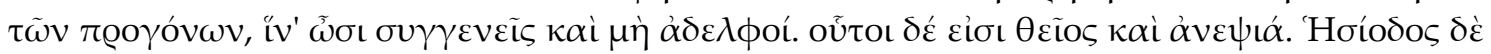

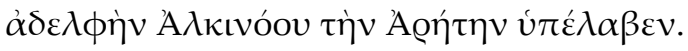

133 Vid. sup. pág. 216.

${ }^{134}$ Vid. sup. pág. 225. 
Diomedes salen del campamento aqueo en una misión nocturna contra los troyanos, cuando a la derecha del camino oyeron una garza ( $\delta \varepsilon \xi \grave{\xi}$ òv $\varepsilon € \omega \delta\llcorner o ̀ v)$,

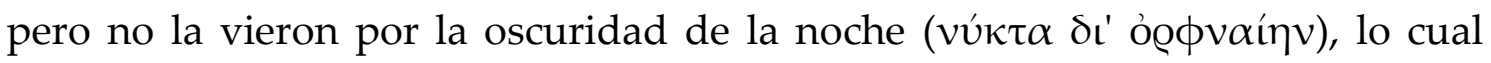
Odiseo interpreta como un buen augurio y lo atribuye a la compañía de Palas Atenea. La comicidad paródica de este pasaje se produce a partir del contraste entre el carácter bélico de la empresa de Odiseo frente a la visita nocturna de

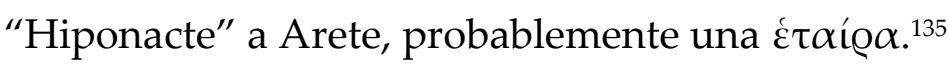

En el fr. 24Dg el narrador describe a Arete en una posición sexual, de rodillas, realizando una felación a "Hiponacte."136

Por último, el fr. 86Dg narra de manera explícita y directa un episodio sexual semejante al del "Epodo de Colonia" de Arquíloco. ${ }^{137}$ Desnudos,

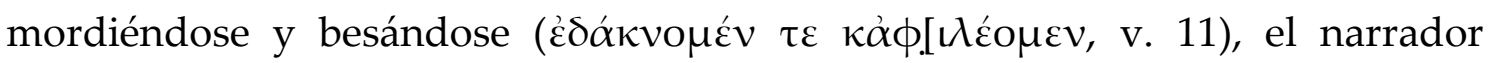
describe el encuentro erótico entre él y la mujer con términos e imágenes deliberadamente vulgares: el verbo $\beta \mathrm{t} v \varepsilon ́ \omega(\mathrm{v}$. 16) es una voz claramente obscena para denotar la realización del acto sexual, ${ }^{138}$ y la comparación, en el verso siguiente, del miembro masculino con una morcilla ( $\dot{\alpha} \lambda \lambda \tilde{\alpha} \varsigma)$ que se frota al realizar el embutido para distribuir parejamente el relleno, en una metáfora que claramente pertenece al humor obsceno que asimila los órganos sexuales masculinos y femeninos a diversos tipos de comidas y productos comestibles. ${ }^{139}$

135 Para la parodia de la "Dolonía" homérica en este fragmento, véase Miralles \& Pòrtulas (1988, pág. 45).

${ }^{136}$ Cf. Henderson (1991, pág. 22).

${ }^{137}$ Vid. sup. pág. 153 ss.

${ }^{138}$ Cf. Henderson (1991, págs. 150-1): “The vulgar vox propria for sexual intercourse in comedy is $\beta เ v \varepsilon \tilde{\imath} v$, which seems to have had the same force and flexibility in Greek as fuck does in English. The connotation is always of violent and/or illicit intercourse."

139 Aunque en la comedia antigua no hay casos en que el término $\dot{\alpha} \lambda \lambda \tilde{\alpha} \varsigma$ sea empleado en referencia al miembro masculino, en Aristófanes, Equ., aparece por supuesto el "Morcillero" (A $\lambda \lambda \alpha \nu \tau 0 \pi \omega \dot{\omega} \eta \varsigma)$, y existen varias alusiones obscenas que juegan con el campo semántico del proceso de producción de la morcilla; cf. Equ. 146; 161; 364; 1242. Véase también Henderson (1991, págs. 144; 152; 179-180; 186). 
El encuentro sexual entre "Hiponacte" y Arete es evidentemente

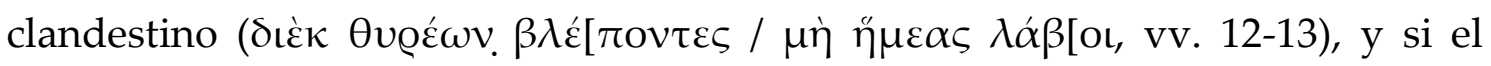

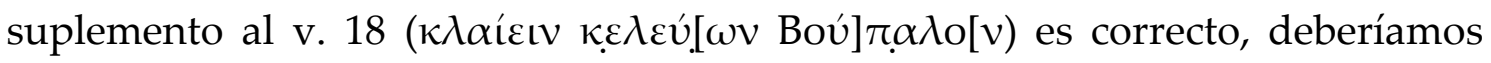
pensar que el carácter ilícito se debe a la figura de Búpalo. Es probable que el narrador, "Hiponacte", describa los encuentros sexuales que mantiene con la misma mujer con la que Búpalo se relaciona. De este modo, "Hiponacte" ubica

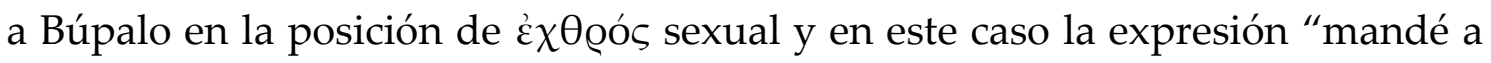
Búpalo a la mierda" podría estar indicando que en esta rivalidad "Hiponacte" se jacta de haber superado a Búpalo ("el que tiene el falo como un buey"). ${ }^{140}$ Una alusión interesante a este verso aparece una vez más en Aristófanes, Equ. 433-34. Allí, en el agón entre Paflagonio y el Morcillero, el primero, ya cansado de las acusaciones e insultos, amenaza al Morcillero con lanzarse sobre él como un vendaval que sacude tierra y mar; a lo cual el Morcillero le responde:

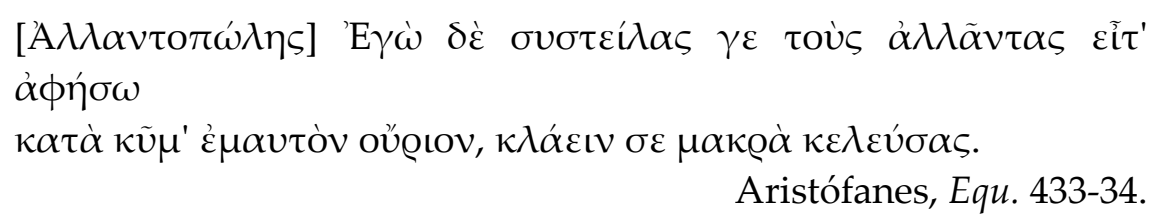

[Morcillero] Y yo plegaré... las morcillas y me dejaré llevar por el oleaje a favor del viento mandándote al cuerno. ${ }^{141}$

El v. 18 del yambo de Hiponacte aparece aquí casi de manera calcada, y también el motivo del v. 21 referido a "plegar las velas/morcillas", aunque en este caso los verbos utilizados por Hiponacte y Aristófanes son diferentes. Esta imagen alude evidentemente a la flaccidez del miembro viril luego del acto sexual. ${ }^{142}$

\footnotetext{
${ }^{140}$ Cf. Rosen (1988, pág. 39).

${ }^{141}$ Traducción de Luis Gil Fernández (1995, pág. 274).

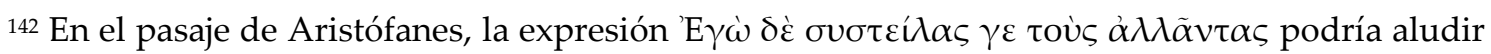
tanto a la flaccidez del miembro viril como a la cobardía del Morcillero ante la amenaza de Paflagonio; esto parece confirmarlo además la intervención de Demóstenes, el instigador del
} 
Finalmente, como se ha observado con anterioridad, hay una recurrencia de juegos de palabras, composiciones léxicas, préstamos y derivaciones etimológicas en los yambos de Hiponacte, en muchos casos destinados al doble sentido de los nombres, como por ejemplo Sano, Búpalo, Metrotimo, Esquilides, Arifanto, que es posible por lo tanto que este doble sentido también sea empleado aquí con el nombre de la mujer en disputa, Arete "virtud", a consecuencia de lo cual podría derivarse una interpretación en torno a la rivalidad artística entre el poeta y el escultor.

\section{CONCLUSIONES PARCIALES}

Como se ha podido observar, estos yambos de estructura narrativa presentan una escenografía explícitamente sexual en la que el narrador se inscribe deícticamente ocupando una posición actancial dentro del relato. Es posible esquematizar los procesos enucivo-enunciativos de estas composiciones de la siguiente manera:

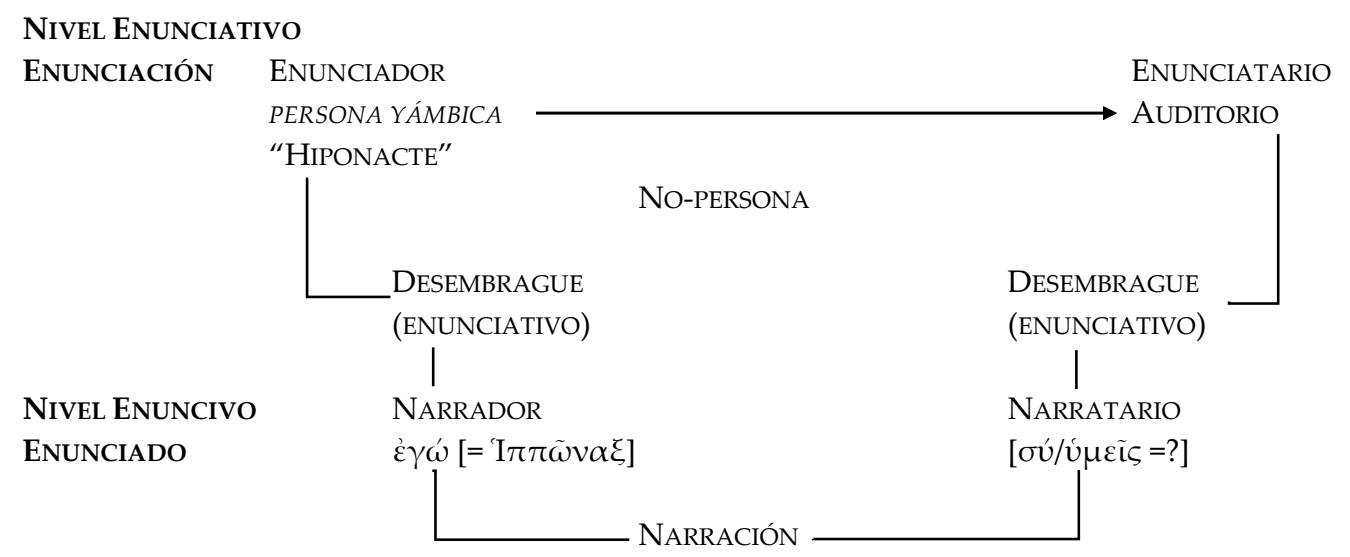

A través del proceso de desembrague enunciativo se instalan en el discurso poético las formas de la enunciación enunciada. Los actantes de la

Morcillero, en la línea inmediatamente posterior, Equ. 434: “Y yo, por si hay una vía de agua,

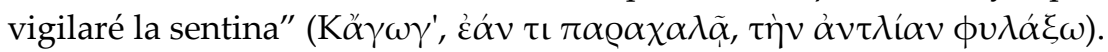


enunciación enunciada se inscriben deícticamente a través de las siguientes formas pronominales y verbales:

Fr. 23. Narrador: $\dot{\varepsilon} \gamma \omega$ (sujeto agente de $\kappa \alpha \tau \eta \cup \lambda i ́ \sigma \theta \eta v)$. Narratario: ninguna, no aparece marcado, pero se presupone en reciprocidad solidaria con el narrador.

Fr. 24. Narrador: $\mu \mathrm{ol}$ (probablemente en la función de receptor de la acción expresada por un verbo que se ha perdido). Narratario: ninguna.

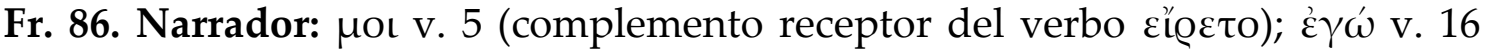

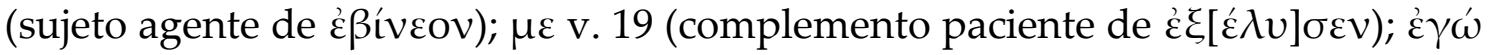
v. 21 (probablemente sujeto agente de un verbo que se ha perdido); y por el

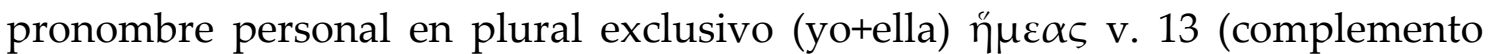

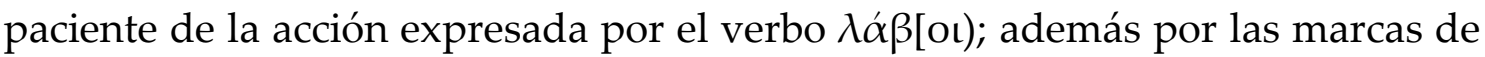

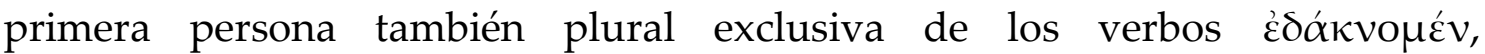

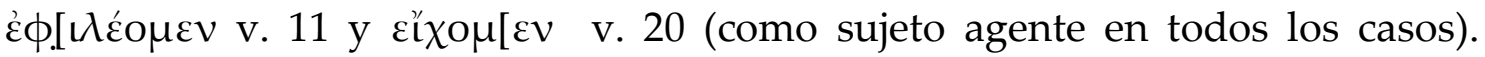
Narratario: ninguna.

En estos fragmentos la identidad del narrador no aparece de manera explícita en el enunciado. Sin embargo, la primera persona en estos yambos, y a lo largo de todo el corpus de Hiponacte en general, refleja una notable consistencia como actor estereotipado. En este caso asume el papel de amante viril dentro de episodios explícitamente sexuales, semejante al rol de "Arquíloco" en las composiciones que involucran a las licámbidas. ${ }^{143}$ Por otro lado, el tándem que constituyen Arete y Búpalo, la posible aparición del nombre de este último en el fr. $86 \mathrm{Dg}$ (Boú] $\pi \alpha \lambda \mathrm{o}[v$ ) y la recurrencia de esta

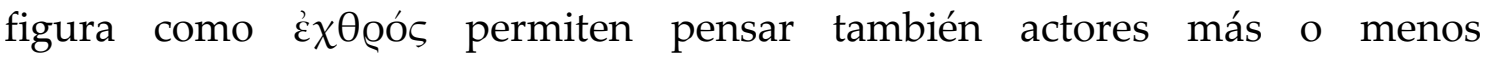
estereotipados para determinadas posiciones actanciales. En este caso, particularmente la posición de narrador sería asumida por "Hiponacte" con el fin de realizar una invectiva contra su adversario sexual.

La ausencia de elementos incompatibles, como así también la fuerte similitud entre las máscaras actoriales que asume la primera persona, sugiere 
que la identidad de ese narrador mantiene una relación de concomitancia con la de la persona yámbica "Hiponacte".

Por su parte, la identidad del narratario tampoco aparece explícitamente en el enunciado narrativo de estos fragmentos, pero de acuerdo con la situación de ejecución del yambo arcaico es posible sostener que la identidad del narratario en estas composiciones aparece en concomitancia con la del enunciatario-auditorio.

\subsection{INVECTIVA PERSONAL}

Aunque es difícil considerar una invectiva personal por fuera de la estructura de interlocución, dada la usual apelación a la persona que se busca insultar, hemos consignado aquí un fragmento que podría ser analizado dentro de un encuadre narrativo. En este yambo dos interlocutores se desean la muerte el uno al otro:

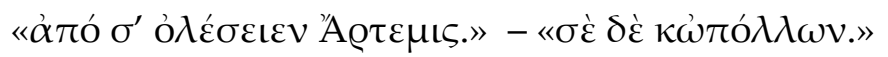

Hiponacte, fr. 35Dg ${ }^{144}$

—«Que Ártemis te liquide». — «Y a ti Apolo».

Es posible suponer que esta interlocución se inserta dentro de un encuadre narrativo como discursos referidos de manera directa. El narrador estaría relatando a su narratario aquello que cada uno de los interlocutores se dijeron. En esta composición es interesante por lo tanto el formato de la $\dot{\alpha} v \tau \iota \lambda \alpha \beta \eta ́$ o división de los discursos entre los interlocutores.

Aunque no es posible conocer la identidad de estos interlocutores, ni siquiera se puede afirmar que uno de ellos aparezca identificado con el narrador, sí se puede deducir que se trata de un hombre y de una mujer, respectivamente. En las intervenciones de Apolo y Ártemis como dioses ${ }^{144}$ Transmitido por Tzetzes, Exeg. Il. A 25 (pág. 83.25-84.2 Hermann). 
vengadores, particularmente cuando se trata de vengar una ofensa dirigida a Leto, la madre de ellos dos, o al representar simplemente el deceso de los individuos, los hombres son ejecutados por el dios, mientras que las mujeres por su hermana. ${ }^{145} \mathrm{~A}$ partir de esto, el hombre estaría deseándole a la mujer que Ártemis se desquite con ella, y la mujer que Apolo haga lo mismo con él. En Aristófanes, Equ. 2-3, Demóstenes lanza un deseo semejante en contra de Pafaglonio: “¡Ojalá! acaben los dioses malamente con ese malvado recién

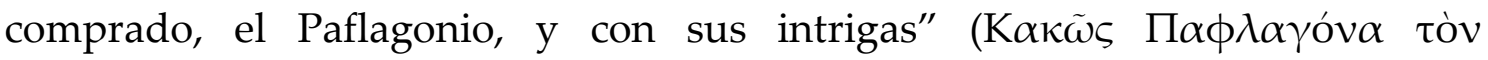

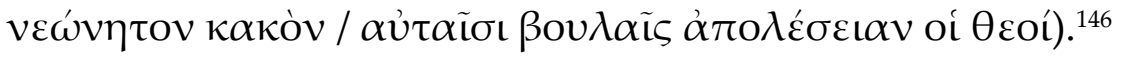

\subsection{EL PUGILATO CÓMICO}

Obviamente, la estructura narrativa es más apropiada al relato de situaciones de disputas y peleas callejeras que a la exposición de invectivas personales; sin embargo, la escenografía enunciativa del pugilato cómico conlleva en sí misma invectivas y ataques personales contra el $\dot{\varepsilon} \chi \theta$ oós. Dentro de esta categoría podemos reunir los ff. 79, 107, 132Dg:

Fr. 79DG

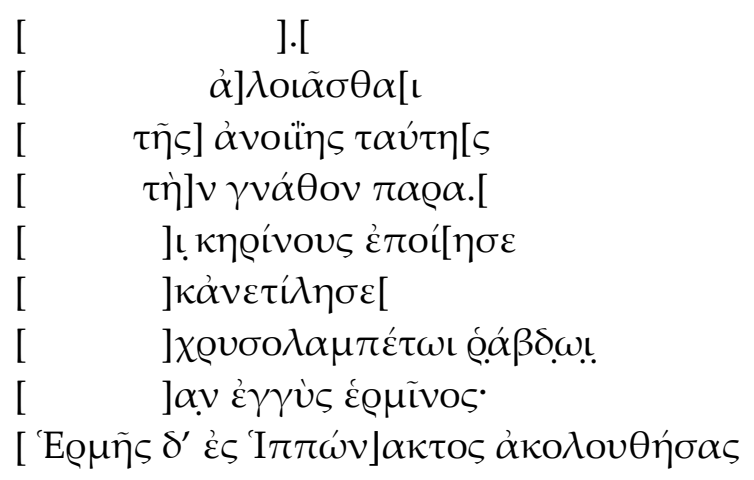

145 Cf. Homero, Il. 24.605-9, donde se narra la ejecución de los hijos varones de Níobe por parte de Apolo y de las hijas por parte de Ártemis, en venganza de que ella se había jactado de haber dado a luz muchos más hijos que Leto. También en Od. 15.409-11, Eumeo le cuenta a Odiseo que en la isla Siría, de donde él proviene, cuando hombres y mujeres llegaban a la ancianidad, Apolo y Ártemis les daban muerte con sus flechas.

146 Traducción de Luis Gil Fernández (1995, pág. 243). 


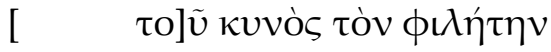

[ ] ] ] [

[ $\mathrm{I} \pi \pi \tilde{\omega} v] \alpha \xi \delta \dot{\varepsilon} v v \kappa \tau \grave{~ B o u ́}[\alpha \lambda o v] .[$

[ ] ] ]

[ M M M $\alpha] \delta \varepsilon \dot{v} \varsigma \kappa \alpha \tau \varepsilon ́ \sigma \kappa \eta \psi[\varepsilon$

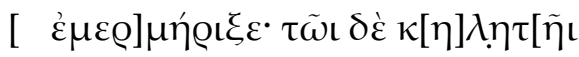

[ ] ] $\quad$ [ $\pi \tilde{v} v \mathrm{v}, \mu \tilde{\tilde{L} \alpha \nu}$.[

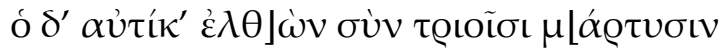

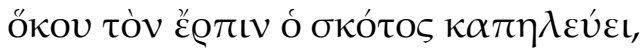

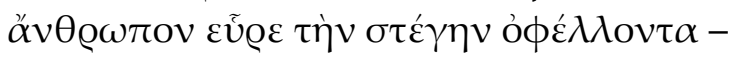

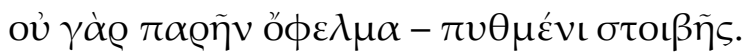

20

Hiponacte, fr. 79Dg ${ }^{147}$

... recibir una paliza...

por esa estupidez

la mandíbula...

... los puso pálidos como la cera...

y se cagó encima...

...con caduceo de áureo resplandor

... cerca del pie de la cama

Y Hermes, luego de acompañarle a casa de Hiponacte,

... del perro al ladrón

... como una víbora silba

... e (Hiponacte?) de noche (a Búpalo?)...

... y consideró (?)...

el (hijo de Maya?) cayó sobre...

... cavilaba; y al encantador

... grande, (como?) una mosca...

$\mathrm{Y}$ al llegar de inmediato con tres testigos

al lugar donde el sombrío vende vino berreta,

encontró un tipo barriendo la habitación

con un atajo de ramas espinosas, porque no tenía escoba.

20

Si bien es difícil precisar la situación narrada, el fr. 79Dg parece describir en los primeros versos una reyerta sorpresiva y furtiva. ${ }^{148}$ La expresión

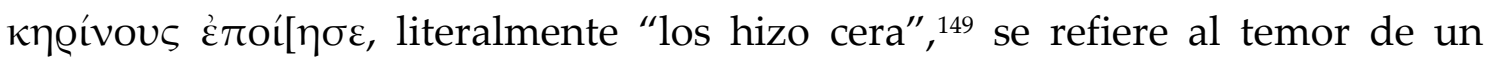
grupo de personas, al punto que uno de ellos llega a liberar sus esfínteres. Los

\footnotetext{
${ }^{147}$ Transmitido por P.Oxy. 2174 fr. 11 col. 1 (1-17).

${ }^{148}$ En los puntos principales de la narración sigo la interpretación de West (1974, págs. 143-44).

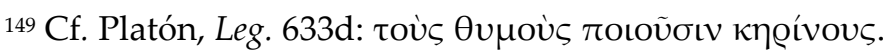


vv. 2-6 podrían retratar una escaramuza semejante a la que se produce en Ach. 348-52 de Aristófanes, cuando el coro intenta lapidar a Diceópolis, particularmente se reproduce la misma imagen escatológica a causa del temor. ${ }^{150}$

En los versos siguientes se narran los acontecimientos de un robo, tal vez en la propia casa de "Hiponacte". El resplandeciente caduceo (v. 7), totalmente ajeno al registro lingüístico del yambo, es la mítica vara con la que Hermes hace dormir y despertar a los hombres, ${ }^{151}$ y aquí podría aludir de manera humorística al bastón utilizado por el ladrón para desmayar de un golpe a su víctima, ya que este aparece junto a la cama (v. 8). También, la mención del perro y el ladrón (v. 10) se ajusta a la investidura de Hermes $\kappa v v \alpha ́ \gamma \chi \chi\rceil \varsigma$, ya que protege a quienes delinquen de los perros guardianes. ${ }^{152}$

Si los suplementos al v. 12 son correctos, ${ }^{153}$ de algún modo "Hiponacte" y Búpalo estarían involucrados en los hechos que se narran, tal vez el último fuera el ladrón. Los vv. 12-16 podrían mencionar un plan para llevar adelante

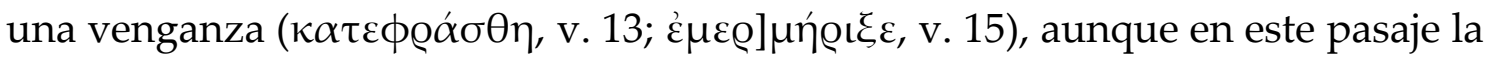
interpretación del texto se vuelve muy incierta. Por último, los vv. 17-20 estarían describiendo la concreción del plan. Una interpretación posible es que la víctima del robo, luego de reconocer al ladrón, se presente con tres testigos en su guarida; al llegar, sin embargo, encuentran a un sujeto barriendo el lugar, quien, ante la falta de escoba, usaba las ramas de un arbusto espinoso.

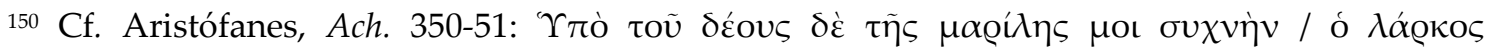

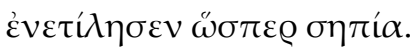

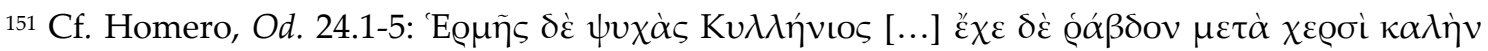

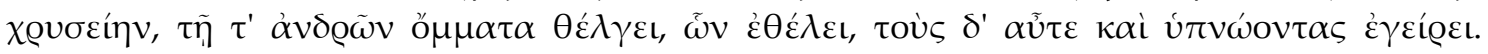
También, Il. 24.343.

152 Vid. sup. pág. 246. En relación a esto, es interesante también el pasaje de Il. 24.445, donde Hermes, al escoltar a Príamo hasta la tienda de Aquiles con la recompensa para rescatar el cuerpo de Héctor, hace dormir a todos los guardias que lo custodian.
}

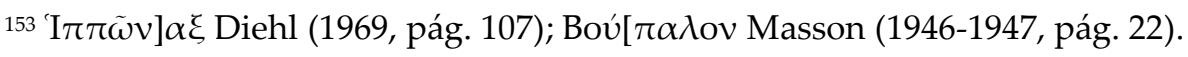


Esta lectura del fragmento, totalmente hipotética, ubicaría nuevamente a

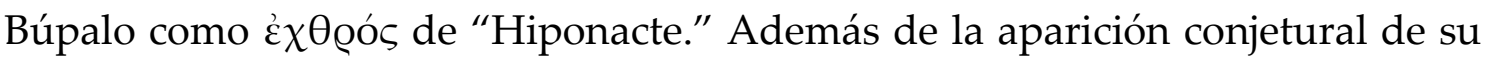

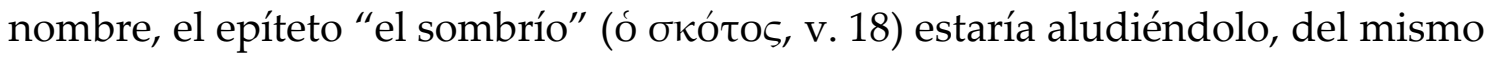
modo que en el fr. 193Dg. ${ }^{154}$ Por otro lado, como se ha visto anteriormente, en los ff. 1-2Dg, Búpalo suplica la ayuda del Hermes "compañero de ladrones"

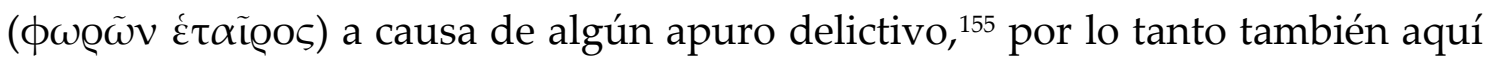
podría estar desempeñando este rol.

FR. 107DG

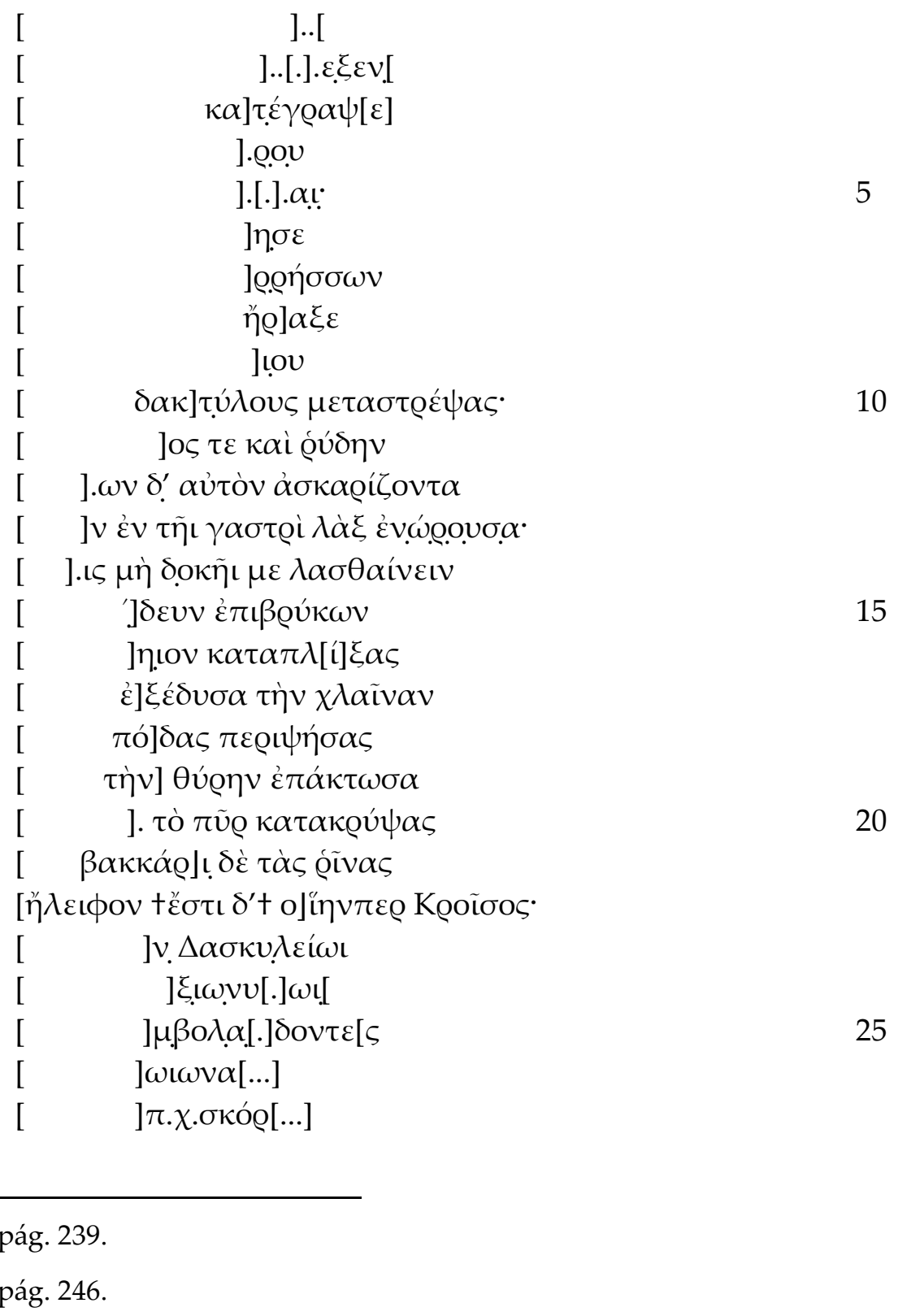

154 Vid. sup. pág. 239.

155 Vid. sup. pág. 246. 


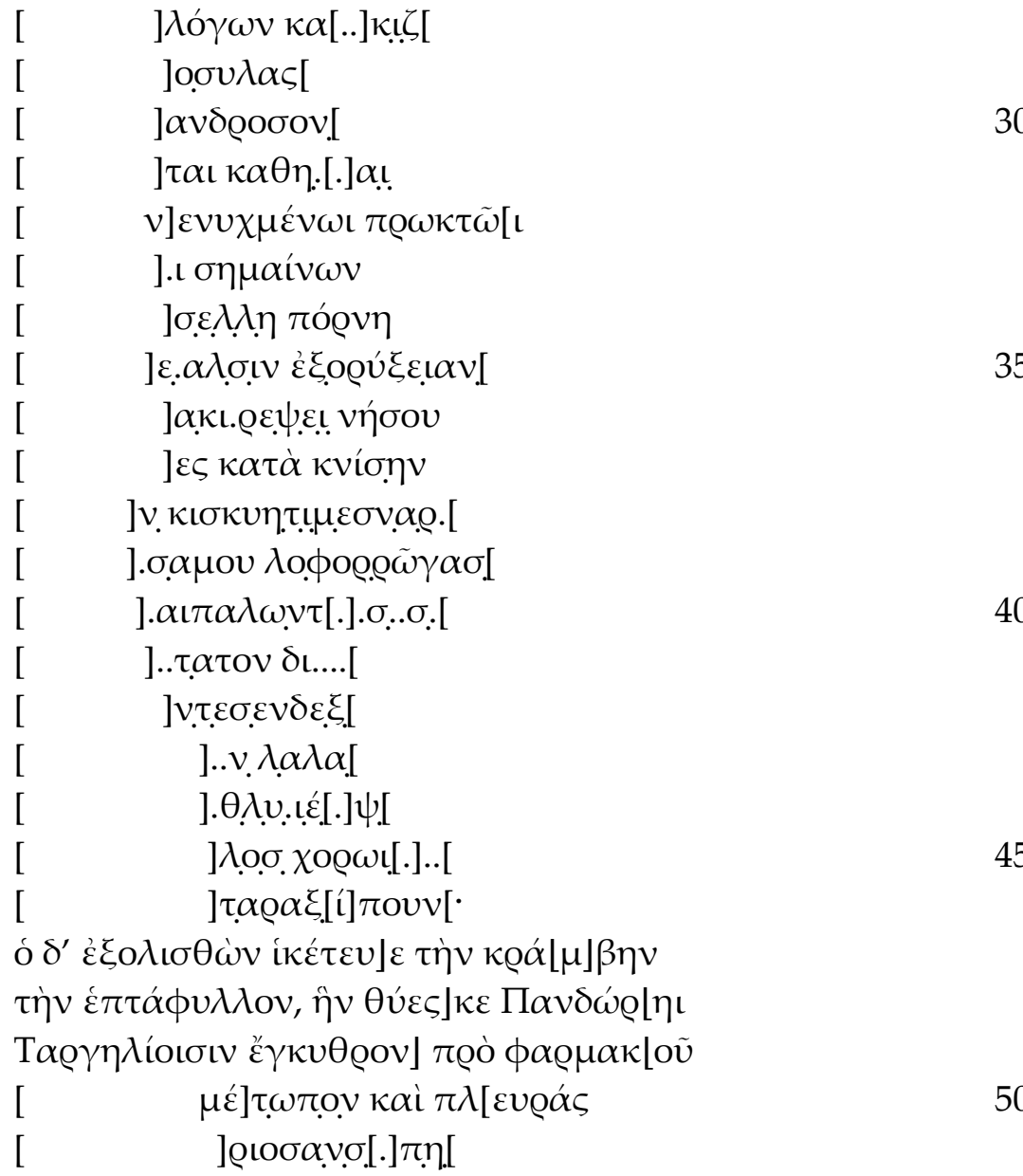

Hiponacte, fr. 107Dg 156

$$
\begin{aligned}
& \ldots \\
& \ldots \\
& \ldots \text { arañó (?)... } \\
& \ldots \\
& \ldots \\
& \ldots \\
& \ldots \\
& \ldots \text { golpeó... } \\
& \ldots \\
& \ldots \text { habiendo retorcido los dedos; } \\
& \ldots \text { y con abundancia } \\
& \ldots \text { a él mientras brincaba } \\
& \ldots \text { sobre su panza salté con los pies } \\
& \ldots \text { para que no pensara en maldecirme } \\
& \ldots \text { rechinando (los dientes?) } \\
& \ldots \text { luego de hacerle una zancadilla } \\
& \ldots \text { quité el manto }
\end{aligned}
$$

156 Transmitido por P.Oxy. 2175 ff. 3-4. 
... después de limpiarme bien los pies

... atranqué la puerta

... luego que tapé el fuego

... y con esencia de nardos las narices

... ungí ... y es(?) igual que (la que usa) Creso

... en Dascileo

... (de dignos hijos? $)^{157}$

... dando...

... de palabras (y maltrataba?) $)^{158}$

... tras despojar

... de un hombre

... con el culo ensartado

... indicando

... puta...

... la azada ellos excavaran... ${ }^{159}$

... de una isla

... por la grasa

$\cdots$

... de Samos (?) a unos piernirrotos.

$\cdots$

$\cdots$

$\cdots$

$\cdots$

...

... al coro

... trastornapiés

y este mientras salía patinando suplicaba por el repollo de siete hojas, que ofrendaba a Pandora en las Targelias en pan antes del sacrificio expiatorio (?) ... el entrecejo y la costilla...

El fr. 107Dg, muy deteriorado y de difícil interpretación, también nos presenta en sus primeros versos una escena ridícula y grotesca de reyerta callejera, pero no es posible conocer el motivo que genera esta pelea ni quién es el contrincante. El narrador manifiesta haber vencido a su adversario luego de hacerle una zancadilla ( $\kappa \alpha \tau \alpha \pi \lambda[1] \xi \alpha \varsigma$, v. 16). Es posible, además, que las

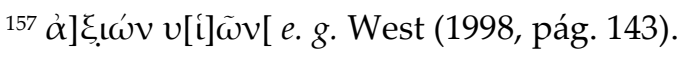

${ }^{158} \kappa \alpha[\tau \alpha \iota] \kappa i ́ \zeta[$ vel $\kappa \alpha[\tau \eta \iota] \kappa i ́ \zeta[$ Diehl (1969).

159 ỏ] $\sigma \alpha \lambda \lambda \sigma$ เv West (1998, pág. 144).
} 


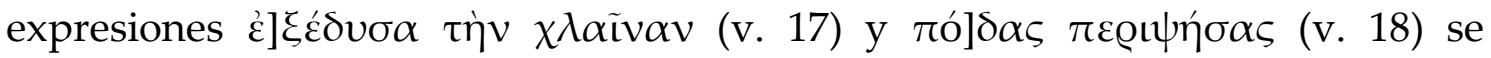
refieran al narrador, luego de derrotar a su contrincante: le quita el manto y se limpia los pies con él. ${ }^{160}$

A continuación, la situación parecería cambiar de tono; ${ }^{161}$ el narrador posiblemente se encierra en su casa, traba la puerta, cubre el fuego y se aplica esencia de nardos en sus narices, igual a la que usa Creso.

Los vv. 25-45 están muy deteriorados y las interpretaciones son totalmente conjeturales. En el v. 46 se alude a alguien o a algo con el calificativo

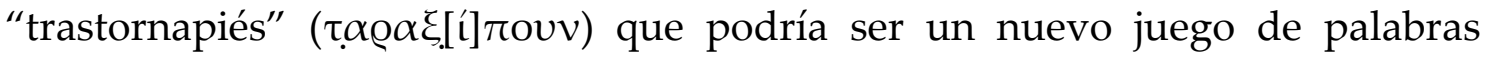

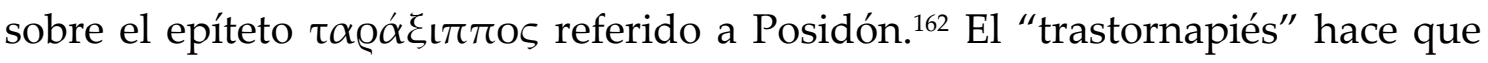
alguien se resbale cómicamente al mismo tiempo que realiza una imprecación. Ateneo, Deipn. 15690a-b, al hablar acerca del repollo, transmite los vv. 47-49 de

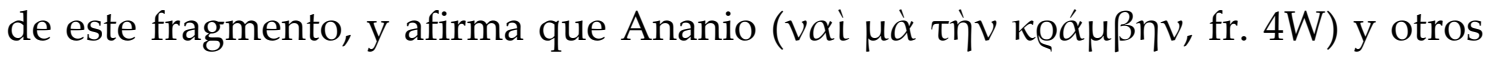
poetas cómicos también utilizan el juramento por esta verdura. En cierta forma, el repollo de siete hojas denuncia el bajo estatus social del personaje, ya que es lo que le consagra a Pandora en las Targelias. Nuevamente Aristófanes viene en nuestra ayuda. En un pasaje bastante afín a los yambos de Hiponacte, refiere un oráculo de Bacis en que se ordena un sacrificio a Pandora, que es un nombre parlante utilizado en esa comedia para la Tierra $(\Gamma \tilde{\eta})$ :

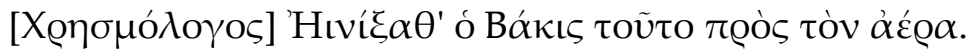

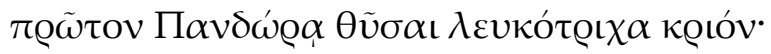

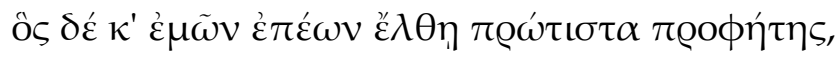

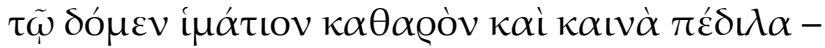

Aristófanes, Av. 970-73163

[Recitador] Eso es lo que mentó Bacis apuntando al aire.

160 Degani (2002, pág. 105 n.158).

${ }^{161}$ West (1974, pág. 145) señala: "No continuous sense can be seen in this long fragment, and we cannot assume that it must belong to the same poem."

162 Cf. Pausanias 6.20.16 y 10.37.4.

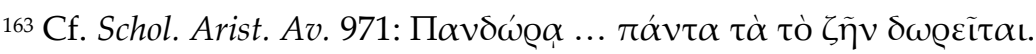


“...sacrifíquese primero a Pandora un cordero de blanca lana.

Y al primerísimo intérprete de mis versos que aparezca

dénle un manto limpio y unas sandalias nuevas..."164

Además del sacrificio a Pandora, es significativa también la alusión al íú́xıov y a los $\pi \varepsilon ́ \delta \iota \lambda \alpha$, prendas frecuentemente solicitadas por el suplicante de Hiponacte. Es probable por lo tanto que la Pandora de Hiponacte no sea la mítica de Hesíodo (Theog. 570; Op. 54), sino la tierra misma en tanto dadora de vida y alimentos. Nada quita, sin embargo, que el nombre haya sido utilizado por su doble sentido para aludir a alguna mujer en particular, al igual que en el fr. 331W de Arquíloco se emplea el nombre П $\alpha \sigma \iota \phi i ́ \lambda \eta$.

Las ofrendas que se realizaban durante las Targelias consistían en semillas $(\sigma \pi \varepsilon \dot{\varepsilon} \mu \alpha \tau \alpha)$ y primicias agrícolas $(\dot{\alpha} \pi \alpha \varrho \chi \alpha i ̀ ~ \kappa \alpha \varrho \pi \tilde{\omega} \nu)$ que venían

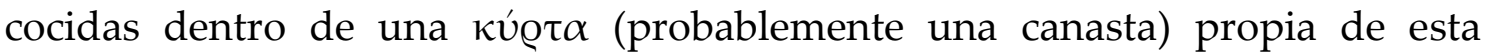
ocasión. ${ }^{165} \mathrm{Y}$ en estas mismas festividades se realizaba la expulsión del $\phi \alpha \varrho \mu \alpha \kappa o ́ s .166$

La descripción del modo en que el personaje patina inesperadamente a causa del "trastornapiés" y trata de evitar la caída, al tiempo que realiza un juramento de manera imprecatoria por el repollo de siete hojas que suele ofrendarle a Pandora, otorga al pasaje un efecto cómico de gran dinamismo que anticipa los gags de la comedia antigua. Tal vez, la imprecación que lanza este personaje anuncie el fatídico desenlace de la caída, con golpes que pueden

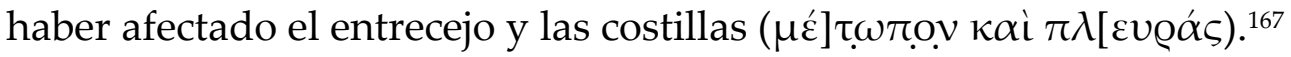

\footnotetext{
164 Traducción de Luis Macía Aparicio (2007, pág. 396).

165 Cf. Hesiquio, $\theta 104$ y 106; Suda $\theta$ 49; véase Degani (2002, pág. 269).

166 Sobre el tema del $\phi \alpha \varrho \mu \alpha \kappa o ́ \varsigma$, vid. inf. pág. 263.

167 Degani (2002, págs. 269-70).
} 
Fr. 132DG

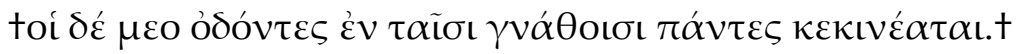

Hiponacte, fr. 132Dg 168

Pero mis dientes se me han quedado todos removidos en las mandíbulas.

Finalmente, aunque no presenta propiamente una escenografía de disputa física, este yambo podría enmarcarse dentro de una narrativa de temática pugilística con intencionalidad humorística. Luego del enfrentamiento, el narrador le estaría refiriendo a su narratario las consecuencias de los golpes que recibió.

\section{CONCLUSIONES PARCIALES}

El fr. 79Dg, a diferencia de los ff. 107 y 132Dg, posee un desembrague de tipo enuncivo, por lo cual instala en el discurso poético las formas del enunciado referido. Por esta razón es conveniente esquematizar este yambo de manera diferenciada:

168 Transmitido por P.Oxy. 2174 fr. 4. 
Nivel ENUNCIATIVO

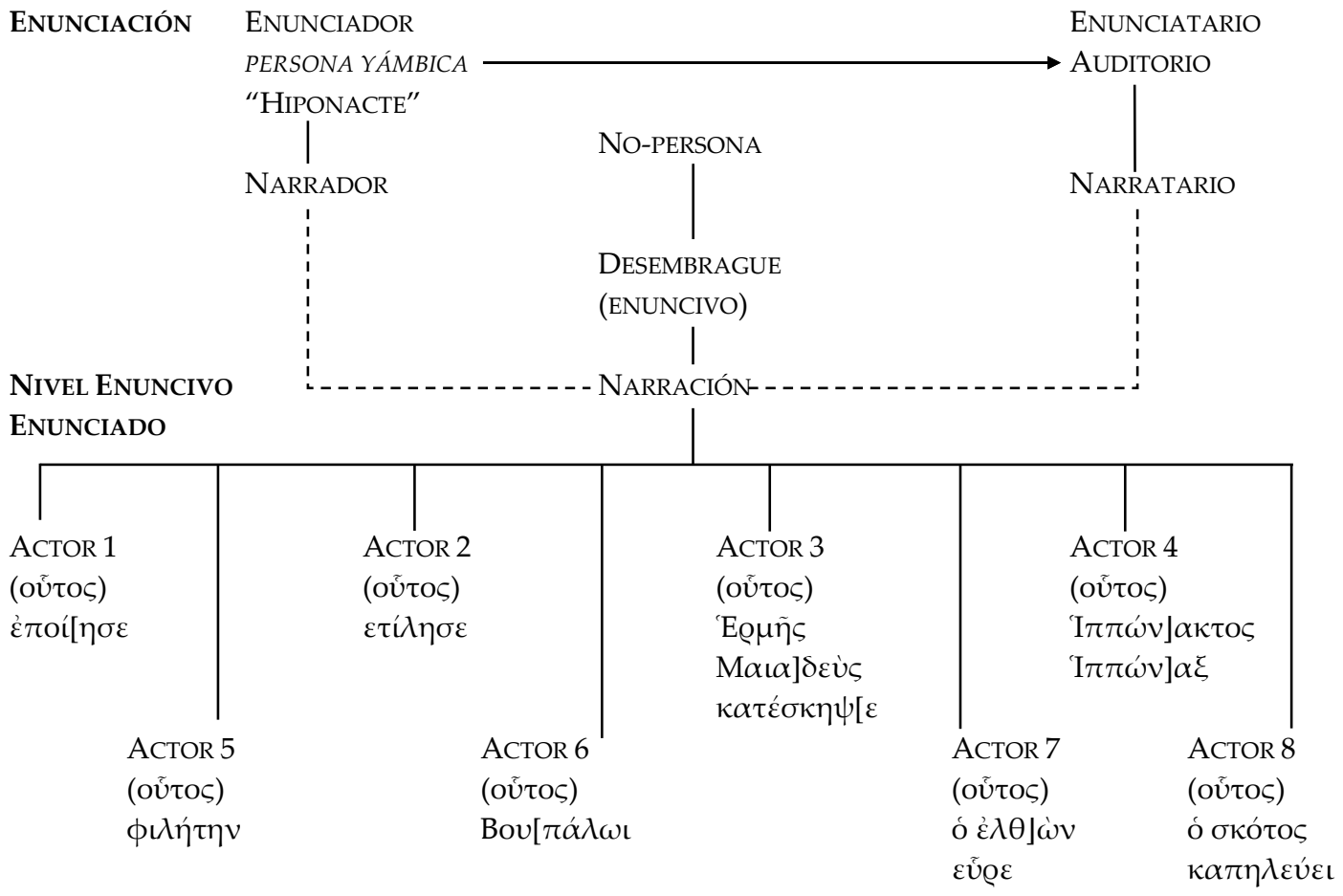

En este fragmento se puede apreciar un proceso de desembrague enuncivo que instala las formas discursivas del enunciado enunciado. La nopersona de la enunciación se manifiesta a través de distintos actores que se inscriben en el texto por medio de verbos en tercera persona, nombres propios y pronombres en función anafórica. Probablemente algunas o varias de las menciones que se han indicado en el esquema refieran un mismo actor, sin embargo, el mal estado del texto no nos permite determinarlo.

Como es posible observar en esta composición ni el narrador ni el narratario aparecen inscriptos deícticamente en el enunciado poético, por lo cual se representan en el esquema dentro del nivel enunciativo y no en el nivel enuncivo, ya que estos actantes funcionan como "sujetos directamente delegados del enunciador y el enunciatario."169 Por lo tanto, los vínculos como destinador y destinatario de la narración han sido consignados a través de líneas discontinuas. Aunque estos actantes no se inscriben en el enunciado

${ }^{169}$ Cf. Greimas \& Courtés (1990, pág. 272). 
poético, es decir no hay ni un 'yo' ni un 'tú' que refiera al narrador o al narratario respectivamente, sí aparece el nombre Hiponacte ( $(\pi \pi \pi \omega \dot{\nu}] \alpha \kappa \tau o \varsigma$ v. 9; I $\pi \pi \omega \dot{\omega}] \alpha \xi$ v. 11) designando a uno de los actores desempeñando un rol dentro de la narrativa. Nuevamente la sphragis nos permite sostener entonces que la identidad del narrador está en concomitancia con la identidad de la persona yámbica "Hiponacte".

Por su parte, los ff. 107 y 132Dg presentan un desembrague tipo enunciativo:

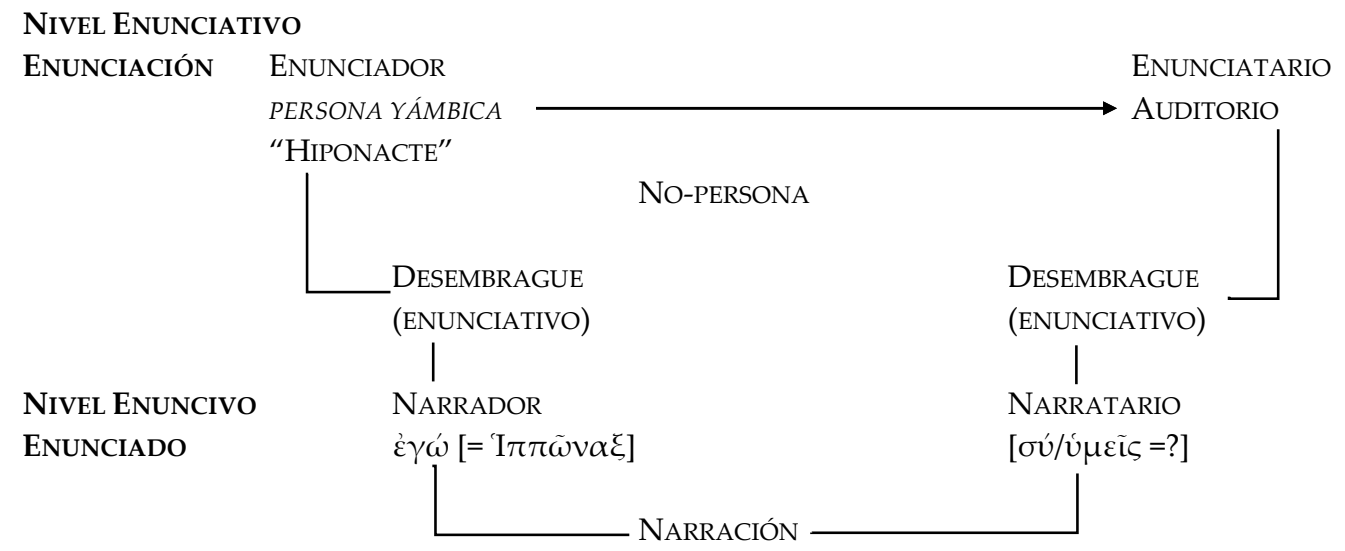

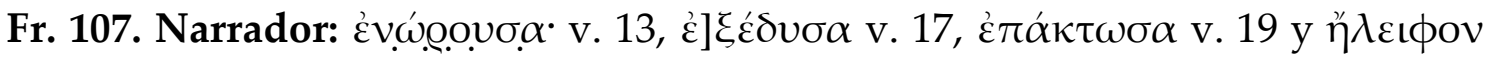
v. 22, (como sujeto agente); y por el pronombre $\mu \varepsilon$ v. 14 (complemento paciente

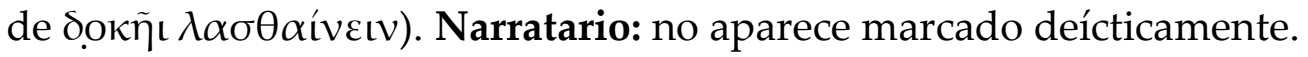

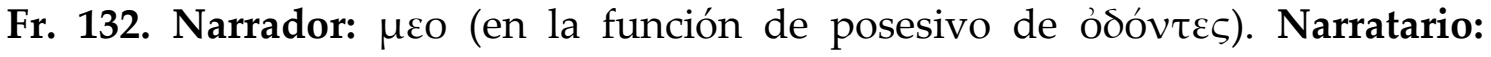
ninguna.

En estos fragmentos nuevamente el narrador aparece involucrado como protagonista en situaciones que remiten de manera estereotipada a disputas físicas contra un contrincante. La aparición reiterada de este rol y la carencia de datos que indiquen la presencia de un personaje diferente ocupando en primera persona esa posición llevan a suponer que el actante narrador en estos casos es ocupado siempre por el mismo actor. Parece lógico admitir que el interlocutor que le solicita que tengan sus ropas porque va a golpear a Búpalo (fr. 121Dg), 
aquél que dice que nuevamente debe pelear con el sombrío Metrotimo (193Dg), o el que afirma ser ambidiestro y no errar jamás sus golpes (fr. 122Dg), sea el mismo actor que ocupa aquí la posición de narrador para relatar sus gestas pugilísticas. Esto nos lleva a sostener por lo tanto que la identidad del narrador aparece en concomitancia con la del enunciador, mientras que la identidad del narratario se correspondería con la del enunciatario-auditorio.

\subsection{VÍCTIMA EXPIATORIA}

En este apartado se han reunido tres fragmentos narrativos que de diferente manera hacen alusión al ritual de la víctima expiatoria. El primero de ellos (46Dg) probablemente refiera una fórmula utilizada en algún momento del ritual en las Targelias. En el segundo (50Dg), la mención de la madera de higuera remite probablemente a uno de los castigos que debía atravesar la víctima expiatoria. Por último, en el tercer fragmento (95Dg) se describe específicamente una escena de curación de impotencia sexual, con una alusión explícita de la tortura física en los rituales de expiación.

Fr. 46DG

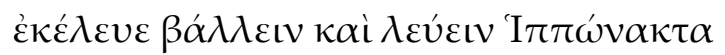

Hiponacte, fr. $46 \operatorname{Dg}^{170}$

Ordenaba que derribaran y lapidaran a Hiponacte.

\section{FR. 50DG}

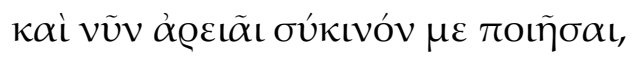

Hiponacte, fr. 50Dg 171

... y ahora amenaza con hacerme de madera de higuera.

170 Transmitido por Querobosco, ad Hephaest. 1.6 (pág. 195.15-25 Consbruch).

171 Transmitido por Et.Gen (pág. 16 Calame). 
FR. 95DG

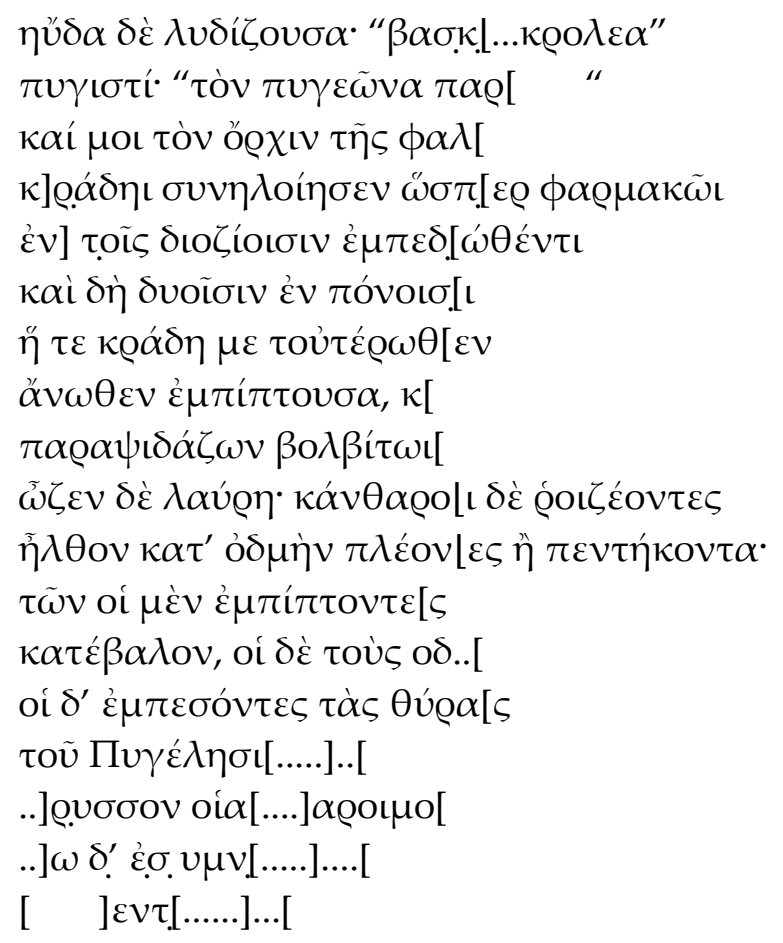

Hiponacte, fr. 95Dg ${ }^{172}$

Y ella gritaba en lidio: "Vení, apurate(?)"

en jerga de culeados: "Tu culo junto... (?)"

Y me machacaba los testículos del (falo?) ...

con la rama de higuera como si fuera la víctima expiatoria,

(atado) en dos ramas cruzadas(?).

Y entre dos martirios...

la rama por un lado me...

desde arriba me caía

salpicándome con mierda

apestaba la letrina; y por el olor llegaron

más de cincuenta escarabajos zumbando.

De ellos unos iban cayendo sobre...

derribaron, otros... sus dientes (?),

otros cayeron sobre las puertas (?)...

del que en Pígela...

(... perforaban?...)

172 Transmitido por PSI 1089 col. 2 Coppola. 
Como hemos observado anteriormente, Tzetzes (Chil. 5.728-58) es una de las fuentes que nos describe la realización del ritual y los padecimientos físicos que debía sufrir la víctima expiatoria para purificación de toda la comunidad. ${ }^{173}$ Este rito, que podría haber surgido antiguamente como modo de conjurar males que afectaban a toda la comunidad (sequías, pestes, desastres naturales, etc.), se restringe dentro del ámbito religioso griego a las fiestas de las Targelias, llevadas a cabo en Ática y Jonia hacia comienzos del verano. En estas festividades, que incluía también la ofrenda de las primicias de la cosecha, ${ }^{174}$ la purificación surge como una condición previa para el inicio de un nuevo ciclo anual, por lo que la figura de la víctima expiatoria ocupaba un papel destacado. El elemento esencial del ritual era la expulsión de la comunidad de una o dos personas, los $\phi \alpha \varrho \mu \alpha \kappa o i ́$, que probablemente encarnaban todas las impurezas acumuladas durante ese año. ${ }^{175}$

El mismo Tzetzes señala que las víctimas expiatorias eran primero escogidas por su fealdad ( con higos secos, panes y quesos, se las vestía con ropas adecuadas y posteriormente se la flagelaba de distintas maneras para concluir con la

173 Vid. sup. pág. 218.

174 Vid. sup. n. 165.

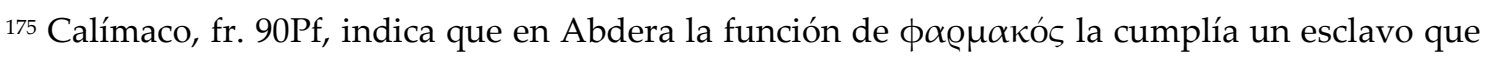
era alimentado magníficamente durante todo el año; el día de la festividad se lo hacía caminar alrededor de las murallas y luego se lo expulsaba a pedradas más allá de los límites de la ciudad. En Atenas, el ritual consistía en reunir a dos hombres de aspecto repulsivo, luego eran adornados con higos y se los expulsaba de la ciudad tirándoles piedras. Estrabón, 10.452, cuenta que cada año los leucadios, en los sacrificios en honor a Apolo, despeñaban a un delicuente desde la atalaya con una finalidad apotropaica, pero ataban a su cuerpo todo tipos de alas de pájaros capaces de suavizar su caída mediante su vuelo; mientras que en el mar, un gran número de hombres en pequeñas barcas lo esperaban para rescatarlo y luego llevarlo más allá de las fronteras de la ciudad. Plutarco, Quaest. conv. 693f, señala que en Queronea todos los años el hambre ( $\beta$ oú $\lambda \iota \mu \rho)$ era expulsado de la ciudad en la forma de un esclavo, que era golpeado con ramas mientras se decía "fuera Hambre, adentro Riqueza y Salud" (

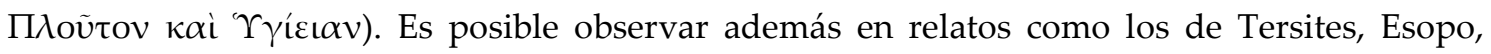
Codro, Penteo, y Edipo, y en la institución del ostracismo, una vinculación con el ritual del

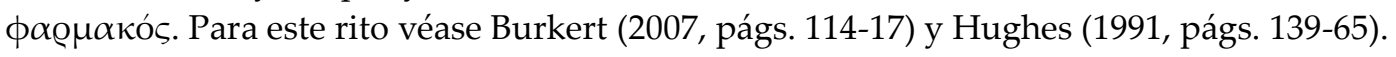


expulsión más allá de los límites de la comunidad. Como ya lo hemos indicado, en Hiponacte aparecen todos estos elementos del rito típico de expiación. ${ }^{176}$

En los ff. 46 y 50Dg, los golpes con ramas de higuera y la lapidación remiten a los castigos sufridos por la víctima ritual. En ambos casos el rito de las Targelias es parodiado, al igual que en otras composiciones en que

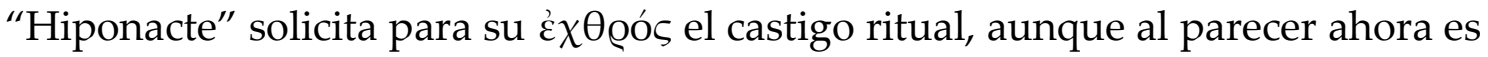

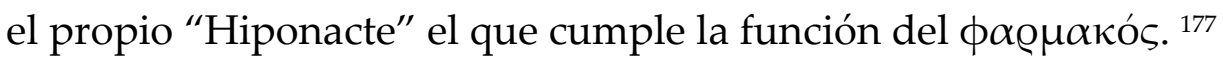

En el fr. 95Dg, por su parte, se comparan explícitamente los padecimientos que sufre el narrador con los que solía tolerar la víctima en este tipo de rituales. Sin embargo, no se trata aquí propiamente de las Targelias, sino de algún tipo de ritual de recuperación de la virilidad o de la cura de la impotencia sexual. El narrador juega el rol de paciente del rito itifálico, llevado a cabo por una mujer ( $\eta v ้ \delta \alpha \lambda v \delta i \zeta \zeta o v \sigma \alpha$ v. 1). Los procedimientos empleados en la cura implican una verdadera tortura: fuertemente sujetado a dos ramas en forma de cruz (v. 5), se lo golpea en el pene con ramas de higuera como a una víctima expiatoria (v. 3), hasta que la cura termina con un final doloroso, y escatológico, para el paciente. ${ }^{178}$

La comicidad de este yambo surge no solo de la descripión del episodio sino también a partir del léxico empleado, en que se conjuga el uso de vocablos

\section{${ }_{176}$ Cf. ff. 6, 26-30Dg; vid. sup. pág. pharmakós218.}

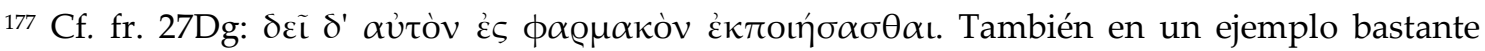
significativo por la cuestión cómico-paródica: fr. 126Dg (vid. sup. pág. 216).

178 El paralelo de este yambo con un pasaje de Petronio, Sat. 138, podría darnos una imagen de la comicidad escatológica de la escena que aparece en el poema de Hiponacte. En la novela de Petronio, el narrador, Encolpio, describe el tratamiento mágico para la cura de la impotencia al cual lo expone Oenotea, sacerdotisa de Príapo: “Oenotea sacó un falo de cuero (scorteum fascinum) y, después de untarlo en una mezcla de aceite, pimienta y ortiga triturada, me lo introdujo suavemente en el ano. Luego, la despiadada vieja me untó una y otra vez las piernas con la misma sustancia. Mezcló un poco de jugo de mastuerzo con abrótano y, rociándome los genitales, tomó una ramas de ortigas verdes y comenzó a golpearme todo el cuerpo hasta la altura del ombligo. (...) Logré escapar, pero con los pies todos ensangrentados..." La relación entre estos textos fue señalada en principio por Latte (1929, págs. 385-88) y desarrollada extensamente por Miralles \& Pòrtulas (1988, págs. 71-119). 
procedentes de un sustratro seguramente popular, la utilización de la lengua popular jonia, términos compuestos deliberadamente cómicos, y barbarismos. ${ }^{179}$ En el primer verso, se han propuesto diferentes suplementos e intrepretaciones para $\beta \alpha \sigma \kappa\lfloor\ldots \kappa \varrho \circ \lambda \varepsilon \alpha$, probablemente dos verbos lidios en imperativo. Hay tres glosas de Hesiquio que podrían ser utilizadas para completar este pasaje: la

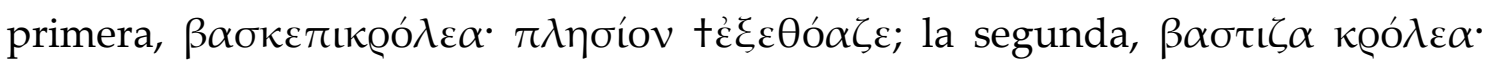

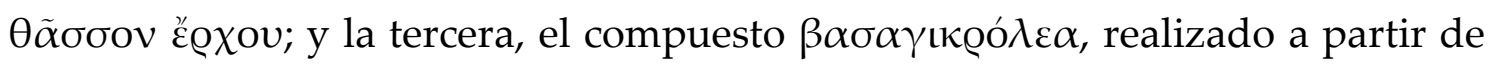

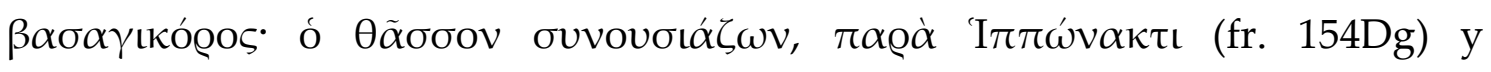

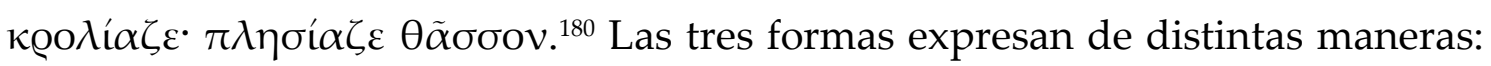
"acercarse rápidamente" al lugar donde está el interlocutor. En el segundo verso, el término $\pi v \gamma \iota \sigma \tau i ́$ probablemente constituya un juego de palabras a partir de $\pi \cup \gamma \eta$ “culo" y de los adverbios que indican una procedencia regional

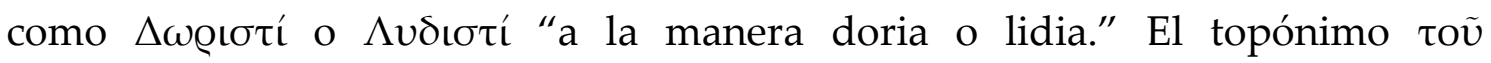

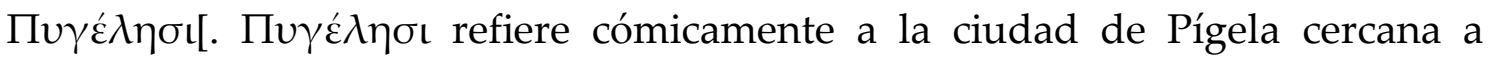
Éfeso, en la costa del mar Egeo. Estrabón (14.1.20) cuenta que esta ciudad fue fundada por Agamenón y sus hombres porque una parte del grupo se enfermó

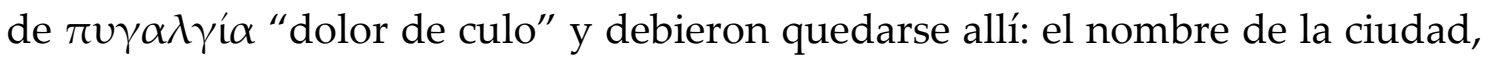
$\Pi u ́ \gamma \varepsilon \lambda \alpha$, recuerda el episodio. ${ }^{181}$

\section{CONCLUSIONES PARCIALES}

Dentro de la escenografía narrativa de la víctima expiatoria, el fr. 46Dg también presenta un proceso de desembrague que se diferencia de los ff. 50 y 95Dg. Por esta razón es necesario nuevamente presentar esquemas diferenciados. El primer caso puede ser analizado de la siguiente manera:

\footnotetext{
179 Para el léxico de este fragmento véase particularmente Suárez de la Torre (1987, págs. 11339).

180 Véase particularmente West (1974, págs. 142-3).

${ }^{181}$ Cf. Teopompo 115F 59 y Harpocración, s. v. Пú $\varepsilon \varepsilon \lambda \alpha$, para la misma etiología de la ciudad.
} 


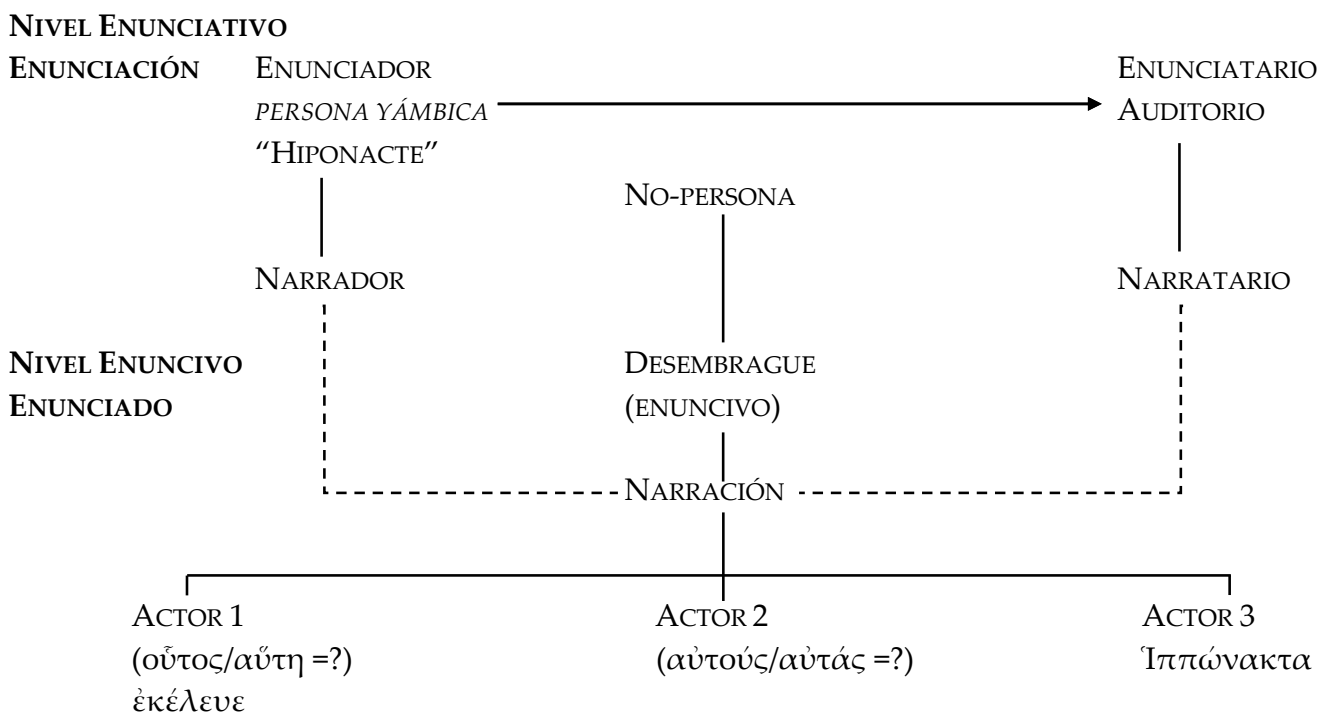

Como se observa en el esquema, el desembrague enuncivo instala en el discurso las formas del enunciado referido. Por lo tanto, el narrador y el narratario no aparecen inscriptos deícticamente en el enunciado. La no-persona de la enunciación se manifiesta por medio de la tercera persona en referencia a tres actores. El primero de ellos (Actor 1) se inscribe en el enunciado por medio

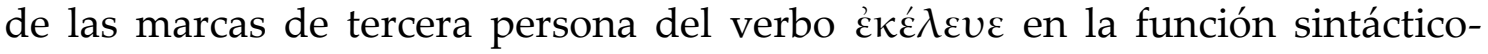
semántica de sujeto agente. El verbo $\kappa \varepsilon \lambda \varepsilon v ́ \omega$ introduce una subordinada completiva en función de complemento directo. Dentro de esta subordinada se presupone tácitamente un acusativo, seguramente plural, como sujeto agente

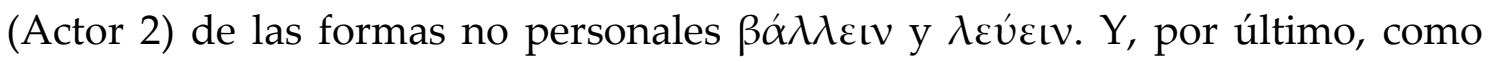
complemento paciente de la acción denotada por esos infinitivos aparece

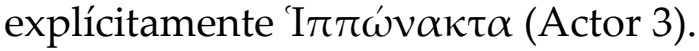

A diferencia del fr. 46Dg, los ff. 50 y 95Dg presentan un desembrague de tipo enunciativo que puede ser analizado a través del siguiente esquema: 


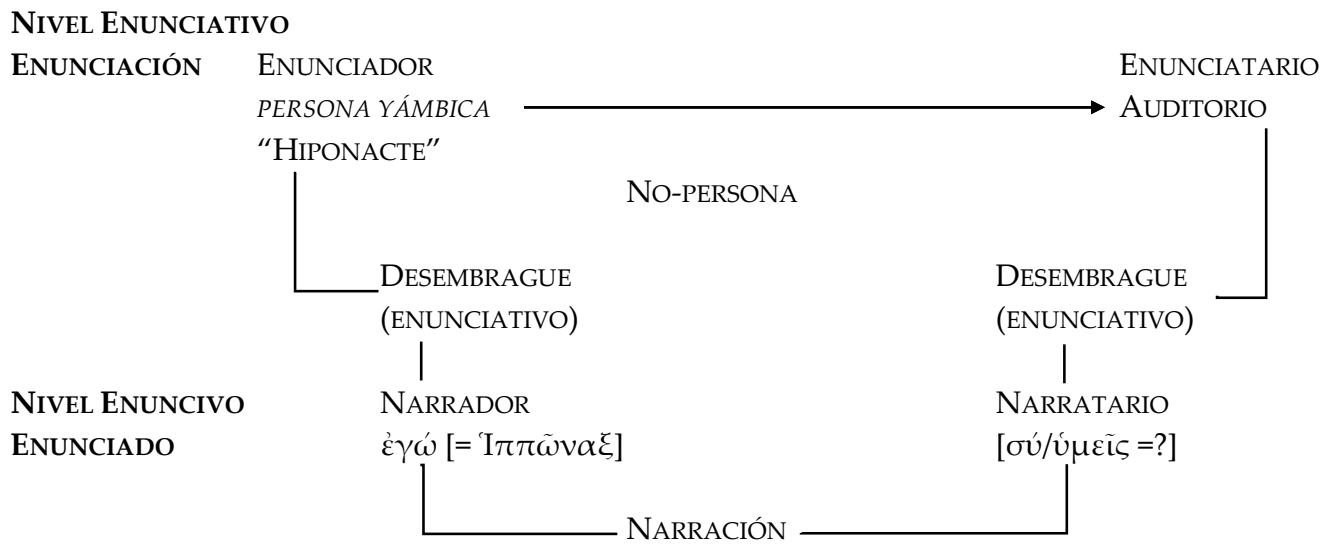

El narrador y el narratario aparecen inscriptos deícticamente en el enunciado poético de estos fragmentos a partir de las siguientes formas pronominales y verbales:

Fr. 50. Narrador: $\mu \varepsilon$ (complemento paciente del infinitivo $\pi$ oเฑ $\sigma \alpha \iota)$. Narratario: ninguna.

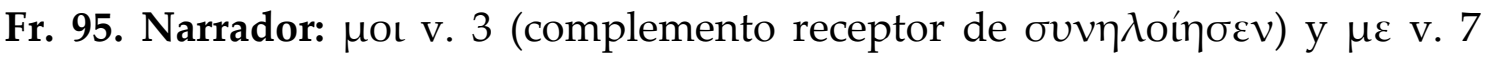
(complemento paciente de $\dot{\varepsilon} \mu \pi i ́ \pi \tau o v \sigma \alpha$ y de otro núcleo verbal en concordancia que se ha perdido). Narratario: ninguna.

Una vez más la aparición del nombre I I $\pi \omega ́ \omega \alpha \kappa \tau \alpha$ (fr 46Dg) en un episodio de padecimiento físico, relacionado en este caso con el ritual de la víctima expiatoria, nos da la pauta de que aquí la identidad del narrador también aparece en concomitancia con la del enunciatario. Es decir, la persona yámbica "Hiponacte" asume en este yambo la máscara de un narrador en primera persona que cuenta ante su narratario una orden dada por un actor desconocido de que padezca los golpes y la lapidación que se le inflige a la víctima expiatoria.

Es posible además que la caracterización del narrador con la máscara de

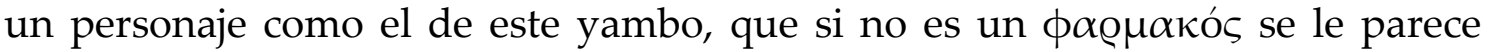
mucho, se haga extensible también a los ff. 50 y 95Dg. En el primero, un narrador con las mismas características relata que un actor desconocido (tal vez 
el mismo del yambo 46Dg) amenaza con hacerlo "de madera de higuera", en alusión a los golpes dados con las ramas de ese árbol en los ritos purificatorios de las Targelias. En el segundo fragmento, el narrador compara explícitamente los tormentos padecidos en el tratamiento ritual para la cura de la impotencia con los azotes dados con ramas de higuera en el pene de la víctima expiatoria.

La proximidad lindante entre este narrador y la figura del $\phi \alpha \varrho \mu \alpha \kappa o ́ \varsigma$ a partir de los padecimientos físicos, que se prestan para una notable comicidad, pone de manifiesto un retrato paródico del rito de purificación llevado a cabo durante las Targelias. Es interesante observar que, en la recurrencia de la parodia a lo largo del corpus, en algunas ocasiones "Hiponacte" solicita que su

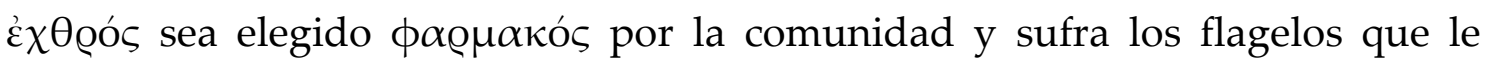
están destinados (fr. 27, 28, 30, 126Dg), y en otras ocasiones, como en los fragmentos vistos anteriormente, "Hiponacte" narra sus padecimientos como si él mismo fuera un $\phi \alpha \varrho \mu \alpha \kappa o ́ s .{ }^{182}$

182 Es llamativa la relación entre la supuesta fealdad de Hiponacte, descripta por Plinio (Nat. hist. 36.4.11-12), Ateneo (Deipn. 12.552c-d) y Eliano, (Var. hist. 10.6), que habría llevado a Búpalo y a Atenis a satirizarlo en una escultura, y la fealdad por la cual uno de los hombres era elegido

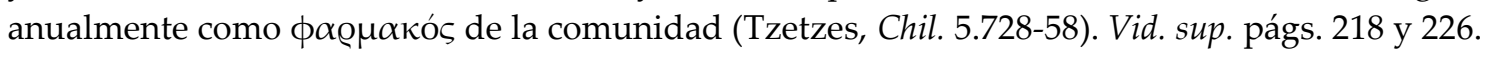




\section{$\underline{4}$}

\section{CALÍMACO}

\section{EL ENMASCARAMIENTO DEL 'YO' EN EL YAMBO DEL PERÍODO HELENÍSTICO}

La información biográfica de Calímaco (c. 320-244 a. C.) transmitida por la entrada del léxico bizantino Suda $(\kappa 227)$ señala que sus padres fueron Bato y Mesatma, ${ }^{1}$ y que nació en la colonia griega de Cirene. Más tarde se trasladaría a Alejandría, donde enseñó por un tiempo gramática en una pequeña villa llamada Eleusis, ubicada en los suburbios de la ciudad. Data el período de su vida durante el reinado de Ptolomeo II Filadelfo (285-246 a. C.) y el segundo año del reinado de Ptolomeo III Evérgetes (246-222 a. C.), con quienes estuvo directamente relacionado al trabajar bajo sus mecenazgos como escritor y

${ }^{1}$ Cf. el epitafio de Bato en el Epigrama 21, donde se señala que el abuelo del poeta también se llamaba Calímaco y fue general del ejército de Cirene. Por otro lado, Bato también es el nombre del fundador de esa ciudad, antepasado del poeta según Estrabón 17.837. 
filólogo en el Mouseion del palacio real de Alejandría y en la Biblioteca, fundados ambos por su padre Ptolomeo I Sóter.

La Suda enumera los distintos géneros y títulos de la extensa producción de Calímaco -habría escrito más de ochocientos volúmenes, aunque probablemente ese número sea exagerado. Entre ellos se encuentran los famosos Пív $\alpha \kappa \varepsilon \varsigma$, un catálogo en prosa de más de 120 rollos sobre los autores y los libros más destacados de la Biblioteca; registros lexicográficos con los nombres de una misma cosa en diferentes regiones de Grecia, como los meses

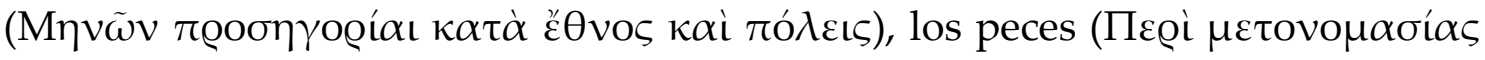

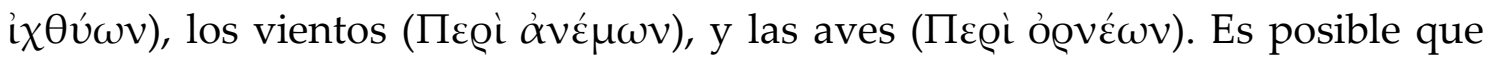
haya escrito también una cantidad considerable de libros sobre denominaciones

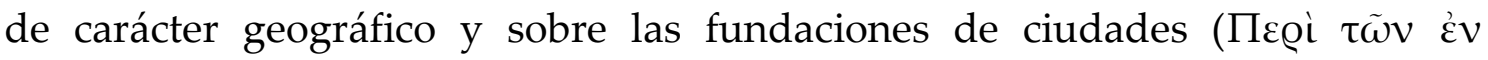

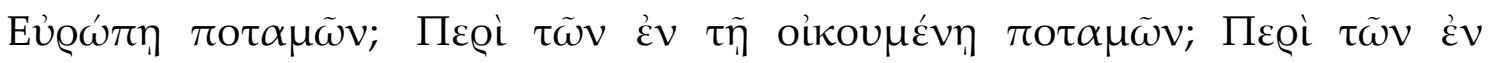

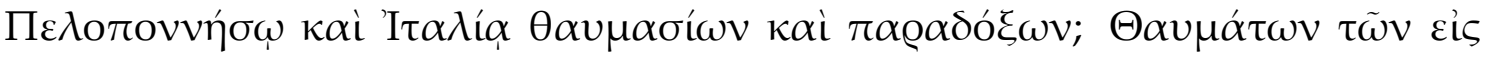

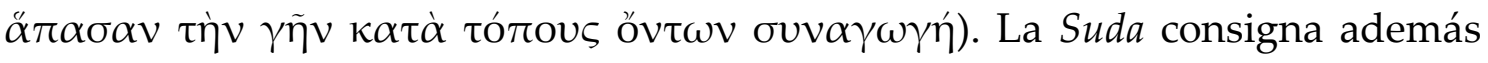

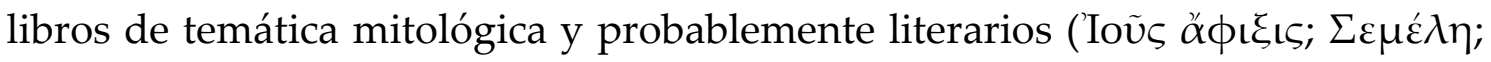

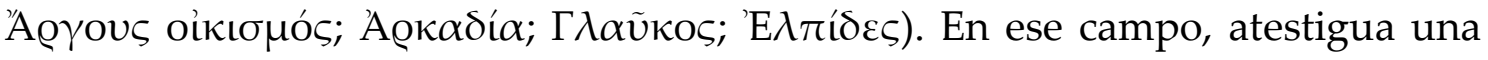
producción propia en una amplia variedad de géneros poéticos, como sátiras, tragedias, comedias, poemas líricos, etc.

De lo que parece haber sido una vasta y heterogénea obra en prosa y en verso, han llegado hasta nuestros días tan solo el libro Himnos, que se conserva íntegro y contiene seis poemas; los Epigramas, una colección de seseinta y tres composiciones; una parte importante de los Aitia, en versos elegíacos, que aborda los orígenes o motivos de distintas celebraciones, costumbres, fundaciones y denominaciones de ciudades y regiones; una colección de Yambos, muy deteriorada; y una gran cantidad de fragmentos en distintos versos, como el epilio Hécale, en hexámetros, y el Epinicio para Sosibio, compuesto en versos elegíacos. 
El auspicioso universo cultural y artístico de la Alejandría ptolemaica le permitió a Calímaco estar en contacto no solamente con toda la tradición poética griega sino también formar parte de una élite intelectual altamente especializada, cuyos miembros debatían a diario sobre poesía, filosofía, historia, política. Es posible que estos debates, como veremos, llevaran a constituir diferentes escuelas o adhesiones estéticas y de pensamiento, y que las confrontaciones de las diversas posturas, además de estimular el estudio y la profundización en los temas, condujeran a posiciones dogmáticas y provocaran el resentimiento entre los eruditos.

Al contrario de lo que podría pensarse por su trabajo de compilador de las producciones antiguas, Calímaco fue un fuerte defensor de la adaptación e innovación de los diferentes géneros al nuevo contexto y a las demandas del mundo helenístico. En lo que ha sobrevivido de su obra se puede observar el trabajo reflexivo sobre una amplia variedad de formas y temas. El carácter exhaustivo de esta reflexión llega hasta tal punto que todo empleo formal pareciera ser deliberadamente alusivo. Sin embargo, es necesario destacar que, en su producción, la reelaboración poética no implica la repetición de los modelos tradicionales, sino, por el contrario, se observa una constante reinvención a través de la variación y la innovación formal. Uno de los rasgos más significativos de esta reinvención es la inmensa vitalidad que la poesía de Calímaco manifiesta en el contexto helenístico, vitalidad propia de los géneros arcaicos y de su ejecución oral en, por ejemplo, el simposio o las festividades públicas. La experimentación formal no parece ser un simple juego literario, sino que busca renovar el vigor de la antigua poesía ante un auditorio más sofisticado y con un horizonte de expectativa estética más complejo. Esta vitalidad se evidencia en la polémica recepción que tuvo su obra en los círculos literarios de Alejandría y las críticas dirigidas contra su variedad formal, sin someterse meramente a la imitación y repetición de los modelos. 
Las características señaladas anteriormente -vitalidad, y variación e innovación formal- pueden observarse claramente en el libro Yambos, que recupera distintas características de la yambografía arcaica pero sobre todo la función yámbica, adaptada a ese nuevo auditorio crítico que constituían los eruditos alejandrinos. El libro es una colección de poemas compuestos en una amplia variedad de metros propios de la yambografía arcaica; el ordenamiento y carácter de estas composiciones han permitido determinar que fue editado de manera programática por el poeta. Los dos papiros que transmiten estos yambos mantienen la misma disposición de los fragmentos y corroboran que se ubicaban a continuación de los Aitia. El primero, P.Oxy. 1011 (s. IV d. C.), conserva los libros 3 y 4 de los Aitia, y los Yambos 1-4, 12, y 13. El segundo, $P$. Mil. 1.18 (s. I-II d. C.), preserva las Diégesis de los libros 3 y 4 de los Aitia, de todos los Yambos, de los cuatro poemas que les continuaban, y de la Hécale. En el epílogo a los Aitia (fr. 112Pf) se anuncia el pasaje a una nueva forma poética:

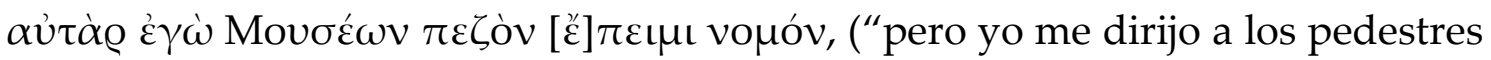
pastos de las Musas"').

El ordenamiento de las composiciones se corresponde perfectamente con

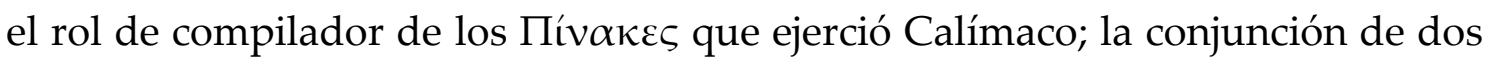
formas poéticas de origen jonio, como lo son elegías y yambos, por su parte, podría manifestar la búsqueda del autor por poner en tensión los géneros destinados a la ejecución poética dentro ámbito del simposio. Independientemente de la discusión que se ha generado acerca de la cantidad de poemas que formaban parte de la colección de Yambos -trece, o diecisiete si se incluyen los ff. 226-229 que Pfeiffer editó bajo el título Mć $\eta$ por considerarlos poemas líricos-, ${ }^{2}$ se acepta casi unánimemente que los Yambos 1 a

\footnotetext{
2 Pfeiffer (1953, págs. xxxvi; 216-25): “Inter librum Iamborum et Hecalam, carmen epicum, a Diegeta quattuor carmina lyrica collocantur." La clasificación de los ff. 226-229 bajo el título de

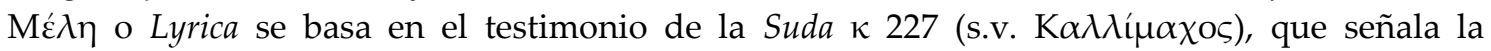
composición de este género por parte de Calímaco. Sobre la discusión acerca de la cantidad de
} 
13 fueron compuestos con una intención programática. Esta instancia se pone en evidencia en los patrones métricos, dialectales, estructurales y temáticos que amalgaman la colección, pero también en la presencia de la figura del poeta yámbico Hiponacte, que atraviesa longitudinalmente la obra.

En efecto, Calímaco emplea en su colección el trímetro yámbico escazonte, denominado también coliambo ( $\chi \omega \lambda i ́ \alpha \mu \beta o \varsigma)$ o hiponacteo. Este patrón métrico, atribuido a Hiponacte, es una variante del trímetro caracterizada por llevar una sílaba larga en la penúltima posición en lugar de breve, lo cual confería a la recitación de los versos una alteración del ritmo que parecía emular en forma caricaturesca la renguera de un cojo ( $\chi \omega \lambda$ óтovৎ). Es el metro de los Yambos 1-4 y 13; los Yambos 5-7 están compuestos en estrofas epódicas, comunes tanto a Arquíloco como a Hiponacte: el primero de ellos es una combinación de coliambos y dímetros yámbicos; el 6 y el 7 alternan trímetros yámbicos e itifálicos. Los Yambos 8-10 están compuestos en trímetros yámbicos, pero tanto del 8 como del 10 se ha conservado una sola línea, lo cual no permite saber si mantenían ese metro a lo largo de cada poema o si en ellos se formaban combinaciones epódicas. Los Yambos 11 y 12 poseen un metro menos común en la yambografía arcaica: el primero está en trímetros braquicatalécticos y el segundo en trímetros trocaico catalécticos.

yambos que componían la colección, véanse Puelma Piwonka (1949, pág. 207); Clayman (1980, págs. 3-7); Lehnus (1993, págs. 95-6); Cameron (1995, págs. 163-73); D’Alessio (1996, págs. 43-7); Kerkhecker (1999, págs. 271-95); Acosta-Hughes (2002, págs. 4-7; 2003, págs. 478-89); y Lelli (2005). Uno de los argumentos que defiende el número de 17 Yambos es la edición de 17 Epodos por parte de Horacio; sin embargo, como lo señala Clayman (1980, pág. 15), es posible que los cuatro poemas del P. Mil. 1.18 fueran añadidos al manuscrito posteriormente para completar el papiro, provocando la atribución incorrecta de estos fragmentos al libro de Yambos: "I have become persuaded that the four poems which follow the original Iambi, call them Mele or whatever, were added to a manuscript of the Iambi in antiquity in order to fill out the "book", and that the total of 17 poems was known at Rome. Whether these were added by the poet himself in an omnibus edition which he made late in life, or by a copyist, they were in place by the time the poems came to Rome and were seen by Catullus, who weote iambic hendecasyllables and Horace who wrote 17 Epodes." 
La variedad dialectal es otras de las características de la colección. Los Yambos 1-5, 8, 10, 12 y 13 están compuestos en jónico; los Yambos 6, 9 y 11 en dórico; y el 7 es una mezcla de dórico y eólico.

Otro rasgo típico es el empleo de la fábula ( $\alpha i ̃ v o \varsigma)$ como dispositivo narrativo, como aparece en los Yambos 2 y 4, y se la puede reconocer también en algunos pasajes de 1, 6 y 7; probablemente haya sido este un elemento destacado por el propio Calímaco en el proyecto del libro. ${ }^{3}$ Su inclusión no es caprichosa, ya que la fábula aparece estrechamente ligada a la poesía yámbica de Arquíloco y, en menor medida, a la de Hiponacte, y ambas formas literarias comparten la función de crítica de las conductas y comportamientos dentro de la comunidad.

Pero, sin lugar a dudas, es la figura de Hiponacte la que confiere cohesión a las diferentes composiciones en torno a una concepción nueva de la poesía yámbica. Las relaciones que se establecen entre el yambo de apertura de la colección y el de clausura son particularmente significativas. En el incio del libro, "Hiponacte" retorna espontáneamente desde el Hades y se presenta ante los eruditos alejandrinos. De este modo, la voz del poeta arcaico aparece como aquella que posee la autoridad para dar inicio al programa yámbico de Calímaco. En el Yambo 13, las alusiones a Éfeso y al coliambo vuelven a convocar la imagen de Hiponacte en la instancia de cierre de la colección.

En estas dos composiciones, además, se representan situaciones de disputa: en el Yambo 1, "Hiponacte" se presenta ante el hostil auditorio de los eruditos que no pierde la oportunidad de manifestar su desprecio a través de murmullos y gestos; en el 13, "Calímaco" debe afrontar la desaprobación y las duras críticas que le dirige uno de los eruditos por su forma de reelaborar la poesía yámbica arcaica. La caracterización de este destinatario inscripto en el enunciado poético parece encarnar a la figura de aquellos intelectuales que

${ }^{3}$ Cf. Lelli (2004, págs. 23-82). 
polemizaban con Calímaco por sus concepciones estéticas dentro del ámbito del Museo alejandrino.

Otro punto de conexión entre ambas composiciones lo constituye la imagen del viaje en el tiempo: en la primera, "Hiponacte" retorna del Hades a la Alejandría contemporánea y narra una antigua parábola sobre las travesías por distintas ciudades de la Grecia arcaica que debió realizar Anfalces con el fin de entregar un premio destinado al mejor de los Siete Sabios; en la segunda, "Calímaco" es acusado de no haber realizado el viaje de iniciación a Éfeso para traer de allí el coliambo.

Los paralelismos, como lo ha destacado Acosta-Hughes, se extienden inclusive hasta las afinidades verbales que se detectan entre estos dos yambos, lo cual ha conducido a considerar la posibilidad de que en este aspecto ambas composiciones hayan sido concebidas como un par. ${ }^{4}$ El cuadro comparativo que presenta Acosta-Hughes es el siguiente:

\begin{tabular}{|c|c|c|c|}
\hline & YAMBO 1 (FR. 191PF) & & YAMBO 13 (FR. 203PF) \\
\hline LÍNEA 11: & $\lambda \alpha \lambda \alpha ́ \alpha \omega \omega \nu$ & LÍNEA 17: & $\lambda \alpha \lambda \varepsilon v \sigma \mid[..] . .[$ \\
\hline LÍNEA 31: & 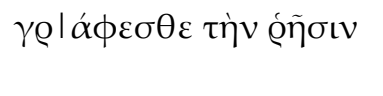 & LÍNEAS 24-25: & $\begin{array}{l}\dot{\eta} \oint \tilde{\eta} \sigma \iota \varsigma \\
\dot{\alpha} \kappa o v[\sigma \tau \varepsilon \dot{\varepsilon} \alpha]\end{array}$ \\
\hline LÍNEA 33: & $\tilde{\omega} \lambda \tilde{\omega} \sigma \tau \varepsilon$ & LÍNEA 24: & $\tilde{\omega} \lambda \tilde{\omega} \sigma \tau^{\prime}$ \\
\hline LÍNEA 89: & $\kappa o v \delta \dot{v} \lambda \omega \kappa \alpha \pi \eta \lambda \varepsilon \tilde{v} \sigma[\alpha \iota$ & LÍNEA 27: & $\dot{\alpha} \pi \varepsilon \mu \pi \sigma \lambda \tilde{\eta}$ \\
\hline LÍNEAS 91-92: & $\begin{array}{l}{[\pi \dot{\varepsilon}] \pi \lambda \mathrm{ov}} \\
\tau \dot{\alpha} \varsigma[\mathrm{Mo}] \dot{v} \sigma \alpha \varsigma\end{array}$ & LÍNEAS 25-26: & $\begin{array}{l}\tau \dot{\varepsilon} \pi \lambda[o v \\
\tau \dot{\alpha} \varsigma \text { Moú } \sigma \alpha \varsigma\end{array}$ \\
\hline
\end{tabular}

Teniendo en cuenta el estado fragmentario del Yambo 13, estos paralelismos verbales parecen ser muy significativos.

A partir de estos argumentos es posible sustentar la hipótesis de que los elementos compositivos, genéricos y temáticos abiertos en el Yambo 1, y desplegados a lo largo de la colección, encuentran finalmente una clausura programática en el Yambo 13. De esta manera, el libro adquiere una estructura

\footnotetext{
${ }^{4}$ Acosta-Hughes (2002, pág. 12): "Iambus 13 closes with the poet's abnegation of a journey to sixth-century Ephesus. It seems clear that Iambi 1 and 13 were conceived in these aspects as a pair. Not only are there the obvius thematic and programmatic parallels, but a striking number of verbal parallels in Iambus 13 recall Iambus 1."
} 
circular (Ringkomposition) en que los itinerarios trazados se bifurcan en una suerte de encrucijada que reenvía nuevamente al primer yambo. ${ }^{5}$

La reelaboración y adaptación al escenario helenístico por parte de Calímaco de la poesía arcaica en general y del yambo en particular se caracteriza por su heterogeneidad, la variedad en las formas, los metros, los dialectos y extensión, que no se ciñen a las determinaciones formales de un único género. ${ }^{6}$ Los investigadores modernos han utilizado diferentes términos para abordar esta diversidad estilística. Puelma Piwonka (1949, págs. 323-35) y Dawson (1950, págs. 141-44) emplean los conceptos de $\pi$ oıkı $\lambda \dot{\alpha} \alpha$ y variatio para describirla. Clayman (1980, pág. 48) interpreta esta diversidad como "artistic organization", cuidadosamente orquestada por el poeta en todos los aspectos; Gutzwiller (1998, pág. 187), por su parte, destaca el carácter orgánico de los Yambos, subraya el paralelismo compositivo de los poemas 1 y 13, 2 y 4, 3 y 5, y

\footnotetext{
${ }^{5}$ Hunter (1997, pág. 41): “The nature of iambic poetry is the explicit subject of two poems in particular, Iambus 1 and Iambus 13, which thus have a special claim to be considered 'programmatic'. The thirteenth Iambus returns to the choliambic metre of the first four poems, the metre most associated with Hipponax, who appears himself in the first Iambus as the authorising 'voice' for these poems, and is apparently spoken in the voice of the poet who to some extent takes up again the themes of Iambus 1 (and indeed of Aitia fr.l); thus the temptation to see a 'closed' poetry book, framed by these two poems, is very strong." A la misma conclusión arriva Kerkhecker (1999, pág. 278): "Finally, there is Iambus XIII. It looks like the poet's final word: a fitting conclusion to the Book. Even more important than the programmatic character are the pervasive connections with Iambus I: metre, theme, and detail of the poem look back to the start. We have come full circle." También Acosta-Hughes \& Stephens (2012, págs. 165-66) observan esta estructura circular: "The 13th Iambus is constructed as the inverse of and as a response to the 1st: in the 1st Iambus Callimachus conjures up the archaic poet, Hipponax, to rail against the critics, and in the 13th Callimachus (Hipponax's alter ego) conjures up the critics to rail against him."
}

6 Clayman (1980, pág. 48): "The Iambi include many types of poems generally considered distinct. The Iambi 1 and 3 are harangues against aischrokerdia; 2 and 4 are moralizing fables; 5 appears to be Hipponactean invective; 6 combines the propemptikon and ekphrasis. 7-11 are all aitia but of different kinds; 7 and 9 are narrated by talking statues on the model of sepulchral epigrams such as 11 certainly is. 8 is an epinicion; 10, a cult aition. The twelfth is a variety of birthday song and finally the thirteenth is the poet's personal justification of this work. These various types of poems are written in five different metrical schemes and three different dialects." 
observa que este libro prefigura la estructura arquitectónica de las ediciones poéticas romanas.

Pero, a pesar del grado de elaboración técnica y artística, los Yambos no se diluyen simplemente en la sofisticación estética, sino que la función de la invectiva yámbica también es adaptada al nuevo escenario y auditorio del

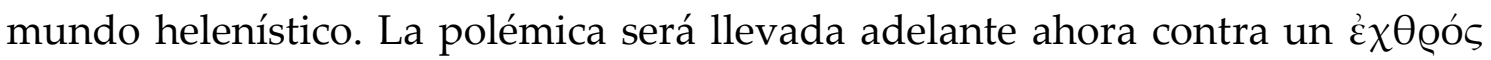
que aparece encarnado en la figura de los filólogos y filósofos alejandrinos. ${ }^{7}$ Precisamente, el Yambo 13 es una defensa de la pluralidad de formas ( $\pi \mathrm{o} \lambda v \varepsilon i ́ \delta \varepsilon\llcorner\alpha)$ de su estética poética frente al juicio de los intelectuales del Museo, especialistas en filología, crítica literaria, y en la recopilación, exégesis y comentario de las obras de la Antigüedad griega. ${ }^{8}$

Debido a que en este capítulo pretendemos abordar los procesos de enmascaramiento del 'yo' en la poesía yámbica de Calímaco, nuestro estudio se centra particularmente en los Yambos 1 y 13. Las razones para esta selección son varias. El empleo de la figura de "Hiponacte" como persona loquens a lo largo del poema que da inicio a la colección, establece desde la apertura del programa poético un visible enmascaramiento del ' $\mathrm{yo}^{\prime}$ ', en tanto que en el poema que cierra el libro, la manifestación de un 'yo', cuya identidad se corresponde directamente con la persona yámbica "Calímaco", implica, desde nuestra perspectiva de análisis, un proceso de desenmascaramiento enunciativo. En segundo lugar, como hemos visto, solo en estas dos composiciones de la colección se inscribe un destinatario que aparece caracterizado como un

\footnotetext{
${ }^{7}$ Lelli (2004, pág. 5): “Critica e polemia letterarie sono dunque un elemento centrale nei Giambi di Callimaco, opera cui il poeta affidò probabilmente, more iambico, le sue segrete convinzioni e i suoi sfoghi viscerali attinenti alla dimensione più intima della propria personalità: la letteratura, la professione di poeta."

8 Acosta-Hughes (2002, pág. 3): "Yet the Hellenistic iambographers were composing iambic poetry not solely as an occasional oral utterance directed at the individual poet's hetairoi [peers] but for a self-consciously literate audience drawn from all over the known world to a huge metropolis in Egypt."
} 
auditorio de eruditos alejandrinos. ${ }^{9}$ Este auditorio se ubica en una posición hostil y antagónica ante "Hiponacte" y "Calímaco", respectivamente, y la situación descripta en cada uno de los poemas implica la confrontación de ideas estéticas dentro del ámbito del Museo alejandrino. En tercer lugar, solamente los Yambos 1 y 13 contienen de manera explícita una reflexión metaliteraria sobre este género poético. ${ }^{10}$ Finalmente, únicamente en estos dos poemas la figura del poeta arcaico Hiponacte aparece de manera substancial en la reflexión sobre el género yámbico.

Para el corpus de Calímaco seguimos el ordenamiento y el establecimiento de los textos en la edición canónica de Pfeiffer (1949). Además, hemos trabajado en conjunto con la edición más actual de D'Alessio (1996) y los comentarios de Clayman (1980); Kerhecker (1999); y Lelli (2004).

\footnotetext{
9 Acosta-Hughes (2002, pág. 91): "A further feature the two poems share is the opening address to a plural audience. Callimachus demonstrates a marked variation from the tradition of archaic iambic in addressing a group as the "object" of the iambos. In both poems one individual (in Iambus 13 the delineated critic), or several individuals singly (in Iambus 1 the different figures drawn from the crowd of literati) come later into focus as the object of invective. Of the Iambi only 1 and 13 have opening lines addressed to a plural audience. (...) The plural audiences of Iambi 1 and 13 do constitute a further shared fea- ture of the two poems, a feature which indicates quite clearly, I would argue, that the two are meant to be appreciated as a pair."
}

${ }^{10}$ Vid. sup. pág. 289 n. 5. 


\section{YАMBO 1 (FR. 191PF)}

\subsection{LA MÁSCARA DE “HIPONACTE” (VV. 1-5)}

El Yambo 1 de Calímaco se inicia en forma abrupta. Una voz identificada con la del poeta Hiponacte irrumpe en escena solicitando la atención del auditorio:

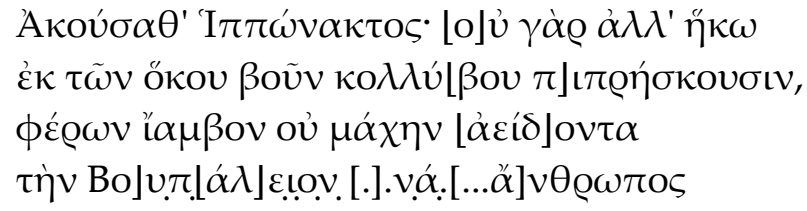

¡Escuchen a Hiponacte! ya que vengo del lugar donde venden un buey por un centavo, trayendo un yambo que no canta mi pelea con Búpalo [.]........h]ombre $\cdots$

Como este primer verso se encuentra citado también, anónimamente, como un ejemplo de coliambo en estudios antiguos de métrica junto a otros versos cuya atribución a Hiponacte ha sido corroborada, se ha especulado que podría ser de su autoría. ${ }^{12}$ A decir verdad, desde este primer verso la voz de

${ }^{11}$ El P.Oxy. 1011 preserva la mayor parte del texto del Yambo 1. En el fol. 2v se lee la inscripción 'KALLIMAXOU IAM[BOI' y las líneas 1 a 10; en el fol. 2r aparecen las líneas 26 a 51. Por su parte, en el fol. 3v encontramos las líneas 54 a 73 y en el fol. $3 \mathrm{r}$ las líneas 78 a 98 . Otro papiro, el P.Oxy. 1363, contiene también las líneas 5 a 34. Algunos versos han sido transmitidos además por tradición indirecta. El metro empleado en el Yambo 1 es el estiquio coliámbico y su dialecto, el jónico literario.

${ }^{12}$ La paternidad del primer verso implica a muchas fuentes antiguas y ha sido muy debatida por los editores modernos. En su edición de Hiponacte, Masson (1962, pág. 101) atribuye la autoría del verso al poeta arcaico; West (1998, pág. 110) lo edita como Hipponax *1 fragmentum sine auctoris indicio certiore receptum; Degani (1991, pág. 163) como Hipponax ${ }^{\circ} 187$ fragmentum dubium; Gerber (1999, págs. 352-3), que sigue la edición de West, lo consigna como Hipponax T6 y fr. 1, pero señala el desacuerdo de los investigadores sobre su autoría. En su edición de los Yambos de Calímaco, Pfeiffer (1949, pág. 161) considera el verso como propio del poeta helenístico y no de Hiponacte. Su argumentación es la siguiente: en primer lugar, sostiene que los escoliastas a Nubes y Ranae de Aristófanes señalan que oủ $\gamma \dot{\alpha} \varrho \dot{\alpha} \lambda \lambda \alpha$ es un 'aticismo' y ellos 
atribuyen la paternidad del verso completo a Calímaco (1933, pág. 268); cf. Sch. Aldinae in Arist.

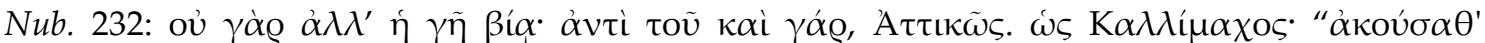

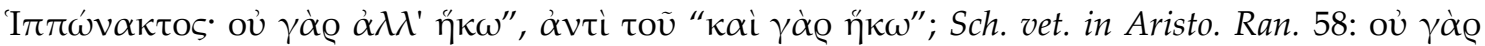

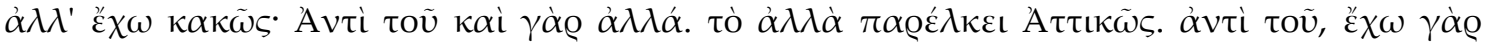

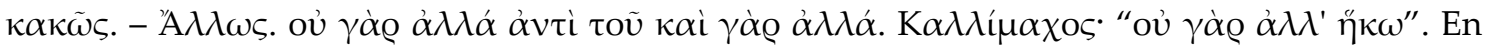
segundo lugar, Pfeiffer (1928, págs. 310, 336) y (1949, pág. 161) señala que diferentes estudios antiguos de métrica utilizan ese verso como ejemplo de coliambo; cf. Hefestión, Ench. met. 5.4

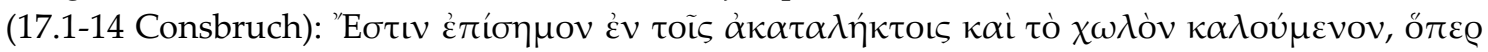

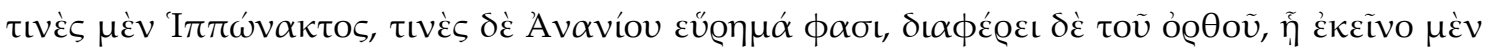

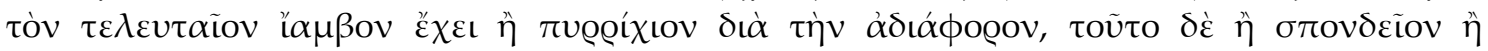

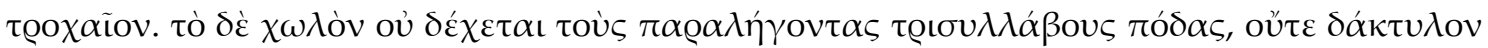

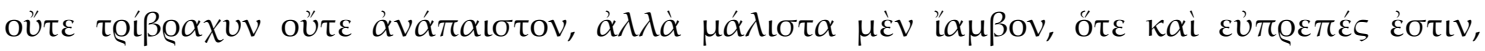

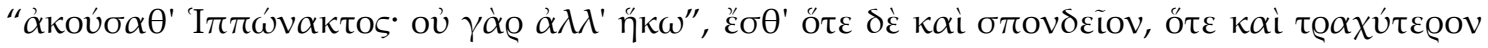

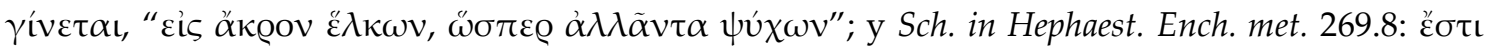

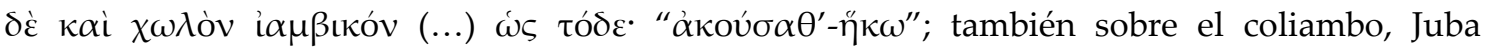
artígrafo apud Rufino, Comm. in metra Terent., Gramm. Lat. vi.562.19 Keil: est autem proceritatis eiusdem versus qui unius pedis differentia nomen amittit. nam quod sexto loco (...) non iambus sed spondeus vel trochaeus accipitur et a longa syllaba incipit, claudum carmen facit et

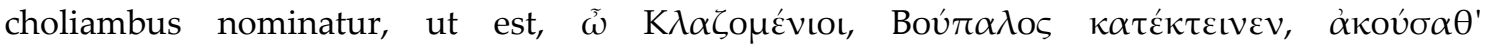
I $\pi \pi \omega \dot{v} \alpha \kappa \tau о \zeta$ oủ $\gamma \dot{\alpha} \varrho \dot{\alpha} \lambda \lambda^{\prime} \eta^{\prime} \kappa \omega$; igualmente, Juba artígrafo apud Mario Plotio, Ars gramm., Gramm. Lat. vi.522.15 Keil: Hipponactium Ananium clodum trimetrum iambicum acatalectum fit hoc modo, cum novissimus pes disyllabus a longa incipiat, cum deberet a brevi, ut iambus

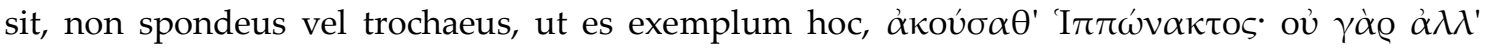

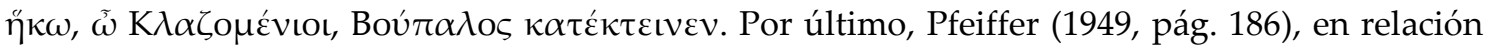
al fr. 195.22Pf y Arquíloco fr. 329W (spurium), sostiene que Calímaco jamás copió totalmente un verso de otro poeta sin modificarlo: "Callimachus numquam totum versum ab alio poeta mutuatus est"; cf. Herter (1937, pág. 216). De acuerdo con estos argumentos, Pfeiffer da por sentado que el verso pertenece a Calímaco y no a Hiponacte. Su conclusión es la siguiente (1949, pág. 161): "metrici scriptores, ut exemplum pentametri primum Aetiorum pentametrum afferunt (v. fr. 1, 2), ita exemplum choliambi primum Callimachi iamborum versum laudant, non Hipponactis; [...] Non Hipponax sed Callimachus ad exemplum comoediae Atticae (unde oủ $\gamma \grave{\alpha} \varrho \dot{\alpha} \lambda \lambda \dot{\alpha}$, v. etiam Headlam-Knox ad Herond. vi 101)." Sin embargo, se pueden oponer algunas objeciones. En primer lugar, en relación a los escolios a Aristófanes y al aticismo de la frase oủ $\gamma \grave{\alpha} \varrho \dot{\alpha} \lambda \lambda \dot{\alpha}$, ha sido demostrado que la antigua doctrina gramatical -y en particular la de los escoliastas de Aristófanes- calificaba como 'aticismo' toda forma anómala o extraña a la

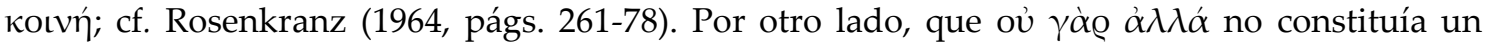

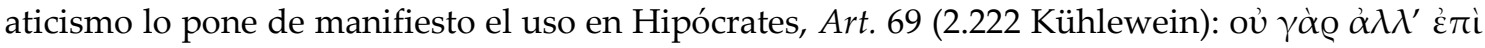

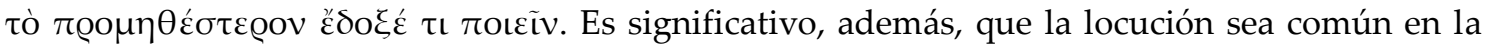

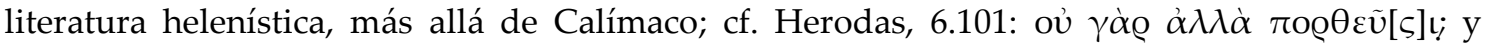

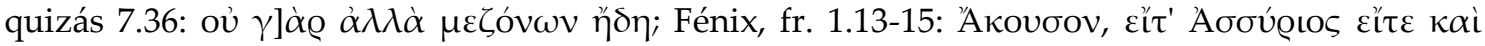

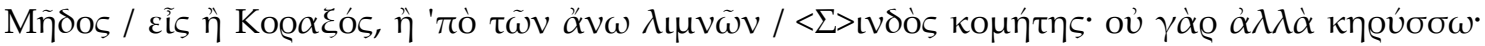
Sorprendentemente, el yambo de Fénix es muy similar al de Calímaco, una voz que habla desde

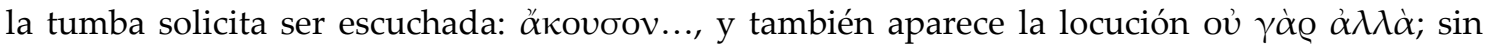
embargo, Fénix no podría haber imitado el poema de Calímaco por diferencias cronológicas, tendría que haberse basado en otra fuente, tal vez Hiponacte mismo. Por otro lado, que los escoliastas de Aristófanes atribuyan el verso a Calímaco no implica que este no lo haya podido tomar del propio Hiponacte. Denniston (1954, pág. 31) señala que la locución está confinada a los yambógrafos, la comedia antigua, Eurípides y Platón, y atribuye el verso $\alpha \hat{\kappa} \kappa o v ́ \sigma \alpha \theta^{\prime}$ I $\pi \pi \omega \dot{\omega} \alpha \kappa \tau о \varsigma^{\circ}$ ov $\gamma \dot{\alpha} \varrho \dot{\alpha} \lambda \lambda^{\prime} \eta^{\prime} \kappa \omega$ al poeta de Éfeso. En segundo lugar, en cuanto a los estudios de 
"Hiponacte" se deja oír ante el auditorio de los eruditos alejandrinos. Todos y cada uno de los procedimientos poéticos empleados por Calímaco en esta primera parte del yambo están destinados a presentar de manera mimética la voz del poeta arcaico. ${ }^{13}$ En esa dirección, precisamente, se justifica su elección del trímetro yámbico escazonte, llamado también hiponacteo. Del mismo modo, el empleo de la autorreferencia en tercera persona (I $\pi \pi \omega \dot{\omega} \alpha \kappa \tau O \varsigma$ ), artilugio poético característico de Hiponacte ${ }^{14}$ denota la búsqueda de imitar la voz del poeta de Éfeso. El imperativo apelativo en segunda persona plural exhortando

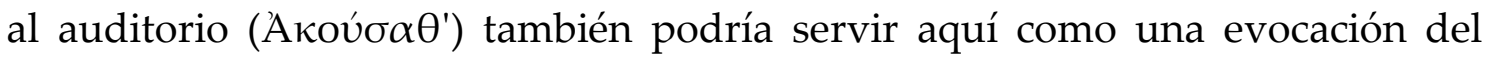
inicio de los poemas yámbicos arcaicos. ${ }^{15}$ Pero, por sobre todo, si había alguna

métrica, Hefestión cita anónimamente dos versos como ejemplos de coliambo: àkov́ $\sigma \alpha \theta^{\prime}$

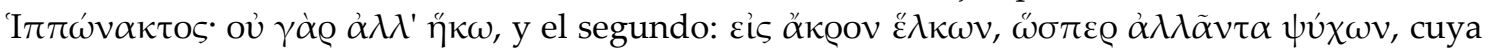
atribución a Hiponacte está confirmada por el P.Oxy. 2174 fr. 16 col. ii + addit. (=fr. 86Dg). En

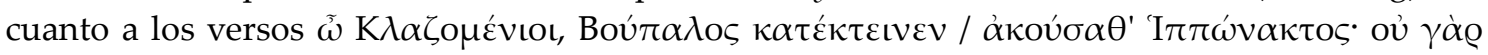
$\dot{\alpha} \lambda \lambda^{\prime} \eta \eta^{\prime} \kappa \omega$, citados en forma anónima por Rufino, y posteriormente por Mario Plotio, como ejemplos de coliambos, ambos los colocan uno a continuación del otro, como si pertenecieran a una misma composición. El primero ha sido atribuido, sin cuestionamientos, a Hiponacte (fr. 17Dg), tanto por su métrica como por las referencias a Clazomenes y a Búpalo. En tercer lugar, la afirmación de que Calímaco nunca copia totalmente un verso de otro poeta sin modificarlo es demasiado categórica. No hay lugar a dudas de que en el Yambo 1 Calímaco hace hablar a Hiponacte por sí mismo, por lo cual podría haber iniciado el poema con sus propias palabras; cf. Degani (2002, págs. 241-3); Vox (1995, pág. 275); Kerkhecker (1999, págs. 28-31).

${ }^{13}$ Acosta-Hughes \& Stephens (2012, pág. 62): “Callimachus does not speak in propria persona in this opening Iambus but ventriloquizes the older poet, a creative decision that provided the bone of contention in the 13th Iambus.Callimachus brings back Hipponax not as a character in a narrative but by an act of mimesis, permitting him to speak in his own voice."

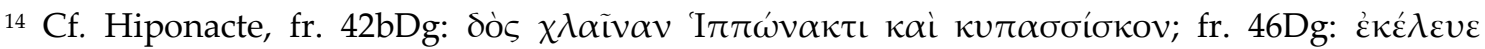

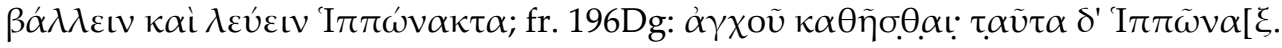

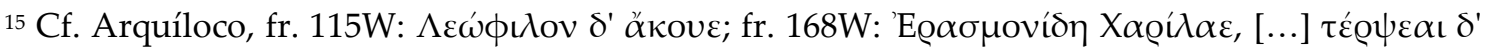

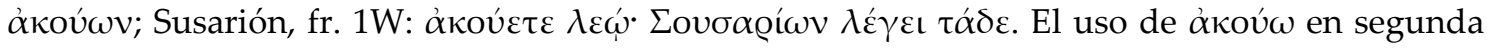
persona con el fin de exhortación o apelación al auditorio también aparece reiteradamente en la

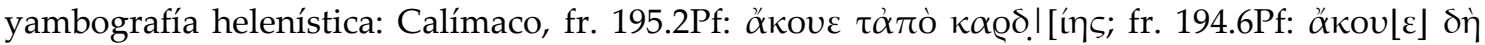

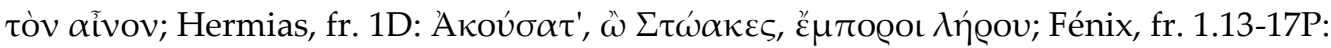

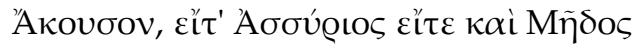

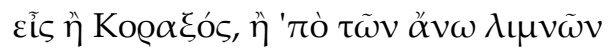

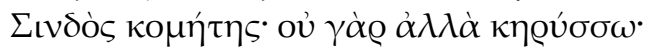

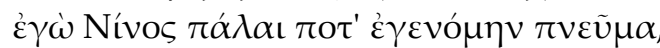

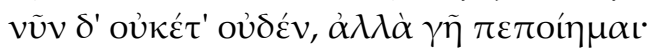


duda acerca de la identidad de la voz que abre el poema, se disipa con la

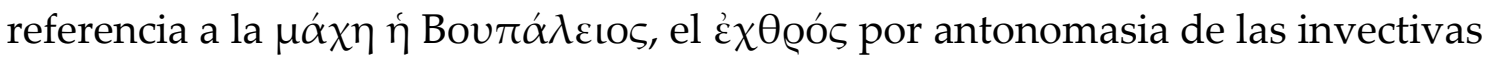
yámbicas de Hiponacte. Detectamos entonces un progreso gradual, a través de diversos indicios, en el descubrimiento de la máscara o la voz empleada por el poeta de Cirene, no otra que la de "Hiponacte". De este modo, quien se presenta ante los eruditos alejandrinos es una suerte de "Hiponacte" redivivo.

El poeta arcaico ha retornado del Hades, el lugar donde se puede comprar un buey por un centavo, ${ }^{16}$ para reunirse con los eruditos del Museo alejandrino en el templo de Serapis, más allá del muro de la ciudad. El regreso de "Hiponacte" parece estar marcado por un programa poético particular, programa que se anuncia en la cláusula del participio y que podría enfatizarse

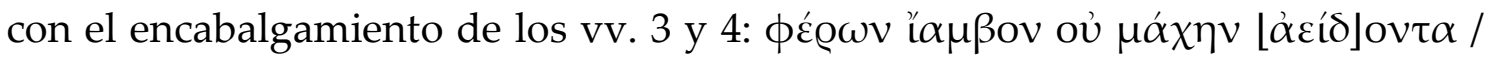

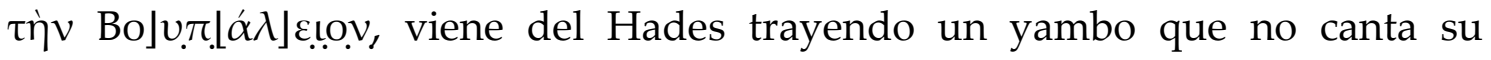
batalla... contra Búpalo. ${ }^{17}$

¡Escucha, si eres asirio o medo, si eres de Corax o si desciendes de los altos lagos con el pelo largo, sindio, ya que hago este anuncio! Yo, Nino, hace mucho tiempo era aliento de vida, pero ahora nada soy, pues me he vuelto polvo.

Es notoria la similitud de los versos yámbicos de Fénix con los de Calímaco. Al igual que Hiponacte en el inicio del Yambo 1, en este poema también aparece la voz de un muerto. Por otro lado, además de iniciarse con el verbo $\alpha$ koú $\omega$ en segunda persona imperativo, aparece

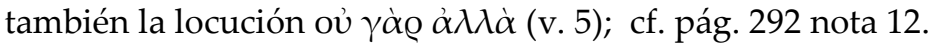

${ }^{16}$ El кó $\lambda \lambda v \beta o \varsigma$ era una moneda de muy poco valor, utilizada en imágenes literarias como

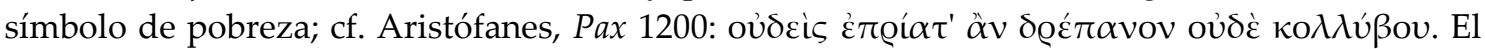
bajo costo de las mercancías en el inframundo parece haber sido algo proverbial, la misma referencia al poco valor de un buey en el Hades aparece en Calímaco, Epigr. 13.6Pf: $\varepsilon \grave{l} \delta \dot{\varepsilon}$ тòv

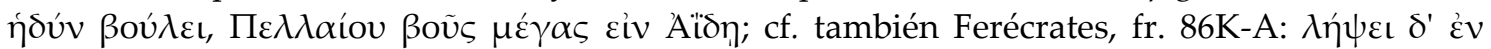

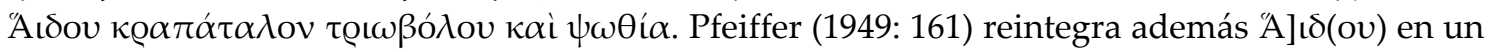
escolio a las líneas 2-3, en el margen derecho del P.Oxy. 1011 fol. 2v.

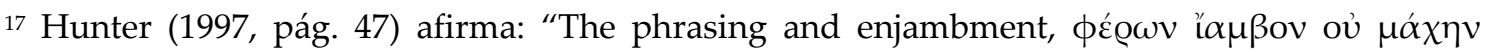

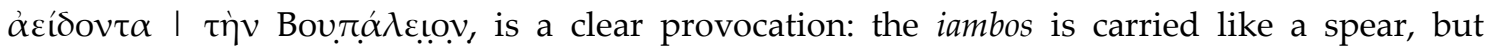
Callimachus/Hipponax is not 'looking for a fight', or rather not a fight with Boupalos, thus leaving the poet free to fight with anyone else." 
Deberíamos preguntarnos entonces, si trae un ľ $\alpha \mu \beta$ os que ya no canta acerca de sus enfrentamientos con Búpalo, si no es el ľ $\alpha \mu \beta o \varsigma$ de invectiva que caracterizó a su poesía por más de tres siglos, ¿qué tipo de yambo es el que "Hiponacte" presenta ahora en una ciudad y en un contexto tan distante y diferente al de la Éfeso del s. VI a.C., como la Alejandría durante el dominio de Ptolomeo II? En principio, las Diégesis que transmiten los argumentos comentados e intrepretados de los Aitia y los Yambos podrían darnos algunos indicios sobre los motivos de "Hiponacte" para regresar, por un breve período, a la Alejandría ptolemaica:

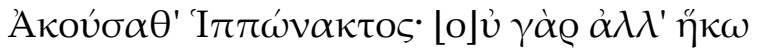

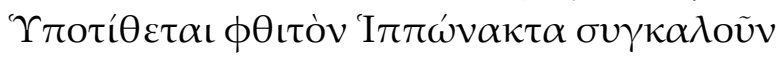

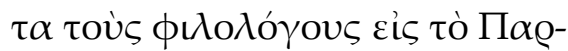

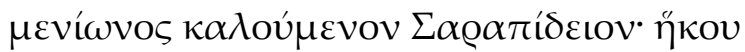

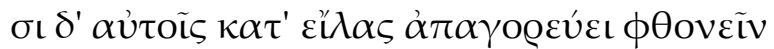
$\dot{\alpha} \lambda \lambda \dot{\lambda} \lambda$ oเs, ...
\end{abstract}

Diégesis 6.1-6 (Scholia ad Fr. 191Pf) ${ }^{18}$

hen a Hipon

Se imagina que Hiponacte, muerto, convoca a los filólogos ${ }^{19}$ en el templo de Serapis, llamado Parmenio. Cuando ellos llegan, en enjambres, él los exhorta a que no tengan envidia

${ }^{18}$ Las Diégesis a todos los Yambos de Calímaco han sido transmitidas por el P. Mil. vogl. 1.18 (c. s. II d. C.).

19 Pfeiffer (1949, pág. 163) consigna en el aparato crítico una varia lectio en la línea 3 de la

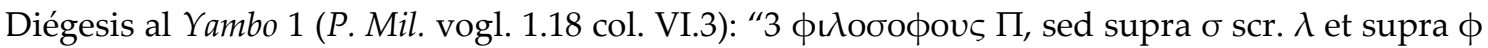

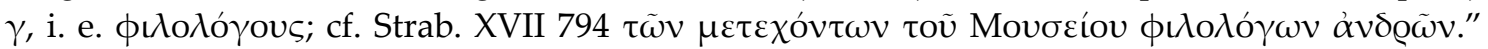

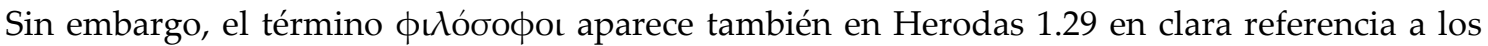
eruditos del Museo de Alejandría, y en diversos textos de época romana para aludir a los sabios

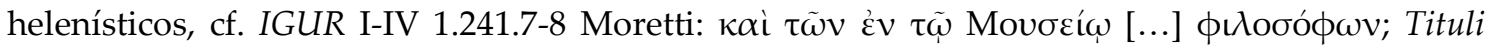

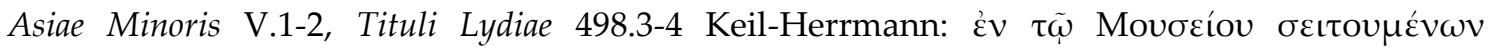

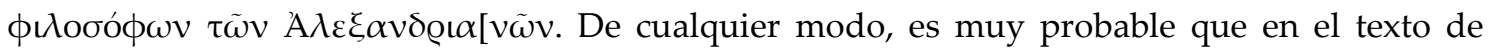
Calímaco no apareciera ninguno de los dos términos; cf. D’Alessio (1996, pág. 577 n. 1). Por su parte, Hunter (1997, pág. 49) considera que, ante la alternativa de lecturas del papiro,

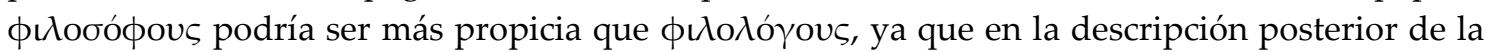
fábula acerca de la copa de Baticles los personajes que intervienen son los $\varepsilon \pi \tau \dot{\alpha} \sigma o \phi \tilde{\omega} v$; cf. Diégesis 6.10. 
La Diégesis, como vemos, nos informa que "Hiponacte" reúne a los eruditos en el templo de Serapis para exhortarlos a dejar de lado las envidias

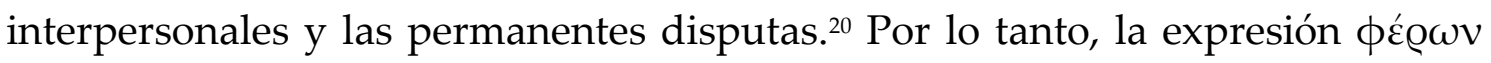

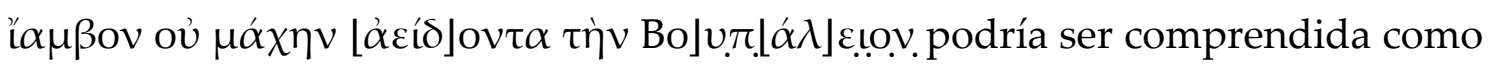
la expresión de un distanciamiento del programa yámbico arcaico y de la vis agresiva que caracterizaba a Hiponacte en sus encendidas invectivas contra Búpalo. Podríamos pensar, por tanto, que Calímaco nos estaría presentando a un "Hiponacte" más moderado, cuya venida tiene el altruista propósito de apaciguar los rencores intelectuales surgidos en el contexto del Museo alejandrino. Se ha interpretado que la intervención de Hiponacte en estos primeros versos del poema calimaqueo los convierte en un proemio programático de la totalidad del libro de Yambos: se presenta un "nuevo

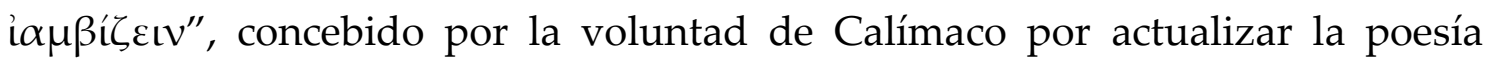
yámbica de acuerdo con el escenario helenístico, adoptando principalmente la métrica, la persona loquens, la fábula y los proverbios del poeta de Éfeso al refinado auditorio de eruditos alejandrinos, dejando de lado, en cambio, la invectiva personal (ỏvo $\mu \alpha \sigma \tau \grave{\imath} \kappa \omega \mu \omega \delta \varepsilon \tilde{\imath} v)$ y las expresiones vulgares típicas de aquel. Por lo tanto, al comienzo del poema, "Hiponacte" tendría la función de

${ }^{20}$ Cf. Cozzoli (2015, págs. 1-16). Las disputas entre los eruditos del Museo alejandrino eran famosas en la antigüedad, tal como lo manifiesta la sátira de Timón el Silógrafo, S. H. 786, transmitida por Ateneo, Deipn. 1.41.1-8 Keibel:

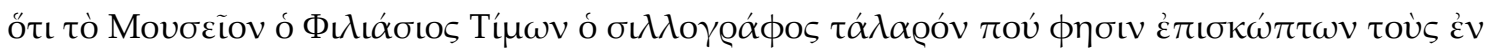

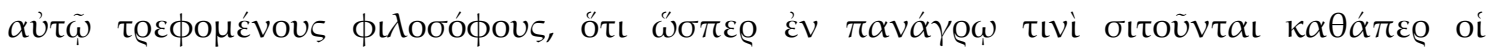

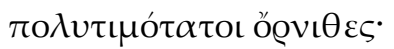

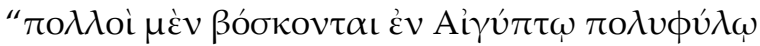

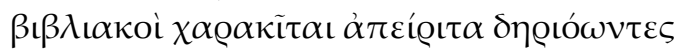

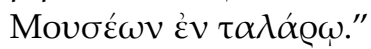

“En cuanto al Museo, Timón de Fliunte, el silógrafo, lo compara en alguna parte con una jaula de pájaros, cuando se burla de los filósofos que viven en él, ya que, al igual que aves muy preciadas, en una jaula son alimentados:

«en la Egipto de múltiples razas, muchos librescos enclaustrados se alimentan mientras disputan sin cesar en la jaula de las Musas.»" 
explicitar la renuncia al carácter bélico del yambo e invitar al auditorio de filólogos a firmar una pax poetica. ${ }^{21}$

Es importante señalar en este punto que la voz de "Hiponacte" es una voz asumida por Calímaco con una determinada intención, responde en todos

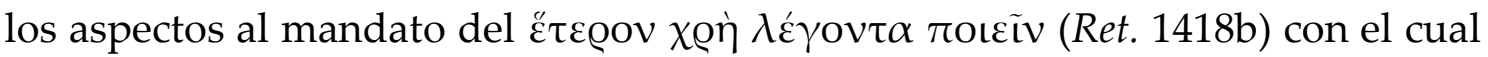
Aristóteles ejemplificaba el modo en que Arquíloco realizaba sus invectivas yámbicas, ${ }^{22}$ vale decir, una máscara que sirve para mostrar las facciones y los gestos del poeta arcaico pero, al mismo tiempo, también para ocultar el rostro del poeta helenístico.

Lamentablemente el v. 5 no se ha conservado, por lo cual no es posible saber si allí "Hiponacte" hacía alusión al carácter preciso de este nuevo yambo que ya no va a cantar la guerra con Búpalo.

\subsection{EL ENJAMBRE DE ERUDITOS (VV. 6-31)}

En los versos sucesivos, debido al mal estado de los papiros, el texto está muy dañado y es fragmentario: en los vv. 12 a 25 apenas si es posible leer una o dos palabras por línea. Sin embargo, aun así se puede deducir que este pasaje aporta datos significativos para precisar el contexto de ejecución poética de "Hiponacte" ante su auditorio helenístico (interno o intradiegético), pero también para establecer algunos vínculos entre este auditorio y el auditorio real de la instancia de ejecución del yambo de Calímaco (auditorio externo o extradiegético):

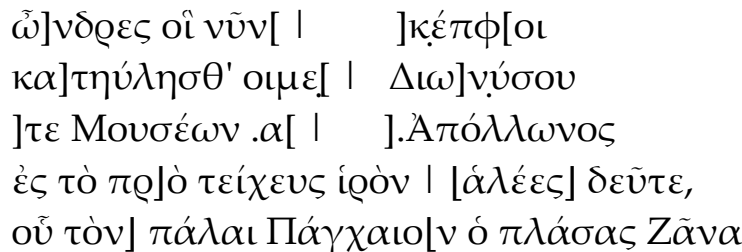

${ }^{21}$ Cf. Cozzoli (1996, pág. 141).

22 Vid. sup. pág. 131.
10 


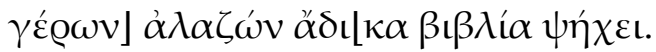

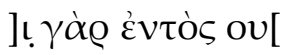

] $\alpha \dot{\gamma} \tau \iota \varsigma \cdot \eta \pi \mathrm{o} \lambda[$

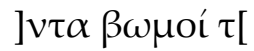

]v. Tอòs Aı $\delta \eta v[$

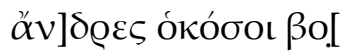

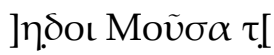

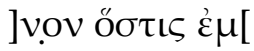

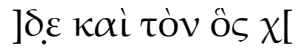

]v. $\varepsilon \tau \alpha i ́ \emptyset \eta v \alpha \tau[$

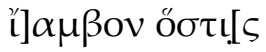

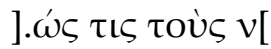

] $\alpha \dot{\mu \varepsilon \tau \varrho \alpha ~ \tau о \iota \varsigma[~}$

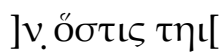

$\pi] \mathrm{o} \lambda \lambda \mathrm{oú} \varsigma \cdot \dot{\varepsilon} v[$

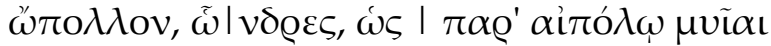

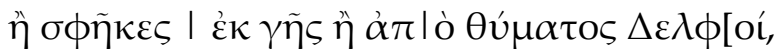

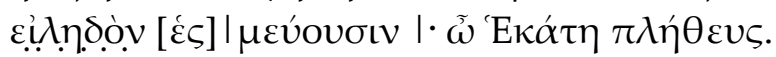

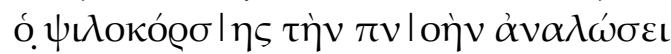

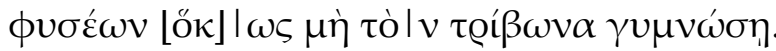

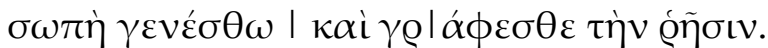

Calímaco, fr. 191.6-31Pf

... hombres de estos tiempos... petreles...

... dominados por el sonido de la flauta... de Dioniso,

... de las Musas... de Apolo...

¡Al templo, delante de los muros! ¡Aquí todos juntos!, donde el viejo charlatán que ideó al antiguo Zeus Panqueo, 10 garabatea libros impíos.

... pues dentro...

... alguien...

... altares...

... al Hades...

... hombres cuantos...

... Musa...

... cualquiera me...

... y aquel que...

... compañera...

... yambo cualquiera que...

... alguien...

... metros...

... cualquiera que...

... muchos...

¡A polo! ¡Los hombres, como moscas junto a un cabrero, o avispas de la tierra, o como los de Delfos por un sacrificio, [se mueven] alrededor, en enjambres! ¡Hécate! ¡Qué multitud! 
-El pelado se quedará sin aliento

de [tanto] resoplar para no verse desnudo de su manto-

¡Que se haga silencio y escriban mi relato!

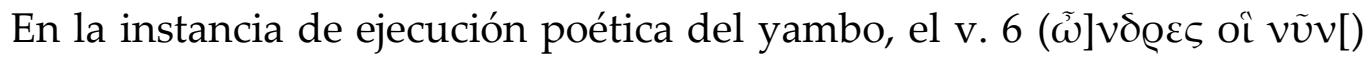
podría dejar de manifiesto que el destinatario de "Hiponacte" ya no es el auditorio de Clazomenes del s. VI a. C. sino el de la Alejandría del s. III a. C. En

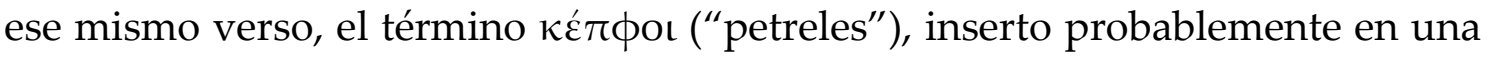
estructura apositiva o comparativa, refiere a esos hombres del presente que

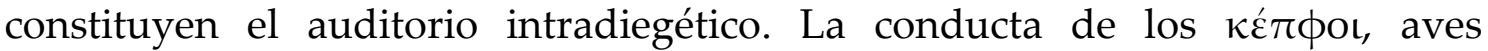
marinas que por su falta de cautela aparecen como presa fácil, es utilizada en la antigüedad griega para simbolizar despectivamente la ingenuidad y candidez de algunas personas. ${ }^{23}$ De este modo, en su primera apelación al auditorio helenístico, "Hiponacte" emplea los apóstrofes irónicos, en tono cómico y caricaturesco ( $\gamma \varepsilon \lambda$ oĩov), típicos de las imprecaciones yámbicas arcaicas. La caracterización como $\kappa \dot{T} T \phi o ı$ podría corresponderse además con las reiteradas imágenes que, en los versos siguientes, representan al auditorio moviéndose en enjambres y cometiendo actos poco razonables en muchedumbre. Entre estas acciones, el verbo $\kappa \alpha \tau \alpha v \lambda \varepsilon ́ \omega(\mathrm{v} .7)$ identifica a aquellos que se dejan influenciar o dominar por el sonido de la flauta. Aunque es muy difícil reconstruir el sentido preciso de este pasaje, la mención de ciertas divinidades -Dioniso, las Musas y Apolo- podría estar sugiriendo distintas corrientes reunidas según las

\footnotetext{
${ }^{23}$ Cf. Aristófanes, Pax 1067-8, en que se alude a la imprudencia humana a través de la imagen de

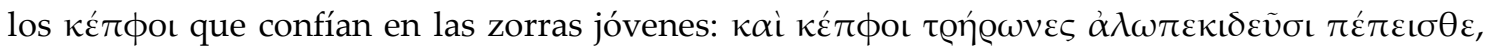

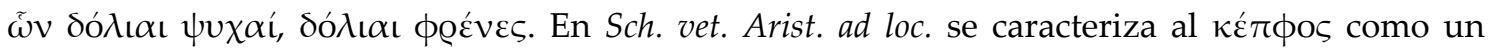
animal tonto ( $\varepsilon u ̈ \eta \theta \varepsilon \varsigma \zeta \tilde{\omega} \mathrm{ov}), \mathrm{y}$ allí mismo se hace referencia al pasaje del yambo de Calímaco:

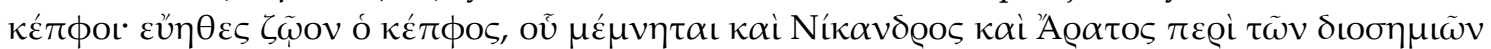

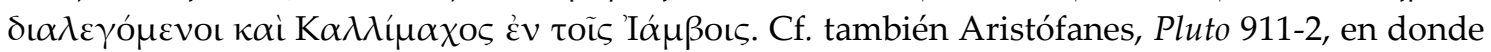

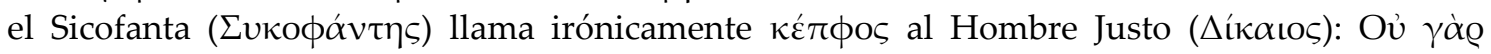

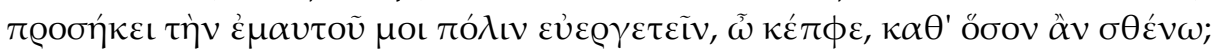


formas poéticas que profesan, ya sea como objeto de estudio y compilación, o como creación poética propia. ${ }^{24}$

Del mismo modo que el v. 6 nos ubica temporalmente frente al auditorio helenístico, los vv. 9-11 sitúan la espacialidad donde se desarrolla la escena: “el

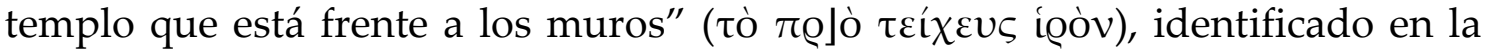
Diégesis 6.3-4 como el santuario de Serapis construido por el arquitecto Parmenio. $^{25}$

La alusión a Evémero de Mesina (ss. IV-III a. C.) en los vv. 10-11, además de conformar una invectiva yámbica, podría funcionar también como una referencia de localización del templo. De acuerdo con varias fuentes antiguas,

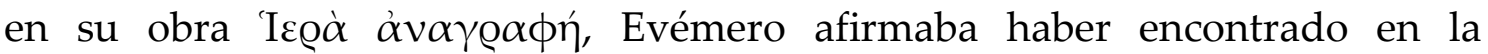
imaginaria isla de Pancaya un enorme templo dedicado a Zeus Trifilio, que contenía una columna con una inscripción en la que se revelaba que todas las divinidades conocidas en realidad habían sido en sus orígenes hombres, y que a causa de sus actos de benevolencia hacia la humanidad habían recibido honras y honores hasta alcanzar finalmente la divinización. Por este motivo Evémero

\footnotetext{
${ }^{24}$ Pfeiffer (1949, pág. 162) indica en aparato crítico que los vv. 7-8 se refieren a los filólogos que se mencionan en Diegesis 6.2-4: "7. sq. viros, quos convocat Hipponax redivivus, Dieg.

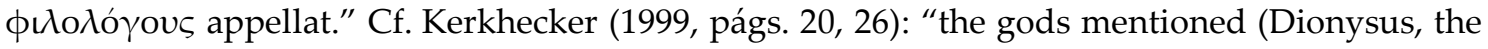
Muses, Apollo) suggest poets or literary scholars (...) Dieg. VI 3 calls them scholars -but can one

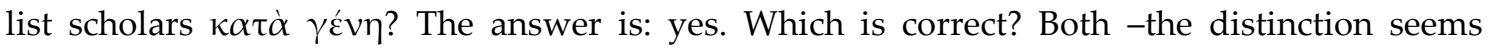
artificial, and may not have been Callimachus'. The Diegesis simplifies. Hipponax' audience, it

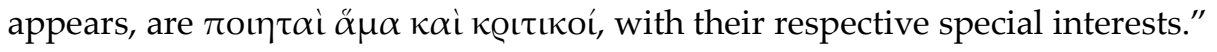

${ }^{25}$ La identificación y la ubicación precisa del santuario al que se alude en el Yambo 1 han sido

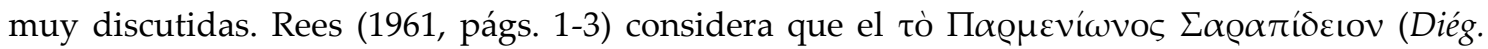
6.3-4) refiere al Gran Templo de Serapis, donde se encontraba una de las bibliotecas más importantes de Alejandría. Sostiene además que este santuario, al igual que el consagrado a la misma divinidad en Menfis, podría haber tenido estatuas en honor a los sabios en su entrada, por lo cual, sería lógico que en este escenario Hiponacte dirigiera a un grupo de

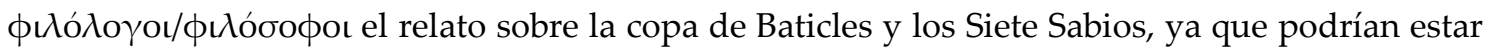
frente a las estatuas de ellos. Sin embargo, hay quienes argumentan que se refiere al consagrado en Racotis, o a uno de los diferentes santuarios de Serapis ubicados en las afueras del muro de Alejandría. Cf. Pfeiffer (1949, pág. xxxix; vol. 2); Fraser (1972, págs. 270-71, 735-6); D’Alessio (1996, pág. 46).
} 
recibió el epíteto de a̋ $\theta \varepsilon \operatorname{cos.}^{26}$ En esa misma dirección, "Hiponacte" califica a Evémero como el viejo que "modeló" o "ideó" ( $\pi \lambda \alpha ́ \sigma \sigma \omega)^{27}$ al Zeus de Pancaya, ${ }^{28}$

${ }^{26}$ Cf. FGrH 63 y Winiarczyk (2002). La mayor parte de los testimonios sobre Evémero y de los

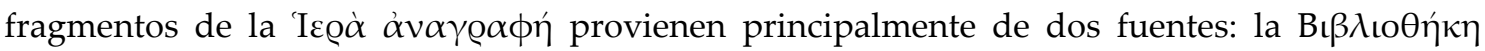
Iбтофıкń de Diodoro Sículo (s. I a. C.) y la Divinae institutiones de Lucio Lactancio (s. I d. C.). De

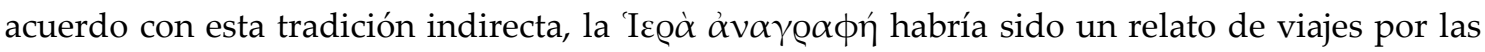
islas del Mar Arábigo narrado en primera persona. Su interpretación sobre el origen humano de los dioses habría gestado hacia la época helenística una corriente ateísta denominada "evemerismo." Varias fuentes refieren los versos del Yambo 1 de Calímaco como testimonio del

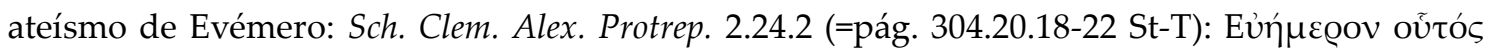

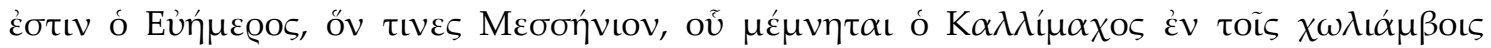

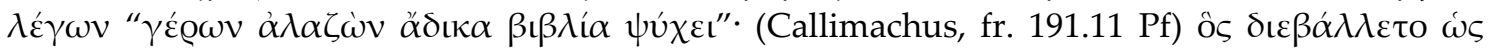

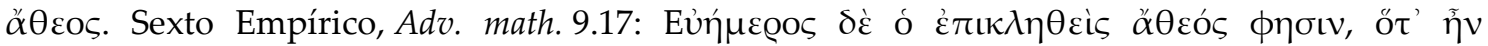

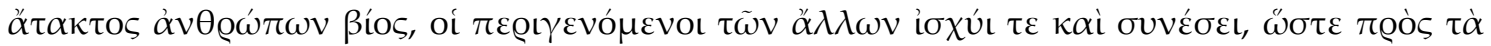

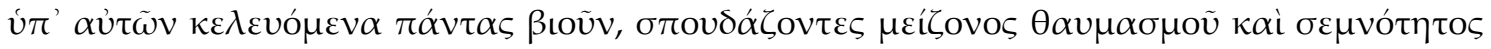

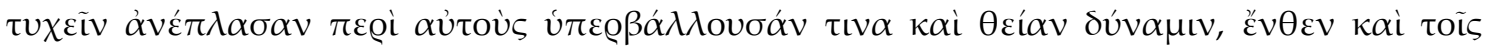

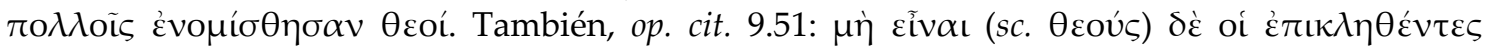

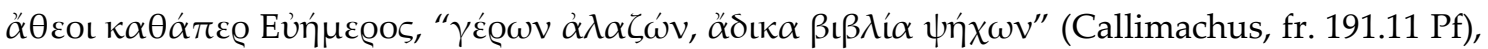

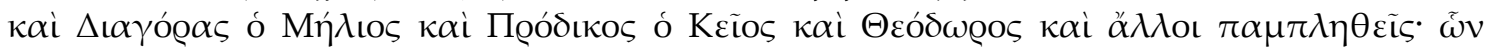

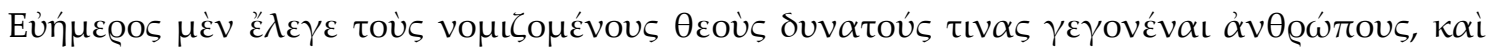

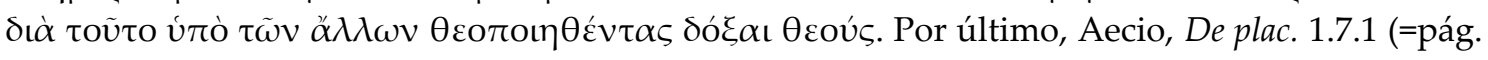

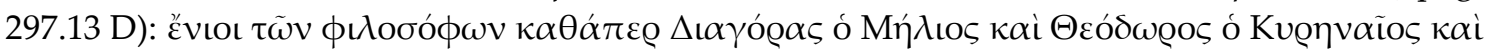
Eưnj

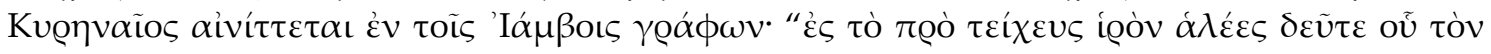

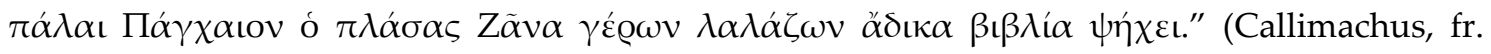
191.9-11 Pf).

${ }^{27}$ El radical $\pi \lambda \alpha \theta$ - tiene el significado de dar determinada forma a la materia, y se emplea particularmente en la escultura; cf. DELG s.v. $\pi \lambda \alpha ́ \sigma \sigma \sigma \omega$.

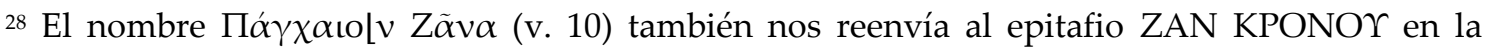
supuesta tumba de Zeus en Creta. Calímaco se refiere irónicamente a esta tumba en el "Himno a Zeus", donde trata particularmente sobre las distintas ciudades que se jactan de ser el sitio de

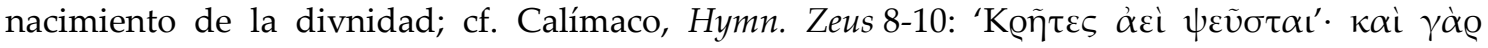

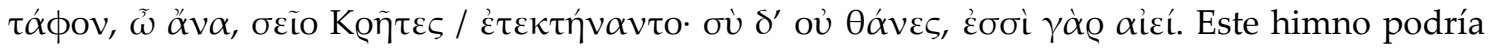
entrañar también una alusión crítica al "evemerismo" de la época, ya que, de acuerdo con Lactancio, Epit. div. inst. 1.2.1-3, Evémero narró el origen de Zeus y de los demás dioses, sus hechos, sus descendencias, e incluso descubrió sus "tumbas": "Euhemerus fuit Messenius, antiquissimus scriptor, qui de sacris inscriptionibus veterum templorum et originem Iovis et res gestas omnemque progeniem collegit; item ceterorum deorum parentes patrias actus imperia obitus, sepulcra etiam persecutus est." Por otro lado, Minucio Félix, Octavius 21.1, nos informa que Evémero enumeraba los hombres que luego fueron reconocidos como dioses por sus méritos comunitarios, los lugares en que ellos nacieron y sus tumbas, entre ellos Zeus y la cueva de Dictea en Creta, testimonio que a pesar de ser tardío nos sirve para determinar que Evémero seguía la tradición cretense sobre Zeus: "ob merita virtutis aut muneris deos habitos Euhemerus exsequitur et eorum natales patrias sepulcra dinumerat et per provincias monstrat, Dictaei Jovis et Apollinis Delphici et Phariae Isidis et Cereris Eleusiniae." Véase particularmente Winiarczyk (2002, págs. 5-7). 
y lo describe como un "charlatán" ( $\dot{\alpha} \lambda \alpha \zeta \omega \dot{\omega} v)^{29}$ que garabatea libros impíos ( $\alpha ð \delta \iota \kappa \alpha \beta \iota \beta \lambda i ́ \alpha \psi \eta ́ \chi \varepsilon \iota)$. Aunque se ha postulado que este pasaje del Yambo 1 podría referirse a una estatua de Evémero, situada frente al templo de Serapis, cuyo gesto consistía en levantar entre las manos un rollo abierto de sus Ired

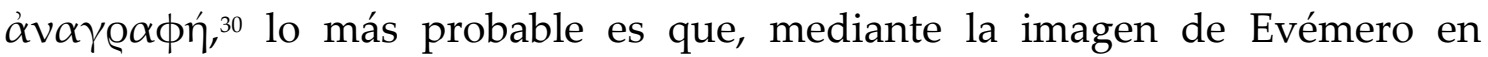
manifiesta ostentación panfletaria de su ateísmo, "Hiponacte" estuviera dirigiendo una invectiva sarcástica contra él y sus seguidores que, activos hacia la época, se reunirían frente al templo de Serapis para publicitar su doctrina. ${ }^{31}$

De los vv. 12 a 25 es muy poco lo que se ha preservado, el P.Oxy. 1363 apenas conserva algunas palabras de la parte central del poema, lo que no permite avanzar con una interpretación convincente de este pasaje. Tal vez se realizara una descripción del citado templo, en atención a la presencia de frases

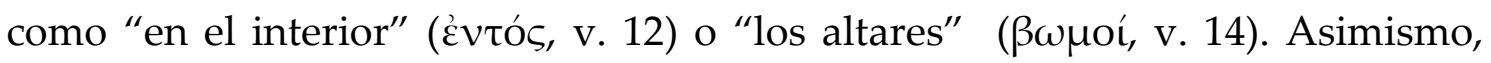
“Hiponacte" parecería estar anunciando su pronto retorno "al Hades" (ז@òs

${ }^{29}$ Seguimos aquí la lectura $\dot{\alpha} \lambda \alpha \zeta \omega \dot{\omega} v$. Pfeiffer (1949, pág. 162) edita $\lambda \alpha \lambda \dot{\alpha} \zeta \omega v$ aunque en ap. crit.

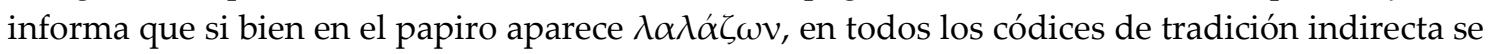

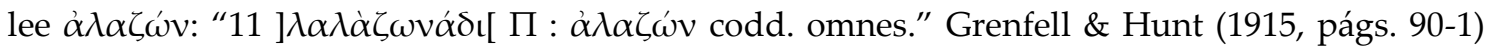
ya habían afirmado mucho antes: " $\lambda \alpha \lambda \alpha \zeta \omega \nu$ was apparently written, though the grave accent on the $\alpha$ implies $\alpha \lambda \alpha \zeta \omega v$, the ordinary reading, which there is no reason to doubt." Además, a diferencia de $\lambda \alpha \lambda \alpha \dot{\zeta} \omega \nu$, que es una forma bastante infrecuente, $\alpha \lambda \alpha \zeta \omega \dot{\omega} v$ es utilizada frecuentemente para referirse en forma cómica a los sofistas; cf. Cratino, fr. 380; Aristófanes, Nubes 102; Platón, Charm. 173c.5.

${ }^{30}$ Rees (1961, pág. 3): "Callimachus might be referring sarcastically and rather typically to a statue of Euhemerus erected in a prominent position in Parmenion's Sarapeum." Sin embargo, el levantamiento de una estatua de Evémero, junto a la de los sabios arcaicos, parece una honra excesiva para un escritor muy cuestionado y que aún vivía o había muerto recientemente. Evémero fue coetáneo de Calímaco, probablemente un poco mayor que él. Diodoro Sículo, Praep. evang. 2.2 (p. 59D), informa que fue amigo de Casandro y que realizó grandes viajes bajo

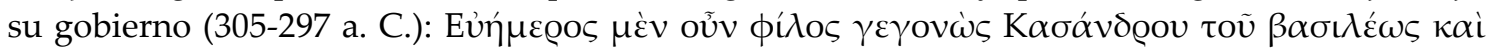

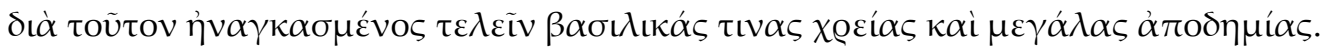

${ }^{31}$ Vox (1995, pág. 280) señala la similitud de este pasaje con Luciano, Nigr. 2, donde el filósofo Nigrino aparece en su casa con un libro en la mano, rodeado por bustos de los Siete Sabios y junto a una tablilla con figuras geométricas y una esfera que representa al universo. A partir de esta escena, Vox argumenta a favor de una datación baja de la composición del Yambo 1 de Calímaco, considerando probable además que Evémero estuviera todavía vivo hacia esa época y que se lo viera vociferando con un rollo en la mano frente al templo de Serapis, rodeado por las estatuas. 
Aıs $\rceil v$, v. 15). Es posible, además, que se estuvieran emitiendo algunas observaciones acerca de la poesía: Moṽ $\alpha \alpha$ (v. 17), Ł̌ $\alpha \mu \beta o v(v .21), \tau \varepsilon \tau \varrho] \alpha ́ \alpha \varepsilon \tau \varrho \alpha$, o tal vez $\varepsilon \xi] \alpha ́ \alpha \varepsilon \tau \varrho \alpha$ o $\pi \varepsilon v \tau] \alpha ́ \alpha \varepsilon \tau \varrho \alpha$ (v. 23). Finalmente, una lista de

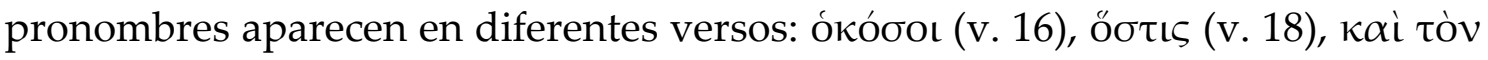

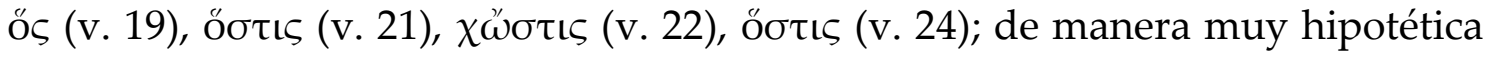
podrían estar aludiendo a personas que seguirían los diferentes tipos de intereses poéticos enunciados previamente. ${ }^{32}$

La lectura se vuelve más fluida entre los vv. 26-31, donde otra vez se hace referencia a los interlocutarios de "Hiponacte": los eruditos alejandrinos. Con la utilización de los vocativos exclamativos $\omega \pi \operatorname{to\lambda \lambda ov,~\tilde {\omega }v\delta \varrho \varepsilon \varsigma ~(v.~26),~} \tilde{\omega}$

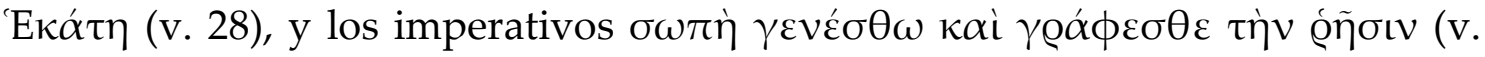
31), el Yambo 1 actualiza la intensidad y la vivacidad oral de la poesía griega arcaica compuesta para la ocasión del simposio. De hecho, a lo largo todo del poema, las marcas de oralidad son uno de los recursos empleados para caracterizar a "Hiponacte". Seguramente Calímaco, consciente de que la naturaleza oral del yambo arcaico termina funcionando como un requisito formal que rige al género, sabe que al utilizar la máscara del yambógrafo de Éfeso se torna necesario actualizar los dispositivos de auralidad del simposio arcaico al ámbito helenístico.

Los eruditos son comparados con 1) moscas que se juntan en torno a un

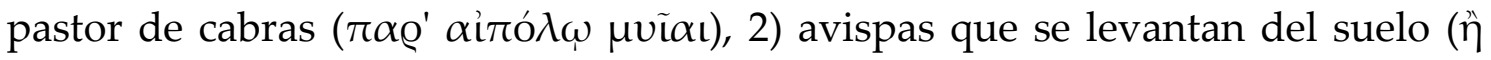
$\sigma \phi \tilde{\eta} \kappa \varepsilon \varsigma \dot{\varepsilon} \kappa \gamma \tilde{\eta} \varsigma),{ }^{33}$ y 3) hombres de Delfos, en ocasión de la ofrenda de un

32 Kerkhecker (1999, págs. 26-7) sostiene conclusivamente: “Lines 16-25 contained a list of Hipponax' addressees, arranged according to their literary pursuits."

${ }^{33}$ El Schol. Flor. a los vv. 26-7 (PSI 1904 fr. b 26-7) reenvía para cada uno de los símiles a dos pasajes de la Ilíada; en el primero (2.469-71) se compara el alistamiento de las tropas aqueas con

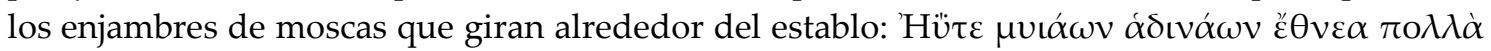

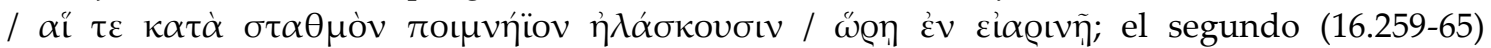
compara a los troyanos en desbandada por un ataque de los aqueos con las avispas de los caminos que, siendo molestadas por los niños, se levantan del piso en enjambres: $\alpha \hat{u} \tau$ ík $\alpha$ $\delta \dot{\varepsilon}$

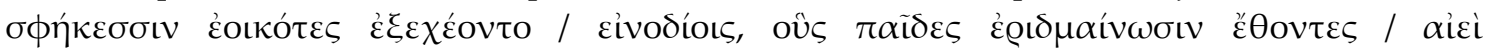


sacrificio animal (ḋสò $\theta u ́ \mu \alpha \tau o \varsigma \Delta \varepsilon \lambda \phi[o u ́) .{ }^{34}$ Ellos rondan en torno al resucitado

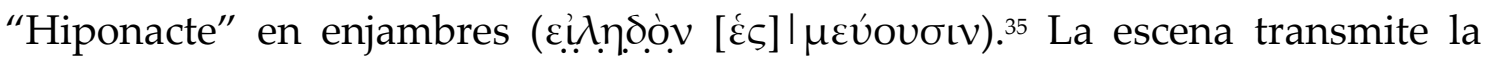
tensión que provoca la confrontación entre lo cómico y lo serio

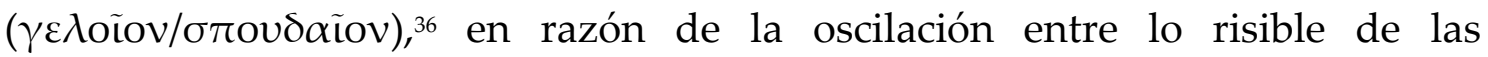
comparaciones cínicas de "Hiponacte", y la hostilidad que ellas podrían provocar en un auditorio de vanidosos eruditos, con una actitud no demasiado benévola y muy poco propensos, suponemos, a las bromas yámbicas, por más literarias que ellas sean. A pesar de la hilaridad que las imágenes suscitan, ciertamente nada bueno puede esperarse ni de las moscas, ni de las abejas, ni de

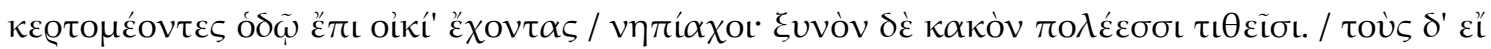

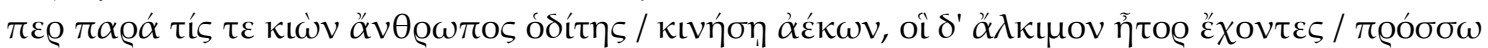

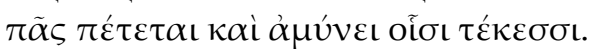

34 Esta referencia alude a una costumbre aceptada entre los habitantes de Delfos, pero caricaturizada por la voracidad que manifiesta. En la Vita Aesopis transmitida en P.Oxy. $1800 \mathrm{fr}$. 2 col. II 32 ss. (= pág. 139-40 G-H) se dice que cuando hay un sacrificio los delfios se ubican en torno al altar llevando un cuchillo, apenas el sacerdote termina de sacrificar a la víctima, ellos se precipitan de manera tumultosa sobre ella, cortan rápidamente la mayor porción que pueden y se van, a punto tal que el hombre que realizó el sacrificio se queda sin nada. El texto informa además que Esopo se burló de los delfios por esta costumbre, razón por la cual ellos se enfurecieron, le tiraron piedras y luego lo arrojaron desde un acantilado: oi $\Delta \varepsilon \lambda \phi o i$

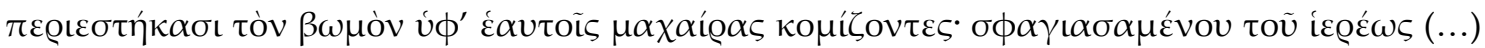

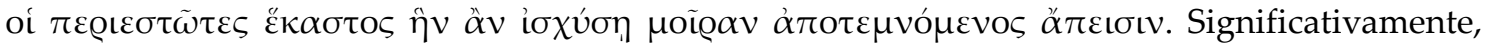
Calímaco se refiere también al episodio de la muerte de Esopo a manos de los habitantes de

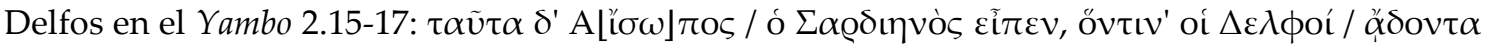

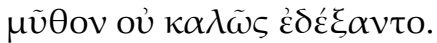

${ }^{35}$ En este pasaje, Pfeiffer (1938, pág. 71) y (1949, pág. 164) conjetura la presencia de un verbo

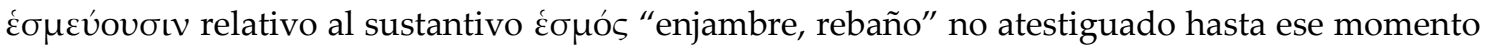
y construido como $\delta \varepsilon \sigma \mu \varepsilon v ́ \omega$ a partir de $\delta \varepsilon \sigma \mu o ́ s$.

36 Demetrio, De elocutione 261.1-6, cuenta que una vez Diógenes, mientras luchaba en unos juegos con un joven hermoso, frotó rápidamente su miembro (contra él), el joven se asustó y se apartó, “¡Coraje, pequeño! -le dijo Diógenes- yo no soy igual a ti en eso." Demetrio agrega después que "el primer impacto del lenguaje de Diógenes causa risa ( $\gamma \varepsilon \lambda$ oĩov), pero que el énfasis implícito es terrible. Se puede decir, en general, que toda forma de discurso cínico

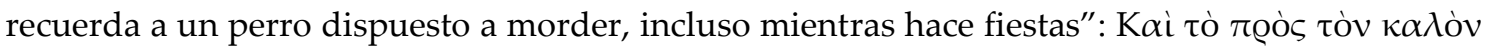

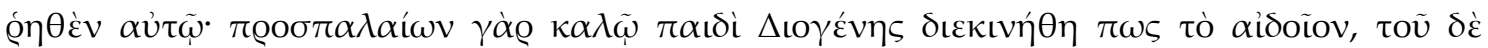

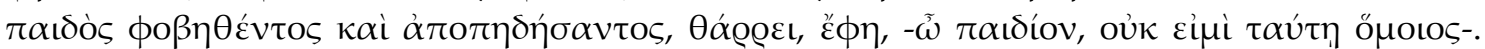

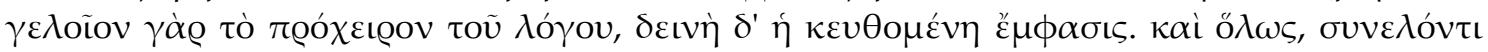

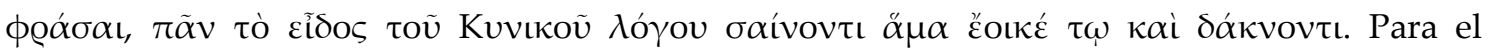
concepto de lo "serio-cómico", véase Gentili (1996, pág. 243), quien sigue la categoría

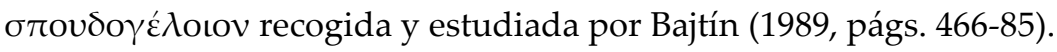


estos hombres de Delfos. El v. 28 cierra con una invocación a Hécate, divinidad ctónica relacionada con el Hades, a donde "Hiponacte" pronto deberá

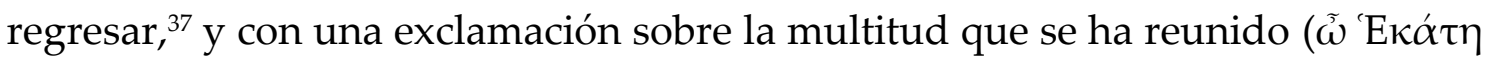
$\pi \lambda \eta ́ \theta \varepsilon v \varsigma)$.

El retorno de "Hiponacte" recuerda distintas escenas de la literatura griega antigua, principalmente de la comedia, en que un reconocido personaje del pasado que se encuentra en el Hades es convocado, ya sea por medio de las prácticas de invocación de los difuntos ( búsqueda al propio inframundo para que intervenga con sus juicios y opiniones ante una situación problemática del presente. ${ }^{38}$ El ejemplo más destacado es el de Ranas de Aristófanes, donde Dioniso, habiendo perdido a sus tres poetas trágicos más importantes y ante la decadencia del género en Atenas, decide descender al Hades para traer nuevamente a la vida a Eurípides. La escena del encuentro con Eurípides se realiza en medio de una disputa literaria que mantiene este último con Esquilo con el fin de determinar quién de ellos es el mejor poeta trágico y así obtener el derecho a sentarse a cenar en la mesa del Hades. El antecedente más importante es el del canto 11 de Odisea: Por medio de los rituales de la vékvı $\alpha$, que involucra el sacrificio de animales, la ofrenda la sangre, miel, agua, harina, y plegarias y votos, Odiseo convoca las almas de los

\footnotetext{
${ }^{37}$ El apóstrofe a Hécate parece remarcar que "Hiponacte" está muerto y debe volver al Hades.

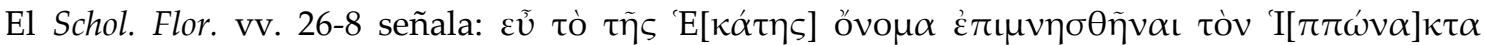

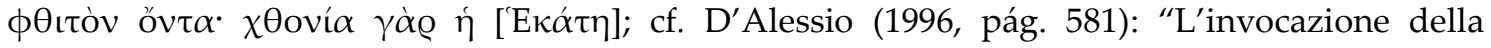
divinità ctonia è appropriata al visitatore dell'oltretomba."

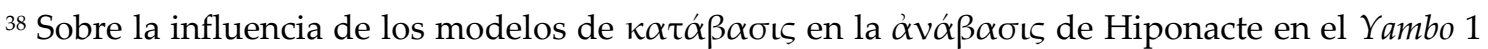
de Calímaco, véase Bergson (1986, págs. 11-6). Además del famoso modelo de Ranas de Aristófanes, Bergson recuerda también las obras Geritades del mismo autor, Arquílocos, Plutones y Quirones de Cratino, Hesíodos de Teleclides, Pitagorista de Aristofonte, y destaca el uso

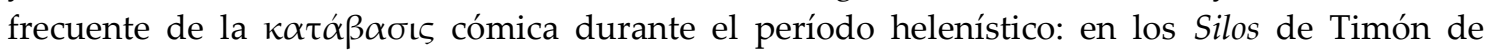
Fliunte, el Descenso al Hades de Sótades y Nekyia de Menipo. Bing (1988, pág. 72) señala la relación entre los Silos de Timón y los Aitia de Calímaco, ya que los dos últimos libros de los Silos y los dos primeros de los Aitia presentan un diálogo del poeta "in a supernatural encounter with authoritative figures of the literary tradition and conceived as a strategy for gaining access to themes from distant past."
} 
muertos que yacen en el Hades, quienes, ante las ofrendas, se van acercando en multitud al hoyo que sirve de pasaje entre los dos mundos, rodeándolo por

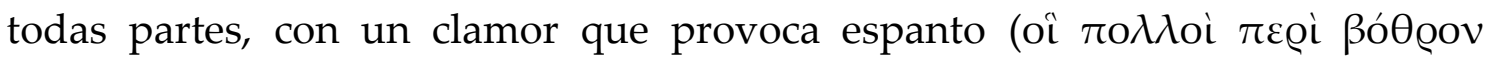

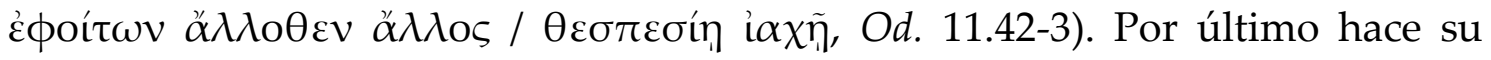
aparición Tiresias, que ofrece su sabiduría al héroe para que pueda hacer frente a las pruebas que deberá afrontar en su retorno a Ítaca.

En el caso del Yambo 1, sin embargo, lo que tenemos no es una

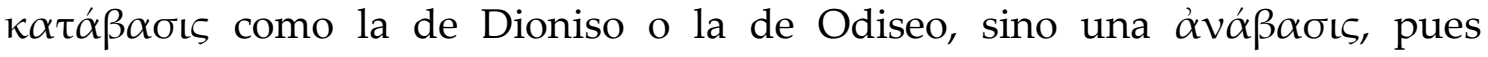
"Hiponacte" asciende al mundo de los vivos. Es más, llega a la Alejandría ptolemaica sin haber sido convocado; los eruditos no han realizado los rituales

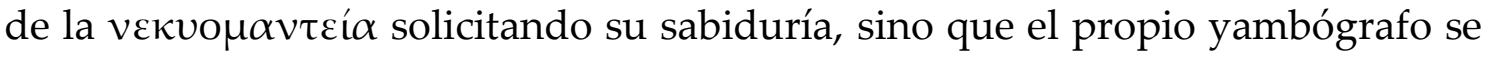
presenta espontáneamente para aconsejarles acerca del modo en que deben comportarse entre ellos. También, al contrario de lo que sucede en Odisea, son los vivos quienes se acercan hacia él en multitudes amenazantes. En este sentido, la exclamación “¡Hécate, qué multitud!” (v. 28), referida a los eruditos que comienzan a rodearlo, aludiría paródicamente a la multitud de muertos que se acercan a los vivos en el momento del descenso al Hades. Como se ve, se invierten los actores y es el muerto el que se sorprende de la muchedumbre que lo acosa.

En los vv. 29-30, "Hiponacte" realiza una imprecación a un individuo

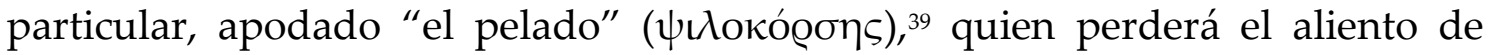
tanto resoplar para que no le quiten su manto. Este apóstrofe proferido contra uno de los supuestos integrantes del auditorio emula las frecuentes invectivas del yambógrafo arcaico, que mezclaba crítica y abuso con un alto grado de comicidad. Es posible, además, que detrás de la invectiva al $\psi$ ılokó@ōৎs se escondiera una crítica velada contra una persona histórica real, contemporánea

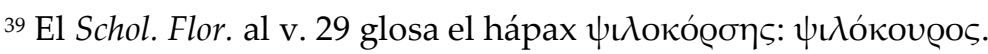


del propio Calímaco. ${ }^{40} \mathrm{Su}$ mención también ha sido interpretada como una posible referencia a uno de los personajes de la comedia ática, probablemente

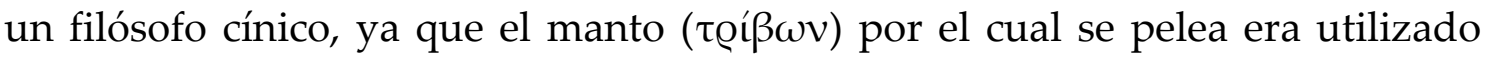
típicamente para caracterizarlo en el teatro. ${ }^{41}$ Si esta lectura es correcta, la crítica a este personaje sería irónica, ya que el temor de verse despojado del $\tau \varrho i ́ \beta \omega v$ implicaría al mismo tiempo verse despojado del estatus de filósofo cínico. ${ }^{42}$

Finalmente, el v. 31 pone de manifiesto la tensión existente a lo largo de todo el Yambo 1 entre cultura oral y cultura escrita, producida por el interés del poeta-filólogo alejandrino por recuperar y actualizar el género arcaico que encarna la figura de Hiponacte: no se oculta la tirantez entre la instancia de composición poética y la ocasión de la ejecución pública. La frase exclamativa

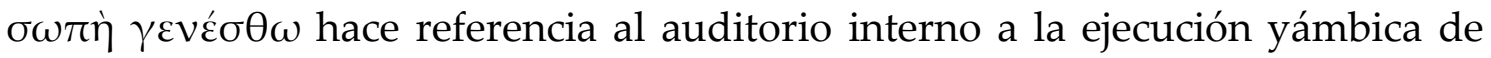

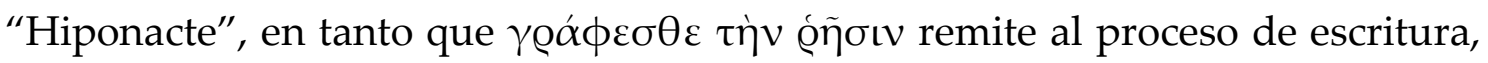

${ }^{40}$ Lelli (2004, pág. 13) señala: “Non mancano dunque, nei Giambi, gli attacchi ad personam, anche

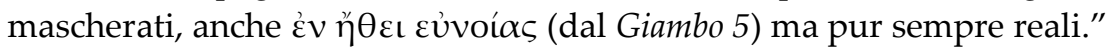

${ }^{41}$ En relación a este personaje, Pfeiffer (1949, pág. 164) señala: "calvi passim deridentur in comoedia Attica. De 'Cynico' cogitavit Vit." El tœí $\beta \omega v$ era una especie de manto corto, rústico y ordinario, utilizado por las clases más bajas y se diferenciaba del ífó́tıov, más estilizado, y de la

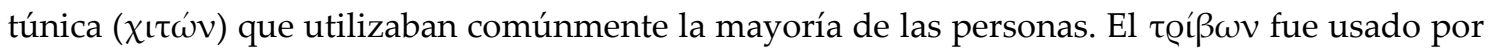
los espartanos y los vestían filósofos como Sócrates por su austeridad; cf. Platón, Symp. 219.b.6:

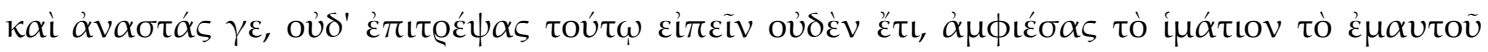

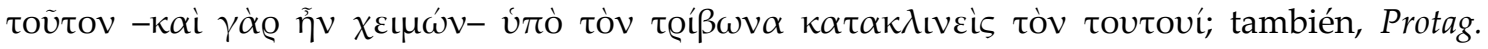

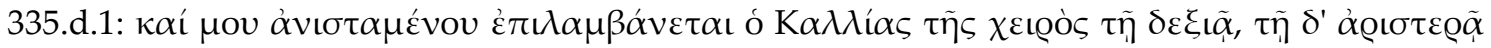

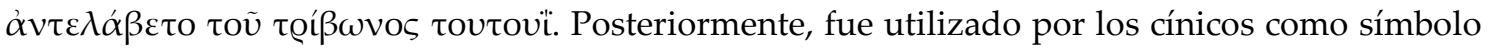

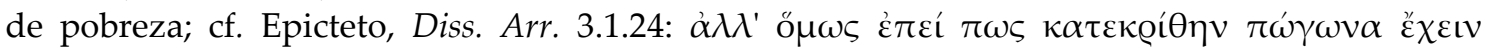

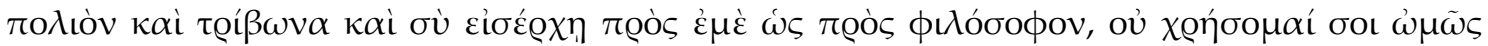

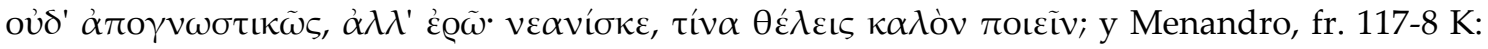

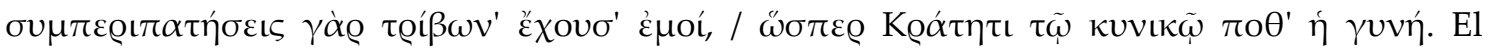
$\tau \propto ́$ $\beta \omega v$ termina siendo la vestimenta que va a caracterizar al filósofo cínico en la comedia.

42 Es necesario recordar que los cínicos recibieron el influjo del yambo sarcástico y mordaz de Hiponacte, y que fueron considerados como paradigmas de agresión, anticonformismo y subversión contra el pensamiento institucionalizado en época helenística. La misma presentación de "Hiponacte" en el templo de Serapis podría ser considerada una diatriba cínica que parodia el contexto filosófico-literario del Museo alejandrino. Para la relación entre la poesía de Hiponacte y la figura del cínico, véase Miralles \& Pòrtulas (1988, págs. 71-119); sobre el Hiponacte de Calímaco y su caracterización como cínico, véanse Clayman (1980, pág. 16) y Natalucci (2003, pág. 541). 
procedimiento natural de composición poética en el período helenístico, y refiere a la conservación y a la transmisión de los poemas para un auditorio posterior, en realidad un falso auditorio paradójicamente lector. ${ }^{43}$

\subsection{LA NARRATIVA. “LA COPA DE BATIClES” (VV. 32-77)}

Luego de pedir silencio y de solicitar que se ponga por escrito aquello que va a decir, "Hiponacte" inicia el relato de la parábola sobre la copa de Baticles y los Siete Sabios:

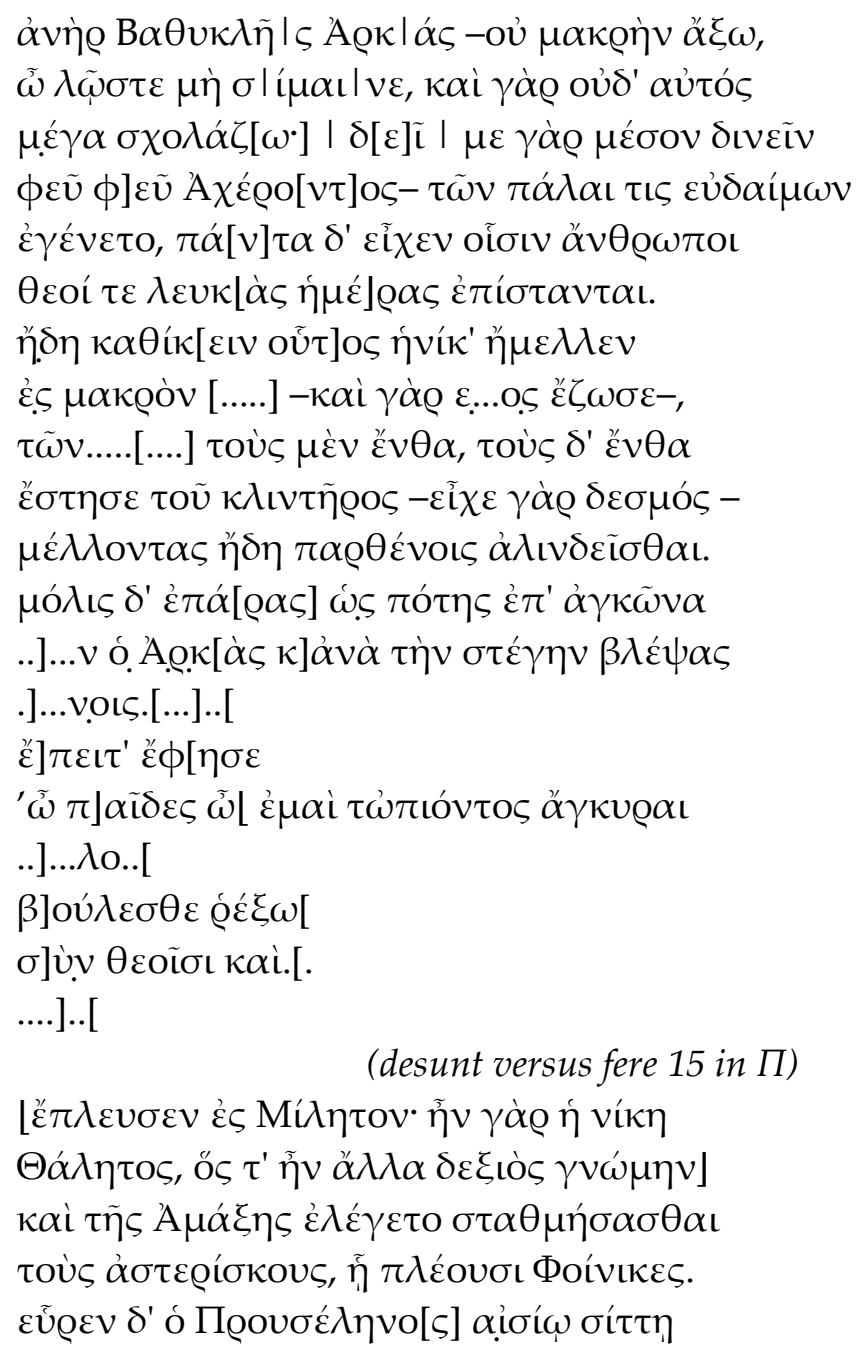

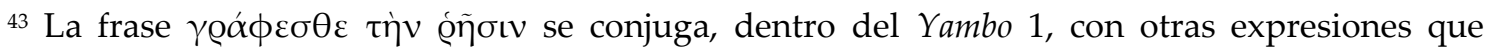

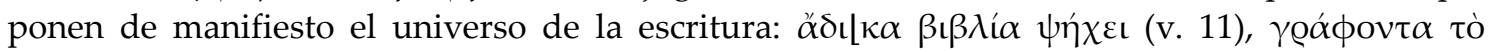

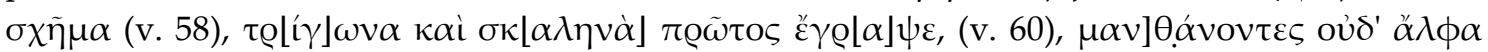
(v. 88). Para las formas de representación de la oralidad y la escritura en los Aitia y Yambos de Calímaco, véase Bruss (2004, págs. 49-70). 


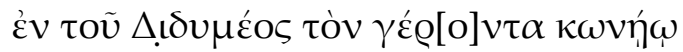

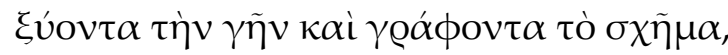

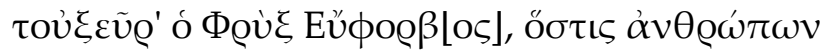

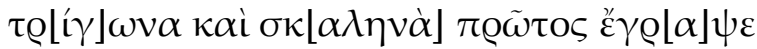

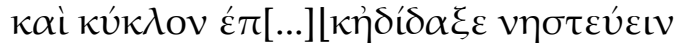

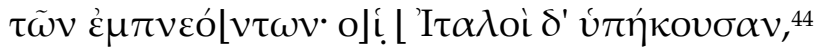

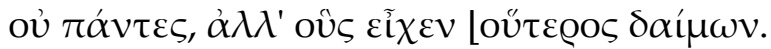

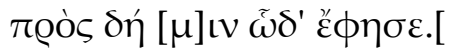

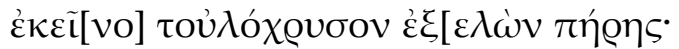

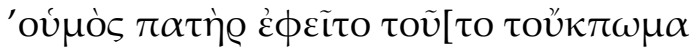

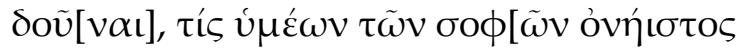

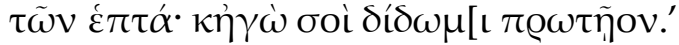

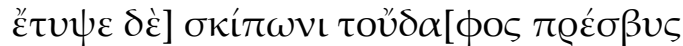

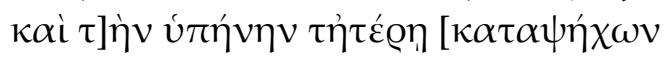

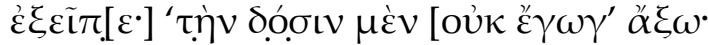

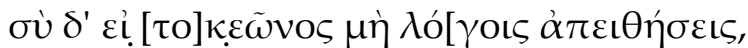

Bíns [............ ] ]

(desunt versus fere 20 in П)

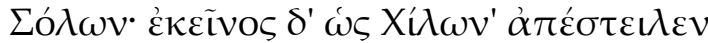

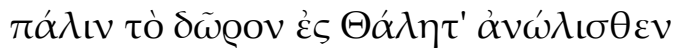

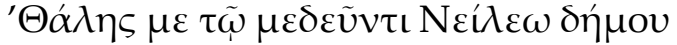

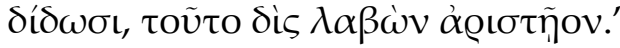

Calímaco, fr. 191.32-78Pf

Baticles, un arcadio -no lo haré demasiado largo,

mi buen amigo no frunzas la nariz, yo tampoco

tengo demasiado tiempo: debo dar vueltas,

¡ay!, en medio del Aqueronte-, era antiguamente

uno de los hombres bienaventurados, tenía todo aquello por

lo que los hombres y los dioses reconocen los días felices. ${ }^{45}$

Cuando ya estaba a punto de arribar

al largo... -de hecho había vivido...-,

de sus [hijos] hizo colocar a unos de un lado, y a los otros

del otro lado de la cama -pues sufría artritis-46

ahora que estaban en edad de revolcarse con las jóvenes.

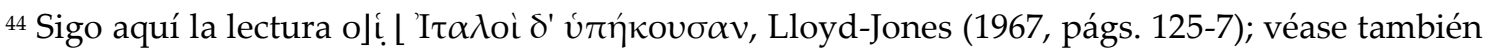
D’Alessio (1996, pág. 586 n. 28).

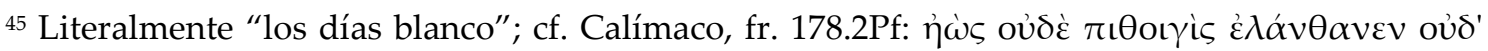

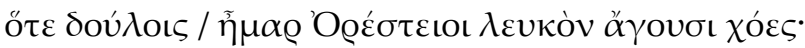

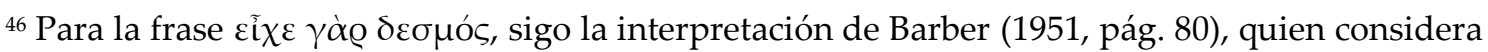

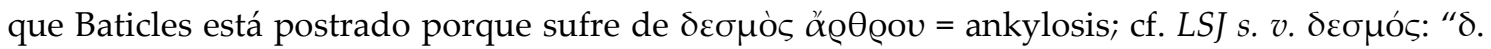
ð̋@O@ov in Hp. Fract. 37 is expld. by Gal. ad loc. as ankylosis." 
Levantándose apenas, como un bebedor, sobre el codo

... el arcadio mirando al techo...

$\ldots$

luego dijo...

"Hijos, anclas de mi partida...

quieren que haga...

con ayuda de los dioses y...

navegó hasta Mileto: la victoria era

de Tales, hábil de pensamiento en otras cosas,

se decía que hizo los cálculos de las estrellitas

del Carro con las que navegan los Fenicios. ${ }^{47}$

El hombre prelunar halló, por un pájaro carpintero favorable,

al anciano en el santuario de Apolo Dídimo: con el puntero

surcaba la tierra y trazaba la figura

que había descubierto el frigio Euforbo, aquél que entre

los hombre (fue) el primero que trazó triángulos y polígonos, ${ }^{48}$

y también el círculo... y predicó abstenerse

de los seres que respiran. Los italianos le obedecieron,

no todos, sino aquellos a los que el otro espíritu dominaba.

Y a él le dijo así...

sacando aquella (copa) toda de oro del saco:

"Mi padre me ha enviado para [entregar esta

copa] al que sea el más conveniente

de los Siete Sabios, y yo te la doy a ti [en primer lugar.]"

[Pero el anciano golpeó] con el bastón el suelo

[y acariciándose] la barba con la otra (mano)

contestó: "el regalo...

pero si no [quieres desobedecer] la voluntad de tu padre,

Bías..."

...

Solón. Y este lo envió a Quilón...

...

de nuevo el regalo retornó a Tales.

“Al protector del pueblo de Neleo, Tales

me ofrenda, tras recibir este premio dos veces."

${ }^{47}$ Es decir, la constelación de la Osa Menor; vid. sup. pág. 322.

48 Sigo aquí la lectura de Pfeiffer (1949: 168) "trigona et polygona"a partir de la glosa de

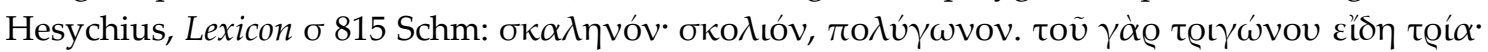

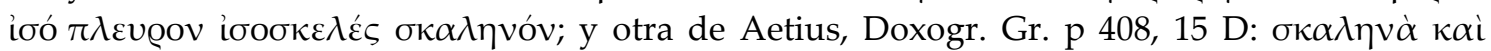

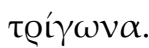


Apenas iniciado el relato de la parábola de la copa de Baticles, "Hiponacte" debe interrumpir su narración para apostrofar nuevamente a un individuo del auditorio. "Hiponacte" le pide que deje de hacer muecas con la nariz, tal vez algún gesto de zozobra por lo que el poeta arcaico puediera llegar a decir, o quizás de impaciencia por el tiempo que esto pueda demandarle (vv. 32-35). Del mismo modo que en los casos anteriores, la interrupción del discurso por medio de un apóstrofe contra un individuo particular otorga a la composición poética la vivacidad y espontaneidad propias de la ejecución oral del yambo arcaico. Pero también actúa como un elemento catalizador de los procesos de enmascaramiento y desenmascaramiento del 'yo' que nos ocupa. A través de estas interrupciones, se pone en evidencia que es "Hiponacte", la máscara asumida por Calímaco, quien habla en propria persona. En este caso en particular, la interpelación a un individuo que forma parte del auditorio interno al yambo remarca la gestualidad tipificada de la máscara "Hiponacte" con el fin de desdibujar los rasgos del rostro de "Calímaco." Además de la comicidad propia del apóstrofe, como ya hemos oportunamente señalado, mediante este

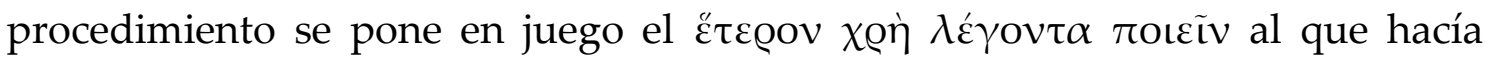
referencia Aristóteles. La mención, en los vv. 32-35, de que su relato no será demasiado extenso porque pronto deberá retornar al Hades pone de manifiesto nuevamente que es "Hiponacte" quien habla y es él el único responsable de lo controvertida y polémica que pueda llegar a ser la parábola de la copa de Baticles que contará.

La Diégesis a este pasaje del Yambo 1 brinda información que permite una mejor interpretación de la parábola que "Hiponacte" les narra a los eruditos reunidos en el templo de Serapis: 


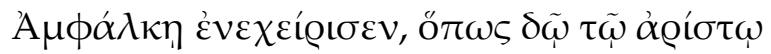

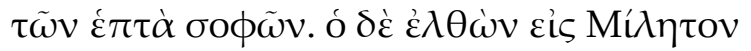

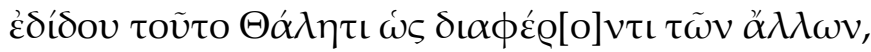

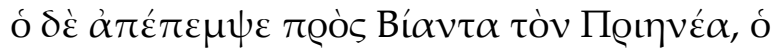

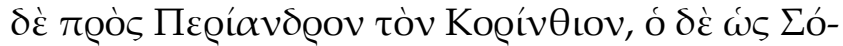

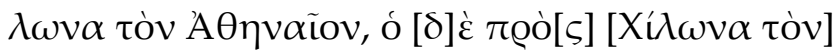

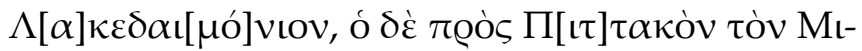

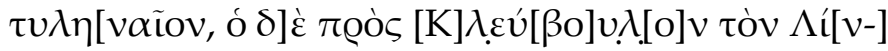

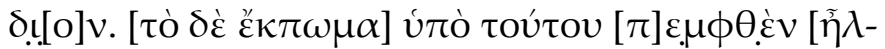

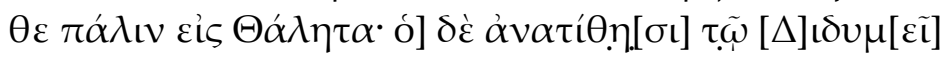

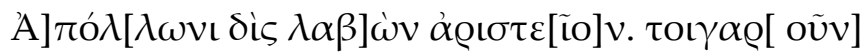

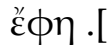
.] $\alpha$ เo .[ .] $\dot{\alpha} \lambda \lambda \dot{\lambda} \lambda \omega v$.

$\kappa \mathrm{Q} . \tau[$ ] $\varepsilon \dot{\varepsilon} \mathrm{o}\langle\zeta \varepsilon \sigma \theta \varepsilon$.

Diégesis 6.5-21 (Scholia ad Fr. 191Pf)

... él los exhorta a que no tengan envidia

unos de otros, contándoles cómo el arcadio Baticles

a punto de morir repartió sus posesiones y encomendó

a su hijo del medio, Anfalces, una copa

de oro para que se la diera al mejor

de los Siete Sabios. Yendo a Mileto

se la dio a Tales, (sabiendo) que sobresalía de los demás.

Pero este se la envió a Bías de Priene,

y este a Periandro de Corinto, este al ateniense Solón,

este al lacedemonio Quilón,

este a Pítaco de Mitilene,

y este a Cleóbulo de Lindos.

Y la copa, enviada por este último, retornó

nuevamente a Tales, quien la consagró a Apolo Dídimo,

tras haberla recibido en premio por segunda vez. Por eso

dijo: " ...................... unos a otros,

disputen."

El comentarista nos propone una interpretación literal del Yambo 1 y de esta historia en particular. "Hiponacte" llega desde el Hades para exhortar a los eruditos alejandrinos a que abandonen las disputas y las envidias entre ellos -lo expresado en el propio yambo (1. 1-6)-, y es con este fin que les cuenta una parábola que involucra a los Siete Sabios (1. 6-21). A pesar de ser reverenciados como los hombres más sapientes de la historia de Grecia, ninguno de ellos se considera lo suficientemente digno como para aceptar la distinción de ser el

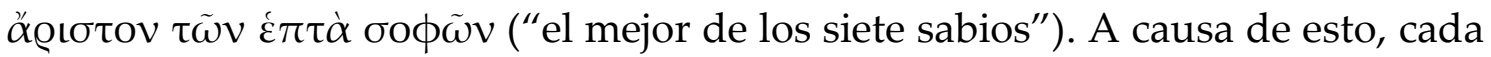


uno rechaza sucesivamente la copa y se la reenvía a otro de los miembros del selecto grupo, hasta que finalmente la copa retorna a Tales, que la consagra de manera definitiva al dios Apolo, el único que puede ser estimado como verdaderamente sabio. ${ }^{49}$ Desde la perspectiva de la Diégesis, la parábola tendría un fin moralizante: mostrarles a los filólogos/filósofos reunidos en el templo de Serapis la humildad de los Siete Sabios. La moraleja podría ser la siguiente: si el

49 Diógenes Laercio, Vit. philos. 1.27-32, transmite varias versiones de esta leyenda, entre ellas la del propio Calímaco. Estas variantes se diferencian en cuanto al premio, al canon de los sabios y al santuario en donde el premio fue consagrado a Apolo. La versión más difundida cuenta que unos jóvenes jonios compraron toda la pesca levantada por la red de unos pescadores milesios. Dentro de la red se hallaba también un trípode de oro, por el cual comenzaron a discutir los jóvenes y los pescadores de Mileto. Al consultar al oráculo de Delfos, el dios vaticinó que el

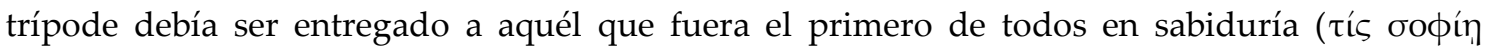

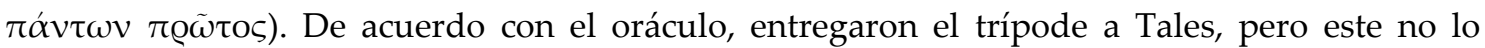
aceptó y se lo envió a otro sabio, y este último al siguiente, y así el trípode pasó de mano en mano hasta llegar a Solón. Al recibirlo, Solón dijo que el dios era el primero en sabiduría (бoфí $\alpha$

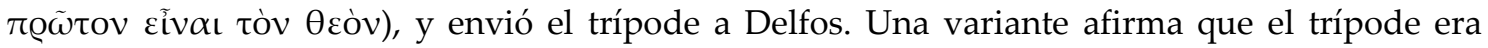
parte de un cargamento enviado por Periandro a Trasíbulo que naufragó cerca de las costas de Cos. Otra sostiene que el trípode fue hallado cerca de Atenas, a orillas del mar. Otra versión afirma que el trípode había sido forjado por Hefesto como regalo de bodas para Pélope e Hipodamia, y que posteriormente llegó a manos de Menelao por medio de Atreo. Cuando Paris raptó a Helena se llevó también el trípode, pero ella lo arrojó al mar, cerca de Cos, porque pensó que sería motivo de disputas. Otra variante de la historia sostiene que en realidad el premio era una copa de oro que había enviado Creso para al más sabio de los griegos. Dentro de las diferentes versiones cambian también los sabios que aparecen destacados, en algunas de ellas es Tales, en otras Solón, Bías, o Misón. Las variaciones en los relatos podrían haberse originado a partir de adaptaciones de una antigua tradición oral con el fin de destacar identidades culturales locales de diferentes regiones de Grecia. Martin (1998, págs. 108-28) relaciona los Siete Sabios griegos con los Siete Rsis de los antiguos textos vedas y remonta esta tradición hasta las culturas indoeuropeas. Diógenes afirma que la versión de Calímaco proviene de un tal Meandr(i)o o Leandr(i)o de Mileto, un historiador que escribió unas Milesiaká; cf. FGrH 491-2. La historia de la copa y su ofrenda a Apolo Dídimo por parte de Tales, según la versión de Calímaco, podría ser producto de las pretensiones de soberanía que los Ptolomeos detentaban sobre Licia, Caria y el sur de Jonia. El templo de Dídima fue restaurado después de la reconquista de Mileto del dominio persa por parte de Alejandro Magno en el año 334 a. C. Es muy probable que Ptolomeo II Filadelfo ejerciera influencia política sobre Mileto durante el período que va de la muerte de Seleuco I Nicátor en el 280 hasta el 258 a. C., lapso en el cual fueron compuestos los Yambos, esto podría explicar la versión de la historia contada por Calímaco. El oráculo de Apolo en Dídima era, después del Delfos, el templo griego más importante del mundo helenístico. La metrópolis que conformaba el templo de Dídima junto a a la ciudad de Mileto, de la cual dependía, constituía la puerta de comunicación comercial y cultural entre el Mediterráneo y Asia Menor. Sobre el templo de Apolo en Dídima y el Yambo 1 de Calímaco, véanse Parke (1986, págs. 121-31) y Cameron (1995, págs. 167-8); sobre el Yambo 1 y los Siete Sabios, véanse Wiersma (1933-1934, págs. 150-4) y Natalucci (2003, págs. 542-5). 
inmejorable Tales de Mileto, que recibió como premio a su sabiduría la copa de oro, no una sino dos veces, nunca se consideró mejor que los demás mortales, ¿qué queda entonces para el enjambre de eruditos alejandrinos? La verdadera sabiduría comienza, como lo muestra la parábola, con la humildad, con el abandono de la vanidad y de la soberbia. ${ }^{50}$

Esta interpretación, sin embargo, lleva a considerar que Calímaco hace revivir a un "Hiponacte" sorprendentemente moderado y conciliador, que ha abandonado las encendidas invectivas contra Búpalo para componer un yambo puramente formal, en coliambos, dentro del registro de lo risible ( $\gamma \varepsilon \lambda$ oĩov),

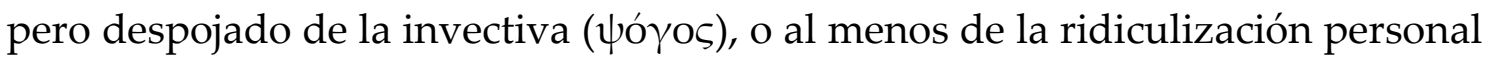
(ỏvo $\mu \alpha \sigma \tau \grave{\imath} \kappa \omega \mu \omega \delta \varepsilon \tilde{\imath} v)$, y que pone en el centro de su poética la parábola y la fábula ( $\alpha$ ĩvos) como elemento pedagógico y moral para la corrección de las conductas individuales. Desde esta perspectiva, además, el objetivo del nuevo yambo sería alcanzar una pax poetica entre los eruditos alejandrinos, es decir, una imagen totalmente opuesta y ajena a la del poeta agresivo y sarcástico que desde el período arcaico y, particularmente, dentro del período helenístico se venía forjando de Hiponacte. ${ }^{51}$

${ }^{50}$ Para Natalucci (2003, págs. 542-5), el yambo helenístico de Calímaco contrapone la parábola frente a la invectiva personal. Esta autora considera que al colocar el $\alpha$ ĩvo $\zeta$ de la copa de Baticles y las figuras ejemplares de los Siete Sabios al inicio de la colección de Yambos, Calímaco quiere poner de manifiesto el rol central de la parábola en la inspiración de una poesía destinada, por tradición y por elección personal, a educar, amonestar y corregir, y señala: "La vera esemplificazione della poetica callimachea deve essere ricercata tuttavia, come si è detto, soprattutto nella favola dei Sette Sapienti, il giambo portato da Ipponatte, che, se nello stile e nel metro imita il 'vecchio', si rivela programmaticamente diverso nei toni dell'invettiva non

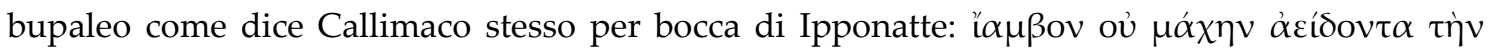

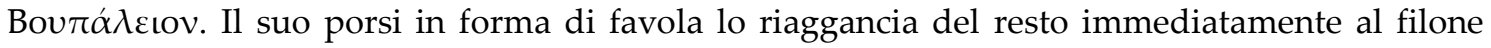
che, all'interno della poesia giambica, si caratterizza come piú esplicitamente gnomico e piú direttamente legato all'idea di saggezza e ad un'etica di misura e prudenza legata alla vita pratica."

${ }^{51}$ Esta interpretación entra en abierta contradicción con la fama que tenía Hiponacte dentro del período helenístico. Fama que se evidencia en varios epigramas que juegan ficcionalmente con la inscripción en la tumba del poeta. Leóndias de Tarento describe a un Hiponacte capaz de arrojar sus invectivas más violentas incluso desde el Hades. Alceo de Mesenia dice que en torno a la tumba del poeta no crece la parra como reparo para el viajero sino arbustos espinosos o con 
En verdad la propuesta de lectura que presenta la Diégesis -la de un "Hiponacte" calimaqueo converso, que en su anábasis desde el Hades, al contrario de lo ocurrido en la catábasis de Ranas de Aristófanes, viene no a

frutos amargos; aquél que se acerque a ella solo deberá conformarse con desearle un descanso benigno a Hiponacte. Teócrito señala la virulencia del poeta arcaico, aunque también pueda ser justo con la persona honrada y noble:

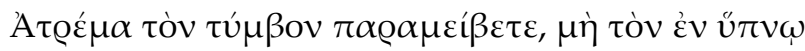

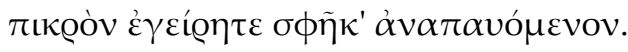

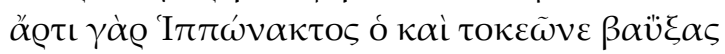
ă

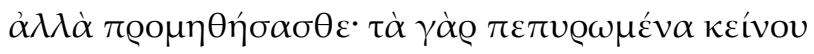

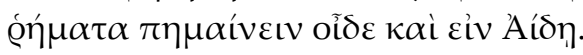

Leónidas, Anth. Pal. 7.408

Pasen ante la tumba suavemente, no sea que despierten a la punzante avispa que descansa en sueños. Hace poco, muy poco, que el alma de Hiponacte, aquel que ladró incluso contra sus padres, descansa en paz. ¡Tengan cuidado! Sus quemantes palabras saben cómo hacer daño incluso desde el Hades.

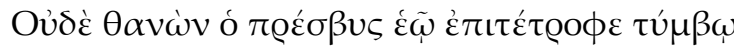

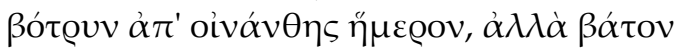

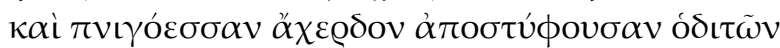

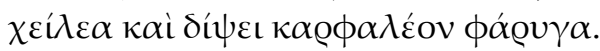

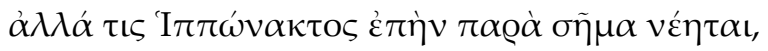

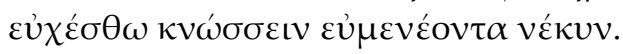

Alceo, Anth. Pal. 7.536

$\mathrm{Ni}$ siquiera muerto el anciano ha hecho crecer en su tumba la cultivada uva de la vid, solo la zarza y el amargo peral silvestre que agría los labios de los viajeros y reseca sus gargantas por la sed. Cuando alguien a la tumba de Hiponacte se acerque, deséele un agradable descanso al muerto.

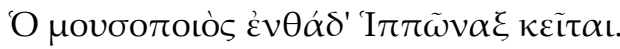

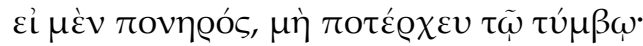

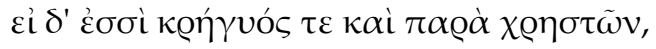

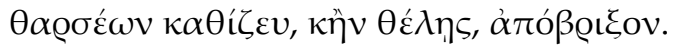

Teócrito, Anth. Pal. 13.3

Aquí yace el poeta Hiponacte.

Si eres malvado, no te acerques a la tumba, pero si eres honrado y desciendes de justos padres, toma coraje y siéntate; y si quieres, duerme un poco. 
juzgar quién es el más sabio sino, por el contrario, a predicar la concordia y la humildad- genera interrogantes. Insta a preguntarnos si Calímaco habría realmente querido expresar que, así como su "Hiponacte” había abandonado su eterna batalla contra Búpalo, los eruditos del Museo deberían también dejar de lado los resentimientos y las envidias que los separaban y vivir en paz bajo el ejemplo de los Siete Sabios.

Aunque el comentarista de la Diégesis parece confirmar esta lectura, es posible también considerar el Yambo 1 de Calímaco desde una perspectiva diferente. En primer lugar, la aparición de dos de los Siete Sabios de la antigüedad, Bías y Misón, en el propio corpus de Hiponacte podría darnos la pauta de que tal vez el tema de la sabiduría había sido ya tratado por el yambógrafo arcaico:

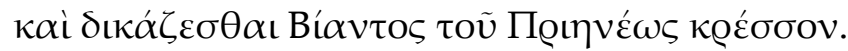

Hiponacte, fr. $12 \mathrm{Dg}^{52}$

y juzgar con mayor contundencia que Bías de Priene.

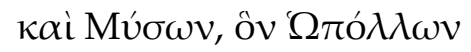

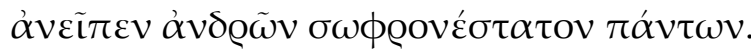

Hiponacte, fr. $65 \mathrm{Dg}^{53}$

y Misón, a quien Apolo

proclamó como el más prudente de todos los hombres.

Ambos fragmentos han sido transmitidos por Diógenes Laercio dentro de contextos que ponen explícitamente de manifiesto el dilema acerca de quién es el mejor de todos los sabios. El fr. 12Dg aparece dentro de una de las versiones consignadas por Diógenes, quien dice haberla tomado de Fanódico y de Sátiro, acerca del trípode de oro y los Siete Sabios. En esta versión, el trípode

\footnotetext{
52 Transmitido por Estrabón 14.1.12; Diógenes Laercio, Vit. phil. 1.84; Suda ß 270 y $\delta 1055$.

${ }^{53}$ Transmitido por Diógenes Laercio, Vit. phil. 1.107.
} 
es encontrado por los pescadores en las costas de Atenas y contiene la inscripción "al sabio." Luego de consultar al oráculo, el trípode es enviado a Bías, quien al recibirlo dice "Apolo es sabio" y no lo acepta. Diógenes señala que Bías se destacaba por su capacidad oratoria en los juicios, en los cuales empleaba su sabiduría para realizar el bien, tal como lo recuerda Hiponacte. ${ }^{54}$

También dentro de los relatos de los certámenes de sabiduría, el fr. 65Dg aparece como uno de los testimonios del oráculo de Delfos ante la pregunta de

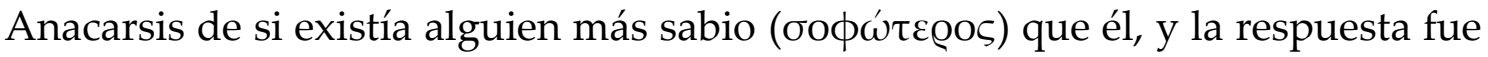
que Misón era de entendimiento más firme..$^{55}$

En período helenístico, el certamen de los Siete Sabios, con el premio de la copa de oro para el mejor, se encuentra también en Fénix de Colofón:

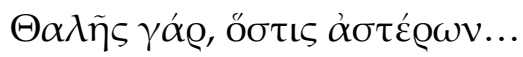

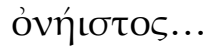

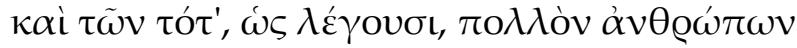

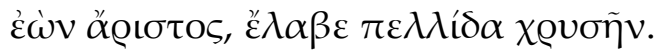

Fénix, fr. 5D

Tales, que era el más eficaz...

(en establecer los cálculos ?) de los astros...

y al ser, como dicen, ampliamente el mejor de los hombres

de su tiempo, obtuvo la copa de oro.

Coincide la composición de Calímaco con el fragmento de Fénix, que también es un yambo, en el premio otorgado, una copa de oro, y en el ganador, Tales. Es interesante además el contexto en que se transmite el yambo de Fénix, porque se relaciona con Hiponacte. Ateneo (Deipn. 11.91), en su catálogo de los distintos tipos de copas del simposio griego, describe la $\pi \varepsilon \lambda \lambda i ́ \varsigma$ como una clase

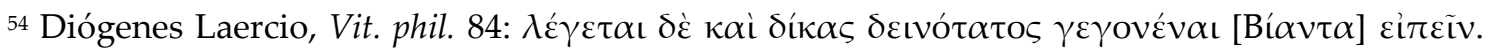

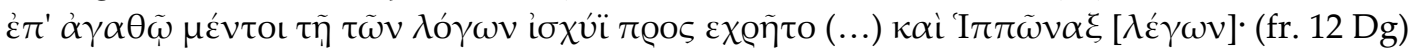

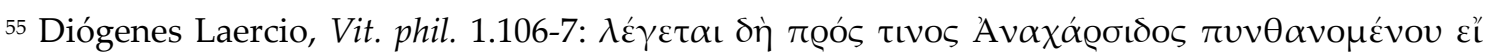

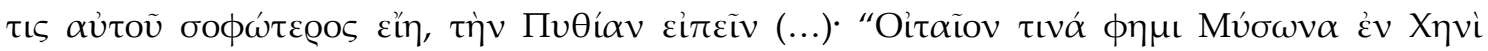

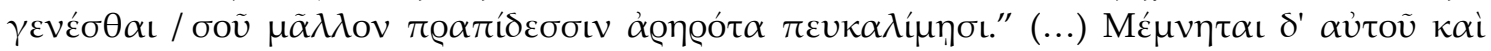
$\mathrm{I} \pi \pi \tilde{\omega} \nu \alpha \xi \varepsilon i \pi \omega \dot{\omega} v \cdot($ fr. $65 \mathrm{Dg})$.
} 
de recipiente de madera utilizado para conservar leche, y señala que Hiponacte emplea este término en dos composiciones: ${ }^{56}$

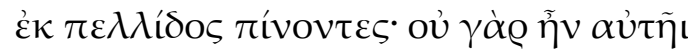

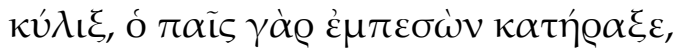

Hiponacte, fr. $20 \mathrm{Dg}$

bebiendo del cubo, ya que ella no tenía

copa; el muchacho la había destrozado al caerse.

$\dot{\varepsilon} \kappa \delta \dot{\varepsilon} \tau \tilde{\eta} \varsigma \pi \dot{\varepsilon} \lambda \lambda \eta \varsigma$

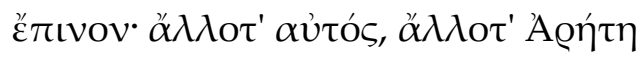

rœoútrıvev.

Hiponacte, fr. 21Dg

y del cubo

bebían; una vez él, otra vez Arete,

brindaban.

A diferencia de la ع̌́ $\pi \omega \mu \alpha$ de la parábola de Baticles, Fénix e Hiponacte utilizan el término $\pi \varepsilon ́ \lambda \lambda \alpha$, tal vez un poco discordante para el ámbito del simposio y sobre todo para ser un premio por sabiduría. Las coincidencias entre Fénix y Calímaco vuelven a ser notorias una vez más. Se ha señalado ya la similitud entre el inicio del Yambo 1 de Calímaco y el fr. 1 de Fénix con respecto a aquella voz que, retornando desde el Hades o desde la tumba, respectivamente, pide por medio del imperativo del verbo $\alpha \kappa o u ́ \omega$ que le presten atención; también se ha marcado en ambas composiciones la aparición

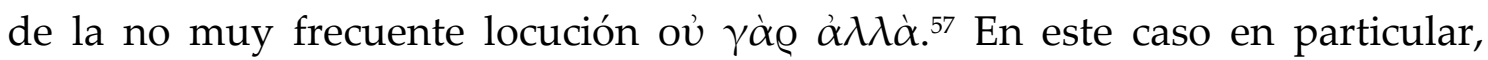
ambos poetas introducen la historia del premio a la sabiduría en composiciones yámbicas, con el mismo premio y ganador, como ya señalamos. Por otro lado,

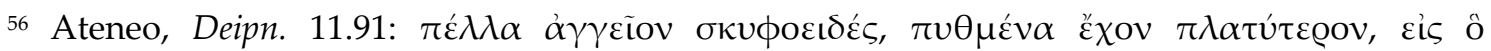

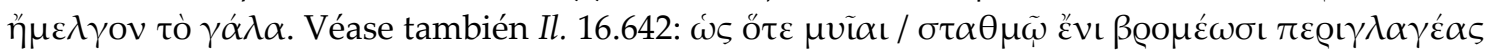

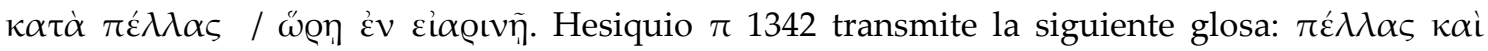
$\pi \dot{\varepsilon} \lambda \lambda \alpha \iota \cdot \pi$

${ }^{57}$ Vid. sup. pág. 292 n. 12. 


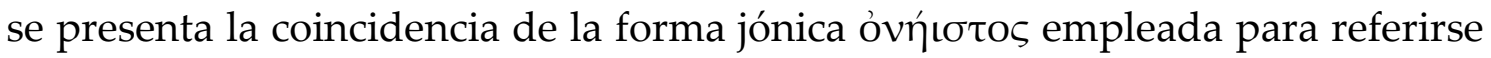
al destacado conocimiento astronómico que tenía el sabio de Mileto. ${ }^{58}$ Por último, y ya fuera del poema en particular, la figura de Hiponacte resulta una referencia indiscutible tanto en los Yambos de Calímaco como en los de Fénix..$^{59}$

Es evidente que las coincidencias entre los dos poetas helenísticos en torno a la figura de Hiponacte, por un lado, y a la historia de la copa de sabiduría, por otro, no es una simple casualidad. Es probable que la transmisión de la tradición de los Siete Sabios haya sido frecuente dentro del simposio helenístico. Una prueba de esto es que Diógenes Laercio toma la información

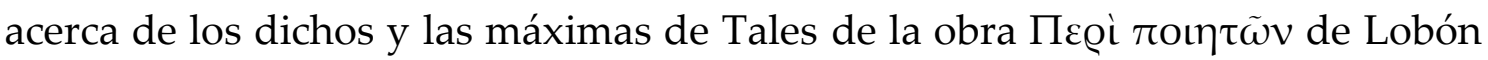
de Argos (s. III a. C.). ${ }^{60}$ Por lo tanto, el tema de los Siete Sabios y del premio para el mejor de ellos podría haber sido un motivo apropiado dentro del simposio de los eruditos alejandrinos en sus discusiones sobre sabiduría y poesía. Probablemente las máximas y proverbios de los Siete Sabios circularan frecuentemente en el simposio helenístico por boca de los eruditos.

Estas máximas y los contextos en que supuestamente habrían sido pronunciadas gestaron la fama particular de cada uno de los sabios, fama que la tradición oral se encargó de difundir perfeccionando las narrativas y estableciendo cánones de los sabios y sus dichos. ${ }^{61}$ Martin (1998, págs. 108-28)

\footnotetext{
${ }^{58}$ Cf. Calímaco, fr. 191.67 Pf, y Fénix, fr. 5.2D.
}

${ }^{59}$ Además de las composiciones en coliambos, y de los préstamos lexicales, de contenido, y del posible empleo de la voz del poeta arcaico en los yambos de los helenísticos, Hiponacte parece representar tanto para Fénix como para Calímaco no solo la fuente más arcaica y pertinente, sino la única, en que la poesía yámbica aborda la tradición de los Siete Sabios.

${ }^{60}$ Cf. Diógenes Laercio, Vit. phil. 1.34-41. Natalucci (2003, pág. 546) sostiene que la tradición sobre los siete sabios habría sido transmitida en el ámbito del simposio alejandrino, ocasión propicia para expresar la propia sabiduría y confrontrarla en un clima de moderación y de equilibrio.

${ }^{61}$ El libro primero de Diógenes Laercio contiene información sobre los sabios y sus dichos que se remonta hasta producciones literarias del s. III a. C. y en algunos casos es posible retrotraerse hasta los logógrafos de los ss. IV y V a. C. Estobeo (Anth. 1.3.173 Hense) transmite una lista de 147 máximas, considerada una copia realizada por Sosiades en el s. III a. C. de las máximas

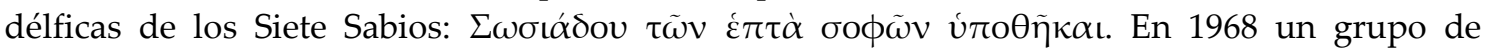


analiza las máximas de los Siete Sabios y las destaca como exponentes de nociones arcaicas de sabiduría que involucran el conocimiento religioso, adivinatorio, político y poético. Si tenemos en cuenta la relación que Martin establece entre la tradición griega y la de los Siete Rsis de los antiguos textos vedas, en donde hay un relato que también involucra una copa (Atharvaveda 10.8.9), el canon de los sabios y sus dichos se enmarca dentro de una tradición que podría remontarse hasta la cultura indoeuropea. En el incipiente mundo panhelénico, esta tradición habría formalizado su representación en seres históricos, según lo manifiestan los distintos cánones de los Siete Sabios, y permitiría distinguir un determinado tipo de saber previo a las sistematizaciones filosóficas y teóricas iniciadas hacia el $\mathrm{s}$. V a. C. La característica más destacada de esta sabiduría, de acuerdo con Martin, es la elocuencia mordaz, verbal y gestual, con la que los sabios comunicaban sus máximas y proverbios dentro de encuadres narrativos elaborados por esa

arqueólogos franceses descubrieron en Ai-Khanum, Afganistán, sitio de la antigua ciudad Greco-Bactriana, una inscripción en la base de una estela del s. III a. C. que contenía un epigrama dedicatorio y las últimas cinco máximas transmitidas en la lista de Sosiades; cf. Robert (1968, págs. 416-57). El epigrama de cuatro líneas pertenece a Clearco de Soli, discípulo de Aristóteles, y allí Clearco mismo afirma haber copiado cuidadosamente en Delfos los sabios consejos de los eruditos del pasado, a fin de llevarlos como presente dedicatorio al santuario de Kineas, héroe fundador de la ciudad greco-bactriana. De acuerdo con Platón, los preceptos de los Siete Sabios existían en el templo de Delfos por lo menos desde antes de la tiranía de los Pisistrátidas en Atenas (527-514 a. C.), y servían como fuente de educación ciudadana; cf. Platón, Hipp. 228c-229a y Prot. 343a; véase además la interpretación de la parábola del Yambo 1 a partir del Protágoras platónico realizada por Acosta-Hughes \& Stephen (2012, págs. 58-68). La coincidencia entre las máximas transmitidas por Sosiades a través de Estobeo y las que se encuentran en el epigrama de Clearco parecen corroborar la existencia y difusión hacia el s. III a. C. de un conjunto de proverbios y dichos de los Siete Sabios cuya forma canónica habría sido la que se encontraba en el templo de Apolo en Delfos. Probablemente estos preceptos hayan sido utilizados como texto didáctico en la educación escolar a partir del s. VI o V a. C. Oikonomides (1980, págs. 179-83) y (1987, págs. 67-76) destaca también otros documentos que contienen preceptos de los Siete Sabios, como una inscripción epigráfica del s. III a. C. proveniente del gymnasium de Miletopolis, en el área de Cícico, con 55 máximas; cf. SIG III ${ }^{3}$ 1268; o, también, el P. Univ. Athen. 2782, un papiro del s. III a. C. procedente de Egipto, el manuscrito más antiguo con preceptos de los Siete Sabios, el cual podría haber sido algún tipo de edición escolar. Lo notable es que los documentos más antiguos de los preceptos de los Siete Sabios: la inscripción de Ai Khanum (Afganistán), la de Miletopolis (Asia Menor), y el P. Univ. Athen. 2782 (Egipto), nos remiten contundentemente a la cultura helenística del s. III a. C. 
misma tradición. Es por ello que define a los Siete Sabios como performers de sabiduría.

Lo interesante de este enfoque es que permite analizar la parábola del Yambo 1 no solo como el relato de una antigua historia con una moraleja adaptada a las circunstancias presentes, sino como la ejecución de una forma de sabiduría y de una tradición que permanece viva en el contexto del simposio alejandrino. Es dentro de esta tradición, revitalizada en el simposio helenístico, donde debe ubicarse la parábola que "Hiponacte" trae ante los eruditos alejandrinos; tradición que, como se ha visto, el mismo poeta arcaico habría promulgado a través de sus yambos.

En sí misma, la parábola de la copa comienza con el arcadio Baticles, un hombre bienaventurado, favorecido por los dioses, que yace recostado en su lecho de muerte. A punto ya de morir, reúne a sus hijos en torno suyo e incorporándose apenas sobre su codo, como un bebedor, les dice: “Hijos, anclas mías, ya estoy partiendo..." En esta parte, el papiro está muy deteriorado, hay una laguna de 13 versos que hace ilegible el texto y no se acierta a saber qué fue exactamente lo que el padre les transmitió. Sin embargo, la Diégesis 6.6-10 nos informa que Baticles repartió sus posesiones entre ellos y encomendó a Anfalces, su hijo del medio, una copa de oro para que se la entregara al mejor de los Siete Sabios. En el v. 52, encontramos a Anfalces arribando a las costas de Mileto para entregarle la copa a Tales, ya que se distinguía por su inteligencia y por sus descubrimientos astronómicos, entre los que se destaca haber establecido los cálculos de la revolución de la Cinosura, Osa Menor, empleada por los fenicios en la navegación. ${ }^{62}$ Auxiliado por un buen augurio, Anfalces

${ }^{62}$ Arato, Phaenom. 36-43 Mair, señala que, para guiarse marítimamente, los griegos habían

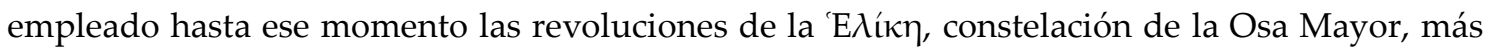
visible pero también menos precisa porque su revolución es demasiado amplia; los fenicios en cambio se guiaban por la Kuvooov́@ $\alpha$, Osa Menor, cuya revolución es mucho más pequeña y

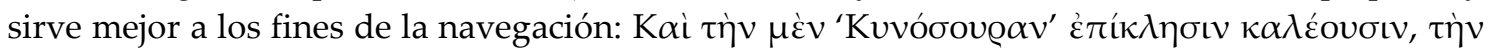

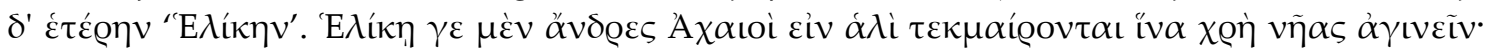


encontró al sabio en el templo de Apolo en Dídima. Tales aparece trazando en la tierra con un puntero un esquema geométrico descubierto por Pitágoras, ${ }^{63}$ quien, de acuerdo con su creencia en la metempsicosis, afirmaba ser una reencarnación del héroe troyano Euforbo, muerto a manos de Menelao. ${ }^{64}$ El relato también hace referencia a la prédica de Pitágoras de alimentarse de vegetales y abstenerse de comer carne, practicada por los pitagóricos y difundida a lo largo de la Magna Grecia. El v. 63 introduce una ironía sobre este precepto, no todos siguieron el vegetarianismo "sino aquellos a los que el

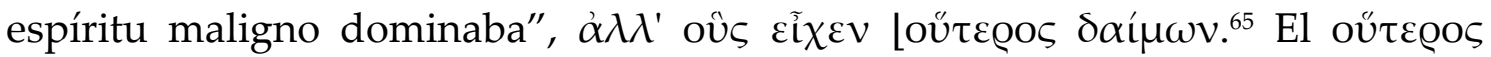
$\delta \alpha\{́ \mu \omega v$ refiere en este caso a la pobreza que dominaba a los pitagóricos y que

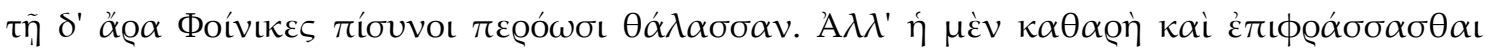

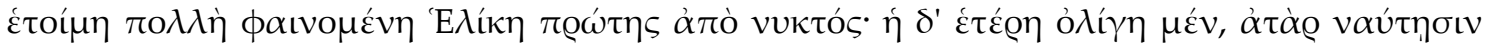

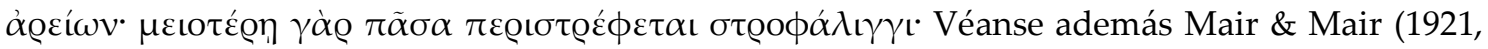
pág. 1921 n. c); D’Alessio (1996, pág. 584 n. 23).

${ }^{63}$ Este $\sigma \chi \tilde{\eta} \mu \alpha$, como muchos críticos han aceptado, podría haber sido el desarrollo gráfico del

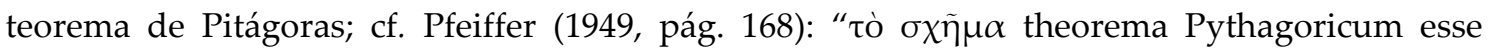
videtur;" Sobre el problema geométrico específicamente en el Yambo 1, véase Di Marco (1998, págs. 98-107) .

${ }^{64}$ Diógenes Laercio, Vit. philos. 1.24-26, después de señalar que Calímaco atribuía a Tales el cálculo de la Osa Menor y citar los propios versos del Yambo 1, dice que Pánfilo le atribuye el haber trazado el triángulo rectángulo en el círculo, pero también dice que otros le asignan este descubrimiento a Pitágoras y nuevamente cita el Yambo 1 para señalar que Calímaco adjudica el

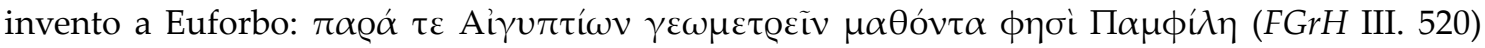

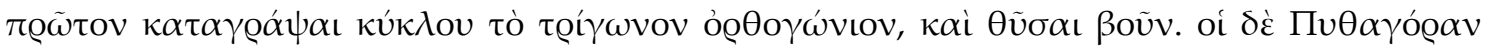

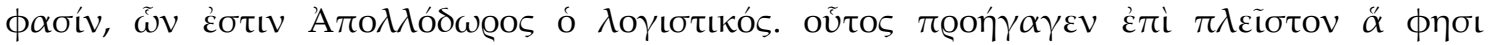

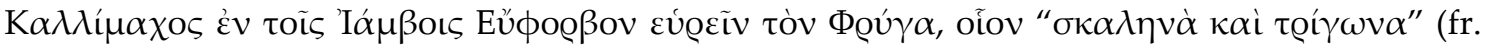

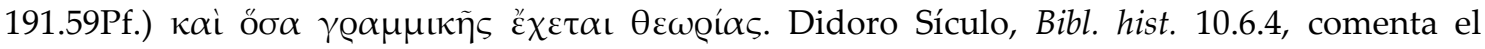
pasaje del Yambo 1 e indica que Calímaco habla de Pitágoras, de los teoremas geométricos que postuló y de aquellos que trajo de Egipto, señala también la creencia de Pitágoras de ser la

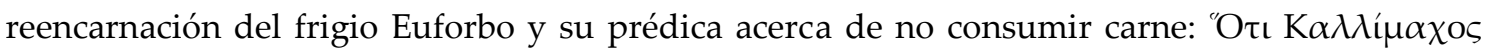

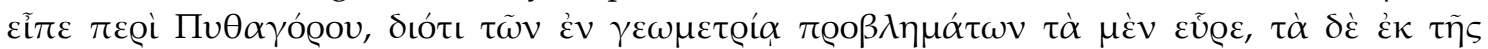

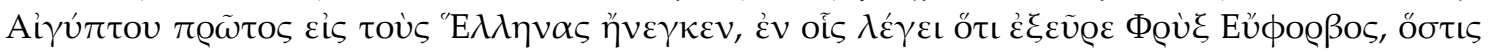

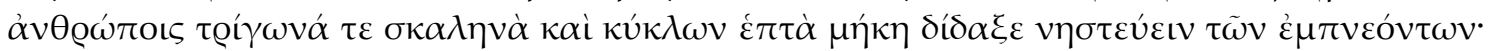

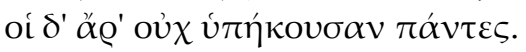

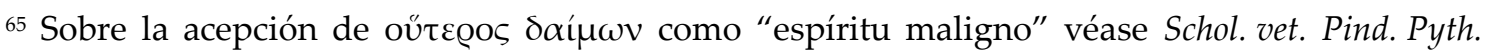

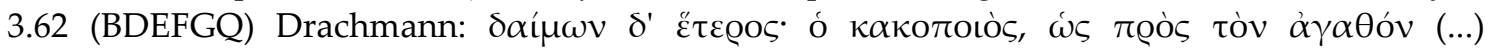

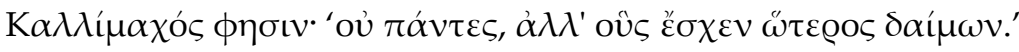


les impedía alimentarse de carne, haciendo del precepto de abstinencia una cuestión puramente económica. ${ }^{66}$

Luego de estas digresiones sobre Pitágoras y los pitagóricos, la narración retorna a la escena del santuario en Dídima. Anfalces, tomando la copa, se la entrega a Tales y le informa sobre la voluntad final de su padre. Sin embargo, Tales realiza el gesto casi estereotípico del sabio que ha reflexionado y ha decidido emitir su sentencia sobre un asunto: golpea con su bastón el suelo y con la otra mano se mece la barba. ${ }^{67}$ Tales no acepta el regalo que le trae Anfalces, pero le dice que si no quiere desobedecer la voluntad de su padre debería llevarle la copa a Bías de Priene. Aquí nuevamente el papiro se presenta muy deteriorado y hay una laguna de 20 versos, pero la Diégesis acude una vez más en nuestra ayuda y nos da la lista de los Siete Sabios que recibieron la copa sucesivamente. Luego de Bías, la copa pasó por las manos de Periandro de Corinto, Solón de Atenas, Quilón de Esparta, Pítaco de Mitilene y Cleóbulo de Lindos, retornando por segunda vez a manos de Tales de Mileto. ${ }^{68} \mathrm{Al}$ recibirla, Tales, en otro gesto de ejecución de sabiduría, graba la copa con la inscripción: “Al protector del pueblo de Neleo, Tales me ofrenda, tras recibir este premio dos veces", y la consagra al dios Apolo en el santuario de Dídima. ${ }^{69}$

66 Aristofonte, fr. 9K, retrata cómicamente el desprendimiento y el vegetarianismo de los pitagóricos al señalar que no era una elección genuina sino que esos preceptos habían surgido a causa de la pobreza, y que si se les hubiera servido carne o pescado se habrían comido hasta los

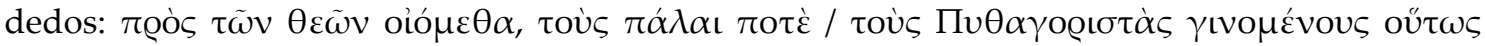

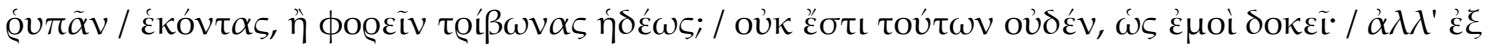

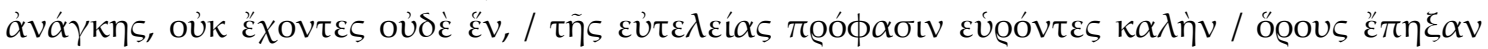

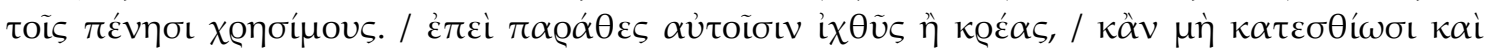

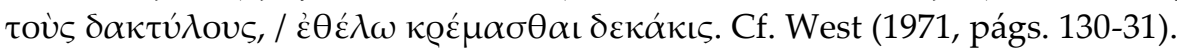

${ }^{67}$ A partir de este tipo de gestualidad, Martin (1998, págs. 108-28) considera a los Siete Sabios como "performers of wisdom."

${ }^{68}$ La lista que da la Diégesis se corresponde con aquella que presenta Demetrio de Falero al citar los preceptos de los Siete Sabios; cf. Estobeo, Anth. 3.1.172 Hense.

${ }^{69} \mathrm{~N} \varepsilon \dot{\lambda} \lambda \varepsilon \omega \varsigma$, hijo de Codro, es el mítico fundador de Mileto. Diógenes Laercio, Vit. philos. 1.28-30, dice que Calímaco, basándose en historiador Leandrio de Mileto, cuenta la historia de la copa de una manera diferente a la real, y agrega que en realidad la inscripción decía: “Tales de 
El relato sobre la copa de Baticles y los Siete Sabios finaliza en este punto. En los versos que restan del Yambo 1, "Hiponacte", antes de retirarse definitivamente al Hades, concluye con una serie de exhortaciones sarcásticas y caricaturescas dirigidas a algunos miembros que componen su auditorio. Pero antes de avanzar con la parte final del poema es necesario exponer aquí la función que podría estar cumpliendo la parábola de la copa dentro del poema.

Como se ha observado anteriormente, ${ }^{70}$ el Yambo 1 ha sido interpretado en general como un poema que emula al género arcaico en su estructura formal, específicamente al coliambo de Hiponacte, pero que ha sido despojado por Calímaco de la invectiva y del ataque personal, elementos característicos del género. Esta interpretación, sin embargo, podría haber sido motivada por el resumen del Yambo 1 que presenta la Diégesis, particularmente cuando el escoliasta señala que "Hiponacte" exhorta a los eruditos para que dejen las envidias entre ellos y con este fin les cuenta cómo el arcadio Baticles...

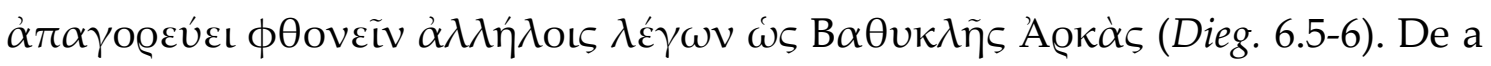
cuerdo con esta lectura, Calímaco habría concebido programáticamente para su libro de yambos la figura de un "Hiponacte" moderado que busca apaciguar los rencores intelectuales surgidos en el contexto del Museo alejandrino. Este "Hiponacte" que predica la paz y la concordia a través de una parábola moralizante se sitúa en una posición literaria sospechosamente opuesta a la vis agresiva y sarcástica del yambógrafo arcaico. ${ }^{71}$

Mileto, hijo de Examias, a Apolo de Delfos (ofrenda) el premio que dos veces ha recibido de los

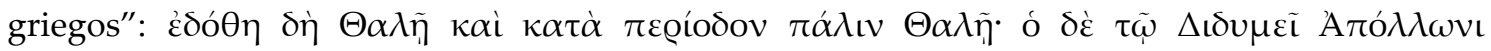

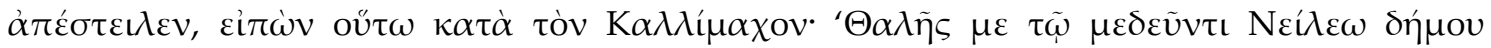

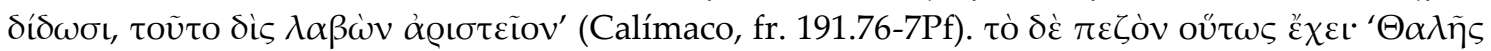

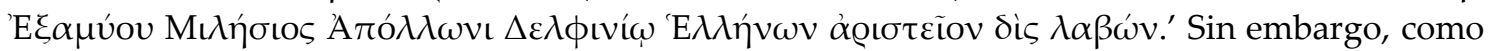
se puede observar en su texto, Diógenes sigue una tradición de la parábola ligada al santuario de Apolo en Delfos, mientras que Calímaco se basa en la tradición de Dídima.

70 Vid. sup. pág. 315.

${ }^{71}$ En su concepción del "nuovo i $\alpha \mu \beta i ́ \zeta \varepsilon ı v^{\prime}$ de Calímaco, Cozzoli (1996, pág. 129) afirma: "Callimaco presenta un Ipponatte inedito: nuovi sono il suo spirito di conciliazione e la sua esortazione alla concordia, nuovo è il suo 'giambo che non canta più la lotta contro Bupalo.' Egli 
Una lectura alternativa, tal vez, sería considerar diferentes niveles por los que se despliega la comunicación poética del yambo. Por un lado, "Hiponacte", en la posición de interlocutor/narrador, se dirige en el plano más superficial del texto a su interlocutario/narratario, esa muchedumbre de eruditos que se acerca al templo de Serapis como moscas, avispas o delfios ante la víctima del sacrificio. En este nivel, propiamente enuncivo, se define entonces la situación de comunicación entre un destinador y un destinatario caracterizados claramente como personajes. $\mathrm{Y}$ es en este nivel también donde debería comprenderse la narración de la copa de Baticles y los Siete Sabios como una parábola didáctica y ejemplificante.

Por otro lado, en un nivel más profundo, el plano enunciativo, la situación de comunicación poética se define a partir del vínculo entre el enunciador y el enunciatario. Es decir, entre "Calímaco" y la representación lingüística de la instancia de recepción del yambo en el contexto de la ejecución poética, identificado como el auditorio externo o extradiegético. ${ }^{72}$

La diferenciación de estos niveles permite considerar que si en el plano enuncivo, el 'yo' inscripto en el enunciado refiere a "Hiponacte" conciliador y moralizante, en el plano enunciativo sin embargo, de acuerdo con la premisa

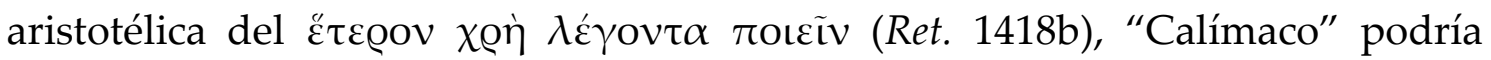
estar llevando contra su enunciatario una invectiva velada tras la máscara del poeta arcaico.

cioè, pur sottolineando le radici ipponattee di questa sua opera, intende al tempo stesso

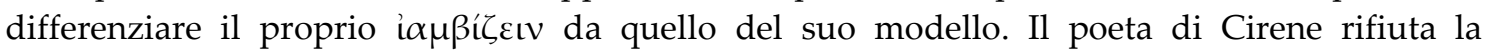
violenza típica di questo genere: tuttavia il suo rifiuto presupone, implicitamente, anche una meditata scelta di un nuovo tipo ben definito di poesia giambica."

72 Véase el esquema en pág. 338. 


\section{4. "HiponACTE": ENTRE LA PARÁbOla MORALIZANTE Y LA CRíticA}

YÁMBICA

Un recorrido transversal a lo largo del yambo podría ayudarnos a delinear las características principales de esta invectiva, para lo cual es necesario detenernos en distintos elementos dentro del poema que proyectan una imagen particular del simposio. La "dimensión metasimpótica", que Fiona Hobden ha expuesto metodológicamente, permite trazar una imagen de la institución del simposio y de la ocasión de ejecución poética a partir del análisis de distintos operadores pragmáticos y referenciales que aparecen dentro de los poemas. ${ }^{73}$

En el Yambo 1, además de la presencia de la figura de Hiponacte y del propio género poético como referencias paradigmáticas del simposio arcaico, aparece la institución simposíaca como escenografía que reactualiza una ocasión específica pero ficticia. Hemos visto, por ejemplo, que cuando "Hiponacte" se dirige a los eruditos alejandrinos (vv. 6-8) nombra a Dioniso, las Musas y Apolo, que además de representar distintos grupos literarios en ese

${ }^{73}$ Cf. Hobden (2013, págs. 22-65): “(...) representations of the symposion at the symposion in song and image construct visions of the event that set out a persuasive view of sympotic performance and communicate ideas (...) Metasympotic representation was thus a diverse but regular feature of sympotic conversation, pursued through poetry as much as art. The focus might shift from the paraphernalia of the andrōn to the performances of the singer, to others in the room. The mode of delivery could also vary from reflection to self-presentation, recommendation, instruction and critique. However, in each instance metasympotic song enabled singer and audience to shape and define their immediate experience in a discursive and sometimes disputational fashion. Performers initiated conversations on sympotic conduct, prioritizing themselves as authorities on the topic and presenting themselves as models for good practice. While they shared strategies and an appreciation of the symposion as a space for drinking, music-making, conversing and loving, the specifics of individual proposals were contingent upon a desire by singers to authorize their contributions, or to challenge their companions." 
contexto, ${ }^{74}$ podrían estar aludiendo también al sonido de la flauta y a las libaciones ofrecidas a las diferentes divinidades dentro del propio simposio. ${ }^{75}$

La misma copa de la parábola aparece como un elemento metasimpótico. ${ }^{76}$ En su lecho de muerte, con los hijos reunidos en torno suyo,

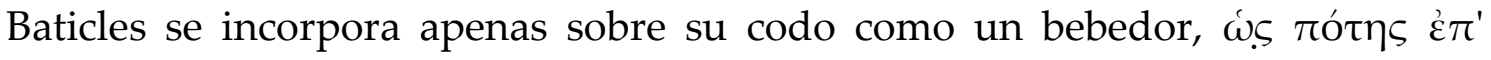
$\dot{\alpha} \gamma \kappa \tilde{\omega} v \alpha($ v. 43), del mismo modo que lo hace un simposiasta recostado sobre la $\kappa \lambda i ́ v \eta$, y le encarga a su hijo Anfalces le entregue la copa mejor de los Siete Sabios. Esta circula de mano en mano por cada uno de los sabios hasta que retorna nuevamente al primero de ellos. La circulación de la copa de un sabio a otro remeda de esta manera el rito de traspaso de la misma entre los simposiastas. En la parábola, asimismo, el viaje de Anfalces hasta Mileto y el posterior recorrido del premio (Priene, Corinto, Atenas, Esparta, Mitilene, Lindos y finalmente Dídima) sugieren un inmenso simposio del cual participan los ya míticos Siete Sabios. De manera alusiva, la imagen del simposio panhelénico funciona también como reflejo de Alejandría bajo la égida de los Ptolomeos, donde fueron reunidos los eruditos más destacados de este tiempo para preservar y continuar la tradición de los sabios arcaicos. ${ }^{77}$

\footnotetext{
${ }^{74}$ Vid. sup. pág. 301 n. 24.

75 Cf. las libaciones inciales del simposio en Calímaco, fr. 203Pf (Yambo 13); fr. 384Pf (Epin. Sosib.); Hymn. Zeus 1.
}

${ }_{76}$ Para un recorrido de la significación de la copa simpótica dentro de la literatura griega véase Gagné (2016, págs. 207-29), quien, en referencia al Yambo 1 de Calímaco, señala que la copa no es una elección obvia como premio en un certamen de sabiduría, lo más esperable sería un trípode, y que tampoco tiene una significación particular como dedicatoria para Apolo más allá del hecho que es de oro y preciosa. Para él la copa de oro de los Siete Sabios puede ser vista funcionando como un símbolo simpótico.

${ }_{77}$ Es interesante observar que en el yambo de Calímaco la sabiduría aparece asociada a la conservación y transmisión de una tradición que trasciende la muerte: "Hiponacte" retorna para traer un yambo, pide además que "escriban" sus palabras; Baticles a punto de morir entrega un premio de sabiduría; Tales dibuja en el suelo el teorema de Pitágoras, quien creía ser la reencarnación del frigio Euforbo; Tales, también, graba una inscripción en la copa y la consagra a la posteridad en el santuario de Apolo en Dídima. 
Vemos, entonces, cómo la copa, en tanto símbolo de sabiduría, posibilita la superposición de planos espaciales y temporales entre la Grecia arcaica y la helenística; pero, al mismo tiempo que vincula a los antiguos sabios con los presentes, se ubica también como un premio en disputa dentro de un certamen. En su designación metonímica, la sabiduría, trasvasada de generación en generación, vincula el espacio simpótico de la tradición yámbica y del certamen de sabiduría con el simposio helenístico y las disputas entre los eruditos alejandrinos. ${ }^{78}$ De este modo, la circulación del vino y de la palabra en el simposio, el traspaso de la copa de oro de sabio en sabio, y la transmisión de sabiduría desde el período arcaico al helenístico otorgan al Yambo 1 una forma claramente circular. Esta forma adquiere mayor dimensión cuando consideramos el carácter programático de todo el libro de Yambos de Calímaco. $^{79}$

Por último, nos parece importante exponer la relación que el Yambo 1 y la parábola de la copa entablan con una mirada ideológica de la soberanía de Ptolomeo II Filadelfo, particularmente el hecho de que Tales, al recibir la copa por segunda vez, la ofrenda a Apolo Dídimo. La preferencia por el sabio de Mileto y por el santuario en Dídima, y no en Delfos, podría haber sido una opción deliberada por parte de Calímaco ${ }^{80}$ Esta elección estaría relacionada con

78 Para el simposio helenístico como espacio de difusión de las obras, véase Cameron (1995, págs. 24-103).

${ }^{79}$ Vid. sup. pág. 344. En forma elíptica el Yambo 13 retoma los temas del simposio, la disputa entre los eruditos del Museo alejandrino, el viaje no realizado a Éfeso, la transmisión del saber y la Alejandría ptolemáica como lugar de concentración de una sabiduría poética panhelénica.

80 Vid. sup. pág. 314 n. 49. Como ya se ha observado, Diógenes Laercio transmite diferentes versiones del certamen de sabiduría que involucra a los sabios arcaicos. En al menos dos de ellas se señala la inscripción de un epigrama en la copa o en el trípode por parte de uno de los sabios, pero en todos los relatos el santuario es el de Delfos. Es posible pensar que hayan convivido diferentes tradiciones orales de la misma historia de acuerdo con los intereses regionales que se buscaran destacar. Wulf (1896, págs. 12-20) recopila once variantes de esta leyenda. En Prot. 343.a-b, de Platón, se dice que los Siete Sabios expresaron su saber con frases breves y que de común acuerdo consagraron estas máximas como principios de sabiduría en una inscripción en el templo de Apolo en Delfos. 
las pretensiones de soberanía que los Ptolomeos reclamaban sobre Licia, Caria y el sur de Jonia. ${ }^{81}$

En relación a la soberanía ptolemaica y el Yambo 1, es posible observar en primer lugar que el epigrama votivo de la copa está dirigido a Apolo a través del mítico Neleo, fundador de Mileto: “Al protector del pueblo de Neleo, Tales

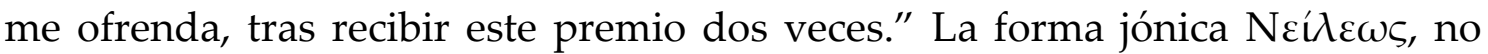

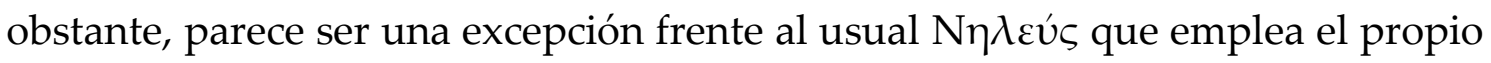
Calímaco y escritores posteriores para referirse al hijo de Codro. ${ }^{82}$ Esto ha llevado a considerar la existencia de un juego de palabras basado en la

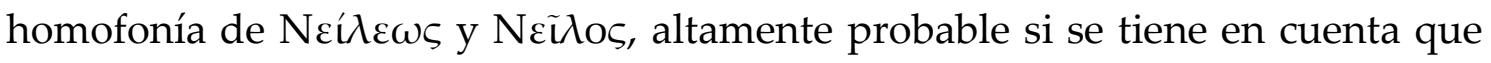
esta es la única versión de los epigramas votivos grabados en la copa de sabiduría en que aparece el nombre de Neleo. ${ }^{83}$ Podría pensarse entonces que, por medio de Calímaco, Tales también le estaría dedicando la copa al protector del pueblo del Nilo, es decir a Ptolomeo II Filadelfo. Y, al mismo tiempo, esta lectura conduce también a considerar la postulación de una analogía entre Apolo y el soberano de Egipto.

${ }^{81}$ Calímaco estaba muy familiarizado con las tradiciones y la cultura de la urbe que constituían Mileto y el santuario de Dídima. En el Hymn. Artem. 225-7 incorpora detalles relacionados con la fundación de Mileto por parte de Neleo y distingue claramente el culto milesio a Ártemis

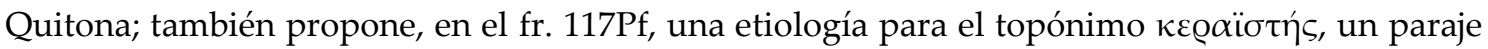
en el camino sagrado que conducía desde Mileto a Dídima (cf. Et.Mag. 504.10 y Et.Gud. 315.28); en Aitia 3, ff. 80-83Pf, cuenta además la historia de amor entre Frigio, hijo del rey de Mileto, y Pieria, hija de una familia noble de Miunte, que por un conflicto bélico entre las dos ciudades debían permanecer separados, pero se encontraban en el templo de Ártemis en Mileto; en el fr. 229Pf relata el don de la profecía otorgado por Apolo a su amado Branco y la consecuente fundación del oráculo de Apolo en Dídima; y en el ff. 194.29-32 Pf se refiere a la plaga que Apolo había enviado en castigo a los milesios y al cese de este castigo por amor a Branco. Sobre el interés de Calímaco en la región véanse Parke (1985, págs. 2-6; 55-6); Cameron (1995, págs. 167-72).

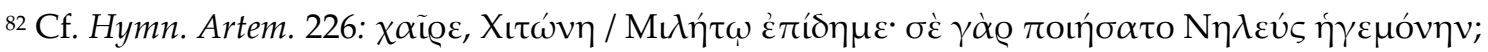

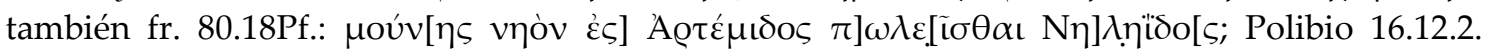
Sobre las variantes del nombre Neleo véanse las notas en ap. cr. al fr. 80.18 (Phrygius et Pieria) en la edición de Pfeiffer (1949, pág. 89); Herda (1998, págs. 1-2); Massimilla (2010, pág. 406); Harder (2012, pág. 682);

${ }^{83}$ Gagné (2016, pág. 4), a partir de una hipótesis de Stephen White (en prensa). 
En segundo lugar, la emergente dinastía ptolemaica en Egipto hacia principios de s. III a. C. condujo a que los los eruditos del Museo alejandrino desplegaran estrategias ideológico-poéticas para la consolidación simbólica de la soberanía de los descendientes macedónicos. En este sentido, durante la primera generación, las estrategias giraban en torno a exaltar los vínculos de Ptolomeo I Soter con Alejandro Magno. Por lo cual, durante este período, el imaginario del poder real se concentró en la imagen de Zeus, padre putativo de Alejandro, y en el legado que detentaba legítimamente Ptolomeo I como sucesor del conquistador griego en la satrapía de Egipto y Libia. En esta primera etapa de la dinastía, a la que probablemente pertenece el Himno a Zeus de Calímaco, Ptolomeo I comenzó a ser asociado a la figura de Zeus Soter. ${ }^{84}$

Luego de la muerte de Ptolomeo I (283 a. C.) y durante el transcurso del reinado de su hijo Ptolomeo II, el imaginario se fue desplazando sutilmente de la preponderante influencia de Zeus hacia la búsqueda de una representación divina que sirviera para fundamentar el ejercicio de un poder autónomo por parte de Ptolomeo Filadelfo. Poéticamente Calímaco favoreció la figura de Apolo como sustento ideológico de la soberanía. A través de los himnos (Himno a Zeus, Himno a Apolo, Himno a Ártemis e Himno a Delos) puede verse que la transición de la figura de Zeus a la de Apolo se produce mediante la acentuación y el contraste de rasgos de continuidad y ruptura entre padre e hijo, entre la supremacía de Zeus y la emergencia de una ideología apolínea del poder y la autoridad. ${ }^{85}$

\footnotetext{
${ }^{84}$ Cf. Stephens (2015, págs. 48-9).

${ }^{85}$ Cf. Barbantani (2011, págs. 178-200); Brumbaugh (2011, págs. 162-3; 169) señala: “Despite the fact that the collection begins with Zeus, the Apolline hymns constitute the dominant voice in the Hymns, making up sixty-five percent of the text. More importantly than the word count, the Apolline hymns also mark an ideological shift in the presentation of kingship. The general model of kingship, a hierarchical one premised on inequality and meritocratic advancement, remains substantially the same throughout, but reading across the Hymns poem by poem, in the order presented moves from Zeus' kingship and towards Apollo's. (...) The substitution of Apollo for Zeus is subtle and emphatically not occasioned by the eris, or strife, that typically
} 
Como ya se ha señalado, Dídima era, luego de Delfos, el oráculo de Apolo más importante del mundo griego. Desde que Alejandro recuperó del dominio persa la ciudad de Mileto y se restauró el santuario de Dídima, la prosperidad de la región fue rápidamente en aumento. A raíz de la ubicación estratégica de su puerto se convirtió prontamente en uno de los centros neurálgicos del intercambio comercial y cultural entre las distintas satrapías que conformaban el mundo helenístico. Luego de la muerte de Alejandro, aunque Mileto estaba bajo el dominio de Lisímaco, las dinastías seléucidas y ptolemaicas se disputaron por más de medio siglo la influencia política sobre esa ciudad y buscaron capitalizar el patrimonio simbólico y religioso que representaba el santuario en Dídima. Esta disputa se desarrolló a través de diversas acciones de política exterior pergeniadas por ambas dinastías con el objetivo de ejercer el protectorado sobre Mileto y de anexar así la región a sus propios reinos. Seleuco I, por ejemplo, imitando la iniciativa de Alejandro de repatriar los tesoros griegos, devolvió a la ciudad la estatua de Apolo esculpida en bronce por Cánaco que los persas habían llevado a Ecbatana en el 494 a. C. ${ }^{86}$ Posteriormente, su hijo y sucesor, Antíoco I, firmó un edicto mediante el cual se comprometía a construir una monumental galería anexa al ágora de Mileto y a realizar aportes anuales para reconstruir íntegramente el santuario y subsidiar su funcionamiento. ${ }^{87}$ En gratitud por estas acciones, Mileto concedió a Antíoco I y a su descendencia la promanteia, es decir, el derecho que se reservaba el oráculo de oír sus consultas y responderle antes que a cualquier otro peticionario. ${ }^{88}$ Hacia finales de la década del 280 a. C., durante la decadencia del

accompanies the replacement of one king with another, particularly in the mythological narratives of the Greek poetic tradition. That this transition is effected smoothly, however, is not to say that eris is completely sublimated in the Apolline hymns."

${ }^{86}$ Cf. Pausanias 1.16 .3 y 8.46.3.

${ }^{87}$ Cf. OGIS 213; Estrabón 14.1.5.

${ }^{88}$ Cf. I.Didyma 479.40-43; Véase particularmente Fontenrose (1988, pág. 105). 
imperio de Lisímaco, muchas ciudades se rebelaron e independizaron de la satrapía de Tracia y Asia Menor. Seleuco I ayudó a Mileto en su independencia y, posteriormente, dio muerte a Lisímaco en la batalla de Corupedio (281 a. C.). Los milesios, en agradecimiento, erigieron una estatua en su honor y lo proclamaron salvador de la ciudad: Seleuco I Soter. ${ }^{89}$ Sin embargo, Seleuco I fue asesinado ese mismo año por Ptolomeo Cerauno, hermanastro de Ptolomeo II, en búsqueda de hacerse con la satrapía de Tracia y Asia Menor. Ante la muerte de Seleuco, Ptolomeo II intentó aprovechar la debilidad de la dinastía seléucida y donó a la ciudad de Mileto una vasta extensión de territorios. ${ }^{90} \mathrm{Y}$ aunque la ciudad mantuvo sus alianzas con el sucedor de Seleuco, Antíoco I, es probable que a partir de esta acción Ptolomeo II desplazara la influencia de la dinastía seléucida sobre la ciudad de Jonia al menos por el transcurso de las dos décadas siguientes. ${ }^{91}$ Sin embargo, entre el 259 y 258 a. C., los milesios otorgaron a Antíco II, rey de los seléucidas desde la muerte de su padre en el 261 a. C., el epíteto de Teos y lo divinizaron en vida a causa de la ayuda que les había prestado para derrocar Timarco, que se había convertido en tirano de la ciudad con la connivencia de Ptolomeo II. ${ }^{92}$

La región habría tenido por lo tanto un doble atractivo para las dinastías seléucidas y ptolemaicas: en primer lugar, el carácter estratégico de Mileto por su ubicación geográfica, su influencia política y su desarrollo económico; y en segundo lugar, el caudal simbólico y religioso que representaba Dídima para el

\footnotetext{
${ }^{89}$ Cf. I.Milet 158.

${ }^{90}$ La donación de estos territorios fue acompañada por una carta real de Ptolomeo II Filadelfo, de la cual los milesios dejaron testimonio en una piedra conmemorativa; cf. I.Milet 139.3-32 y 3.122-6. Véase Welles (1934, pág. 74).

${ }^{91}$ Para la relación entre los Ptolomeos y la ciudad de Mileto véanse Huss (2001, pág. 262) y Ehrhardt (2003, págs. 286-9). Cameron (1995, pág. 167) señala que el Yambo 1 de Calímaco debe haber coincidido con la reconstrucción del santuario (270 y 260 a. C.) con fondos donados por Ptolomeo II.
}

${ }_{92}$ Cf. Apiano, Syriaca 344. 
mundo griego de la época. Con respecto a esto último, ese oráculo de Apolo había revelado la ascendencia divina de Alejandro Magno como hijo de Zeus. ${ }^{93}$

Por lo tanto, dentro de la disputa por la hegemonía del poder político sobre la región, la promulgación de un origen divino por parte del oráculo habría sido considerada de gran importancia para la legitimación simbólica de la dinastía ptolemaica, particularmente porque reinados como el de los seléucidas en la satrapía de Babilonia o el de los ptolomeos en Egipto se encontraban aún en proceso de consolidación dentro territorios extranjeros y en regiones de complejas transposiciones culturales y políticas.

El evidente interés de Calímaco en Mileto y su zona de influencia, explícitamente acentuado en la etiología del santuario y del oráculo de Apolo en Dídima, ${ }^{94}$ se podría encuadrar dentro de una topografía que pone de manifiesto las aspiraciones de poder de Ptolomeo II sobre la región. En otras palabras, la relevancia de Mileto y Dídima en la obra de Calímaco se correspondería con la importancia política que la ciudad y el santuario de Apolo tenían para la dinastía del imperio ptolemaico.

De acuerdo con esta lectura, el auditorio alejandrino del Yambo 1 podría haber comprendido la parábola de la copa de Baticles no solamente como un relato erudito sobre los Siete Sabios de la Grecia arcaica, sino también como una composición literaria que en algún punto tocaba temas de actualidad política para la corte ptolemaica. El viaje imaginario de la copa, que parte de la propia Alejandría a través del relato de "Hiponacte", viaja por distinas ciudades de la antigüedad de la mano de los sabios locales, es consagrada posteriormente en el

\footnotetext{
${ }^{93}$ Calístenes fr. 124.14a (=Estrabón 17.1.43) reporta el famoso episodio de Alejandro Magno en el oráculo de Amón en Siwa y la declaración de su descendencia como hijo de Zeus. También transmite la proclamación del oráculo de Dídima en la que se manifestaba el nacimiento divino de Alejandro. Historias similares a las de Alejandro se contaban acerca de Seleuco I Nicator, pero como descendiente de Apolo, ascendencia que habría sido pronunciada también por el oráculo de Dídima. Cf. Cameron (1995, pág. 171); Brumbaugh (2011, págs. 211-3).

${ }^{94}$ Calímaco aborda temáticamente el santuario de Dídima y la ciudad de Mileto en seis poemas que pertenecen a cuatro colecciones diferentes; vid. sup. pág. 330 n. 81.
} 
santuario de Dídima y retorna con el cierre de la parábola a la Alejandría contemporánea, podría haber despertado en el auditorio la imagen de una soberanía panhelénica desde el encuadre ideológico de la dinastía ptolemaica. Esto no significa que Ptolomeo II tuviera aspiraciones sobre cada una de las ciudades que se nombran en el relato, pero sí que ellas se enmarcan dentro del ideario panhelénico heredado de Alejandro. En cierta forma, la geografía poética que teje Calímaco a través de la narrativa mítica y etiológica de los Yambos, y de su obra en general, podría haber tenido fundamentación en una geografía política. ${ }^{95}$ Dentro de esta interpretación pueden entenderse las distorsiones deliberadas de ciertos relatos y tradiciones míticas como, por ejemplo, la elección del santuario de Apolo en Dídima y no en Delfos o la inscripción de la copa que, de acuerdo con Diógenes Laercio, difiere de las versiones canónicas. ${ }^{96}$

Es posible sostener, por lo tanto, que la consagración de la copa a Apolo Dídimo en el Yambo 1 podría haber tenido un trasfondo simbólico e ideológico relacionado con acontecimientos políticos vigentes durante el reinado de Ptolomeo II. Posiblemente uno de los fines de esta construcción simbólica fuera el de vincular y fundamentar el linaje de la dinastía ptolemaica con la figura de Apolo. ${ }^{97}$ Por esta razón, la dedicatoria del premio de sabiduría a la divinidad

\footnotetext{
${ }^{95}$ Asper (2011, págs. 155-77) considera que Calímaco crea en su obra el espacio panhelénico del poder ptolemaico, y muestra a través de los conceptos de "geopoética" y "geopolítica" cómo detrás de la narrativa mitológica del poeta se manifiesta el presente político e ideológico de los ptolomeos. Su análisis se centra en cinco regiones relevantes en los Aitia, los Himnos y los Yambos: Mileto, Ática, Ceos, Cos, y Roma-Sicilia.
}

96 Vid. sup. pág. 314 n. 49.

${ }^{97}$ La identificación de Ptolomeo II con la figura de Apolo aparece en Hymn. Del. 162-197 de Calímaco, donde se narra que Leto al llegar a Cos para dar a luz escucha a su hijo Apolo que desde el vientre le dice que no se detenga en esa isla porque las Moiras la han destinado para

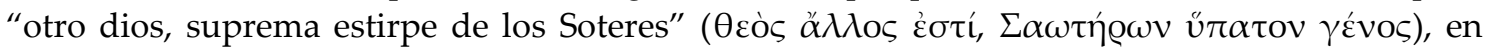
alusión a Ptolomeo II Filadelfo, nacido en Cos. En el mismo pasaje, Apolo anuncia que los continentes y las islas acudirán bajo la corona del macedonio y se someterán de buena voluntad, vaticinando la derrota de los gálatas que amenazan a los helenos $\mathrm{y}$, en cierto modo, 
también podría recaer por transición sobre la propia persona de Ptolomeo Filadelfo.

\section{5. “CAlímaco” E “Hiponacte”. La máscara detrás de la máscara}

Finalmente, se debería considerar por qué Calímaco eligió el yambo arcaico para transmitir una parábola que pone de manifiesto y fortalece esta vinculación simbólica, ¿por qué no un epinicio?, ¿por qué particularmente la figura de "Hiponacte"? La superposición de planos temporales y espaciales entre el período arcaico y el helenístico, entre los sabios de la antigüedad y los eruditos alejandrinos, podría conducirnos a reconsiderar la afirmación de que la elección de este género poético haya recaído únicamente en la preferencia métrica y formal adaptada a una intención pedagógica y moralizante, es posible también que esta preferencia parta de la propia función de crítica y polémica inherente al género yámbico. En este sentido, como se ha argumentado, esa copa mítica que viaja de mano en mano, de un sabio a otro, rememora el acto de las libaciones que se realizan en la apertura del simposio y por esta razón podría identificarse también con la copa que se pasan los eruditos unos a otros, quizás, en la instancia misma de ejecución del Yambo $1 .^{98}$ Este simposio podría

manifestando la vigencia del ideal panhelénico bajo el reinado de los ptolomeos. El vínculo y la identificación de Ptolomeo II con el dios aparece mucho más explícita en el Hymn. Apoll. 25-7:

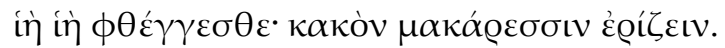

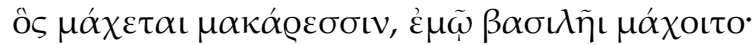

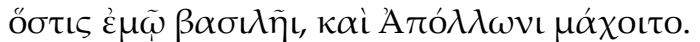

¡Griten hié, hié! Es malo rivalizar con los bienaventurados. El que confronta con los bienaventurados, confronta con mi rey: quien a mi rey ataca, también ataca a Apolo.

${ }^{98}$ De cualquier modo, Cameron (1995, págs. 24-102) analiza los contextos literarios y sociales del mundo helenístico, particularmente ligados a la producción poética de Calímaco. Su estudio reexamina las evidencias que sustentan las caracterizaciones modernas de Calímaco y de sus contemporáneos como eruditos recluidos, encerrados en la biblioteca de Alejandría escribiendo sus obras, y aislados de la cultura y la sociedad helenística. Cameron sostiene que los poetas asociados con la biblioteca participaban de una tradición en que la ejecución pública de poesía continuaba sin grandes disrupciones desde el pasado clásico; argumenta además que el 
no haber existido, tampoco la copa, ni siquiera es necesario que haya habido una ejecución pública del yambo de Calímaco para interpretar que aquí lo que se pasa "de mano en mano" es metonímicamente la sabiduría. El ritual simpótico entabla, de este modo, un conjunto de paralelismos identitarios entre los dos niveles. Las personas, el espacio y el tiempo de la narración (ellos, allá, en otro tiempo) se superponen e interpretan en reciprocidad con las personas, el espacio y el tiempo de la enunciación poética (nosotros, aquí, ahora).

En este sentido, es interesante la conclusión a la que arriba Calame (2009, pág. 5) al analizar cómo, en el fr. 17V de Safo, la relación lingüística del poema "teje" el tiempo y espacio de un pasado heroico, a partir de un relato mítico, con el "hic et nunc of its performance":

(...) the poem mentions only some elements of plot and some proper names borrowed from the great heroic epic. Except for the nuance, nevertheless, that Sappho's mythographic récit, the time and space of the heroic action are narrowly linked to the time and space of the sung action, of the song act represented by the poem's performance: the order of 'myth' penetrates the order of 'ritual'!

simposio helenístico era el escenario natural para la ejecución de las distintas formas poéticas después de los festivales públicos, tal vez el contexto social más importante dentro del mundo cultural de los Ptolomeos para la performance de literatura no remunerativa. En la misma línea, Cozzoli (2015, pág. 2) afirma: “In età ellenistica il simposio allargato o ristretto è ormai divenuto lo spazio performativo principal in cui i poeti comunicano, pubblicano e trasmettono in anteprima letteraria ad un uditorio ampio o più selezionato le loro creazioni, non ancora diffuse in un'edizione scritta e difinitiva. Il 'nuovo convito' tra dotti, nato per così dire dalle ceneri di quello attico, passato attraverso le esperienze di quello filosofico, diviene quindi un circuito privilegiato di formazione, di discussione, di diffusione e di propaganda per la poesia elitaria; di riflesso, o, di conseguenza, anche i letterati tendono a configurare la forma dei loro testi scritti come discussioni simposiali reali o immaginarie, spesso ideali o idealizzate; oppure utilizzano modalità di comunicazione improntate ad un codice simposiale. Secondo una fenomenologia già tipica della poesia aurale l'occasione continua a condizionare la forma con cui si struttura il testo scritto o è addirittura presupposta, inglobata in esso. Il Simposio è cioè divenuto non solo la metafora mediatica con si pubblicizza e si esprime il proprio modello poetico e culturale, ma si presta ad essere considerato in un certo senso un sistema per descrivere la circolazione letteraria intertestuale di questo periodo storico in toto." Para el simposio como contexto de ejecución real de la poesía helenística y en particular de Calímaco, véanse Morrison (2007, págs. 37-42); Bing (2009, págs. 106-15); Acosta-Hughes \& Stephens (2012, págs. 84-104). 
Siguiendo a Calame, por lo tanto, es posible sostener que, al igual que la narración mítica en el poema de Safo, en el Yambo 1 de Calímaco, a través de la parábola de Baticles, la mítica copa del certamen de sabiduría "penetra" en la copa del simposio helenístico. En consecuencia, una aproximación desde el análisis discursivo y de la enunciación poética nos ayudaría a precisar los diferentes planos de comunicación y a determinar si, además de la imitación formal del género arcaico, es posible considerar también una función de invectiva o crítica yámbica en el poema de Calímaco.

Partiendo del nivel más superficial del texto, en el plano enuncivo, la primera persona que aparece inscripta en el enunciado refiere deícticamente a "Hiponacte", y en oposición dialógica aparece una segunda persona plural que

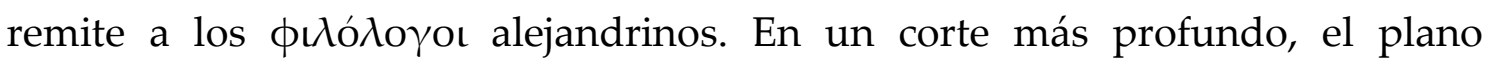
enunciativo, la situación de comunicación poética se define a partir del vínculo entre el enunciador y el enunciatario. El primero identificado con "Calímaco", en tanto representación lingüística del destinador de la ejecución poética (diferenciado de la figura histórica y biográfica del poeta Calímaco), y el segundo identificado con el auditorio, entendido como representación lingüística de la instancia del destinatario. Podríamos esquematizar esta estructura enunciativo-enunciva de la siguiente manera:

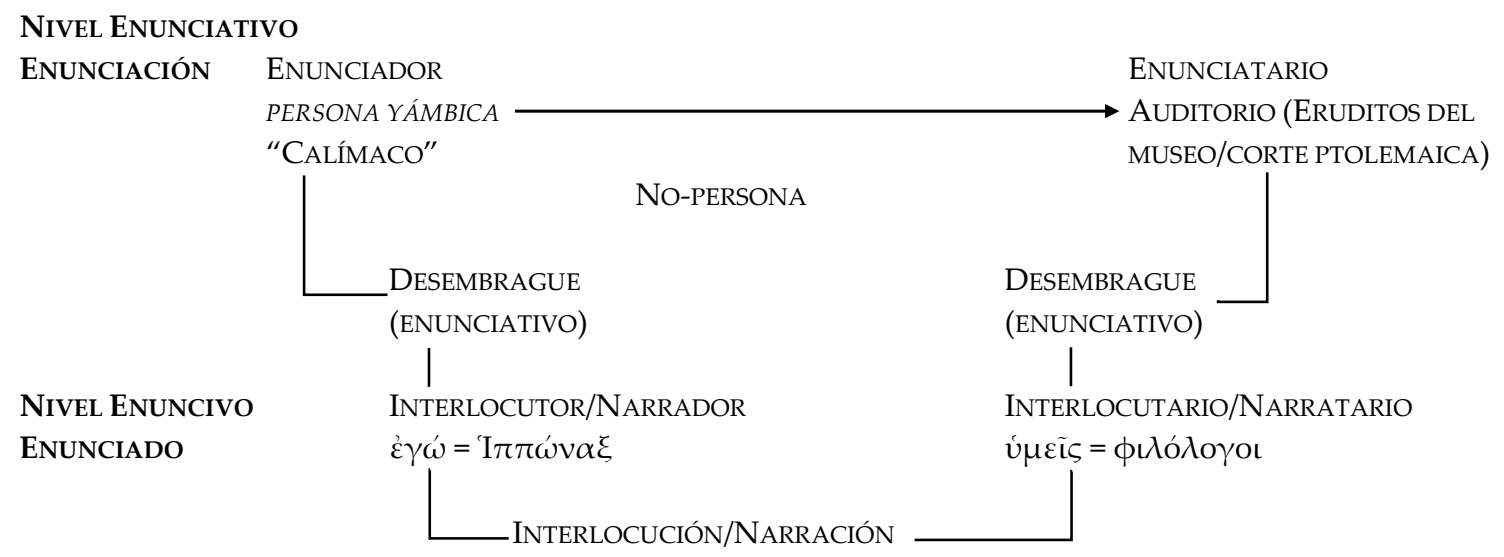


El esquema nos muestra una disyunción desde la instancia de enunciación hacia la del enunciado a través de un proceso de desembrague enunciativo que instala en el discurso las formas de la enunciación enunciada. ${ }^{99}$ El yambo presenta dos estructuras discursivas, la interlocución y la narración. Como se puede observar, en ambos casos I $\mathrm{I} \pi \tau \omega \boldsymbol{\omega} \alpha \xi$ asume las posiciones

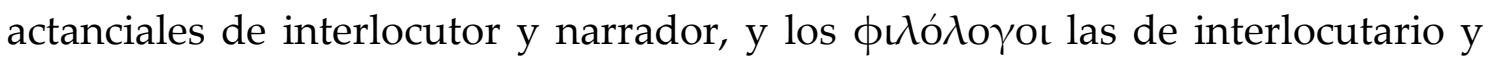
narratario, respectivamente. Por lo tanto, la identidad del interlocutor/narrador manifiesta una relación de no concomitancia con la del enunciador, mientras que la del interlocutario/narratario puede se considerada, aunque de manera tipificada, en concomitancia con el enunciatario.

Esto nos permitiría pensar por lo tanto que la intención conciliadora de la fábula que trae "Hiponacte" se ubica en el nivel de comunicación entre el interlocutor/narrador y el interlocutario/narratario, mientras que en el nivel comunicativo entre el enunciador y el enunciatario el yambo podría contener en su totalidad otro tipo de acto ilocutivo.

En la instancia del hic et nunc de la ejecución poética del Yambo 1 ¿cuál de aquellos eruditos del Museo alejandrino y de la corte ptolemaica que componían el auditorio podría haberse arrogado el derecho de retener para sí esa copa que parte del relato mítico y se identifica la copa de sabiduría que circula en el simposio?, ¿cuál de todos sería capaz de considerarse mejor que los antiguos sabios o siquiera compararse con ellos?, ¿quién podría interrumpir definitivamente la circulación del premio al mejor de los sabios que el arcadio Baticles puso en movimiento? Probablemente ninguno de los eruditos, que provenían de distintas ciudades de la Grecia helenística y que vivían en Alejandría a expensas de los ptolomeos, habría sido capaz de atribuirse la consideración de ser merecedor del premio. Por esta razón, la copa seguirá su

99 Dentro del yambo se producen distintos embragues y desembragues ya que hay

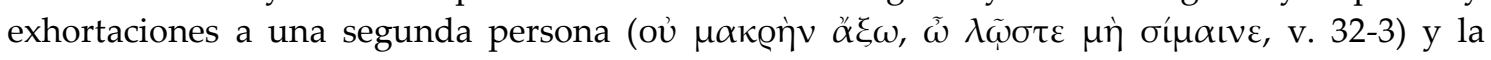
interpolación misma de la fábula implica también disyunciones internas. 
periplo y retornará a las manos de la persona yámbica "Calímaco" quien, al igual que Tales al dedicarla a Apolo Dídimo, terminará consagrándola a través de su poema al único verdaderamente sabio, Ptolomeo II Filadelfo, representante de la soberanía apolínea.

Finalmente, el análisis discursivo del Yambo 1 nos ha permitido observar que, en la superposición de planos enunciativos y enuncivos, el "nuovo $\grave{\imath} \alpha \mu \beta\left\langle\zeta \varepsilon \iota v^{\prime \prime}\right.$ propuesto por Calímaco podría haber implicado no solamente la adaptación formal del yambo arcaico, sino también el enmascaramiento de la función de invectiva y crítica propia de este género para dirigirla contra el culto auditorio alejandrino en el contexto de las polémicas intelectuales del Museo y la corte ptolemaica. ${ }^{100}$

El Yambo 1 concluye, luego del relato de los Siete Sabios, con el retorno a la interlocución entre "Hiponacte" y los filólogos (vv. 79-98). Este pasaje, muy deteriorado y fragmentario, equilibra la primera parte (vv. 1-31) y constituye el cierre del poema. La máscara del poeta arcaico vuelve a dirigirse nuevamente

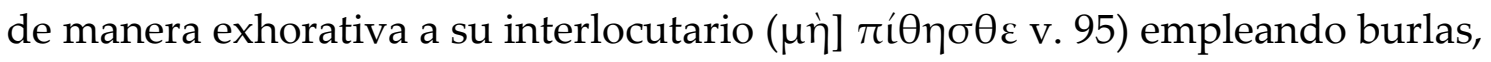
invectivas y ridiculizaciones. "Hiponacte" ataca de manera personal el comportamiento de los filólogos pero nadie aparece nombrado individualmente:

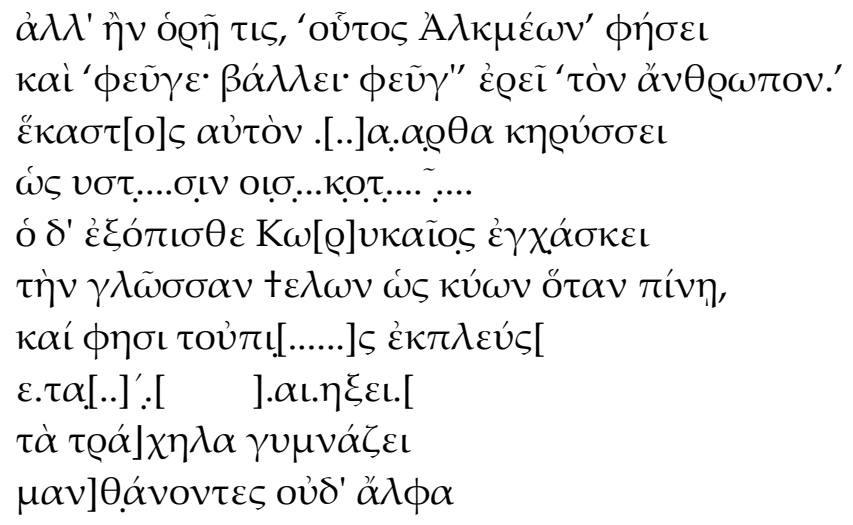

100 Vid. sup. pág. 297 n. 20. Para las polémicas intelectuales dentro del ámbito del Museo y la corte ptolemaica en relación particularmente a un recorrido detallado de la obra de Calímaco, véanse Cameron (1995, págs. 24-103); Lelli (2004), Acosta-Hughes \& Stephens (2012, pág. 83). 


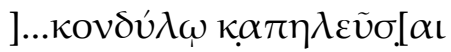

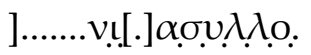

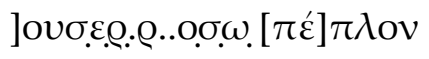

90

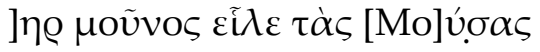

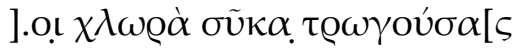

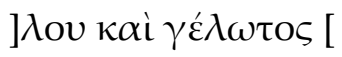

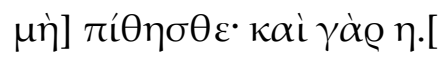

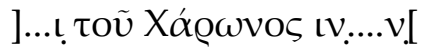

95

]$\omega \dot{\lambda} \lambda v \varepsilon \kappa \dot{\alpha} \pi \mathrm{\pi} \pi \lambda \varepsilon \tilde{\imath} v \omega \ddot{\varrho}$

]ท́ $\sigma \alpha \varsigma \varepsilon[\quad] \tau \omega \kappa v \sigma \omega$

Calímaco, fr. 191.78-98Pf

Pero si alguien lo ve, dirá: "Ahí está Alcmeón",

y exclamará: “ihuye -que golpea- huye de ese hombre!”.

Cada uno ... pregona...

como...

y detrás el Coriceo abriendo la boca

con la lengua (...) como un perro cuando bebe,

y dice...

...

... ejercita el cuello...

$\ldots$

los que no saben ni la "a"

comerciar con el puño

...

...manto

... solo tomó a las Musas

... que comen higos verdes

...y de risa

(si no) me hacen caso. Ya

95

(la barca?) de Caronte

... y es hora ya de navegar

... al culo (?) ${ }^{101}$

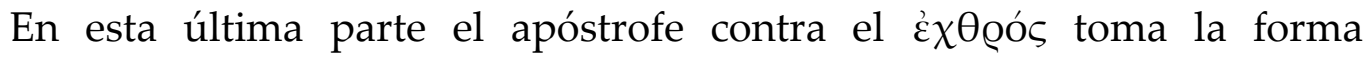
enunciativa de la invectiva personal arcaica. La referencia a Alcmeón (vv. 78-9), personaje que míticamente encarna la figura del enajenado violento en la tradición griega, ${ }^{102}$ podría constituir una crítica yámbica de manera tipificada

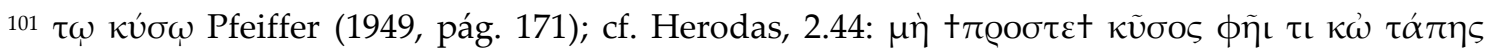

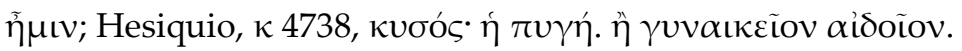

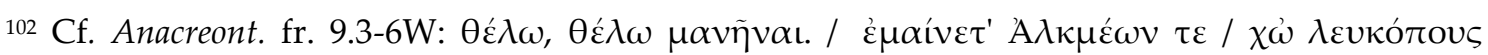

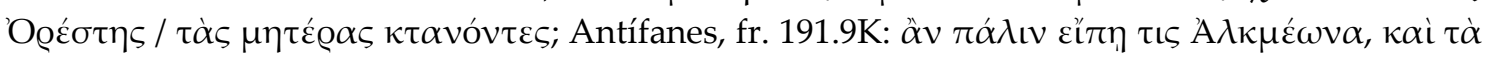


contra algún erudito, aunque lo más probable es que "Hiponacte" se compadezca burlonamente del propio “Calímaco”, ya que en el Yambo 13 (vv. 19-22) uno de los eruditos amonesta al cirenaico por su locura. ${ }^{103}$ La alusión al habitante de Córico (vv. 82-4), ciudad de Jonia que se hizo famosa porque sus hombres espiaban a los comerciantes en los puertos para saber qué mercaderías transportaban y cuáles eran los destinos, y luego transmitían la información a los piratas, ${ }^{104}$ podría constituir, junto con la analogía del perro, una denuncia contra el espionaje o las intrigas chismosas dentro del ámbito intelectual. ${ }^{105}$ Los tres versos siguientes están muy deteriorados, tal vez quien "ejercita el cuello" (v. 86) sea el mismo coriceo en sus actos de escucha y divulgación. Posiblemente en los vv. 88-9 la acusación de ignorancia esté dirigida contra algunos eruditos. ${ }^{106}$ Antes de anunciar su retorno al Hades (vv. 95-8), "Hiponacte" se refiere a alguien que se encuentra solo en la composición de la poesía, entre tantos ignorantes y comerciantes que tratan de vender sus engaños a puñetazos, y que esta elección le ha procurado únicamente pobreza. La mención de las Musas que comen higos verdes podría encuadrarse dentro de la imaginería de la miseria, y podría aludir a la propia condición de los poetas yámbicos. ${ }^{107}$

El ataque yámbico en la parte final confirmaría la intencionalidad crítica e invectiva del relato mítico de la copa de Baticles y del poema en general en

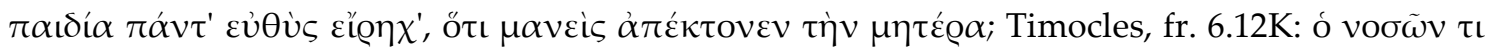

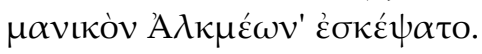

${ }^{103}$ Vid. inf. pág. 352.

${ }^{104}$ Cf. Estrabón 14.1.32.

${ }^{105}$ Kerkhecker (1999, pág. 46) señala que la referencia al habitante de Córico podría remitir a una metodología de plagio entre los eruditos alejandrinos.

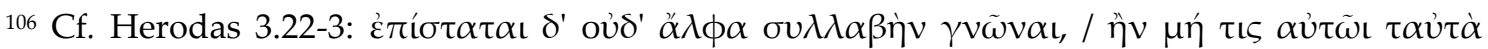
$\pi \varepsilon v \tau \alpha ́ \kappa \iota \varsigma \beta \omega ́ \sigma \eta \iota$.

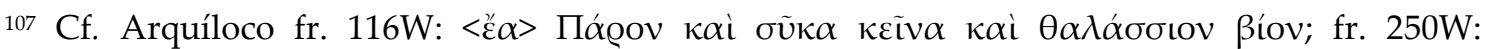

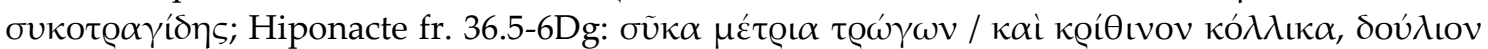

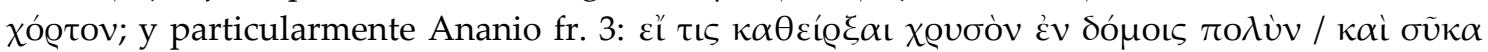

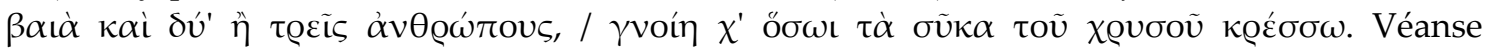
Clayman (1980, pág. 16); D’Alessio (1996, pág. 589 n. 39); Kerkhecker (1999, pág. 47). 
desmedro del reduccionismo que supondría una mera adaptación formal a un contenido didáctico. Al emplear la máscara de "Hiponacte", Calímaco es consciente de la premisa aristotélica que señala la necesidad de poner en boca de un tercero las invectivas y las críticas que se dirigen contra un adversario.

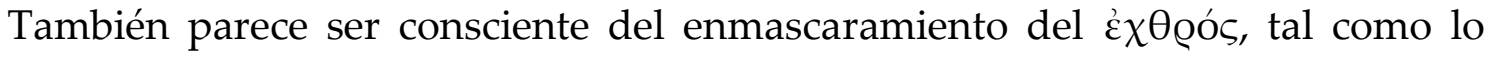
hacían los yambógrafos arcaicos al utilizar nombres parlantes y caracteres tipificados que provocaban mayor comicidad y, a causa de ello, consolidaban la contundencia de la invectiva. La parábola de Baticles también debe ser considerada dentro de esta función, probablemente la adaptación para el sofisticado y culto auditorio helenístico de otro género de relatos utilizado en el período arcaico para enmascarar la crítica de las conductas individuales; nos referimos a la fábula. ${ }^{108}$ Es posible que Calímaco, al componer sus yambos, tuviera presente que estos enmascaramientos, al igual que el metro y lo risible, eran condicionamientos formales regidos y legitimados por el género en su

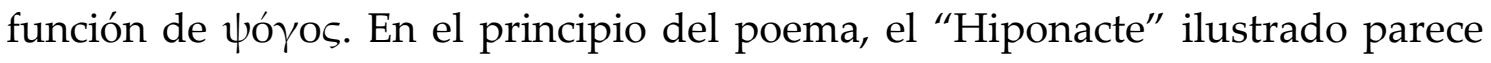

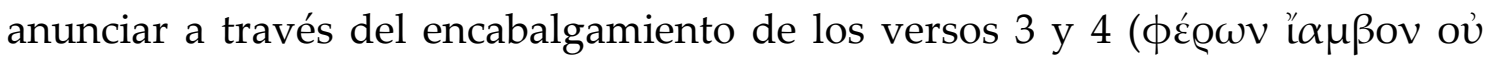

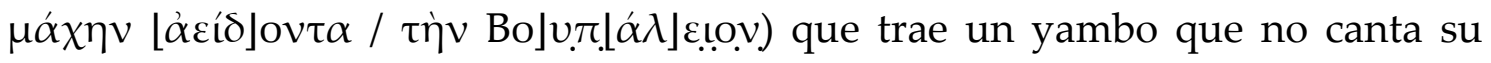
pelea con Búpalo... sino con los eruditos alejandrinos. Por lo tanto, ante tan sofisticado auditorio, propone un culto relato sobre sabios; sin embargo, esa parábola podría ser considerada como una nueva manzana de la discordia arrojada esta vez sobre el simposio de los eruditos, con la leyenda "para el más sabio".

En el Yambo 1 de Calímaco, detrás de la máscara de "Hiponacte", que abre el poema con sus exhortaciones y lo cierra con sus apóstrofes, aparece otra máscara: la persona yámbica "Calímaco", que atraviesa toda la composición, pero cuyos gestos son más visibles en la interpolación de la parábola.

${ }^{108}$ Cf. fr. 192Pf (Yambo 2). Véase el empleo yámbico de la fábula en Arquíloco (vid. sup. págs. 100 y 102). 


\section{YАМВO 13 (FR. 203PF)}

\subsection{VIAJAR A ÉFESO}

Como hemos señalado al comienzo de este capítulo, el Yambo 13 retoma los hilos compositivos, genéricos y temáticos abiertos en el 1 y desarrollados a lo largo de la colección, para darles una clausura. Si en el primer poema de la colección la persona poética de "Hiponacte" se erigía como voz de autoridad desde donde se inicia y se legitima la resurrección de la poesía yámbica en el período helenístico, en el Yambo 13 esa autoridad parece trasladarse transitivamente hacia la persona de "Calímaco". Por lo tanto, se podría postular que a lo largo de la colección de Yambos se cimenta la sucesión del legado poético de Hiponacte, y de la yambografía arcaica en general, erigiéndose a la persona yámbica "Calímaco" como el heredero. ${ }^{109}$

A partir del comentario que transmite la Diégesis es posible reponer parte de la información perdida: saber, por ejemplo, que el Yambo 13 era una defensa por parte de Calímaco de su propia concepción poética. Posiblemente se trataba de una pieza significativa para comprender el ambiente intelectual del período helenístico y las controversias literarias en las que Calímaco estaba involucrado. A raíz de que esta composición constituye un cierre programático de la colección y de que se evidencia aquí un decidido alegato a favor de sus concepciones estéticas, es probable que en el poema se desarrollararan algunas ideas y valoraciones compositivas, formales y temáticas. Por lo que se puede deducir de la defensa en relación a la $\pi 0 \lambda v \varepsilon เ \delta \varepsilon i ́ \alpha$ de sus composiciones, es

109 Cf. Herodas 8, donde la voz poética se autoproclama heredera de la yambografía de Hiponacte. Muchos han considerado que en el Yambo 13, la figura del crítico refiere al propio Herodas; cf. Knox (1925-1926, págs. 241-55) Herter (1973, pág. 221); Dawson (1946, págs. 130, 136); Puelma Piwonka (1949, págs. 344-57); Clayman (1980, pág. 70); Fuhrer (1992, págs. 214, 807); Kerkhecker (1999, pág. 268). 
también posible que en este yambo se hubiera presentado una fundamentación de la técnica poética empleada por el cirenaico.

El poema se inicia con una libación en primera persona a las Musas y a Apolo, que remite directamente al ámbito del simposio:

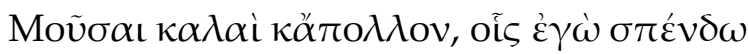

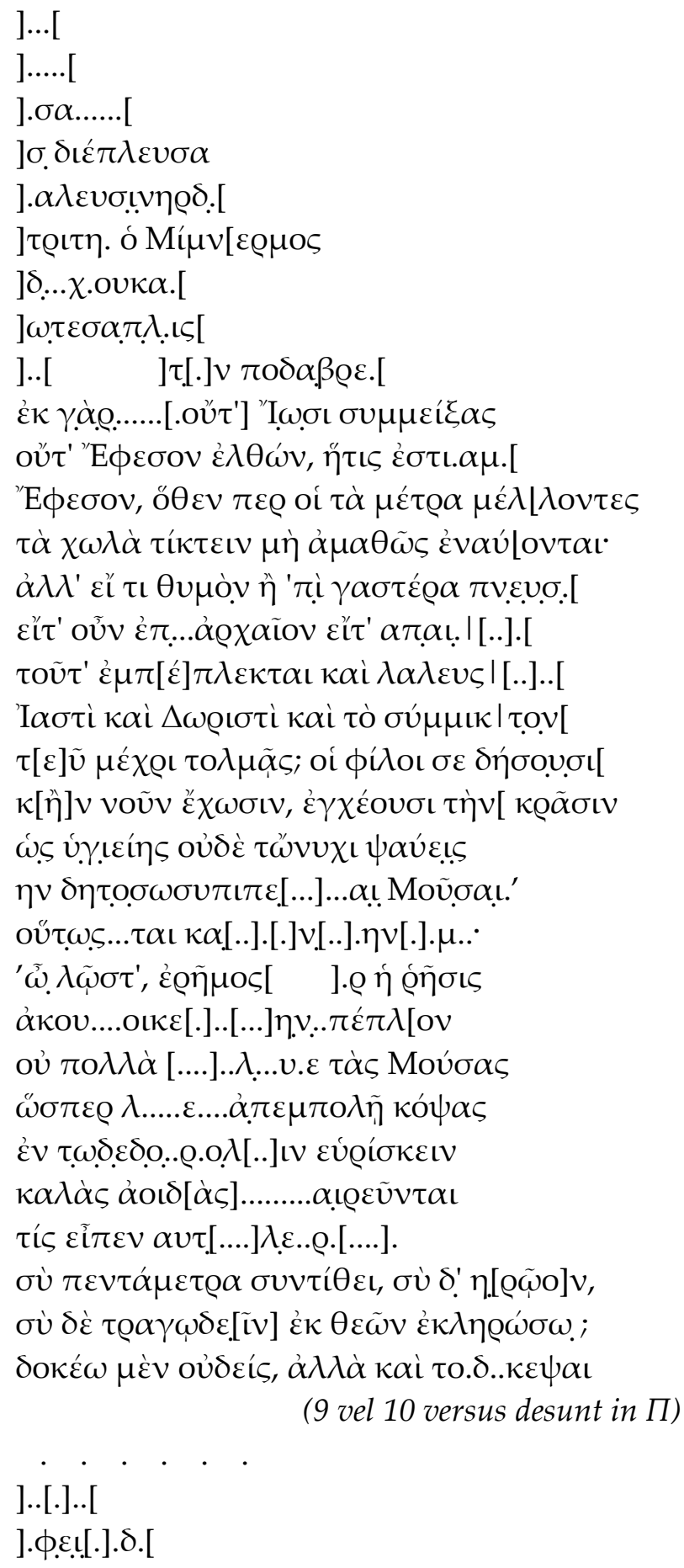




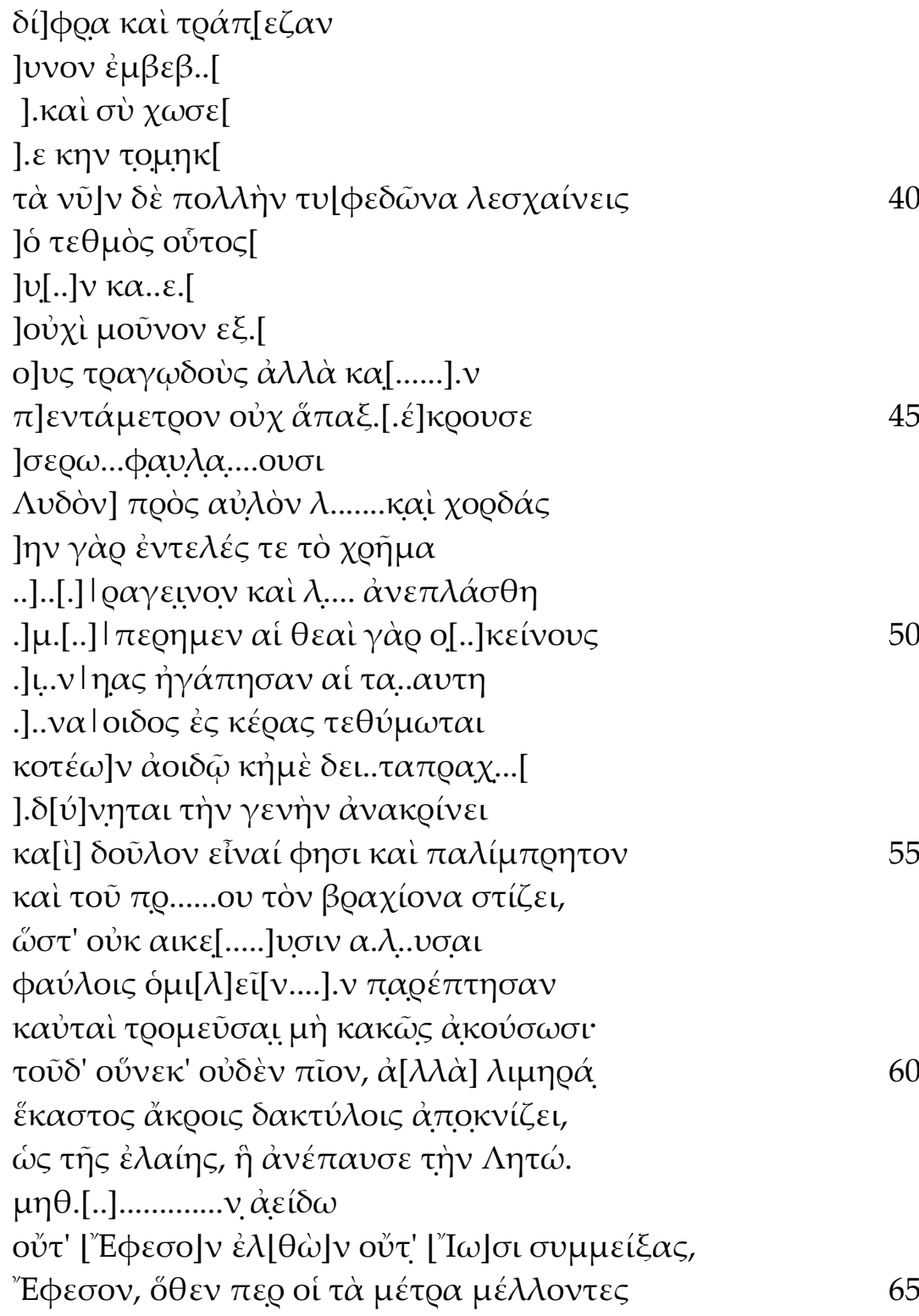

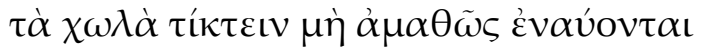

Calímaco, fr. 203Pf 110

Bellas Musas y Apolo, a quienes ofrezco libaciones

$$
\begin{aligned}
& \text { ]...[ } \\
& ] \ldots . . .[ \\
& ] \ldots \ldots . .[ \\
& \text {... he atravesado el mar... } \\
& \text {... } \\
& \text {... tercera(?) Mimn[ermo]... }
\end{aligned}
$$$$
5
$$

${ }^{110}$ La mayor parte del fr. 203Pf ha sido transmitido por el P.Oxy. 1011: fol 6r contiene las líneas 2-33, fol. 6v contiene las líneas 34-66. La Diégesis 9 (P. Mil. 1.18) provee la línea 1. 
porque desde... sin haberte mezclado con los jonios ni haber ido a Éfeso, que es...

a Éfeso, de donde encienden su fuego los que no estúpidamente pretenden concebir versos cojos; Pero si algo al corazón o al vientre inspira (?) si entonces... antiguo o si ... esto está enredado y parlotean (?) $)^{112}$ en jónico y en dórico y en una mezcla. ¿Hasta dónde te atreves a llegar? Tus amigos te atarán $\mathrm{y}$, si tienen cabeza, verterán la (mezcla?) $)^{113}$

ya que no tocas ni con una uña la salud ... las Musas."

Así....

"Querido amigo, sin defensa... el discurso escucha... manto

no muchas... a las Musas

como... en venta a los golpes

en esto... hallar

hermosos cantos...

¿Quién dijo...

"tú debes componer pentámetros, y tú versos heroicos, y tú hacer tragedias de los dioses has obtenido"?

Nadie, creo yo, pero considera también esto ${ }^{114}$

$\cdots$

$\ldots$

... la silla y la mesa...

$\cdots$

$\cdots$

Pero ahora parloteas con mucho humo ... esta regla...

$\ldots$

(que) no solo hexámetros (compuso) $)^{115}$

trágicos sino también...

el pentámetro no una sola vez pulsó (?)

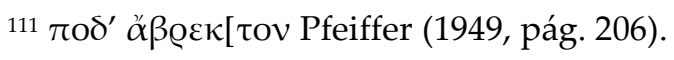

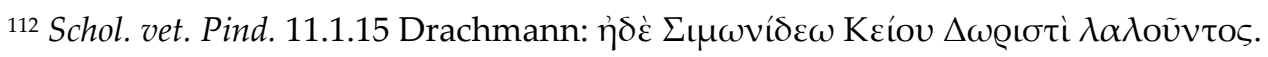

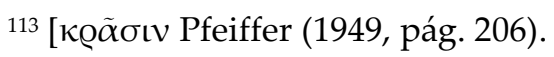

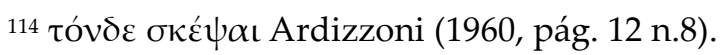

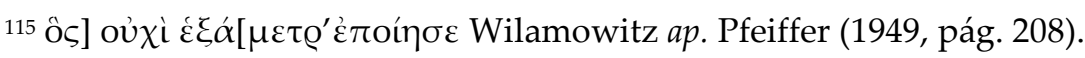


al son de la flauta (lidia) ... y de las cuerdas

... era en verdad completa la obra...

... y... fue plasmada...

... de hecho las diosas... a aquellos

... amaron...

... el poeta esparce furia con sus cuernos,

... enfurecido con el poeta, y también a mí

... pueda, indaga su estirpe

y dice que es un esclavo y vendido varias veces

y del... pone la marca en el brazo

para que no...

se junte con los miserables... pasaron volando

también ellas temiendo escuchar agravios.

Por esto nada suculento, sino pedazos de hambre

cada uno rasguña con la punta de los dedos,

como si fuera el olivo que dio descanso a Leto.

... yo canto

sin haber ido a Éfeso y sin haberme mezclado con los jonios,

a Éfeso, de donde encienden su fuego los que

no estúpidamente pretenden concebir versos cojos.

El texto de la Diégesis resume brevemente el punto central de las críticas contra Calímaco y repone parte de la información que falta:

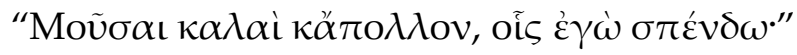

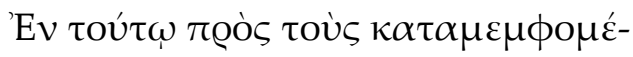

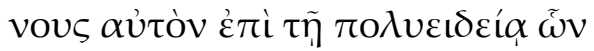

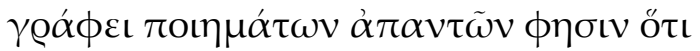

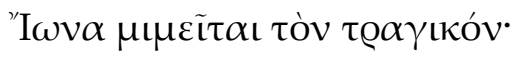

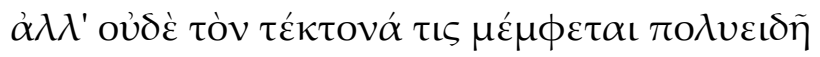

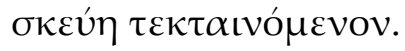

Diégesis 9.32-38 (Scholia ad Fr. 203Pf)

“Bellas Musas y Apolo, a quienes ofrezco libaciones"

En este (poema), confrontando con aquellos que lo critican

por la variedad formal de los

poemas que escribe, dice que

él imita al trágico Ión.

(Y que) tampoco se critica al artesano la variedad

de artesanías que fabrica. 
El Yambo 13 constituye por lo tanto una especie de alegato poético ante al planteo acusatorio de los eruditos contra las ideas estéticas de Calímaco, ${ }^{116}$ particularmente contra su particular concepción del género yámbico. ${ }^{117} \mathrm{De}$ acuerdo con la Diégesis, esta acusación recae sobre la $\pi 0 \lambda v \varepsilon\llcorner\delta \varepsilon i ́ \alpha$ de su poesía, $^{118}$ un término que no aparece a lo largo del yambo y que podría considerarse una conceptualización del comentarista para especificar el motivo de las críticas. La respuesta de Calímaco habría sido que él sigue el ejemplo de Ión de Quíos, ${ }^{119}$ y que nadie reprocha tampoco a un artesano por la variedad de artesanías que construye.

La libación a las Musas y a Apolo evoca el uso arcaico según el cual este rito podía ser comprendido como metáfora de la obra poética. ${ }^{120} \mathrm{El}$ simposio

116 En el prólogo de los Aitia Calímaco también expone una defensa de sus consideraciones estéticas frente a las críticas de sus detractores.

${ }^{117}$ La crítica de los eruditos podría estar dirigida contra toda la obra poética de Calímaco, es decir contra la variedad de géneros que aparecen en toda su obra, sin dedicarse solo a uno; o específicamente contra la mezcla de formas poéticas que aparecen en los Yambos. Esto podría depender también de si en la línea 35 de la Diégesis se lee $\alpha \dot{\pi} \alpha \dot{v} \tau \omega \nu$ (Norsa \& Vitelli) o $\alpha \grave{\pi} \alpha \nu \tau \tilde{\omega} \nu$ (Maas); cf. Pfeiffer (1949, pág. 205).

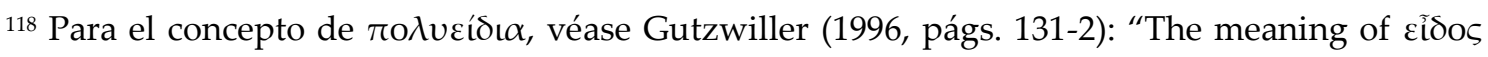
that underlies this usage of $\pi 0 \lambda v \varepsilon$ ' $\delta \varepsilon\llcorner\alpha$, then, is not 'poem' or 'song' but simply 'type', 'kind' with the posible reference to any number of literary subdivisions."

119 Ión de Quíos (c. 480-423 a. C.) era conocido en la antigüedad por la amplia variedad de géneros que abarcaban sus obras, tanto en verso como en prosa. El Schol. Arist. Pax 835 (=FGrH 392 T2) sostiene que Ión se hizo famoso por escribir tragedias, ditirambos, comedias, epigramas, peanes, himnos, canciones de simposios, encomios, elegías; y por haber escrito obras en prosa

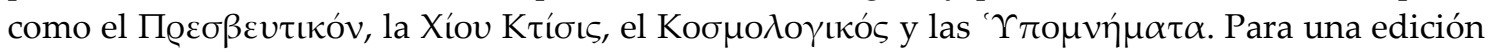
de los testimonios y fragmentos de Ión de Quíos, véase Leurini (1992). La elección de un antecedente multifacético como Ión (poeta, historiador, filósofo) podría ser útil a Calímaco también para cuestionar las categorizaciones genéricas vigentes en el período helenístico. Es sumamente interesante además el hecho de que el nombre "Ión" podría vincularse con el diálogo homónimo de Platón, en donde Sócrates debate con el rapsoda Ión (tal vez de Éfeso) la idea de que un poeta puede ser inspirado por la divinidad solamente en un solo tipo de poesía; cf. Platón, Ion 534c. Para este tema, véase Acosta-Hughes \& Stephens (2012, págs. 47-57).

120 Cf. Pfeiffer (1949, pág. 207): “Mousai kalai ubi libatio non in sacrificio, sed in convivio fingitur". Véanse también Kerkhecker (1999, pág. 252): “Again, the incipit establishes the

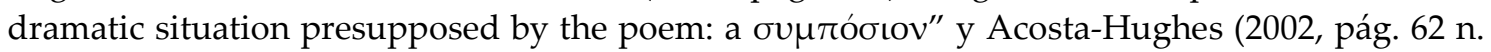
ad v. 1): "If the poet means to evoke a specific setting of libation, a symposium may, as Pfeiffer suggests, be the more likely. Several of Callimachus' epigrams evoke a symposiastic setting." Lelli (2004, pág. 123): “Metaforicamente aperto con una libagione alle Muse e a Apollo, simbolo 
aparece, de este modo, como escenografía que reactualiza una ocasión específica, un encuentro de los eruditos del Museo. ${ }^{121} \mathrm{Al}$ igual que en el Yambo 1, estos eruditos tienen una actitud hostil, pero en este caso "Calímaco" habla en propria persona.

Lamentablemente el carácter fragmentario del texto no permite dividir de manera precisa las rhesis de cada uno de los actores, aun así es posible distinguir principalmente tres secciones: la libación a las Musas y a Apolo (v. 1), el planteo acusatorio (al menos del v. 5 al 22) y el alegato defensivo de "Calímaco" (vv. 24-66).

\subsection{EL PLANTEO ACUSATORIO}

Luego del verso inicial sigue un pasaje prácticamente ilegible. De los vv. 2-10 solo pueden discernirse los términos $\delta\llcorner\varepsilon ́ \pi \lambda \varepsilon v \sigma \alpha(\mathrm{v} .5) \mathrm{y}$, siguiendo los

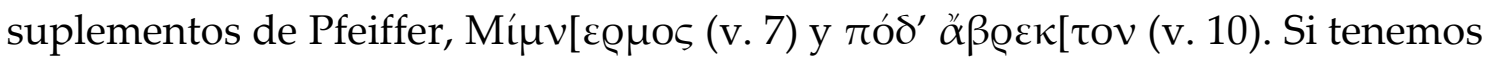
en cuenta que en los vv. 11-14 se le recrimina a "Calímaco" no haber viajado nunca a Éfeso, el verbo $\delta \varepsilon \varepsilon ́ \pi \lambda \varepsilon v \sigma \alpha$ ("he navegado a través...") podría aparecer en boca de un adversario desautorizando el atrevimiento de "Calímaco" al inmiscuirse en el género yámbico y en el elegíaco, ${ }^{122}$ ya que él jamás navegó

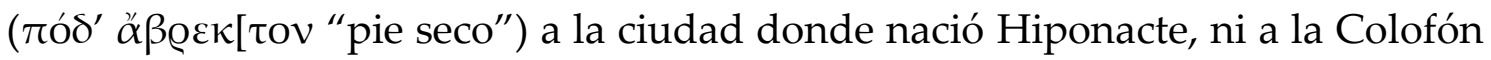
de Mimnermo. ${ }^{123}$ Esta lectura se apoya también en un pasaje de los Aitia que ha

già arcaico di composizione letteraria." Sobre el sentido metafórico de la libación en este verso, véanse también D'Alessio (1996, pág. 645 n. 157); Depew (1992, págs. 316-17).

${ }^{121}$ Vid. sup. pág. 327; cf. Kerkhecker (1999, pág. 252): “This could be a private party, or a meeting

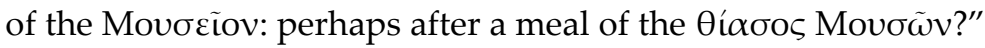

122 En Aitia 1.11Pf, también dentro de un contexto de polémica literaria por la brevedad de los poemas de Calímaco, se destacan como superiores las composiciones de pocos versos de Mimnermo y de Filitas frente a aquellas extensas y de muchos versos; cf. D’Alessio (1996, págs. 370-71).

${ }^{123}$ Kerkhecker (1999, pág. 255) señala que probablemente lo que el crítico le estaría diciendo sería algo así como: "you pretend to follow Mimnermus and Hipponax; but you have not even been to Ionia where their poetry still flourishes (...) but you keep your feet dry (i.e. you stay at home...)". Véase también Puelma Piwonka (1949, pág. 338). De manera diferente, Lelli (2004, 
sido interpretado como una declaración del propio Calímaco de no haber realizado jamás un viaje por mar. ${ }^{124}$

La acusación en los vv. 11-14 de no haberse mezclado con los jonios, en principio, parecería referirse también al tópico del viaje a Éfeso, lugar donde

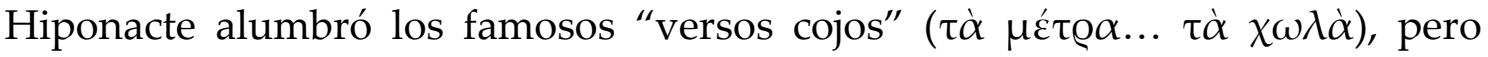
también se podría vincular al uso de los dialectos en los Yambos. Esta cuestión ha sido ampliamente debatida por los estudiosos. ${ }^{125}$ Algunos han sostenido que el viaje nunca realizado por Calímaco representa, en sentido figurado, la marcada distancia de Calímaco con respecto al modelo yámbico de Hiponacte. La crítica consistiría en el hecho de haber adoptado "la poesia coliambica arcaica pur essendo del tutto estraneo al contesto originario."126 Otros consideran que remite a la falta de contacto directo con Jonia, una denuncia contra el carácter puramente libresco de Calímaco; en cierta forma se le estaría reprobando no haber realizado el viaje de peregrinación que asociaba la inspiración con la visita a los lugares que pudieran rememorar un determinado tipo de poesía. ${ }^{127}$ Lelli (2004, págs. 129-34) propone vincular el motivo del viaje con los dialectos ("jónico", "dórico", "parloteo", "mezcla", vv. 18-9) y, a partir de una referencia común relacionada con Homero que aparece en un pasaje de

págs. 128-29) considera que en este pasaje, al mencionarse a Mimnermo, no se podría estar aludiendo a Éfeso sino simplemente a Colofón: "il $\delta\llcorner\varepsilon ́ \pi \lambda \varepsilon v \sigma \alpha$ di v. 5, a chiunque lo si voglia attribuire, non può riguardare già il viaggio a Efeso di cui si parla sicuramente da v. 11, ma un altro viaggio; la menzione di Mimnermo a v. 7, infatti, non può in alcun modo riguardare la poesia giambica (né, pertanto, il viagio ad Efeso)."

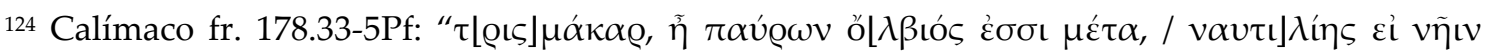

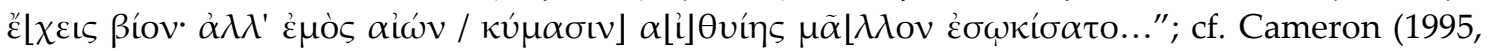
págs. 210-13); D’Alessio (1996, pág. 645 n. 159).

125 Para un relevamiento de las distintas perspectivas véase Lelli (2004, págs. 127-29); también, Antúnez (2006, págs. 67-78).

${ }^{126}$ Fantuzzi (1993, pág. 47); cf. Clayman (1976, pág. 31); Lehnus (1993, pág. 95).

127 Cf. Treu (1963, págs. 277-80); Bing (1988, págs. 11-48), con amplia documentación sobre este tópico. 
Ps.-Plutarco, ${ }^{128}$ concluye que, en la visión de los detractores, Homero habría podido emplear muchos dialectos porque había viajado y conocía todas las formas dialectales de Grecia, pero el carácter libresco del cirenaico, particularmente en lo linguístico-formal, carecería de consideración por la propia "imposibilità di aver appreso un dialetto senza aver soggiornato in loco." 129 Por lo tanto, es probable que uno de los puntos cruciales de la crítica se centrara en la $\lambda \dot{\varepsilon} \xi ı$ de los Yambos. Es dable suponer que en los vv. 18-9 no se le esté objetando solamente la variedad de dialectos sino el empleo desordenado y la mezcla entre ellos. ${ }^{130}$ En efecto, los Yambos 1-5, 8, 10, 12 y 13 están en dialecto jónico, los Yambos 6, 9 y 11 en dórico, y el 7 en dórico y eólico, como ya señalamos.

El discurso del crítico finaliza con un apóstrofe contra "Calímaco" (vv. 19-22), en que agresivamente se le recrimina sus pretensiones y se condena su locura. La alusión a la locura nos remite a la figura de Alcmeón en los versos finales del Yambo 1. Tal vez el detractor de "Calímaco" fuera uno de aquellos eruditos contra los que "Hiponacte" dirige sus invectivas yámbicas antes de retornar al Hades. Los paralelismos con el Yambo 1, a través de elementos comunes como la figura de Hiponacte, el simposio, las disputas entre los eruditos y la propia locura de los yambógrafos, ponen en evidencia el carácter programático de la colección calimaquea.

\subsection{EL ALEGATO DEFENSIVO}

Tras el ataque del crítico, "Calímaco" comienza su alegato defensivo. El

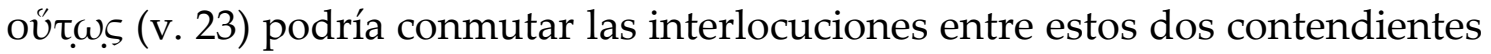

\footnotetext{
128 Ps. Plutarco, Vit. Hom. 2.8: “Empleando una lengua variada mezcló los rasgos de todos los dialectos de los griegos, de lo cual resulta evidente que viajó por toda Grecia y cada uno de sus pueblos."

${ }^{129}$ Lelli (2004, pág. 132).

${ }^{130}$ Cf. Clayman (1976, pág. 32).
} 
dentro de un encuadre narrativo. ${ }^{131}$ Las primeras palabras de "Calímaco" advierten a su contrincante que la acusación no quedará sin defensa, en un inicio que podría tener un tono judicial. ${ }^{132}$ Los vv. 25-9 son casi ilegibles, pero pueden tomarse algunas equivalencias verbales en relación al final del Yambo 1,

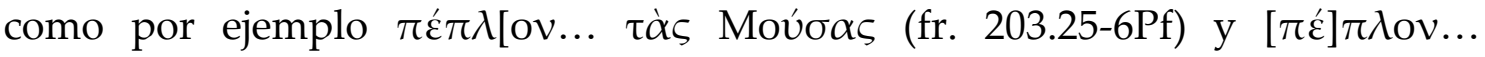

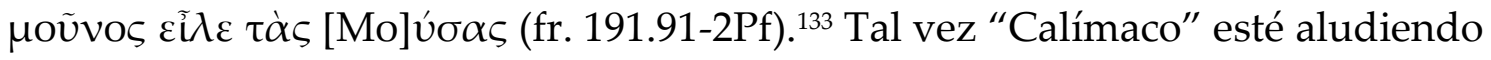
aquí, o aun citando, las propias palabras de "Hiponacte", y caracterizando de forma paralela a los eruditos del poema que abre la colección y al crítico que polemiza con el poeta de Cirene. En la misma dirección, las palabras $\alpha \pi \varepsilon \mu \pi \sigma \lambda \tilde{\eta}$

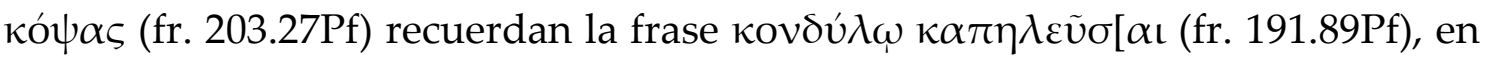
alusión a alguien que "vende sus productos a los golpes".

En los versos restantes se concentra la parte más destacada que se ha conservado de la defensa de "Calímaco" en lo referente a lo que, en palabras del comentarista de la Diégesis, es la $\pi 0 \lambda v \varepsilon i ́ \delta \varepsilon \iota \alpha$. En primer lugar, los vv. 30-33 cuestionan particularmente la premisa "un poeta, un género". ${ }^{134}$ En este pasaje, "Calímaco" parece situarse en franca oposición a la concepción poética

131 Pfeiffer (1949, pág. 207) consigna únicamente la lectura al verso 23 sin ninguna nota en

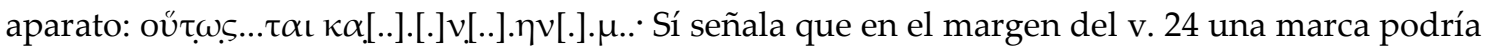
indicar el cambio de interlocutor al igual que en el Yambo 4.46Pf: "24 in marg. sin. signum /, initium responsi indicans, ut supra fr. 194,46". Cf. Führer (1967, pág. 37). Clayman (1980, pág. 46) sostiene: "The speech of the adversaries appears to end at line 22 and Callimachus' reply begins two lines later (203.24)". En el mismo sentido, Kerkhecker (1999, pág. 259) afirma: "The end of the critic's speech is marked by and Abschlussformel in 23. If this is correct interpretation of the line, it provevides an important clue to the form of the poem: it proves the presence of a framing narrative."

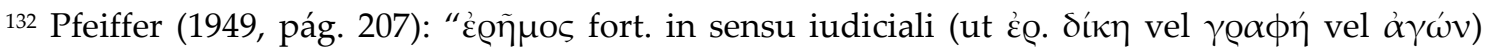
cum negatione: causa non indefensa est i.e. non sine defensione velut absens me damnari patiar."

${ }^{133}$ Para otros paralelos verbales entre los Yambos 1 y 13, véase Acosta-Hughes (2002, pág. 90): "Iambus 13 closes with the poet's abnegation of a journey to sixth-century Ephesus. It seems clear that Iambi 1 and 13 were conceived in these aspects as a pair. Not only are there the obvius thematic and programmatic parallels, but a striking number of verbal parallels in Iambus 13 recall Iambus 1."

${ }^{134}$ Cf. Kerkhecker (1999, pág. 261). 
expuesta por Platón en el Ión (531e-534e). ${ }^{135}$ De acuerdo con el filósofo, si la

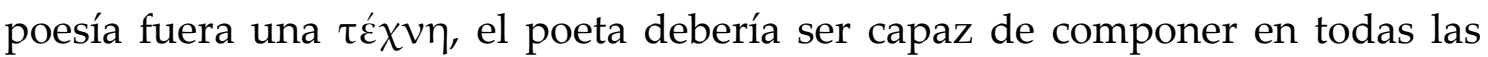
formas literarias existentes: por ejemplo, comedias y tragedias. ${ }^{136}$ Sin embargo, cada poeta es especialista únicamente en una determinada forma literaria; ninguno es capaz de dominar todas las formas, lo cual demuestra que la poesía no es una $\tau \dot{\chi} \chi \vee \eta$ sino un don divino. ${ }^{137}$ Precisamente lo que "Calímaco" pone en discusión aquí es la consideración de la poesía como producto de la inspiración divina y no como técnica. ${ }^{138}$

Las referencias al artesano y a Ión de Quíos que transmite la Diégesis, en un juego de homonimia con el protagonista del diálogo de Platón, podrían haber sido empleadas en los versos siguientes como exempla de la $\pi$ o $\lambda v \varepsilon i ́ \delta \varepsilon\llcorner\alpha$ calimaquea. De manera conjetural, los vv. 35-40 podrían aludir a la $\tau \varepsilon ́ \chi v \eta$ del

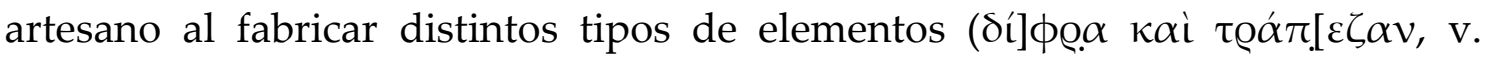
36):139 luego de una enumeración de estas distintas producciones, el ejemplo concluiría con el categórico "y ahora parloteas sin sentido."

El segundo ejemplo se recrea en los vv. 41-49. El pasaje enumera los diversos géneros cultivados por Ión: el épico ( $\dot{\xi} \dot{\alpha}[\mu \varepsilon \tau \varrho \alpha, \mathrm{v} .43)$, el trágico

135 Vid. sup. pág. 349 n. 119.

${ }^{136}$ Cf. Platón, Symp. 223d.

137 Platón, Ión 534b-c: "Pero no es en virtud de una técnica como hacen todas estas cosas y hablan tanto y tan bellamente sobre sus temas, cual te ocurre a ti con Homero, sino por una predisposición divina, según la cual cada uno es capaz de hacer bien aquello hacia lo que la Musa le dirige; uno compone ditirambo, otro loas, otro danzas, otro epopeyas, otro yambos. En las demás cosas cada uno de ellos es incompetente. En las demás cosas cada uno de ellos es incompetente. Porque no es gracias a una técnica por lo que son capaces de hablar así, sino por un poder divino, puesto que si supiesen, en virtud de una técnica, hablar bien de algo, sabrían hablar bien de todas las cosas." Trad. Emilio Lledó (1981, pág. 257).

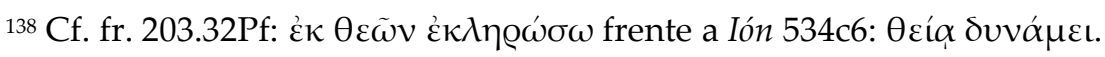

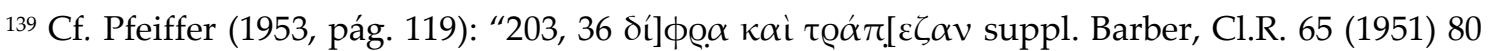

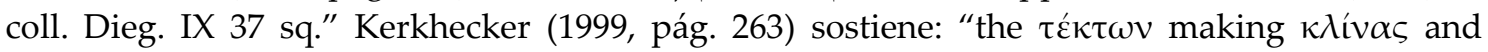
$\tau \varrho \alpha \pi \varepsilon \dot{\zeta} \zeta \alpha \varsigma$ is the first example which Socrates uses to launch his final indictment of poetry on the opening pages of Republic X. The choice of the $\tau \dot{\varepsilon} \kappa \tau \omega v$ helps Callimachus to make his point against Plato." 


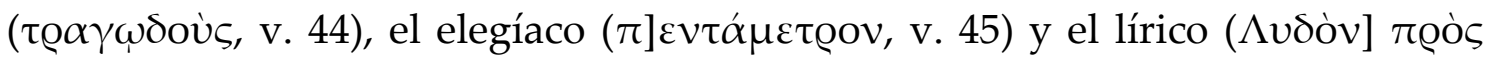

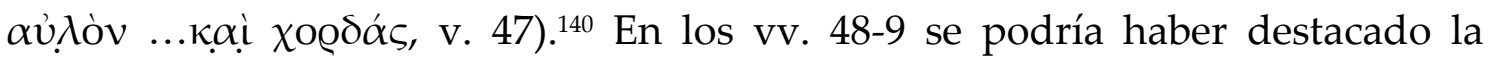
excelencia de la obra de Ión a pesar de la cantidad de géneros en los que había incursionado. La figura de Ión aparece por lo tanto como un referente

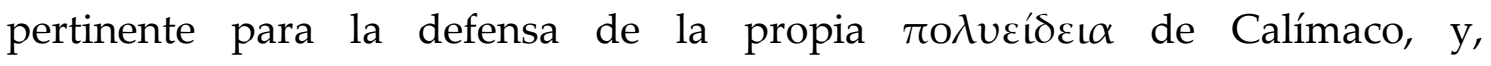
particularmente, para confrontar con la prescripción estética derivada de las ideas transmitidas en el diálogo platónico: "un poeta, un género". El sentido de

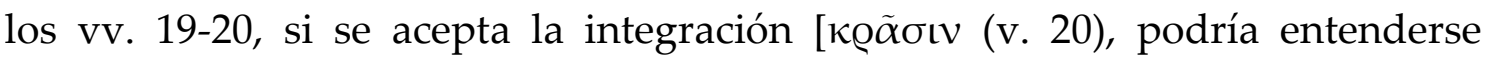
entonces como una exhortación por parte del crítico a que se dedique a cultivar solamente un género poético.

El último pasaje (vv. 50-66) presenta un descargo personal por parte de "Calímaco" acerca de las envidias y las enemistades poéticas. En los vv. 52-3 se denuncia expresamente el rencor que los poetas sienten por otros poetas, en una imagen tradicional que se remonta hasta Hesíodo, Trabajo y días 25-6: "el alfarero siente rencor por el alfarero y el carpintero por el carpintero, el mendigo envidia al mendigo y el aedo al aedo". ${ }^{141}$ Esta misma imagen podría haber sido abordada también por Arquíloco en el yambo sobre el carpintero Carón, que comentamos en su momento. ${ }^{142}$

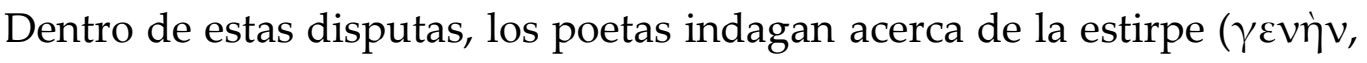
v. 54) de los demás y los catalogan en relación al género que profesa cada uno,

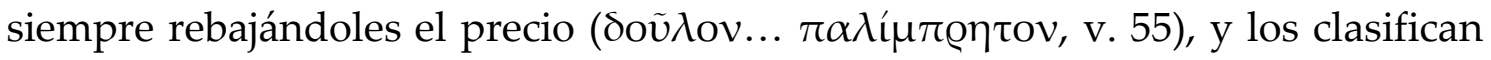

\footnotetext{
140 Schol. Arist. Pax 835 (=FGrH 392 T2) transmite los diferentes géneros que cultivó Ión de Quíos; vid. sup. pág. 349 n. 119.

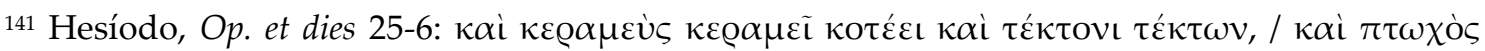

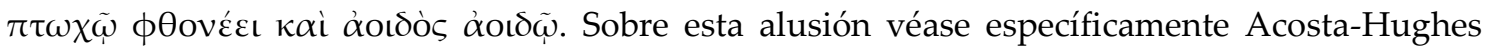
(2002, págs. 95-9)

142 Vid. sup. pág. 131. La imagen de la envidia entre los carpinteros y entre los poetas en Hesíodo, Calímaco y, probablemente, también en Arquíloco (fr. 19W) parece no ser un hecho meramente fortuito, en particular si se tiene en cuenta la comparación que postula Calímaco en

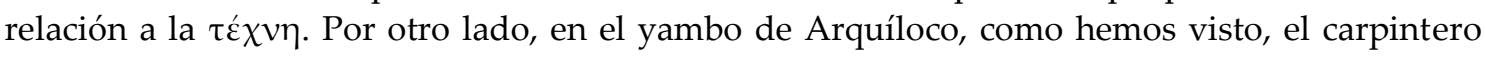
Carón aparece hablando en propria persona.
} 


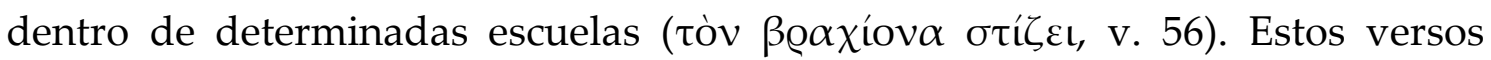
parecen una alusión al afán clasificador y calificador dentro del ambiente filológico alejandrino, no solo de la antigua poesía sino también de la producción poética vigente. Es evidente que "Calímaco" denuncia la malicia con que los poetas se refieren a sus colegas y a sus producciones. Al mismo tiempo estaría respondiendo a la pregunta formulada en los vv. 30-32; serían ellos mismos los que deciden en su catalogación qué género poético le corresponde a los demás, no la divinidad.

Los vv. 57-59 describen las consecuencias de estas disputas estéticas. Las Musas no pueden convivir con los miserables (v. 58) y se van por el temor de oír agravios contra ellas mismas (v. 59). Por estas razones, los poetas no pueden alcanzar nada fructífero ni importante, solo pequeñas raciones de inspiración que no logran satisfacer a nadie, como si se tratara del olivo que dio descanso a Leto (v. 61). Este pasaje contiene varias alusiones. La metáfora de la poesía como una porción de comida puede constituir una respuesta a la invectiva que le dirige su detractor al final de su rhesis (vv. 21-2): los poetas miserables inmersos en las disputas y envidias no pueden tomar de las Musas más que migajas de inspiración poética con las puntas de los dedos, del mismo modo que "Calímaco" no alcanza a tocar con la punta de su uña la salud. El olivo en que descansó Leto alude a los mordiscos que se le daba al árbol sagrado en el ritual ejecutado en Delos. ${ }^{143}$

Finalmente, los vv. 63-66 conforman una estructura agonal enfrentada a los vv. 11-14. "Calímaco" le responde a su detractor con las mismas palabras que él había utilizado en la parte central de su crítica. El recurso de repetir el

${ }^{143}$ Cf. Calímaco, Yambo 4.84Pf, donde aparece otro escenario de polémica encarnado en el agón entre el laurel y el olivo. Pero particularmente cf. Hymn. Delos 321 y Schol. in Hymn. Del. 321. El escoliasta señala que el ritual de Delos consistía en "correr alrededor del altar de Apolo, golpearlo con un látigo, y luego morder el olivo sagrado con las manos atadas por la espalda."

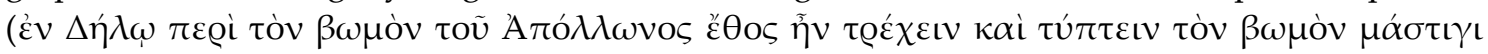

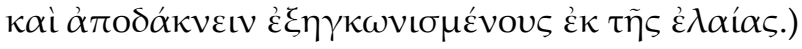


argumento de sus detractores de manera especular es empleado en otros textos que también abordan estas polémicas literarias. ${ }^{144}$ No se excusa por no haber realizado el viaje a Éfeso, real o metafórico; directamente parece desestimar la pretendida importancia que esa perenigración supone. Esta respuesta podría vincularse directamente con el primer verso del Yambo 1, "Calímaco" no tiene necesidad de viajar a Éfeso porque es el propio "Hiponacte" el que retorna desde el Hades. Este punto refuerza el carácter programático y anular del libro de Yambos.

\subsection{El DESENMASCARAMIENTO DEL 'YO’. LA MÁSCARA DE “CALÍMACO”}

Desde el punto de vista discursivo, como puede observarse, en el Yambo 13 ya no es "Hiponacte" quien asume la primera persona en el nivel enuncivo sino el propio "Calímaco". En el primer verso, la invocación a las Musas y a Apolo establece la escenografía del simposio como ocasión específica de la polémica entre "Calímaco" y su detractor. Es muy probable, entonces, que el auditorio se sumergiera directamente en el contexto simposíaco, representado de manera mimética a través del rito de las libaciones, y luego interpretara el encuadre narrativo de la polémica literaria. ${ }^{145}$ Por lo tanto, la deixis de primera

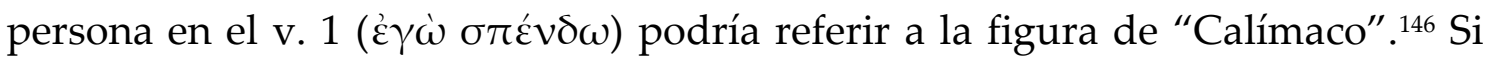

${ }^{144}$ Cf. Contra los Telquines (Aitia 1.1) y la parte final del Himno a Apolo.

145 Kerkhecker (1999, pág. 253) señala: "the incipit establishes, not only the dramatic setting, but also the narrative frame and argumentative perspective of the poem. This is more than the first utterance in a dramatic quarrel: through his narrative, the narrator exercises control. $\dot{\varepsilon} \gamma \omega \dot{\omega}$ in line 1 is emphatic, presumably contrastive, and probably indicative of a claim exlusive to the speaker."

${ }^{146}$ De este parecer son Puelma Piwonka (1949, pág. 228); Kerkhecker (1999, págs. 252-3); AcostaHughes (2002, págs. 70-3); Acosta-Hughes \& Stephens (2012, pág. 47). Por el contrario, Pfeiffer

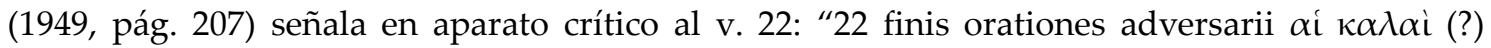
Moṽ $\sigma \alpha \mathrm{\iota}$, cuius initium fort. v. 1 est: Moṽ $\sigma \alpha \iota \kappa \alpha \lambda \alpha \iota^{\prime \prime}$, considerando que todo el pasaje corresponde a la rhesis del crítico. 
esta hipótesis es correcta, luego de la primera intervención de "Calímaco", que podría extenderse a lo largo de algunos versos, aparecería la rhesis del crítico. ${ }^{147}$ Particularmente en lo que refiere a la interlocución entre "Calímaco" y su detractor es necesario señalar una cuestión particular en cuanto a la estructura narrativa en la que está inserta. De acuerdo con Führer (1967, pág. 37), Clayman

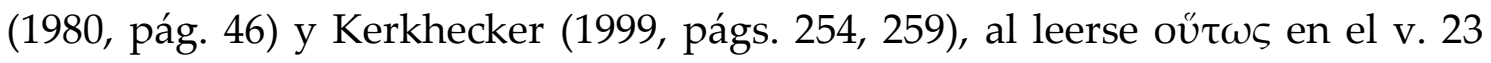
debe pensarse en una fórmula que finaliza el discurso del crítico (Abschlussformel) para dar paso a la réplica de "Calímaco". ${ }^{148}$ Por lo cual, dentro del texto que se ha conservado, el v. 23 sería el único indicio del encuadre narrativo.

Antes de continuar con el análisis discursivo, podríamos esquematizar la escenografía de polémica literaria a través de los siguientes procesos enuncivoenunciativos:

147 No es posible determinar en qué punto preciso se produce esta conmutación de interlocutores. Pfeiffer (1949, pág. 205) señala que entre el final del Yambo 12 y el v. 2 del Yambo 13 hay aproximadadmente 9 o 10 versos que se han perdido. Posiblemente en ese pasaje "Calímaco" finalizaría el acto de libación y aparecería también el cambio de interlocutores.

148 Vid. sup. pág. 353 n. 131. Al señalar la marca en el margen del v. 24, que podría indicar un cambio de interlocutor, Pfeiffer (1949, pág. 207) sostiene que esa misma marca aparece también en el margen del Yambo 4.46Pf, donde se produce el fin de la rhesis del laurel y comienza la del olivo. Podría sostenerse entonces, de manera conjetural, que en el Yambo 13 la manera formular de introducir las rheseis sería semejante a la del Yambo 4. 


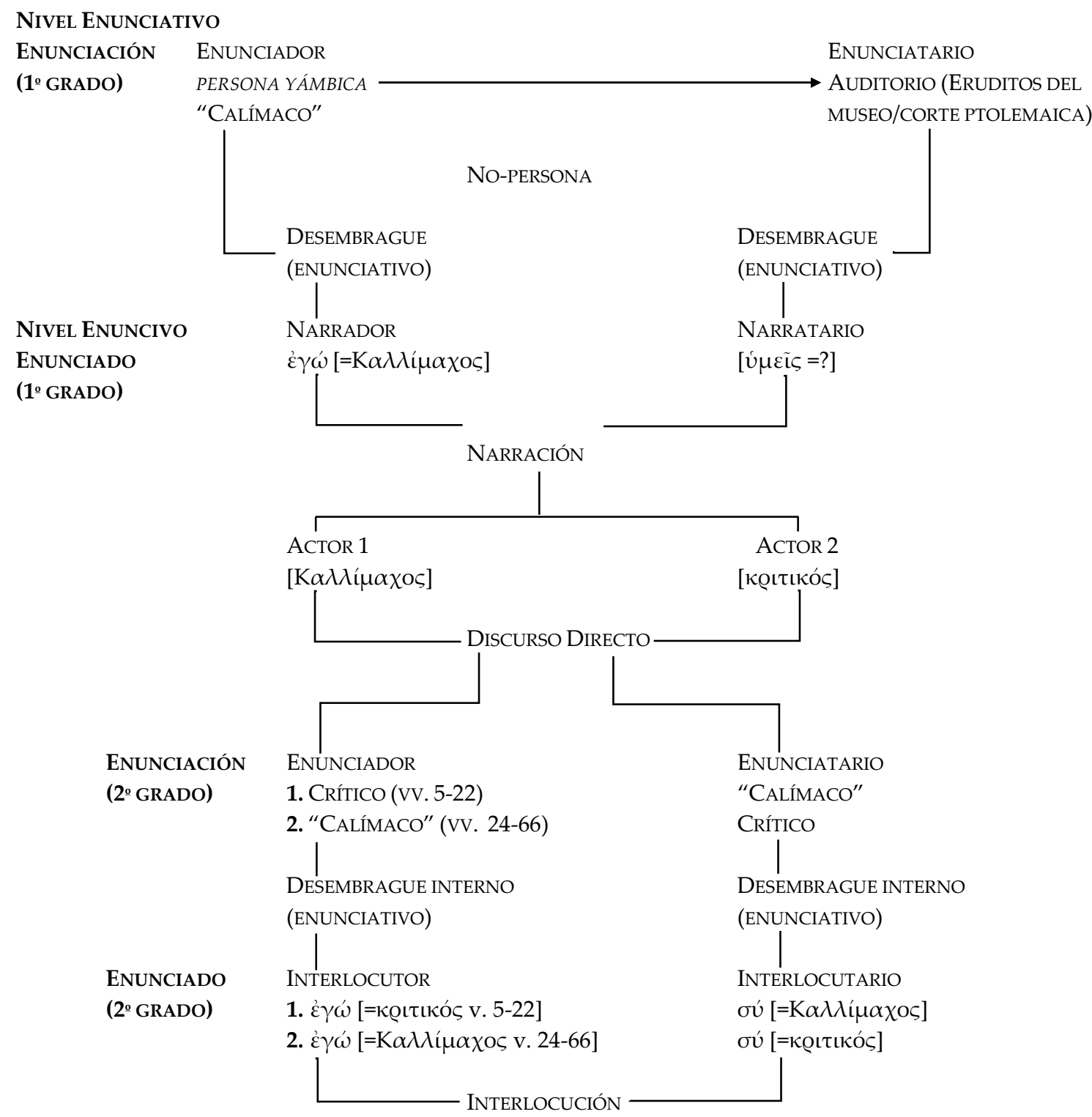

Si se acepta la hipótesis del encuadre narrativo de la interlocución, debería postularse aquí un primer desembrague de tipo enunciativo que instala las formas de la enunciación enunciada. Sin embargo, como hemos observado, lo fragmentario del texto no nos permite saber si el narrador y/o el narratario aparecían inscriptos deícticamente en el enunciado, ya que lo único que se ha conservado de la estructura narrativa es el v. 23: oút $\omega$ s... $\tau \alpha$ เ $\kappa \alpha[. .].[.[] v.[..] . \eta v[.] . \mu . . ;$ es decir, un adverbio intrepretado como parte de una 
Abschlussformel. ${ }^{149}$ Pero si las intervenciones del crítico y de "Calímaco" estaban delimitadas por fórmulas de inicio y final de los discursos referidos en forma directa, entonces el narrador necesariamente debería haber aparecido deícticamente en el enunciado. ${ }^{150}$ No así el narratario, ya que su inscripción deíctica dentro del nivel enuncivo depende de un señalamiento explícito por parte del narrador. Por esta razón, y a pesar que la mala conservación del texto no nos transmite ningún índice que refiera a estos actantes, es posible sostener que en el enunciado se manifestaban las marcas de un desembrague enunciativo y las figuras del narrador y narratario estaban inscriptas dentro del nivel enuncivo. ${ }^{151}$

La narración transmite la interacción verbal entre dos actores a partir de discursos referidos de manera directa. Para que estos dos dominios enunciativos coexistan, es necesario que se produzca un desembrague interno que permita desacoplar el sistema de referencias de la enunciación de $1^{o}$ grado, ligada al enunciador primario, y establecer un nuevo sistema de referencias propio de la enunciación de $2^{\underline{o}}$ grado, con sus propios actores y actantes. En este caso el desembrague interno es de tipo enunciativo, ya que nuevamente instala formas discursivas de una enunciación enunciada.

149 Si las rheseis del crítico y de "Calímaco" estaban delimitadas por fórmulas de inicio y final de sus intervenciones, entonces el narrador necesariamente debería haber aparecido deícticamente en el enunciado por la concomitancia de identidad que se da entre este y el interlocutor, pero no así el narratario, ya que depende de un señalamiento explícito por parte del narrador.

${ }^{150}$ La inscripción deíctica del narrador en el enunciado se debe a la concomitancia de identidad con el interlocutor dentro del discurso directo. Simplificando, el narrador ("Calímaco"), al transmitir a su narratario la respuesta que le dio a su detractor utilizando un discurso referido de manera directa, tendría que haber empleado fórmulas en primera persona, como por

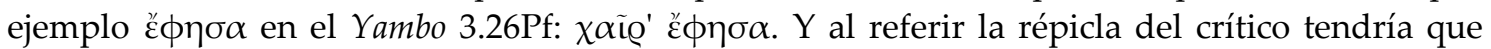

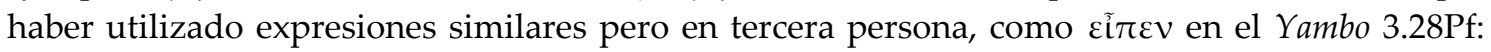

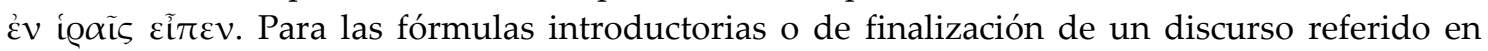
forma directa, véanse Edwards (1970, págs. 1-36), Olson (1994, págs. 141-51) y Beck (2008, págs. 162-83).

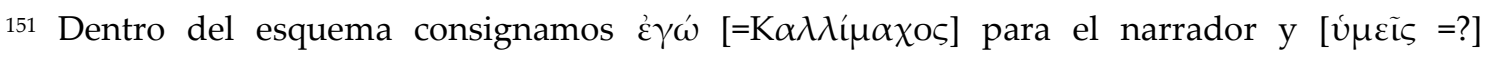
narratario. 
En el relato intervienen dos actores, cuyas identidades no aparecen en el texto pero se pueden restituir a partir del resumen que transmite la Diégesis. Estos actores serían "Calímaco" y el crítico que debate con él. ${ }^{152}$

La enunciación de $2^{\underline{o}}$ grado se presenta como una estructura de interlocución que se segmenta en dos rheseis; la primera de ellas corresponde a la intervención del crítico, que asume la posición actancial de interlocutor en los vv. 5-22, en tanto que "Calímaco" se ubica en la posición de interlocutario. La segunda rhesis corresponde a la repuesta de "Calímaco" a su detractor, invirtiendo los roles en los vv. 24-66. Como ya hemos observado en relación a

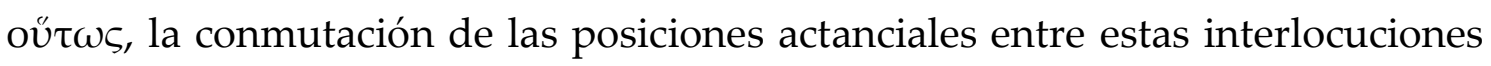
se produciría por medio de una expresión formular de inicio y finalización de discursos. ${ }^{153}$ Dentro de la interlocución, los actantes se inscriben deícticamente en el enunciado a través de las diferentes formas pronominales en primera y segunda persona:

Primera rhesis (vv. 5-22)

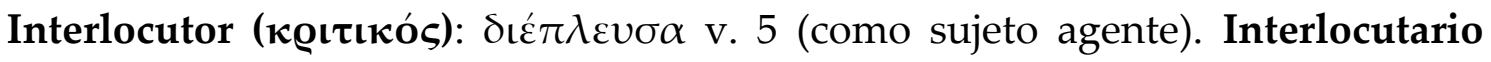

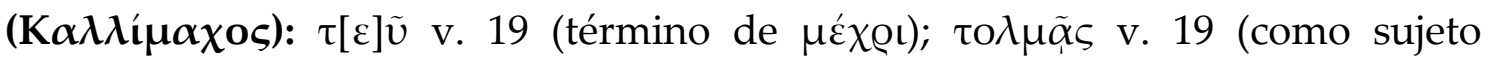

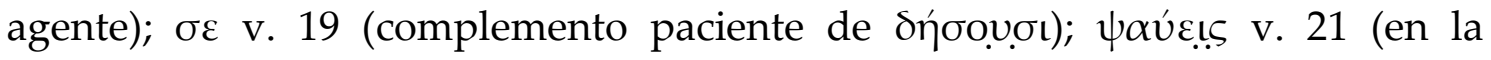
función de sujeto agente).

\section{Segunda rhesis (vv. 24-66)}

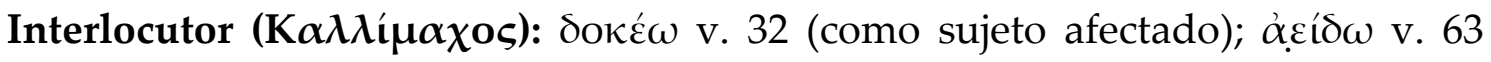

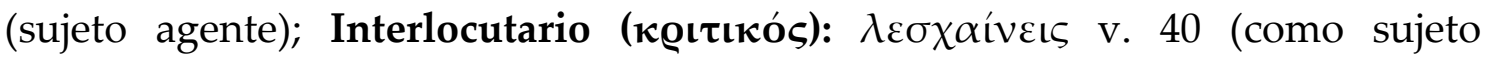
agente).

\footnotetext{
152 Por el hecho mismo de que sus identidades no aparacen explícitamente en la narración, estos actores han sido consignados entre corchetes en el esquema: Actor 1 [K $\alpha \lambda \lambda$ í $\alpha \alpha \chi \circ]$, Actor 2

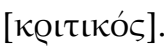

153 La expresión formular implicaría un proceso de embrague hacia la instancia de la enunciación primaria y un posterior desembrague a una nueva instancia de enunciación secundaria. Este proceso de desembrague-embrague-desembrague es lo que posibilita acoplar y desacoplar las interlocuciones en estilo directo de los personajes de la narración, pero no se han consignado en el esquema para no dificultar su seguimiento.
} 
La concomitancia de identidad entre el narrador y uno de los actores evidencia que en este yambo la persona yámbica "Calímaco" asume la defensa

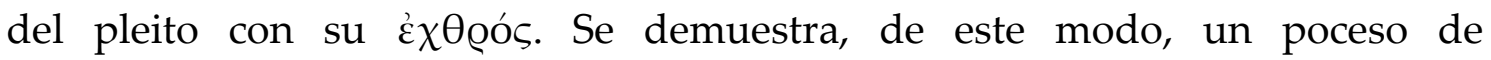
desenmascaramiento con respecto al Yambo 1, ya no es "Hiponacte" quien se enfrenta a los eruditos helenísticos sino "Calímaco" en propria persona. Sin embargo el desenmascaramiento nunca es total, "Calímaco" tiene el control de la narrativa y compone a su medida la máscara de su detractor. Del mismo modo que en los yambos arcaicos "Arquíloco" e "Hiponacte" acentuaban las muecas caricaturescas de Licambes y Búpalo, aquí los gestos del crítico se enfatizan y se hacen previsibles para dar paso al alegato de defensa. En los vv. 63-65, "Calímaco" responde a la acusación de no haber realizado el viaje a Éfeso exactamente con las mismas palabras que utilizó su adversario, los gestos de su contrincante le sirven como espejo para dar forma a su propia máscara. Probablemente a través de la tipificación maniquea de este personaje se ridiculizan las críticas de los detractores reales. Al construir la máscara de su

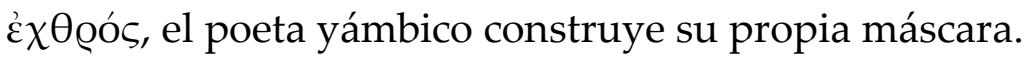

Por último, si en el Yambo 1 "Hiponacte" se constituye en la voz autorizada para la ejecución yámbica, en el 13, al asumir en primera persona la

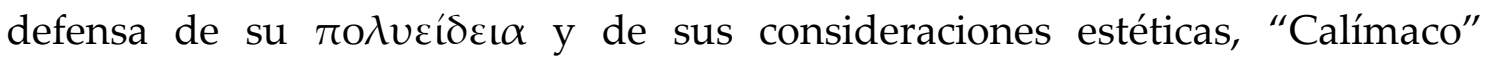
también asume en la concomitancia de identidad entre la instancia enunciva y la enunciativa una posición de autoridad con respecto al yambo helenístico. Es

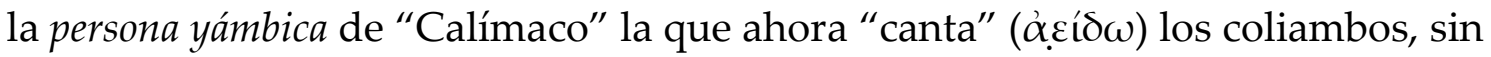
la necesidad de haberse mezclado con los jonios ni de haber ido a Éfeso, real o metafóricamente, en búsqueda de una trasposición exacta de la poética yámbica, ni de la legitimación de sus pares. 


\section{$\underline{5}$ \\ CONCLUSIONES}

El recorrido de nuestro análisis ha demostrado que el enmascaramiento del 'yo' en la poesía yámbica, tanto en sus expresiones arcaicas como helenísticas, podría contarse entre los elementos más característicos del yambo. Y encontramos que los orígenes rituales del género también pueden tener algún tipo de vinculación con el enmascaramiento de la persona yámbica que hemos venido investigando.

Nos referimos, concretamente, a la importancia crucial que, dentro de los antiguos cultos, tenía la máscara. ${ }^{1}$ Ya sea el disfraz de anciana con que Deméter se presenta en Eleusis durante el mítico encuentro con Yambe, disfraz que se reactualiza en las danzas y procesiones eleusinas, ya sea la piel de ciervo que llevan las ménades, o las máscaras de sátiros que cubren los rostros de los

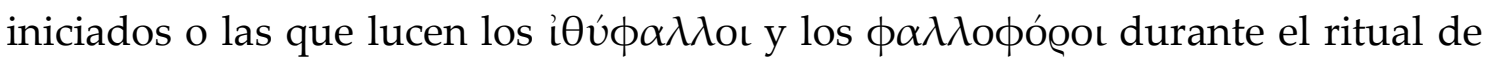
Dioniso, el enmascaramiento aparece como un elemento destacado en las narrativas míticas y en las conmemoraciones religiosas que se encuentran entre los antecedentes de nuestro género poético. ${ }^{2}$

\footnotetext{
${ }^{1}$ Dentro del panteón griego, el uso de máscaras rituales está confinado particularmente a tres divinidades: Artemis, Deméter y Dioniso. Son muchos los testimoniso literarios e iconográficos que transmiten la utilización de máscaras en los rituales dionisíacos y eleusinos. Véase Burkert (2007, págs. 142-45).

2 En Suda $\theta 494$ se señala que el $\theta$ gí $\alpha \mu \beta 0 \varsigma$, consagrado a Dioniso, recibió su nombre porque antes de que las máscaras $(\pi \varrho 0 \sigma \omega \pi \varepsilon \tilde{\alpha} \alpha)$ fueran inventadas, los iniciados se cubrían
} 
En esa misma dirección, también reparamos muy especialmente en la situación de enmascaramiento que está presente en los relatos que narran la iniciación poética de los dos yambógrafos arcaicos, tanto Arquíloco como Hiponacte. En efecto, en la "Inscripción de Mnesiepes" (de mediados de s. III a.

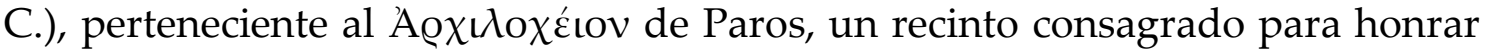
a Arquíloco como héroe local, se narra la Dichterweihe del poeta. En ella se cuenta que, siendo Arquíloco un joven, fue enviado por su padre Telesicles a buscar una vaca al campo para venderla en el mercado. En su camino se cruzó con unas mujeres que regresaban de sus labores y comenzó a a burlarse de ellas

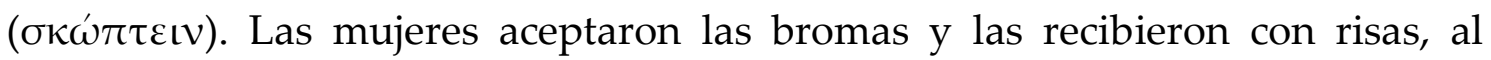
tiempo que le preguntaron por qué llevaba la vaca. El joven les respondió que estaba en venta, a lo que las mujeres ofrecieron pagarle un precio justo, e inmediatamente desaparecieron junto con el animal. A cambio, Arquíloco encontró a sus pies una lira; rápidamente comprendió el sentido del regalo recibido: quienes se le habían aparecido no eran sino las mismísimas Musas. ${ }^{3}$

El relato de la iniciación poética de Hiponacte, por su parte, nos ha llegado en el comentario de Querobosco al tratado métrico de Hefestión (in Heph. 3.1), en medio de otras historias concernientes a los probables orígenes

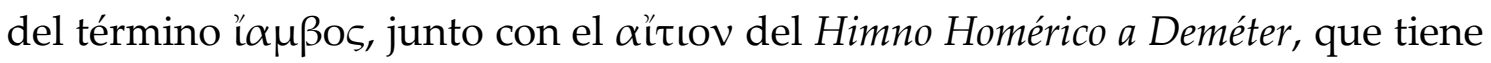
como protagonista, según comentamos en su momento, a la criada del rey Céleo. El autor refiere brevemente la historia de un encuentro entre el

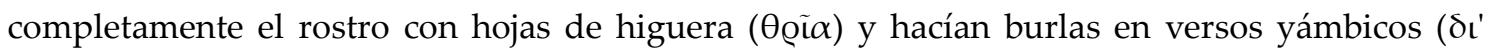

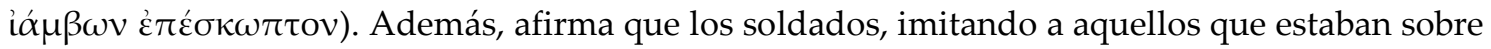

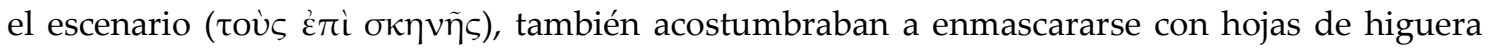

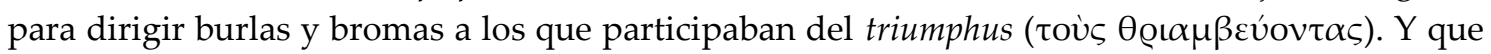
en algunas ciudades, cuando las higueras habían florecido, los niños tenían la costumbre de cortar los higos junto con las hojas y jugar con ellas recitando tetrámetros yámbicos (í́x $\mu \beta \iota \alpha$ $\tau \varepsilon \tau \varrho \alpha ́ \mu \varepsilon \tau \varrho \alpha)$. Acerca de la tragedia, Suda $\theta$ 282, sostiene que Tespis fue el primero en pintarse el rostro con plomo blanco, luego comenzó a cubrirse con flores de portulaca, hasta que finalmente inventó la máscara de lino. Véase particularmente Pickard-Cambridge (1966, págs. 69-79) .

${ }^{3}$ Mnesiepis inscriptio E1 col. II 22-55 Clay. Para esta inscripción véase Clay (2004). 
yambógrafo Hiponacte y una anciana, también de nombre Yambe, que se encontraba a la orilla del mar lavando lana. Hiponacte se acerca a la mujer y toca el recipiente en que lavaba, ante lo cual ella no tarda en reaccionar y lo

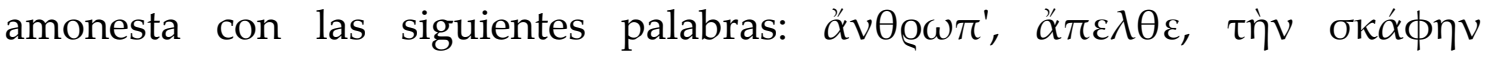

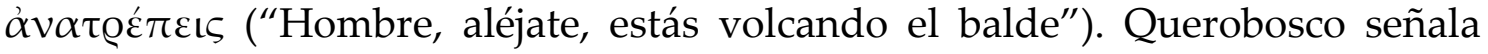
que el yambo tomó su nombre precisamente a partir del metro de este verso pronunciado por la anciana; otros, sin embargo, interpretan que la anécdota nos refiere en realidad el surgimiento del coliambo. ${ }^{4}$ El verso en cuestión no aparece en las ediciones tradicionales de Hiponacte, como la de Degani o West; sin embargo, Brown (1988, págs. 478-81) y Rosen (1988, págs. 174-79) han argumentado, cada uno por su lado, que es muy poco probable que el contexto y el verso en que las palabras de Yambe fueron pronunciadas hayan sido inventados por algún gramático, Querobosco u otro, para explicar el origen del metro yámbico, y proponen pensar que haya formado parte de algún poema del propio Hiponacte. ${ }^{5}$ Para ambos, ese poema recreaba una escena de iniciación poética semejante a la de Arquíloco y Hesíodo. ${ }^{6}$ Posteriormente, Fowler (1990,

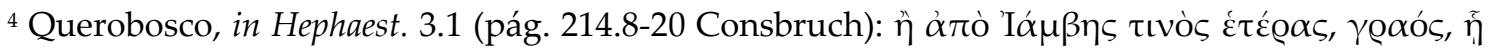

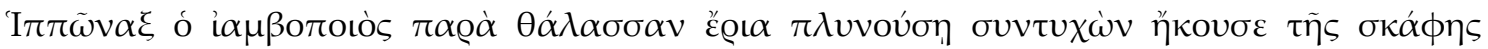

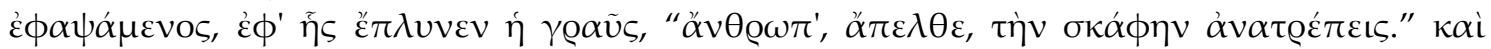

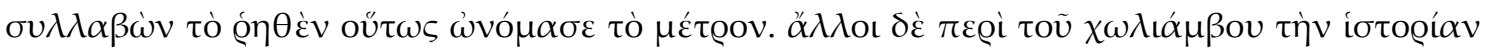

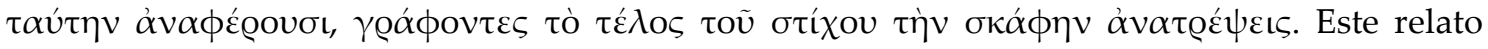
aparece de diferentes maneras en varios gramáticos de la antigüedad: nuevamente en Querobosco, in Hephaest. 5.4 (pág. 229.10-15 Consbruch); Schol. [B] Hephaest. 20.4 (págs. 299.17300.3 Consbruch); Tricha, Lib. de novem metris 1 (pág. 370.11-16 Consbruch); Gramm. Ambros.,

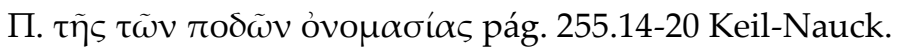

${ }^{5}$ A partir de los artículos de Brown y Rosen, Gerber (1999, págs. 497-99) edita el verso como fr. 183.

${ }^{6}$ La escena de la iniciación poética es un patrón narrativo tradicional con elementos en cierta medida estereotipados: consiste básicamente en la epifanía de una divinidad, frecuentemente las Musas, y el otorgamiento del don de la palabra poética al individuo elegido por esta divinidad. El relato más representativo de este tópico en el mundo griego antiguo es el episodio del encuentro de Hesíodo con las Musas en el Monte Helicón, narrado por el propio poeta (Theog. 1-36). En relación a Arquíloco y Hesíodo, aunque los relatos son claramente equivalentes, es notable el tono solemne y sentencioso de las Musas en el poeta épico

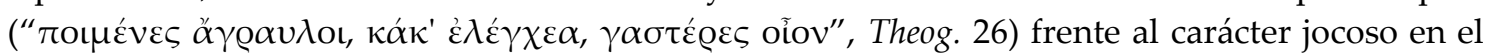

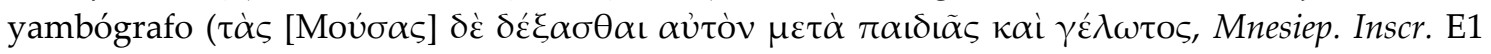


págs. 1-22) advierte que en un códice anónimo, Vaticanus Palatinus Graecus 356, consignado en aparato crítico por Consbruch como paralelo al texto de Querebosco, además del verso ya citado, se leen dos líneas en metro yámbico que también podrían haber formado parte del poema de Hiponacte. ${ }^{7}$ De este modo, Fowler propone editar el fragmento de la siguiente manera:

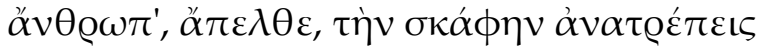

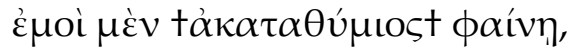

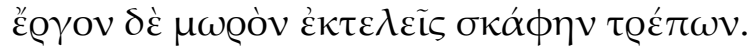
¡Hombre, aléjate! Estás por volcar el balde.
No me pareces desagradable,
pero harás algo estúpido si vuelcas el balde.

Lo interesante es que, a diferencia del pasaje de Querobosco que

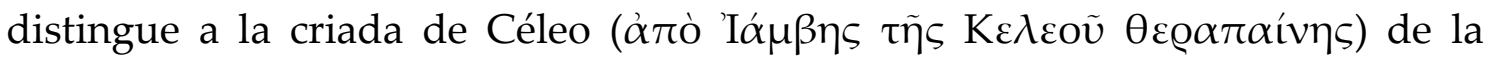

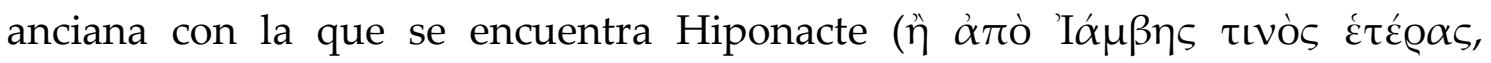

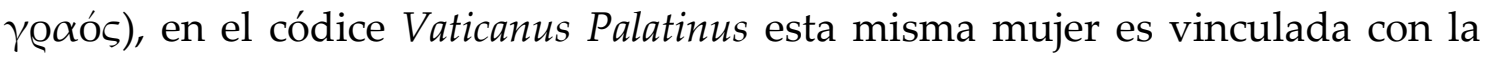
tradición eleusina ( $\dot{\varepsilon} \vee$ 'E $\lambda \varepsilon v \sigma \tilde{\imath} v \mathrm{l})$, por lo que podría llegar a sostenerse que se trata de una misma mujer. Aun cuando sea posible que la versión transmitida por el códice fuera una mezcla de dos tradiciones diferentes, como sostiene Brown, ${ }^{8}$ sin embargo, si se admite la existencia de un poema de Hiponacte en el

col. II 31). Es probable que este contraste se corresponda con el temperamento propio de cada uno de los géneros poéticos. En el caso de Hiponacte, Yambe, implicada directamente en el a ́́t tov del yambo y asociada al culto eleusino, puede funcionar como dispensadora del don de la palabra en este género poético como sustituta de las Musas. Para los relatos de inciación poética de Arquíloco y Hesíodo véanse West (1966, págs. 158-61); Breitenstein (1971, págs. 9-28); Calame (1995, págs. 58-74); Brillante (1990, págs. 7-20); Williams (1994, págs. 96-112); Ornaghi (2009).

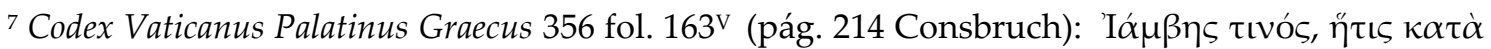

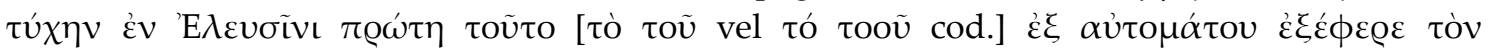

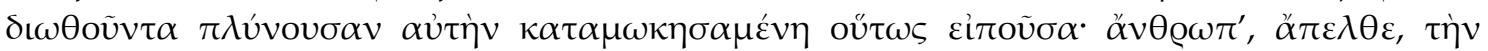

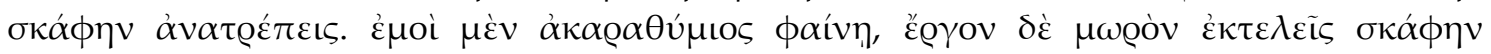
$\tau \varrho \varepsilon ́ \pi \omega \nu$.

${ }^{8}$ Brown (1988, pág. 479 n.3) considera que la versión de esta historia que aparece en el codex Palatino con la mención de Eleusis implica una mezcla de diferentes tradiciones. 
que narraba su iniciación poética, él mismo podría haber escogido introducir en su relato la Yambe de tradición eleusina. ${ }^{9}$

Sin duda ambos relatos, el de Mnesiepes, que constituye un $\alpha$ ľtıov retrospectivo de la iniciación poética de Arquíloco, y el que transmite Querobosco, que podría contener los versos de un relato compuesto por el propio Hiponacte, tienen ostensibles diferencias. Aun así, coinciden en un aspecto esencial: los personajes míticos que ocupan la posición de iniciadores en la poética yámbica, las Musas para Arquíloco y Yambe para Hiponacte, aparecen tras una máscara enunciativa. Las Musas directamente se esconden bajo el disfraz de mujeres que regresan de las labores en el campo, y Yambe bajo la máscara de una anciana. Las dos escenas contienen elementos que caracterizan las respectivas poéticas: por un lado, de manera similar a Yambe frente a Deméter, es significativo que "Arquíloco" sea el que tome la iniciativa de burlarse de las mujeres y que ellas reciban estas bromas con risas y de manera divertida $(\mu \varepsilon \tau \dot{\alpha} \pi \alpha \iota \delta \iota \tilde{\alpha} \varsigma \kappa \alpha \grave{\imath} \gamma \varepsilon \dot{\varepsilon} \lambda \omega \tau o \varsigma) .{ }^{10}$ Por otro lado, Yambe ya no es la graciosa muchacha que hizo reír a Deméter, según la versión del himno homérico dedicado a ella, sino una vieja que increpa en coliambos a "Hiponacte" porque está a punto de volcar el recipiente que ella utiliza para lavar. Desde la perspectiva de nuestro análisis, es posible postular que es el enmascaramiento enunciativo de estas iniciadoras poéticas el que se ha trasladado a los propios autores.

A lo largo de nuestro trabajo hemos tratado de demostrar que la máscara enunciativa se ha conservado tanto en el yambo literario de la Grecia arcaica como en el de la época helenística. A través del concepto de persona yámbica hemos definido un tipo particular de dispositivo poético que permite al enunciador asumir ante su enunciatario diferentes roles en el enunciado

\footnotetext{
${ }^{9}$ Rosen (1988, pág. 177) y Fowler (1990, pág. 3).

${ }^{10}$ Mnesiepis inscriptio E1 col. II 31 Clay.
} 
poético. Por otro lado, la determinación de diversas escenografías enunciativas han sido el medio de abordar los roles que asume la persona yámbica en la actuación de las diferentes interlocuciones y narraciones.

El corpus seleccionado de Arquíloco ha puesto en evidencia que en el período arcaico temprano la persona yámbica puede asumir en el enunciado poético una amplia variedad de roles. Entre ellos, hemos considerado preferentemente aquellas manifestaciones de carácter personal en las cuales el 'yo' transmite, por ejemplo, su aflicción ante un acontecimiento histórico concreto y cercano (fr. 20W), o bien expresa su preferencia por un determinado tipo de jefe militar (fr. 114W), o comunica ciertas reflexiones acerca de su propia función como poeta dentro de la comunidad (ff. 120, 121, 126 y 215W), o revela su deseo sexual por una mujer (fr. 118-119W), o realiza otros tipos de declaraciones que parecen involucrar de manera singular a su persona (ff. 200, 216, 296W). Pero también hemos visto que puede asumir el rol de interlocutor en una apelación directa a personas históricas y reales, como Erxias (ff. 88, 89, 110W), Glauco (ff. 96, 105-106, 131-132W), y Pericles (fr. 124W), o a personajes ficticios o personas disimuladas detrás de un nombre ficticio, como Carilao, Cericidas (ff. 167, 168 y 185-187W), Licambes (ff. 172-181W) y Neobule (ff. 188192W), o a divinidades a quienes dirige una plegaria: Apolo (fr. 26W), Hefesto (fr. 108W) y Zeus (fr. 197W). Del mismo modo, llega a hablarle a su propia persona, situando a su corazón en el rol de interlocutario de una exhortación (fr. $128 \mathrm{~W})$. Puede, igualmente, tomar distancia de las manifestaciones personales y desempeñar de manera paródica el rol de aedo homérico, solicitándole a las

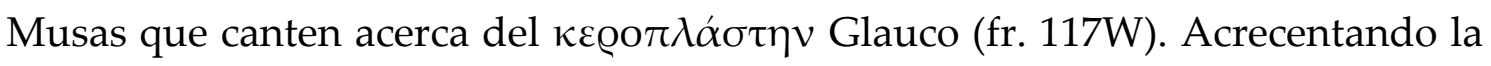
distancia, llega a asumir directamente un rol ficcional y a hablar por boca de otros personajes (ff. 19, 122W). Otras veces "Arquíloco" se inscribe en el enunciado poético en la posición actancial del narrador, desempeñando roles 
también disímiles, como los del soldado en episodios bélicos (ff. 23, 38, 196196aW), o el amante en situaciones eróticas y sexuales (ff. 34-37, 47W).

Precisamente esta variedad que acabamos de señalar en la asunción de roles en el enunciado del poema es lo que caracteriza a la persona yámbica "Arquíloco". Estos roles pueden ir desde aquellos anclados a lo autobiográfico o personal hasta la presentación de un 'yo' netamente ficcional.

Con Hiponacte, representante del período arcaico tardío, el enmascaramiento persiste, pero la persona yámbica asume un rol mucho más estereotipado. El 'yo' llega a reducirse a la voz de un actor perteneciente a los estratos más bajos de la sociedad, sea esclavo o mendigo, que protagoniza situaciones de índole tragicómica. En el corpus estudiado no hallamos manifestaciones de carácter personal. El 'yo' se manifiesta, por ejemplo, como suplicante, profiriendo plegarias paródicas dirigidas a Hermes (ff. 42, 43, 10, 208Dg), a Zeus (fr. 47Dg), o a Atenea (fr. 49Dg), ante la necesidad de bienes materiales y enseres cotidianos: comida, vestimenta, calzado, dinero, entre otros, o directamente les reprocha a esas mismas divinidades no haber respondido afirmativamente a sus pedidos; en algunas de estas ocasiones el reclamo consistá en la ayuda para salir de situaciones absurdas y ridículas. Al igual que "Arquíloco" (fr. 117W), "Hiponacte" puede asumir de manera paródica el rol de aedo homérico y solicitar a la Musa que cante acerca "del Eurimedontiada, la Caribdis tragamares" (fr. 126Dg). Muchas otra veces desempeña un rol de injuriador, dirigiendo invectivas contra enemigos caracterizados de manera grotesca por su gula, lascivia, ineptitud o baja condición social (ff. 129, 17, 18, 70, 39, 41, 33, 190Dg). Entre todos estos roles asumidos llama la atención, por su reincidencia, el del púgil cómico, siempre en situaciones de contiendas graciosas (ff. 121, 122, 193, 196Dg). Cuando se trata de poemas con estructura narrativa, el yo de "Hiponacte" reproduce prácticamente los mismos episodios que como interlocutor. Cuenta, por 
ejemplo, cómo un personaje le solicitaba a Hermes que lo ayudara a salir de una situación complicada (ff. 1-2Dg), o detalla los encuentros sexuales que mantuvo con Arete $(23,24,86 \mathrm{Dg})$, o relata las peleas de las que participó (ff. 79, 107, 132Dg). Con detalle también describe las penosas situaciones en las que ocupa el rol de víctima expiatoria o paciente que se somete a un rito para curar su impotencia sexual (ff. 46, 50,95Dg).

Fácil de ver que lo que distancia a "Arquíloco" de "Hiponacte" es la variedad y amplitud de su espectro. El 'yo' del primero es variable y se materializa en una pluralidad de manifestaciones, que atienden además a la percepción histórica y política de las guerras por la colonización de Tasos, manifestando impresiones sobre los acontecimientos de la batalla, o consideraciones acerca de cuestiones poéticas como el ditirambo, el peán y el yambo, o formulaciones gnómicas con fines pedagógicos, juicios de valor, bromas y burlas dirigidas a los compañeros del simposio; no calla historias eróticas y sexuales, ni tampoco las crueles invectivas contra los adversarios, incluso a través de fábulas que exponen y denuncian las conductas de estos individuos. En "Hiponacte", en cambio, se trata de un 'yo' más limitado, carente de cualquier tipo de reflexión seria, cuyas manifestaciones van dirigidas a provocar directa y exclusivamente la risa. Si "Arquíloco" se revela como una persona yámbica pluridimensional en sus expresiones, "Hiponacte" se manifiesta de manera unidimensional: aquel 'yo' que le reprocha a Hermes no haberle concedido nunca un manto y zapatillas podría ser perfectamente el mismo que anuncia que golpeará a Búpalo en un ojo o que describe los tormentos que sufrió tratando de curar su impotencia.

No es ocioso destacar, nuevamente, que aquellas expresiones de sentimientos, juicios de valor, deseos, o pensamientos que aparecen particularmente en los yambos de Arquíloco y que hemos denominado "manifestaciones de carácter personal" no implican una declaración confesional 
e introspectiva por parte de un 'yo' individual. Por el contrario, como ya hemos observado en las secciones correspondientes, las emociones y los pensamientos que se formulan en el poema son aquellos con los que el resto del grupo comunitario se identifica. Es decir, en este tipo de composiciones, destinadas a ser ejecutadas ante un auditorio compuesto por un minúsculo y selecto número de miembros, el 'yo' es representativo de los pensamientos y emociones compartidos por ese grupo comunitario. En Hiponacte, en particular, el 'yo' se manifiesta unidimensional básicamente porque emplea de manera estereotipada el aspecto más risible de la poesía yámbica. A diferencia de "Arquíloco", la persona yámbica "Hiponacte" vale más como un comediante o entretenedor en el ambiente festivo del simposio arcaico. ${ }^{11}$

Calímaco conduce al yambo a un escenario nuevo. El proceso de enmascaramiento del ' $\mathrm{yo}^{\prime}$, en el período helenístico, se vuelve un recurso metapoético utilizado deliberadamente como marcador literario de la especificidad del género. Queda inmerso en un libro programático, destinado a la edición y preservación escrita de los textos de Calímaco, y por lo tanto, las formas de producción, transmisión y recepción de las composiciones difieren ampliamente de aquellas que caracterizaban a la poesía yámbica arcaica, ligada a la ocasión de ejecución oral dentro del ámbito del simposio. En ese sentido, la persona poética de "Hiponacte" en el texto de Calímaco no es otra cosa que un artilugio enuciativo en la ejecución del programa de la persona yámbica de los poetas arcaicos. La máscara del de Éfeso, presente desde el primer yambo, se

${ }^{11}$ West (1974, págs. 32-3): “The speaker addresses himself sometimes to the public (Hippon. $1 \tilde{\omega}$

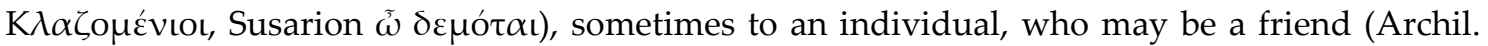
$48.7 \tilde{\omega} \Gamma \lambda \alpha \tilde{v} \kappa \varepsilon$, in a sexual narrative), but is more often the subject of mockery or worse (Archil.

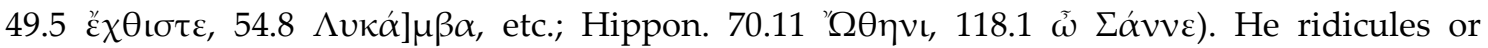
denounces particular persons or universal types, in an amusing or entertaining way, or he tells tales of titillating sexual adventures or other low doings. He may represent himself as something of a clown, he may assume a different character altogether, at least at the beginning of the performance. Archilochus can become Charon the carpenter (19), or a father speaking to his daughter (122); Hipponax can become a backstreet burglar or a grumpy old peasant; Semonides can perhaps become a prostitute (16) or a cook (24)." 
erige, en sus modos y en sus formas, como la voz de autoridad que legitima la resurrección de la poesía yámbica en la Alejandría de los Ptolomeos. La elección de la tradición del coliambo y del temperamento poético de Hiponacte por parte de Calímaco responde a la necesidad de ridiculizar a los eruditos alejandrinos sin echar mano de la ridiculización en forma personal (ỏvo $\mu \alpha \sigma \tau i$ $\kappa \omega \mu \omega \delta \varepsilon \tilde{\imath} v)$, delineando a cambio, de manera estereotipada, su caricatura cómica. Escondiendo su propia identidad detrás de una máscara famosa por su

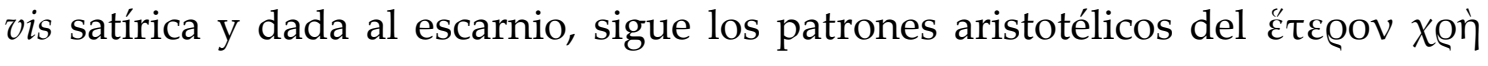

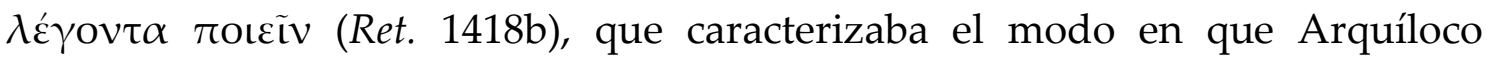
realizaba sus invectivas. Pero la adopción de la máscara hiponactea es solo momentánea. En el último yambo de la colección, según hemos visto, y de cara a las críticas dirigidas contra sus concepciones poéticas, Calímaco se posiciona como actor protagónico de su narrativa y asume en propria persona la defensa de su estética delante de los eruditos. Este proceso de desenmascaramiento enunciativo ilustra el traslado de la autoridad poética de "Hiponacte" a "Calímaco", que recibe el legado de la antigua yambografía pero bajo la nueva percepción literaria del mundo helenístico.

Finalizamos, pues, con la formulación de algunas conclusiones generales a las que nos ha permitido arribar nuestra investigación. En primer lugar, es evidente que entre los condicionamientos que la composición de un yambo impone a su autor, tanto en el plano formal como de contenido, se destacan la la

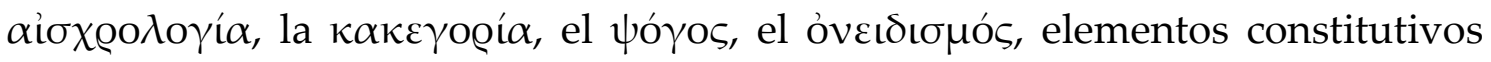

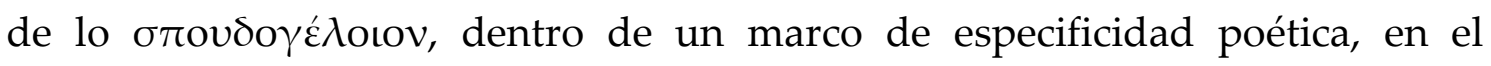
ámbito del simposio arcaico, similar y a la vez contrapuesto a su expresión en los rituales religiosos.

En segundo lugar, y en la misma dirección que lo anteriormente expuesto, consideramos que los procesos de enmascarmiento enunciativos son 
también un requisito formal del género yámbico, heredado tal vez de las máscaras utilizadas en los antiguos rituales eleusinos y dionisíacos. Esta máscara, que hemos denominado persona yámbica, legitima dentro del contexto

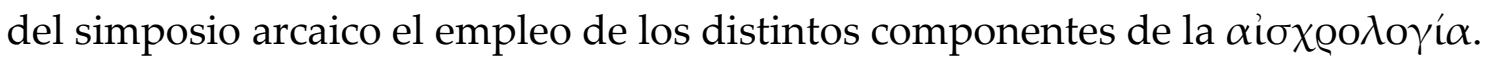

En tercer lugar, la persona yámbica, a través de los procesos de desembrague, tiene la capacidad de inscribirse en el enunciado poético en una tonalidad de voz que puede ir desde un 'yo' cercano a la manifestación personal hasta un 'yo' ficcional, en todos los casos un rol que esa persona yámbica asume frente a un 'tú' en la ocasión precisa de ejecución poética dentro del contexto del simposio. A raíz de esto último, la persona yámbica opera a través de un proceso de enmascaramiento, nunca total, del 'yo' personal por medio del 'yo' ficcional, y, en sentido inverso, un desenmascaramiento del 'yo' ficcional a través del 'yo' personal. Por esta razón, la persona yámbica nunca es reductible totalmente a ninguno de los dos anclajes, sino que estriba en medio de ellos.

En cuarto lugar, consideramos que existe, dentro del ámbito de la ejecución poética, un estatuto regido por el género que regula el pacto de codificación y decodificación de la persona yámbica, y que este pacto podría tener también su origen en el mismo principio que rige la figuración de la máscara material en los rituales eleusinos y dionisíacos.

En quinto lugar, consideramos que el pacto de codificación y decodificación se renueva en cada ejecución secundaria de los poemas yámbicos. En las ejecuciones secundarias, la persona yámbica como máscara enunciativa adquiriría una función más convencional. Es decir, el ejecutante se enmascararía bajo la persona yámbica del poeta al que representa, síntesis en 
cierto modo estereotipada, que le permitiría un marco de legalidad más cercano a la caracterización, y que no sería productivo en la trasgresión genérica. ${ }^{12}$

Por último, nuestro análisis nos lleva a considerar que, en época helenística, el yambo era ya un género literario totalmente fosilizado. Calímaco le da nueva vida, recuperándolo y reelaborándo, a partir de su conocimiento erudito de los procesos de enmascaramiento regidos por el género, los que utilizó productivamente para generar su propia persona yámbica. Las características particulares de esta persona yámbica aparecerán ahora desligadas de las determinaciones propias de una poética compuesta para la ocasión oral y repentizada del simposio y, en su nueva factura, evidenciará los trazos de la composición escrita, alcanzando un mayor grado de estilización. De este modo, la función polémica del yambo, manifiesta en la sátira y la crítica, adquiere un mayor grado de sofisticación ante un auditorio de filólogos y eruditos especializado en cuestiones de filología y estética literaria, ya que precisamente la disputa pone también al yambo, en tanto composición poética, en el centro de la disputa.

12 Platón, Symp. 531.a, atestigua la representación de los poemas de Arquíloco en ejecuciones secundarias. En ese pasaje, Sócrates le pregunta al rapsoda Ión si él puede ejecutar solo poemas de Homero o es capaz de hacerlo también de Hesíodo y Arquíloco. Acerca de este tema véase Lavigne (2005). 


\section{BIBLIOGRAFÍA}

\section{EDICIONES DE LOS AUTORES ANALIZADOS}

Bergk, T. (1882). Poetae Lyrici Graeci, (4º ed.,Vol. 2). Leipzig: Teubner.

Campbell, D. A. (1982). Greek Lyric Poetry. A Selection of Early Greek Lyric, Elegiac and Iambic Poetry (2o ed.). Bristol: Bristol Classical Press.

D'Alessio, G. B. (1996). Callimaco: Inni Epigrammi Ecale Aitia Giambi e altri frammenti. Milano: Biblioteca Universale Rizzoli.

Dawson, C. M. (1950). The Iambi of Callimachus: A Hellenistic Poet's Experimental Laboratory. YCS, 11, 1-168.

de Sousa Medeiros, W. (1961). Hipónax de Efeso. Fragmentos dos Iambos. Coimbra.

Degani, E. (1991). Hipponactis Testimonia et Fragmenta. Stuttgart \& Leipzig: Teubner.

Degani, E., \& Burzacchini, G. (1977). Lirici greci. Anthologia. Firenze: La nuova Italia.

Degani, E., Marzullo, B., \& Dover, K. J. (1977). Poeti greci giambici ed elegiaci. Milano: Mursia.

Diehl, E. (1969). Anthologia Lyrica Graeca.Iamborum Scriptores (Vol. 3). Leipzig: Teubner.

Edmonds, J. M. (1931) Elegy and Iambus, (Vols. 1-2). London: Heinemman.

Gallavotti, C. (1946). Callimaco. Il libro dei Giambi. Naples: Macchiaroli.

Gerber, D. E. (1999). Greek Iambic Poetry. Cambridge, Mass.-London: Harvard University Press.

Harder, A. (2012). Callimachus: Aetia. Oxford: Oxford University Press.

Lasserre, F., \& Bonnard, A. (1958). Archiloque: Les Fragments. Paris: Les Belles Lettres.

Mair, A. W., \& Mair, G. R. (1921). Callimachus and Lycophron. Aratus. London: William Heinemann.

Masson, O. (1962). Les fragments du poète Hipponax. Paris : Klincksieck. 
Nicolosi, A. (2007). Ipponatte, Epodi di Strasburgo. Archilocho, Epodi di Colonia. Bologna: Pàtron Editore.

Norsa, M., \& Vitelli, G. (1934). Diegeseis di poemi di Callimaco: in un papiro di Tebtynis. Firenze: Ariani.

Page, D. L. (1962). Poetae Melici Graeci. Oxford: Clarendon Press.

Page, D. L. (1974). Supplementum Lyricis Graecis. Oxford: Clarendon Press.

Pfeiffer, R. (1949). Callimachus. Fragmenta (Vol. 1). Oxford: Clarendon Press.

Pfeiffer, R. (1953). Callimachus. Hymni et Epigrammata (Vol. 2). Oxford: Clarendon Pres.

Rodríguez Adrados, F. (1990). Líricos Griegos. Elegíacos y yambógrafos arcaicos (Vols. I-II). Madrid: CSIC.

Schneidewin, F. G. (1839). Delectus Poesis Graecorum Elegiacae, Iambicae, Melicae (Vols. IIIII). Göttingen: Vandehoeck et Ruprecht.

Stephens, S. A. (2015). Callimachus. The Hymns. Oxford: Oxford University Press.

Tarditi, G. (1968). Archiloco. Introduzione, testimonianze sulla vita e sull'arte, testo critico, traduzione. Roma: Ed. dell'Ateneo.

Treu, M. T. (1959). Archilochos. München: Ernest Heimeran.

Trypanis, C. A. (1958) Callimachus. Fragments. Cambridge, Mass., \& London: Loeb.

West, M. L. (1998). Iambi et elegi ante Alexandrum cantati (3ํe․). Oxford: Clarendon Press.

\section{EDICIONES DE OTROS AUTORES ANTIGUOS}

Bekker, I. (1816). Ionannis Tzetzae. Antehomerica, homerica et posthomerica. Berlin: Reimer.

Bekker, I. (1854). Suidae Lexicon. Berlin: Reimer.

Bernabé Pajares, A. (1987). Poetae epici Graeci, testimonia et fragmenta. Pars I. Leipzig: Teubner.

Boissonade, J. F. (1851). Tzetzae Allegoriae Iliadis. Pselli Allegoriae. Paris: Lutetiae.

Burnet, J. (1900-1907). Platonis Opera. (Vols. 1-5). Oxford: Clarendon Press.

Càssola, F. (1994). Inni Omerici. Milano: Mondadori. 
Consbruch, M. (1906). Hephaestionis Enchiridion. Leipzig: Teubner.

Davies, M. (1988). Epicorum Graecorum Fragmenta. Göttingen: Vandenhoeck \& Ruprecht.

de Stefani, A. (1909-1920). Etymologicum Gudianum (Vols. 1-2). Leipzig: Teubner.

Diels, H. \& Kranz, W. (1951-1952). Die Fragmente der Vorsokratiker (5o ed., Vols. 1-3). Berlin: Weidmann.

Dindorf, K. W. (1855). Scholia graeca in Homeri Odysseam. Oxford: Typographeo Academico.

Drachmann, A. B. (1903-1927). Scholia vetera in Pindari carmina (Vols. 1-3). Leipzig: Teubner.

Dübner, F. (1842). Scholia graeca in Aristophanem. Paris: Didot.

Elmsley, P. (1818). Euripidis Medea. Oxford: Clarendon Press.

Foley, H. P. (1993). The Homeric Hymn to Demeter. Princeton: Princeton University Press.

Fraenkel, E. (1957). Horace. Oxford: Clarendon Press.

Gaisford, T. (1848). Etymologicon Magnum. Oxford: Typographo Academico.

Godley, A. D. (1920). Herodotus (Vols. 1-4). London: Heinemann \& New York: Putnam's Sons.

Hausrath, A. \& Hunger, H. (1970). Corpus Fabularum Aesopicarum (2oe., Vols. 1.1-2.1). Leipzig: Teubner.

Hercher, R. (1866). Claudii Aeliani de natura animalium libri xvii, varia historia, epistolae, fragmenta (Vol. 2). Leipzig: Teubner.

Hicks, R. D. (1925-1926). Diogenes Laertius. Lives of Eminent Philosophers (Vols. 1-2). Cambridge, Mass.: Harvard University Press \& London: Heinemann.

Hudson-Williams, T. (1910). The Elegies of Theognis. London: G. Bell and Sons Ltd.

Jacoby, F. (1923-1958). Die Fragmente der griechischen Historiker (Vols. 1-3). Leiden: Brill.

Kassel, R. \& Austin, C. (1983 -). Poetae Comici Graeci (Vols. 1-8). Berlin: G. de Gruyter.

Kassel, R. (1966). Aristotelis de arte poetica liber. Oxford: Clarendon Press.

Keibel, G. (1887-1890) Athenaei Naucratitae. Deipnosophistarum. Leipzig: Teubner.

Keil, H. (1855-1880) Grammatici Latini (Vols. 1-7). Leipzig: Teubner. 
Keller, O. (1902). Scholia in Horatium Vetustiora (Vol. 1). Leipzig: Teubner.

Kiessling, T. (1826). Ioannis Tzetzae historarum variarum Chiliades. Leipzig: Sumtibus F. C. G. Vogelii.

Leone, P. L. (2007). Ioannis Tzetzae. Historiae. Galatina: Congedo.

Lobel, E. \& Page, D. (1955). Poetarum Lesbiorum Fragmenta. Oxford: Clarendon Press.

Maass, E. (1887). Scholia graecae in Homeri Iliadem. Oxford: Clarendon Press.

Mayhoff, K. D. T. (1875-1906). C. Plini Secundi Naturalis historiae libri XXXVII. Leipzig: Teubner.

Meineke, A. (1852-1853). Strabonis Geographica (Vols. 1-3). Leipzig: Teubner.

Monro, D. B. \& Allen, T. W. (1920) Homeri Opera (Vols. 1-5). Oxford: Oxford University Press.

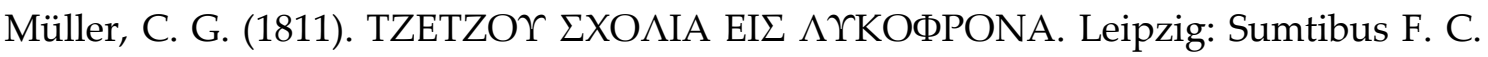
G. Vogelii.

Oldfather, C. H.; Sherman, C. L.; Welles, C. B.; Geer, M. R.; Walton, F. R. (1960-1991). Diodorus of Sicily (Vols. 1-12). Cambridge, Mass.: Harvard University Press \& London: Heinemann.

Paton, W. R. (1916-1918). The Greek Anthology. Cambridge, Mass.: Harvard University Press \& London: Heinemann.

Perrin, B. (1914-1920). Plutarch's Lives (Vols. 1-10). Cambridge, Mass.: Harvard University Press \& London: Heinemann.

Perry, B. E. (1952). Aesopica. A Series of Texts Relating to Aesop or Ascribed to him or Closely Connected with the Literary Tradition that Bears his Name (Vol. 1). Urbana: Illinois University Press.

Richardson, N. J. (1974). The Homeric Hymn to Demeter. Oxford: Oxford University Press.

Roberts, W. R. (1902). Demetrius on Style. Cambridge: Cambridge University Press.

Ross, W. D. (1959). Aristotelis ars rhetorica. Oxford: Clarendon Press.

Schmidt, M. (1857). Hesychii alexandrini lexicon. Jena: Hermann Dufft.

Schneider, R., Uhlig, G. \& Hilgard, A. (1867-1919). Grammatici graeci recogniti et apparatu critico instructi (Vols. 1-4). Leipzig: Teubner. 
Schneidewin, F. W. (1839). Eustathii prooemium. Commentariorum Pindaricorum. Göttingen: Librariae Dieterichianae.

Shorey, P. \& Laing, G. J. (1919). Horace. Odes and Epodes. Chicago: B. H. Sanborn \& Co.

Sommerstein, A. H. (1981-2001). The Comedies of Aristophanes (Vols. 1-11). Warminster: Aris \& Phillips.

West, M. L. (1966). Hesiod. Theogony. Oxford: Clarendon Press.

West, M. L. (1978). Hesiod. Works and Days. Oxford: Clarendon Press.

Zanker, G. (2009). Herodas: Mimiambs. Oxford: Aris \& Phillips.

\section{ESTUDIOS Y BIBLIOGRAFÍA GENERAL ${ }^{1}$}

Acosta-Hughes, B. (2002). Polyeideia: The Iambi of Callimachus and the Archaic Iambic Tradition. Berkeley: University of California Press.

Acosta-Hughes, B. (2003). Aesthetics and Recall: Callimachus frs. 226-9 Pf. Reconsidered. CQ, 53(2), 478-89.

Acosta-Hughes, B., \& Stephens, S. A. (2012). Callimachus in Context: from Plato to the Augustan Poets. Cambridge: Cambridge University Press.

Albiani, M. G., Alvoni, G., Barbieri, A., Bossi, F., Burzacchini, G., \& Citti, F. (2004). Filologia e storia. Scritti di Enzo Degani (Vol. I). Hildesheim: Georg Olms Verlag.

Aloni, A. (1988). L'ýovxí $\alpha$ di Archiloco (P. Köln 2,58). MD, 253-64.

Aloni, A. (2009). Poesia e biografia: Archiloco, la colonizzazione e la storia. $A O F L, 1,64-$ 103.

Aloni, A., \& Iannucci, A. (2007). L'elegia greca e l'epigramma dalle origini al $V$ secolo. Firenze: Le Monnier.

Anderson, A. S. (2012). Archilochus, Telephus, and the Warrior Ethos. Diss. Master of Arts in Classics. Illinois: Graduate College, University of Illinois.

Antúnez, D. R. (2006). La imagen del viaje a Éfeso en el Yambo XIII de Calímaco. Synthesis, 13, 67-78.

Ardizzoni, A. (1960). Callimaco Ipponatteo. AFLC, 28, 7-20.

${ }^{1}$ Las publicaciones periódicas se expresan según las abreviaturas de L'Année Philologique. 
Arrigoni, G. (1983). Amore sotto il manto e iniziazione nuziale. QUCC, 15, 7-56.

Asper, M. (2011). Dimensions of Power: Callimachean Geopoetics and the Ptolemaic Empire. En B. Acosta-Hughes, S. A. Stephens, \& L. Lehnus (Edits.), Brill's Companion to Callimachus (págs. 155-77). Boston \& Leiden: Brill.

Bádenas de la Peña, P. (Ed.). (1985). Fábulas de Esopo. Vida de Esopo. Madrid: Gredos.

Bajtín, M. (1989). Teoría y estética de la novela. Madrid: Taurus.

Bal, M. (1985). Narratology: Introduction to the Theory of Narrative. Toronto: University of Toronto Press.

Barbantani, S. (2011). Callimachus on Kings and Kingship. En B. Acosta-Hughes, S. A. Stephens, \& L. Lehnus (Edits.), Brill's Companion to Callimachus (págs. 178-200). Boston \& Leiden: Brill.

Barber, E. A. (1951). The Fragments of Callimachus - Pfeiffer R.: Callimachus. Volumen I: Fragmenta. $C R, 78-80$.

Barigazzi, A. (1973-1974). Note al nuovo Archiloco. MCr, 8/9, 5-10.

Bartol, K. (1993). Greek, Elegy and Iambus: Studies in Ancient Literary Sources. Poznan.

Beck, D. (2008). Character-Quoted Directed Speech in the 'Iliad'. Phoenix, 62(1-2), 16283.

Benveniste, E. (1966). Problèmes de linguistique générale (Vol. 1). Paris: Gallimard.

Benveniste, E. (1974). Problèmes de linguistique générale (Vol. 2). Paris: Gallimard.

Bergson, L. (1986). Kallimachos, Iambos I (Fr. 191 Pf.), 26-28. Eranos, 84, 11-6.

Bernabé Pajares, A. (1979). Fragmentos de épica griega. Madrid: Gredos.

Berranger, D. (1992). Archiloque et la rencontre des Muses à Paros. Rev. Ét. Anc., 94, 175-85.

Bing, P. (1988). The Well-Read Muse. Present and Past in Callimachus and the Hellenistic Poets. Göttingen: Vandenhoeck \& Ruprecht (Hypomnemata 90).

Bing, P. (2009). The Scroll and the Marble. Studies in Reading and Reception in Hellenistic Poetry. Ann Arbor: University of Michigan Press.

Böhme, J. (1929). Die Seele und das Ich im homersiche Epos. Leipzig \& Berlin: Teubner.

Bonanno, M. G. (1980). Nomi e soprannomi archilochei. MH, 37(2), 65-88. 
Bonanno, M. G. (1993). Sull'identità dell'io lirico nella poesia greca arcaica. En B. Amata (Ed.), Cultura e lingue classiche 3 (págs. 31-60). Roma: L'Erma di Bretschneider.

Bonanno, M. G. (2012). Archiloco risanato (fr. 128 W). MD, 68, 175-9.

Bonati, I. (2013). Glosse esotiche nei frammenti di Ipponatte di Efeso. Ricerche a confronto. Dialoghi di Antichità Classiche e del Vicino Oriente (págs. 29-46). Bologna \& Trento: Edizioni Saecula.

Boserup, I. (1966). Archiloque ou Epigone Alexandrin? CEM, 27, 28-38.

Bossi, F. (1990). Studi su Archiloco. Bari: Adriatica Editrice.

Bowie, E. L. (2001). Early Greek Iambic Poetry: The Importance of Narrative. En A. Cavarzere, A. Aloni, \& A. Barchiesi, Iambic Ideas: Essays on a Poetic Tradition from Archaic Greece to the Late Roman Empire (págs. 1-27). Lanham, Md. : Rowman and Littlefield.

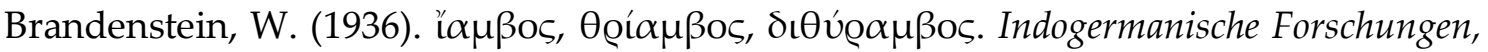
$54,34-8$.

Breitenstein, T. (1971). Hésiode et Archiloque. Odense: Odense University Press.

Brelich, A. (1976). Aristofane: commedia e religione. En M. Detienne (Ed.), Il mito. Guida storica e critica (págs. 105-18). Bari: Laterza.

Bremmer, J. N. (1980). An Akkadian Hasty Bitch and the New Archilochus. ZPE, 39, 28.

Bremmer, J. N. (1983). Scapegoat-Rituals in Ancient Greece. HSPh, 299-320.

Bremmer, J. N. (1994). Greek Religion. Oxford: Oxford University Press.

Brillante, C. (1990). Archiloco e le Muse. QUCC, 35(2), 7-20.

Brown, C. G. (1988). Hipponax and Iambe. Hermes, 116, 478-81.

Brown, C. G. (1995). The Parched Furrow and the Loss of Youth : Archilochus fr . 188 West. QUCC, 50(2), 29-34.

Brown, C. G. (1997). Iambos. En D. E. Gerber (Ed.), A Companion to the Greek Lyric Poets (págs. 13-88). Leiden, New York \& Köln: Brill.

Bruit Zaidman, L., \& Schmitt Pantel, P. (1992). Religion in the ancient Greek city. Cambridge: Cambridge University Press.

Brumbaugh, M. E. (2011). Constructing Ideologies of Kingship in the Hymns of Kallimachos. Diss. Doctor of Philosophy. Los Angeles: University of California. 
Bruss, J. S. (2004). Lessons from Ceos: Written and Spoken Word in Callimachus. En M. A. Harder, R. F. Regtuit, \& G. C. Wakker, Callimachus II (Hellenistica Groningana v. 7) (págs. 49-70). Leuven: Peters.

Budelmann, F. (Ed.). (2010). The Cambridge Companion to Greek Lyric. Cambridge: Cambridge University Press.

Bühler, K. (1990). Theory of Language. The Representational Function of Language. Amsterdam: John Benjamins.

Burkert, W. (1983). Homo Necans. Berkeley: University of California Press.

Burkert, W. (2007). La religión griega arcaica y clásica. Madrid: Abada.

Burzacchini, G. (1973-1974). Nota al nuovo Archiloco. MCr, 8/9, 18.

Cairns, D. L. (1993). Aidōs. The Psychology and Ethics of Honour and Shame in Ancient Greek Literature. Oxford: Clarendon Press.

Calame, C. (1995). The Craft of the Poetic Speech. Ithaca: Cornell University Press.

Calame, C. (2009). Referential Fiction and Poetic Ritual: Towards a Pragmatics of Myth (Sappho 17 and Bacchylides 13). Trends in Classics, 1, 1-17.

Cameron, A. (1995). Callimachus and his Critics. Princeton: Princeton University Press.

Campbell, D. A. (1978). The Cologne Archilochus: 'A Beard Coming'? CQ, 28, 473-4.

Carey, C. (1986). Archilochus and Lycambes. CQ, 36 n. s. (1), 60-7.

Carey, C. (2010). Iambos. En F. Budelmann (Ed.), The Cambridge Companion to Greek Lyric (págs. 149-67). Cambridge: Cambridge University Press.

Casanova, A. (1976). Un'interpretazione del nuovo Archiloco. Prometheus, 2, 18-40.

Cataudella, Q. (1974). Nuovo Archiloco. Cultura e Scuola, 13, 32-8.

Chantraine, P. (1933). La formation des noms en grec ancien. Paris: Champion.

Chantraine, P. (1968-1980). Dictionnaire ètymologique de la langue grecque. Histoire des mots (Vols. 1-4). Paris: Klincksieck.

Chatman, S. (1978). Story and Discourse. Ithaca, New York: Cornell University Press.

Clay, D. (2004). Archilochos Heros. The Cult of Poets in the Greek Polis. Washington: Harvard University Press.

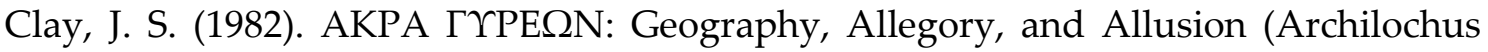
Fragment 105 West). AJPh, 103, 201-4. 
Clayman, D. L. (1976). Callimachus' Thirtheenth Iamb: The Last Word. Hermes, 104, 2935.

Clayman, D. L. (1980). Callimachus' Iambi. Leiden: Brill (Mnemosyne, suppl. 59).

Coppola, G. (1929). Archiloco o imitazione ellenistica? SIFC, 7, 155-68.

Coquet, J. C. (1989). Le discours et son sujet. Essai de grammaire modale (Vol. 1). Paris: Klincksieck.

Courtés, J. (1997). Análisis semiótico del discurso. Madrid: Gredos.

Cozzoli, A. T. (1996). Il I giambo e il nuovo iambizein di Callimaco. Eikasmós, 7, 129-47.

Cozzoli, A. T. (2015). Filosofi e filologi a simposio. I Silli di Timone di Fliunte e il primo dei Giambi di Callimaco. Aitia, 5, 1-16.

Crespo Güemes, E. (2006). Homero. Ilíada. Madrid: Gredos.

Croiset, A. \&. (1913). Histoire de la littérature grecque. Paris.

Da Cunha Corrêa, P. (2009). Armas e varôes. A guerra na poesia de Arquíloco. Sâo Paulo: Editora da UNESP.

D'Accunto, M. (2007). Ipponatte e Boupalos, e la dialettica tra poesia e scultura in età arcaica. $R A, 44,227-68$.

Darcus, S. M. (1977). -phron Epithets of thumos. Glotta, 55, 178-82.

Dawson, C. M. (1946). An Alexandrian Prototype of Marathus? AJPh, 67, 1-15.

de Jong, I. J. (1987). Narrators and Focalizers: The Presentation of the Story in the Iliad. Amsterdam: B.R. Güner.

Degani, E. (1974). Il nuovo Archiloco. AER, n.s. 19, 113-28.

Degani, E. (1975). ПАРE QUCC, 20, 229.

Degani, E. (1977). Sul nuovo Archiloco (Pap. Colon. inv. 7511). RCCM, 1, 15-43.

Degani, E. (2002). Studi su Ipponatte. Hildesheim: Georg Olms Verlag.

Degani, E. (2004 ). Per una traduzione di Ipponatte. En M. G. Albiani, G. Alvoni, A. Babieri, F. Bossi, G. Burzacchini, \& F. Citti, Filologia e storia. Scritti di Enzo Degani (págs. 101-12). Hildesheim: Georg Olms.

Degani, E. (2004). La lingua dei barbai nella letteratura greca arcaica: esotismi ipponattei. En M. G. Albiani, G. Alvoni, A. Barbieri, F. Bossi, G. Burzacchini, \& 
F. Citti, Filologia e storia. Scritti di Enzo Degani (págs. 123-30). Zürich \& New York: Olms.

Degani, E. (2007). Ipponatte. Frammenti. Bologna: Pàtron.

Delatte, A. (1955). Le Cycéon. Breuvage rituel des Mystères d'Eleusis. Paris: Les Belles Lettres.

Denninston, J. D. (1954). The Greek Particles (2ํe․). Oxford: Clarendon Press.

Depew, M. (1992). Iambeion Kaleitai Nun. Genre, Occasion, and Imitation in Callimachus frr. 191 and 203 Pf. TAPA, 122, 313-30.

Detienne, M. (1973). Les Maîtres de vérité dans la Grèce archaïque (2º ed.). Paris: Maspero.

Di Marco, M. (1998). Un problema di geometria nel 'Giambo' I di Callimaco (fr. 191, 59 ss. Pf.). RCCM, 40(1/2), 95-107.

Dover, K. J. (1964). The Poetry of Archilochos. Archiloque. Entretiens sur l'antiquité classique, 10, 183-222.

Ducrot, O. (1984). El decir y lo dicho. Buenos Aires: Hachette.

Duran, M. (2000). El jefe de la fiesta en el fragmento 114 West de Arquíloco. AC, 69, 201-4.

Ebert, J., \& Luppe, W. (1975). Zum neuen Archilochus-Papyrus: Pap. Colon. inv. 7511. ZPE, 223-33.

Edwards, M. W. (1970). Homeric Speech Introductions. HSPh, 74, 1-36.

Ehrhardt, N. (2003). Poliskulte bei Theokrit und Kallimachos: das Beispiel Milet. Hermes, 131(3), 269-89.

Fantuzzi, M. (1993). Il sistema letterario della poesia alessandrina nell III sec. a. C. En G. Cambiano, L. Canfora, \& D. Lanza (Edits.), Lo spazio letterario della Grecia antica. La produzione e la circolazione del testo. L'Ellenismo (Vol. 1 t. 2, págs. 31-73). Roma: Salerno.

Faraone, C. (2004). Hipponax Fragment 128W: Epic Parody or Expulsive Incantation? ClAnt, 23(2), 209-45.

Felson Rubin, N. (1981). Radical Semantic Shifts in Archilochus. CJ, 77(1), 1-8.

Felson, N. (Ed.). (2004). The Poetics of Deixis in Alcman, Pindar, and Other Lyric. Arethusa, 37(3).

Fernández, C. (2008). Aristófanes. Lisístrata. Buenos Aires: Losada. 
Fillmore, C. J. (1975). Santa Cruz Lectures on Deixis 1971. Bloomington: Indiana University Linguistics Club.

Fludernik, M. (1991). Shifters and Deixis: Some Reflections on Jakobson, Jespersen, and Reference. Semiotica, 3/4, 193-230.

Fontenrose, J. E. (1988). Didyma: Apollo's Oracle, Cult, and Companions. Berkeley: University of California Press.

Fowler, R. L. (1990). Two More New Verses of Hipponax (and a Spurium of Phliloxenus)? ICS, 15(1), 1-22.

Fränkel, H. F. (1968). Wege und Formen frühgriechischen Denkens (3 ed.). München: Beck.

Fränkel, H. F. (1924). Eine Stileigenheit der frühgriechischen Literatur I und II. GGN, 63-127.

Fränkel, H. F. (1993). Poesía y Filosofía de la Grecia Arcaica. Una historia de la épica, la lírica y la prosa griegas hasta la mitad del siglo quinto. Madrid: Visor.

Fraser, P. M. (1972). Alexandria Ptolemaica. Oxford: Clarendon Press.

Friedländer, P. (1929). Retractationes. Hermes, 64(2), 376-84.

Frisk, H. (1960). Griechisches etymologisches Wörterbuch . Heidelberg: Carl Winter Universitätsverlag.

Führer, R. (1967). Formproblem-Untersuchungen zu den Reden in der frühgriechischen Lyrik. Munich: Zetemata 44.

Fuhrer, T. (1992). Die Auseinandersetzung mit den Chorlyrikern in den Epinikien des Kallimachos. Basel \& Kassel: Reinhardt.

Gagné, R. (2016). The World in a Cup: Expomatics In and Out of the Symposium. En V. Cazzato, D. Obbink, \& E. Prodi (Edits.), The Cup of Song: Ancient Greek Poetry and the Symposium (págs. 207-229). Oxford: Oxford University Press.

Gallavotti, C. (1973-1974). Note al nuovo Archiloco. MCr, 8/9, 22-31.

García Teijeiro, M. (1983). Innovaciones sintácticas en la 'koiné'. Unidad y pluralidad en el Mundo Antiguo. Actas del VI Congreso Español de Estudios Clásicos, (págs. 247-77). Madrid.

García Teijeiro, M. (1989). Recursos fonéticos y recursos gráficos en los textos mágicos griegos. Revista Española de Lingüística, 19(2), 233-50.

Gärtner, T. (2008). Kritische Bemerkungen zu den Fragmenten des Hipponax. Wiener Studien, 121, 53-6. 
Gasparri, C. (1982). Archiloco a Taso. QUCC, 11, 33-41.

Genette, G. (1980). Narrative Discourse. An Essay in Method. Ithaca, New York: Cornell University Press.

Genette, G. (1989). Figuras III. Barcelona: Lumen.

Gentili, B. (1976). Nota ad Archiloco, P. Col. 7511; Fr. 2 Tard., 2 West. QUCC, 21, 17-21.

Gentili, B. (1982). Archiloco e la funzione politica della poesia del biasimo. QUCC, 11 n.s., $7-28$.

Gentili, B. (1996). Poesía y público en la Grecia antigua. Barcelona: Quaderns Crema.

Gerber, D. E. (1973). Eels in Archilochus. QUCC, 16, 105-9.

Gerber, D. E. (1989). Archilochus fr. 34 West. AClass, 32, 99-103.

Gerber, D. E. (Ed.). (1997). A Companion to the Greek Lyric Poets. Leiden, New York \& Köln: Brill.

Gerlach, W. (1937). Staat und Staatschiff. Gymnasium, 127-39.

Giannini, A. (1958). Archiloco alla luce dei nuovi ritrovamenti. Acme, 11, 57-68.

Gil Fernández, L. (1995). Aristófanes. Comedias I. Los acarnienses. Los caballeros. Madrid: Gredos.

Graham, A. J. (1978). The Foundation of Thasos. ABSA, 73, 61-98.

Graham, A. J. (2001). Thasian Controversies. En J. Graham, Collected Papers on Greek Colonization (págs. 365-402). Leiden.

Greimas, A. J. (1966). Sémantique structurale. Recherche de méthode. Paris: Larousse.

Greimas, A. J. (1987). Semántica Estructural. Madrid: Gredos.

Greimas, A. J., \& Courtés, J. (1990). Semiótica. Diccionario razonado de la teoría del lenguaje (Vol. 1). Madrid: Gredos.

Greimas, A. J., \& Courtés, J. (1991). Semiótica. Diccionario razonado de la teoría del lenguaje (Vol. 2). Madrid: Gredos.

Grenfell, B. P., \& Hunt, A. S. (1915). The Oxyrhynchus Papyri XI. London: Egypt Exploration Society.

Günther, H. C. (1996). Zu dem Kölner Archilochospapyrus. Lexis, 14, 61-9.

Gutiérrez, D. (2012). Comentario y traducción de un fragmento de Hiponacte. AFC, 25, 61-78. 
Gutzwiller, K. J. (1996). The Evidence for Theocritean Poetry Books. En M. A. Harder, R. F. Regtuit, \& G. C. Wakker (Edits.), Theocritus (págs. 119-48). Groningen: Egbert Forsten.

Gutzwiller, K. J. (1998). Poetic Garlands: Hellenistic Epigrams in Context. Berkeley \& Los Angeles: University of California Press.

Hanson, V. D. (1989). The Western Way of War: Infantry Battle in Classical Greece. New York: Alfred A. Knopf.

Hanson, V. D. (Ed.). (1991). Hoplites: The Classical Greek Experience. London: Routledge.

Hauvette, A. H. (1905). Archiloque, sa vie et ses poesies. Paris: Albert Fontemoing.

Hays, G. (1994). Exorcising Hipponax: Petitioners and Beggars in Greek Poetry. Lexis, 12, 11-26.

Henderson, J. (1976). The Cologne Epode and the Conventions of Early Greek Erotic Poetry. Arethusa, 9(2), 159-79.

Henderson, J. (1991). The Maculate Muse. Obscene Language in Attic Comedy. Oxford: Oxford University Press.

Henrichs, A. (1980). Riper than a Pear: Parian Invective in Theokritos. ZPE, 39, 7-27.

Herda, A. (1998). Der Kult des Gründerheroen Neileos un die Artemis Kithone in Milet. JÖAI, 67, 1-48.

Herter, H. (1937). Kallimachos. Bursians Jahresbericht, 255, 82-218.

Herter, H. (1973). Kallimachos aus Kyrene. RE Supplementband XIII, 184-266.

Hiller von Gaertringen, F. (1900). Archilochosinschrift aus Paros. AM, 25, 1-22.

Hjelmslev, L. (1972). Ensayos lingüísticos. Madrid: Gredos.

Hjelmslev, L. (1974). Prolegómenos a una teoría del lenguaje (2oed.). Madrid: Gredos.

Hjelmslev, L. (1976). El lenguaje. Madrid: Gredos.

Hobden, F. (2013). The Symposion in Ancient Society and Thought. Cambridge: Cambridge University Press.

Hughes, B. (1996). Callimachus, Hipponax, and the Persona of the Iambographer. MD, $37,205-16$.

Hughes, D. D. (1991). Human Sacrifice in Ancient Greece. Londres: Routledge.

Hunter, R. L. (1997). (B)ionic man: Callimachus' Iambic Programme. PCPhS, 43, 41-52. 
Huss, W. (2001). Ägypten in hellenistischer Zeit 332-30 v. Chr. München: C. H. Beck.

Ianovitz, O. A. (1970). Una note semantica: l'Hermes Kandaulas del frammento 4 Diehl de Ipponatte. Atti del Congresso Internazionale di Linguistica e Tradizioni Popolari, (págs. 163-69). Udine.

Ieranò, G. (1997). Il ditirambo di Dioniso. Le testimonianze antiche. Pisa: Istituti Editoriali e Poligrafici Internazionali.

Immisch, O. (1890). Zu griechischen Dichtern. Philologus, 49, 198-203.

Isler-Kerényi, C. (2007). Dionysos in Archaic Greece. An Understanding through Images. Leiden \& Boston: Brill.

Jacoby, F. (1941). The Date of Archilochos. CQ, 35(3/4), 97-109.

Jakobson, R. (1984). Russian and Slavic Grammar. Studies 1931-1981. (L. R. Waugh, \& M. Halle, Edits.) Berlin, New York \& Amsterdam: Mouton.

Jespersen, O. (1922). Language. Its Nature, Development and Origin. London: Allen and Unwin.

Jespersen, O. (1924). The Philosophy of Grammar. London: Allen and Unwin.

Jurenka, H. J. (1900). Archilochos von Paros. Aus den Fragmenten dagestellt. JahresBericht d. Maximilians-Gymn., 1-15.

Kamerbeek, J. C. (1961). Archilochea. Mnemosyne, 4(14), 1-15.

Kamerbeek, J. C. (1976). Remarques sur le nouvel Archiloque (P. Colon. inv. 7511). Mnemosyne, 29, 113-28.

Kantzios, I. (2005). The Trajectory of Archaic Greek Trimeters. Boston \& Leiden: Brill.

Kerbic, R. B. (1983). The Paintings in the Cnidian Lesche at Delphi and their Historical Context. Leiden: Brill (Mnemosyne suppl. 80).

Kerbrat-Orecchioni, C. (1990-1992). Les interactions verbales (Vols. 1-2). Paris: Armand Colin.

Kerbrat-Orecchioni, C. (1997). La enunciación. De la subjetividad en el lenguaje. Buenos Aires: Edicial.

Kerényi, C. (1956). The Trickster in Relation to Greek Mythology . En P. Radin, The Trickster. A Study in American Indian Mythology (págs. 173-91). New York: Philosophical Library.

Kerkhecker, A. (1999). Callimachus' Book of Iambi. Oxford: Clarendon Press. 
Kirkwood, G. M. (1961). The Autorship of the Strasbourg epodes. TAPhA, 92, 267-82.

Kirkwood, G. M. (1974). Early Greek Monody. Ithaca \& London: Cornell University Press.

Kivilo, M. (2010). Early Greek Poets' Lives. The Shaping of the Tradition. Leiden \& Boston: Brill.

Knox, A. D. (1925-1926). Herodas and Callimachus. Philologus, 81, 241-55.

Koenen, L. (1974). Ein wiedergefundenes Archilochos-Gedicht? Poetica, 6, 468-512.

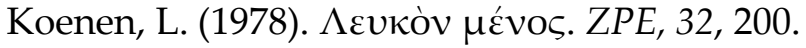

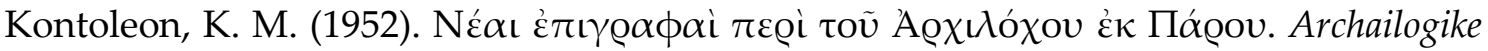
Ephemeris, 91, 32-95.

Kranz, W. (1961). SPHRAGIS: Ichform und Namensiegel als Eingangs- und Schlußmotiv antiker Dichtung. RhM, 104(1), 3-46; 97-124.

Kühner, R., \& Gerth, B. (1898). Ausführliche Grammatik der griechischen Sprache (Vol. 2). Hannover \& Leipzig: Hahnsche Buchhandlug.

Lasserre, F. (1947). Le fragment 74 d'Archiloque. $M H, 4(1), 1-7$.

Lasserre, F. (1956). Un nouveau poème d'Archiloque. $M H, 13$, 226-35.

Lasserre, F. (1957). Les premiers poèmes d'Archiloque. $R P h, 31(3)$, 52-62.

Lasserre, F. (1975). Archiloque et la fille aux cheveux blonds. AC, 44(2), 506-30.

Latacz, J. (1992). "Freuden der Göttin gibt's ja fûr junge Männer mehrere..." Zur Kölner Epode des Archilochos (Fr. 196a W.). MH, 49(1), 3-12.

Latte, K. (1929). Hipponacteum. Hermes(64), 385-88.

Latte, K. (1955). Oxyrhynchus Papyri. Part XXII. Gnomon, 27, 491-99.

Lavigne, D. E. (2005). Iambic Configurations: Iambos from Archilochus to Horace. Diss. Doctor in Philosophy. Stanford: Department of Classics - Stanford University.

Lefkowitz, M. R. (1976). Fictions in Literary Biography: The New Poem and the Archilochus Legend. Arethusa, 9(2), 181-89.

Lefkowitz, M. R. (1978). The Poet as Hero: Fifth-Century Autobiography and Subsequent Biographical Fiction. CQ , n. s. 28, 459-69.

Lefkowitz, M. R. (1991). First-Person Fictions: Pindar's Poetic 'I'. Oxford: Clarendon Press. 
Lefkowitz, M. R. (2012). The lives of the Greek poets (2ํe․). Baltimore, Maryland: The Johns Hopkins University Press.

Lehnus, L. (1980). ОІФО $\Lambda \mathrm{\Sigma}$ : Alla ricerca della fonte di una glossa. Scripta Philologa, 2, $159-86$.

Lehnus, L. (1993). Callimaco tra la polis e il regno. En G. Cambiano, L. Canfora, \& D. Lanza (Edits.), Lo spazio letterario della Grecia antica. La produzione e la circolazione del testo. L'Ellenismo (Vol. 1 t. 2, págs. 75-105). Roma: Salerno.

Lelli, E. (2004). Critica e polemiche letterarie nei Giambi di Callimaco. Alessandria: Edizioni dell'Orso.

Lelli, E. (2005). Callimaco. Giambi XIV-XVII. Roma: Edizioni dell'Ateneo.

Leurini, L. (1992). Ionis Chii Testimonia et Fragmenta. Amsterdam: A. M. Hakkert.

Levinson, S. C. (1983). Pragmatics. Cambridge: Cambridge University Press.

Liddell, H. G., Scott, R., \& Jones, H. S. (1996). A Greek-English Lexicon (9oed.). Oxford: Clarendon Press.

Lledó , E. (Ed.). (1981). Platón. Diálogos I. Madrid: Gredos.

Lloyd-Jones, H. (1967). Callimachus, fr. 191.62. CR, 17 n.s.(2), 125-7.

Lobel, E., \& Roberts, C. H. (1954). The Oxyrhynchus Papyri XXII. London: Egypt Exploration Society.

Lyons, J. (1977). Semantics (Vol. 2). Cambridge: Cambridge University Press.

Macía Aparicio, L. M. (2007). Aristófanes. Comedias II. Las nubes, Las avispas, La paz, Los pájaros. Madrid: Gredos.

Maingueneau, D. (2004). La situation d'énonciation entre langue et discours. En V.V.A.A., Dix ans de S.D.U. (págs. 197-210). Craiova: Editura Universitaria Craiova.

Maingueneau, D. (2010). Manuel de linguistique pour les textes littéraires. Paris: Armand Colin.

Marcaccini, C. (2001). Costruire un'identità, scrivere la storia: Archiloco, Paro, e la colonizzazione di Taso (Vol. 20). Florence: Studi e testi.

Marcovich, M. (1975). A New Poem of Archilochus. P. Colon. inv. 7511. GRBS, 15, 5-14.

Martin, R. P. (1998). The Seven Sages as Performers of Wisdom. En C. Dougherty, \& L. Kurke (Edits.), Cultural Poetics in Archaic Greece: Cult, Performance, Politics (págs. 108-28). Oxford: Oxford University Press. 
Marzullo, B. (1973-1974). Note al nuovo Archiloco. $M C r$, 8/9, 32-92.

Massimilla, G. (2010). Callimaco. Aitia. Libro terzo e quarto. Roma \& Pisa: Fabrizio Serra.

Masson, O. (1946-1947). Les 'Épodes de Strasbourg': Archiloque ou Hipponax? Quelques problèmes relatifs au texte d'Hipponax. REG, 59/60, 8-27.

Masson, O. (1951). Encore les 'Épodes de Strasbourg'. REG, 64, 427-42.

Merkelbach, R. (1975). Nachträge zu Archilochos. ZPE, 16, 220-2.

Merkelbach, R., \& West, M. L. (1974). Ein Archilochos-Papyrus. ZPE, 14, 97-113.

Miller, P. A. (1994). Lyric Texts and Lyric Consciousness. London \& New York: Routledge.

Miralles, C. (1986). El yambo. EClás, 28(90), 11-26.

Miralles, C., \& Pòrtulas, J. (1983). Archilochus and the Iambic Poetry. Roma: Edizioni dell'Ateneo.

Miralles, C., \& Pòrtulas, J. (1988). The Poetry of Hipponax. Roma: Edizioni dell'Ateneo.

Montanari, O. (1973-1974). Note al nuovo Archiloco. $M C r, 8 / 9,93-5$.

Moran, W. (1978). An Assyriological Gloss on the New Archilochus Fragment. HSPh, $82,17-9$

Morrison, A. D. (2007). The Narrator in Archaic Greek and Hellenistic Poetry. Cambridge: Cambridge University Press.

Müller, C. W. (1985). Die Archilochoslegende. Rhein. Mus., 128, 99-151.

Müller, K. O. (1875). Geschichte der griechischen Literatur I (3º ed.). Stuttgart: Albert Heitz.

Murray, O. (1990). Sympotic History. En O. Murray, Sympotica: A Symposium on the Symposium (págs. 3-13). Oxford: Clarendon Press.

Murray, O. (Ed.). (1990). Sympotica: A Symposium on the Symposium. Oxford: Clarendon Press.

Nagy, G. (1976). "Iambos:" Typologies of Invective and Praise. Arethusa, 2(9), 191-205.

Nagy, G. (1990). Pindar's Homer: The Lyric Possession of an Epic Past. Baltimore \& London: The Johns Hopkins University Press.

Nagy, G. (1996). Poetry as Performance. Homer and Beyond. Cambridge: Cambridge University Press. 
Nagy, G. (1999). The Best of Achaeans. Concepts of the Hero in Archaic Greek Poetry (2o ed.). Baltimore: The Johns Hopkins University Press.

Nagy, G. (2004). Transmission of Archaic Greek Sympotic Songs: From Lesbos to Alexandria. $C I, 31,26-48$.

Natalucci, N. (2003). Il Giambo 1 di Callimaco e i Siete Sapienti. En F. Benedetti, \& S. Grandolini, Studi di filologia e tradizione greca in memoria di Aristide Colonna (págs. 539-51). Napoli: Studi e ricerche di filologia classica.

Nicolosi, A. (2012). P. Oxy. XVIII 2176 Fr. 6.12 (=Hippon. Fr. 131 E Dg.; 118 D W.). ZPE, 180, 49-50.

Ober, J. (1991). Hoplites and Obstacles. En V. D. Hanson, Hoplites: The Classical Greek Battle Experience (págs. 173-96). London : Routledge.

Oikonomides, A. (1980). The Lost Delphic Inscription with the Commandments of the Seven and P. Univ. Athen. 2782. ZPE, 37, 179-83.

Oikonomides, A. (1987). Records of the 'Commandments of the Seven Wise Men' in the 3rd c. B.C. ZPE, 63, 67-76.

Olender, M. (1989). Aspects of Baubo: Ancient Texts and Contexts. En D. Halperin, J. J. Winkler, \& F. I. Zeitlin (Edits.), Before Sexuality: The Construction of Erotic Experience in the Ancient Greek World (págs. 83-113). Princeton: Princeton University Press.

Olson, D. S. (1994). Equivalent Speech-Introduction Formulae in the 'Iliad'". Mnemosyne, 47(2), 145-51.

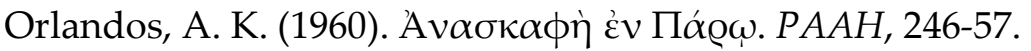

Ornaghi, M. (2009). La lira, la vacca e le donne insolenti. contesti di ricezione e promozione della figura e della poesia di Archiloco dall'arcaismo all'ellenismo. Minima philologica 5. Alessandria: Edizioni dell'Orso.

Owen, S. (2003). Of Dogs and Men: Archilochus, Archaeology and the Greek Settlement of Thasos. PCPhS, 49, 1-18.

Pabón, J. M. (1993). Homero. Odisea. Madrid: Gredos.

Page, D. L. (1961). Various Conjectures. PCPhS, n.s. 7, 68-9.

Page, D. L. (1964). Archilochus and the Oral Tradition. Archiloque. Entretiens sur l'antiquité classique, 10, 117-63.

Parke, H. W. (1933). Greek Mercenary Soldiers: From the Earliest Times to the Battle of Ipsus. Oxford: Clarendon Press. 
Parke, H. W. (1985). The Oracles of Apollo in Asia Minor. London: Croom Helm.

Parke, H. W. (1986). The Temple of Apollo at Didyma: The Building and its Function. JHS, 106, 121-31.

Parker, R. (1991). The Hymn to Demeter and the Homeric Hymns. Greece and Rome, 38, $1-17$.

Peek, W. (1955). Neues von Archilochos. Philologus, 99, 4-50.

Peek, W. (1955-1956). Neue Bruchstücke frühgriechischer Dichtung. WZHalle, 5, 189207.

Peek, W. (1956). Die Archilochos-Gedichte von Oxyrhynchos II. Philologus, 100, 1-28.

Pellizer, E. (1990). Outlines of a Morphology of Sympotic Entertainment. En O. Murray (Ed.), Sympotica: A Symposium on the Symposion (págs. 177-84). Oxford: Clarendon Press.

Perrotta, G. (1938). Il poeta degli epodi di Strasburgo. SIFC, 15, 3-41.

Perrotta, G. (1939). Ancora gli epodi di Strasburgo. SIFC, 16, 177-88.

Pfeiffer, R. (1928). Ein neues Altergedicht des Kallimachos. Hermes, 63, 302-41.

Pfeiffer, R. (1933). Ein Epodenfragment aus dem Iambenbuche des Kallimachos. Philologus, 88, 265-71.

Pfeiffer, R. (1938). Neue Lesungen und Ergänzungen zu Kallimachos-Papyri. Philologus, 93, 61-73.

Pickard-Cambridge, A. W. (1966). Dithyramb Tragedy and Comedy (2oed.). Oxford: Clarendon Press.

Podlecki, A. J. (1974). Archilochus and Apollo. Phoenix, 28(1), 1-17.

Podlecki, A. J. (1984). The Early Greek Poets and their Times. Vancouver: University of British Columbia Press.

Pouilloux, J. (1954). Recherches sur l'histoire et les cultes de Thasos: De la foundation de la cité à 196 avant J. C. (Vol. I). Paris: Études Thasiennes.

Pouilloux, J. (1955). Glaukos: Fils de Leptine Parien. BCH, 79, 73-86.

Pouilloux, J. (1964). Archiloque et Thasos: histoire et poésie. Archiloque. Entretiens sur l'antiquité classique, 10, 3-27.

Pouilloux, J. (1986). La fondation de Thasos: archéologie, litterature et critique littéraire. Hommages à Charles Delvoye. En J. Pouilloux, D'Archiloque à Plutarque. 
Littérature et réalité (págs. 114-24). Lyon: Maison de l'Orient et de la Méditarranée.

Privitera, G. A. (1957). Archiloco e il ditirambo letterario presimonideo. Maia, 95-110.

Privitera, G. A. (1965). Archiloco e le divinità dell' Archilocheion. RFIC, 93, 5-25.

Puelma Piwonka, M. (1949). Lucilus und Kallimachos. Zur Geschichte einer Gattung der hellenistisch-römischen Poesie. Frankfurt am Main: Klostermann.

Race, W. H. (1992). How Greek Poems Begin. YCS(29), 13-28.

Racionero, Q. (1994). Aristóteles. Retórica. Madrid: Gredos.

Rankin, H. D. (1977). Archilochus' Chronology and Some Possible Events of his Life. Eos, 65, 5-15.

Rankin, H. D. (1977a). Archilochus of Paros. New Jersey: Noyes Press.

Rankin, H. D. (1977b). Archilochus' Chronology and Some Possible Events of his Life. Eos, 65, 5-15.

Redfield, J. M. (1975). Nature and Culture in the Iliad: the Tragedy of Hector. Chicago: University of Chicago Press.

Rees, B. R. (1961). Callimachus, Iambus 1.9-11. CR, 11 n. s. (1), 1-3.

Robert, L. (1968). De Delphes a l'Oxus: Inscriptions grecques nouvelles de la Bactriane. CRAI, 112(3), 416-57.

Robertson, N. D. (1998). The Two Processions to Eleusis and the Program of the Mysteries. AJPh, 547-575.

Rodríguez Adrados, F. (1955). Origen del tema de la nave del estado en un papiro de Arquíloco (56a Diehl). Aegyptus, 1, 206-10.

Rodríguez Adrados, F. (1956). Sobre algunos papiros de Arquíloco. PP, 11, 38-48.

Rodríguez Adrados, F. (1976). Orígenes de la lírica griega. Madrid: Biblioteca de la Revista de Occidente.

Roscher, W. H. (1888). Der kykeon des Hipponax. Jahrb. für Klass., 34, 522-524.

Rosen, R. (1987). Hipponax Fr. 48 Dg. and the Eleusinian Kykeon. AJPh, 108(3), 416-26.

Rosen, R. M. (1987). Hipponax Fr. 48 Dg. and the Eleusinian Kykeon. AJPh, 108(3), 41626.

Rosen, R. M. (1988). A Poetic Initiation Scene in Hipponax? AJPh, 109(2), 174-79. 
Rosen, R. M. (1988). Hipponax, Boupalos, and the Conventions of de Psogos. TAPhA, 118, 29-41.

Rosenkranz, M. L. (1964). Gli 'atticismi' negli scoli ad Aristofane. Helikon, 4, 261-78.

Rösler, W. (1980). Dichter und Gruppe: Eine Untersuchung zu den Bedingungen und zur historischen Funktion fruher griechischer Lyrik am Beispiel Alkaios. München: W. Fink.

Rösler, W. (1985). Persona Reale o Persona Poetica? L'Interpretazione dell'Io nella Lirica Greca. QUCC, 19, 131-44.

Rotstein, A. (2010). The Idea of Iambos. Oxford: Oxford University Press.

Russo, J. (1974). The Inner Man in Archilochus and the "Odyssey". GRBS, 15(2), 139-52.

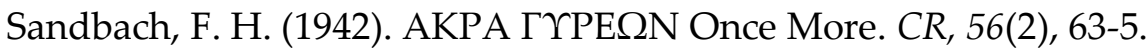

Scarpi, P. (1976). Letture sulla religione classica: L'inno omerico a Demeter. Elementi per una tipologia del mito. Firenze: Olschki.

Scherer, A. (1964). Die Sprache des Archilochos. Archiloque. Entretiens sur l'antiquité classique, 10, 87-108.

Schmid, W., \& Stählin, O. (1929). Geschichte der griechischen Literatur (Vol. 1). München.

Schmitt-Pantel, P. (1990). Sacrificial Meal and the Symposion: Two Models of Civic Institutions in the Archaic City? En O. Murray (Ed.), Sympotica: A Symposium on the Symposion (págs. 14-33). Oxford: Clarendon Press.

Seaford, R. (2006). Dionysos. New York: Routledge.

Simonin-Grumbach, J. (1975). Pour une typologie des discours. En J. Kristeva, J. C. Milner, \& N. Ruwet (Edits.), Langue, discours, société: pour Émile Benveniste (págs. 85-121). Paris: Seuil.

Sisti, F. (1975). Sul Pap. Col. inv. 7511. RCCM, 17, 221-32.

Slater, W. J. (Ed.). (1991). Dining in a Classical Context. Ann Arbor: The University of Michigan Press.

Slings, S. R. (1975). Three Notes on the New Archilchus Papyrus. ZPE, 18, 170.

Slings, S. R. (1986). Archilochus: New Fragments from the Sosthenes Inscription. ZPE, $1-3$.

Slings, S. R. (1987). Anonymus: Commetary on Poem(s) of Hipponax. En J. M. Bremer, A. M. van Erp Taalman Kip, \& S. R. Slings, Some Recently Found Greek Poems: Text and Commentary (págs. 70-94). Leiden, New York \& Köln: Brill. 
Slings, S. R. (1987). Archilochus: First Cologne Epode. En J. M. Bremer, Some Recently Found Greek Poems (págs. 24-61). Leiden: Brill (Mnemosyne supp. 99).

Slings, S. R. (1987). Archilochus: First Cologne Epode. En J. M. Bremer, Some Recently Found Greek Poems (págs. 24-61). Leiden: Brill (Mnemosyne 99).

Slings, S. R. (1987). Commetary on Poem(s) of Hipponax. En J. M. Bremer, A. M. van Erp Taalman Kip, \& S. R. Slings (Edits.), Some Recently Found Greek Poems: Text and Commentary (págs. 70-94). Leiden, New York \& Köln: Brill (Mnemosyne 99102).

Slings, S. R. (Ed.). (1990). The Poet's I in Archaic Greek Lyric. Amsterdam: VU University Press.

Snell, B. (1944). Zu den Fragmenten der griechischen Lyriker. Philologus, 96, 282-92.

Snell, B. (1953). The Discovery of the Mind. The Greek Origins of European Thought. Cambridge: Harvard University Press.

Steffen, W. (1961). Proceeding of the 9th. International Congress of Papyrology. Die neuen Iambengedichte des Archilochos, (págs. 18-29). Oslo.

Stella, L. A. (1986). Note archilochee (in margine alle nuove scoperte archeologiche. BollClass, 7, 81-100.

Stoessl, F. S. (1976). Das Liebesgedicht des Archilochos. RhM, 119, 242-66.

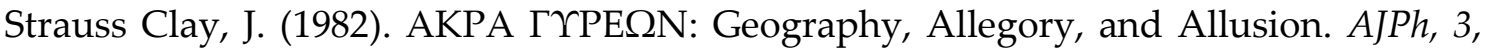
201-4.

Strauss Clay, J. (1986). Archilochus and Gyges: An Interpretation of Fr. 23 West. QUCC, 24 n.s.(3), 7-17.

Suárez de la Torre, E. (1987). Hiponacte cómico. Emerita, 55, 113-39.

Suárez de la Torre, E. (2002). Yambógrafos griegos. Madrid: Gredos.

Tarditi, G. (1956). La nuova epigrafe archilochea e la tradizione biografica del poeta. $P P, 11,122-39$.

Tarditi, G. (1958). Motivi epici nei tetrametri di Archiloco. PP, 26-46.

Tarditi, G. (1959). In margini alla cronologia di Archiloco. RFIC, 37, 113-8.

Tarditi, G. (1968). Archiloco. Introduzione, testimonianze sulla vita e sull'arte, testo critico, traduzione. Roma: Ed. dell'Ateneo.

ten Brink, B. (1851). Hipponacteorum epimetrum alterum. Philologus, 6, 727-30. 
Theiler, W. (1974). Ein wiederfefundenes Archilochos-Gedicht? Poetica, 6, 469-512.

Theiler, W. (1977). Die Überraschung des Kölner Archilochos. MH, 34, 56-71.

Toohey, P. (1988). Archilochus' General (fr. 114W): Where Did He Come From? Eranos, $86,1-14$

Treu, M. T. (1963). Selbstzeugnisse alexandrinischer Dichter. En G. Garbarino, \& P. Pecchiura (Edits.), Miscellanea di studi alessandrini in memoria di Augusto Rostagni (págs. 273-90). Torino: Bottega d'Erasmo.

Treu, M. T. (1968). Archilochos. RESuppl., 11, 136-56.

Treu, M. T. (1976). Archilochos und die Schwestern. RhM, 119, 97-126.

Tsagarakis, O. (1977). Self-Expression in Early Greek Lyric Elegiac and Iambic Poetry. Wiesbaden: Franz Steiner Verlag.

Van Dijk, G. J. (1997). Ainoi, Logoi, Mythoi: Fables in Archaic, Classical, and Hellenistic Greek Literature : With a Study of the Theory and Terminology of the Genre. Leiden: Brill (Mnemosyne 166).

Van Sickle, J. (1975). The Doctored Text. Translating a New Fragment of Archilochus. $M L N, 90,872-85$.

Van Sickle, J. (1975). The New Erotic Fragment of Archilochus. QUCC(20), 123-56.

Verdenius, W. J. (1982). A Commentary on Hesiod Works and Days, vv. 1-382. Leiden.

Verschueren, J. (2002). Para entender la pragmática. Madrid: Gredos.

Versnel, H. S. (1970). Triumphus: An Enquiry into the Origin, Development and Meaning of the Roman Triumph. Leiden: Brill.

Vox, O. (1995). Sul Giambo I di Callimaco. Rudiae, 7, 275-87.

Vox, O. (1998). Il poeta e il carpentiere (Archiloco e Carone). QUCC, 29(2), 113-8.

Webster, P., Perrine, D. M., \& Ruck, C. A. (2000). Mixing the kykeon. Eleusis, 4, 1-25.

Welcker, F. G. (1844). Kleine Schriften I. Bonn: E. Weber.

Wellek, R., \& Warren, A. (1948). Theory of Literature. New York: Harcourt, Brace, and Company.

Welles, C. B. (1934). Royal Correspondence in the Hellenistic Period. New Haven: Yale University Press.

West, M. L. (1971). Callimachus on the Pythagoreans. CR, 21 n.s.(3), 130-1. 
West, M. L. (1974). Studies in Greek Elegy and Iambus. Berlin \& New York: Walter de Gruyter.

West, M. L. (1975). Archilochus Ludens: Epilogue of the Other Editor. ZPE, 16, 217-9.

West, M. L. (1977). Two Notes on the Cologne Epode of Archilochus. ZPE, 26, 44-8.

West, M. L. (1992). Ancient Greek Music. Oxford: Oxford University Press.

West, M. L. (1993). Greek Lyric Poetry. Oxford: Oxford University Press.

West, M. L. (1997). The East Face of Helicon. West Asiatic Elements in Greek Poetry and Myth. Oxford: Oxford University Press.

West, M. L. (1998). Grated Cheese fit for Heroes. JHS, 190-1.

West, S. (1988). Archilochus Message Stick. CQ (n. s.), 38(1), 42-8.

Wheeler, E. (1991). The General as Hoplite. En Hanson, V. D. (Ed.), Hoplite: The Classical Greek Experience (págs. 121-70). London: Routledge.

Wiersma, W. (1933-1934). The Seven Sages and the Prize of Wisdom. Mnemosyne, 1(2), 150-54.

Will, F. (1969). Archilochus. New York: Twayne.

Williams, F. (1994). Archilochus and the eunuch: the persistence of a narrative pattern. Classics Ireland, 1, 96-112.

Wilson, P. (2003). The Sound of Cultural Conflict: Kritias and the Culture of Mousikê in Athens. En C. Dougherty, \& L. Kurke (Edits.), The Cultures within Ancient Greek Culture: Contact, Conflict, Collaboration (págs. 181-206). Cambridge: Cambridge University Press.

Winiarczyk, M. (2002). Euhemeros von Messene. Leben, Werk und Nachwirkung. München \& Leipzig: K. G. Saur.

Wood, H. (1966). On a Fragment Falsely Ascribed to Archilochus. MH, 23, 228-33.

Wulf, H. (1896). De fabellis cum collegii septem sapientium memoria coniunctis quaestiones criticae. Halle: Karras.

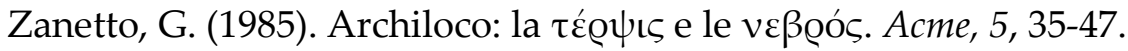

Zimmermann, B. (1992). Dithyrambos. Geschichte einer Gattung. Göttingen: Vandenhoeck \& Ruprecht (Hypomnemata 98). 